UNIVERSIDADE DE SÃO PAULO

FACULDADE DE EDUCAÇÃO

TANYA CECÍLIA BOTTAS DE OLIVEIRA E SOUZA

Análise de uma proposta de formação continuada de professores no contexto da diversidade

São Paulo

2008 



\title{
Análise de uma proposta de formação continuada de professores no
} contexto da diversidade

\author{
Dissertação apresentada à Faculdade de \\ Educação da Universidade de São Paulo para \\ obtenção do título de Mestre em Educação. \\ Área de concentração: Psicologia e Educação \\ Orientadora: Prof ${ }^{\mathrm{a}}$. Dr ${ }^{\mathrm{a}}$. Elcie F. Salzano \\ Masini
}

São Paulo 
AUTORIZO A REPRODUÇÃO E DIVULGAÇÃO TOTAL OU PARCIAL DESTE TRABALHO, POR QUALQUER MEIO CONVENCIONAL OU ELETRÔNICO, PARA FINS DE ESTUDO E PESQUISA, DESDE QUE CITADA A FONTE.

Catalogação na Publicação

Serviço de Biblioteca e Documentação

Faculdade de Educação da Universidade de São Paulo

371.13

S48a
Oliveira e Souza, Tanya Cecília Bottas de Análise de uma proposta de formação continuada de professores no contexto da diversidade / Tanya Cecília Bottas de Oliveira e Souza ; orientação Elcie Fortes Salzano Masini. São Paulo : s.n., 2008.

318 p. : il.

Dissertação (Mestrado - Programa de Pós-Graduação em Educação.Área de Concentração : Psicologia e Educação) - Faculdade de Educação da Universidade de São Paulo.

1. Vygotsky, Lev Semenovich 2. Formação continuada do professor 3. Educação especial 4. Deficientes - Educação 5. Ensino e aprendizagem 6. Interdisciplinaridade 7. Ensino público I. Masini, Elcie Fortes Salzano, orient. 


\section{FOLHA DE APROVAÇÃO}

Tanya Cecília Bottas de Oliveira e Souza

Análise de uma proposta de formação continuada de professores no contexto da diversidade

Dissertação apresentada à Faculdade de Educação da Universidade de São Paulo para obtenção do título de Mestre.

Área de concentração: Psicologia e Educação

Aprovado em:

\section{Banca Examinadora}

Prof $^{a}$ Dra. Elcie F. Salzano Masini

Instituição: Universidade de São Paulo

Assinatura:

Prof. Dr. Marcos José Da Silveira Mazzotta

Instituição: Universidade de São Paulo

Assinatura:

Prof $^{a}$ Dra. Eliana Maria Ormelezi

Instituição: Universidade Presbiteriana Mackenzie Assinatura: 



\section{DEDICATÓRIA}

À minha mãe, que mesmo ausentando-se durante a produção deste trabalho, permaneceu como memória viva, por sua generosidade e sabedoria, que foi e continua sendo fonte constante de inspiração para que eu busque meus ideais;

Ao meu pai, exemplo de determinação, respeito e zelo pelo bem público, que me trouxe, por intermédio de sua trajetória profissional e pessoal, grandes ensinamentos sobre a arte de conciliar posições e encontrar caminhos alternativos diante dos grandes dilemas existentes no trabalho com a comunidade;

À minha família: Sergio, companheiro constante de jornada, pelo estímulo, apoio e cumplicidade diante de tantos desafios e por me ensinar, em nossa convivência, a ser persistente e buscar sempre aquilo em que eu acredito; meus filhos Talita, Felipe e Julia, que enfrentaram os momentos de ausência e turbulência, compreendendo e valorizando minhas conquistas; meu desejo é que consigam realizar seus sonhos em um mundo mais humano, justo e solidário;

Às crianças e jovens das escolas com quem convivi e aprendi a ser mais solidária e a valorizar a diversidade humana. 



\section{AGRADECIMENTOS}

À minha orientadora, Prof ${ }^{a}$. Dra . Elcie A. F. Salzano Masini, que, neste período de descobertas e crescimento, foi mais do que uma profissional competente, trazendo-me o estímulo necessário, na hora certa, com a dose de carinho de quem ensina com paixão;

Ao Prof. Dr. Marcos José da Silveira Mazzotta, pelas valiosas contribuições teóricas transmitidas por suas publicações e também pelos apontamentos precisos e reveladores realizados durante o exame de qualificação;

À Profa . Dr ${ }^{\mathrm{a}}$. Eliana Maria Ormelezi, pela análise cuidadosa e idéias pertinentes sugeridas por ocasião do exame de qualificação, que me fizeram buscar e encontrar novos dados;

Aos meus professores do mestrado, em especial à Profa . Marta Kohl de Oliveira, que, por meio de seus conhecimentos, possibilitou que a teoria histórico-cultural passasse a ter muito mais significado para mim;

Às escolas que abriram suas portas e me receberam com tanto carinho para o desenvolvimento do trabalho de campo;

A todos os educadores com quem me orgulho de ter convivido, por acreditarem, mesmo diante dos conflitos, na condição de aprendizagem da criança, e por permitirem que o cotidiano de sua sala de aula fosse, também, espaço para minhas aprendizagens; em especial, às professoras participantes da pesquisa, que me confiaram dados tão especiais de sua vida profissional e gentilmente dispuseram-se a dedicar momentos para encontrarmos, juntas, respostas a tantas perguntas, muitas delas, inclusive, pouco discutidas;

À Bel e à Aparecida, que trouxeram luz ao projeto de pesquisa e com quem aprendi muito nestes primeiros ensaios como pesquisadora;

À Márcia, que, com seu carinho e competência, ajudou-me nos momentos de maior sufoco com a informática; 

Às minhas constantes e preciosas amigas Eliana, Eliane, Élide, Irene e Sonia, parceiras de idéias e ideais, de projetos e conquistas, de encantos e desencantos... que me apoiaram e contribuíram de diferentes maneiras na produção deste trabalho; que esta semeadura ofereça frutos àqueles por quem sempre lutamos;

À Luciana, pela atenta contribuição na revisão de texto, o meu carinho. 

"Uma vez que um ator foi colocado, simultânea ou sucessivamente, dentro de uma pluralidade de mundos sociais não homogêneos, às vezes até contraditórios, ou dentro de universos sociais relativamente coerentes, mas que apresentam, em certos aspectos, contradições, então trata-se de um ator com o estoque de esquemas de ações ou hábitos não homogêneos, não unificados, e com práticas conseqüentemente heterogêneas (e até contraditórias), que variam segundo o contexto social no qual será levado a evoluir.”

B. Lahire 



\section{RESUMO}

OLIVEIRA e SOUZA, Tanya Cecília Bottas de. Análise de uma proposta de formação continuada de professores no contexto da diversidade. 2008. 318 p. Dissertação (Mestrado) - Faculdade de Educação, Universidade de São Paulo, São Paulo, 2008.

O objetivo desta dissertação foi o de analisar a Proposta de Formação Continuada do Professor em parceria com a equipe interdisciplinar, desenvolvida pela Secretaria de Educação de São Bernardo do Campo no período de 1996-2003. Identificar com professores da rede municipal de ensino desse Município que atuam na Educação Especial e que vivenciaram esse processo: como repercutiu em suas práticas e se modificou a visão que possuíam sobre a deficiência; se conferiu-lhes instrumentos que os auxiliassem a enfrentar as situações do dia-a-dia, no atendimento à diversidade e na compreensão das situações dela decorrentes; se contribuiu para refletir sobre o seu papel profissional na mediação de um projeto pedagógico mais flexível e transformador; se levou a mudanças no âmbito do "ser professor", do "saber" e do "fazer pedagógico". Este trabalho está fundamentado nos estudos da psicologia histórico-cultural de Vygotsky e seus seguidores, nas concepções que embasam a formação do professor e nas contribuições dos pressupostos sobre a Interdisciplinaridade. A metodologia adotada foi o da modalidade qualitativa, imprescindível à análise das percepções e significados atribuídos pelos participantes a esse modelo formativo, expressos em entrevistas e com uso de questionários. A análise dos dados das entrevistas foi realizada em três etapas: 1) categorização das respostas das entrevistadas; 2) categorização definida sob o prisma das teorias que fundamentaram a investigação; 3) reflexões sobre as categorizações, estabelecendo uma convergência dos dados analisados na perspectiva dos dois grupos de categorias. Evidenciaram-se: a importância do processo formativo, valorizando o papel do professor e propiciando crescimento profissional; a contribuição da atividade partilhada e dos vários campos teóricos para apropriação de conhecimentos sobre a criança e suas condições de aprendizagem, fortalecendo o professor para a tomada de decisões mais refletidas e autônomas; as dificuldades relativas à formação dos profissionais da equipe que coordenavam o processo; a pouca clareza na definição dos papéis dos diferentes profissionais; o pouco envolvimento de alguns e excesso de demanda de outros; as dificuldades estruturais e de organização das unidades, deflagrando ausência de sintonia entre Secretaria de Educação e Escola. A análise mostrou que a proposta auxiliou os educadores entrevistados a reconhecerem a importância de um projeto pedagógico elaborado em bases teóricas que ampliem a condição de o professor intervir na aprendizagem de seus alunos com mais clareza e decisão. Por outro lado, assinalou a importância de realizar modelos de formação que ofereçam ao professor um referencial de trabalho mais voltado à análise, reflexão e reconstrução da prática.

Palavras-chave: Formação do professor. Deficiência. Interdisciplinaridade. 



\begin{abstract}
OLIVEIRA e SOUZA, Tanya Cecília Bottas de. Analysis of the Continuous teacher Development Project, in a diversity context. 2008. 318 p. Dissertation (Master of science) Faculdade de Educação, Universidade de São Paulo, São Paulo, 2008.

This dissertation has as an objective the analysis of the Continuous Development Project, in partnership with an interdisciplinary group, developed by the São Bernardo Educational Department between the years of 1996-2003; to identify along with teachers who work with special education in that city and which have had such experience: how it reflected on their teaching and if it modified their point-of-view on the impairments; if it gave them tools to help with everyday occurrences such as the observation of the diversities and the comprehension of situations occurring due to them; if it helped them to ponder about their roles in the conciliation of more flexible and changing academic tasks; if it led to a transformation on their abilities of "being teachers", having "knowledge" and "academic skills". It has been based on Vygotsky (and disciples) historical-cultural psychology studies, regarding the concepts that support the development of the teacher and their contributions to interdisciplinary group formation. The implemented methodology considered quality, essential to the examination of the perceptions and meanings the participants assigned to this development standard, through interviews and surveys. The interviews analysis was carried on in three steps: $1^{\text {st }}$ was the classification of the answers; the classification 2 , defined under the hood of the theories that sustained the study; pondering on the classifications leading to a convergence of verified data on the points-of-view of both classified groups. The significance of the developing process valuing the role of the teacher and providing with professional growth became evident; the contribution of the shared activities and academic fields for the gathering of knowledge of kids and for the learning processes, stimulating the teacher on more pondered and independent decision making; the difficulties related to the development of the professionals on the group that coordinated the project; the lack of understanding on the definition of roles of the distinct professionals; the lack of commitment of some professionals and the excessive demand of others; the structural and organizational obstacles of the facilities showing the deficient synchronization between the School Board and the School itself. The analysis has shown that the project helped the surveyed educators to recognize the value of an academic project supported on conceptual basis, which broadens the role of the educators on a clearer and more independent teaching method. On the other hand, it has revealed the importance of the creation of a development standard which can provide the teacher with analytic, pondered, and skill remodeled work orientation.
\end{abstract}

Keywords: Teachers skill development. Deficiency. Interdisciplinary groups. 



\section{LISTA DE SIGLAS}

APAE Associação de Pais e Amigos dos Excepcionais

ASIITE Associação Santo Inácio para Integração do Trabalhador Especial

CMAPDV Centro Municipal de Apoio ao Portador de Deficiência Visual

CNE/CEB Conselho Nacional de Educação/Câmara de Educação Básica

DERDIC Divisão de Educação e Reabilitação dos Distúrbios da Comunicação

EEPSG Escola Estadual de Primeiro e Segundo Grau

EMEB Escola Municipal de Educação Básica

EMEBE $\quad$ Escola Municipal de Educação Básica Especial

EMEDAC Escola Municipal de Educação de Deficientes da Audiocomunicação

EMEI Escola Municipal de Educação Infantil

FENEIS Federação Nacional de Educação e Integração do Surdo

FUNDEF Fundo de Manutenção e Desenvolvimento do Ensino Fundamental e de Valorização do Magistério

HTPC Horário de Trabalho Pedagógico Coletivo

HTPL Horário de Trabalho Pedagógico Livre

INES-RJ Instituto Nacional de Educação de Surdos- Rio de Janeiro

LDBEN Lei de Diretrizes e Bases da Educação Nacional

LIBRAS Língua Brasileira de Sinais

NEDAC Núcleo de Educação de Deficientes da Audiocomunicação

PAP Professor de Apoio Pedagógico

PME Plano Municipal de Educação

PPE Projeto Pedagógico Educacional

PUCSP Pontifícia Universidade Católica de São Paulo

SEC Secretaria de Educação e Cultura

UERJ Universidade Estadual do Rio de Janeiro 



\section{SUMÁRIO}

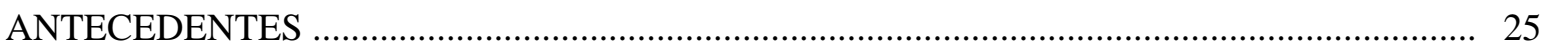

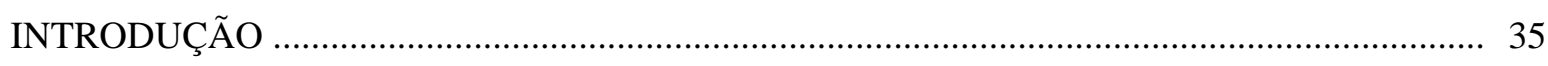

CAPÍTULO I: FUNDAMENTAÇÃO TEÓRICA ................................................................ 41

1.1. Contribuições da psicologia histórico-cultural ................................................................ 42

1.2. Formação continuada: o resgate do cotidiano do professor .............................................. 56

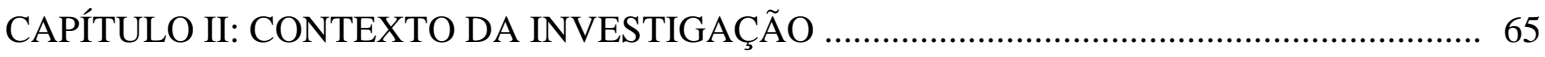

2.1. A realidade educacional: um breve relato .................................................................... 66

2.1.1. Concepções sobre formação docente, deficiência e diversidade ............................. 67

2.2. A construção de uma proposta ................................................................................ 74

2.2.1. Concepções e idéias sobre a educação para a criança com deficiência ..................... 76

2.2.2. A construção de uma proposta de acompanhamento do professor ............................ 94

2.2.2.1. Procedimentos para viabilizar a proposta ................................................. 96

2.2.2.1.1. Programação ............................................................................. 97

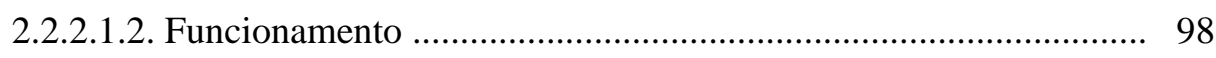

2.2.2.1.3. Sistemática de atuação ................................................................ 100

2.2.2.1.3.1. Construção e viabilização do Projeto

Pedagógico Educacional ......................................... 100

2.2.2.1.3.2. Interação: Escola-Família-Comunidade ....................... 100

2.2.2.1.3.3. Construção de instrumentos de trabalho ...................... 100

2.2.2.1.4. O projeto em andamento .............................................................. 101

2.2.2.1.4.1. Primeira etapa: reconhecimento da realidade ............. 101

2.2.2.1.4.2. Segunda etapa: estratégias de intervenção ................. 102

2.2.2.1.4.3. Terceira etapa: elaboração de propostas ...................... 102

2.2.2.1.4.4. Quarta etapa: discussão avaliativa .............................. 103 

3.1. Opção metodológica

3.2. Sujeitos da pesquisa

3.3. Fontes, procedimentos e instrumentos de coleta de dados

3.3.1. Fontes e instrumentos de coleta de dados

3.3.2. Procedimentos

3.3.2.1. Registros de dados 126

3.3.2.2. Análise de dados 127

3.4. Dialogando com os dados 130

3.4.1. Quadros da primeira categorização

3.4.2. Comentários sobre os significados levantados 164

3.4.3. Segunda categorização 174

3.4.3.1. Categorias conceituais 174

CAPÍTULO IV: REFLEXÕES SOBRE OS DADOS ANALISADOS 197

4.1. As marcas de uma vivência 197

4.2. Tomada de consciência sobre o papel profissional 199

4.3. Transformações nas concepções das educadoras 205

4.4. Transformações da prática pedagógica: aprendizagem baseada no contexto escolar 209

CONSIDERAÇÕES FINAIS 219

REFERÊNCIAS 223

GLOSSÁRIO 231

APÊNDICES 237

ANEXOS 257 



\section{ANTECEDENTES}

“A história atual de uma determinada prática só pode ser revelada em sua complexidade quando investigada em suas origens de tempo e espaço [...]."

Ivani Fazenda

Desenvolver esta investigação numa realidade em que está cravada boa parte de minha trajetória profissional torna-se uma tarefa instigante, a qual realizo com entusiasmo, mas que nem por isso se torna fácil. Sistematizá-la, estudar questões que são especialmente sensíveis para quem, em grupo, acreditou na possibilidade de mudanças das relações formativas entre equipe e professores, acentua a responsabilidade.

Este estudo está ancorado em uma experiência de trabalho vivida pela equipe de orientação técnica da Escola Municipal de Educação Básica Especial “Neusa Bassetto”, escola para surdos da qual a pesquisadora fazia parte, como psicóloga, até 1997, passando, após esse período, a coordenar as equipes técnicas da Educação Especial na Secretaria de Educação do Município de São Bernardo do Campo até 2003.

Selecionar aspectos desses seis anos que possam transparecer com mais nitidez e fidedignidade a experiência de um grupo de educadores - concepções, procedimentos, atitudes e valores de seus protagonistas - é uma tarefa complexa.

Ao retomar fatos, consultar registros, relembrar etapas que foram se sucedendo, a pesquisadora sentiu necessidade de apresentá-los, não em uma ordenação que marcasse a temporalidade dos fatos, mas em uma propagação dialética com os significados que esses conteúdos tiveram uns para os outros, suscitando relações centrais para a formação do professor, um dinamismo que associamos à órbita do sistema estelar genialmente ilustrado por Amaral (1999, p. 66): “[...] dependendo de qual elemento se elege como aquele que define a órbita dos demais, teremos sempre novos e novos desenhos”.

A órbita do sistema estelar é aqui tomada como metáfora para referirmo-nos à forma com que o grupo se articulava em torno de uma meta, um projeto, uma proposta liderada por diferentes 
atores, ora da equipe, ora do corpo docente, num movimento decisivo para o estabelecimento das relações e superação das dificuldades diante do empreendimento idealizado.

Desse percurso, marcado por reflexões, questionamentos e dúvidas, os dados não serão relatados numa seqüência linear. Nesta história, circundam pensamentos, fenômenos, preocupações, aspectos da trajetória de nossa experiência como educadores, que serão recuperados enquanto conectados com a proposta desta dissertação. Nesta retomada, será feita uma reconstrução de idéias, onde passado e presente estabelecem uma relação relevante com a problemática que nos propusemos a estudar. Retomada não de partes distintas, mas de um todo que possui interfaces que se complementam, contradizem, contrastam e até colidem, exigindo, por isso, constantes revisões.

Tomados por uma avalanche de demandas, algumas pertinentes, outras referentes a questões muito distantes de nosso papel, integrávamos as equipes que mantinham o acompanhamento às escolas municipais. No entanto, não deixávamos de nos envolver nesse emaranhado de solicitações importantes, que não podiam ser excluídas de nossas preocupações, o que nos impedia, muitas vezes, de mantermos a sistemática de acompanhamento ao professor conforme planejávamos.

Nesse descompasso de funções, tínhamos de estar sempre nos avaliando, pois era fatal: o professor ficava sozinho com suas dificuldades, à espera de respostas, e nós, frustrados, por não conseguirmos equacionar nossos propósitos com demandas mais pertinentes. A espera duradoura do professor e o sentimento de incompetência da equipe propagavam em nós uma intensa insatisfação pelo trabalho. Diante de estruturas escolares tão distintas, nem sempre abertas e flexíveis à criação de espaços para essas trocas, a aproximação da equipe com o professor ficava bem prejudicada. As solicitações e queixas caíam, muitas vezes, num vazio. Os obstáculos de ordem institucional comprometiam as relações, criando impasses difíceis de serem resolvidos, pois o professor sentia-se inseguro e desmotivado, principalmente quando não era ouvido. O desejo de ser atendido e poder resolver situações aparentemente insolúveis provocava no educador uma grande insatisfação e o sentimento de não ser compreendido, devido ao tempo passado e à intensidade do vivido.

Apesar de esse quadro ficar, muitas vezes, impregnado de ressentimentos e ainda parecer insolúvel, a circulação de idéias e a oportunidade de esses atores expressarem suas 
necessidades e descontentamentos ofereciam momentos de trocas e de mais compreensão em relação ao que ocorria. Os bloqueios poderiam ser solucionados na medida em que assumíssemos a sistemática do trabalho e era nesse espaço que o papel da equipe ficava evidente. Era necessário fazer um recorte e eleger prioridades comuns; planejar e reavaliar requeria uma constância.

A comunicação idealizada ressaltava a importância de se fortalecer a ação docente, ponto chave para que fossem rompidos a alienação e o silêncio, tão freqüentes. Assim foi que, ao “ouvir” o professor, procurava-se interpretar, compreender, explicar e propor transformações. Criava-se um canal aberto ao diálogo e à reciprocidade, tornando tanto o professor quanto a equipe mais conscientes de suas possibilidades e limitações.

Se o objetivo estava atrelado à reflexão sobre a prática docente, tínhamos de criar uma organização interna e institucional que possibilitasse a definição das competências de cada um, priorizando os espaços de trocas e a produção de conhecimento. No entanto, esses desencontros eram, por vezes, extremamente desestimulantes. A falta de clareza de onde devíamos partir chegava a nos distanciar do professor.

Eram muitas as tentativas para encontrar "nosso eixo" juntamente ao grupo e, nesse movimento, aprendemos que crescíamos de formas bem diferentes com cada um dos educadores. Nossos parceiros de idéias traziam uma bagagem de experiências peculiares, manifestando-se de acordo com suas convicções e interesses, e estes, mesmo nem sempre coerentes com os princípios propostos, ensejavam novas análises e, portanto, deveriam ser valorizados.

Acreditávamos que, nesses espaços, nasceriam projetos planejados com envolvimento de vários autores, em parceria com diferentes saberes, em um movimento de troca que fundamentasse nossas ações. Era preciso envolver a todos, indistintamente, e encontrar um caminho. Além de revelar o valor do saber de cada um e da experiência acumulada pelos diferentes profissionais, era necessário refletir sobre os conteúdos, aqueles considerados mais relevantes, formulando questões que dessem abertura a novas propostas de aprendizagem.

Organizávamos um cronograma de visitas às salas de aula com o propósito de chegarmos mais próximo do que era relatado pelos professores. Conhecer a sala de aula aumentava nossa 
capacidade de propor pistas mais reais. Compartilhar as dificuldades e os êxitos e mediar essa construção de saberes aquecendo nossas relações criavam um momento insubstituível de encontro. "Se podes olhar, vê. Se podes ver, repara” (SARAMAGO, 2005).

Era preciso discutir não apenas as situações concretas observadas pelo professor, mas também descobrir seus significados e os condicionantes de tantas “arestas”. Compartilhá-las suscitava novas análises na descoberta de pontos obscuros. Mais confiante diante das ocorrências, o professor poderia pensar com mais autonomia seu próprio trabalho.

Aprender a olhar e poder ver sem rótulos e preconceitos, saborear os dados e dar aos professores o devido valor era o motivo de tantos registros realizados para legitimarmos as orientações e reflexões. Poderíamos compreender “de que lugar” falava o professor e “olhar”, “ver”, "reparar” em cada detalhe dessa dinâmica tão rica em trocas.

\begin{abstract}
Normalmente não conseguimos perceber os limites, necessidades e possibilidades dos alunos. Eles vão sendo revelados no processo de trabalho. Alguns alunos "camuflam”, outros são mais transparentes. Nem sempre as possibilidades são evidentes. Faz-se necessário buscar formas de “decodificar” este aluno, extrapolar o que é "visível” (Profa . de Educação Especial da Secretaria Municipal de São Bernardo).
\end{abstract}

Ao relatar os dados, era necessário que os educadores aprendessem a ser mais claros, objetivos, e não disfarçassem o indisfarçável, afinal "as palavras são assim, disfarçam muito, vão-se juntando umas com as outras, parece que não sabem aonde querem ir [...]” (SARAMAGO, 2005).

Os relatos, tematizações e análises precisavam criar uma forma que recuperasse a realidade existente com mais clareza e objetividade e, para isso, a mediação de um parceiro competente era decisiva para o crescimento do grupo.

Pensar coletivamente exigia-nos muita pesquisa, nem sempre fácil, pois os espaços existentes eram muito limitados. Além dos horários para esse fim, recorríamos aos horários de recreio e de atividades em que os professores não estivessem no comando da classe. Em nome das 
trocas, planos e pedidos de socorro, atropelávamos situações, e isso nem sempre era bem aceito por alguns funcionários distantes da realidade vivida.

À parte todos os atropelos decorrentes da busca incessante por momentos de diálogo, e contando com o inevitável acúmulo de atividades, éramos, às vezes, impelidos a concentrar esforços em determinadas decisões que nos afligiam, em detrimento de outras. Mesmo considerando a existência de situações que mereceriam ser analisadas com diferentes profissionais - e, nesse sentido, tais situações demandavam mais tempo e envolvimento do grupo -, buscávamos sobrepor tais dificuldades e priorizar sempre a produção coletiva. Tratava-se de uma marca não muito fácil de ser mantida.

Decisões individuais pareciam, para muitos, algo mais racional e "prático”, em vista dos escassos horários de planejamento coletivo. Abordar questões referentes ao aluno e sua singularidade tão marcante sempre provocava muitas discussões, principalmente quando se referiam à indisciplina e agressividade. Conhecer sua história familiar, seu contexto sociocultural, as condições e recursos internos era algo fundamental para se obter mais domínio quanto à complexidade das situações.

As relações interpessoais mereciam atenção especial, no sentido de se reverem resistências e posturas, muitas vezes arraigadas de preconceitos. Era um caminho inesgotável e as contradições e erros eram recursos de análise e descoberta de novas respostas que poderiam auxiliar na compreensão da realidade e subjetividade do aluno, de suas capacidades, possibilidades e de como estas poderiam ser dinamizadas no grupo. As situações poderiam gerar infinitas leituras e se propagavam sem "hora marcada”, criando sérios dilemas ao professor, os quais deveriam ser trabalhados.

Hoje, com mais clareza, poderíamos discutir fundamentos teóricos referentes às vinculações histórico-culturais, nas quais os sujeitos estão imersos, desencadeando múltiplas direções na forma de compreendê-los e de levar o professor a uma nova interpretação das razões ocultas de tantas dificuldades e de quais concepções, conceitos e idéias assegurariam à prática docente, naquele momento, bases explicativas para nossas inquietações.

Era um estudo que exigia rigor, pois mesmo sendo proposto um novo discurso sobre os alunos com deficiência, diante de situações envolvendo fracasso escolar, não faltavam 
interpretações reveladoras de idéias e concepções organicistas, atribuindo-lhes características imutáveis, dando-se ênfase ao déficit. Admitia-se que as dificuldades e problemáticas de aprendizagem enfrentadas na sala de aula eram resultantes da falta de recursos internos do aluno para aprender, em decorrência de fatores hereditários e maturacionais, isto é, o conjunto de condições orgânicas é que prescreviam os limites dos alunos e refletiam nas expectativas e significados sobre as deficiências, socialmente construídos. Sendo assim, nossa responsabilidade em transpor esses conceitos e representações tão deterministas sobre a deficiência exigia explicações sobre os processos de conhecimentos que não poderiam ser esgotados mediante uma única perspectiva teórica.

Mesmo ressignificando a deficiência e alterando os marcantes rótulos sobre incapacidade e limites, associados à identidade das pessoas com deficiência, não se poderia ignorar que o reconhecimento do valor do outro estava na aceitação e identificação das diferenças individuais, como também na compreensão das condições reais de cada sujeito.

Se, por um lado, questionavam-se concepções que induziam à criação de expectativas pedagógicas limitadoras, por outro, acenava-se para os riscos de se pregar um discurso genérico sobre as deficiências que, na visão de Mazzotta (2007), "mascaram diferenças individuais acenando para uma inclusão radical ou incondicional”.

A compreensão dos problemas enfrentados pela escola possuía muitas facetas, que poderiam ser explicadas por um conjunto de conhecimentos inter-relacionados, referentes a vários campos teóricos. Era necessário analisar com coerência a própria interdependência de fatores relacionados à prática docente, à constituição do sujeito e à preponderância de um sobre o outro; discutir concepções que trouxessem uma visão mais completa da criança, compreendendo o aluno não apenas como um aparato cognitivo. Diante das situações do cotidiano, sujeitos psicológicos operam, reagem, organizam e interpretam as experiências de forma muito específica e singular, resultante da confluência de fatores de diferentes ordens, comparecendo, nesse processo, fatores socioculturais, afetivos e cognitivos, além dos orgânicos.

Ao assumir uma perspectiva sócio-histórica, considera-se que, no contexto da educação para pessoas com deficiência, o papel da escola se destaca ao propiciar situações singulares que contemplem a diversidade de condições, observando os recursos, ações e medidas 
necessárias que ofereçam possibilidades diferenciadas de o ensino tornar-se fecundo para suprir as necessidades básicas de sua aprendizagem.

Na abordagem dessas questões, outros espaços de formação foram compondo esse cenário dialógico: cursos com carga horária variada fundamentavam nossa prática, além das assessorias voltadas a propor vôos mais altos, envolvendo-nos em projetos integrados à comunidade e à definição de diretrizes. Nessa rede de possibilidades formativas, em complementação às atividades nas escolas, tivemos grandes progressos. Gradativamente, a participação do grupo foi ganhando forma e podemos afirmar que, a despeito da costumeira descontinuidade existente nos programas ao término de cada governo, ainda hoje observamos focos de nosso trabalho resistindo ao "intemperismo" dos organismos norteadores das políticas educacionais que foram se sucedendo.

A possibilidade de investigar o percurso formativo sobre os processos de construção da prática pedagógica, nesse contexto específico, originou-se de alguns questionamentos:

- Que efeitos as reflexões voltadas para o cotidiano do professor produziriam e se estas permitiriam a ele rever concepções, ampliar seu saber e, de forma mais segura, refletir sua prática e as condições específicas dos alunos?

- De que forma os cursos e oficinas que compunham o Plano Formativo contribuiriam para que o professor conseguisse estabelecer relações entre as discussões teóricas e as situações do cotidiano?

- Como o professor redefinia sua práxis? Foi possível dialogar com a teoria e a prática e fazer desse procedimento um instrumento de compreensão das características psicológicas e socioculturais do aluno e das complexas relações entre aprendizagem, desenvolvimento e ensino?

Neste estudo, optamos por analisar essa versão formativa particular, desenvolvida com professoras da Educação Especial a partir de situações por elas relatadas, admitindo-se que a expressão da história dessas educadoras e dos conteúdos ocultos deu forma às condições constitutivas da verdadeira trama, que ofereceu sustentação à realidade educacional pesquisada. Conhecê-la, segundo Rockwell e Ezpeleta (1989), poderia ser um ponto de 
partida para a identificação do conteúdo real de alternativas pedagógicas e políticas.

Admite-se que conhecer é destacar também as formas concretas nas quais essas docentes se apoiaram e projetaram seu trabalho e como reformularam conceitos e práticas que hoje se refletem em sua ação pedagógica.

O propósito de conhecer essa realidade, a partir dos depoimentos das professoras, valoriza a análise das peculiaridades formativas vivenciadas por elas e avalia se podem ter propiciado a incorporação de recursos para o enfrentamento de circunstâncias aparentemente insolúveis.

Esse propósito implica crer na possibilidade de reconstruir as influências desses momentos legitimados pela visão das educadoras, de acordo com a vivência de cada uma, e analisar o recorte realizado por elas dessas complexas situações que coexistiram e marcaram sua vida profissional. “Toda volta à escola traz novos indícios para compreender, a partir destes sujeitos, a 'lógica' de certas atividades observadas na escola e reconstruir as redes que as unem a outros âmbitos” (ROCKWELL e EZPELETA, 1989, p. 23).

Entende-se, dessa forma, que haveria um presente marcado por "vestígios” dos processos formativos daquele período, um presente reconhecido e marcado pela totalidade de fenômenos e relações estabelecidos naquele contexto educacional, que ainda hoje afetam o desenvolvimento profissional das educadoras.

As demandas surgiam e as idéias apresentadas para atender às emergências nem sempre traziam soluções imediatas. Indagávamos sobre como o grupo conseguiria ultrapassar esse círculo vicioso, centrado na reprodução dos sintomas, e atingir a essência dos conflitos.

O que, muitas vezes, tornava-se deveras frustrante era a aparente falta de domínio sobre questões diretamente relacionadas à proposta pedagógica. Observava-se que algumas professoras temiam não saber reagir aos costumeiros conflitos e colocavam em risco o equilíbrio do grupo, desencadeando buscas por respostas mais diretas, referentes ao "controle de condutas”.

As relações interpessoais e motivações que permeiam as ações dos alunos e do professor davam oportunidade para interessantes discussões. Nessa direção, a atuação das equipes, 
numa compreensão interdisciplinar dos conflitos, trazia ricas contribuições. Por outro lado, a apatia e o desinteresse dos alunos, mesmo que aparentemente fossem questões mais fáceis de se lidar, também mobilizavam sentimentos de incompetência. Eram momentos essenciais para se pensar se havia sintonia entre o aluno e a proposta ou, até mesmo, com outras crianças e com o professor.

Essa parceria mais próxima entre equipe e professor tornava mais claro o lugar que seria possível ocuparmos nesta proposta. Se, por um lado, poderia estar sendo construída uma relação de troca fértil, que ofereceria condições para uma atuação com maior domínio e autonomia, por outro, corríamos riscos permanentes de serem criados elos de dependência alienantes e um “contramodelo” que não se estabelecia na superação dos limites, mas na manutenção da fragilidade do educador que, na teoria, admitíamos ser possível evitar.

Sem conferir críticas desfavoráveis ao funcionamento dessa parceria, muitas vezes essa relação não se legitimava, deixando de contribuir para a construção dos princípios dialógicos tão almejados. Apesar do empenho, a tônica voltada para uma visão colaborativa às vezes se perdia, e na interação entre os profissionais eram geradas imposições de conhecimentos e valores, hierarquizando saberes. O diálogo intersubjetivo tão propagado não poderia descaracterizar o saber e a competência do professor.

Por trás dessas realidades tão opostas, estão presentes diferentes formas de organização e planejamento, relações muito peculiares, intenções e experiências próprias a cada profissional, resultantes da maneira como a comunicação se estabelece, quer mantendo o despreparo, quer alimentando relações positivas de crescimento gradual de ambos os lados, no enfrentamento de pontos frágeis - falhas e incertezas - e na valorização das conquistas.

Ao sabor dessas circunstâncias - ora de desconforto diante de tantas solicitações e problemas, ora de satisfação frente a cada nova descoberta do grupo -, nossos propósitos se fortaleciam. Íamos estabelecendo uma ponte entre os discrepantes resultados presentes a cada momento em nossas relações: os acertos e as possibilidades misturavam-se aos enganos e falhas, amenizando nossa impotência diante da clareza de nossos limites.

Constatávamos, a cada momento, que as ferramentas só agiriam com mais força ao serem conectadas umas às outras. Com esses fundamentos, fomos construindo essa experiência com 
muitos professores, não com a totalidade deles, mas a imensa disponibilidade desse grupo conseguia, pouco a pouco, entusiasmar os mais refratários. A parceria e os conhecimentos gerados naquele espaço enriqueciam-nos profissionalmente e era isso que nos importava. Mesmo assim, era evidente que a fragmentação e a falsa hierarquia entre os profissionais fragilizavam a relação do grupo.

Superar a dicotomia entre teoria e prática exigia repensar nossos conceitos e prática, sem transformar a escola num território demarcado por “domínios” da equipe técnica - de um lado, pesquisadores e teóricos; de outro, professores em defesa da prática e da ação. Acreditamos que repensar essa distinção exige complementaridade de conhecimentos, superando falsas manifestações de soberania de uns sobre os outros, como se sozinhos “pudéssemos resolver todas as mazelas do caótico estado que se encontram os currículos dos cursos de formação do educador” (FAZENDA, 2001, p. 78).

Para tornarmos observáveis nossas possibilidades de estabelecer uma parceria realmente produtiva, era necessário submeter nosso planejamento a uma permanente avaliação, sabendose que a construção e reconstrução do conhecimento fazem-se melhor quando partilhadas por muitos.

Esta dissertação emergiu da escolha de um caminho para analisar essa experiência, um acompanhamento do que permaneceu e do que foi aprendido. Pode ser entendida como um balanço do que foi realizado por profissionais empenhados na descoberta de rumos que conjugassem a formação do educador e o ensino comprometido com identidades plurais. Pode ser vista como um estudo de uma realidade em que educadores, no contexto da diversidade e da deficiência, revelam as veredas para o enfrentamento de problemas.... cerceados pelas dificuldades.... na busca de um projetar-se no horizonte dos possíveis. 


\section{INTRODUÇÃO}

"Quem forma, se forma;

Quem ensina, aprende a ensinar;

Quem aprende, ensina ao aprender.”

Paulo Freire

Esta dissertação surgiu de um profundo interesse pela formação de professores e pela busca de caminhos para construir uma formação humanizadora e dialógica. Humanizadora entendida como o investimento, não apenas no Plano dos Conhecimentos Formais voltados aos processos de ensino e aprendizagem, mas também caminhar na perspectiva de situar o professor numa posição em que ele possa descobrir seu papel, ao mesmo tempo em que se “dá ouvido à sua voz” (Cf. MELUCCI, 2004, p. 115). Trata-se, então, de uma instância não préformada, pois na dialogicidade eclodem as peculiaridades, as diferenças, o que vai se construindo na reflexão sobre o vivido e o que se estuda nos livros.

Uma proposta nesses moldes envolve o processo de identificação de necessidades dos professores, que podem se apresentar em dois níveis (Cf. ESTRELA, MADUREIRA e LEITE, 1999): 1) no plano objetivo, referente às necessidades expressas ligadas ao desenvolvimento da ação pedagógica (problemas, dificuldades ou carências); 2) no plano subjetivo, referente ao que os professores sentem (desejos e interesses).

Considerar esses dois níveis implica a crença de que não é possível descartar aspectos que fazem parte da experiência docente e de sua experiência de vida. Envolve algo mais do que construir conhecimento sobre o ensinar; de que as necessidades manifestas pelo professor não podem ser interpretadas apenas como dificuldades técnico-metodológicas frente ao processo educativo, mas também expressão dos desafios enfrentados que não foram atingidos, o que, na sua visão, exigir-lhe-ia maior conhecimento para atender às exigências pedagógicas.

As necessidades nesta perspectiva são, sobretudo, constructos interpretativos que os professores vão manifestando quando estabelecem mediações entre os constrangimentos que sentem na prática e os desejos que têm (IBID, p. 29). 
A concretização desse tipo de proposta só se viabiliza em um processo de formação enquanto trajetória contínua, oferecendo substratos que transcendam às questões pontuais ou técnicometodológicas de solucionar problemas práticos e de conhecimento; incide em diferentes contextos que abrem espaço para a compreensão de que a formação implica um projeto político pedagógico. “Cada necessidade humana foi transformada em uma construção interpessoal e social que exprime pela linguagem, a percepção da falta e a tensão para superála” (MELUCCI, 2004, p. 39).

O tema "formação continuada do educador" não é novo, mas permanece alvo de interesse de profissionais e estudiosos preocupados em avaliar e debater, mais amplamente, as oscilações sofridas na condução de programas geridos pelas políticas públicas, que têm se mostrado pouco capazes de criar estruturas autônomas, que forneçam às instituições recursos para buscar, com mais clareza, os propósitos essenciais de uma escola crítica que forme pessoas com independência para pensar e agir.

Uma revisão do tema revela que, no Brasil, os estudos sobre formação continuada do professor já eram, na década de 60, apresentados com a denominação “educação permanente”, com o objetivo de aperfeiçoar a formação profissional para que o ensino atingisse os ideais que levariam à transformação da sociedade (Cf. LIMA, 2001). De certa forma, essas idéias vieram influenciar as produções acadêmicas futuras, que se propagaram em diferentes direções. Os estudos específicos de formação continuada voltaram-se, em sua grande maioria, para a análise de propostas governamentais de experiências bem variadas, apresentando, segundo André (2002), importantes contribuições.

A importância do assunto, entretanto, não conseguiu propagar essas experiências para as realidades locais, havendo, com muita freqüência, a transposição das responsabilidades organizativas para agências formadoras contratadas sem qualquer familiaridade com o cenário da escola pública.

Tais agências submetem as escolas a modelos de Formação Docente estruturados de forma genérica, revelando total desconhecimento de seu público e das reais necessidades do contexto educativo, suscitando questionamentos, principalmente quando o assunto relacionase à complexa problemática envolvida no fracasso e exclusão dos alunos. 
Paulo Freire (1979) considera necessário contextualizar a realidade educacional para compreendê-la, voltar-se para suas raízes espaço-temporais, para sua herança e influências socioculturais, enfim, considerá-la como fruto das interações e trocas intersubjetivas, necessárias para criar condições capazes de responder aos constantes desafios do mundo, às incertezas do professor e à transitoriedade das situações.

O que é relevante em uma proposta de formação continuada para que o professor atenda efetivamente ao projeto pedagógico e revele domínio na superação das dificuldades ao longo de sua prática?

Responder a essa pergunta exige dos profissionais envolvidos em uma proposta de formação docente continuada a sistematização e análise de dados sobre os recursos cognitivos e afetivos referentes às situações complexas das relações e comunicação entre diferentes sujeitos que vivenciaram tal proposta.

Nessa perspectiva, a mola propulsora na definição da problemática desta dissertação constituiu-se em buscar respostas a essas inquietações e aprofundar conhecimentos sobre a formação continuada do professor. Para isso, é apresentada e analisada uma proposta de formação continuada ocorrida em um município do Estado de São Paulo.

Buscando explicitar a proposta, são apresentados os antecedentes de seu surgimento, ocupando espaço de destaque as peculiaridades e complexidades das múltiplas relações que compuseram a construção coletiva dessa proposta formativa em estudo.

Quanto à estrutura do trabalho, a fundamentação teórica é apresentada no capítulo I, sendo composta por três pilares: o primeiro refere-se às contribuições da psicologia históricocultural de Vygotsky (1989, 1996, 2003), em que são discutidas as relações com os programas de formação continuada do professor, na perspectiva de refletir as situações fecundas e determinantes do processo educativo para constituição do funcionamento psicológico dos sujeitos, num curso de interações e mediações socioculturais, que recuperam a importância da ação pedagógica e do ensino. Tais idéias assinalam a importância da aprendizagem para o desenvolvimento e as implicações significativas da atuação e intervenção, partilhando e promovendo transformações indispensáveis para que o sujeito se aproprie de seu contexto cultural. 
O segundo pilar contempla os fundamentos teóricos sobre formação continuada do professor, envolvendo as concepções desenvolvidas por Pimenta (2005), Nóvoa (1995), Contreras (2002) e outros. Destaca-se, nessas abordagens, a importância do educador como profissional reflexivo, valorizando a ação docente na definição de posições transformadoras que contribuam para fortalecer sua identidade e a tomada de decisões como sujeito de sua formação.

Integrando-se a essas concepções, o terceiro foco presente no estudo são as contribuições específicas sobre a Interdisciplinaridade como fator teórico-metodológico, da construção do conhecimento, que se consolida na complementação com outros conhecimentos e por diferentes óticas. Envolve a concepção de que a formação continuada do professor requer uma perspectiva dialógica, interativa, rompendo com a tradicional visão fragmentada das áreas de conhecimento, fundamentando-se na interpretação de diferentes campos teóricos.

Esses referenciais teóricos fornecem explanações para que se compreendam os elos entre a formação do professor e os processos de aprendizagem dos alunos, no que diz respeito às condições engendradas pelas práticas, intencionalmente planejadas, no contexto da diversidade. Constituem posições teóricas que fazem “eco uma às outras”1 e que, em uma relação dialética entre ensino e aprendizagem, despertam para os sentidos e significados que envolvem o educador na complexa tarefa educativa.

O capítulo II refere-se à configuração do cenário em que foram construídas as relações formativas referentes à proposta em estudo, centrada numa dinâmica de múltiplas relações que compuseram a construção coletiva do projeto pedagógico daquela realidade escolar, envolvendo educadores da Educação Especial.

No capítulo III, encontra-se delineada a metodologia do estudo, de natureza qualitativa, uma vez que possibilita uma análise mais aprofundada do contexto investigado, envolvendo situações do cotidiano das escolas e todas as etapas da investigação: coleta e organização dos dados, tratamento, análise e discussão de dados.

\footnotetext{
${ }^{1}$ A expressão é utilizada por Bernard Charlot em Os jovens e o saber, Editora Artmed, 2001, referindo-se às contribuições de diferentes abordagens teóricas na compreensão da problemática da relação do sujeito com o saber.
} 
No quarto capítulo, abordamos como último tópico as considerações finais desta investigação.

Tal estruturação ocorreu tendo como diretriz os seguintes objetivos:

\section{Geral:}

Analisar o que permaneceu de uma proposta de formação continuada de professores de Educação Especial.

\section{Específicos:}

1. Analisar se houve transformações nas concepções dos educadores sobre a forma como o aluno constrói seu conhecimento e sobre o processo de ensinoaprendizagem, e se tais transformações ofereceram melhores condições para a compreensão da deficiência;

2. Verificar se houve transformações em sua prática pedagógica e se a proposta trouxe mais segurança para atender às demandas do cotidiano;

3. Levantar quais significados essa experiência proporcionou aos educadores que dela participaram e se ela contribuiu para transformar a visão deles sobre seu papel profissional e de seu próprio desenvolvimento como autores desse processo. 


\section{Capítulo I}

\section{FUNDAMENTAÇÃO TEÓRICA}

“[...] parte-se da análise das práticas dos professores quando enfrentam problemas complexos da vida escolar, para a compreensão do modo como utilizam o conhecimento científico, como resolvem situações incertas e desconhecidas, como elaboram e modificam rotinas, como experimentam hipóteses de trabalho, como utilizam técnicas e instrumentos conhecidos e como recriam estratégias e inventam procedimentos e recursos.”

Pérez Gómez

Este capítulo diz respeito ao referencial teórico de análise da experiência educacional, tema desta dissertação. Os dois subitens deste capítulo - psicologia histórico-cultural e formação continuada -, expostos a seguir, foram retomados do eixo teórico da proposta interdisciplinar que alicerçou as atividades dessa experiência educacional, no espaço escola. Das conceituações básicas de cada um desses itens, foram levantadas as categorias para análise do material coletado com as participantes desta pesquisa: professoras que passaram pela experiência de formação no contexto da diversidade.

A matriz teórica para análise do material coletado resgatou conceituações básicas de cada um desses dois itens, nos quais estão implícitas concepções de homem, escola, aprendizagem e desenvolvimento, concepções estas consideradas fundamentais, que dizem respeito à formação docente no contexto da educação para as pessoas com deficiência.

Desse conjunto de dados, serão levantadas categorias para análise do material, enredando cada percepção, palavra, sentimento e significado expresso, projeto criado, desafio suplantado e, até mesmo, intenções, desejos não concretizados, mesclando conquistas e frustrações registradas na memória e na experiência concreta desses atores. 


\subsection{Contribuições da psicologia histórico-cultural ${ }^{2}$}

Inspirada nas idéias de Vygotsky, a experiência de formação enredou suas tramas na busca da compreensão da complexa realidade enfrentada pelos educadores na escola, num cenário sociocultural singular e repleto de contradições. Nesse sentido, voltou-se para as interações ali estabelecidas, exigindo uma reflexão ampla e profunda das idéias, valores, crenças, concepções, modos de agir e pensar, interesses sociais, políticos, uma série de fatores e condições próprias aos contextos, grupos e sujeitos.

A psicologia histórico-cultural chama a atenção para as experiências vividas pelos indivíduos ao longo de suas vidas, marcadas pelos fatores fundamentais da cultura, acumulados historicamente, pautando as condições que produzem e propiciam a elaboração de conhecimentos. Esse postulado vygotskyano para a Educação é particularmente importante, por envolver a compreensão do psiquismo humano e dos processos de desenvolvimento relativos à forma singular e subjetiva que configura a história dos sujeitos e a forma como estes reagem às experiências e aos determinantes sociais. Vygotsky, nesse sentido, deixa clara a inter-relação dinâmica entre aprendizado e desenvolvimento e como os processos de desenvolvimento podem ser estimulados pela aprendizagem escolar, sem desconsiderar a “rede interna e subterrânea”3 que constitui o psiquismo humano, essencial na compreensão da heterogeneidade e singularidade entre grupos e entre indivíduos. Essa ligação com a cultura não os impede, no entanto, de interagirem ativamente fazendo a sua releitura da realidade vivida, como analisa Oliveira:

Ao postular a cultura como constitutiva do psiquismo, por outro lado, essa abordagem não a toma como uma força que se impõe a um sujeito passivo, moldando-o com padrões preestabelecidos. Ao contrário, a ação individual, com base na singularidade dos processos de desenvolvimento de cada sujeito

\footnotetext{
${ }^{2}$ Um dos representantes mais importantes da teoria histórico-cultural, sem dúvida, é Lev Seminovich Vygotsky (1896-1937). Por ter vivido em uma época em que a União Soviética estava envolta em grandes transformações sociais, pós-revolução russa, Vygotsky dirigiu sua atenção para delinear um trabalho crítico às ciências daquela época. Naquele contexto, buscou aproximar-se da psicologia, desenvolvendo um trabalho de formação de professores de crianças com deficiência, impulsionando seus estudos sobre o desenvolvimento do pensamento humano em suas dimensões filogenética, ontogenética, sociogenética e microgenética. Influenciado pelos postulados do método dialético, aprofundou seus estudos sobre as transformações que ocorrem ao longo da vida do homem como ser cultural e histórico.

${ }^{3}$ Vygotsky (1989) postula que devem ser fornecidos ao professor dados que esclareçam como os processos de aprendizagem podem estimular o desenvolvimento. Para tanto, é necessário revelar essa "rede interna e subterrânea” do desenvolvimento nos escolares.
} 
consiste em constante recriação da cultura e negociação interpessoal. Se assim não fosse, teríamos cultura sem história e geração de sujeitos idênticos em cada grupo cultural (OLIVEIRA, 2003, p. 56-57).

No que se refere à formação docente, período contínuo vivenciado pelos educadores no desenvolvimento de conhecimentos que possam aprimorar suas habilidades diante das demandas do dia-a-dia, esses postulados vygotskyanos oferecem fundamentos essenciais para a compreensão da multiplicidade de questões que devem ser pensadas sobre o percurso do educador, principalmente na condição de agente transformador de seu processo formativo. $\mathrm{O}$ modo como o professor participa desse processo, incorporando em sua bagagem diferentes maneiras de atuação e significados sobre a educação, pode constituir-se em fator importante para a criação de outros discursos sobre a natureza plural do aluno e sobre a própria condição de seu papel, ao transgredir esquemas de aprendizagem pré-estabelecidos e oferecer novas possibilidades ao ensino. Conforme argumenta Oliveira (1997, p. 56):

\begin{abstract}
A imensa multiplicidade de conquistas psicológicas que ocorrem ao longo da vida de cada indivíduo gera uma complexa configuração de processos de desenvolvimento que será absolutamente singular para cada sujeito. [...] em cada situação de interação com o mundo externo, o indivíduo encontra-se em um determinado momento de sua trajetória particular, trazendo consigo certas possibilidades de interpretação e re-significação do material que obtém dessa fonte externa.
\end{abstract}

Nesse aspecto, as propostas formativas podem apresentar ao professor oportunidades enriquecedoras para que ele transcenda as situações concretas da sala de aula. Nos processos de interação, refletindo a prática, o professor faz uso de habilidades cognitivas (mecanismos metacognitivos) lançando mão do pensamento verbal e desenvolvendo, assim, maneiras mais elaboradas de compreender as situações, organizar um planejamento intencional e tomar decisões mais conscientes e seguras.

Essas condições formativas associadas à singularidade com que cada sujeito interpreta e direciona seu projeto de vida profissional confirmam a multiplicidade de caminhos percorridos pelos educadores e a forma peculiar com que reelaboram suas experiências e dão destinos muito particulares aos acontecimentos vivenciados. Inseridos em seu contexto de trabalho, esses educadores, segundo Oliveira (1997), trazem para as situações vivenciadas 
uma bagagem de conhecimentos, informações e valores, adquiridos mediante experiências e relações interpessoais, delineando o desenvolvimento de práticas com uma peculiar capacidade de refletir seus próprios processos de aprendizagem.

Ao defender uma abordagem teórica pautada na valorização e nas transformações do sujeito, Vygotsky e Luria (1996), ao longo de sua vida, esclarece as implicações psicológicas de um ser participante de sua própria existência e contribui para a compreensão e discussão, no campo do desenvolvimento humano, transcendendo às possibilidades universais da espécie e às determinações unicamente maturacionais, de caráter biológico, para discutir o domínio da herança cultural. O caráter social e histórico das concepções do autor busca explicar o funcionamento das funções psicológicas superiores do homem, advindo de processos sociais e históricos moldados por instrumentos e recursos culturais e por diferentes formas de mediação. O aluno, subjetivamente constituído por meio de uma transformação históricocultural singular - fruto da interação de processos biológicos, mentais, cognitivos e afetivos -, possui uma organização psíquica complexa, que não pode ser reduzida a fatores básicos, exigindo do educador uma forma diferenciada de planejar suas mediações.

Frente a essa concepção, não é qualquer projeto pedagógico que pode criar condições e garantias para que essa transformação ocorra. Nesse sentido, as posições de Vygotsky (1983, 2003) apontam para a importância de um ensino que incida no avanço das capacidades do sujeito, ativando-o e potencializando-o para a aquisição de funções mais elaboradas.

Ainda que se reconheça a importância da matriz biológica, esse sujeito subjetivo, histórico, ao ser imerso na cultura, herda formas específicas de um funcionamento psicológico que vai se diferenciando e se manifestando em mudanças qualitativas em seu comportamento. Para Vygotsky, a criança atravessa diferentes estágios de desenvolvimento caracterizados de diferentes maneiras, em função da forma como ela se relaciona com o mundo. A esse respeito, o autor argumenta:

No processo de seu desenvolvimento, a criança não só cresce, não só amadurece, mas, ao mesmo tempo - e isso é a coisa mais fundamental que se pode observar em nossa análise da evolução da mente infantil - a criança adquire inúmeras novas habilidades, inúmeras novas formas de comportamento. No processo de desenvolvimento, a criança não só amadurece, mas também se torna reequipada. É exatamente esse 
"reequipamento" que causa o maior desenvolvimento e mudança que observamos na criança à medida que se transforma num adulto cultural (VYGOTSKY e LURIA, 1996, p. 177).

Esse processo de transformação, definido por Vygotsky como um funcionamento psicológico tipicamente humano, transpõe os processos elementares relacionados essencialmente às funções biológicas (sensações e reflexos orgânicos restritos ao corpo) para processos mais sofisticados, adquirindo habilidades cognitivas e formas de pensamento (abstração, categorização do pensamento, pensamento lógico, consciência, intenção, planejamento, ações voluntárias e deliberadas, conhecimento metalingüístico) capazes de estabelecerem relações complexas, intervindo e transformando o ambiente.

Segundo Vygotsky (2003), formas adultas culturais de comportamento substituem, gradualmente, formas primitivas da infância; desenvolvem-se novas habilidades, novas formas de pensamento lógico e atitudes em relação ao mundo. Para Vygotsky e Luria (1996, p. 177): "É natural, pois, que a ciência deva indagar a respeito dos modos pelos quais a mente primitiva da criança se transforma, passo a passo, na mente de um homem adulto cultural”.

Esses aspectos dizem respeito ao modo como são construídos os processos educativos e as intervenções planejadas, condições consideradas por Vygotsky essenciais ao desenvolvimento de um pensamento mais complexo e ações deliberadas. Salienta-se a importância dos processos intersubjetivos, bem como os sentidos e significados que permeiam tais processos, dando rumos específicos à aprendizagem dos alunos. O modo como são mediadas as relações e acontecimentos no interior da sala de aula irá propiciar diferenciadas formas de participação dos alunos e da produção de valores, compondo novas possibilidades que contribuirão para a constituição de sua subjetividade. 
As transformações e esse refinamento do processo psicológico que definem intenções próprias, diante das experiências singulares, contribuem para delinear uma trajetória particular na história do sujeito, composição e interação de diferentes planos genéticos ${ }^{4}$, os quais Vygotsky procurou descrever para explicitar com mais clareza o percurso do homem cultural no caminho da evolução psicológica. Embora existam situações comuns desse patrimônio das pertinências culturais - valores, conhecimentos, um complexo sistema simbólico de representação, formas de agir e pensar -, o funcionamento psicológico não se configura de forma linear, previsível, pois a interpretação que cada sujeito realiza desse mapa ontogenético é irreproduzível, diversa, singular e indeterminada.

Na vida de cada sujeito, destaca-se uma correlação de forças e significados de diferentes contextos socioculturais, dentre os quais escola, comunidade e família compõem o cenário de influências de demandas e, até mesmo, de pressões. Nesse âmbito, reafirma-se o papel da Educação e da Educação Especial como importantes recursos de mediação e definição de mecanismos institucionais para o desenvolvimento e aprendizagem.

A instituição escola afigura-se como uma ilustração de que “[...] para explicar as formas mais elevadas do comportamento humano, precisamos revelar os meios pelos quais o homem aprende a organizar e a dirigir o seu comportamento” (Vygotsky, 1989, p. 48). As relações, nessa instituição, expressam a forma como os indivíduos elaboram seus significados: nas relações sociais, convivem com um mundo de informações e experiências impregnadas de significações, que interferem nas ações e começam a dar contorno à vida das pessoas, de diferentes formas e intensidades. Diante dessa riqueza de estímulos e dados, o ser humano reage, resiste, influencia-se, responde, ativa seus próprios recursos internos e, dinamicamente, na dialética e confronto das relações, reelabora e incorpora como seu o produto das práticas sociais de múltiplos atores, as quais vão acompanhando e tonalizando suas atividades e a forma como vê o mundo e a si próprio. Assim, o sentido atribuído aos objetos e aos fenômenos envolvidos nas interações carrega aspectos ideológicos, imprime

\footnotetext{
${ }^{4}$ A posição de Vygotsky, conforme afirma Oliveira (1995), é essencialmente genética e, nessa perspectiva, procura compreender a gênese, ou seja, a origem e o desenvolvimento dos processos psicológicos explicitados mediante a correlação de diferentes níveis evolutivos: o filogenético (desenvolvimento da espécie humana), sociogenético (história dos grupos sociais), ontogenético (desenvolvimento do indivíduo) e microgenético (desenvolvimento dos processos psicológicos específicos a cada sujeito). Esse último, segundo a autora (IBID, 2003), não foi nomeado propriamente por Vygotsky - apesar de estarem claramente expressos em sua obra, de forma mais esparsa -, mas por James Wertsch.
} 
valores, interfere, dirige e seleciona os olhares sobre a realidade, funcionando como instrumento de organização das ações dos indivíduos.

O autor alerta para o modo como os sujeitos constroem sentidos e significados e os compartilham culturalmente, interferindo na maneira como interpretam o mundo. Os significados construídos pelos educadores e partilhados pela escola manifestam-se nas atitudes e relações com os alunos, diante das diferenças e condições que eles possuem, reafirmando estigmas ou considerando esse dado como fator relevante para a definição de condutas pedagógicas específicas.

Na perspectiva da educação para a criança com deficiência, esse aspecto tem particular importância para Vygotsky (1983), que assinala que as leis que regulam o desenvolvimento infantil são as mesmas para a criança com deficiência, sendo apenas seu desenvolvimento que se dá de outro modo, devido à estrutura específica de seu organismo e personalidade: “a especificidade da estrutura orgânica e psicológica, o tipo de desenvolvimento e de personalidade, e não as proporções quantitativas, distinguem a criança com deficiência da normal” (IBID, 1983, p. 12).

Para o autor, as teorias e práticas educativas não conseguem adquirir resultados se forem construídas tendo como base princípios e definições negativos. Nesse aspecto, Vygotsky considera que o processo de desenvolvimento da criança com deficiência fica duplamente aprisionado aos determinantes sociais: por um lado, imprimindo no indivíduo um sentimento de inferioridade, reflexo de uma representação social da deficiência marcada por traços de um desenvolvimento deficitário; por outro, proporcionando uma orientação compensatória adaptada unicamente às condições do meio, criada para um tipo de homem normal. O autor ressalta que os limites da criança são definidos muito mais pelas condições sóciopsicológicas que pela deficiência em si; o contexto social em que a criança vive constrói uma estrutura de relações que pode facilitar ou limitar a construção de alternativas de desenvolvimento. 
Tendo como foco as transformações da criança com deficiência, a defectologia ${ }^{5}$ fortalecia a idéia de que: "todo defeito cria estímulos para elaborar uma compensação e os estudos da criança com deficiência não deve se limitar a determinar o nível da gravidade da insuficiência, mas considerar obrigatoriamente os processos compensatórios que conseguem de diferentes modos e com outros meios construir um caminho distinto, que considere as peculiaridades de cada criança” (VYGOTSKY, 1983, p. 17).

As preocupações marcantes do autor sobre a dimensão biológica do funcionamento psicológico revelam um funcionamento cerebral flexível, capaz de se adaptar a diferentes funções devido às interações mantidas com o meio, fonte inesgotável de conhecimentos. Define, assim, em seus postulados, que é mediante as atividades práticas e interações estabelecidas pelo sujeito, ao longo de sua vida, que as funções psíquicas se desenvolvem. Os postulados de Vygotsky (1983, 1988, 2003) sobre a construção do conhecimento vinculada às práticas sociais colocam em evidência a importância do aprendizado e do sistema de mediação, orientados por um planejamento deliberado.

A teoria formulada por Vygotsky procura analisar a função mediadora presente nas práticas escolares. Os educadores elaboram seus conhecimentos, idéias, percepções e hipóteses sobre os alunos baseados em suas experiências de vida pessoal e profissional, subsidiando-os nas situações educativas. São situações “carregadas de conceitos, relações e práticas sociais” (OLIVEIRA, 2003, p. 28), que permeiam o processo de construção cultural da significação e é responsável pelo modo como os indivíduos representam o mundo. "Enquanto sujeito do conhecimento, o homem não tem acesso direto aos objetos, mas um acesso mediado, isto é, feito através dos recortes do real operados pelos sistemas simbólicos de que dispõe” (IBID, 1992, p. 26).

Para Vygotsky e Luria (1996), o ser humano está imerso num mundo de mediações socioculturais altamente simbólicas, permeadas por instrumentos e signos. Palavras, idéias e imagens vão fornecendo significados e, de certa forma, “direcionam” o sujeito para uma percepção específica sobre os objetos e situações. Essas formas de mediação, criadas pelo homem ao longo de sua história como produtos culturais, vão induzindo sua atividade

\footnotetext{
${ }^{5}$ Segundo Vygotsky (1983), a defectologia caracterizava-se como uma pedagogia que enfatizava as influências culturais mais do que as orgânicas no desenvolvimento das pessoas com deficiência, marcando o caráter social da Educação.
} 
psicológica, ao internalizar e estabelecer conceitos, que o autor descreve como um fenômeno de influências “de fora para dentro":

Passando de fora para dentro, a fala constituiu a função psicológica mais importante, representando o mundo externo dentro de nós, estimulando o pensamento e também, como acreditam vários autores, lançando os alicerces para o desenvolvimento da consciência (VYGOTSKY e LURIA, 1996, p. 213).

Do ponto de vista da construção dos processos psicológicos, Vygotsky destaca o processo de internalização como fundamental à discussão sobre a aprendizagem e apropriação de conhecimentos, conceituado como a reconstrução interna de uma operação externa, envolvendo uma série de transformações:

a) Uma operação que inicialmente representa uma atividade externa é reconstruída e começa a ocorrer internamente. [...] b) Um processo interpessoal é transformado num processo intrapessoal. Todas as funções no desenvolvimento da criança aparecem duas vezes: primeiro, no nível social, e, depois, no nível individual; primeiro, entre pessoas (interpsicológica), e, depois, no interior da criança (intrapsicológica). [...] c) A transformação de um processo interpessoal num processo intrapessoal é o resultado de uma longa série de eventos ocorridos ao longo do desenvolvimento (IBID, 2003, p. 75).

A partir desses pressupostos, fica expressa a dimensão do papel do outro, dispositivo central para o desenvolvimento da mente da criança, impulsionando-a a aprender, destacando-se, assim, as correlações marcantes entre ensino, aprendizagem e desenvolvimento.

Não é necessário sublinhar que a característica essencial da aprendizagem é que engendra a área de desenvolvimento potencial, ou seja, que faz nascer, estimula e ativa na criança um grupo de processos internos de desenvolvimento no âmbito das inter-relações com outros, que, na continuação são absorvidos pelo curso interior de desenvolvimento e se convertem em aquisições internas da criança.

Considerada deste ponto de vista, a aprendizagem não é, em si mesma, desenvolvimento, mas uma correta organização da aprendizagem da criança, que conduz ao desenvolvimento mental, ativa todo um grupo de processos de desenvolvimento, e esta ativação não poderia produzir-se sem a 
aprendizagem. Por isso, a aprendizagem é um momento intrinsecamente necessário e universal para que se desenvolvam na criança estas características humanas não naturais, mas formadas historicamente (VYGOTSKY, 1988, p. 115).

Segundo Oliveira (1995), essa concepção de ensino-aprendizagem focaliza a idéia de processo que engendra a relação entre quem ensina e quem aprende, um "outro” social, que se manifesta por intermédio de diferenciadas situações, materializadas por intermédio de processos deliberados para essa tarefa, utilizando-se de artefatos culturais e, principalmente, da linguagem, elemento essencial para a aprendizagem.

[...] quando a aprendizagem é, sim, um resultado desejável de um processo deliberado, explícito, intencional, a intervenção pedagógica é um mecanismo privilegiado. E a escola é o lugar, por excelência, onde o processo intencional de ensino-aprendizagem ocorre (IBID, 1995, p. 57).

Por meio das relações que são estabelecidas com o outro, é que o sujeito se conscientiza do espaço ocupado por ele, de suas condições e saberes e dos novos passos a serem conquistados.

Esses pressupostos evidenciam a relevância das interações sociais e das oportunidades em que são discutidas e partilhadas idéias; das possibilidades de o educador, na interação com o outro (regulação interpsicológica), e por meio de um processo de regulação externa, refletir sobre a prática, vir a reelaborar concepções, internalizar novas idéias, novos modos de conceituar a realidade e a redirecionar a atuação (regulação intrapsicológica).

A possibilidade de compartilhar situações evidencia a relação intrínseca existente entre o contexto sociocultural e o funcionamento psicológico do sujeito, de forma que "uma operação que inicialmente representa uma atividade externa é reconstruída e começa a ocorrer internamente” (VYGOTSKY, 2003, p. 75). Reflexões sobre os problemas da prática pedagógica e da aprendizagem dos alunos suscitam o estabelecimento de idéias em um prisma transformador, prospectivo, ao se planejarem condições favoráveis para o desenvolvimento do aluno. 
Esses aspectos dizem respeito diretamente à relação entre desenvolvimento e aprendizagem, analisada pelo autor por meio da formulação do conceito de zona de desenvolvimento proximal, envolvendo dois níveis de desenvolvimento: o nível de desenvolvimento real e o nível de desenvolvimento potencial.

Vygotsky entendia como nível de desenvolvimento real ou efetivo "o nível de desenvolvimento das funções mentais da criança que se estabeleceram como resultado de certos ciclos de desenvolvimento já completados” (VYGOTSKY, 2003, p. 111). Já o nível de desenvolvimento potencial refere-se àquilo que a criança é capaz de realizar, só que mediante a ajuda de outra pessoa. A distância entre ambos, ou seja, entre o que a criança é capaz de realizar de forma autônoma e o que ela realiza com a ajuda do outro, o autor denomina zona de desenvolvimento proximal.

Nesse sentido, são valorizados os possíveis avanços que, segundo Vygotsky, ainda não amadureceram - uma zona de desenvolvimento proximal desencadeadora de novas competências, mediante ajuda explícita do outro mais capaz, que proporciona novos dados à condição atual de desenvolvimento. Vygotsky (2003, p. 113) afirma que:

[...] a zona de desenvolvimento proximal define aquelas funções que ainda não amadureceram, mas que estão presentemente em estado embrionário. Essas funções poderiam ser chamadas de "brotos" ou "flores" do desenvolvimento, ao invés de "frutos" do desenvolvimento. O nível de desenvolvimento real caracteriza o desenvolvimento mental retrospectivamente, enquanto a zona de desenvolvimento proximal caracteriza o desenvolvimento mental prospectivamente.

Para Vygotsky, a aprendizagem, ao ser orientada para níveis de desenvolvimento que já foram alcançados, não é eficaz, pois não investe em um novo estágio do processo de desenvolvimento, pelo contrário, vai a reboque desse processo. Para o autor (IBID, 2003, p. 117), “o bom aprendizado é aquele que se adianta ao desenvolvimento”.

Do mesmo modo, segundo postulados de Vygotsky, o educador, ao compartilhar coletivamente seu trabalho numa dinâmica de interlocução das situações pedagógicas, em um processo dialético com seus pares, pode constituir uma práxis voluntária e conscientemente 
orientada, pressupondo a internalização de conhecimentos que, até então, ainda não dominava.

Nessa ótica, a linguagem torna-se dispositivo essencial da espécie humana no desenvolvimento da comunicação e interação social, servindo como sistema de mediação semiótica, conceito central na obra de Vygotsky. No campo do conhecimento, representa também a possibilidade de o indivíduo: a) transcender as fronteiras da experiência sensível, transitando das situações concretas de sua experiência pessoal para o mundo essencialmente teórico, referindo-se aos objetos, mesmo na ausência destes; b) penetrar na essência das relações; c) desenvolver um processo de abstração e generalização de conhecimentos, por meio da organização de idéias e reflexão sobre a realidade, questionando-a e estabelecendo hipóteses. A partir disso, o indivíduo estaria instrumentalizado a buscar novas soluções.

Dessa forma, segundo a teoria histórico-cultural, a palavra outorga ao homem a possibilidade de ele interagir com o mundo por meio de signos mediadores que o auxiliarão nas atividades psíquicas, de forma semelhante à utilização de instrumentos nas ações concretas (VYGOTSKY, 2003, p. 70). Entretanto, o autor enfatiza que há diferenças entre instrumentos e signos, na medida em que o papel do instrumento na mediação de ações concretas é interferir no objeto e transformá-lo, orientado por uma atividade externa. Por outro lado, o signo permeia uma atividade interna com o objetivo de controlar o próprio indivíduo, ou seja, sua atividade psíquica e, nesse sentido, segundo Vygotsky, promover a ampliação de inúmeras formas de operações psicológicas. Em seus postulados, fica expressa a importância de como os signos auxiliam o homem a controlar voluntariamente sua atividade psicológica, contribuindo com a atenção, memória, retenção de dados, nomeação e conceituação dos objetos do mundo exterior. Em contato com as informações que recebe no dia-a-dia, o homem interpreta-as e estabelece relações, integrando-as ao seu sistema conceitual.

As considerações do autor revelam que, ao se apropriar de instrumentos culturais (físicos ou simbólicos) construídos pela humanidade, o homem vai gradativamente se diferenciando e se sobrepondo às heranças da espécie, contribuindo para a evolução sociocultural, refutando a idéia de desenvolvimento como sistema organicamente pré-determinado.

Instrumentalizado de diferentes meios, esse homem cultural aperfeiçoa suas possibilidades de criar, intervir e transformar a realidade, por meio dos recursos (conceituais) internalizados que 
lhe fornecem um olhar mais específico sobre os fatos, um saber mais aprofundado, ampliando a compreensão da realidade.

\begin{abstract}
Enriquecendo o vocabulário, a fala que foi apreendida, e por meio da qual se construíram conceitos, também alterou o pensamento da criança; deu-lhe maior liberdade; permitindo-lhe operar com uma série de conceitos que anteriormente eram inacessíveis. A fala tornou possível o maior desenvolvimento de uma nova lógica que, até então, só existia na criança em estágios iniciais (VYGOTSKY, 2003, p. 213).
\end{abstract}

Nessa direção, de acordo com os postulados de Vygotsky, a linguagem como um sistema de mediação permite aos educadores, envolvidos em um processo dialógico, tomarem posse de idéias, conceitos e informações, reconstruírem e recriarem, na interação com os demais educadores, um universo de significações que interpretem a realidade.

A interação e a comunicação interpessoal tornam-se, assim, mobilizadoras de processos sociais reguladores das atividades, sendo um aspecto, segundo Vygotsky, "necessário e universal do processo de desenvolvimento das funções psicológicas culturalmente organizadas e especificamente humanas” (IBID, 2003, p. 118). Portanto, na visão do autor, os sujeitos podem compreender os fenômenos e estabelecer relações pertinentes entre os diferentes momentos envolvidos nas situações vivenciadas, mediante a interlocução entre seus pares. Assim, podemos entender como a linguagem permite aos educadores, ao problematizarem suas práticas nas situações formativas e ao planejarem intervenções pertinentes para o redirecionamento do ensino, desenvolverem formas sistemáticas de constituição e reorganização dos processos cognitivos. Segundo Vygotsky, a gênese desse processo, especificamente humano, pode ser observada, de forma rudimentar, assim que a criança desenvolve a fala. Para o autor:

Antes de controlar o próprio comportamento, a criança começa a controlar o ambiente com ajuda da fala. Isso produz novas relações com o ambiente, além de uma nova organização do próprio comportamento. A criação dessas formas caracteristicamente humanas de comportamento produz, mais tarde, o intelecto, e constitui a base do trabalho produtivo: a forma tipicamente humana do uso de instrumentos (IBID, 2003, p. 33). 
A linguagem compreendida como importante instrumento mediador do pensamento amplia as condições para o desenvolvimento do exercício reflexivo e para a organização das ações, assumindo uma função superior de caráter psicológico, ao regular as relações comunicativas, ao mesmo tempo em que retroalimenta o pensamento. Mediado pela linguagem, o homem, nas interações sociais, reconstrói internamente a realidade, apropriando-se de conhecimentos que, sozinho, não obteria. Nessa perspectiva, Vygotsky (1989, p. 104) acrescenta:

O significado das palavras é um fenômeno de pensamento, apenas na medida em que o pensamento ganha corpo por meio da fala, e só é um fenômeno da fala na medida em que esta é ligada ao pensamento, sendo iluminada por ele.

Essas discussões teóricas, reveladoras do papel da intervenção pedagógica, apontam para a necessidade de uma releitura do significado atribuído aos projetos formativos, para que esses habilitem o professor a tomar decisões, refletir sobre sua prática e reconstruir novas abordagens de ensino; que tenham como base a singularidade dos indivíduos e a idéia de transformação dos sujeitos, diante de um processo educativo dinâmico, plural e mutável.

Diante dos impasses educativos, como afirma Japiassu (1976), é importante ressaltar as condições motivacionais que mobilizam o educador a avaliar seus próprios limites e considerar, de forma crítica e responsável, a necessidade de complementação, para consolidar uma atuação pedagógica que invista no avanço dos alunos. Spinelli (2002) contribui para tornar mais clara a idéia, quando afirma que a visão multidisciplinar, na qual os diferentes profissionais se detêm exclusivamente às suas atividades, não oferece condições para o domínio da complexidade das situações; o modelo interdisciplinar possibilita ir além delas, obrigando o profissional a:

[...] entender o mais possível o olhar dos outros; reconhecer que, no campo do humano, órgãos, funções, habilidades, sentimentos, desejos, fantasias, inibições enredam-se; que o material dessa rede é a linguagem; que a qualidade da rede (quanto menos nós ela tenha) é muito mais fundamental ao futuro do sujeito do que cada uma das suas partes; que cada profissional conhecer o campo dos outros e os limites do seu saber organiza as idéias e as ações do conjunto, põe a linguagem da equipe "nos eixos”, dá um rumo harmônico às ações de cada um (SPINELLI, 2002, p. 209). 
Quanto à Interdisciplinaridade, evidencia-se nas idéias de Japiassu e Spinelli o ponto de articulação pautado no diálogo, que possibilita o confronto de saberes, por meio do exercício dialético, aproximando as partes do todo. Nessa perspectiva, a busca pela complementação e revisão de pressupostos antagônicos consiste no "esforço por aproximar, comparar, relacionar e integrar os conhecimentos” (JAPIASSU, 1976, p. 52). Essa ênfase estabelece elos entre os saberes, para que seja desencadeado um processo de reorganização de práticas e recursos, indispensáveis à superação dos problemas complexos apresentados ao professor, um movimento flexível de se voltar um para o outro e desnudar-se de preconceitos que fragmentam o ser humano (FAZENDA, 2002a).

Partindo-se desses fundamentos, a transformação da prática só é conquistada quando o educador coloca em dúvida cada passo já percorrido, numa atitude de busca pela complementação e reconhecimento dos limites do próprio saber diante da complexidade dos fenômenos envolvidos no trabalho pedagógico.

Vygotsky formulou suas concepções admitindo que, para explicar essa forma tipicamente humana de comunicação, era imprescindível buscar as origens desse processo consciente do comportamento nas condições externas da vida social e como essas condições refletem no mundo interno, na elaboração de formas específicas de reagir e criar "motivos complexos de comportamento", ou seja, as ações produzidas por interferência do pensamento conscientemente orientado. A linguagem constitui-se, assim, “em instrumento decisivo do conhecimento humano” (LURIA, 1987, p. 22), na medida em que formula conceitos e transforma experiências individuais em coletivas, como "meio de comunicação e de contato social” (VYGOTSKY, 2001, p. 130). A partir dessa referência, Vygotsky postula que a "fala começa a servir ao intelecto e os pensamentos começam a ser balizados” (VYGOTSKY, 1989, p. 37) e, nesse sentido, a linguagem traz importantes contribuições para a compreensão dos processos reflexivos de organização do pensamento.

As concepções de Vygotsky enfatizam o valor da experiência e a produção de uma formação pautada na reflexão sobre a prática. O domínio desse saber, na perspectiva vygotskyana, amplia a visão dos objetivos a serem traçados e propicia determinadas condições para desenvolver uma análise mais particularizada dos fenômenos, acompanhando suas transformações e peculiaridades. 
As categorias levantadas dos pressupostos teóricos constituíram o referencial para a análise dos depoimentos das professoras sobre as posições por elas assumidas no atendimento às demandas educativas de alunos com deficiências. Essas categorias constituirão o quadro referencial para analisar: a) se esse processo formativo propiciou transformação nas professoras que passaram pela experiência; b) se essa experiência construída na confluência de diversos saberes constituiu uma aprendizagem continuada de constante reflexão sobre o seu próprio fazer, partilhado coletivamente.

\subsection{Formação continuada: o resgate do cotidiano do professor}

Conforme Fusari e Rios (1995), formação continuada é um “processo de desenvolvimento da competência ${ }^{6}$ dos educadores, compreendidos como todos aqueles que têm como ofício transmitir - criando, criticando e aprimorando - o conhecimento histórico e socialmente construído em uma sociedade” (p. 38). O professor é sujeito e objeto do processo de formação docente, identificando a construção do fazer pedagógico pautado na pesquisa, reflexão e análise crítica da totalidade de condições da realidade educacional.

Nesses pressupostos, a formação continuada se constrói tendo como referência o professor em ação, atuando como protagonista de seu projeto de trabalho, sendo levado a reconhecer diferentes contextos educativos e compreender as contingências de diferentes ordens que o desafiam e que podem ser explicadas na perspectiva de uma ação mediada por seus pares ${ }^{7}$. Para tanto, não se pode prescindir da análise do professor, sujeito e objeto do conhecimento, pois o contexto educativo envolve relações imprevisíveis, situações e conseqüências singulares, tarefa impossível de ser esgotada de forma genérica sem o elo teoria e prática.

\footnotetext{
${ }^{6}$ Segundo os autores, mencionar competência implica duas dimensões: a dimensão técnica e a dimensão política, complementares tanto no plano teórico quanto nas relações cotidianas do professor, sem excluir uma ou outra. A ética talvez atue como dimensão articuladora desses processos, abrindo espaços para a reflexão e o questionamento crítico dos valores que norteiam as ações. O conjunto sistematizado de conhecimentos, estratégias e meios do educador (dimensão técnica) articula-se com suas escolhas e definições movidas pelo compromisso profissional (dimensão política) (FUSARI e RIOS, 1995, p. 40).

${ }^{7}$ Segundo Vygotsky (2003), a construção do conhecimento e a constituição do sujeito não dependem apenas dos processos de maturação orgânica, mas principalmente das interações sociais e trocas estabelecidas com seus semelhantes. Nesse aspecto, a mediação de parceiros (pares) mais experientes fornecendo pistas ou resolvendo um problema em colaboração contribui, segundo a teoria histórico-cultural, para que o indivíduo possa dominar novos conhecimentos.
} 
A valorização dos processos de cooperação epistêmica interdisciplinar, segundo Japiassu (1976), pode proporcionar o enriquecimento de cada organismo, assegurando-lhe interações complementares, orientadas para um fim e movidas por um sentido humano e social, em busca da compreensão das ações e contingências sócio-históricas que afetam e transformam os sujeitos. Destaca-se, nessa perspectiva teórica, a importância da relação de reciprocidade e da interação partilhada, num processo de co-autoria e co-responsabilidade, mais do que justaposição de conteúdos. Exige-se, segundo Pimenta (2005), que se contemplem outros conhecimentos, instrumentalizando o "olhar com outras teorias, estudos, olhares de outros sobre o objeto”.

A tônica desses autores busca discutir, sobretudo, a formação do educador como construção de saberes que se faz na relação com o outro, num movimento de complementação e reconstrução da prática, no exercício coletivo de pensar e refletir sobre a complexidade dos fenômenos que emergem do cotidiano, para a construção de um novo conhecimento. Esse modo de pensar a construção do conhecimento, rompendo com o isolamento das áreas, destaca a possibilidade de os educadores perceberem, confrontarem e planejarem suas práticas, pressupondo um processo de trocas, regulação, organização dos conhecimentos pedagógicos e, conseqüentemente, um domínio maior sobre seu fazer pedagógico. Refletir a própria prática significa transformar seu fazer pedagógico em objeto de investigação constante, um dinâmico movimento partilhado de ação-reflexão-ação.

A participação das diferentes áreas, segundo Japiassu, pressupõe o reconhecimento daquilo que falta a cada uma delas, adotando uma linguagem comum como sustentação do diálogo integrado por vários campos teóricos, proporcionando elos entre conhecimentos teóricos e prática. "Há uma interdependência profunda entre o nível teórico e o das aplicações que dele decorrem” (IBID, 1976, p. 87). Para o autor, é impossível conhecer o ser humano se não houver uma inter-relação dos conhecimentos que cada disciplina domina com os problemas da prática, manifestando-se, assim, uma atitude de superação da dicotomia entre teoria e prática.

Bruner (2001) contribui para o estudo dessa questão ao afirmar que "saber é igual a fazer” (p. 145). Há, em suas concepções, a busca do sentido para o conhecimento indo ao encontro da prática, impulsionando-a à condição de corpo que materializa a cultura. Nesse aspecto, fazer cultura significa "fazer o que as coisas ao seu redor exigem" (IBID, p. 146); concretizar em 
possibilidades a explicação conceitual. Suas idéias ficam mais bem explicitadas quando se refere à epígrafe de autoria de Francis Bacon, utilizada por Vygotsky em seu livro "Pensamento e Linguagem”. Ao traduzi-la, Vygotsky apresenta sua preocupação interdisciplinar, exaltando a intercomunicação do saber e do fazer. Diz a inscrição: “Nem a mão, nem o intelecto, sozinhos, valem muito; as ferramentas ${ }^{8}$ e os auxílios aperfeiçoam (ou complementam) as coisas”.

Bruner exalta a intercomunicação do saber e do fazer e esclarece que não é a "teoria” que instrui a ação, pois a habilidade é uma forma de saber fazer as coisas, não derivando da teoria; esta estaria auxiliando a habilidade, aperfeiçoando a visão sobre as ações e, nesse sentido, compartilhar esses conhecimentos torna mais visível e, de certa forma, mais consistente a prática. Incidir no aspecto complementar desses conceitos, segundo Bruner, destitui o confronto e confere ao saber da experiência um campo de análise e pesquisa. Essas proposições apontadas pelo autor reiteram que a formação continuada dos professores, ao estabelecer como ponto de partida a reflexão sobre a prática, possibilita a ressignificação dos saberes do professor, ao mesmo tempo em que estabelece pontos de chegada, conferindo razão e sentido à prática, ou melhor, consolidando os conhecimentos científicos que fundamentam, orientam e confirmam a finalidade da ação docente como ação transformadora das condições educativas.

O discurso, sozinho, não transforma; o que o faz é a ação impregnada de intenções fertilizadoras da práxis. Segundo Monteiro (2005), Kant também fornece dados que, já naquela época (século XVIII), demonstravam sua preocupação com teorias que respondessem à prática, às demandas da vivência, acreditando que a opção teórica ofereceria rumos e contribuiria com questionamentos elucidativos aos fenômenos estudados.

Nesse quadro conceitual, considera-se que o saber docente decorrente das experiências do cotidiano fornece meios às práticas pedagógicas, delineando caminhos, e as diferentes ciências fornecem instrumentos de compreensão e transformação das condições existentes.

\footnotetext{
${ }^{8}$ Vygotsky descreve "ferramentas” como dispositivos externos de controle dos processos mentais: “a linguagem, vários sistemas de contagem, técnicas mnemônicas, sistemas de símbolos algébricos, obras de arte, esquemas, diagramas, mapas e desenhos mecânicos, todos os tipos de sinais convencionais” (Vygotsky, 2003).
} 
A aproximação dos postulados desses autores em torno da valorização do caráter reflexivo da ação pedagógica é sugestiva, sendo capaz de acolher os problemas do cotidiano e construir novos conhecimentos referentes à realidade educativa, uma dimensão dinâmica pautada na articulação contínua entre a formação e a atividade docente.

Segundo Pimenta (2005), esse processo compreende a construção de conhecimentos sobre o ensinar mediante a reflexão crítica em relação à sua atividade, ou seja, pelos processos de reflexão na ação e de reflexão sobre a reflexão na ação. Para a autora (2005, p.18), “a reflexão é atributo dos seres humanos”. No entanto, conceituar professor reflexivo (grifo da autora) representa mais do que o reconhecimento de atributos; envolve, sobretudo, a valorização da prática profissional como elemento desencadeador de conhecimentos mediante a reflexão, análise e problematização dessa prática. O conhecimento na ação, tácito e implícito à ação docente, não é suficiente, em vista da singularidade das situações que emergem no dia-a-dia. Segundo a autora, novos desafios são continuamente apresentados ao professor, exigindo novas buscas, apropriação de teorias, problematização e diálogo, em um processo investigativo constante de reflexão sobre a reflexão na ação (grifo da autora), abordagem utilizada por Schön e de vital importância na formação dos professores.

Os fundamentos de Pimenta, de valorização da condição do professor como agente de transformação dos saberes da prática, transpõem o significado de técnico executor de propostas. A formação continuada é assim concebida como processo de elaboração de conhecimentos sistematizados, sustentado pela articulação entre a reflexão da prática e os fundamentos teóricos que possam explicar os fenômenos educativos.

Conforme esclarece Chakur (1995), a reflexão na ação ocorre no diálogo do pensamento com a realidade, com a situação-problema e, portanto, desenvolve-se simultaneamente com a ação. Por outro lado, na reflexão sobre a ação e sobre a reflexão na ação, o sujeito se afasta e analisa retrospectivamente a situação-problema, como também sua própria ação. Realiza-se, nesse sentido, um processo de análise para compreender a situação, o contexto em que se deu a ação e as condições para a reelaboração de novas estratégias, dois processos complementares que conduzem o educador a refletir sobre o saber fazer e o saber compreender as situações do cotidiano escolar. 
A valorização da prática refletida, segundo Pimenta (2005) e Chakur (1995), é um aspecto revelador que atua na mediação das situações enfrentadas pelo professor na superação das incertezas, dos dilemas e da instabilidade própria às práticas sociais, inseridas nos contextos historicamente determinados.

Na visão de Pimenta (2005), a ação docente abriga significados, visões de mundo que transcendem as condições imediatas, interagindo questões do âmbito da sala de aula e da escola, questões do cenário sociocultural, político, educacional e ideológico; por outro lado, interagem, ao mesmo tempo, questões organizacionais que envolvem, entre outros aspectos, o projeto pedagógico e o currículo.

No âmbito dessas discussões, o debate entre os profissionais é essencial, baseado no confronto de idéias e no significado que cada professor atribui à atividade docente. Resgatam-se, ao mesmo tempo, valores, representações, proposições sobre suas conquistas e conflitos, o modo como cada profissional analisa e se posiciona no mundo, suas escolhas, saberes e projetos de vida, uma rede de significados que vão sendo incorporados e atuam como mediadores nas relações e construções coletivas.

Nesse debate, a visão do coletivo é prontamente expressa por Freire (1987), admitindo que ninguém elabora conhecimentos sozinho. O autor afirma que ninguém evolui e se conscientiza separado dos demais; a consciência é mantida viva quando tem oportunidade de circular entre as subjetividades.

Em sua teoria, Nóvoa (1995) considera esse aspecto, ao admitir que as práticas de formação continuada organizadas em torno da realidade individual dos professores contribuem com o isolamento deles. Em contrapartida, as abordagens coletivas contribuem para a emancipação profissional, levando-se em conta uma "perspectiva crítico-reflexiva”, assegurando aos professores meios para a elaboração de um pensamento autônomo. A abordagem do autor admite que a formação não se constrói por acumulação de conhecimentos, tão peculiar nas propostas oferecidas em cursos e seminários, mas pela reflexão crítica dos problemas cruciais da prática pedagógica associada à reconstrução permanente da identidade do professor.

Pimenta (2003) considera que a identidade não é um dado imutável, e sim passível de ser transformada. Destaca os processos de construção dos sujeitos historicamente situados, 
admitindo que a profissão docente interage em um dado contexto, em um momento histórico, estabelecendo relações complexas de mediação de práticas, em resposta às demandas sociais. A emergência da realidade enfrentada pelo professor está associada às exigências sociais construídas em torno da identidade desse profissional e isso tudo deve servir de base aos processos formativos. Esses posicionamentos marcam a concepção de formação continuada, em busca de respostas às demandas do cotidiano desse contexto específico, consolidando o processo num continuum.

Segundo Fusari e Rios (1995), uma política pautada na educação do educador em serviço deve seguir pressupostos coerentes com uma visão democrática de educação e, nesse aspecto, é imprescindível voltar-se para a realidade concreta do educador e para o conjunto de fatores condicionantes (estruturais e conjunturais) que delineiam seu espaço. A formação concebida pelos autores envolve a participação dos professores apontando os problemas que enfrentam no cotidiano de seu trabalho, como ponto de partida e de chegada do processo formativo.

Outro aspecto implícito na análise do professor reflexivo é o das condições e riscos provenientes da busca de coerência entre a atuação do educador e suas convicções. Destacamse questões sobre o desenvolvimento da responsabilidade e o aumento da capacidade de decisão do professor, de forma que, a despeito das contradições enfrentadas, vá em busca de uma "prática educativa igualitária e libertadora” (CONTRERAS, 2002, p. 187). A realidade dos projetos formativos deixa em aberto um enfoque reflexivo dessa natureza, com padrões ideológicos que discutam a transformação social, pois definir padrões ideológicos e valores morais requer do professor interrogar-se sobre sua própria vida e sua posição frente à escola.

[...] um processo de reflexão crítica permitiria aos professores avançarem para um processo de transformação da prática pedagógica, mediante sua própria transformação como intelectuais críticos e isso requer, primeiramente, a tomada de consciência dos valores e significados ideológicos implícitos nas atuações de ensino e nas instituições que sustentam e, em segundo lugar, uma ação transformadora dirigida a eliminar a irracionalidade e a injustiça, existentes em tais instituições (IBID, 2002, p. 165).

O autor atribui destaque a essa visão transformadora, necessária aos processos reflexivos, mais que à reflexão isolada das questões sobre a exclusão escolar, da manutenção das 
desigualdades e da capacidade de o professor enfrentar esses desafios, projetos formativos, questionando e propondo mudanças.

A concepção crítico-reflexiva de Nóvoa (1995) considera que a formação do professor deve buscar compreender os fenômenos envolvidos na complexa relação existente no processo ensino-aprendizagem. $\mathrm{O}$ autor declara como pressuposto que a tarefa docente transcende a um fazer técnico. O professor, sujeito da ação pedagógica, deve ser considerado como agente crítico de transformação da realidade, e não apenas um executor de métodos e técnicas impostos como fórmula mágica de resolução dos problemas educativos.

Nessa perspectiva, como argumenta Nóvoa, “a lógica da racionalidade técnica opõe-se sempre ao desenvolvimento de uma práxis reflexiva” do professor e, nesse aspecto, consideram-se inseparáveis a prática e a teoria, inseridas à capacitação docente, que se transforma em um processo dinâmico, em que interagem três dimensões: a dimensão epistemológica (relação com o “saber”), a dimensão ontológica (relação com o “ser”) e a dimensão praxiológica (relação com o “fazer” pedagógico). Admite-se que, para compreender o significado exercido por esse processo formativo, é preciso estudá-lo em sua totalidade, na confluência das diferentes dimensões que compõem essa estrutura teórica da Formação Docente ${ }^{9}$ :

- Dimensão epistemológica: Voltada a assegurar os conhecimentos e concepções que alimentam o saber do professor, fundamentam a prática e explicam os fenômenos envolvidos no processo educativo. Fornece pistas e mobiliza vários saberes, com o propósito de compreender as situações complexas e singulares do processo escolar.

Conhecimento não se reduz à informação. Esta é um primeiro estágio daquele. Conhecer implica um segundo estágio, o de trabalhar com as informações, identificando-as, analisando-as e contextualizando-as. O terceiro estágio relaciona-se à inteligência, à consciência ou à sabedoria. Inteligência relaciona-se à arte de vincular conhecimento de maneira útil e pertinente [...] (PIMENTA, 2003, p. 167).

- Dimensão ontológica: Envolve o reconhecimento do professor como sujeito social e histórico, constitutivo e articulador do processo educacional. Destaca seu caráter

\footnotetext{
${ }^{9}$ A configuração dessa estrutura está apresentada no anexo $n^{\circ} .1$ deste trabalho.
} 
político e transformador da realidade escolar. Consideram-se, também, os aspectos pessoais e relacionais do professor, sua visão de mundo, identidade, valores, vivências, experiências profissionais, história e convicções, aspectos que o identificam como um sujeito contextualizado: “[...] uma educação para ser válida precisa considerar a vocação ontológica do homem, vocação de ser sujeito - e as condições em que vive: neste exato lugar, neste momento, neste determinado contexto" (FREIRE, 1980, p. 34).

- Dimensão praxiológica: Voltada para o espaço pedagógico enquanto continente que acolhe o aluno e onde se desenvolvem as práticas educativas. Contexto enriquecido pelas relações humanas mediadas pelo professor buscando concretizar projetos e reafirmar seu papel crítico-reflexivo. Identifica-se, assim, o espaço pedagógico como paisagem primordial que imprime um contorno ao objeto de estudo e abriga a matériaprima da formação continuada, com sua realidade multiforme. Segundo André (1989), o cotidiano escolar deve integrar uma análise do microcosmo (sala de aula/escola) e dos fenômenos que integram a estrutura social.

O que é necessário, em síntese, é tentar transcender o nível micro, acompanhando os diversos "fios" que vinculam às estruturas macro-sociais, com o cuidado de não cair no outro extremo, ou seja, querer analisar uma realidade particular como uma "totalidade social", isto é, como uma situação que se esgote em si mesma.

A pesquisa precisa buscar estabelecer esta mediação entre o momento singular expresso no cotidiano escolar e o movimento social, o que parece só pode ser conseguido através de uma postura teórica muito consciente, de uma visão de escola muito definida e de um esforço analítico bastante árduo (ANDRÉ, 1989).

Para Nóvoa (1995), a formação docente na perspectiva crítico-reflexiva apontada, deve oferecer ao professor instrumentos para a construção de um pensamento autônomo, considerando para a formação docente: o desenvolvimento pessoal (produzir a vida do professor), o profissional (produzir a profissão docente) e o organizacional (produzir a instituição escolar).

Promover um trabalho crítico-reflexivo, para o autor, exigiria envolver como conteúdo formativo as práticas que o professor desenvolve e as experiências que compartilha nos 
ambientes coletivos. Na formação docente, devem ser mobilizados, ainda segundo o autor, saberes científicos, saberes da prática reflexiva e saberes envolvidos no posicionamento da militância pedagógica, dotando o professor de meios favoráveis ao enfrentamento das problemáticas do dia-a-dia.

Concluindo, verifica-se que o processo de organização dos aportes teóricos surge como forma de delinear um diálogo da teoria com a representação e compreensão que os educadores possuem de suas vivências sócio-históricas, face à formação recebida. Configura-se como um caminho teórico-metodológico de análise do processo de transformação da prática educativa e o modo como se concretiza a mediação do professor instaurando nuances na elaboração de significados sobre a deficiência e o lugar atribuído ao aluno que apresenta essa condição. 


\section{Capítulo II \\ CONTEXTO DA INVESTIGAÇÃO}

“[...] haverá sempre um lugar específico da enunciação.”

Denise Najmanovich

A afirmação de diversos autores (FREIRE, 1979; LAHIRE, 2002; MORIN, 2004) é unânime quanto à importância e necessidade de apresentar a composição pluralista das peculiaridades histórico-culturais de uma pesquisa para propiciar a compreensão de sua estrutura.

Najmanovich (2004), discutindo questões para pesquisa no e do cotidiano, chama a atenção sobre a especificação “do lugar do qual se fala”. Admite que, para ser fiel aos aspectos debatidos em pesquisa, é imprescindível analisar como eles surgiram e como suas concepções foram se desenvolvendo, não apenas no meio científico, mas no conjunto da sociedade. Segundo a autora de $O$ sujeito encarnado, "não se trata de debater os temas de modo abstrato, mas contextualizar de uma forma peculiar, em uma cultura e em um momento determinado” (IBID, 2004, p. 43), as idéias desse contexto particular, analisando o risco de os contextos em pesquisa serem apresentados de forma compartimentada, como se fossem campos neutros, “isolados, confinados e ahistóricos” (IBID, 2004).

Esta pesquisa analisa uma realidade escolar emoldurada por idéias, na complexidade das relações humanas engendradas naquele espaço específico, representado pelas escolas onde atuavam as educadoras entrevistadas.

Partindo das idéias de Najmanovich, é estabelecido um delineamento do contexto da investigação em pauta, referindo-se a dois tópicos convergentes: a) a composição de idéias, concepções e significados das educadoras que influenciaram suas práticas e b) as injunções ideológicas das equipes que estão expressas na apresentação da programação e sistemática de trabalho. 


\subsection{A realidade educacional: um breve apanhado}

O período em que a experiência ocorreu diz respeito ao conjunto de condições, idéias e teorias que marcavam a realidade vivenciada naquele cenário específico: os significados atribuídos à escola, aos sujeitos, à deficiência, ao papel desempenhado pelo educador e às relações estabelecidas com a instituição, os alunos, a comunidade e os demais educadores.

Naquele contexto epistêmico, as relações e construções desenvolvidas pelos educadores estavam fortemente polarizadas: educação especial e educação inclusiva. As concepções defendidas em cada segmento confrontavam-se e estabeleciam demarcações como se fossem estruturas incompatíveis, em que reinavam contraposições, dicotomias, temores e moralismo intimidador, cavando entre seus “seguidores” um abismo intransponível.

A cisão entre as duas áreas de ensino refletia um movimento por vezes opressivo e antiético. Os conflitos e divergências não retratavam apenas um confronto de paradigmas, mas um espetáculo marcado por uma visível fragmentação de idéias e estruturas que inviabiliza relações de diálogos. Eram estabelecidas prerrogativas tão excludentes e polarizadas, que não eram possíveis a idealização e construção de projetos complementares flexíveis que estivessem de acordo com as necessidades e peculiaridades de cada aluno.

O professor, num esforço louvável, incorporava propostas genéricas e superficiais, distantes de sua realidade, que lhe eram determinadas, portanto nem sempre abertas ao debate. $\mathrm{O}$ radicalismo com que as idéias surgiam provocava as mais diversas reações, principalmente porque elas não ofereciam a segurança necessária para que os educadores enfrentassem esses desafios. Diante da necessidade, para que não fossem responsabilizados por inviabilizar o processo educativo, conformavam-se em enfrentar, sozinhos, demandas de implicações institucionais.

Nesse contexto educacional, desenvolveu-se a experiência analisada, tema desta dissertação, espaço que reunia idéias, fundamentos, uma organização institucional atrelada a uma multiplicidade de cargos, funções, mecanismos operacionais e técnicos, envolvendo diferentes atores em diferentes escalas de poder e decisão e que, por vezes, segmentava o desenvolvimento de ações coletivas de forma mais integrada. 
Por outro lado, contava-se com um trabalho colaborativo e um compromisso solidário, acolhedor da população, como princípio daqueles que acreditavam que ensinar, reproduzindo a máxima de Paulo Freire (2001), “exigia um querer bem aos educandos”. Essas questões não prescindiam de uma análise científica que pudesse balancear os caminhos e descaminhos, acertos e erros de uma realidade específica com suas problemáticas educacionais, sociais e humanas, características que merecem, aqui, ser destacadas:

- O abandono do modelo clínico de compreensão da deficiência e do fracasso escolar ocorria progressivamente, preservando, no entanto, nas atitudes e na atuação dos profissionais, traços que reforçavam hipóteses prescritivas do desenvolvimento dos alunos;

- A instituição escolar, ao discutir questões ligadas à diversidade e à deficiência em geral, aglutinava responsabilidades que transcendiam a aspectos eminentemente pedagógicos, tais como os referentes à saúde do aluno e à promoção social, entre outros, desfocando e sobrecarregando, muitas vezes, o processo de escolarização;

- A parceria estabelecida entre a equipe técnica e o professor contestava a desvalorização do papel desse profissional; entretanto nutria, muitas vezes, a dependência do conhecimento de especialistas;

- A escola, mesmo voltada para a luta contra a exclusão social do aluno com deficiência, não se apercebia de seus próprios preconceitos, refletidos em propostas pouco desafiadoras, que não apostavam no potencial desse aluno;

- Patologia e fracasso escolar eram tratados como problemática individual do aluno e da família que o concebeu, encobrindo matizes da incompetência das instituições de gerirem propostas que transformassem essa realidade;

- A divisão polarizada, rígida e inflexível dos discursos sobre a melhor opção educativa para alunos com deficiência impedia a criação de contextos educativos sem fronteiras, que trabalhassem com meios pedagógicos complementares.

\subsubsection{Concepções sobre formação docente, deficiência e diversidade}

Os estudos sobre o atendimento educacional existente para alunos com deficiência na rede pública (CARVALHO, 2003; KASSAR, 2000; CRONIK, 2003) expressam a dificuldade dos 
profissionais de reconhecerem esse alunado como parte integrante do universo escolar e se responsabilizarem em gerir propostas que não recaíssem no tratamento padronizado oferecido aos seus alunos “tradicionais”. Na visão de Ferreira e Ferreira (2004), “vivemos um momento na educação em que coexistem a incapacidade da escola para ensinar todos os seus alunos e a presença de fato de alunos com deficiência, que são estranhos para ela”.

Havia, por assim dizer, uma evidente dissociação entre os projetos idealizados favoráveis às exigências legais e as estruturas educacionais que ainda se mantinham inalteradas nas condições mínimas para desenvolver um processo de inclusão identificado com a realidade de cada contexto.

Na relação com a pessoa com deficiência, não são raras, segundo os autores, as manifestações de estranhamento e impotência por parte dos profissionais que, muitas vezes, por falta de escuta, negam a possibilidade de tentar. Na concepção de Skliar (2003), as peculiaridades dos alunos levam os educadores, diante de seu despreparo, a “domesticar o outro”, a evitar a experiência, ou ainda, a querer se apoiar na falta de recursos da escola para justificar a exclusão de tantas crianças.

Assistia-se, a todo o momento, à sutil eliminação de muitos dos alunos das escolas, um processo que, segundo Mazzotta e Sousa (2000, p. 97):

[...] concretiza-se de diversas maneiras e com diferentes intensidades, não só em relação ao tempo e espaço em que ocorre, mas também em relação aos segmentos e pessoas envolvidas. Assim, não devemos abstrair dos mecanismos específicos de discriminação ou marginalização dos deficientes, sob o risco de, em nome de uma educação para todos, manter, temporariamente, dados alunos na escola sem que lhes sejam garantidas condições de aprendizagem.

Na concepção de Mazzotta e Sousa, são grandes os riscos que correm as crianças incluídas nas escolas unicamente como estampagem de alguns programas que almejam ser considerados progressistas. Muitas vezes, a imperiosa necessidade de provocar mudanças no sistema educacional gerou medidas superficiais e pouco cuidadosas na maneira como devem ser estruturadas as condições de ensino, na maioria das escolas públicas. Assim, diante dessas 
condições, para não manter inalterado esse quadro, na proposta da experiência educacional considerou-se essencial discutir formas de influir na concepção dos programas de formação continuada, no âmbito da atenção à diversidade como princípio norteador de mudanças na educação.

Administrar esse processo no contexto escolar, segundo os autores citados, tem provocado polêmicos debates, principalmente quando a questão transcende os discursos teóricos e se é chamado a viabilizar as idéias. Em muitos casos, cientistas e educadores ainda estão distanciados e suas contribuições não conseguiram transformar os propósitos ideológicos em práticas que retirem a escola desse cenário tão comprometedor e intolerante. Diversidade, deficiência e diferenças entre alunos ainda são fatalmente associadas à incapacidade de aprender, provocando nos profissionais os mais diversos sentimentos e expressões, por vezes oscilantes e polarizados, reveladores de descaso, falta de compromisso, negação, censura, dúvida, desconfiança e, também, inquietação, abertura, reconhecimento, buscas e acertos.

Inúmeros, portanto, são os sentidos e significados criados por educadores ainda distantes de se considerarem preparados para desenvolverem um projeto pedagógico para a maioria das crianças brasileiras. Nesse aspecto, Skliar (1998, p. 6) considera:

A diferença, como significação política, é construída histórica e socialmente; é um processo e um produto de conflitos e movimentos sociais, de resistências às assimetrias de poder e de saber, de uma outra interpretação sobre a alteridade e sobre o significado dos outros no discurso dominante.

As diferenças sociais e pessoais são transformadas em desigualdades, permeando certa hierarquia nas relações entre os indivíduos, em que se destacam aqueles que possuem mais direitos, autoridade, controle sobre o capital cultural e social.

Entretanto, mesmo considerando que a questão não deva ser vista de forma isolada e pontual aos indivíduos, essas concepções carregadas de significado político-ideológico sobre a diversidade e as pessoas com deficiência mascaram, muitas vezes, as reais necessidades das pessoas e concebem suas peculiaridades como se fossem aspectos que possam ser analisados globalmente. Na realidade, como assegura Padilha (2004), as concepções e paradigmas dessa 
esfera são extremamente complexos e necessitam ser estudados sob um prisma integrador entre indivíduo, sociedade e cultura.

Os julgamentos - muitas vezes excludentes - manifestados pelas escolas investiam de forma perversa e intolerante nos contextos educacionais, adotando como pressuposto a padronização do ensino em práticas e currículos únicos, preterindo a valorização das diferenças individuais e a garantia de acesso ao ensino para todos os alunos.

Nesse aspecto, ficava expressa a pouca clareza existente quanto à preservação dos direitos dos indivíduos, tão comum às políticas públicas que privilegiam o assistencialismo, indicativo de um contexto social pouco envolvido no combate às desigualdades. Freqüentemente, educadores, pais e alunos submetem-se ao princípio da desigualdade entre as pessoas, criando elos indenizatórios e não requerendo tratamento diferenciado como direito.

Dessa maneira, as pessoas com deficiência, identificadas por idéias tão contraditórias, foram se submetendo a uma série de fatores de caráter psicossocial que as impediam, muitas vezes, de transpor essas barreiras de significados, tão estigmatizantes, expressas nas interações e nas atitudes carregadas de preconceitos. Pode-se dizer que também os educadores se vêem envolvidos numa engrenagem extremamente perversa que os coloca ora como algozes incompetentes, cerceadores ao acesso à escola dos alunos com deficiência, ora como vítimas dessa mesma engrenagem, que dificulta sua atuação ao exigir o desenvolvimento de programas que não atendem às reais necessidades da população atendida.

Assim sendo, a educação fica diante de uma evidente oposição de princípios: por um lado, a declaração dos direitos humanos preconiza a igualdade e liberdade de todos os cidadãos numa compreensão universal, incorporando a idéia de que defende as relações éticas e democráticas; por outro, há uma visão distorcida do direito à diferença, interpretado como uma desigualdade. Benevides (2004) esclarece essas questões, admitindo ser premissa básica o que parece contradição, ao considerar que a "diferença não é sinônimo de desigualdade, assim como igualdade não é sinônimo de homogeneidade e de uniformidade”. Nessa direção, a autora complementa: 
O direito à diferença, portanto, é um corolário da igualdade na dignidade. O direito à diferença nos protege quando as características da nossa identidade são ignoradas ou contestadas; o direito à igualdade nos protege quando essas características são motivo para exclusão discriminação e perseguição (BENEVIDES, 2004, p. 63).

Como tais questões poderiam ser mais bem abordadas pela Educação? Que consonância existia entre as demandas de uma sociedade altamente complexa e exigente - aliada às necessidades e peculiaridades do sujeito - e as condições ofertadas pela escola? Esses fatores nem sempre se relacionam, tornando-se, muitas vezes, motivo de exclusão de um grande número de crianças.

Não se podia ignorar a pluralidade de condições e a forma peculiar como cada indivíduo interpreta e se apropria das experiências, das práticas sociais, dos instrumentos semióticos, sabendo-se que “[...] há situações escolares que podem requerer significativas intervenções e recursos diferenciados ou mesmo especializados para atender apropriadamente as necessidades educacionais de alguns alunos” (MAZZOTTA, 2006, p. 10).

Para Vygotsky, as questões do campo da deficiência estão ligadas às leis gerais do desenvolvimento de todos os indivíduos, devendo, no entanto, ser respeitadas as peculiaridades próprias do funcionamento psicológico das crianças com deficiência e oferecer a cada uma delas o "processo correto de educação” (1983, p. 153). A condição orgânica, as especificidades biológicas e o tipo de desenvolvimento não devem ser ignorados; no entanto, são as experiências sociais que ampliam as possibilidades do individuo.

Em sua teoria, Vygotsky (1983) revela que a sociedade está adaptada à organização e funcionamento psicofisiológico normal, mas, diante de um processamento orgânico com deficiência, necessita-se ressignificá-lo de acordo com as condições existentes. Há necessidade de uma reorganização substancial para que o contexto sociocultural interprete a deficiência e possam ser criadas formas de acesso aos seus bens culturais. As formas como são interpretadas as alterações e deficiências vão definir e direcionar a qualidade das intervenções e mediações oferecidas pelas instituições de ensino.

Frente a esses aspectos, as condições peculiares do sujeito, definidas por muitos como “inadequação para se adaptar” ao ensino e à sociedade, tinham sido acentuadamente afetadas 
por elaborações solidamente construídas, que depositavam no sujeito com deficiência características rotuladoras e estigmatizantes, uma condição que, sob certo aspecto, o desqualificava para ser inserido nos diferentes contextos sociais. Ficava expresso como as pressões sociais podem regular e direcionar os sujeitos com deficiência, prescrevendo-lhes, na concepção de Skliar (1999), normas e hábitos medievais determinantes na forma como devem aprender para serem iguais à maioria da população.

Mesmo reconhecendo a existência de uma estrutura orgânica específica e as condições peculiares que alunos com deficiência aprendem, era especialmente relevante destacar, diante das questões abordadas, a importância dos programas criados pela escola e pelo processo pedagógico, contribuindo para a abertura de oportunidades transformadoras para a aquisição de novas competências.

Admitia-se que a forma como as práticas educativas eram engendradas estava marcadamente ligada às concepções assumidas pelos educadores em relação aos processos de desenvolvimento e aprendizagem e ao papel atribuído à intervenção pedagógica, como fatores reguladores do funcionamento psicológico.

A partir das concepções da psicologia sobre o funcionamento mental, Vygotsky (1983), em seus estudos sobre os problemas de defectologia, destacou como, no contexto escolar, diferentes formas de planejamento poderiam criar caminhos alternativos de ação e "recursos compensatórios” ${ }^{\# 0}$ que oferecessem variadas condições de aprendizagem. Nesse sentido, não se pode ignorar a complexa relação entre o tipo de desenvolvimento singular dos alunos e a necessária ênfase das propostas intencionais, consideradas por Vygotsky como "processos compensatórios”, ou seja, substitutos, superestruturados e niveladores do desenvolvimento e da conduta (IBID, 1983, p. 14).

Orientados na direção oposta à deficiência, esses processos educativos parecem contrariar uma tendência prescritiva dos limites, geralmente impostos para a aprendizagem dos alunos, tendo como perspectiva a reorganização das funções adaptativas e a busca de caminhos alternativos para o desenvolvimento. Há, por assim dizer, uma pluralidade de recursos e

\footnotetext{
${ }^{10}$ Termo utilizado por Vygotsky (1983) para se referir à criação de condições educativas adequadas à adaptação do aluno à escola, favorecendo a compensação de dificuldades geradas pelo meio na relação com a deficiência.
} 
medidas que fogem ao tipo padronizado de respostas previstas pela maioria dos currículos e avaliações instituídos sem a necessária contextualização.

Nessa perspectiva, a compreensão das formas como o sujeito aprende foi deslocada do campo das capacidades individuais, orgânicas, para o campo das relações sociais, no contexto em que está inserido, assumindo-se uma visão política e social na medida em que se concebeu não haver "homens isolados", mas resultantes de um espectro de lugares e momentos, interferindo em suas experiências e papéis sociais.

O homem é expressão de raízes espaço-temporais, o que, na afirmação de Freire (1979, p. 61), representa o compromisso com a sua realidade e a garantia desta sociedade para com ele, fruto das relações conseqüentes estabelecidas, em respostas aos desafios enfrentados. Fica assim expressa a ênfase fornecida à capacidade de transformação das práticas educativas como condição de emergência de processos compensatórios, ou seja, desenvolvimento de formas alternativas de ação.

Vygotsky (1983, p. 153) admitiu serem esses os processos essenciais ao desenvolvimento do sujeito com deficiência, traduzidos por experiências, recursos, práticas, organizações dos espaços planejados para oferecer "o processo correto de educação, de atividades laborais, sociais, pessoais e familiares".

Não seria qualquer projeto pedagógico que poderia criar condições e garantias para que essa transformação ocorresse. As posições de Vygotsky $(1983,2003)$ constituíram sugestões, nesse sentido, ao apontar a importância de um ensino que incidisse no avanço das capacidades do sujeito, ativando-o e potencializando-o para a aquisição de funções mais elaboradas. Sua obra assinalou que para enfrentar a realidade educacional, criar estratégias e conduzir o processo educativo com desenvoltura, o professor necessitaria ter uma articulação de conhecimentos sobre a complexidade dos fenômenos provenientes das situações escolares, das quais, muitas vezes, ele não tem pleno domínio. Ao lado desse conhecimento, também seria indispensável que o professor tivesse consciência dos próprios significados cognitivos e afetivos presentes em suas atitudes e ações.

O acesso da criança com deficiência à escola, em uma realidade na qual ocorre despreparo dos profissionais e altos índices de exclusão e fracasso escolar, em função da ausência de 
recursos adaptados, evidencia a necessidade de que sejam discutidas as contradições desse momento histórico e as disparidades existentes entre o discurso oficial e as propostas colocadas à disposição dos educadores.

\subsection{A construção de uma proposta}

Dependendo do contexto e da abertura que possa existir, os sujeitos revelam possibilidades de não se renderem às idéias constituídas, rompendo com as condições limitadoras, evidenciando um modo singular de desenvolver seu percurso. Ainda que a qualidade das propostas educativas seja um aspecto de extrema importância e, nesse sentido, esteja envolvida uma complexa trama de fatores, dentre os quais se destaca o papel da formação docente, Rego (2003) identifica como razões imponderáveis (grifo do autor) os efeitos específicos, particulares e, talvez, inesperados que são provocados nos sujeitos.

As idéias e concepções da teoria histórico-cultural instauraram um pensamento menos determinista ao focalizar a educação e as práticas educativas num processo dialético menos classificatório da deficiência, em que o sujeito tem oportunidade de estabelecer trocas recíprocas, ao longo de sua história.

No programa de formação docente da experiência em estudo, o sentido apontado pela teoria histórico-cultural de elaboração de processos mediadores mais pertinentes constituiu um esteio para a criação de um ambiente propício à aprendizagem. Foi enfatizada, por meio de discussões sobre os processos de desenvolvimento e aprendizagem, a importância das práticas escolares como geradoras do desenvolvimento das funções psicológicas. Atribui-se destaque à dimensão sócio-histórica e às relações interpessoais, evidenciando-se o valor que a aprendizagem assume na construção do ser humano e de sua subjetividade. Foi assinalada a impossibilidade de o aparato orgânico sobreviver sem que o substrato do ambiente cultural estivesse apto a contribuir para que cada indivíduo delineasse seu percurso, interagisse, estabelecesse relações com o outro e, nessa integração de habilidades, significados e sentidos, pudesse apropriar-se de conhecimentos e compartilhá-los. 
[...] Embora Vygotsky enfatize o papel da intervenção no desenvolvimento, seu objetivo é trabalhar com a importância do meio cultural e das relações entre os indivíduos na definição de um percurso de desenvolvimento da pessoa humana, e não propor uma pedagogia diretiva, autoritária. Nem seria possível supor, a partir de Vygotsky, um papel de receptor passivo para o educando: Vygotsky trabalha explícita e constantemente com a idéia de reconstrução, de reelaboração, por parte do indivíduo, dos significados que lhe são transmitidos pelo grupo cultural (OLIVEIRA, 1993, p. 63).

A partir dessa perspectiva vygotskyana, os professores desse processo de formação percorreram percursos bem diferentes, interagindo com uma multiplicidade de exemplos de situações vivenciadas pelos colegas e sofrendo transformações em sua bagagem, enriquecida pela aprendizagem dos alunos e por sua própria aprendizagem.

Firmaram-se, nesse cenário educativo, os propósitos de compartilhar com o professor discussões dessa natureza, colocadas não apenas no imaginário de cada um, mas surgindo de processos entranhados nas vivências e apontando disfarces na maneira como as pessoas estruturavam suas argumentações e construíam julgamentos.

Autores como Mazzotta (1993, 1998, 2003), Masini (1999, 2004) e Amiralian (1999) refletiram sobre as necessárias transformações no sistema de ensino, na organização escolar e, principalmente, no apoio ao trabalho docente. A proposta da experiência, apoiada nas concepções desses autores, considerou que a qualidade das intervenções pedagógicas, ricas em situações desafiadoras, pudesse atender às necessidades básicas de aprendizagem dos professores, ao propiciar maior compreensão sobre a pluralidade de condições do ser humano, fosse do ponto de vista biológico, cultural ou social.

O objetivo da formação era que as dúvidas e incertezas, limites ou bloqueios, restrições e incompreensões dos educadores diante do trabalho com a diversidade pudessem desdobrar-se em inquietações provocativas para que eles buscassem alternativas e, num momento coletivo, organizassem-se criticamente para que, mesmo sendo uma pequena e microscópica célula, encontrassem caminhos apropriados à educação da criança com deficiência. 


\subsubsection{Concepções e idéias sobre a educação para a criança com deficiência}

Conforme foi exposto anteriormente, durante o período estudado nesta dissertação conviviam concepções diversas sobre o aluno com deficiência e as propostas educacionais para seu atendimento. Concomitantemente, coexistiam atitudes que evidenciavam as concepções que dirigiam as práticas, maneiras e estratégias de ensinar. De certa forma, acreditava-se que todos os instrumentos necessários para orientar a criança e seus familiares já haviam sido utilizados, mas questões fundamentais de seu desenvolvimento não foram garantidas pela aprendizagem propiciada.

O discurso sobre a deficiência, pautado na incapacidade dos sujeitos, era marcante na formação do professor. As representações médicas e terapêuticas impunham-lhe a criação de um espaço educativo sob a influência de uma visão patológica do sujeito, sustentando a idéia de que a deficiência era um problema individual, cabendo à família, sozinha, resolvê-lo.

Subjacente a essas concepções, considerava-se que as dificuldades escolares dos alunos com deficiência eram decorrentes da existência de um aparato orgânico deficitário, impeditivo de que eles aprendessem, ou seja, da ausência de condições favoráveis ao desenvolvimento. A dimensão biológica, portanto, isentava a responsabilidade da escola pelos desencontros entre ensino e aprendizagem e o fracasso escolar desses alunos não poderia estar sustentado por visões tão reducionistas, provocando tão baixa expectativa pedagógica.

Essa concepção patologizante da deficiência era pautada no déficit e determinada pelas condições biológicas, sem menção às questões culturais, econômicas e sociais, que pudessem estar comprometendo a performance escolar. Na educação de surdos, essas questões eram agravadas pelo fator lingüístico, provocando interpretações polarizadas na defesa da língua oral ou de sinais.

O discurso sobre o papel relevante da escola e do professor como mediador do processo de desenvolvimento do aluno, baseado nas idéias de Vygotsky, convivia com interpretações ambíguas quanto à capacidade intelectual dos alunos de aprenderem. Diante de resultados inconsistentes do processo escolar, ao mesmo tempo em que era registrado um inconformismo dos profissionais - apontando em direção à necessidade de se reverem os métodos de ensino, os conteúdos ensinados e as práticas que se afastavam das condições específicas necessárias 
para que os alunos aprendessem -, argumentava-se sobre a impossibilidade de a escola resolver todos os problemas que determinados alunos traziam.

O conceito de inteligência discutido por Oliveira (1997) fundamentava as tematizações propostas aos educadores, ao refletir práticas propiciadoras da superação dos limites impostos aos indivíduos, considerados mais ou menos dotados, condições estas altamente exploradas pela psicometria e pelos testes de aferição e predição do desempenho escolar. Essas idéias constituíram um contraponto às concepções de desenvolvimento e aprendizagem propostas por Vygotsky para a Educação, isto é, a escola se propondo a investir, de forma prospectiva, em idéias que considerassem as transformações que a criança fosse manifestando, valorizando, assim, a emergência de aspectos considerados a essência, os "brotos” ou "flores" do desenvolvimento (VYGOTSKY, 2003, p. 113). “[...] De qualquer forma, o outro, o desconhecido, tende a ser olhado a partir do referencial do observador e de sua cultura, e não compreendido de seu próprio ponto de vista” (OLIVEIRA, 1997).

Quanto à formação de professores, durante muito tempo as políticas voltadas a essa área foram pautadas em treinamentos distantes de representarem as necessidades educativas ${ }^{11}$. As propostas eram desfocadas do contexto escolar, centradas unicamente em conhecimentos que davam pouca importância aos "saberes da escola”. As preocupações voltavam-se para temas específicos, destinados a “tratar” a insuficiência do ensino, buscando “fórmulas mágicas” para resultados pouco eficazes, organizando os clássicos pacotes que interpretam para o professor o significado dos problemas, tais como o fracasso escolar, a violência nas escolas, a evasão escolar e a indisciplina, sintomas evidentes do pouco domínio da escola em questões tão importantes.

O cotidiano escolar e a complexidade dos fenômenos envolvidos na escolarização dos alunos chocavam-se com o despreparo do professor. As instituições educacionais padeciam com a desinformação, motivo pelo qual persistiam políticas públicas que viam a escola como mecanismo reprodutor de conhecimento, não respondendo às novas demandas vividas pelos

\footnotetext{
${ }^{11}$ A evolução das políticas de formação do professor foi cuidadosamente analisada por Souza (2005), que explicitou os aspectos ideológicos, políticos, pedagógicos e sociais que influenciaram os diferentes momentos das administrações públicas da cidade de São Paulo. Suas transformações e rupturas, muitas vezes drásticas, marcam a descontinuidade das gestões, dissociadas, em muitos momentos, das necessidades e condições educativas, estando mais a serviço dos interesses políticos daqueles períodos. Percursos semelhantes são fatalmente identificados em outros municípios que não fogem da lógica e compreensão que muitos gestores têm sobre "bens públicos".
} 
educadores, fosse no tratamento de questões de ordem pedagógica, envolvidas nas relações de ensino-aprendizagem, ou daquelas decorrentes de questões profissionais, reequipando os educadores com instrumentos de trabalho e de afirmação de seu papel profissional.

Por muito tempo, as equipes estiveram referenciadas por um modelo clínico de atuação compatível com as concepções assumidas naquele período, voltadas para representações médicas e terapêuticas dos alunos. O espaço educativo, o ensino e a ação pedagógica assumiam um valor complementar na história dos alunos, considerando-se, quase sempre, que a raiz de suas dificuldades de aprendizagem estava associada a uma "organicidade impeditiva” do sucesso escolar esperado.

As atividades formativas realizadas, inicialmente, por esse grupo de profissionais estavam baseadas nos sintomas dos problemas, com o foco voltado para o diagnóstico das dificuldades da criança e a orientação dos pais, muitas vezes responsabilizados pelas dificuldades do filho.

O trabalho de orientação ao professor envolvia, nessa época, a explicação e análise das condições da criança, bem como a construção de propostas pedagógicas para a melhoria da aprendizagem.

As críticas existentes à Educação Especial, em particular à manutenção de escolas especiais as quais, para muitos, representam a materialização do "confinamento" ou da exclusão de alunos com deficiência -, requerem um tratamento cuidadoso. Se, por um lado, a educação básica tem como objetivo garantir a formação adequada a todos os alunos, indistintamente, no ensino regular, conforme o estabelecido pela Lei de Diretrizes e Bases da Educação Nacional (LDBEN), por outro, na escola pública, há uma realidade perversa, pautada na construção de práticas voltadas para uma visão etnocêntrica e intolerante do sujeito, amputando a diversidade e, em decorrência da força da globalização e do pensamento neoliberal, a determinação de princípios voltados para a perfeição e homogeneidade humana. Tendo como referência tal aspecto, as críticas, muitas vezes, deixam de analisar os determinantes históricos que, pautados em processos políticos, econômicos e sociais, estiveram presentes na configuração das diferentes formas de atendimento educacional. 
Concorre, para compor esse quadro, a controvertida cultura do "fracasso escolar"12 que, na década de 80, instituiu mecanismos de exclusão em função do baixo aproveitamento dos alunos, avaliando-os de maneira preconceituosa e revelando, assim, os critérios seletivos da escola pública. Quando ligadas a fatores orgânicos, as diferenças individuais, características aos seres humanos, podem necessitar de apoios ou programas especializados, tendo surgido para esse fim os setores público e privado ${ }^{13}$ de ensino, proporcionando recursos voltados às pessoas com deficiência.

Considerando a existência de necessidades específicas e a exigência de apoios para a construção de práticas voltadas às diferenças individuais, avalia-se a importância de se desenvolverem ações em parceria para atenuar a fragmentação entre as diferentes áreas de ensino e o isolamento da Educação Especial. De certa forma, o movimento para assegurar o direito à escola para todos, numa época em que os mecanismos seletivos ainda excluem as oportunidades educacionais dos alunos, revela quão importante se torna a complementação das diferentes estruturas de ensino.

Tal posição poderia equacionar a impossibilidade de o sistema de ensino assumir totalmente as complexas demandas colocadas à escola, principalmente porque "entende-se que cada educando na relação concreta com a educação escolar poderá demandar uma situação de ensino-aprendizagem comum, especial, uma situação combinada (comum e especial) ou ainda, preferencialmente uma situação compreensiva (inclusiva)” (MAZZOTTA, 1998).

É preciso colocar à disposição de alunos reais escolas concretas que ofereçam o ensino de que eles necessitam. Parece um paradoxo, entretanto é legítimo dizer que a escola não pode fornecer tratamento igual a todas as crianças e, no que diz respeito às necessidades especiais, essa recomendação exigiria transformações e adaptações na escola, oferecendo estrutura e recursos adequados às demandas peculiares de cada sujeito. “[...] Acreditamos que ainda por alguns anos nosso sistema escolar dependerá de auxílios e serviços educacionais escolares

\footnotetext{
${ }^{12}$ Na concepção de Patto (1992), fica evidente a incapacidade crônica de a escola pública escolarizar a maioria das crianças brasileiras, principalmente dos segmentos mais pobres. A cultura do "fracasso escolar" revela as concepções contrárias às diferenças individuais.

${ }^{13}$ Januzzi (1996) faz referência a setores ligados à educação pública "como aquela que é oficial, mantida e controlada pela União, estados e municípios, gratuita, custeada pelos impostos" e à educação privada como aquela "administrada por pessoa física e/ou jurídica, como associações religiosas, filantrópicas, comunitárias ou empresariais, podendo ser paga ou gratuita” (JANUZZI, 1996a, p. 1).
} 
especiais ou especializados para, de fato, atender com competência alunos que apresentam necessidades educacionais especiais” (MAZZOTTA, 2002, p. 34).

Os movimentos considerados progressistas pró-inclusão recuperam o direito de a criança com deficiência “ser”, “estar” e “permanecer” incluída nas escolas regulares, entretanto a organização das políticas educacionais revela um total desconhecimento das emergências existentes no respeito à singularidade dos alunos com deficiência, evidenciado pela ausência de condições e recursos das escolas e pela pobreza implícita nos projetos educativos, distantes de responder "as necessidades requeridas para seu atendimento" (MASINI, 2004). Constatase uma educação que, na concepção da autora:

[...] não propicia a inclusão ao matricular de forma indiscriminada alunos com deficiência, sem realizar estudos sobre as condições específicas requeridas e o correspondente preparo de professores e transformações no contexto das escolas para o atendimento da criança com deficiência (IBID, 2004, p. 31).

A escola tem se mostrado despreparada para desenvolver projetos voltados à pluralidade dos sujeitos. Pelo contrário: impõe parâmetros disciplinares alinhando procedimentos e formas de agir e pensar dirigidos para um sujeito “universal” e abstrato e, como se não bastasse, vulnerabiliza os alunos ao envolvê-los em programas inatingíveis, que só podem ser alcançados por poucos, mesmo sustentando a defesa de uma Escola para Todos.

\footnotetext{
Como bem sabemos, tais políticas de inclusão - uma bandeira que tem atraído boa parte dos pedagogos progressistas - têm enfrentado várias dificuldades. De um lado, essas políticas têm esbarrado na resistência de muitos educadores conservadores. De outro lado, elas têm enfrentado dificuldades de ordem epistemológica ou mesmo prática, seja quando pretendem tratar de modo generalizante e indiferenciado às inúmeras identidades culturais que "povoam" aquilo que se costuma denominar de “todo social” (VEIGA NETO, 2001, p. 109).
}

Não há dúvidas quanto à importância e o valor dessa incansável luta empreendida pelos movimentos pró-políticas inclusivas dos últimos anos. Suas conquistas só provocam indignação quando tratadas superficialmente e atravessadas por relações de poder a serviço de 
interesses que nem sempre priorizam as necessidades das pessoas com deficiência. Mas não se trata unicamente de traduzir em propostas o significado da diversidade humana sem as genéricas distorções classificatórias, segundo a "norma” instituída. Contesta-se a violência com que as práticas educativas tratam a singularidade dos alunos, não apenas os com deficiências, mas todos os sujeitos diferentes que "teimam em não se manterem dentro dos limites nítidos” (VEIGA NETO, 2001).

Mesmo ao se considerar a permanente necessidade de uma reavaliação e reformulação nas políticas públicas educacionais, torna-se importante a manutenção da Educação Especial como estrutura e modalidade de ensino pertinente ao estabelecimento de diretrizes, serviços e recursos educacionais especiais que possam defender as “diferenças” entre os sujeitos, suas peculiaridades, sem padrões genéricos, distantes de representarem a pluralidade de condições que esses sujeitos possuem.

Tais concepções nortearam o trabalho formativo com os educadores na rede municipal de ensino de São Bernardo do Campo, na perspectiva de construir uma educação atenta às necessidades específicas de todos os alunos, de todas as condições, em escolas especiais ou regulares.

O foco, a partir desse projeto formativo, estava dirigido para um novo modelo de trabalho, rompendo a polarização entre educação regular em busca do status de "educação inclusiva" e educação especial. As mudanças propostas buscavam uma confluência de saberes, transformando aquele espaço gerenciador de políticas educacionais em um lugar de diálogo entre profissionais das diferentes áreas (regular e especial).

Dessa forma, era necessário refletir as práticas - tornando-as instrumentos de real transformação -, fortalecer e respeitar suas conquistas, rever ambigüidades, contribuir coletivamente para a construção de uma educação possível, comprometida com a diversidade sem imposição e exigência de "filiação ideológica” ou sem que se tivesse, indiscriminadamente, de “aplaudir ou reprovar” (MASINI, 2004) a adoção de posições.

Existem muitas idéias e procedimentos a serem avaliados. Outros poderiam propiciar importantes contribuições para a escola regular, revendo posições principalmente quanto à heterogeneidade dos grupos e à falta de compromisso com que os projetos educativos tratam a 
singularidade de seu alunado. Portanto, o investimento e esforço partilhados, principalmente em benefício da formação docente, representariam um avanço na compreensão da pluralidade de caminhos que a aprendizagem pode requerer.

A partir do suporte técnico das assessorias de Masini, Skliar e Heymayer ${ }^{14}$, foi discutida intensamente com o grupo de trabalho a importância de olhar as diferenças sem fragmentação, em que as identidades dos sujeitos (condição, língua, cultura e história) fossem reconhecidas sem as estigmatizantes oposições criadas entre normalidade e anormalidade, ou entre maioria ouvinte e minoria surda, ou ainda, entre língua oral e língua de sinais, videntes e cegos, que sugeriam o domínio inevitável de um sobre o outro.

Pretendia-se adotar abordagens que provocassem uma transformação na postura educacional, no sentido de reconhecer, tanto nas questões do campo cognitivo, quanto nas do campo lingüístico ou do campo sensorial, que a visão do deficiente não poderia estar vinculada a um sistema hierárquico de valores em que a educação - e também a Educação Especial - se apoiava, no qual as crianças com deficiência eram colocadas como ”incapazes”, "não ouvintes", "não videntes”. A identidade dos sujeitos com deficiência não poderia ser concebida em oposição a uma normalidade idealizada que os profissionais buscavam ressignificar.

Assim, no período de 1997 a 2002, com a contratação de assessorias, teve-se, pois, configurado o quadro de condições questionadas, que foram sendo objeto de análise para introdução de mudanças: assumir novos paradigmas e ir ao encontro de uma visão mais integradora do sujeito, alicerçada na compreensão das peculiaridades dos indivíduos e na necessidade de provê-las com base nas suas múltiplas capacidades. Por outro lado, as condições institucionais não poderiam ser ignoradas e, nessa direção, a complexidade das situações exigia ferramentas eficazes que oferecessem aos educadores uma estrutura educacional sustentável, voltada à realidade de cada contexto educativo.

A transformação da postura educacional compreendida envolvia grandes desafios a serem conquistados com os diferentes grupos de profissionais nas diferentes áreas: ampliação dos

\footnotetext{
${ }^{14}$ É importante destacar o papel das assessorias de Elcie A. F. S. Masini para a área de deficiência visual, de Carlos Skliar para a área de deficiência auditiva e de Úrsula Heymayer para as áreas de deficiências mental e múltiplas, desenvolvendo um trabalho com professores e equipes técnicas para a reformulação das propostas da Educação Especial, no período de 1997 a 2002.
} 
conhecimentos sobre as deficiências; acesso à aprendizagem para crianças com severos comprometimentos intelectuais ou que apresentassem quadros psicológicos e neurológicos graves; adaptação estrutural das escolas visando a maior autonomia e participação dos alunos com deficiência visual e física; além do reconhecimento da condição bilíngüe do aluno com surdez e da língua de sinais como primeira língua, aquela que poderia ser considerada veículo de comunicação e transmissão cultural para o surdo.

Sem deixar de trazer a comunidade escolar como um todo, foi discutido o significado de implantar uma política educacional voltada ao reconhecimento da diversidade dos sujeitos, sem descaracterizar as deficiências e os aspectos socioculturais envolvidos nesse processo. Portanto, tais idéias não poderiam ser negligenciadas, nem pelos profissionais e funcionários das escolas, nem pelos pais, participantes diretos dessa relação dialógica.

Contudo, esse processo para subsidiar a formulação de políticas da Educação Especial não ocorreu de maneira uniforme e linear, mesmo porque, dependendo das necessidades educativas identificadas, cada assessoria traçava rumos bem específicos. Ainda que mantivessem abordagens bem diferenciadas, as assessorias foram identificadas como instrumento enriquecedor de reflexão, delineamento de propostas e linhas de ação, dialeticamente construídas com os grupos, sem que os mesmos tivessem de omitir suas inquietações, discordâncias e pontos de vista.

Dessa forma, frente aos problemas vividos, o grupo sentia-se responsabilizado a descobrir o ponto articulador do processo de aprendizagem, percebendo que este estava centrado na sala de aula, nas práticas educativas reflexivas, intencionalmente criadas para sujeitos singulares, em um contexto educativo transcendente ao determinismo pedagógico imposto por propostas que pretendiam alinhar as formas de pensar e agir.

Os educadores necessitariam adquirir uma compreensão mais abrangente e complexa sobre os processos de ensino-aprendizagem e as diferenças psicológicas existentes entre os sujeitos, desvinculada da visão classificatória dos alunos pelo rendimento escolar.

Se, por um lado, as diferenças entre eles eram percebidas por alguns educadores como advindas de fatores endógenos determinantes de seu desenvolvimento, por outro, numa posição antagônica, avaliava-se também que as transformações sofridas pela criança faziam 
parte de um funcionamento universal, sendo as "metamorfoses" percebidas, parte de um processo independente do aprendizado. Estavam, assim, orientados por concepções que enfatizavam que o desenvolvimento abria caminho para a aprendizagem e, nesse "compasso de espera”, as propostas eram criteriosamente dosadas e delineadas para que a aprendizagem pudesse ser consolidada no "momento certo", quando a criança estivesse pronta, ou seja, quando suas estruturas internas estivessem preparadas e amadurecidas para se "submeterem a determinadas experiências”. Essas fronteiras impediam a criação de percursos mais ousados e menos classificatórios, num ritmo excessivamente "respeitoso e lento", aguardando o momento em que se admitia estar a criança pronta ou em condições de aprender.

Levando-se em conta esses aspectos, havia questões importantes a serem revistas:

- Os processos psicológicos referentes às estruturas superiores do pensamento eram considerados invioláveis, independentes das características dos sujeitos, das condições sociais, emocionais e culturais. Segundo Oliveira (1997, p. 48), “[...] existe uma clara tendência inatista, isto é, de atribuição das capacidades humanas a algum tipo de dotação ou pré-disposição já presente no momento do nascimento do indivíduo”.

- A idéia da existência de mecanismos universais do funcionamento psicológico humano revelava-se contraditória à complexidade do processo de ensinoaprendizagem, ao impor uma sucessão linear de aprendizagens guiadas pela maturação da criança, negando, assim, a relevância das diferenças entre sujeitos.

\begin{abstract}
A idéia do respeito à realidade do aluno é, portanto, bastante proeminente nessa abordagem. Levada ao extremo, tal abordagem poderia conduzir a um relativismo radical e a uma postura espontaneísta, que não admitiria nenhuma intervenção que alterasse o modo de funcionamento próprio de diferentes indivíduos ou grupos, já que o percurso adequado de desenvolvimento está pressuposto na própria idéia de desenvolvimento proposta por essa abordagem (IBID, 1997, p. 53).
\end{abstract}

De uma forma ou de outra - por não se acreditar no potencial da criança ou porque a práticas educativas não a desafiavam -, essas posições revelam idéias orientadas por concepções sobre o funcionamento psicológico do aluno com deficiência que podem criar falsas impressões 
sobre a capacidade da escola de provocar mudanças em seu desenvolvimento. Observa-se um imobilismo ou mesmo ausência de expectativas educacionais e, conseqüentemente, riscos de serem estabelecidos prognósticos pouco otimistas quanto à capacidade dos alunos de aprenderem.

Buscava-se desvelar o lugar ocupado pela criança e pelo jovem nesse contexto educativo e, a partir daí, trazer diferentes campos da ciência para ampliar a compreensão sobre o alcance e limites da ação docente e, dessa forma, criar disposições favoráveis quanto à capacidade da escola de alterar os rumos do desenvolvimento dos alunos.

Nessa confluência de posições teóricas, muitas dúvidas não eram esclarecidas, pelo simples fato de que a equipe também deixava evidente a própria incompreensão de vários aspectos, ficando clara a ausência de domínio, por alguns educadores, sobre as abordagens teóricas que fundamentam a constituição do psiquismo humano e a dimensão do papel do professor na mediação dos processos de aprendizagem.

Mas outras emergências eram apontadas para responder às necessidades educativas dos sujeitos surdos, com deficiência mental, deficiências visuais e físicas, e essas emergências não se limitavam à formação dos educadores como projeto restrito àquela realidade. $\mathrm{O}$ foco desses estudos requeria políticas educacionais de formação, mais amplamente organizadas com toda a rede de ensino, promovendo ações que possibilitassem ressignificar a deficiência e legitimar a contribuição pedagógica na superação dos limites dos alunos.

As discussões referentes a esse tema eram apontadas como pertencentes a um campo nevrálgico. O tratamento proposto ao conceito de deficiência trazia um espectro de valores, estereótipos e representações que reforçavam processos de discriminação e exclusão, além de ser descrito de maneira tão genérica, sendo impossível reconhecer de qual sujeito se falava. Eram terminologias tão vazias que "significam tudo e nada ao mesmo tempo" (LARROSA e SKLIAR, 2001). No ímpeto integrador, a deficiência, a diferença e a diversidade ${ }^{15}$ perdem o significado, universalizando-se condições tão singulares aos indivíduos.

\footnotetext{
${ }^{15}$ Vários autores têm criticado o uso exaustivo dessas noções. Skliar (1999) chama atenção para o sentido de "deficiência”, "diversidade“ e "diferença”. Segundo o autor, "a 'diversidade’ cria um falso consenso, uma idéia de que a normalidade permeia a condição dos 'diversos' e, ao mesmo tempo, mascara a visão etnocêntrica em conter a diferença” (IBID, 1998, p. 13).
} 
Grande parte da euforia integracionista propõe idéias de um ser humano universal inexistente, negando, assim, a importância das diferenças individuais. Ao estabelecer um ensino indiferenciado, no intuito de generalizar o conhecimento, esse contexto escolar democrático ensina e avalia, promovendo alguns e, ao mesmo tempo, produzindo o fracasso e a exclusão escolar de um grande número de alunos.

Idealiza-se uma educação inclusiva, redentora, na ilusão de propiciar condições para que todos aprendam, sem que sejam considerados os impactos de uma realidade educacional que sucateia as escolas, tornando o trabalho docente improdutivo e indigno.

Assiste-se, assim, à materialização de inúmeros desencontros entre: o ensino e a aprendizagem; o desempenho "esperado" e o "aferido"; a condição escolar desejável e a oferecida aos alunos.

Sawaia (2006) analisa esse complexo processo de exclusão, interpretando as condições de injustiça e desigualdade em que são mantidos os indivíduos:

A sociedade exclui para incluir e esta transmutação é condição da ordem social desigual, o que implica o caráter ilusório da inclusão. Todos estamos inseridos de algum modo, nem sempre decente e digno, no circuito reprodutivo das atividades econômicas, sendo a grande maioria da humanidade inserida através da insuficiência e das privações, que se desdobram pra fora do econômico (IBID, 2006, p. 8).

Configura-se, dentro da ética e do espírito solidário proposto pela Declaração dos Direitos Humanos, a criação de recursos que garantam respeito e dignidade a todos os seres humanos. No entanto, como analisa a autora, nem todos conseguem obter esses direitos, mas dentro dos limites possíveis às estruturas sociais e econômicas criam-se atalhos, pulverizam nas escolas nuances de um pensamento acolhedor, mesmo que estejam estampadas as precárias condições de uma educação “merecida” a quem não possui meios de conquistá-la com todos os recursos aos quais tem “direito”.

Assim, a busca pelo direito a melhores condições de ensino não poderia ser interpretada de forma restrita, voltada unicamente ao contexto da sala de aula. Haveria outros campos a serem 
estudados que contracenariam com a escola: as questões institucionais, sociais e do campo das políticas públicas. O olhar do professor necessitava dominar outros ângulos, fazer outras leituras fundamentais à compreensão da totalidade do ser e da amplitude de fatores que tornam peculiar a transformação de cada sujeito.

Romper com uma visão linear de desenvolvimento pré-determinista das capacidades humanas exigiria transgredir um modelo secular de medicalização da deficiência, que enfatiza a dimensão orgânica deficitária como impedimento para a aprendizagem.

Por outro lado, ao considerar a importância das experiências pessoais e culturais para a formação e desenvolvimento do psiquismo do homem, recoloca-se em discussão a problemática da deficiência interpretada como de natureza imutável e permanente, contrapondo-se à concepção histórico-cultural, que desafia os limites impostos pela constituição orgânica.

O problema não está na existência de posições reveladoras do substrato biológico comprometido do sujeito com deficiência, pois esse aspecto está posto como indiscutível. O contestável é conceber a criança como portadora de uma identidade indiferenciada, associando-a com mais ênfase ao déficit e aos seus comprometimentos, em detrimento da capacidade de transformação e desenvolvimento conquistados por ela, de forma singular, diante das experiências culturais oferecidas ao longo de sua história.

Essa discussão traz à tona a relevância do papel da escola como esteio enriquecedor dos processos de desenvolvimento, recuperando, assim, a combinação dialética entre aprendizagem e desenvolvimento, “interagentes e mutuamente dependentes”, no dizer de Vygotsky (2003). Segundo Oliveira (1997), a idéia de desenvolvimento já pressupõe a idéia de transformação:

[...] a transformabilidade do sujeito ao longo do processo de desenvolvimento, a importância da intervenção educativa e a relevância da escola como instituição na sociedade letrada, ocupam lugar central nas postulações da abordagem histórico-cultural (OLIVEIRA, 1997, p. 58). 
Tais análises eram problematizadas com os diferentes segmentos ligados à escola e até mesmo com a própria comunidade escolar, que se apoiava, muitas vezes, em uma visão muito paternalista da deficiência, caracterizada por critérios exclusivos às possibilidades cognitivas dos alunos, avaliando-os genericamente como seres incompletos.

Os avanços que podíamos obter seriam para atender às necessidades da criança especial. Dependendo do nível de deficiência, as atividades deverão ser elaboradas para que possam atingir seus objetivos, ou seja, estar compatível ao nível da criança (Professora da Educação Especial).

[...] sempre alegra perceber os progressos, tanto no comportamento quanto na realização das atividades, mas receio as dificuldades que o aluno vá enfrentar. Por isso, procuro adequar a programação às suas possibilidades (Professora da Educação Especial).

No desenvolvimento da ação pedagógica, o professor, muitas vezes, tem uma visão pouco transgressora diante de concepções pré-deterministas herdadas em sua formação. Parece ter receio de oferecer desafios aos alunos, preferindo não lhes impor frustrações.

Por tudo o que estava acontecendo nacionalmente, também a Educação Especial do município buscava novas referências. Assinalava-se a importância de se redefinir seu papel, sem as tão conhecidas catástrofes, em geral favoráveis à desestruturação de órgãos e segmentos, assumindo posições totalitárias, fazendo acreditar que só eliminando os serviços especializados seriam obtidos resultados progressistas. Buscava-se rever concepções, provocar mudanças, sem eliminar mecanismos e saberes tão necessários ao trabalho com educadores e alunos. Tratava-se de abrir a discussão para aspectos da instituição que estavam cristalizados, sem perder o caminho já percorrido, construindo percursos de aproximação com outras áreas de ensino, de forma crítica, num processo de transformação das práticas pedagógicas como um todo. “O sentido de se pesquisar na interdisciplinaridade está na sabedoria de descobrir, conhecer, aprender, sem destruir o construído” (FAZENDA, 2001, p. 18).

De certa forma, o fracasso escolar enfrentado pelos alunos da escola regular, os índices assustadores de abandono escolar e os mecanismos excludentes arraigados nas práticas 
escolares não poderiam prescindir do diálogo com outros saberes, reconhecendo o valor das ações pedagógicas especializadas como alternativa de superação desses obstáculos.

A distinção dessas nuances vivenciadas nas escolas especiais e no processo de acompanhamento das escolas regulares não era algo muito fácil e exigia clareza à habitual polarização existente entre escola especial e escola regular. Era imperativo não penetrar nessa falácia desagregadora e construir um pensamento mais complementar, sem rupturas tão drásticas e, para isso, as assessorias representaram um movimento de maior criticidade na reconstrução da Educação Especial, sem que se padecesse dos habituais processos de negação da deficiência, tão determinantes nas práticas de homogeneização humana.

Independentemente das posições teóricas assumidas por cada um dos assessores, as orientações e discussões propostas nos encontros formativos tomavam rumos próprios, revestindo-se dos significados e sentidos que o grupo ia construindo sobre a deficiência, fazendo desses momentos de construção de conhecimento um processo de convivência e expressão de posições enriquecedoras. Nesse contexto, era de reconhecida importância a mediação proporcionada por esses docentes com cada grupo de educadores, oferecendo oportunidades para reflexão de temas polêmicos referentes às diretrizes educacionais, que não se definem tão rapidamente e sem os conflituosos debates. No que se refere às concepções de deficiência e à educação a ela destinada, exigia-se a apropriação de novas abordagens, que não poderia ser resultante de uma superposição de idéias ou por definição externa do grupo ${ }^{16}$.

Rompendo com esse quadro, a Secretaria de Educação do Município de São Bernardo do Campo imprimiu, a partir de 1997, uma nova concepção à formação continuada em serviço, tendo como proposta o desenvolvimento de programas fundamentados em princípios de

\footnotetext{
${ }^{16}$ A elaboração de uma concepção de deficiência, observadas as condições de cada sujeito, principalmente quando acompanhadas de outros comprometimentos, foram permitindo situar as pessoas com deficiência (mental, sensorial, neurológica e outras) no mundo, significando-as como sujeitos pertencentes a um grupo, sem, no entanto, transformá-las em "objetos de estudo indiferenciados" com pouco lugar para suas diferenças, singularidades e necessidades específicas. Admite-se que as limitações podem gerar problemas de aprendizagem, mas que não podem ser generalizadas a todos os indivíduos com deficiência, nem mesmo ser justificativa para as deficiências pedagógicas. Apesar do diagnóstico médico, acredita-se que cada sujeito com deficiência deve ter um caminho particular, diferenciado, pois há por trás uma constituição subjetiva que requer um processo educativo, recursos e estratégias com adaptações próprias.

Tais proposições suscitaram interpretações bastante complexas na Educação de Surdos, que contou também com as contribuições de Moura em cursos e seminários. A autora ajudou a refletir a importância dos processos culturais, das trocas, das possibilidades de os alunos partilharem suas experiências e como essas condições ficam truncadas nas relações entre surdos e ouvintes, principalmente quando estes não dominam o código lingüístico daqueles.
} 
valorização e reconhecimento da diversidade e pluralidade cultural, numa perspectiva educacional polissêmica, na qual, ao se escolher a melhor opção educativa, são respeitadas as características e necessidades dos alunos.

As ações educativas começaram, nessa fase, a revelar mais preocupações com as necessidades e especificidades de seu alunado. A Educação Especial do município cumpriu, nesse contexto, um importante papel ao refletir com os educadores da rede de ensino o distanciamento existente entre a escola e as condições favoráveis para atendimento à diversidade.

Ampliaram-se, assim, as discussões sobre a educação inclusiva e a parceria da Educação Especial, que se desafiou nesse percurso, com a Educação Regular, abrindo-se espaços para a implementação de projetos voltados às necessidades de todas as crianças.

[...] De um lado há concordância a respeito da inclusão como oposição à exclusão de crianças com deficiências do ensino comum. Neste sentido, todos passam a defendê-la e ninguém se arriscaria a se pronunciar contra ela. De outro lado, há discordância quanto à inclusão indiscriminada, na qual, sem qualquer avaliação prévia, a criança com deficiência é matriculada na escola regular, sem análise de suas condições e das necessidades requeridas para seu atendimento, quer do ponto de vista de recursos humanos, quer do ponto de vista das adaptações físicas e materiais (MASINI, 2004, p. 31).

As discussões formativas não ficavam subordinadas cegamente a uma única concepção sem a necessária análise das amarras ideológicas existentes em quaisquer dos modelos analisados. A adoção de diretrizes estava pautada em políticas educacionais contrárias à baixa expectativa ou às representações do deficiente, na perspectiva da "cultura do fracasso" e da limitação. No entanto, explorar esses caminhos deixando para trás antigos dogmas era um horizonte ainda nebuloso para muitos e, nesse aspecto, não seria possível subtrair o conhecimento do professor, mas transformá-lo.

O quadro (ainda) muito presente da incapacidade crônica de a escola pública escolarizar a maioria das crianças brasileiras, principalmente dos segmentos mais pobres, evidenciado por Patto (1992), propunha sérias discussões sobre os riscos das argumentações que associavam o fracasso escolar das crianças a fatores biopsicológicos: problemas físicos, sensoriais, 
intelectuais, neurológicos, emocionais e de ajustamento. O significado conferido por muitos educadores às necessidades educativas especiais associava-as à incapacidade de aprender, o que provocava no professor especializado sérios temores e resistência à inclusão de seus alunos.

Essas concepções expressas pela escola, segundo Oliveira (1997), tratam as diferenças individuais como sendo inatas ou herdadas socialmente, numa visão imobilista, referindo-se ao ensino que está aí posto como a alternativa “possível” ou "merecida” para quem possui "limites”. De certa forma, a maneira diferente de a criança com deficiência aprender e utilizar os conhecimentos representava uma ameaça para a "suposta segurança" das escolas, irremediavelmente obedientes a padrões curriculares.

Essas reflexões desempenharam papéis muito específicos, dependendo da nuance dada pelos protagonistas envolvidos nos grupos de trabalho. A discussão de novas abordagens para a educação do aluno com deficiência trazia em si divergências, considerando principalmente as dificuldades existentes na construção de práticas capazes de reconhecer as diferentes formas de caminhar de cada aluno. A experiência de alguns professores revelava incertezas quanto à inclusão de muitos de seus alunos, conforme pode ser observado a seguir:

As nossas dificuldades maiores estão na integração com os profissionais nas escolas estaduais onde os alunos estão integrados. Parece não haver planejamento antecipado e há muita resistência em aceitar o aluno com deficiência (Professora da Educação Especial).

Paralelamente às preocupações já apontadas por Masini (2004), Padilha (2007) também manifesta alertas sobre a inclusão questionando:

Uma coisa é o direito de aprender, adquirir conhecimentos científicos, apropriar-se da cultura, ter acesso aos bens materiais e simbólicos por ela produzidos, significar o mundo, alfabetizar-se, ser leitor, conhecer seus deveres e direitos e lutar por eles, participar da vida política, ter voz e voto, poder votar e ser votado. Outra coisa é, de maneira irresponsável, colocar nossos alunos - crianças e jovens que tanto necessitam de uma boa escola diante de uma expectativa enganosa do que tem sido denominado de “inclusão escolar” (PADILHA, 2007, p. 101). 
Desse modo, pode-se supor que, ao serem elaborados programas motivados por concepções tão polarizadas, havia o risco de se delimitarem fronteiras e, no confronto de posições e disputa de domínios, de a rede municipal não avançar em favor de uma melhor compreensão do aluno incluído. Constatar oposições poderia ser muito enriquecedor na superação das dificuldades enfrentadas pelas escolas, no entanto estas deveriam ser trabalhadas e, nesse sentido, tais revisões não poderiam ocorrer isoladamente, mas compor as diretrizes das políticas educacionais envolvendo todos os segmentos da rede de ensino.

Acredita-se que a proposta de inclusão tenha dificuldades em se consolidar, mediante construções isoladas, pela iniciativa e boa vontade de alguns educadores mais ousados, sem a necessária definição de uma política de ação. Destacam-se em Masini (2000) recomendações importantes referentes à elaboração de projetos educacionais mais abertos e inclusivos.

A autora assinala a necessidade de que:

- cada um conheça seus próprios limites, pessoais e de formação, e no que pode contribuir para a inclusão da criança com deficiência;

- sejam examinados as condições e limites das escolas;

- sejam analisadas as formas possíveis para que a inclusão se realize em benefício da criança deficiente;

- os projetos educacionais se façam em uma dialética teórica/ prática, em uma constante avaliação do que ocorre com a criança com deficiência (MASINI, 2004, p. 33).

Toma-se como referência nessas discussões a construção de práticas educativas elaboradas mediante reflexão crítica de suas finalidades, concepções, procedimentos e estrutura, observando-se as condições de a escola atender às especificidades dos educandos.

A compreensão das idéias apresentadas acima oferece mais clareza, uma vez que circunscrevem o contexto e fornecem um quadro descritivo sobre as concepções e fundamentos que direcionaram o trabalho dos educadores nas escolas onde atuavam. As manifestações e dizeres sobre as mudanças ocorridas na dinâmica interativa vivenciada por cada uma das educadoras reconstruirão a lógica desse contexto de trabalho, oferecendo uma imagem mais nítida da "figura" e do "fundo" da pesquisa. 
Os projetos de formação continuada em serviço foram desenvolvidos com todos os educadores da Educação Especial, assinalando como foco da ação formativa o contexto escolar e as relações tecidas no cotidiano da sala de aula, no enfrentamento das complexas situações escolares, desafiadoras do saber docente.

Olhares diversos, saberes que se complementavam, refletindo e analisando a prática do professor nas reuniões e momentos de formação: parecia ser esse o projeto a ser construído sob a liderança do diretor da unidade em parceria com a equipe, uma arquitetura não muito fácil de ser conquistada e de efeitos oscilantes. Dependendo do grupo, assistia-se a coordenações cuidadosas, hábeis, democráticas, mediadores exigentes, mas acolhedores, ou a percursos desgastantes e trabalhosos e nem sempre com os efeitos esperados. Alternar as coordenações e procedimentos, para que as relações fossem mais harmoniosas e o grupo produzisse, poderia ser uma saída nem sempre consolidada.

A principal característica desse modelo de formação referia-se à ação partilhada por professor e equipe técnica e, dessa parceria, decorriam encaminhamentos muito peculiares a cada nova etapa de trabalho. A ênfase dessa relação dialógica entre educadores de diferentes áreas do conhecimento pretendia transformar a escola e a sala de aula em espaços de pesquisa, onde todos se comprometessem com os avanços e as dificuldades existentes.

Em consonância com o Projeto Pedagógico Educacional das escolas e com o Programa de Formação instituído pela Secretaria de Educação, eram elaborados os Planos de Trabalho das escolas com o objetivo de direcionar e integrar as ações dos profissionais, em resposta às demandas do grupo. No entanto, o resultado do percurso e os vínculos estabelecidos refletiam a organização, as prioridades e descobertas que alimentavam cada momento do grupo de trabalho. 


\subsubsection{A construção de uma proposta no acompanhamento do professor}

“(...) a visão ativa solitária da mente é extremamente equivocada - provavelmente uma projeção de nossa ideologia ocidental individualista. Nós não aprendemos um modo de vida e formas de empregar a mente sem auxílio, sem apoio, nus perante o mundo. E não é apenas a aquisição da linguagem que faz com que as coisas sejam assim, é o “toma lá, dá cá” da conversação que torna a colaboração possível. Pois a mente ativa não só é ativa por natureza, mas também busca o diálogo e o discurso com outras mentes, também ativas. E é por meio deste processo discursivo e de diálogo que passamos a conhecer o Outro e seus pontos de vista, suas histórias. Aprendemos muitíssimo não apenas sobre o mundo, mas sobre nós mesmos, pelo discurso com os outros.”

J. Bruner

Almejando encontrar saídas para os problemas que o ensino apresentava e direcionar uma política de valorização dos profissionais da educação, a gestão pública do município criou uma estrutura delegando às equipes técnicas a responsabilidade pela formação continuada do professor. Em se tratando da Educação Especial, a atuação das equipes agregava outro viés, ao levar em conta a necessidade de o profissional estar engajado na escola e, conseqüentemente, mais próximo do professor, o que, muitas vezes, estimulava a criação de falsas idéias sobre a impossibilidade de o professor enfrentar sozinho as situações envolvidas no campo da deficiência.

Historicamente construída no município, a Educação Especial criou um modelo de trabalho interdisciplinar instituindo nas unidades educacionais especializadas equipes técnicas que pudessem compartilhar com o professor a complexidade e heterogeneidade de sua “clientela",17.

\footnotetext{
${ }^{17}$ Terminologia utilizada para se referir à população-alvo da Educação Especial. O termo revela as concepções de deficiência, as quais dão ênfase aos encaminhamentos clínicos identificados como recurso necessário ao atendimento de uma "constituição orgânica deficitária". Entretanto, mesmo diante de uma nítida transformação nessas concepções mais organicistas, com relação à educação da pessoa com deficiência, o termo ainda é amplamente utilizado nos meios educacionais em geral.
} 
O enfoque clínico já não respondia às questões educacionais, exigindo um novo tipo de atuação. Essa mudança gradual e necessária trouxe para a equipe novos desafios, assumidos com mais força e clareza no período analisado pela pesquisa.

A mudança do modelo de atuação voltava-se para a sala de aula, já não mais centrado unicamente na criança, considerando como necessária a apropriação de conhecimentos que fornecessem mais clareza às complexas relações entre ensino, aprendizagem e desenvolvimento. Nessa correlação de fatores, já se admitia que os universos do professor e do aluno compartilham a construção do conhecimento e o processo de transformação dos sujeitos.

A adoção desses novos referenciais na orientação e formação do professor partia do princípio que os educadores necessitavam ter maior domínio sobre sua prática, compreender as dimensões da escolarização e dos determinantes que atuavam na constituição dos sujeitos. A Proposta Formativa aqui apresentada tem, sinteticamente, o objetivo de esclarecer a estrutura de trabalho que foi elaborada para compartilhar com o professor suas incertezas e reunir novas idéias sobre as práticas educativas.

Na elaboração do programa, era necessário considerar as demandas educativas e as condições do contexto que delimitavam os propósitos, princípios e detalhamento das etapas do projeto de trabalho. Sob essa ótica, o programa integrava ações no sentido de encontrar caminhos alternativos para fortalecer a construção do projeto pedagógico educacional, eixo vital da escola, sendo elas:

- a ação formativa concebida como processo de pesquisa e reflexão da práxis docente;

- a busca, na teoria, do sentido da prática;

- a compreensão do processo de ensino-aprendizagem como resultante da interrelação de vários sistemas, estudados por diversos campos teóricos, alimentando o conhecimento e a tomada de decisão pelo professor;

- a constituição da singularidade do sujeito e as diferentes formas de aprender e representar a realidade, refletindo suas necessidades, interesses e motivações. 


\subsubsection{Procedimentos para viabilizar a proposta}

O modelo de ação partilhada buscava imprimir uma nova concepção aos diferentes papéis (professor, orientador pedagógico, psicólogo, fonoaudiólogo, assistente social e terapeuta ocupacional), conferindo à atividade docente, parte essencial da relação, a autoria do processo educativo.

A abordagem teórico-metodológica assumida voltava-se para a valorização dos questionamentos e à proposição de aspectos que suscitassem a reflexão e aprofundamento das queixas do professor.

As observações, registros e relatórios elaborados nas diferentes atividades docentes e nas visitas realizadas à sala de aula pelos profissionais da equipe poderiam constituir-se em rico material de análise e reflexão. A sistematização das atividades, nesse contexto, pretendia levar o grupo à tomada de consciência sobre seus propósitos, tornando o registro de dados uma “marca” que, ao ser tematizada, abriria espaço para se reconsiderarem posições, conduzindo a uma revisão e reavaliação das práticas.

Nesse sentido, o caminho para a autonomia, trabalhoso exercício de abertura para o “outro”, não era muito fácil de ser conquistado. Em cada etapa, desde a elaboração do plano de trabalho, acompanhamento de projetos e registros de dados até a avaliação do processo coletivo, a participação do professor era necessária, mas nem sempre conquistada.

Diante dessas necessidades tão emergentes, buscou-se definir algumas metas que pudessem traduzir as dificuldades em respostas concretas ao trabalho docente, explicitadas a seguir:

Geral: Tematizar a prática docente, refletindo na e sobre a ação pedagógica, para que fossem construídos saberes que fundamentassem o trabalho.

\section{Específicas:}

1. Criar espaços de diálogo entre os educadores, valorizando o registro das situações vivenciadas como recurso de análise e reflexão;

2. Estabelecer relações entre a prática e as concepções que a fundamentam, subsidiando a análise da realidade; 
3. Avaliar o processo evolutivo das propostas e atividades planejadas, descobrindo o sentido despertado nas crianças e os efeitos em sua aprendizagem.

A organização das atividades mobilizando os profissionais da equipe a estabelecerem objetivos comuns e em sinergia parecia indispensável para que os diferentes momentos da ação pedagógica fossem partilhados. Portanto, era de vital importância o processo de elaboração, acompanhamento, avaliação e reconstrução do projeto pedagógico em conjunto com o professor, abertura que poderia propiciar a identificação dos efeitos provocados pelas propostas no desenvolvimento das aprendizagens dos alunos.

Isso significava que a tarefa dos profissionais deveria romper a grade que distanciava professores e equipes, o que tornava a parceria uma forma propícia de comunicação e investigação das condições e efeitos das práticas proporcionadas aos alunos.

\subsection{Programação}

A atuação da equipe no Projeto de Formação Docente ambicionava seguir um percurso que recuperasse a relação com o professor e a importância de utilizar a prática pedagógica como matéria-prima do processo formativo. Pretendia-se elaborar uma programação voltada às necessidades da escola e integrá-la ao Projeto Pedagógico Educacional (PPE), trazendo para discussão situações reais, de forma que o professor pudesse refletir sobre sua ação e elaborasse novos saberes para fundamentar seu trabalho.

De certa forma, essa experiência pretendia valorizar a "escuta"18 do professor, no entanto, para “se voltar para o outro”, deveria também ser ressignificado o papel de cada membro da equipe. O lugar ocupado por cada profissional não poderia partir de um "exercício teorizador”, com contribuições potenciais de seu campo de atuação. A idealização do lugar ocupado por cada um só se confirmaria na prática e a contribuição dos diferentes profissionais avaliava-se ser instrumento necessário para a construção de um trabalho conjunto. Os saberes necessários à atuação do professor exigiam conhecimentos construídos em parceria com diferentes áreas, portanto a execução dessa proposta não poderia prescindir do compromisso e

\footnotetext{
${ }^{18}$ O processo de "escuta” tem implicações importantes na identificação do "outro" como referencial do processo formativo.
} 
envolvimento dos profissionais na relação com o "outro", buscando a sintonia e reciprocidade de idéias.

A experiência de trocas entre educadores exigiria a retomada de alguns pontos:

- Quanto a equipe, integrada, poderia contribuir para a formação do professor sem submetê-lo a prescrições teóricas distantes de suas buscas?

- Quanto essa equipe “se escutava” e, nessa direção, adquiria capacidade para escutar o professor?

Essas inquietações provocavam uma conflagração de idéias nem sempre tomadas como as melhores condições existentes.

A avaliação dos projetos de trabalho e o diagnóstico da realidade da escola contribuíam para a definição das prioridades a serem estudadas pelo Plano de Ação da equipe que, teoricamente, deveria estar vinculado às metas e objetivos da unidade escolar, sinalizando para ações complementares e funcionando como um referencial do percurso a ser tomado pelos profissionais. As situações do cotidiano contribuíam para que a aproximação e o diálogo fossem concretizados, e as demandas do professor tornassem-se o foco estruturante ${ }^{19}$ da convergência de ações da equipe.

Concretamente, a responsabilidade pela formação e acompanhamento do professor ficava a cargo da equipe técnica, complementada pelas assessorias, além das ofertas de cursos planejados pela Secretaria de Educação para toda a rede de ensino municipal.

\subsection{Funcionamento da equipe}

As situações reais da sala de aula tornaram-se o campo de trabalho das atividades formativas e, para esse acompanhamento da equipe, era fundamental uma sistemática definida de ações e

\footnotetext{
${ }^{19}$ A pesquisadora denomina foco estruturante o ponto articulador entre as inúmeras ações da equipe, ou seja, a ênfase que deveria ser dada às situações, pelos profissionais, conferindo sentido e significado às propostas formativas. Definimos, portanto, foco estruturante como o alvo do trabalho que dirigia o entrelaçamento das elaborações da equipe, interligando o espectro de interpretações possíveis.
} 
procedimentos que oferecessem clareza ao processo a ser desenvolvido, remetendo progressivamente o grupo a uma visão mais completa da realidade.

A proposta estabelecida entre os profissionais das diferentes áreas (orientação pedagógica, psicologia, fonoaudiologia, serviço social e terapia ocupacional) não estava focada na criança isoladamente ou em situações estanques, mas na visão interdisciplinar do processo de escolarização da criança e na essência dos problemas observados pelo professor. Essa nova forma de pensar e organizar o trabalho da equipe procurava estruturar um planejamento focado na ação docente e, assim, obter mais dados para analisar e antever com o professor dificuldades e conflitos.

A rotina pedagógica como foco estruturante da convergência de múltiplos olhares não é uma abordagem comumente utilizada em atividades formativas. Do ponto de vista dessas abordagens, os conteúdos trabalhados nas formações vinculam-se, em geral, a um campo teórico com discursos isolados, alheios à realidade da escola. É conferida aos especialistas a competência de ditar caminhos avidamente incorporados pelos educadores como "benefício para todos os males”.

Nessa experiência, rompe-se com a cultura da importação de propostas prontas, priorizando o lugar de onde parte o grupo e o universo de saberes do professor como possibilidade de se repensar a prática.

A rotina estrutura-se de acordo com as atividades programadas para cada semana, exigindo uma troca constante de informações entre os integrantes da equipe, a fim de garantir a evolução das atividades, tais como:

- Elaboração do Plano de Ação Conjunta;

- Análise das situações em equipe, envolvendo complementação e aprofundamento da investigação;

- Contribuição com os fundamentos de cada área, na perspectiva de que a escola seja entendida em sua totalidade, envolvendo mais compreensão da subjetividade do professor e respeito à diversidade do aluno para a construção de novos modelos de ensino-aprendizagem;

- Avaliação periódica das atividades e objetivos. 


\subsection{Sistemática de atuação}

\subsection{Construção e viabilização do Projeto Pedagógico Educacional}

- Visitas à sala de aula e outros espaços educativos, mediante solicitação do professor ou como procedimento do profissional, no intuito de ampliar dados de análise;

- Elaboração de registros e propostas para subsidiar as reflexões;

- Disponibilidade para a escuta das situações emergenciais, conflitos, dúvidas e dificuldades;

- Problematização de temas que sirvam como ponto articulador de propostas e projetos;

- Pesquisa de material teórico, como base para as reflexões e elaboração de propostas;

- Organização de espaços formativos para tematizações que contribuam para a análise de experiências;

- Avaliação periódica das mudanças ocorridas no processo pedagógico e participação no grupo de formação.

\subsection{Interação: escola - família - comunidade}

- Construção de vínculos com a família, ajudando-a a compreender o horizonte de possibilidades da criança, minimizando seus temores quanto à escolarização;

- Criação de espaços de diálogo, vivências e orientação à comunidade, propiciando mais informações sobre a pessoa com deficiência;

- Organização de grupos de trabalho, estimulando pais e comunidade a participar das lutas e decisões de interesse coletivo da pessoa com deficiência.

\subsection{Construção de instrumentos de trabalho}

- Elaboração de pesquisas teórico-práticas que contribuam para ampliar a compreensão das condições dos alunos;

- Manutenção de diálogo com profissionais de outras instituições e clínicas que atuam com os alunos para complementação de dados; 
- Criação de oportunidades de formação intra-equipe para aprofundar o olhar sobre as reais necessidades do professor.

\subsection{O projeto em andamento}

\subsection{Primeira etapa: reconhecimento da realidade}

Trata-se do momento em que foram analisadas as condições do contexto escolar e suas diferentes dimensões que, direta e indiretamente, interferem no trabalho pedagógico. $\mathrm{O}$ diagnóstico coletivo, realizado ao final de cada ano letivo, era considerado um instrumento valioso que oferecia dados essenciais para o planejamento do trabalho.

Eram realizadas observações e intervenções na sala de aula com intuito de se aumentar a compreensão dos dados para auxiliar a reflexão do grupo.

Para tanto, os dados eram trabalhados mediante a análise de:

- Registros de aulas;

- Relatórios;

- Planos de trabalho;

- Avaliações semestrais contendo a evolução das atividades e do processo de aprendizagem do aluno;

- Entrevistas com educadores para aprofundamento das informações;

- Vivências de sensibilização e expressão das dificuldades.

A primeira fase do projeto tinha uma duração muito variável, dependendo da forma como transcorria o processo avaliativo no ano e o levantamento das prioridades a serem trabalhadas. Nas últimas reuniões pedagógicas do ano, eram realizadas avaliações das metas, envolvendo levantamento dos objetivos atingidos e análise das dificuldades. Muitas vezes, as avaliações exigiam novas análises no início do ano, dependendo da configuração do grupo, principalmente quando ocorriam contratações de professores exigindo capacitação. 


\subsection{Segunda etapa: estratégias de intervenção}

Esse momento caracterizava-se essencialmente na análise de dados para estabelecer relações entre as queixas, questionamentos, dificuldades registradas pelo professor e situações observadas quanto às manifestações dos alunos e o percurso da proposta de trabalho. Os procedimentos priorizavam o trabalho em grupo, entretanto, dependendo da situação, as trocas eram individuais.

A sistematização dos dados buscava transformar as situações em hipóteses que oferecessem material de reflexão sobre a ação pedagógica, buscando fundamentos teóricos que pudessem explicá-las. Por outro lado, era importante que, a cada novo projeto elaborado, algumas questões fossem esclarecidas quanto à natureza da proposta e àquilo que se intencionava construir com as atividades pedagógicas:

- O que se quer desenvolver? Que objetivos estão envolvidos na atividade?

- Quem são os alunos envolvidos nas propostas e atividades? Suas necessidades educativas estão sendo contempladas?

- Como serão conduzidas as atividades para despertar mais interesse e impacto na aprendizagem?

- Quais os caminhos alternativos? Que estratégias pedagógicas favorecem a aprendizagem para diferentes crianças? Que experiências de aprendizagem podem estimular os alunos, de acordo com seu potencial, a suplantar bloqueios?

Com esses questionamentos, tornava-se importante identificar quanto as propostas educativas estavam sendo planejadas, considerando a singularidade dos alunos e a peculiaridade dos caminhos a serem percorridos em função das necessidades educativas de cada um.

\subsection{Terceira etapa: elaboração de propostas}

Tendo-se como foco a compreensão do sentido e significado que as atividades despertam nos alunos, procurava-se, nessa etapa, chegar à "raiz" das situações apontadas como difíceis de serem resolvidas, ou seja, o eixo da discussão estava vinculado à idéia de que o fazer 
pedagógico deveria pautar-se na clareza de objetivos, resgatando a totalidade e complexidade das situações educativas.

Era necessário resgatar as peculiaridades do cenário, ressaltando aspectos que se articulassem a outros dados para orientar a análise das situações problematizadas. Para tanto, haveria necessidade de registros claros e detalhados sobre as intervenções do professor e as transformações ocorridas nas situações de aprendizagem e, para isso, a sala de aula deveria ser espaço de estudo da equipe. Pensar em resultados desejáveis para o processo educativo deveria partir da apropriação do espaço escolar, local onde as relações reflexivas poderiam situar os profissionais e promover a conscientização dos fenômenos, a internalização de conhecimentos e a criação de novos caminhos intencionalmente planejados. Os procedimentos poderiam incluir:

- Análise dos questionamentos, reconstruindo as situações a partir dos registros existentes;

- Reflexões voltadas a estabelecer uma ponte com as concepções teóricas, fundamentando a prática;

- Elaboração de propostas coerentes com as concepções e idéias refletidas.

Nesse aspecto, poderiam ser encontradas condições para se desvendar o que, para Vygotsky (2003), significou a tarefa essencial na abordagem das funções psicológicas: estudá-las no processo de mudanças, em todas as suas fases, para que sua essência fosse compreendida. Do ponto de vista do autor, a gênese dos processos psicológicos está pautada nas relações sociais; a mediação intencional da escola das práticas educativas e das experiências coletivas em que a criança está imersa exerce um papel essencial em seu desenvolvimento psicológico. Portanto, no que concerne aos encaminhamentos do processo formativo, as tematizações da prática docente podem ter sido determinantes para o professor, segundo a concepção históricocultural, na criação de condições favoráveis à mudança.

\subsection{Quarta etapa: discussão avaliativa}

As propostas eram discutidas no intuito de que fossem gerados novos projetos de trabalho e se confirmasse a evolução do desenvolvimento do aluno. A partir dos dados levantados, 
analisados e refletidos com os educadores, as ações dessa fase concretizavam a autoria do professor em confrontar dados e identificar pontos que se complementassem, para definir novas etapas dos Projetos e Planos de Trabalho.

Colocava-se como recurso a valorização da ação pedagógica sistemática consciente e intencional, contribuindo para o permanente desenvolvimento do sujeito, agente de uma história peculiar. As diferenças entre os sujeitos não deveriam ser consideradas como barreiras para se atingir "pontos de chegada”, mas uma referência para o "ponto de partida”.

A avaliação do Projeto de Trabalho compreendia itens referentes aos objetivos traçados no Projeto Pedagógico Educacional (PPE) da escola, anualmente. A ênfase na participação do sujeito nas atividades pretendia identificar, na interação grupal, um fator que refletisse os múltiplos aspectos determinantes do envolvimento do aluno na aprendizagem. Nesse item, encontram-se vários fatores interligados, que poderiam demonstrar os mecanismos internos à atividade pedagógica, comprometendo a participação e o não aproveitamento escolar. Por outro lado, a presença de dados registrando o tipo de organização e a sistemática da rotina pedagógica refletiria a compreensão que o professor possuía sobre a importância do planejamento e da intencionalidade das propostas pedagógicas.

Alguns pontos desvelavam mais claramente as condições que estariam gerando mudanças ou provocando resistências na proposta.

\section{EVIDÊNCIAS PARA ANÁLISE AVALIATIVA}

Relacionadas ao aluno:

- Presença de condições favoráveis à participação ativa do aluno no grupo;

- Presença de condições desfavoráveis à participação ativa do aluno no grupo.

\section{Relacionadas à ação docente:}

- Registros evidenciando rotina escolar com mais organização e diversidade de propostas;

- Registros evidenciando desajuste da rotina escolar, refletindo no empobrecimento das propostas. 
Analisada no item Contextualizando a educação no município (ver Apêndice A), a trajetória da equipe da Educação Especial não foi linear e progressiva. Desse processo, emergiram situações conflitantes voltadas às dificuldades de ordem administrativa e pedagógica, quanto ao número de profissionais das equipes, muitas vezes, insuficiente para o trabalho formativo. Nesse contexto, as condições necessárias para a educação das pessoas com deficiência sempre exigiram discussões e uma rigorosa negociação, por parte da gestão pública, dirigida à manutenção dos compromissos e permanência dos recursos educacionais especializados, aspecto este amplamente defendido por profissionais e pela própria comunidade escolar. Nesse enfrentamento, sempre foi marcante a mobilização de uma parcela dos pais mais atuantes, revelando seu poder de argumentação e conquista.

Todas as produções desse grupo deram-se num contexto em que educadores, funcionários, gestores e pais relacionavam-se uns com os outros de maneira bem peculiar, levando sua contribuição para a escola. De certa forma, esse movimento coletivo refletia positivamente nos educadores, fortalecendo sua atuação diante das dificuldades aparentemente insuperáveis, tais como: a não participação de muitos pais; pouco apoio dos gestores; divergências entre educadores; temores frente à aprendizagem dos alunos; dilemas frente à própria atuação profissional; inconstância de recursos; poucos horizontes profissionais para os alunos; lutas constantes por melhores condições de ensino, muitas vezes, não totalmente compreendidas.

Foram sinais que despertaram no grupo a importância da ação coletiva, refletindo nas decisões e propostas a partir da organização, sistemática de atuação e enfrentamento dos desafios, tendo como alicerce o projeto pedagógico educacional. 


\section{Capítulo III \\ METODOLOGIA}

“[...] partimos da neutralidade pretendida, passamos à não neutralidade reconhecida, ou até suportada, para chegarmos à não-neutralidade valorizada. A não-neutralidade valorizada é o reconhecimento do eu como objeto de pesquisa possível, porque, na verdade, o eu somos nós.”

Magda Soares

\subsection{Opção metodológica}

A análise desta proposta de formação continuada, desenvolvida com professores em parceria com as equipes técnicas, foi realizada tendo como base dados expressos pelas educadoras que vivenciaram essa proposta formativa.

Por serem mais apropriados aos objetivos da investigação, os procedimentos teóricometodológicos pautaram-se pela modalidade qualitativa caracterizada, segundo Lüdke e André (2004), pelo caráter dinâmico e ativo das interações estabelecidas entre pesquisador e pesquisados, para a compreensão das múltiplas relações que emergiram no contexto estudado. Conforme admitem essas autoras, o papel do pesquisador é o de servir como "veículo inteligente e ativo” entre os conhecimentos acumulados e os novos dados coletados. Segundo Alves (1991), o pesquisador revela-se como o principal e mais confiável instrumento de pesquisa, por sua capacidade de adaptação e, justamente, pelo conhecimento e domínio da área, auxiliando-o na leitura dos dados coletados.

Diante dessas questões, e principalmente pelo envolvimento da pesquisadora com o objeto de estudo - do qual fez parte constituindo esse um cenário impregnado de significados -, o delineamento da pesquisa exigiu alguns cuidados, como circunscrever o campo de estudo e destacar alguns pontos que pudessem prevenir ambigüidades ou possíveis posicionamentos parciais, obtidos por meio de recortes subjetivos.

A fonte de dados, essencial para elucidar o ocorrido na prática pedagógica das professoras participantes da experiência, foi o resgate dos aspectos que permaneceram em suas memórias e a releitura que faziam dessa experiência. 
Reconhecendo, como assinalam Bogdan e Biklen (1994), a importância dos dados descritivos, coletados por meio de entrevistas e questionários, buscou-se apreender o maior número possível de detalhes dessa experiência e de seus significados para cada uma das participantes, e como esses significados interferiram em suas interações educacionais cotidianas, posteriores à experiência.

A coleta de dados foi realizada por meio de entrevistas gravadas e posteriormente transcritas. A análise requereu uma abordagem metodológica que permitisse apreender o significado desse cenário para cada uma das participantes. “Ao considerar os diferentes pontos de vista dos participantes, os estudos qualitativos permitem iluminar o dinamismo interno das situações, geralmente inacessível ao observador externo” (LÜDKE e ANDRÉ, 2004, p. 12).

As situações reconstruídas pela pesquisadora, dos dados coletados, objetivaram adquirir informações com uma pluralidade de pontos de vista que descortinassem na análise os efeitos provocados pelos programas formativos, mesmo que as educadoras admitissem ter vivenciado situações muito semelhantes. Lahire (1997, p. 36;39) afirma que:

\begin{abstract}
Existem sempre, em cada ser social, em qualquer grau, competências, maneiras de ser, saber e habilidades, ou esboços de disposições delineadas, porém não atualizadas em algum momento da ação, ou, em algum momento da vida, que podem ser postas em ação em outros momentos, em outras circunstâncias [...], o microscópio investigativo possibilita identificar a heterogeneidade daquilo que presumimos terem efeitos homogêneos.
\end{abstract}

Nessas condições, a análise dos dados registrados preservou a riqueza de conteúdo subjetivo, considerando o contexto e o conjunto de interações que complementavam as informações e formas de pensar dos professores sobre as vivências na formação continuada. Segundo o mesmo autor, os comportamentos singulares só podem ser explicados se forem levadas em consideração as situações em sua totalidade, como uma "rede de interdependência” construída a partir das relações sociais, seja de forma harmoniosa ou contraditória.

O significado atribuído pelos sujeitos às suas experiências e a análise realizada pela pesquisadora são as fontes da pesquisa. Cada interpretação abre-se para novos conhecimentos que, ao serem partilhados entre as pessoas, compõem novas interpretações e significados. 
Nessa perspectiva, como afirma Machado (2004, p. 70), “conhecer é como enredar, tecer significações, partilhar significados”.

Esse tratamento metodológico de resgate de uma prática fundamentada a partir do depoimento de professoras que a vivenciaram, constituiu o estabelecimento de um "fio condutor" de nexos que apontaram, no contexto vivido, ganhos, limites e novas questões a serem estudadas.

Diferentes campos teóricos correlacionados foram consultados para ampliar a compreensão do tema em estudo, contribuindo também para a elaboração dos instrumentos de investigação (roteiro das entrevistas ${ }^{20}$, questionário de identificação das participantes e seleção dos documentos institucionais).

Na análise, o roteiro da entrevista, levando em consideração os objetivos da investigação, e também um conjunto de pontos básicos que refletissem as experiências formativas vivenciadas pelas participantes constituíram o primeiro nível de categorização.

O segundo nível de categorização resultou de diferentes elos do "Esboço Teórico"21, concebido para a realidade estudada, referente a questões ligadas ao:

- “saber” (dimensão epistemológica) - referências quanto às concepções que fundamentam a prática das professoras entrevistadas;

- “ser professor” (dimensão ontológica) - referências quanto à percepção que cada uma possui de seu papel profissional e o conhecimento das condições que permeiam seu agir individual, singular;

- “fazer” (dimensão praxiológica) - referências quanto à tomada de decisão na condução do trabalho e da ação pedagógica: como cada entrevistada reflete, analisa e reconstrói sua prática.

\footnotetext{
${ }^{20}$ Criamos um esquema semi-estruturado, como é assinalado por Lüdke e André (2004, p. 34), a fim de fornecermos mais liberdade ao diálogo entre entrevistador e entrevistado. Algumas questões balizadoras foram criadas, possibilitando, assim, intervenções mais livres, sem uma seqüência rígida, que serviram de estímulo à narrativa das professoras.

${ }^{21} \mathrm{O}$ esboço teórico (Anexo $\mathrm{n}^{\circ}$. 1) idealizado pela pesquisadora, representando uma estrutura formativa constituída pela relação dinâmica entre diferentes dimensões, está baseado nos fundamentos de Nóvoa (1995) para uma Teoria de Formação do Professor.
} 
Atentando-se aos objetivos da pesquisa, houve o cuidado com a amplitude das questões, a forma como foi conduzida a entrevista, a elaboração da pergunta. "Saber perguntar”, segundo Fazenda (2001), envolve uma arte, de natureza não apenas de âmbito cognitivo e racional, voltar-se para aspectos da singularidade de cada um dos sujeitos, como expressa Lahire (1997, p. 32), com um questionamento discreto:

Deslocando o olhar para os casos particulares, ou melhor ainda, para a singularidade evidente de qualquer caso a partir do momento em que se consideram as coisas no detalhe, o sociólogo mostra aquilo que os modelos teóricos fundados no conhecimento estatístico e na linguagem de variáveis ignoravam ou pressupunham [...].

A abordagem qualitativa permitiu transitar na realidade pesquisada com mais clareza contextual, partindo da história concreta dos educadores participantes. Eisner e Peshkin (1990), em publicação sobre a pesquisa qualitativa em educação, admitem que os estudos qualitativos conseguem dar transparência à capacidade do ser humano para julgar e avaliar, exigindo do pesquisador mais atenção aos detalhes expressos: coerência, encadeamento das idéias, habilidade para captar o “expresso” e o “subexpresso”, ou seja, idéias subjacentes nem sempre tão claras.

Suficientemente abrangente, essa abordagem ofereceu uma oportunidade para a pesquisadora interagir com as pesquisadas, possibilitando que mergulhasse nas peculiaridades por elas expressas, estimulando um movimento dialético de diálogo da participante com suas próprias idéias.

A pesquisa qualitativa, segundo Lahire (1997, p. 33):

[...] procura sublinhar a importância de se levarem em consideração situações singulares, relações efetivas entre os seres sociais interdependentes, formando estruturas particulares de coexistência ("uma família”) em vez de correlações entre variáveis que são recomposições sociológicas de realidades sociais às vezes "fortes" demais, desestruturantes demais ou abstratas demais para compreender certas modalidades do social e, com isso, certos aspectos das realidades sociais em seu conjunto. 
A opção pela metodologia qualitativa nesta investigação, reiterando esse autor, está necessariamente ligada à natureza do objeto em estudo e aos contextos envolvidos: a partir dos depoimentos das educadoras, compreender em que medida a vivência da formação docente teoricamente fundamentada conseguiu atender às necessidades educativas de suas práticas pedagógicas.

Está implícita, nesta proposta de investigação, a crença de que ao expressarem suas experiências, argumentos, valores, modo de pensar e agir, as participantes da pesquisa estariam revelando um conjunto de significados pessoais fortemente marcados pela cultura. (Cf. BRUNER, 1997). Assim sendo, ao se estabelecerem relações entre processos singulares dos indivíduos e processos sociais, abandona-se o distanciamento entre o indivíduo e a sociedade ou entre o objetivo e o subjetivo (Cf. SATO e SOUZA, 2001).

Mediante essa interação entre a micro e a macro-realidade escolar, entre a escola e seu entorno, poder-se-ia desvelar a complexidade das situações do cotidiano das educadoras em sua singularidade, sem perder a visão do todo.

A relevância da pesquisa fundamentada na Interdisciplinaridade (Cf. FAZENDA, 2001) repousa na valorização das experiências obtidas pelo pesquisador, mediante trabalho conjunto, que se abre ao conhecimento dos fenômenos analisados por uma multiplicidade de saberes. Uma realidade complexa, um contexto de relações dinâmico, um conjunto de ações permanentemente em transformação não se conhece, na concepção de Thiollent (1982), “a partir de uma fotografia instantânea”. O diálogo construído entre pesquisador e os sujeitos participantes permitiu que esse encontro não fosse uma simples somatória de informações, exigindo cuidados para alcançar o que permaneceu das principais idéias dessa caminhada.

Frente ao imprescindível debate quanto à proximidade da pesquisadora de seu objeto de estudo, é preciso explicitar que a posição ocupada por ela foi a de assumir uma consciência reflexiva, ao dialogar com as educadoras participantes da investigação; ao cuidar que expressões, interações, acontecimentos recuperados não perdessem a sua inteireza; ao analisar detalhes, no tempo presente, sobre o que interagiu e influenciou suas práticas. 
A proximidade da pesquisadora com as pesquisadas foi projetando um conjunto de dados com novos significados, emergindo uma realidade social que não é dada e acabada. Nesse sentido, “o pesquisador não pode ser um observador imparcial situado fora da situação que ele analisa” (OLIVEIRA e OLIVEIRA, 1985, p. 23).

Sem perder seu papel e sem se distanciar dos objetivos propostos, a pesquisadora buscou interpretar criticamente o sentido dos relatos, reconhecendo que ao participar do mesmo universo de experiências dos sujeitos, a complexidade da tarefa foi ainda maior. A interação estabelecida nesse período com as educadoras participantes envolvendo motivações, interesses e posições subjetivas puderam elucidar com mais clareza o conjunto de representações e comportamentos, muitas vezes expressos de forma vaga e pouco clara, sem fragilizar a cientificidade dos dados ou incorrer em distorções.

O fato de a pesquisadora estar imersa no cotidiano das participantes e na situação vivida pode tornar a realidade menos impenetrável, incoerente, incompreensível. É possível, segundo Oliveira e Oliveira (1985), criar condições de forma que pesquisador e participantes ajudemse mutuamente, tomem distância da realidade vivida e, diante dela, "possam, discutindo-a, decifrá-la e agir sobre ela” (IBID, 1985, p. 32).

\subsection{Sujeitos da pesquisa}

As educadoras que fizeram parte da pesquisa foram selecionadas mediante critério de participação na experiência, de forma duradoura, no período proposto para análise (1996 a 2003). Foram escolhidas aquelas cujas atividades profissionais não tinham sido interrompidas por freqüentes ausências, fossem por licenças ou por afastamentos, e que tinham mantido um vínculo mais permanente com uma mesma escola e equipe técnica.

Nessa perspectiva, os critérios de inclusão dos sujeitos foram:

- Participação constante dessas professoras no processo formativo e nas reuniões, o que implicava amplo conhecimento da proposta;

- Interesse em participar da pesquisa;

- Representatividade de diferentes áreas da deficiência. 
Considerou-se que, no conjunto, essas professoras pudessem documentar um maior número possível de aspectos desse processo formativo. Cada uma delas fez uma leitura subjetiva da maneira peculiar como cada grupo, em cada escola, desenvolveu essa experiência com seu grupo de trabalho. Essas educadoras, embora envolvidas com o mesmo projeto, advinham de contextos educativos variados, o que, em sua essência, configurava uma dinâmica bem peculiar, refletindo a heterogeneidade dos espaços onde exerciam suas funções.

Assim, os dados puderam ser gerados de forma mais variada e abrangente, reunindo uma pluralidade de informações que propiciaria captar, no âmbito do contexto escolar, o "ser professor”, o “fazer pedagógico” e o domínio do “saber”, da formação recebida naquele período. Propiciaria retomar fatores peculiares determinantes do processo de construção de cada experiência em particular, tonalizadas pelo contexto coletivo, como aponta Fazenda (2003a, p. 75):

[...] uma prática individual bem sucedida contextualiza-se em determinada história de vida particular, que por sua vez é produzida em um determinado espaço e num tempo historicamente determinado. A história atual de uma determinada prática só pode ser revelada em sua complexidade quando investigada em suas origens de tempo e espaço - por isso a importância fundamental de que o pesquisador da prática investigue a mesma não só em sua ação imediata, tal como ela aparentemente se revela, mas permita-se compreender os condicionantes históricos que a determinaram. (grifos da autora)

Nas páginas a seguir, apresentamos os quadros-resumo contendo dados dos sujeitos entrevistados. 


\section{SUJEITO DA PESQUISA}

1. Identificação: Beija-Flor

\begin{tabular}{|c|c|}
\hline Idade & 46 \\
\hline Área de atuação & Escola Especial Múltiplas Deficiências /Inclusão \\
\hline Formação & Pedagogia \\
\hline Ano de conclusão & 1984 \\
\hline Habilitação & Deficiência Mental \\
\hline Instituição & Instituição Particular \\
\hline Tempo de atuação na instituição & 24 anos \\
\hline $\begin{array}{l}\text { Ano de ingresso na Rede } \\
\text { Municipal }\end{array}$ & 1983 \\
\hline $\begin{array}{l}\text { Outras habilitações/ } \\
\text { especializações }\end{array}$ & $\begin{array}{c}\text { Administração, Orientação e Supervisão Escolar; } \\
\text { Magistério } 1^{\mathrm{a}} \text { a } 4^{\mathrm{a}} \text { série }\end{array}$ \\
\hline Outros cursos & $\begin{array}{c}\text { Desenvolvimento Infantil; Distúrbios Globais do } \\
\text { Desenvolvimento etc. }\end{array}$ \\
\hline $\begin{array}{l}\text { Obras, autores, publicações que } \\
\text { contribuíram para a formação }\end{array}$ & $\begin{array}{l}\text { Educação Especial (falta algo aqui) Estimulação } \\
\text { Precoce: uma introdução à obra de Feuerstein; A } \\
\text { inteligência e os déficits intelectuais - Gunnar } \\
\text { Kyien; Psicologia da Educação - Cesar Coll; } \\
\text { Avaliação e Intervenção em Multideficiências - } \\
\text { MEC, entre outros }\end{array}$ \\
\hline
\end{tabular}




\begin{tabular}{|c|c|}
\hline \multicolumn{2}{|c|}{ SUJEITO DA PESQUISA } \\
\hline 2. Identificação: Manoela & \\
\hline Idade & 56 \\
\hline Área de atuação & $\begin{array}{c}\text { Escola Especial } \\
\text { Múltiplas Deficiências }\end{array}$ \\
\hline Formação & Letras / Pedagogia \\
\hline Ano de conclusão & 1979 / 1984 \\
\hline Habilitação & Deficiência Mental \\
\hline Instituição & USP \\
\hline Tempo de atuação na instituição & 33 anos \\
\hline $\begin{array}{c}\text { Ano de ingresso na Rede } \\
\text { Municipal }\end{array}$ & 1974 \\
\hline $\begin{array}{l}\text { Outras habilitações/ } \\
\text { especializações }\end{array}$ & $\begin{array}{l}\text { Administração e } \\
\text { Supervisão Escolar } \\
1^{\circ} \text { e } 2^{\circ} \text { graus }\end{array}$ \\
\hline Outros cursos & $\begin{array}{l}\text { Indisciplina Escolar; Distúrbios Globais } \\
\text { do Desenvolvimento; Inclusão; Aspectos } \\
\text { Neurológicos da Aprendizagem etc. }\end{array}$ \\
\hline $\begin{array}{l}\text { Obras, autores, publicações que } \\
\text { contribuíram para a formação }\end{array}$ & $\begin{array}{c}\text { Marcos Mazzotta, Vitor da Fonseca, Emília } \\
\text { Ferreiro, Ana Teberosky, Vygotsky, Wallon, } \\
\text { Piaget, entre outros }\end{array}$ \\
\hline
\end{tabular}




\begin{tabular}{|c|c|}
\hline \multicolumn{2}{|c|}{ SUJEITO DA PESQUISA } \\
\hline \multicolumn{2}{|l|}{ 3. Identificação: Ana } \\
\hline Idade & 35 \\
\hline Área de atuação & Classe Integrada / Inclusão \\
\hline Formação & Pedagogia \\
\hline Ano de conclusão & 1997 \\
\hline Habilitação & Deficiência Mental \\
\hline Instituição & Instituição Particular \\
\hline Tempo de atuação na instituição & 9 anos \\
\hline $\begin{array}{c}\text { Ano de ingresso na Rede } \\
\text { Municipal }\end{array}$ & 1998 \\
\hline $\begin{array}{l}\text { Outras habilitações/ } \\
\text { especializações }\end{array}$ & \\
\hline Outros cursos & $\begin{array}{l}\text { Desenvolvimento Infantil; Distúrbios Globais do } \\
\text { Desenvolvimento; Alfabetização - PROFA; } \\
\text { Desenvolvimento Neurológico etc. }\end{array}$ \\
\hline $\begin{array}{l}\text { Obras, autores, publicações que } \\
\text { contribuíram para a formação }\end{array}$ & $\begin{array}{c}\text { Vygotsky, Paulo Freire, Piaget, Zabala, entre } \\
\text { outros }\end{array}$ \\
\hline
\end{tabular}




\begin{tabular}{|c|c|}
\hline \multicolumn{2}{|c|}{ SUJEITO DA PESQUISA } \\
\hline \multicolumn{2}{|l|}{ 4. Identificação: Maria } \\
\hline Idade & 47 \\
\hline Área de atuação & Centro de Apoio-Estimulação Essencial/Inclusão \\
\hline Formação & Pedagogia \\
\hline Ano de conclusão & 1977 \\
\hline Habilitação & Deficiência Mental \\
\hline Instituição & USP \\
\hline Tempo de atuação na instituição & 7 anos \\
\hline $\begin{array}{c}\text { Ano de ingresso na Rede } \\
\text { Municipal }\end{array}$ & 1994 \\
\hline $\begin{array}{l}\text { Outras habilitações/ } \\
\text { especializações }\end{array}$ & Supervisão Escolar \\
\hline Outros cursos & $\begin{array}{l}\text { Desenvolvimento Infantil; Distúrbios Globais do } \\
\text { Desenvolvimento; Formação Básica em } \\
\text { Deficiência Física; Síndrome de Down etc. }\end{array}$ \\
\hline $\begin{array}{l}\text { Obras, autores, publicações que } \\
\text { contribuíram para a formação }\end{array}$ & $\begin{array}{c}\text { Obras versando sobre Educação Especial, } \\
\text { Múltiplas Deficiências, Desenvolvimento e } \\
\text { Aprendizagem, Distúrbios Globais do } \\
\text { Desenvolvimento }\end{array}$ \\
\hline
\end{tabular}




\begin{tabular}{|c|c|}
\hline \multicolumn{2}{|c|}{ SUJEITO DA PESQUISA } \\
\hline \multicolumn{2}{|l|}{ 5. Identificação: Luísa } \\
\hline Idade & 35 \\
\hline Área de atuação & Centro Apoio / Inclusão \\
\hline Formação & $\begin{array}{l}\text { Tiflopedagogia } \\
\text { Psicopedagogia }\end{array}$ \\
\hline Ano de conclusão & 1996 \\
\hline Habilitação & Deficiência Visual \\
\hline Instituição & $\begin{array}{c}\text { Russian State Pedagogical University named A.I. } \\
\text { Hertzen }\end{array}$ \\
\hline Tempo de atuação na instituição & 7 anos \\
\hline $\begin{array}{l}\text { Ano de ingresso na Rede } \\
\text { Municipal }\end{array}$ & 2000 \\
\hline $\begin{array}{l}\text { Outras habilitações/ } \\
\text { especializações }\end{array}$ & Psicopedagogia \\
\hline Outros cursos & $\begin{array}{c}\text { Desenvolvimento Infantil; Distúrbios Globais de } \\
\text { Desenvolvimento; Surdocegueira e Múltipla } \\
\text { Deficiência; Comunicação Alternativa; } \\
\text { Avaliação Funcional da Visão; Paulo Freire: } \\
\text { Teoria e Práxis; Políticas e Organização da } \\
\text { Educação Básica; Direitos Humanos e Educação } \\
\text { para Paz; Currículo Funcional e Ecológico; } \\
\text { Orientação e Mobilidade; PROFA; } \\
\text { Psicopedagogia }\end{array}$ \\
\hline $\begin{array}{l}\text { Obras, autores, publicações que } \\
\text { contribuíram para a formação }\end{array}$ & $\begin{array}{c}\text { Vygotsky, Paulo Freire, Davidov, Leontiev, } \\
\text { Adorno, entre outros }\end{array}$ \\
\hline
\end{tabular}




\begin{tabular}{|c|c|}
\hline \multicolumn{2}{|c|}{ SUJEITO DA PESQUISA } \\
\hline \multicolumn{2}{|l|}{ 6. Identificação: Bianca } \\
\hline Idade & 53 \\
\hline Área de atuação & Escola Especial para Surdos \\
\hline Formação & Pedagogia \\
\hline Ano de conclusão & 1980 \\
\hline Habilitação & Deficiência Auditiva \\
\hline Instituição & PUC/SP \\
\hline Tempo de atuação na instituição & 25 anos \\
\hline $\begin{array}{c}\text { Ano de ingresso na Rede } \\
\text { Municipal }\end{array}$ & 1982 \\
\hline $\begin{array}{l}\text { Outras habilitações/ } \\
\text { especializações }\end{array}$ & $\begin{array}{c}\text { Magistério de Matérias Pedagógicas de } 2^{\circ} \text { Grau e } \\
\text { LIBRAS (FENEIS) }\end{array}$ \\
\hline Outros cursos & $\begin{array}{l}\text { Desenvolvimento Infantil; Escrita como segunda } \\
\text { língua do surdo, entre outros }\end{array}$ \\
\hline $\begin{array}{l}\text { Obras, autores, publicações que } \\
\text { contribuíram para a formação }\end{array}$ & $\begin{array}{c}\text { Cecília Moura, Carlos Skliar, Wilma Favorito, } \\
\text { Zilda Gesueli, entre outros }\end{array}$ \\
\hline
\end{tabular}




\section{SUJEITO DA PESQUISA}

7. Identificação: Larissa

\begin{tabular}{|c|c|}
\hline Idade & 46 \\
\hline Área de atuação & Escola Especial para Surdos \\
\hline Formação & Pedagogia \\
\hline Ano de conclusão & 1983 \\
\hline Habilitação & Deficiência Auditiva \\
\hline Instituição & FMU/SP \\
\hline Tempo de atuação na instituição & 25 anos \\
\hline $\begin{array}{l}\text { Ano de ingresso na Rede } \\
\text { Municipal }\end{array}$ & 1982 \\
\hline $\begin{array}{l}\text { Outras habilitações/ } \\
\text { especializações }\end{array}$ & Psicopedagogia \\
\hline Outros cursos & $\begin{array}{l}\text { Ed. Surdos, LIBRAS, Aquisição do Português } \\
\text { como segunda língua }\end{array}$ \\
\hline $\begin{array}{l}\text { Obras, autores, publicações que } \\
\text { contribuíram para a formação }\end{array}$ & $\begin{array}{c}\text { Carlos Skliar, Cecilia Moura, Wilma Favorito, } \\
\text { Zilda Gesueli, entre outros }\end{array}$ \\
\hline
\end{tabular}

Foram entrevistadas sete professoras especializadas. A presença de educadores exclusivamente do sexo feminino reflete a realidade do quadro da Educação, integrado quase na totalidade pelo sexo feminino e ocupado na Educação Especial, pelo sexo masculino, apenas em áreas específicas, como Educação Física.

Trata-se de professoras entre 35 e 56 anos; duas solteiras, duas divorciadas e três casadas; quatro delas não têm filhos e as demais, entre um e dois filhos; formadas em pedagogia com habilitação em deficiência mental, auditiva e visual, quatro delas trabalham com deficiência mental, duas na área de deficiência auditiva e uma na área de deficiência visual, áreas em que atuam desde o ingresso na rede de ensino público municipal de São Bernardo do Campo. 
Suas atividades docentes são desenvolvidas em escolas especiais para múltiplas deficiências (Manoela e Beija-Flor), em escola para alunos com surdez (Bianca e Larissa), em classe integrada no ensino fundamental (Ana), em centros de apoio de Estimulação Essencial e para alunos com deficiência visual (Maria e Luísa, respectivamente), atuando também como professoras itinerantes, no acompanhamento aos alunos incluídos na rede regular de ensino, infantil e fundamental.

Além dessas especializações, algumas delas possuem outras habilitações - supervisão, orientação e administração escolar - duas delas, além da Pedagogia, possuem curso de LIBRAS fornecido pela FENEIS; uma delas cursou Psicopedagogia e outra, além da Pedagogia, cursou Letras.

Quanto à formação e qualificação profissional, revelam preferencialmente uma busca por cursos e leituras que lhes ofereçam habilidades específicas, necessárias à sua área de atuação, principalmente diante das preocupações em estarem bem preparadas para atuarem com alunos com múltiplas deficiências. Entretanto, algumas assinalaram também buscarem temas e conteúdos que ampliassem a visão de educação e de referenciais mais atualizados sobre leitura e escrita.

De um modo geral, as educadoras parecem ter se mantido em constante formação, quer seja por meio de cursos oferecidos pela administração pública municipal, quer seja por iniciativa própria, a fim de se atualizarem. Nos questionários, fazem referência a cursos que tratam sobre os grandes conflitos e contradições da sala de aula, relativos às problemáticas emocionais e de comportamento do aluno. Com relação às leituras, destacam-se obras de autores que enfocam questões relacionadas aos problemas de aprendizagem, distúrbios globais do desenvolvimento, alfabetização e conhecimentos específicos ligados aos eixos curriculares.

Esses aspectos revelam que, para essas educadoras, a busca por formação representa uma parte importante de seu percurso. O tempo de exercício profissional nas unidades escolares varia de 7 a 33 anos, sendo que quatro delas em jornada integral, três em jornada simples na prefeitura e uma delas leciona, além do ensino municipal, na rede estadual. É marcante o fato de as entrevistadas terem um tempo de permanência duradouro nas escolas em que trabalham, não tendo sido registrada nenhuma transferência de unidade. 


\subsection{Fontes, procedimentos e instrumentos de coleta de dados}

\subsubsection{Fontes e instrumentos de coleta de dados}

A elaboração dos instrumentos considerou a necessidade de criar situações favoráveis à manifestação e expressão das participantes para que fossem recuperadas as vivências de um contexto formativo, ainda muito presente em suas vidas.

Sendo assim, atribuiu-se às informações fornecidas pelos educadores o principal instrumento de análise, na medida em que revelavam pontos de vista enunciados pelos próprios protagonistas das situações em estudo. A “voz" do professor e sua subjetividade transformaram-se em fonte valiosa de informações dos fenômenos estudados - projeto que ele próprio contribuiu para sua construção. Sua visão crítica, motivações e interesses dão um contorno à "realidade percebida como totalidade presente, universo de significados, fonte de múltiplos sentidos” (GAMBOA, 1989, p. 106).

Os dados foram coletados de documentos oficiais e por meio de dois instrumentos, elaborados com o objetivo de levantar aspectos da vivência formativa das participantes e suas concepções.

- Questionário: com objetivo de obter um delineamento do perfil das professoras entrevistadas, contém dados de identificação sobre elas, tais como: idade, sexo, estado civil, etnia, formação acadêmica, atuação profissional, tempo de experiência, jornada de trabalho e informações referentes à sua participação em atividades e cursos de formação (Anexo $n^{\circ}$. 3). Aplicado apenas aos sujeitos participantes, como instrumento complementar à entrevista.

- Entrevista a partir de um roteiro, envolvendo um elenco de aspectos que permitiram à pesquisadora situar os tópicos essenciais à análise dos resultados desse processo, ao mesmo tempo em que permitiram a manifestação das idéias das entrevistadas, constituindo-se recurso desencadeador de dados fundamentais para o aprofundamento

\footnotetext{
${ }^{23}$ Aparelho utilizado: W-10 Hardware Digital Voice.
} 
de temas centrais propostos na experiência. O esquema elaborado para condução das entrevistas (Anexo $\mathrm{n}^{\circ} .4$ ), apoiadas na relação entrevistador e entrevistado, mantidas em forma de diálogo, permitiu que fossem feitas adaptações, quando necessárias, considerando algumas preocupações apontadas por Lüdke e André (2004, p. 35), respeitando-se o universo próprio de quem fornece as informações, opiniões, impressões, enfim, todo o material em que a pesquisa está interessada.

- Documentos Institucionais da Secretaria de Educação e Cultura, dentre eles, os mais significativos para o estudo:

> Caderno de Metas do Departamento de Ações Educacionais, referentes a 2001, 2002 e 2003;

Proposta Curricular.

Nesses dois últimos documentos estão registrados os princípios e diretrizes educativas que nortearam a construção do Projeto Político-Pedagógico e delinearam as metas e estrutura do Programa de Formação Docente, detalhado e desenvolvido pelas unidades escolares, envolvendo professores e equipe técnica. São documentos avaliados anualmente por todos os segmentos e programas, onde estão registrados o desenvolvimento das atividades, os resultados conquistados e as prioridades a serem consideradas, na criação de recursos para sua implantação.

Buscaram-se, assim, dados que oferecessem condições para se obter o domínio do objeto a ser pesquisado e as pessoas envolvidas tivessem oportunidade de falar sobre seu contexto profissional, sem crivos ou seleções de dados.

\subsubsection{Procedimentos}

As participantes foram informadas previamente dos objetivos da pesquisa e da organização formal do trabalho, quer seja: horários, local da atividade, procedimentos e recursos a serem utilizados, principalmente referentes à entrevista, considerada o instrumento central da pesquisa e à utilização de gravações em áudio ${ }^{23}$, preservando o direito de anonimato aos entrevistados. 
Nessa oportunidade, foram esclarecidas dúvidas, possibilitando às educadoras inteirarem-se das finalidades do estudo, principalmente quanto à sua participação e ao controle das informações que estariam fornecendo, tendo contato com a transcrição, quando então poderiam se assegurar da exatidão dos dados, havendo possibilidade de estarem fazendo uma autocorreção, melhorando dados que admitissem terem sido pouco esclarecidos em seu depoimento, já que a compreensão da realidade vivida por elas e as controvérsias tão presentes, com todas suas sutilezas, não poderiam ser mal interpretadas.

Para um melhor entendimento do trabalho, colocamos à disposição dos diretores e dos participantes o resumo do projeto de pesquisa, que lhes ofereceu mais dados e, assim, puderam estabelecer seus questionamentos com relação à contribuição que avaliaram ter condições de fornecer à investigação.

Foi explicitado também o papel da pesquisadora, tendo em vista sua proximidade com as participantes, estabelecida no período em que ocupou o cargo de chefe da Educação Especial, coordenando as equipes técnicas, como também no período em que foi membro da equipe.

Nesse sentido, tais aspectos mereceram cuidados, principalmente porque estavam envolvidos sentimentos e vínculos profissionais muito particulares a cada uma e representações que impunham considerar, com muita clareza, questões que pudessem interferir na confiança que estaria sendo ali depositada. De certa forma, esse duplo papel, como educadora e pesquisadora, como já foi analisado nesta dissertação, não poderiam limitar a capacidade de resposta favorável deste trabalho em relação aos interesses e seriedade da pesquisa e suscitar ambigüidades que comprometessem o enriquecimento do material.

As entrevistas foram agendadas previamente com a direção da escola e realizadas no próprio local de trabalho das entrevistadas, sendo que cada uma teve oportunidade de programar a melhor data, de forma que não interferisse na rotina escolar nem nas atividades com os alunos. 
O local reservado para as entrevistas, cedido pelas diretoras das escolas onde as professoras exercem suas atividades, proporcionou condições para que fosse gravada, com certa tranqüilidade, a coleta de dados.

Foi solicitado que cada participante respondesse ao questionário e somente os sujeitos envolvidos na pesquisa responderam às questões.

A partir dos pressupostos estabelecidos nos tópicos a serem explorados na entrevista, optou-se por deixar que cada participante se manifestasse mais livremente, oportunidade de contato privilegiado para expressar naturalmente suas considerações sobre a experiência vivida, sendo formulada uma questão desencadeadora, dessa interação: “O que você destacaria em sua trajetória como tendo sido determinante na formação continuada em serviço, desenvolvida em parceria com a equipe interdisciplinar?”.

Essa questão funcionou como recurso balizador frente ao fenômeno analisado, mesmo sabendo-se da impossibilidade de serem estabelecidos padrões de equivalência e que cada entrevista tomaria caminhos bem específicos

Os tópicos complementares foram planejados somente com o intuito de estimular a entrevistada a aprofundar sua análise e buscar “dados" e "fatos" 25 esclarecedores do sentido e significado das "narrativas”, na perspectiva do "narrador”. Foram possibilidades de estar colhendo, das impressões e fatos evocados pelas entrevistadas, a "fisionomia dos acontecimentos”, o que, na visão de Bosi, representam aspectos para sua própria análise e interpretação (BOSI, 1994, p. 59).

\footnotetext{
${ }^{25}$ Comumente utilizamos a expressão "dados” em vez de "fatos”, mas, segundo Sato e Souza (2001, p. 43), “é necessário refletir sobre elas”. Segundo o dicionário Aurélio, o "dado" é algo que se "dá”, "o que se apresenta à consciência como imediato, não construído ou não elaborado"; "fato" designa "coisa ou ação feita; caso, acontecimento feito". É interessante observar o contraste apontado por Sato e Souza entre os dois termos. No primeiro, as autoras referem-se a uma concepção de realidade - o realismo -, pautada na visão de Hammersley (1992, apud SATO e SOUZA, 2001), que adota a idéia de que existe uma realidade independente ao pesquisado, cuja natureza pode ser conhecida, e que o objetivo do pesquisador é produzir relatos que correspondam àquela realidade.

Já no segundo termo, as autoras consideram que o construtivismo, ao admitir a idéia de que "as pessoas constroem o mundo social", tanto por meio de suas interpretações como das ações baseadas nessas interpretações, estaria mais voltado a utilizá-lo. Entendemos, todavia, que tanto o pesquisador quanto os participantes de pesquisas se submetem a diferenciadas condições em que "dados" inicialmente prontos vão sendo trabalhados, interpretados, "significados" e compreendidos como "fatos" contextualizados e com a tonalidade de quem os estuda intensivamente. Ambos, na medida em que olham os acontecimentos, constroem "fatos". Ambos falam, interpretam ou deixam de falar e interpretar devido às concepções prévias ou criadas no decorrer da investigação (Ibid, 2001).
} 
As participantes foram estimuladas a falar da experiência vivida, na qual estiveram envolvidas entre os anos de 1996 a 2003, período considerado representativo para serem compreendidas as condições e os determinantes envolvidos nesse percurso, ligados à formação continuada em serviço, nas unidades escolares.

\subsubsection{Registros de dados}

As entrevistas duraram, em média, 1 hora e meia, tendo despertado grande interesse nas participantes, que demonstraram confiança e disposição em contribuir com o relato de suas experiências. No total, foram 15 horas de gravação, transcritas por uma profissional especializada. Esse material escrito, associado às gravações de áudio, forneceu dados valiosos para a interpretação das nuances expressas.

Recuperar dados vividos desencadeou nas participantes preocupações quanto à clareza dos depoimentos; relatar suas impressões mobilizou-as a desenvolver uma análise investigativa sobre a própria prática, avaliando a sua coerência e as condições em que foi construída, conferindo-lhe significados.

Surgiu, durante as entrevistas, uma multiplicidade de questões, de conhecimentos incorporados, alongando cada entrevista, como um espaço de releitura das situações mais significativas.

Foi possível construir, nas entrevistas, um contexto interativo entre pesquisadora e entrevistada, pautado na manutenção de um clima receptivo e aberto às colocações das participantes. Criou-se também a oportunidade singular para as participantes articularem diferentes dados de uma temporalidade marcante para suas vidas, levando em consideração a diversidade de experiências provenientes de espaços educativos tão diferentes e, em especial, por terem vivenciado uma complexa interação com diferentes áreas do conhecimento, representadas pelos profissionais que compunham as equipes técnicas das unidades escolares. 


\subsubsection{Análise de dados}

"Chega mais perto e contempla as palavras. Cada uma tem mil faces secretas sob a face neutra e te pergunta, sem interesse pela resposta, pobre ou terrível, que lhe deres:

Trouxeste a chave?”

Carlos Drummond de Andrade

A pesquisadora, de posse do expresso pelas educadoras, fez sua leitura estabelecendo relações e dando forma, como quem faz o movimento em um jogo de peças a serem conectadas, atraídas pelo sentido observado e revelado pelos sujeitos em um processo de intersubjetivação desses conteúdos.

Houve, nesse aspecto, um movimento para tornar claro e desvelar os conteúdos, compreendêlos e interpretá-los. Cuidados foram tomados para que as visões de mundo, homem e realidade e as concepções prévias, ou mesmo as construídas pela pesquisadora no decorrer do estudo, não interferissem na compreensão e análise dos dados. Consistiu uma abordagem de “captar os significados atribuídos pelos participantes” (ALVES, 1991, p. 59), segundo essa autora, essencialmente hermenêutica.

Coerentemente com a fundamentação do capítulo I, buscou-se estruturar o Plano de Análise realizando-o em três etapas:

\section{Etapa 1 - Primeira categorização das entrevistas}

A - Definição das categorias:

Foi realizada a partir da retomada dos objetivos e das perguntas das entrevistas, voltadas para obter respostas a esses objetivos. O estabelecimento dessas categorias como referencial para a análise das entrevistas constituiu-se em etapa cuidadosa para tornar mais objetivo este processo. Foram arroladas 8 categorias, que chamaremos de Categorias Descritivas, baseadas nos tópicos das entrevistas, conforme segue:

- Pontos determinantes da experiência;

- Transformações na atuação que perduram; 
- Contribuições e falhas da experiência;

- Condições que favoreceram a relação com o aluno e a intervenção;

- Condições que possibilitaram trocas e conhecimento interdisciplinar;

- Relação com o aluno com deficiência, impasses instaurados;

- Concepções de deficiência;

- Referenciais teóricos que ajudaram no manejo do cotidiano escolar.

B - Categorização dos dados das entrevistas:

A categorização dos dados das entrevistas foi realizada por meio de leitura exaustiva e minuciosa das entrevistas, verificando, na transcrição, a elegibilidade e coerência do material escrito, eliminando expressões e pausas desnecessárias, que viessem a dificultar a compreensão das idéias narradas.

A partir daí, buscou-se complementá-las com os dados do áudio e com as anotações da pesquisadora, feitas durante a entrevista. Mais do que identificar a densidade de conteúdos, a finalidade foi reconhecer, nos dados expressos e nas opiniões das educadoras, os sentidos atribuídos às situações.

Dessa forma, os dados, um a um, foram sendo organizados a partir das categorias, realizando as conexões com os tópicos contidos no roteiro. Foi um procedimento cuidadoso, que exigiu tempo e muito critério para que os itens fossem enumerados e recortados, de acordo com o objetivo da pesquisa. Devido ao grande volume de dados, não podíamos correr o risco de interpretar as afirmações deslocadamente e não retirar das informações o conteúdo pertinente aos diferentes tópicos propostos no roteiro.

C - Organização, em quadros, dos dados categorizados:

Objetivando auxiliar a visualização das afirmações das participantes, procuramos compor os depoimentos da forma mais completa possível, para se obter, a partir desses quadros, um panorama mais integrado dos temas abordados pelas entrevistadas em cada item formulado na entrevista, sem ignorar a peculiaridade de cada uma delas. Diante dessa organização do conteúdo, procuramos levantar “o que a entrevistada mostrou com o dado” e, a partir dele, 
fazer algumas inferências e interpretações dos significados que cada uma deu às questões abordadas.

Com essa organização, buscamos nos apropriar melhor do conjunto de informações produzidas e, ao lê-las e relê-las, delinear o posicionamento de cada entrevistada. De posse de todo material produzido, o passo seguinte foi abordá-lo de forma integrada, buscando ressaltar os significados convergentes, estabelecendo comentários que fornecessem uma compreensão de como as educadoras interagiram com as situações, naquele contexto específico.

\section{Etapa 2 - Segunda categorização das entrevistas}

A - Definição das categorias:

Os dados analisados foram retomados e submetidos a uma segunda categorização, objetivando analisar, sob outro prisma, a existência de transformações provocadas no âmbito do "ser professor", do "saber” e do "fazer pedagógico", tendo como referencial teórico as concepções da psicologia histórico-cultural e da Formação Docente, numa perspectiva críticoreflexiva da prática, proposta por Nóvoa (1995, 1999, 2000), articuladas às idéias sobre Interdisciplinaridade em que transversalizam essas concepções, apresentadas no capítulo I.

Daí considerar a necessidade de serem criadas três novas categorias, que chamaremos de Categorias Conceituais, delineadas para sistematizar o conteúdo das entrevistas, a partir dos referenciais dessa vertente epistemológica apontada na configuração teórica (Anexo n. 1):

- Percepção e sentimentos das educadoras em relação ao papel profissional que exerciam no projeto pedagógico: referindo-se aos processos que interferem e produzem o "ser professor" (dimensão ontológica), ou seja, as condições que permeiam seu agir individual, singular, nutrindo sua vida como profissional;

- Idéias e concepções sobre a pessoa com deficiência e seu modo de conhecer, que embasaram a prática do educador: referindo-se aos processos que fundamentam o seu “saber” (dimensão epistemológica), ou seja, as concepções que fundamentam a prática das professoras entrevistadas; 
- Práticas docentes incorporadas: referindo-se aos processos que abordam o fazerpedagógico (dimensão praxiológica), ou seja, a tomada de decisão na condução do trabalho: como as entrevistadas refletem, analisam e reconstroem sua prática.

Os dados foram então classificados de acordo com essas novas categorias estabelecidas, envolvendo todos os depoimentos e buscando integrá-los, a partir da convergência das manifestações referentes ao “ser”, ao “fazer” e ao “conhecer” das professoras entrevistadas.

\section{Etapa 3 - Reflexão sobre os dados analisados}

Buscamos, à luz dos referenciais teóricos da fundamentação que norteou o trabalho, relacionar esses dois grupos de dados categorizados, refletindo os sentidos e significados fornecidos pelas entrevistadas, que traduzem as transformações ocorridas, em sua formação, a partir da proposta vivenciada.

\subsection{Dialogando com os dados}

"Mire veja: o mais importante e bonito do mundo é isto: que as pessoas não estão sempre iguais, ainda não foram terminadas - mas que elas vão sempre mudando. Afinam ou desafinam. Verdade maior. É o que a vida me ensinou. Isso me alegra, montão.”

João Guimarães Rosa

São apresentados, nas páginas a seguir, os dados analisados das informações fornecidas pelas entrevistadas, conforme seqüência abaixo.

Quadro I - Categorização da entrevista de Beija-Flor

Quadro II - Categorização da entrevista de Manoela

Quadro III - Categorização da entrevista de Ana

Quadro IV - Categorização da entrevista de Maria

Quadro V - Categorização da entrevista de Luísa

Quadro VI - Categorização da entrevista de Bianca

Quadro VII - Categorização da entrevista de Larissa 


\subsubsection{Quadros da primeira categorização ${ }^{26}$}

Quadro I - Categorização da entrevista de Beija-Flor

\begin{tabular}{|c|c|c|}
\hline $\begin{array}{l}\text { Categorias } \\
\text { descritivas }\end{array}$ & O que a entrevistada mostrou & Interpretação \\
\hline $\begin{array}{l}\text { Pontos } \\
\text { determinantes } \\
\text { da experiência }\end{array}$ & $\begin{array}{l}\text { Ter tido com a equipe a "possibilidade } \\
\text { de abordar várias questões, } \\
\text { relacionadas à criança e de olhá-la de } \\
\text { diferentes ângulos ..., ampliando } \\
\text { conhecimentos sobre como se } \\
\text { relacionar com o aluno, discutidos por } \\
\text { vários profissionais... traçar um } \\
\text { caminho. ... eu elaborava o que mais } \\
\text { interessava para meus alunos....". }\end{array}$ & $\begin{array}{l}\text { Ter sido ouvida na equipe, } \\
\text { ampliando conhecimentos } \\
\text { para atendimento dos alunos, } \\
\text { com mais autonomia. }\end{array}$ \\
\hline $\begin{array}{l}\text { Transformações } \\
\text { na atuação que } \\
\text { perduram }\end{array}$ & $\begin{array}{l}\text { Ter aprendido, compartilhando com os } \\
\text { profissionais, a desenvolver um } \\
\text { trabalho de conquista e estabelecer } \\
\text { parceria com o professor do ensino } \\
\text { regular; a compreender a família; a } \\
\text { interpretar um diagnóstico e ver as } \\
\text { possibilidades da criança, o seu } \\
\text { potencial, e como desenvolver } \\
\text { estratégias que a desafiassem. “Mudou } \\
\text { meu jeito de olhar para o aluno... } \\
\text { descobrindo possibilidades que eu não } \\
\text { acreditava... Ver a criança por inteiro } \\
\text { e perceber que mesmo nas trocas de } \\
\text { fralda... é um espaço pedagógico, } \\
\text { porque... eu falo, aconchego... consigo } \\
\text { ter esta tranqüilidade hoje porque eu } \\
\text { tive esta formação anterior". }\end{array}$ & $\begin{array}{l}\text { Ter aprendido a: ver o } \\
\text { pedagógico, compreender as } \\
\text { dificuldades do professor na } \\
\text { escola regular; acolher a } \\
\text { família; descobrir que cada } \\
\text { criança é uma e requer a } \\
\text { elaboração de um trabalho } \\
\text { diferenciado para ela acessar } \\
\text { suas possibilidades. }\end{array}$ \\
\hline $\begin{array}{l}\text { Aspectos que } \\
\text { contribuíram } \\
\text { para a atuação } \\
\text { como docente }\end{array}$ & $\begin{array}{l}\text { Ter adquirido autonomia, maior } \\
\text { responsabilidade para trabalhar e ter } \\
\text { uma equipe unida para essas trocas. } \\
\text { "Isso foi um diferencial que } \\
\text { possibilitou que o meu profissional } \\
\text { crescesse como professora." }\end{array}$ & $\begin{array}{l}\text { Ter crescido, participando de } \\
\text { uma equipe que contribuiu } \\
\text { com conhecimentos e apoio, } \\
\text { adquirindo autonomia e } \\
\text { responsabilidade. }\end{array}$ \\
\hline $\begin{array}{l}\text { Principais } \\
\text { falhas } \\
\text { observadas }\end{array}$ & $\begin{array}{l}\text { Dificuldades, “... faltava tempo para } \\
\text { discutir o suficiente... refletir, fazer } \\
\text { material, mas a gente tinha subsídios e } \\
\text { sabia onde procurar. Às vezes, a } \\
\text { equipe não conseguia andar como }\end{array}$ & $\begin{array}{lr}\text { Dificuldades } & \text { para } \\
\text { consecução do } & \text { planejado: } \\
\text { falta de } & \text { tempo; } \\
\text { heterogeneidade } & \text { de } \\
\text { condições dos } & \text { profissionais } \\
\end{array}$ \\
\hline
\end{tabular}

${ }^{26}$ Nos quadros das entrevistas, procuramos compor os depoimentos de forma mais completa possível. Contudo, para se obter um panorama mais integrado dos temas abordados pelas entrevistadas, foram feitos recortes, indicados por meio de reticências entre colchetes, sem, entretanto, comprometer a compreensão do exposto e ignorar a peculiaridade de cada entrevista realizada. Nos casos em que houve pausas nas falas das entrevistadas ou expressões incompletas, foram utilizadas apenas reticências. 


\begin{tabular}{|c|c|c|}
\hline & $\begin{array}{l}\text { planejava, muitas demandas... alguns } \\
\text { profissionais só conseguiam caminhar } \\
\text { com uma coordenação mais direta, } \\
\text { ficando, às vezes, à margem de muitas } \\
\text { coisas... tínhamos profissionais mais e } \\
\text { outros menos compromissados... acho } \\
\text { que não se tinha maturidade para o } \\
\text { trabalho complementar... outros } \\
\text { sabiam trabalhar muito mais } \\
\text { centrados na sua área, mas... havia } \\
\text { uma cumplicidade,... não parecia tão } \\
\text { compartimentado... a decisão era } \\
\text { sempre centrada, na pedagogia... as } \\
\text { discussões aconteciam com a } \\
\text { participação das diferentes áreas”. }\end{array}$ & $\begin{array}{l}\text { da equipe; necessidade de } \\
\text { direcionamento ou de nível } \\
\text { de envolvimento com o } \\
\text { grupo/interesse; tendência a } \\
\text { agir voltado para o seu saber } \\
\text { específico. }\end{array}$ \\
\hline $\begin{array}{l}\text { Condições que } \\
\text { favoreceram a } \\
\text { relação com o } \\
\text { aluno e a } \\
\text { intervenção }\end{array}$ & $\begin{array}{l}\text { Ter sido interessante estar com a } \\
\text { equipe "atuando lado a lado, como } \\
\text { professor coordenador ... pude } \\
\text { contribuir com a minha experiência } \\
\text { como professor, e os profissionais } \\
\text { entenderam melhor o lado do } \\
\text { professor e se apropriaram também da } \\
\text { dinâmica da sala de aula, para } \\
\text { compartilhar estes momentos com o } \\
\text { professor... O planejamento era } \\
\text { cuidadoso, refletido com uma nova } \\
\text { forma de ver a criança". Ter } \\
\text { momentos de trocas com profissionais } \\
\text { específicos, ora com a equipe toda, } \\
\text { "para, dentro da sala de aula, } \\
\text { trabalhar com a gente... recordo das } \\
\text { discussões e como foi rico este } \\
\text { período... isso não acontece só de } \\
\text { ouvir... e decidir mudar. Você escuta, } \\
\text { discute, reflete, atua e diante das } \\
\text { dificuldades que podem sempre } \\
\text { ocorrer, você tematiza algo mais } \\
\text { específico para seu aluno". }\end{array}$ & $\begin{array}{l}\text { Atividades individuais e } \\
\text { coletivas como contextos de } \\
\text { aprendizagem, valorizando o } \\
\text { processo formativo, de } \\
\text { reflexão e planejamento; } \\
\text { proximidade da equipe com } \\
\text { as experiências do professor, } \\
\text { propiciando nova visão da } \\
\text { sala de aula e do aluno. }\end{array}$ \\
\hline
\end{tabular}




\begin{tabular}{|c|c|c|}
\hline $\begin{array}{l}\text { Condições que } \\
\text { possibilitaram } \\
\text { trocas } \\
\text { conhecimento } \\
\text { interdisciplinar }\end{array}$ & $\begin{array}{l}\text { Que o apoio da equipe foi muito } \\
\text { importante no acompanhamento às } \\
\text { escolas regulares: "Nós tínhamos estes } \\
\text { momentos de desabafos, de trocas. As } \\
\text { discussões aconteciam com as } \\
\text { diferentes áreas e isto ampliava muito } \\
\text { nosso conhecimento sobre } \\
\text { aprendizagem, sobre a criança." Que } \\
\text { o diagnóstico da criança não era } \\
\text { compreendido como estudo rotulativo: } \\
\text { "ele funcionava como desencadeador } \\
\text { de uma análise sobre as necessidades } \\
\text { educativas da criança, ajudava o } \\
\text { professor com informações iniciais } \\
\text { sobre os recursos necessários para o } \\
\text { trabalho". "[...] abria-se um leque de } \\
\text { possibilidades, compartilhando } \\
\text { discussões teóricas e sobre a prática." } \\
\text { Que, a partir dessas trocas, foi possível } \\
\text { criar-se "um referencial de } \\
\text { intervenção das professoras } \\
\text { itinerantes para subsidiar nosso } \\
\text { trabalho no regular". Que, diante do } \\
\text { crescimento do Programa de Inclusão, } \\
\text { foi necessário "um trabalho novo com } \\
\text { os professores que iam chegando para } \\
\text { o grupo, pois muitos nunca tinham } \\
\text { dado aula para uma criança com } \\
\text { deficiência, sem experiência no } \\
\text { Especial e nem no Regular". Em } \\
\text { duplas, os professores mais antigos do } \\
\text { Especial ajudavam os mais novos. Que } \\
\text { a equipe mediou discussões com } \\
\text { diretores e professores sobre } \\
\text { "adaptação curricular, atitudes frente } \\
\text { ao aluno e à família e até questões } \\
\text { estruturais, tais como espaço para o } \\
\text { professor ser ouvido e falar de seus } \\
\text { alunos... redução de número de alunos } \\
\text { nas salas, auxiliar de salas... etc.". }\end{array}$ & $\begin{array}{l}\text { As condições destacadas } \\
\text { referem-se } \\
\text { estabelecimento de um } \\
\text { trabalho colaborativo, no } \\
\text { qual parceiros mais } \\
\text { experientes partilhavam suas } \\
\text { idéias, no intuito de somar } \\
\text { conquistas e dividir } \\
\text { dificuldades. Destacam-se, } \\
\text { também, os espaços de } \\
\text { construção coletiva para } \\
\text { análise das situações do } \\
\text { contexto educativo, tendo-se } \\
\text { como base a teoria. }\end{array}$ \\
\hline
\end{tabular}




\begin{tabular}{|c|c|c|}
\hline $\begin{array}{l}\text { Relação com o } \\
\text { aluno com } \\
\text { deficiência, } \\
\text { impasses } \\
\text { instaurados }\end{array}$ & 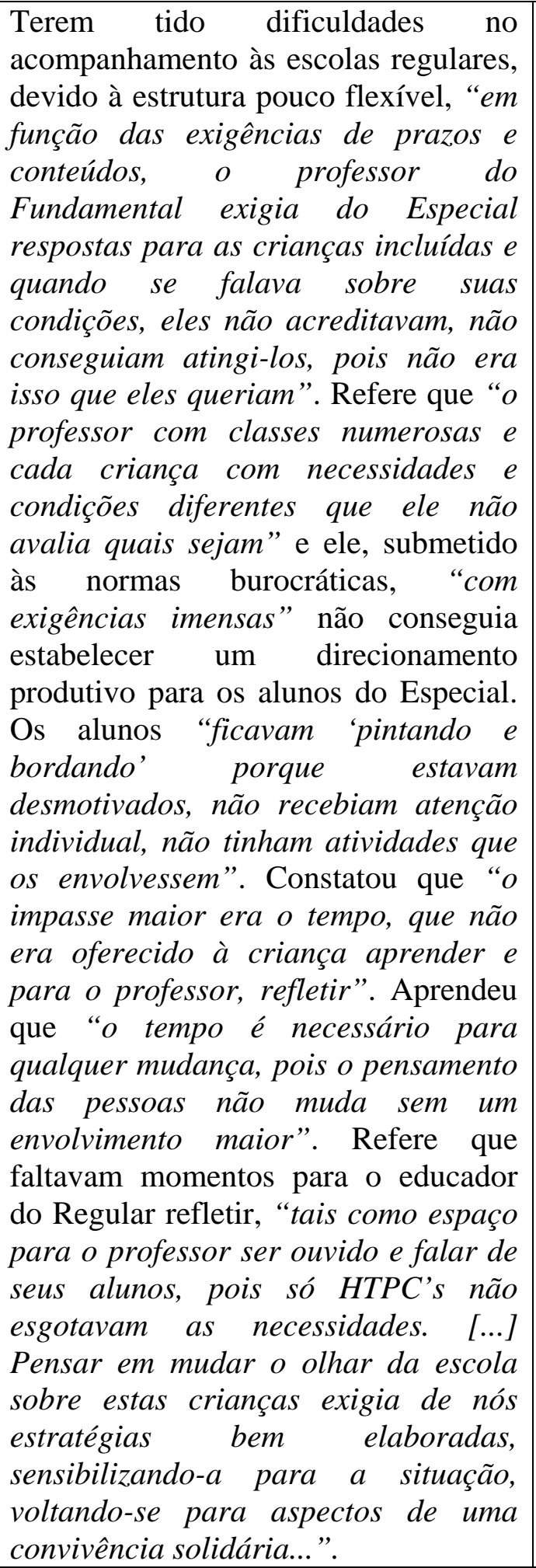 & $\begin{array}{l}\text { Dificuldades enfrentadas } \\
\text { com os alunos: desinteresse, } \\
\text { desmotivação e problemas de } \\
\text { caráter comportamental } \\
\text { estavam relacionados } \\
\text { diretamente às condições da } \\
\text { estrutura e organização } \\
\text { institucional do Ensino } \\
\text { Regular, que estabelecia } \\
\text { padrões curriculares e de } \\
\text { avaliação muito distantes da } \\
\text { realidade do aluno com } \\
\text { deficiência, impondo ao } \\
\text { professor conteúdos e prazos } \\
\text { impossíveis de serem } \\
\text { cumpridos em uma escola } \\
\text { que pretendia ser inclusiva. } \\
\text { O depoimento mostra que } \\
\text { coexistiam a essas condições } \\
\text { o despreparo do professor em } \\
\text { lidar com esse alunado e uma } \\
\text { falta de sintonia dos gestores } \\
\text { em abrir espaços formativos } \\
\text { mais voltados às } \\
\text { necessidades docentes e dos } \\
\text { alunos. }\end{array}$ \\
\hline
\end{tabular}




\begin{tabular}{|c|c|c|}
\hline $\begin{array}{l}\text { Concepções de } \\
\text { deficiência }\end{array}$ & $\begin{array}{l}\text { Destaca que aprendeu com a equipe a } \\
\text { ver por trás das manifestações da } \\
\text { criança "potencialidades } \\
\text { possibilidades... e procurar novos } \\
\text { caminhos, para ela, fazendo } \\
\text { intervenções que a desafiassem". Que } \\
\text { por meio da formação, onde esses } \\
\text { temas eram tratados, aprendeu a olhar } \\
\text { sua transformação, "ele sabia algumas } \\
\text { coisas e iria aprender algumas } \\
\text { comigo, mas depois eu vi que ele tinha } \\
\text { possibilidades imensas, e aí a gente } \\
\text { vai apontando isso com um trabalho } \\
\text { diferenciado, pois cada criança é uma } \\
\text { criança". Que cada uma tem o seu } \\
\text { ritmo de aprendizagem, que nem } \\
\text { sempre é respeitado, admitindo que } \\
\text { “todo mundo tem que saber aquilo e } \\
\text { em determinada época”. }\end{array}$ & $\begin{array}{l}\text { Evidencia-se como ponto de } \\
\text { destaque uma visão na qual } \\
\text { se coloca ênfase nas } \\
\text { possibilidades de } \\
\text { transformação da criança e a } \\
\text { condição singular de cada } \\
\text { sujeito, manifestada por um } \\
\text { modo peculiar de aprender, } \\
\text { nem sempre considerado } \\
\text { pelas práticas educativas, que } \\
\text { devem mobilizar o aluno à } \\
\text { aprendizagem e dinamizar } \\
\text { seu desenvolvimento. }\end{array}$ \\
\hline \begin{tabular}{lr}
\multicolumn{2}{l}{ Referenciais } \\
teóricos & que \\
ajudaram & no \\
manejo & do \\
cotidiano & \\
escolar &
\end{tabular} & $\begin{array}{l}\text { Aprender a relacionar os fundamentos } \\
\text { teóricos com a realidade. } \\
\text { “Conseguíamos vincular teoria e a } \\
\text { prática, voltadas para a sala de aula, } \\
\text { discutindo propostas e estudos de } \\
\text { caso, descobrindo, enfim, o aluno." } \\
\text { Que a escolarização da criança, na } \\
\text { perspectiva de um processo igualitário } \\
\text { e cidadão, precisa criar condições } \\
\text { educacionais que possam oferecer “o } \\
\text { máximo de coisas, que ela possa estar } \\
\text { ganhando, ou seja... estar mais atenta, } \\
\text { mais acordada, mais alimentada, mais } \\
\text { aconchegada... com estímulos visuais, } \\
\text { sensoriais”. Que conseguiu } \\
\text { compreender a importância de se ter } \\
\text { uma visão da família como parceira e } \\
\text { não como um grupo que só “tem que } \\
\text { fazer tarefas... que o professor } \\
\text { manda”. }\end{array}$ & $\begin{array}{l}\text { Orientações } \\
\text { incorporadas por meio de } \\
\text { discussões coletivas entre } \\
\text { professores e assessoria, } \\
\text { repensando o fazer cotidiano } \\
\text { e compreendendo } \\
\text { significado das propostas } \\
\text { oferecidas à criança. } \\
\text { O significado da escola deve } \\
\text { revestir-se de valores que } \\
\text { reconheçam a importância da } \\
\text { apropriação de } \\
\text { conhecimentos } \\
\text { possibilitem que } \\
\text { desenvolvimento da criança. } \\
\text { Valorização da família como } \\
\text { participante ativa do } \\
\text { processo educacional. }\end{array}$ \\
\hline
\end{tabular}


Quadro II - Categorização da entrevista de Manoela

\begin{tabular}{|c|c|c|}
\hline $\begin{array}{l}\text { Categorias } \\
\text { descritivas }\end{array}$ & O que a entrevistada mostrou & Interpretação \\
\hline $\begin{array}{l}\text { Pontos } \\
\text { determinantes } \\
\text { da experiência }\end{array}$ & $\begin{array}{l}\text { Ter tido a colaboração da equipe, quando } \\
\text { solicitada "sempre trazia acréscimos à } \\
\text { prática... possibilitando tomar novas } \\
\text { decisões, descobrir novos caminhos no } \\
\text { modo de agir"; a troca de experiências } \\
\text { entre os profissionais contribuía para o } \\
\text { desenvolvimento de “um pensamento } \\
\text { mais autônomo". }\end{array}$ & $\begin{array}{l}\text { Com a colaboração da } \\
\text { equipe, foi possível } \\
\text { compreender as situações } \\
\text { do cotidiano escolar e } \\
\text { definir rumos apropriados } \\
\text { para sua prática, com mais } \\
\text { autonomia. }\end{array}$ \\
\hline $\begin{array}{l}\text { Transformações } \\
\text { na atuação que } \\
\text { perduram }\end{array}$ & $\begin{array}{l}\text { Ter-se apropriado de concepções e de } \\
\text { novas abordagens teóricas “acerca do } \\
\text { desenvolvimento e da aprendizagem, de } \\
\text { conteúdo psiquiátrico e referente às } \\
\text { relações interpessoais...”, contribuindo } \\
\text { para que adquirisse “um novo olhar sobre } \\
\text { os alunos”. Admite que “a educação está } \\
\text { em constante movimento, não pára, e } \\
\text { você vai adquirindo estas aprendizagens } \\
\text { e trazendo para frente”. }\end{array}$ & $\begin{array}{l}\text { Apropriação de concepções } \\
\text { que ampliaram sua visão } \\
\text { sobre o aluno, a deficiência } \\
\text { e a educação e sobre esse } \\
\text { dinamismo. }\end{array}$ \\
\hline $\begin{array}{l}\text { Aspectos que } \\
\text { contribuíram } \\
\text { para a atuação } \\
\text { como docente }\end{array}$ & $\begin{array}{l}\text { Ter, a experiência partilhada com a } \\
\text { equipe, possibilitado "tomar decisões, } \\
\text { intervir, refletir, compreender, organizar, } \\
\text { transformar, enriquecendo minha prática } \\
\text { e me tornando um educador mais } \\
\text { comprometido"; trazido retornos } \\
\text { positivos: “... incentivada... naturalidade } \\
\text { com o outro, você troca... tudo flui... as } \\
\text { pessoas se aproximam... rende muito } \\
\text { mais” ; a equipe conhecia cada professor. }\end{array}$ & $\begin{array}{l}\text { Apoiada pela equipe e as } \\
\text { relações no envolvimento } \\
\text { com o trabalho docente, } \\
\text { sentir-se valorizada e } \\
\text { fortalecida para a tomada } \\
\text { de decisões e o } \\
\text { desenvolvimento } \\
\text { profissional. }\end{array}$ \\
\hline $\begin{array}{l}\text { Principais } \\
\text { falhas } \\
\text { observadas }\end{array}$ & $\begin{array}{l}\text { Dificuldades vinculadas à estrutura } \\
\text { institucional e aos espaços destinados à } \\
\text { formação: “... falta de dinamismo da } \\
\text { própria escola ... tive que me virar } \\
\text { sozinha, ... os espaços de HTPC não } \\
\text { conseguiam dar conta, ... os encontros } \\
\text { com a equipe apresentavam, na maioria } \\
\text { das situações, um caráter superficial”; } \\
\text { dificuldades mais comprometedoras } \\
\text { centradas numa fragmentação entre } \\
\text { professor e equipe, relacionada à disputa } \\
\text { de poder: “... o que emperra é a estrutura } \\
\text { e a maneira de cada um encarar o seu } \\
\text { saber: eu sou professor e o outro é } \\
\text { técnico... a escola tem que funcionar com } \\
\text { essas funções entrelaçadas, tem que } \\
\text { haver um dinamismo, que tanto o }\end{array}$ & $\begin{array}{l}\text { Ausência de: 1) estrutura } \\
\text { institucional compatível ao } \\
\text { desenvolvimento das } \\
\text { atividades formativas } \\
\text { (questão não assumida pela } \\
\text { escola); 2) organização } \\
\text { coletiva do grupo (equipe, } \\
\text { professores e direção) para } \\
\text { aproveitarem as } \\
\text { oportunidades e recursos } \\
\text { existentes e imprimirem } \\
\text { melhor qualidade ao } \\
\text { trabalho, atendendo às } \\
\text { necessidades do grupo } \\
\text { (ocorria pela ausência de } \\
\text { coesão grupal). }\end{array}$ \\
\hline
\end{tabular}




\begin{tabular}{|c|c|c|}
\hline & $\begin{array}{l}\text { professor quanto a equipe não tenham } \\
\text { oculta a questão do poder... nem } \\
\text { professor se chega à equipe e a equipe } \\
\text { não se chega ao professor... não havia } \\
\text { uma visão de coletivo na equipe que } \\
\text { impulsionasse o grupo ... eu acho que } \\
\text { ficava fragmentado..., mas eu acho que o } \\
\text { professor tem uma dose de culpa nisso; } \\
\text { quantas vezes será que a gente, como } \\
\text { grupo, solicitou adequadamente para } \\
\text { essa equipe que fosse mais próxima... } \\
\text { Não dá para falar que a culpa é só do } \\
\text { outro... tem que ver onde falhamos e } \\
\text { tentar consertar...”; dificuldades por } \\
\text { excesso de demanda, interrompendo a } \\
\text { sistemática de trabalho da equipe: “... } \\
\text { estudos, entretanto, se perdiam na } \\
\text { prática, pois o envolvimento da equipe } \\
\text { com os professores não era contínuo ... } \\
\text { muito solicitados para atividades fora da } \\
\text { escola...”. }\end{array}$ & \\
\hline $\begin{array}{l}\text { Condições que } \\
\text { favoreceram a } \\
\text { relação com o } \\
\text { aluno e a } \\
\text { intervenção }\end{array}$ & $\begin{array}{l}\text { Ter compreendido a importância dos } \\
\text { diferentes contextos de aprendizagem “... } \\
\text { qualificam o nosso trabalho pedagógico } \\
\text { atendendo às necessidades e interesses } \\
\text { dos alunos, respeitando suas } \\
\text { especificidades, buscando alternativas } \\
\text { para um melhor desempenho e } \\
\text { organização da rotina... expandir para } \\
\text { além da sala de aula, com a participação } \\
\text { efetiva da família no processo } \\
\text { educacional ... que contribuísse para o } \\
\text { desenvolvimento progressivo da } \\
\text { independência e autonomia frente às } \\
\text { diversas situações”. Ter considerado } \\
\text { favoráveis as intervenções planejadas, “... } \\
\text { demonstrando, fornecendo pistas, } \\
\text { instruindo, dando assistência, } \\
\text { interferindo no desenvolvimento } \\
\text { proximal dos alunos, contribuindo para } \\
\text { os processos de elaboração e } \\
\text { desenvolvimento que não ocorreriam } \\
\text { espontaneamente”. }\end{array}$ & $\begin{array}{l}\text { Ênfase à importância do } \\
\text { intercâmbio entre o projeto } \\
\text { pedagógico e os diferentes } \\
\text { contextos vivenciados pelo } \\
\text { aluno, fornecendo } \\
\text { diretrizes planejadas às } \\
\text { atividades e conhecimentos } \\
\text { propostos. }\end{array}$ \\
\hline $\begin{array}{l}\text { Condições que } \\
\text { possibilitaram } \\
\text { trocas e } \\
\text { conhecimento } \\
\text { interdisciplinar }\end{array}$ & $\begin{array}{l}\text { Que as experiências vivenciadas como } \\
\text { professora-coordenadora ofereceram } \\
\text { condições de compartilhar com os } \\
\text { professores suas aprendizagens “... além } \\
\text { da teoria, eu ajudava o professor na } \\
\text { prática, entrava na sala de aula ... Eu } \\
\text { tive professores resistentes que quando }\end{array}$ & $\begin{array}{l}\text { As experiências na } \\
\text { mediação do projeto } \\
\text { pedagógico, com seus } \\
\text { pares, nas situações } \\
\text { cotidianas do professor, } \\
\text { permitiram construir } \\
\text { saberes e estabelecer }\end{array}$ \\
\hline
\end{tabular}




\begin{tabular}{|c|c|c|}
\hline & $\begin{array}{l}\text { eu entrava na sala para observar, dizia: } \\
\text { ‘que será que ela vai observar?’”. } \\
\text { Foram situações que parecem ter } \\
\text { contribuído para que avaliasse as } \\
\text { condições encontradas pelas equipes, } \\
\text { quais as dificuldades vivenciadas e, por } \\
\text { outro lado, quais as estratégias que } \\
\text { poderiam minimizar dificuldades na } \\
\text { convivência entre professor e equipe: “... } \\
\text { depende da gente ir quebrando isso... } \\
\text { depende da sua açâ, porque se você só } \\
\text { observa e não dá retorno para ela, ela } \\
\text { vai ser um elemento que não vai te } \\
\text { respeitar, vai se queixar”. Adotando } \\
\text { novas formas de compartilhar esse } \\
\text { modelo formativo, as assessorias } \\
\text { buscaram traduzir as necessidades do } \\
\text { professor: “... houve acompanhamento } \\
\text { mais de perto: seus desejos, suas } \\
\text { diferenças, seus saberes, suas } \\
\text { angústias... Por exemplo, a assessoria da } \\
\text { professora Úrsula teve uma contribuição } \\
\text { importantíssima em nosso grupo, que até } \\
\text { hoje direciona nosso trabalho.” }\end{array}$ & $\begin{array}{l}\text { relações colaborativas } \\
\text { diante das dificuldades, } \\
\text { apesar da resistência de } \\
\text { alguns professores, } \\
\text { abordando-as de forma que } \\
\text { houvesse harmonização } \\
\text { entre as expectativas do } \\
\text { professor e suas atitudes } \\
\text { pessoais e as necessidades } \\
\text { e exigências do projeto } \\
\text { formativo. } \\
\text { Parece comparar o que } \\
\text { conseguiu fazer com o que } \\
\text { gostaria que a equipe } \\
\text { realizasse e não conseguia } \\
\text { fazer. }\end{array}$ \\
\hline $\begin{array}{l}\text { Relação com o } \\
\text { aluno com } \\
\text { deficiência, } \\
\text { impasses } \\
\text { instaurados }\end{array}$ & $\begin{array}{l}\text { Que o processo inclusivo ampliou a } \\
\text { função social das escolas possibilitando o } \\
\text { acesso de “crianças e jovens com } \\
\text { deficiências múltiplas e de maior } \\
\text { gravidade, que outrora ficavam somente } \\
\text { em casa"... para que "buscassem } \\
\text { atendimento, surgindo então a } \\
\text { necessidade de atendimento } \\
\text { especializado com recursos, adaptações } \\
\text { de grande porte e com currículo } \\
\text { diferenciado". Para oferecer recursos } \\
\text { apropriados, foi necessário rever } \\
\text { estruturas, concepções e adaptar } \\
\text { currículo. Os impasses só poderiam ser } \\
\text { contornados com intervenções que } \\
\text { respondessem às necessidades peculiares } \\
\text { dos alunos. “Procuro respeitar seus } \\
\text { interesses fazendo com que cada um } \\
\text { tenha formas de expressar suas } \\
\text { necessidades, preferências e desenvolva } \\
\text { independência ... procuro enfatizar } \\
\text { aspectos de maior funcionalidade nas } \\
\text { minhas práticas, garantindo, na medida } \\
\text { do possível, que os conteúdos } \\
\text { acadêmicos tenham relação com o } \\
\text { cotidiano do aluno, favorecendo sua }\end{array}$ & $\begin{array}{l}\text { Sentir as propostas } \\
\text { inclusivas como um } \\
\text { desafio, também pelos } \\
\text { professores especializados, } \\
\text { que, até então, atuavam } \\
\text { com uma população de } \\
\text { menor gravidade. } \\
\text { Revela o cuidado } \\
\text { depositado na elaboração } \\
\text { de propostas acolhedoras } \\
\text { das necessidades dos } \\
\text { alunos e na organização de } \\
\text { espaços educativos, } \\
\text { relacionados à sua } \\
\text { realidade. }\end{array}$ \\
\hline
\end{tabular}




\begin{tabular}{|c|c|c|}
\hline & $\begin{array}{l}\text { inclusão social, proporcionando } \\
\text { atividades significativas do seu interesse } \\
\text { e competência, para que possa executá- } \\
\text { las e ser valorizado pelas pessoas.” }\end{array}$ & \\
\hline $\begin{array}{l}\text { Concepções de } \\
\text { deficiência }\end{array}$ & $\begin{array}{l}\text { Que a concepção de deficiência } \\
\text { internalizada está atrelada a uma visão de } \\
\text { ser humano “em desenvolvimento” que } \\
\text { ofereça oportunidade de participação em } \\
\text { “... uma sociedade inclusiva que respeite } \\
\text { as diversidades”. E, nessa perspectiva, } \\
\text { “... as atividades devem levar em } \\
\text { consideração: a criança e o jovem no seu } \\
\text { contexto global de vida; o } \\
\text { desenvolvimento de competências } \\
\text { necessárias à realização das tarefas } \\
\text { presentes e futuras, de acordo com sua } \\
\text { idade cronológica”. }\end{array}$ & $\begin{array}{l}\text { Destaca: } \\
\text { • capacidade de } \\
\text { transformação sob } \\
\text { condições educativas } \\
\text { específicas que favoreçam } \\
\text { os processos de } \\
\text { aprendizagem e } \\
\text { desenvolvimento; } \\
\text { • respeito à diversidade } \\
\text { dos alunos, provendo-os de } \\
\text { experiências significativas } \\
\text { que se concretizam na } \\
\text { observância das diferentes } \\
\text { dimensões contextuais. }\end{array}$ \\
\hline $\begin{array}{l}\text { Referenciais } \\
\text { teóricos que } \\
\text { ajudaram no } \\
\text { manejo do } \\
\text { cotidiano } \\
\text { escolar }\end{array}$ & $\begin{array}{l}\text { Que diante da variedade de } \\
\text { manifestações, própria da deficiência, } \\
\text { "nós, educadores, temos uma } \\
\text { responsabilidade muito grande em saber } \\
\text { como direcionar o conhecimento destes } \\
\text { alunos, prestando atenção ao que ele fez } \\
\text { e as relações que estabelece com outras } \\
\text { crianças e com os adultos”. } \\
\text { Que as assessorias e cursos trouxeram } \\
\text { contribuições, abordando concepções } \\
\text { teóricas diversas, mas que "na minha } \\
\text { prática, na análise feita com os alunos } \\
\text { durante vários anos, Vygotsky teve uma } \\
\text { contribuição bastante significativa, } \\
\text { embasando vários projetos realizados”. } \\
\text { Que a partir de seus postulados } \\
\text { compreendeu a importância das } \\
\text { intervenções que planejava, "fazendo } \\
\text { junto, demonstrando, fornecendo pistas, } \\
\text { instruindo, dando assistência”, buscando } \\
\text { formas para "interferir no } \\
\text { desenvolvimento proximal de meus } \\
\text { alunos, contribuindo para os processos } \\
\text { de elaboração e desenvolvimento que } \\
\text { não ocorreriam espontaneamente”. }\end{array}$ & $\begin{array}{l}\text { Forte ressonância no } \\
\text { significado do seu papel } \\
\text { profissional, conferindo à } \\
\text { sua prática conhecimentos } \\
\text { da teoria histórico-cultural } \\
\text { que a ajudaram a inovar e } \\
\text { atender às especificidades e } \\
\text { particularidades de cada } \\
\text { aluno, manifestando-se } \\
\text { como educador atento e } \\
\text { exigente com a apropriação } \\
\text { de conhecimentos que o } \\
\text { embasem na mediação da } \\
\text { aprendizagem. }\end{array}$ \\
\hline
\end{tabular}


Quadro III - Categorização da entrevista de Ana

\begin{tabular}{|c|c|c|}
\hline $\begin{array}{l}\text { Categorias } \\
\text { descritivas }\end{array}$ & O que a entrevistada mostrou & Interpretação \\
\hline $\begin{array}{l}\text { Pontos } \\
\text { determinantes } \\
\text { da experiência }\end{array}$ & $\begin{array}{l}\text { Que o seu despreparo inicial foi superado } \\
\text { pelo apoio da equipe técnica: “... este } \\
\text { período foi um ponto de referência, pois } \\
\text { lá eu tinha toda a equipe: fonoaudióloga, } \\
\text { psicóloga, orientadora pedagógica, } \\
\text { assistente social... e trabalhava todo } \\
\text { mundo junto”. Que os estudos e reflexões } \\
\text { contribuíram para estabelecer... “relações } \\
\text { da prática com a teoria, buscando o } \\
\text { equilibrio, de acordo com os nossos } \\
\text { objetivos...” e para "ter sempre clareza } \\
\text { da nossa intencionalidade”. Que esse } \\
\text { processo procurou responder às } \\
\text { necessidades do aluno e aprender... } \\
\text { “como olhar para essa criança com } \\
\text { deficiência, como proceder, o que } \\
\text { ajuda”. Que os profissionais... “com seus } \\
\text { saberes e experiências”, juntamente com } \\
\text { o professor contribuíram, “para a } \\
\text { evolução dos alunos e para buscar novos } \\
\text { conhecimentos diante de um novo } \\
\text { desafio, ou dificuldade”. }\end{array}$ & $\begin{array}{l}\text { Revela que: } \\
\text { - a falta de prática foi } \\
\text { suprida pelo apoio da } \\
\text { equipe técnica; } \\
\text { - a relação estabelecida } \\
\text { entre a teoria com as } \\
\text { situações do cotidiano } \\
\text { buscava criar uma } \\
\text { sistemática de trabalho que } \\
\text { esclarecesse quanto à } \\
\text { intencionalidade e } \\
\text { adequação das práticas, no } \\
\text { sentido de atingir os } \\
\text { objetivos propostos; } \\
\text { - diferentes saberes } \\
\text { convergiam para buscar } \\
\text { maior compreensão sobre a } \\
\text { realidade enfrentada, num } \\
\text { clima de cooperação. }\end{array}$ \\
\hline $\begin{array}{l}\text { Transformações } \\
\text { na atuação que } \\
\text { perduram }\end{array}$ & $\begin{array}{l}\text { Que a assessoria da professora Úrsula } \\
\text { possibilitou transformações na prática, } \\
\text { mediante reflexões sobre as } \\
\text { possibilidades de as propostas } \\
\text { oferecerem desafios aos alunos: “Ela } \\
\text { sempre questionava o professor, se } \\
\text { aquela atividade ... estava oferecendo } \\
\text { oportunidades para a criança pensar... } \\
\text { tem desafios para ela elaborar e } \\
\text { construir conhecimento?”. Que esses } \\
\text { questionamentos desafiavam o professor } \\
\text { a refletir as condições das estratégias; } \\
\text { provocar na criança operação mental } \\
\text { enriquecedora: “Isso se torna... um } \\
\text { desafio. Ser executor é muito fácil, } \\
\text { inclusive para nós, professores. O que } \\
\text { você realiza, de fato, está mudando o } \\
\text { pensamento do aluno? Temos que fazer } \\
\text { com que ele pare para pensar e elabore. } \\
\text { Para isto, era necessário estudar. É esta } \\
\text { a grande questão para a criança com } \\
\text { deficiência, oferecer situações que } \\
\text { promovam elaboração do pensamento”. } \\
\text { Valoriza os ganhos referentes à criança: } \\
\text { “Nós aprendemos a ter um olhar mais }\end{array}$ & $\begin{array}{l}\text { Lamenta a descontinuidade } \\
\text { imposta pela Secretaria de } \\
\text { Educação, ao suprimir a } \\
\text { proposta que foi } \\
\text { responsável pela } \\
\text { experiência obtida e que } \\
\text { repercute até hoje, } \\
\text { auxiliando-a nas } \\
\text { dificuldades que encontra } \\
\text { como professora da classe } \\
\text { integrada, no ensino } \\
\text { regular. } \\
\text { Indica como } \\
\text { transformações: } \\
\text { - compreensão das } \\
\text { necessidades do aluno, para } \\
\text { elaboração de atividades } \\
\text { desafiadoras, que garantam } \\
\text { o enriquecimento da } \\
\text { atividade mental da } \\
\text { criança. }\end{array}$ \\
\hline
\end{tabular}




\begin{tabular}{|c|c|c|}
\hline & $\begin{array}{l}\text { específico, sem rotular” a criança, } \\
\text { voltado para “... perceber suas } \\
\text { necessidades para que o trabalho ficasse } \\
\text { mais facilitado”. Que, sem a } \\
\text { continuidade dessa proposta formativa, } \\
\text { os professores sentem-se, hoje, muito } \\
\text { perdidos e sem apoio: “... a Secretaria da } \\
\text { Educação cortou nosso vínculo com o } \\
\text { Especial e nós estamos isoladas, dando } \\
\text { aula para crianças com necessidades } \\
\text { especiais das classes integradas, sem } \\
\text { qualquer assessoria específica”. }\end{array}$ & \\
\hline $\begin{array}{l}\text { Aspectos que } \\
\text { contribuíram } \\
\text { para a atuação } \\
\text { como docente }\end{array}$ & $\begin{array}{l}\text { Que, ao ocupar a vaga de professora da } \\
\text { classe integrada no Ensino Fundamental, } \\
\text { conseguiu “desenvolver o trabalho com } \\
\text { segurança, sem o suporte técnico } \\
\text { constante, com flexibilidade e dinamismo } \\
\text { para estabelecer a parceria com os } \\
\text { professores do Regular”. O apoio técnico } \\
\text { tinha como perspectiva “mostrar as } \\
\text { diferentes formas de trabalhar e as } \\
\text { professoras de classes integradas não se } \\
\text { sentirem sozinhas e perdidas... trocávamos } \\
\text { as dificuldades que cada professor tinha } \\
\text { para integrar o seu aluno e trabalhar com } \\
\text { os professores, pois havia escolas que } \\
\text { eram muito resistentes à inclusão. Até a } \\
\text { comunidade via com maus olhos. Havia } \\
\text { também o trabalho específico com as } \\
\text { famílias dos alunos, com a colaboração da } \\
\text { assistente social”. }\end{array}$ & $\begin{array}{l}\text { Assinala entre os aspectos } \\
\text { que contribuíram: } \\
\text { - flexibilidade e dinamismo } \\
\text { para estabelecer trocas com } \\
\text { os professores do Regular; } \\
\text { - segurança para } \\
\text { desenvolver o trabalho com } \\
\text { autonomia, sem o suporte } \\
\text { técnico tão constante; } \\
\text { - reflexão, com a equipe, } \\
\text { de problemáticas do } \\
\text { cotidiano, referentes ao } \\
\text { aluno e às famílias, e } \\
\text { maneiras de conduzir o } \\
\text { trabalho em parceria com } \\
\text { as professoras do ensino } \\
\text { fundamental. }\end{array}$ \\
\hline $\begin{array}{l}\text { Principais } \\
\text { falhas } \\
\text { observadas }\end{array}$ & $\begin{array}{l}\text { Que uma das grandes falhas era o } \\
\text { distanciamento entre as equipes do } \\
\text { Especial e do Regular: "O Especial sempre } \\
\text { achou que o Fundamental não olhava com } \\
\text { carinho nossos alunos, que não iria tratar } \\
\text { como a gente trata. Mas, todo mundo } \\
\text { pensando neles, refletindo sobre o ensino } \\
\text { para eles... é um olhar diferente”. Outro } \\
\text { aspecto refere-se ao envolvimento dos } \\
\text { profissionais: "Você tem que estar bem } \\
\text { envolvido e às vezes você vê profissionais } \\
\text { que agem de forma superficial... em todas } \\
\text { as áreas tem isso. Às vezes falha o } \\
\text { compromisso, em alguns passos”. Que } \\
\text { uma maior integração entre os profissionais } \\
\text { das equipes poderia mobilizar os menos } \\
\text { atuantes para que tivessem maior } \\
\text { envolvimento e, assim, aproveitassem a } \\
\text { "ação positiva daqueles mais atuantes". }\end{array}$ & $\begin{array}{l}\text { Indica: necessidade de } \\
\text { maior proximidade entre as } \\
\text { equipes da Secretaria de } \\
\text { Educação, reiterando a } \\
\text { importância da } \\
\text { complementação de } \\
\text { experiências e } \\
\text { conhecimentos entre } \\
\text { profissionais de diferentes } \\
\text { equipes e, também, entre as } \\
\text { do Especial, objetivando } \\
\text { maior equilíbrio entre } \\
\text { parceiros mais e menos } \\
\text { envolvidos. }\end{array}$ \\
\hline
\end{tabular}




\begin{tabular}{|c|c|c|}
\hline $\begin{array}{l}\text { Condições que } \\
\text { favoreceram a } \\
\text { relação com o } \\
\text { aluno e a } \\
\text { intervenção }\end{array}$ & $\begin{array}{l}\text { Que há uma constante aprendizagem do } \\
\text { professor: “Sempre estamos aprendendo } \\
\text { novos conhecimentos, novas atitudes em } \\
\text { relação ao aluno". Que, a partir da } \\
\text { parceria com a equipe, refletindo a } \\
\text { prática, a educadora depositou maior } \\
\text { confiança em seu trabalho trazendo mais } \\
\text { segurança para lidar no dia-a-dia: "As } \\
\text { tematizações ajudavam a rever nossa } \\
\text { prática... Somente a teoria não é } \\
\text { suficiente para compreender o } \\
\text { termômetro de cada aluno...”. Que, ao } \\
\text { relacionar a teoria com a prática, } \\
\text { compreendia “como lidar melhor nos } \\
\text { momentos de agressividade e o que posso } \\
\text { fazer para que isto não aconteça...”. Que } \\
\text { essas situações “fazem você não cometer } \\
\text { erros com os alunos". Que descobriu “o } \\
\text { quanto a música facilita a aprendizagem } \\
\text { dos alunos com distúrbios globais do } \\
\text { desenvolvimento ou com dificuldades de } \\
\text { oralidade e concentração. Como ajudar } \\
\text { os alunos na interação grupal, no } \\
\text { autocontrole”. Que, como professora } \\
\text { itinerante no acompanhamento aos } \\
\text { alunos incluídos no ensino regular, } \\
\text { "procurava ajudar, de alguma forma, } \\
\text { para que a professora da classe... } \\
\text { explorasse outros espaços...”. }\end{array}$ & $\begin{array}{l}\text { Condições relacionadas a: } \\
\text { - oportunidades de manter- } \\
\text { se sempre atualizada, } \\
\text { renovando seus } \\
\text { conhecimentos, pensando } \\
\text { em procedimentos e novas } \\
\text { formas de agir; } \\
\text { - reflexão da prática, } \\
\text { possibilitando-lhe criar } \\
\text { diversificadas situações de } \\
\text { aprendizagem e valorizar } \\
\text { recursos específicos, outras } \\
\text { linguagens e espaços } \\
\text { variados para a realização } \\
\text { das atividades; } \\
\text { - sentir-se segura e com } \\
\text { mais habilidade para } \\
\text { compreender as situações } \\
\text { complexas do cotidiano e } \\
\text { formular maneiras } \\
\text { alternativas para atender às } \\
\text { necessidades de cada } \\
\text { aluno. }\end{array}$ \\
\hline $\begin{array}{l}\text { Condições que } \\
\text { possibilitaram } \\
\text { trocas e } \\
\text { conhecimento } \\
\text { interdisciplinar }\end{array}$ & $\begin{array}{l}\text { Que sua inicial submissão diante dos } \\
\text { profissionais da equipe transformou-se em } \\
\text { uma real parceria: “Aos poucos, as meninas } \\
\text { foram compreendendo o que eu tinha de } \\
\text { expectativas com relação ao meu trabalho } \\
\text { e comecei a ser mais respeitada" como } \\
\text { parceira, trocando “... sobre práticas de } \\
\text { letramento ligadas ao trabalho, pois eu } \\
\text { tinha uma turma de jovens mais velhos não } \\
\text { alfabetizados". Que diferentes áreas } \\
\text { abriram espaço para "oferecer alternativas } \\
\text { diante das dificuldades”, convergindo em } \\
\text { torno do mesmo objetivo "cada um na sua } \\
\text { área...”. Que foi importante ter domínio } \\
\text { sobre o diagnóstico do aluno, conhecer as } \\
\text { várias dimensões que o constituem: "suas } \\
\text { necessidades, qual o canal de melhor } \\
\text { acesso para o conhecimento”. Avalia ser } \\
\text { "necessário que o professor tenha } \\
\text { conhecimentos sobre as deficiências e } \\
\text { buscar práticas que facilitem a interação } \\
\text { com o aluno”. }\end{array}$ & $\begin{array}{l}\text { Destaca: } \\
\text { - aceitação do saber do } \\
\text { professor, sentindo-se } \\
\text { respeitada mediante } \\
\text { atividades colaborativas; } \\
\text { - objetivo comum em torno } \\
\text { das propostas, buscando } \\
\text { assegurar uma } \\
\text { complementação de idéias; } \\
\text { - importância fornecida aos } \\
\text { dados que esclarecessem as } \\
\text { condições da criança e suas } \\
\text { necessidades, traduzindo-as } \\
\text { em práticas que beneficiem } \\
\text { sua interação. }\end{array}$ \\
\hline
\end{tabular}




\begin{tabular}{|c|c|c|}
\hline $\begin{array}{l}\text { Relação com o } \\
\text { aluno com } \\
\text { deficiência, } \\
\text { impasses } \\
\text { instaurados }\end{array}$ & $\begin{array}{l}\text { Que "cada um constrói seu } \\
\text { conhecimento dentro de sua realidade e } \\
\text { necessidade”. Que, nessa perspectiva, } \\
\text { para enfrentar os desafios do cotidiano, } \\
\text { procurava encontrar meios e recursos } \\
\text { específicos para aproximar-se dos alunos: } \\
\text { "Eu me lembro de uma aluna muito } \\
\text { difícil, que se mordia... sangrava os } \\
\text { lábios, jogava as coisas... comecei a } \\
\text { trabalhar a auto-estima dela... Eu } \\
\text { comecei a passar batom na hora de ir } \\
\text { embora, a me olhar no espelho, para } \\
\text { despertar nela algo parecido... ela ficou } \\
\text { olhando e eu ofereci passar batom nela e } \\
\text { ela quis. Eu dei para ela uns batonzinhos } \\
\text { e sempre depois da higiene bucal, ela } \\
\text { passava o batom comigo. Comecei a } \\
\text { perceber que ela parou de se morder } \\
\text { quando passou a se olhar no espelho. } \\
\text { Com uma coisa aparentemente simples, } \\
\text { refletindo sobre o que ela estaria } \\
\text { sentindo ao se agredir e agredir os } \\
\text { outros, percebendo que nos momentos } \\
\text { que eu me arrumava ela parava de se } \\
\text { agredir. Observando esses detalhes... } \\
\text { consegui que ela tivesse maior } \\
\text { equilíbrio...”. Que, a partir desse } \\
\text { momento, ficou claro para a educadora a } \\
\text { importância de "sempre refletir, rever o } \\
\text { processo de intervenções...”. }\end{array}$ & $\begin{array}{l}\text { É destacada a necessidade } \\
\text { de se conhecer a realidade } \\
\text { dos alunos, seus desejos, } \\
\text { possibilidades, a dinâmica } \\
\text { das interações e o modo } \\
\text { como reagem às } \\
\text { experiências. Observar a } \\
\text { emergência dos conflitos } \\
\text { possibilita ao educador } \\
\text { planejar com mais clareza } \\
\text { as intervenções e } \\
\text { estratégias, criando-se ricas } \\
\text { experiências de } \\
\text { crescimento. }\end{array}$ \\
\hline $\begin{array}{l}\text { Concepções de } \\
\text { deficiência }\end{array}$ & $\begin{array}{l}\text { Que, independente das dificuldades da } \\
\text { criança, “... o professor tem que apostar } \\
\text { na superação desta dificuldade e } \\
\text { trabalhar para isto. É o nosso papel, } \\
\text { intervir nessa mudança... Intervir para } \\
\text { que a aprendizagem da criança evolua... } \\
\text { se por acaso ela nasceu com alguma } \\
\text { dificuldade, em hipótese alguma vai ficar } \\
\text { estável nessa dificuldade, ele vai se } \\
\text { modificar e o mundo vai modificá-lo”. } \\
\text { Que sua concepção de deficiência } \\
\text { considera o sujeito como autor “de seus } \\
\text { atos, de seus conhecimentos... } \\
\text { respeitando-os e favorecendo sua auto- } \\
\text { estima” e seu papel é “fazer que eles se } \\
\text { vejam como sujeitos com } \\
\text { responsabilidades...”. }\end{array}$ & $\begin{array}{l}\text { Revela a capacidade de } \\
\text { transformação dos sujeitos, } \\
\text { considerando-os autores de } \\
\text { sua história, mediante } \\
\text { relações sociais e } \\
\text { intervenções educativas } \\
\text { propiciadoras. As } \\
\text { condições biológicas e } \\
\text { funções psíquicas do } \\
\text { sujeito são assim apontadas } \\
\text { como mutáveis, na medida } \\
\text { em que as práticas } \\
\text { educativas atuem } \\
\text { intensamente nessa } \\
\text { transformação dos } \\
\text { processos de } \\
\text { desenvolvimento e } \\
\text { aprendizagem. }\end{array}$ \\
\hline
\end{tabular}




\begin{tabular}{|c|c|c|}
\hline $\begin{array}{l}\text { Referenciais } \\
\text { teóricos que } \\
\text { ajudaram no } \\
\text { manejo do } \\
\text { cotidiano } \\
\text { escolar }\end{array}$ & $\begin{array}{l}\text { Que reconhece que o processo de } \\
\text { aprendizagem do professor é contínuo e } \\
\text { que ela não se sente totalmente pronta: “.... } \\
\text { a gente sempre está aprendendo e eu } \\
\text { sempre me senti desafiada para o } \\
\text { trabalho... estas experiências formativas } \\
\text { eliminam a ansiedade. Toda teoria que } \\
\text { vamos estudando vão ajudando também a } \\
\text { ter um olhar diferenciado para o nosso } \\
\text { trabalho, que nos ajuda a ter iniciativa na } \\
\text { busca de novas práticas. Todos os } \\
\text { conhecimentos sobre desenvolvimento } \\
\text { infantil dos textos de Piaget, } \\
\text { principalmente, com os estudos de } \\
\text { Vygotsky, que me ensinaram que a } \\
\text { interação intencional do homem com o } \\
\text { meio possibilita aprendizagem e o } \\
\text { desenvolvimento. }\end{array}$ & $\begin{array}{l}\text { Revela que os referenciais } \\
\text { teóricos ajudaram-na a } \\
\text { fazer uma leitura mais } \\
\text { específica dos modos como } \\
\text { o aluno aprende e se } \\
\text { desenvolve, e a valorizar as } \\
\text { condições em que a ação } \\
\text { pedagógica provê sua } \\
\text { transformação. O processo } \\
\text { formativo pautado nas } \\
\text { experiências vivenciadas } \\
\text { por ela deu sentido às suas } \\
\text { constantes buscas. }\end{array}$ \\
\hline
\end{tabular}

Quadro IV - Categorização da entrevista de Maria

\begin{tabular}{|c|c|c|}
\hline $\begin{array}{l}\text { Categorias } \\
\text { descritivas }\end{array}$ & O que a entrevistada mostrou & Interpretação \\
\hline $\begin{array}{l}\text { Pontos } \\
\text { determinantes } \\
\text { da experiência }\end{array}$ & $\begin{array}{l}\text { Que, dos aspectos determinantes da } \\
\text { experiência, destacaria as situações } \\
\text { advindas de dois momentos: "na Escola } \\
\text { Especial e no Centro de Apoio de } \\
\text { Estimulação Essencial". Foram unidades } \\
\text { que mantiveram um trabalho importante } \\
\text { com a assessoria da professora Úrsula } \\
\text { Heymayer. Ela "nos ajudou na } \\
\text { organização da rotina de trabalho, nas } \\
\text { intervenções individuais dos alunos, nas } \\
\text { discussôes em grupo e nos } \\
\text { encaminhamentos bem direcionados". Por } \\
\text { um período mais breve, também contribuiu } \\
\text { nesse processo o professor Rinaldo } \\
\text { Voltolini, "discutindo aspectos } \\
\text { relacionados à constituição do sujeito, } \\
\text { numa abordagem psicanalítica, que } \\
\text { chamou muito a minha atenção, pois se } \\
\text { tratava de um saber que eu não sabia } \\
\text { possuir... atrelando a Pedagogia à } \\
\text { Psicanálise”. Foram momentos formativos } \\
\text { importantes, que lhe possibilitou } \\
\text { "receber informações de assuntos que eu } \\
\text { desconhecia, pude reorganizar } \\
\text { conhecimentos, vivenciar situações, } \\
\text { comparar práticas, tirar conclusões e } \\
\text { aprimorar o meu pensamento". }\end{array}$ & $\begin{array}{l}\text { Destaca a convergência do } \\
\text { suporte técnico } \\
\text { compartilhado com as } \\
\text { assessorias, } \\
\text { compreendendo aspectos } \\
\text { de natureza teórica e a } \\
\text { organização de questões } \\
\text { relacionadas à estrutura de } \\
\text { trabalho e à proposta } \\
\text { pedagógica. Reconhece } \\
\text { que as situações } \\
\text { ofereceram oportunidades } \\
\text { de adquirir novos } \\
\text { conhecimentos que } \\
\text { subsidiassem as ações } \\
\text { educativas e orientassem } \\
\text { para novas reformulações. }\end{array}$ \\
\hline
\end{tabular}




\begin{tabular}{|c|c|c|}
\hline $\begin{array}{l}\text { Transformações } \\
\text { na atuação que } \\
\text { perduram }\end{array}$ & $\begin{array}{l}\text { Que as aprendizagens adquiridas } \\
\text { contribuíram para que mudasse "todo o } \\
\text { processo de trabalho e continuasse } \\
\text { mudando, tanto o meu como a estrutura, } \\
\text { a organização, o funcionamento de toda } \\
\text { a unidade e os profissionais que } \\
\text { passaram e permanecem desde aquela } \\
\text { época”. Que se sentia privilegiada em } \\
\text { compartilhar esse projeto com “as } \\
\text { pessoas que trabalhei da área de } \\
\text { Pedagogia, Psicologia, Fonoaudiologia. } \\
\text { Era uma formação com um número } \\
\text { reduzido de profissionais, o que } \\
\text { possibilitava uma troca melhor". }\end{array}$ & $\begin{array}{l}\text { Assinala, basicamente, } \\
\text { mudanças relacionadas às } \\
\text { condições concretas da } \\
\text { estrutura institucional, tais } \\
\text { como organização e } \\
\text { funcionamento do contexto } \\
\text { educativo. No entanto, } \\
\text { refere-se à oportunidade } \\
\text { que esses profissionais, de } \\
\text { maneira próxima, } \\
\text { contribuíram para sua } \\
\text { formação. }\end{array}$ \\
\hline $\begin{array}{l}\text { Aspectos que } \\
\text { contribuíram } \\
\text { para a atuação } \\
\text { como docente }\end{array}$ & $\begin{array}{l}\text { Que adquiriu “novos e diferentes } \\
\text { conhecimentos” e, com essas } \\
\text { experiências, sentiu-se: “mais fortalecida } \\
\text { nas ações, nos recomeços, nas novas } \\
\text { práticas". A parceria com áreas } \\
\text { específicas contribuiu “para que eu } \\
\text { pudesse ampliar conhecimentos, } \\
\text { modificar meu pensamento, e buscar um } \\
\text { caminho pedagógico agregador de } \\
\text { diferentes informações, saberes”. Que, } \\
\text { nesse processo, o grupo conquistou a } \\
\text { possibilidade de "falar das relações e } \\
\text { avaliar a parceria; construir um clima } \\
\text { tranqüilo, onde a gente separava o } \\
\text { pessoal do profissional...”. }\end{array}$ & $\begin{array}{l}\text { Revela que a aquisição de } \\
\text { novos conhecimentos } \\
\text { tornou-a mais segura como } \\
\text { profissional, tendo } \\
\text { proporcionado novas idéias } \\
\text { e interferido no } \\
\text { desenvolvimento de sua } \\
\text { prática. } \\
\text { Retrata um contexto de } \\
\text { crescimento pessoal e } \\
\text { profissional, decorrente da } \\
\text { criação de um clima } \\
\text { cooperativo, onde as } \\
\text { relações eram analisadas. }\end{array}$ \\
\hline $\begin{array}{l}\text { Principais } \\
\text { falhas } \\
\text { observadas }\end{array}$ & $\begin{array}{l}\text { Que, no cotidiano, “alguns profissionais } \\
\text { não consideravam o papel do professor, } \\
\text { ou melhor, o meu saber como } \\
\text { professora”. Entretanto pondera: “podia } \\
\text { até ser porque eu era nova no trabalho } \\
\text { com crianças de } 0 \text { a } 6 \text { anos”. Argumenta } \\
\text { que o fato de não darem valor aos } \\
\text { conhecimentos do professor parecia ser } \\
\text { incoerente, pois “... para saber do aluno } \\
\text { tinham que recorrer a mim”. Outra } \\
\text { dificuldade refere-se à ausência dos } \\
\text { profissionais, que "nem sempre estavam } \\
\text { presentes”. }\end{array}$ & $\begin{array}{l}\text { Contesta a visão de alguns } \\
\text { profissionais que } \\
\text { desconsideram o saber do } \\
\text { professor, mas se pautam } \\
\text { em suas informações para } \\
\text { fazerem suas análises. } \\
\text { Sua crítica recai, também, } \\
\text { na descontinuidade das } \\
\text { relações, em vista de os } \\
\text { profissionais se ausentarem } \\
\text { da unidade. }\end{array}$ \\
\hline $\begin{array}{l}\text { Condições que } \\
\text { favoreceram a } \\
\text { relação com o } \\
\text { aluno e a } \\
\text { intervenção }\end{array}$ & $\begin{array}{l}\text { Que foram relevantes as “discussões e } \\
\text { tematizações da prática, além dos } \\
\text { momentos que havia com a assessoria, com } \\
\text { temáticas que eram aprofundadas”. } \\
\text { Reconhece que "a cada dia, as crianças } \\
\text { vêm diferentes, então... tudo isto é uma } \\
\text { busca constante... um conhecimento que }\end{array}$ & $\begin{array}{l}\text { Revela que as discussões } \\
\text { sobre os temas vinculados } \\
\text { à prática, com } \\
\text { aprofundamento teórico, } \\
\text { foram sistemáticas, que } \\
\text { ajudaram o professor, de } \\
\text { maneira processual, a }\end{array}$ \\
\hline
\end{tabular}




\begin{tabular}{|c|c|c|}
\hline & $\begin{array}{l}\text { não tem fim, porque quando você acha que } \\
\text { já sabe tudo sobre uma criança, surge } \\
\text { outra... que você fala ... ‘e agora, o que eu } \\
\text { vou fazer?””. Diante disso, o professor “... } \\
\text { está sempre em busca de novos } \\
\text { conhecimentos”. } \\
\text { Que a relação com a família também } \\
\text { “ajudava a transformação do olhar da mãe } \\
\text { para com a criança... discutir aspectos da } \\
\text { relação mãe-filho e da própria relação } \\
\text { escola-família”. }\end{array}$ & $\begin{array}{l}\text { construir saberes que lhe } \\
\text { permitiram responder, } \\
\text { permanentemente, aos } \\
\text { constantes desafios que lhe } \\
\text { eram apresentados no dia- } \\
\text { a-dia. Da interação e } \\
\text { orientação à família } \\
\text { derivaram condições } \\
\text { oportunas para o trabalho } \\
\text { com as crianças. }\end{array}$ \\
\hline $\begin{array}{l}\text { Condições que } \\
\text { possibilitaram } \\
\text { trocas } \\
\text { conhecimento } \\
\text { interdisciplinar }\end{array}$ & $\begin{array}{l}\text { Que a tônica das relações entre equipe e } \\
\text { professor foi se transformando: “fomos nos } \\
\text { integrando, eu recebia informaçôes, } \\
\text { conhecimentos e usava na minha prática, e, } \\
\text { com isto, eu comecei a falar com mais } \\
\text { segurança do meu trabalho e a equipe } \\
\text { começou a me entender, e eu a elas”. } \\
\text { Menciona que, nesse movimento, conseguiu } \\
\text { se posicionar e conquistar seu espaço: “eu } \\
\text { pertenço a este grupo, vocês vão ter que me } \\
\text { ouvir, ouvir o que a professora tem a dizer, e } \\
\text { não só ouvirmos o que a Psicologia, a } \\
\text { Fonoaudiologia têm a dizer”. Que considera } \\
\text { fundamental o professor ser valorizado: “as } \\
\text { pessoas saberem te ouvir; o que parece que } \\
\text { não é certo é colocarem de uma forma } \\
\text { impositiva...”. Por outro lado, "começaram } \\
\text { a ver que todos ali tinham o seu lugar...”. } \\
\text { Assim sendo, admite que "quando o } \\
\text { professor se sente seguro, respeitado em } \\
\text { suas ações, encontra parceiros, quer seja } \\
\text { colegas ou profissionais da equipe, para } \\
\text { arriscar, planejar, acertar, errar, começar } \\
\text { de novo... tudo fica mais fácil”. Reconhece, } \\
\text { entretanto, que: “a qualidade da parceria é } \\
\text { importante, mas vai muito de o professor } \\
\text { conquistar seu espaço”. Considera, } \\
\text { também, que as condições que provocaram } \\
\text { essas mudanças nas relações “foram } \\
\text { decorrentes de procedimentos intencionais, } \\
\text { avaliando, buscando transformar esse jeito } \\
\text { de fazer do professor um mero executor”. } \\
\text { Aliada a essa visão, já não mais impositiva, } \\
\text { de trazer os conhecimentos para serem } \\
\text { compartilhados com o professor do } \\
\text { Regular: "pude compreender melhor como } \\
\text { chegar na unidade escolar e ter esse } \\
\text { professor como parceiro... tendo o cuidado } \\
\text { de mostrar que eu considerava o } \\
\text { conhecimento que ele tinha da criança”. }\end{array}$ & $\begin{array}{l}\text { Destaca, entre as } \\
\text { condições: } \\
\text { - posicionamento mais } \\
\text { firme e seguro da } \\
\text { educadora; } \\
\text { - criação de novos sentidos } \\
\text { para sua participação como } \\
\text { co-autora do processo } \\
\text { formativo, assumindo seu } \\
\text { espaço já não mais como } \\
\text { “mera executora”, } \\
\text { configurando seu saber } \\
\text { como parte essencial da } \\
\text { relação ensino- } \\
\text { aprendizagem; } \\
\text { - que essas condições } \\
\text { puderam provir da } \\
\text { compreensão de que tanto } \\
\text { professor quanto a equipe } \\
\text { necessitam atuar em } \\
\text { parceria, na } \\
\text { complementação de } \\
\text { saberes. }\end{array}$ \\
\hline
\end{tabular}




\begin{tabular}{|c|c|c|}
\hline $\begin{array}{l}\text { Relação com o } \\
\text { aluno com } \\
\text { deficiência, } \\
\text { impasses } \\
\text { instaurados }\end{array}$ & $\begin{array}{l}\text { Que essas experiências possibilitaram } \\
\text { “enxergar a criança para além da } \\
\text { deficiência ou das limitações”, } \\
\text { inquietando-se frente aos } \\
\text { comprometimentos da criança: “eu me } \\
\text { pergunto - 'Onde está a criança, neste } \\
\text { corpo? Quais os caminhos e recursos } \\
\text { que eu poderia utilizar para ela } \\
\text { conseguir mostrar seus sentimentos, } \\
\text { desejos... O que posso oferecer?’. } \\
\text { Considera que o maior impasse é: } \\
\text { "Desvendar essa criança...”, sendo } \\
\text { necessários “investigação, observação, } \\
\text { planejamento, estratégias, parcerias, } \\
\text { idas e vindas, reflexões, aposta... } \\
\text { descobertas...” que tragam para a criança } \\
\text { “a possibilidade de perceber-se no } \\
\text { mundo, descobrir-se criança, fazendo } \\
\text { escolhas, estabelecendo relações, sendo } \\
\text { compreendida... ouvida... participando”. } \\
\text { Sendo auxiliada com “recursos } \\
\text { específicos, tais como adaptações de } \\
\text { mobiliário e material pedagógico, } \\
\text { acionadores, posicionamentos mais } \\
\text { adequados ou ainda recursos } \\
\text { relacionados à percepção sensorial com } \\
\text { utilização de contrastes, texturas, } \\
\text { tamanho de objetos...”. }\end{array}$ & $\begin{array}{l}\text { Assinala que atuar sobre } \\
\text { uma realidade com } \\
\text { inúmeros desafios e } \\
\text { situações, aparentemente } \\
\text { intransponíveis, exigiu uma } \\
\text { nova visão e, com base } \\
\text { nela, outra criança foi } \\
\text { sendo desvelada. Foram } \\
\text { emergindo novas } \\
\text { características, outras } \\
\text { possibilidades e uma } \\
\text { dinâmica constante de } \\
\text { estudo e planejamento, } \\
\text { colaborando com a } \\
\text { transposição dos limites. } \\
\text { Enfatiza a elaboração } \\
\text { cuidadosa das } \\
\text { intervenções, analisando as } \\
\text { melhores alternativas para } \\
\text { que a condição orgânica } \\
\text { não impedisse seu } \\
\text { desenvolvimento. }\end{array}$ \\
\hline $\begin{array}{l}\text { Concepções de } \\
\text { deficiência }\end{array}$ & $\begin{array}{l}\text { Que, independente da condição da } \\
\text { criança com deficiência, “existe um } \\
\text { sujeito que eu preciso conhecer, através } \\
\text { de parcerias produtivas, estratégias bem } \\
\text { elaboradas, adaptações e recursos } \\
\text { específicos e um ambiente acolhedor...”, } \\
\text { oferecendo “possibilidade de ajudá-lo a } \\
\text { se transformar, a reconhecer suas } \\
\text { necessidades, desejos... fazer uso de sua } \\
\text { consciência e agir no mundo". }\end{array}$ & $\begin{array}{l}\text { Evidencia uma visão em } \\
\text { que prevalece a capacidade } \\
\text { de transformação da } \\
\text { criança, tendo como base } \\
\text { propostas e recursos } \\
\text { específicos que ofereçam a } \\
\text { ela variadas condições de } \\
\text { aprendizagem e } \\
\text { manifestação. }\end{array}$ \\
\hline $\begin{array}{l}\text { Referenciais } \\
\text { teóricos que } \\
\text { ajudaram no } \\
\text { manejo do } \\
\text { cotidiano } \\
\text { escolar }\end{array}$ & $\begin{array}{l}\text { Que, “ao iniciar o trabalho com crianças } \\
\text { de } 0 \text { a } 6 \text { anos com múltiplas deficiências } \\
\text { e transtornos globais do } \\
\text { desenvolvimento, deparei-me com um } \\
\text { universo desafiador, em alguns } \\
\text { momentos, desconhecido". Foram vários } \\
\text { autores e temas: "Piaget, Vygotsky, fases } \\
\text { do desenvolvimento, construção do } \\
\text { conhecimento, como a criança aprende, } \\
\text { desenvolvimento infantil à luz da } \\
\text { Psicanálise, instrumentos metodológicos, } \\
\text { compromisso com a criança e sua família }\end{array}$ & $\begin{array}{l}\text { Destaca que, diante da } \\
\text { imprevisível realidade } \\
\text { vivenciada como } \\
\text { professora de crianças com } \\
\text { comprometimentos mais } \\
\text { acentuados, houve } \\
\text { necessidade de articular } \\
\text { diferentes saberes que } \\
\text { pudessem compor novas } \\
\text { formas de pensar as } \\
\text { questões da deficiência. }\end{array}$ \\
\hline
\end{tabular}




\begin{tabular}{|l|l|l|}
\hline & a. organização e estrutura dos & \\
atendimentos, rotina da educação & \\
infantil, inclusão, parceria com os & \\
professores do ensino regular”, que & \\
puderam contribuir para que dialogasse & \\
com “questões fundamentais que & \\
& exigiram estudo, aprendizado,mudanças \\
e maior conhecimento". & \\
\hline
\end{tabular}

Quadro V - Categorização da entrevista de Luísa

\begin{tabular}{|c|c|c|}
\hline $\begin{array}{l}\text { Categorias } \\
\text { descritivas }\end{array}$ & O que a entrevistada mostrou & Interpretação \\
\hline $\begin{array}{l}\text { Pontos } \\
\text { determinantes } \\
\text { da experiência }\end{array}$ & $\begin{array}{l}\text { Que a experiência compartilhada com a } \\
\text { equipe foi um processo de continuidade } \\
\text { dos estudos desenvolvidos na academia, } \\
\text { pois sabia “que não estava tudo pronto, e } \\
\text { que a coisa não terminava ali... um } \\
\text { momento básico importantíssimo para } \\
\text { começar a trilhar esse caminho de ser } \\
\text { um educador... que a gente está o tempo } \\
\text { todo procurando se aperfeiçoar”. } \\
\text { Destaca que no período vivenciado com } \\
\text { essa experiência, “... esse tipo de } \\
\text { interação tornou-me uma profissional } \\
\text { mais consciente e crítica, tanto em } \\
\text { minhas ações, quanto nas relações, no } \\
\text { planejamento das aulas, considerando a } \\
\text { condição visual do aluno e suas } \\
\text { necessidades escolares, os seus } \\
\text { interesses, expectativas dos familiares, } \\
\text { respeitando-os, avaliando o aluno de } \\
\text { forma processual”. }\end{array}$ & $\begin{array}{l}\text { Conta que a formação } \\
\text { inicial foi complementada } \\
\text { pelo processo formativo na } \\
\text { interação com a equipe, no } \\
\text { contexto escolar, mudando } \\
\text { muito seu pensamento e } \\
\text { suas ações. Reconhece que } \\
\text { transformou suas atitudes e } \\
\text { expectativas em relação ao } \\
\text { aluno e à família, tornando- } \\
\text { se mais aberta e flexível à } \\
\text { sua condição, } \\
\text { compreendendo a } \\
\text { construção do saber como } \\
\text { contínua e processual. }\end{array}$ \\
\hline $\begin{array}{l}\text { Transformações } \\
\text { na atuação que } \\
\text { perduram }\end{array}$ & $\begin{array}{l}\text { Que aprendeu a ter um olhar voltado } \\
\text { para... “essa condição de processo... e } \\
\text { que as respostas não são imediatas na } \\
\text { educação, de perceber o caminho das } \\
\text { coisas, que tudo depende de uma } \\
\text { construção, principalmente na educação } \\
\text { especial...”. Admite, por isso, que foi } \\
\text { muito importante “a prática de registro e } \\
\text { reflexão e ver que essa escola tem um } \\
\text { contexto, que essa escola está } \\
\text { construindo uma prática”. Argumenta } \\
\text { que o professor enfrenta situações } \\
\text { desconhecidas e que, muitas vezes, não } \\
\text { as domina "porque trabalhamos com } \\
\text { pessoas, e o que significa, por exemplo, }\end{array}$ & $\begin{array}{l}\text { Destaca, entre as } \\
\text { transformações que } \\
\text { permanecem: } \\
\text { - a maneira dinâmica como } \\
\text { começou a ver as situações } \\
\text { educativas, acompanhando } \\
\text { e valorizando as pequenas } \\
\text { mudanças dos alunos; } \\
\text { - compreensão do contexto } \\
\text { escolar como espaço de } \\
\text { aprendizagem que abriga } \\
\text { as características humanas } \\
\text { complexas, que não podem } \\
\text { ser explicadas sem que se } \\
\text { particularizem as condições }\end{array}$ \\
\hline
\end{tabular}




\begin{tabular}{|c|c|c|}
\hline & $\begin{array}{l}\text { 'acuidade visual 0,2, se com apenas } \\
\text { noventa e oito décimos de visão o } \\
\text { individuo não enxerga, mas o que eu faço } \\
\text { com estes dados?' 'Como lidar com cada } \\
\text { um dos alunos, se cada um aproveita } \\
\text { diferente?Como vou aproveitar melhor a } \\
\text { visão, a comunicação?' ... são saberes } \\
\text { que não se resumem ao contato com o } \\
\text { aluno; eu tenho que ter fundamentos da } \\
\text { deficiência visual para atingi-lo melhor” }\end{array}$ & $\begin{array}{l}\text { que as envolvem; } \\
\text { - examinar e interpretar as } \\
\text { condições de } \\
\text { aprendizagem, } \\
\text { contextualizando-as de } \\
\text { acordo com a singularidade } \\
\text { de cada aluno. }\end{array}$ \\
\hline $\begin{array}{l}\text { Aspectos que } \\
\text { contribuíram } \\
\text { para a atuação } \\
\text { como docente }\end{array}$ & $\begin{array}{l}\text { Que, ao chegar ao Centro de Apoio, teve } \\
\text { clareza desde o início que teria “com } \\
\text { quem dividir as idéias que até então } \\
\text { tinha que tomar algumas decisões, quase } \\
\text { que sozinha”. Que os “maiores ganhos } \\
\text { eram essas trocas... eu começava a olhar } \\
\text { questões que até então eu não tinha } \\
\text { parado para pensar... São conhecimentos } \\
\text { que estão envolvidos, que você vai } \\
\text { exercitando com o outro... ter todo } \\
\text { aquele olhar para o contexto histórico } \\
\text { das situações sociais... Analisar o porquê } \\
\text { das coisas...”. Por exemplo, "a gente } \\
\text { tem uma mania de culpabilizar a família } \\
\text { por tudo o que acontece de ruim para a } \\
\text { criança... ‘a família que não faz, que não } \\
\text { dá'”. Que, hoje, com esses } \\
\text { conhecimentos, “a gente consegue } \\
\text { elaborar a proposta, estabelecer } \\
\text { objetivos permeando todos os } \\
\text { programas; consegue fazer uma } \\
\text { avaliação baseada na evolução do aluno, } \\
\text { naquilo que ele já sabe, e não no que } \\
\text { falta”. No entanto, "nas escolas } \\
\text { regulares que eu acompanho como } \\
\text { professor itinerante, o professor fica } \\
\text { sozinho...”. Que, diante das dificuldades } \\
\text { “a gente já deduz que o professor deve } \\
\text { estar sozinho... não conseguindo ter } \\
\text { idéias, pensar de outras formas a } \\
\text { situação que ele está vivendo, sem } \\
\text { espaço de troca”. }\end{array}$ & $\begin{array}{l}\text { Aspectos que contribuíram: } \\
\text { - possibilidade de trocar } \\
\text { idéias com a equipe, } \\
\text { compartilhando decisões, } \\
\text { refletindo sobre sua prática } \\
\text { e, com maior clareza, } \\
\text { elaborar propostas } \\
\text { integrando todos os } \\
\text { programas; } \\
\text {-ter acesso a vários saberes, } \\
\text { ampliando a percepção } \\
\text { sobre as questões que } \\
\text { interferem na relação } \\
\text { ensino-aprendizagem; } \\
\text { - conseguir problematizar } \\
\text { as situações, avaliando o } \\
\text { processo de } \\
\text { desenvolvimento dos } \\
\text { alunos com ênfase em seus } \\
\text { ganhos. }\end{array}$ \\
\hline $\begin{array}{l}\text { Principais } \\
\text { falhas } \\
\text { observadas }\end{array}$ & $\begin{array}{l}\text { Que a falta de clareza na definição dos } \\
\text { papéis, dificultava a atuação dos } \\
\text { profissionais: “até onde vai a } \\
\text { intervenção de cada um... e como o } \\
\text { professor deve se apropriar desse } \\
\text { saber... onde está o limite da atuação de } \\
\text { cada um?”. Que constatou dificuldades }\end{array}$ & $\begin{array}{l}\text { Destaca: } \\
\text { - indefinição dos papéis } \\
\text { profissionais, que talvez } \\
\text { tenha dificultado a } \\
\text { diferenciação de } \\
\text { responsabilidades entre os } \\
\text { membros do grupo; }\end{array}$ \\
\hline
\end{tabular}




\begin{tabular}{|c|c|c|}
\hline & $\begin{array}{l}\text { na relação dos conhecimentos teóricos } \\
\text { com a prática: "Havia momentos que } \\
\text { fluíam muito bem e eu me sentia me } \\
\text { apropriando de conhecimentos, e em } \\
\text { outros momentos... 'o que eu faço com } \\
\text { isso efetivamente... como eu transito para } \\
\text { a prática?’”. Que, devido à imaturidade } \\
\text { do grupo para selecionar as temáticas de } \\
\text { discussão, “não se conseguia filtrar... os } \\
\text { 'n’ motivos por que aconteceu uma } \\
\text { situação 'x', ... estabelecer uma pauta e } \\
\text { segui-la, pois o grupo é muito ansioso”. } \\
\text { Que o excesso de demanda da equipe } \\
\text { impedia que as atividades conseguissem } \\
\text { ser compartilhadas com regularidade: } \\
\text { "Às vezes, eu planejei, registrei, eu } \\
\text { mesma, e li o meu registro, e coloquei lá } \\
\text { muitas indagações e, às vezes, não } \\
\text { consegui compartilhá-las”. }\end{array}$ & $\begin{array}{l}\text { - dificuldades na } \\
\text { confluência dos } \\
\text { conhecimentos teóricos } \\
\text { com algumas situações do } \\
\text { cotidiano; } \\
\text { - ausência de uma } \\
\text { organização de prioridades } \\
\text { que dessem conta do tempo } \\
\text { e espaço disponíveis para } \\
\text { suprir as necessidades do } \\
\text { grupo. }\end{array}$ \\
\hline $\begin{array}{l}\text { Condições que } \\
\text { favoreceram a } \\
\text { relação com o } \\
\text { aluno e a } \\
\text { intervenção }\end{array}$ & $\begin{array}{l}\text { Que destaca os momentos em que foi } \\
\text { possível “...sentar, planejar, registrar e } \\
\text { refletir o registro. Então, por felicidade, } \\
\text { estava num grupo em que isso era uma } \\
\text { prática”. Que, nesses momentos, o } \\
\text { "diálogo com o outro, a gente começa a } \\
\text { ver outras questões que sozinho não vê”. } \\
\text { Que, da mesma forma, o diálogo com o } \\
\text { aluno também contribuiu para o } \\
\text { professor: “ao propor a atividade, saber } \\
\text { se...o aluno... julga-se capaz de realizá-la } \\
\text { sozinho; e, quando a finaliza, saber por } \\
\text { que escolheu aquele caminho, aquele } \\
\text { jeito”. Foram estratégias que, na relação } \\
\text { com o aluno, possibilitaram-lhe “mapear } \\
\text { um pouco como ele pensa”. Que, na } \\
\text { interação com os alunos, estimulava: “um } \\
\text { tem que ouvir o outro, valorizar sua } \\
\text { tentativa e a do outro, mas, juntos, } \\
\text { definirmos o que é cientificamente } \\
\text { melhor”. }\end{array}$ & $\begin{array}{l}\text { Assinala, entre as } \\
\text { condições: } \\
\text { - utilização de } \\
\text { procedimentos } \\
\text { metodológicos, } \\
\text { sistematizando as trocas } \\
\text { entre os membros do } \\
\text { grupo; } \\
\text { - estabelecimento de uma } \\
\text { relação dialógica entre } \\
\text { educadores e entre } \\
\text { educador e alunos, } \\
\text { valorizando a troca de } \\
\text { idéias direcionadas à } \\
\text { compreensão e solução das } \\
\text { situações complexas. }\end{array}$ \\
\hline $\begin{array}{l}\text { Condições que } \\
\text { possibilitaram } \\
\text { trocas e } \\
\text { conhecimento } \\
\text { interdisciplinar }\end{array}$ & $\begin{array}{l}\text { Que os profissionais da equipe abriram } \\
\text { espaço para refletir as questões } \\
\text { educacionais como um todo: “As } \\
\text { situações batem na nossa porta e a gente } \\
\text { precisava desse olhar que nos foi dado” } \\
\text { por meio de "saberes importantes de } \\
\text { áreas do conhecimento humano... Coisas } \\
\text { que, só a Pedagogia, não me dá }\end{array}$ & $\begin{array}{l}\text { Comenta que a parceria } \\
\text { possibilitou adquirir novas } \\
\text { aprendizagens, } \\
\text { contribuindo para: } \\
\text { - compreender, com mais } \\
\text { fundamentos, a dinâmica } \\
\text { educativa e as interações } \\
\text { com os sujeitos que a }\end{array}$ \\
\hline
\end{tabular}




\begin{tabular}{|c|c|c|}
\hline & $\begin{array}{l}\text { resposta”. Que os relatórios semestrais } \\
\text { dos alunos “foram conquistados em uma } \\
\text { construção com a equipe... passo a } \\
\text { passo, pensando em cima da nossa } \\
\text { elaboração... apontavam várias coisas } \\
\text { muito interessantes que você não se } \\
\text { pergunta... ‘quem vai ler?””. Que } \\
\text { aprendeu a se preocupar com as palavras } \\
\text { que utiliza, “verificar se é realmente esse } \\
\text { sentido que você está querendo dar, o } \\
\text { que você realmente está querendo falar } \\
\text { dessa pessoa...”. Que, atualmente, essa } \\
\text { construção é coletiva, intensa, “mas você } \\
\text { olha o aluno por inteiro e o grupo } \\
\text { contribui para esta constituição... uma } \\
\text { visão mais interdisciplinar". Que esses } \\
\text { conhecimentos ofereceram novas } \\
\text { aprendizagens para que interviesse em } \\
\text { três níveis: na “interação direta com o } \\
\text { aluno”, tentando “entender o processo } \\
\text { que o aluno faz para se apropriar do } \\
\text { conhecimento... interpretar melhor o } \\
\text { sujeito”; na “interação com as escolas } \\
\text { regulares, onde eu vou lidar com vários } \\
\text { profissionais, desde o inspetor ...até o } \\
\text { professor, diretor”; e na relação com a } \\
\text { família, “compreendê-la em seu contexto, } \\
\text { vê-la como parceira”. }\end{array}$ & $\begin{array}{l}\text { constituem: aluno, } \\
\text { familiares e profissionais } \\
\text { com quem se relacionava } \\
\text { no ensino fundamental; } \\
\text { - rever a maneira como os } \\
\text { relatórios sobre as } \\
\text { condições de aprendizagem } \\
\text { e a produção de } \\
\text { conhecimentos dos alunos } \\
\text { eram elaborados, } \\
\text { permitindo explicitar as } \\
\text { concepções do professor, } \\
\text { bem como analisar de que } \\
\text { forma esses pontos de vista } \\
\text { repercutiam no leitor. }\end{array}$ \\
\hline $\begin{array}{l}\text { Relação com o } \\
\text { aluno com } \\
\text { deficiência, } \\
\text { impasses } \\
\text { instaurados }\end{array}$ & $\begin{array}{l}\text { Que, na área da deficiência visual, a } \\
\text { comunicação é muito importante para se } \\
\text { estabelecer contato com o aluno: “É pela } \\
\text { comunicação que você vai trazer } \\
\text { saberes, que não é só tateando... o tempo } \\
\text { todo. Se eu não consigo me comunicar } \\
\text { com os alunos, isso dá muita angústia, } \\
\text { porque não sabemos que caminhos } \\
\text { seguir”. Que essas questões são, em } \\
\text { geral, extremamente complexas, e que o } \\
\text { professor fica no “front”, sentindo-se } \\
\text { muito angustiado, porque “tem casos que } \\
\text { não sabia como incluir, por causa da } \\
\text { comunicação”. Que, através das } \\
\text { observações da equipe foi possível “... } \\
\text { planejar, registrar, refletir” e } \\
\text { compreender melhor “... o tempo do } \\
\text { aluno, as oportunidades que ele precisa } \\
\text { realmente para observar e deduzir a } \\
\text { atividade”. Que, assim como essa } \\
\text { dificuldade, outros impasses, de igual }\end{array}$ & $\begin{array}{l}\text { Ressalta, entre os desafios: } \\
\text { - buscar formas possíveis } \\
\text { de comunicação com o } \\
\text { aluno, que garantissem ao } \\
\text { professor intervir de } \\
\text { maneira mais eficiente, ou } \\
\text { seja, capacidade do } \\
\text { educador para desenvolver } \\
\text { modos de interagir com o } \\
\text { aluno por meio de várias } \\
\text { linguagens, fator } \\
\text { fundamental para professor } \\
\text { e aluno partilharem } \\
\text { conhecimentos; } \\
\text { - compartilhar com o } \\
\text { professor do Regular as } \\
\text { aprendizagens que exigiam } \\
\text { uma atuação mais refletida } \\
\text { e planejada, buscando } \\
\text { procedimentos que não } \\
\text { despertassem juízo prévio e }\end{array}$ \\
\hline
\end{tabular}




\begin{tabular}{|c|c|c|}
\hline & $\begin{array}{l}\text { importância, advindos do } \\
\text { acompanhamento dos alunos no ensino } \\
\text { regular, exigiram maior atenção: “No } \\
\text { início, a gente era pouco experiente, a } \\
\text { gente chegava e despejava uma série de } \\
\text { orientações... o professor do Regular não } \\
\text { recebia bem, era muito difícil e eu fico } \\
\text { pensando qual seria minha reação se eu } \\
\text { estivesse no lugar dele, com esse desafio } \\
\text { de trabalhar com uma criança com } \\
\text { deficiência; que, na maioria das vezes, } \\
\text { não se sente preparado para trabalhar... } \\
\text { o professor olhava com desconfiança...”. } \\
\text { Que, refletindo com a equipe, traçou com } \\
\text { ela outras maneiras de chegar à escola: “a } \\
\text { gente começou, primeiro, a falar com o } \\
\text { trio gestor, para apresentar a proposta } \\
\text { de acompanhamento do aluno incluído e } \\
\text { de parceria com a escola.” Com essa } \\
\text { abordagem, a situação “foi mudando...”. }\end{array}$ & $\begin{array}{l}\text { provocassem resistências } \\
\text { do professor, } \\
\text { contemplando variadas } \\
\text { realidades, em diferentes } \\
\text { escolas. }\end{array}$ \\
\hline $\begin{array}{l}\text { Concepções de } \\
\text { deficiência }\end{array}$ & $\begin{array}{l}\text { Que a visão que possui sobre a } \\
\text { deficiência visual ressalta a importância } \\
\text { desse sentido como "responsável por } \\
\text { grande parte das informações recebidas } \\
\text { do ambiente, do controle do corpo, do } \\
\text { espaço... promovendo a integração da } \\
\text { pessoa”. Que, dessa forma, "as crianças } \\
\text { videntes aprendem por imitação, } \\
\text { espontaneamente, brincando, explorando } \\
\text { objetos que lhes chamam a atenção } \\
\text { visualmente". Que, associada a esses } \\
\text { aspectos, revela-se uma insegurança nos } \\
\text { pais, por não saberem “como educar os } \\
\text { filhos, e, com a revelação da deficiência } \\
\text { da criança, essa insegurança toma } \\
\text { dimensões ainda maiores". Que, } \\
\text { tomando essas considerações como } \\
\text { referência: “Entendo que se a criança, } \\
\text { desde o nascimento ou o mais cedo } \\
\text { possível, não contar com a educação } \\
\text { sistematizada, organizada, onde possa } \\
\text { ser ensinada pelos caminhos perceptuais } \\
\text { que apresenta, a deficiência poderá } \\
\text { delimitar a sua relação com o } \\
\text { conhecimento". }\end{array}$ & $\begin{array}{l}\text { Considera que a } \\
\text { interpretação da deficiência } \\
\text { visual requer analisar a } \\
\text { dimensão que o sentido da } \\
\text { visão tem para a } \\
\text { aprendizagem e o } \\
\text { desenvolvimento das } \\
\text { pessoas; que as práticas, de } \\
\text { forma dinâmica, } \\
\text { necessitam, igualmente, } \\
\text { trabalhar na perspectiva } \\
\text { dos ganhos e criar } \\
\text { oportunidades para os } \\
\text { alunos com deficiência } \\
\text { visual construírem } \\
\text { significados. } \\
\text { Essas considerações } \\
\text { sugerem uma concepção de } \\
\text { deficiência que admite não } \\
\text { ser estável, uma vez que as } \\
\text { práticas educativas são } \\
\text { citadas como } \\
\text { desencadeadoras dos } \\
\text { processos de } \\
\text { desenvolvimento e } \\
\text { aprendizagem. }\end{array}$ \\
\hline
\end{tabular}

\footnotetext{
${ }^{27}$ Trio gestor - representado pelo diretor, assistente e coordenador pedagógico da escola regular.
} 


\begin{tabular}{|c|c|c|}
\hline $\begin{array}{l}\text { Referenciais } \\
\text { teóricos que } \\
\text { ajudaram no } \\
\text { manejo do } \\
\text { cotidiano } \\
\text { escolar }\end{array}$ & $\begin{array}{l}\text { Que, nos momentos de reflexão, em } \\
\text { parceria com os profissionais da equipe, } \\
\text { “fui reapresentada para teóricos, pelo } \\
\text { olhar dessas pessoas, que ampliaram a } \\
\text { visão sobre a Educação... sobre o } \\
\text { desenvolvimento anátomo-fisiológico e } \\
\text { psicológico da criança e do } \\
\text { adolescente”. Que foram oportunidades } \\
\text { que possibilitaram elaborar, “de forma } \\
\text { mais crítica, as propostas } \\
\text { pedagógicas”... e, com essas diversas } \\
\text { contribuições teóricas, adquiriu uma nova } \\
\text { visão de que “o desenvolvimento não tem } \\
\text { regra fixa, não é que não se tenha } \\
\text { parâmetro de desenvolvimento, mas esse } \\
\text { desenvolvimento gradual e contínuo... vai } \\
\text { ter um jeito próprio, um ritmo próprio”. } \\
\text { Que hoje, com essa experiência, “eu } \\
\text { percebo que as situações que } \\
\text { ‘incendiavam' já não incendeiam mais, } \\
\text { pois me sinto mais forte para } \\
\text { resolver...”. }\end{array}$ & $\begin{array}{l}\text { Assinala que os } \\
\text { referenciais teóricos: } \\
\text { - ofereceram base para } \\
\text { refletir e orientar, de forma } \\
\text { mais consciente e segura, a } \\
\text { construção das propostas } \\
\text { pedagógicas e a tomada de } \\
\text { decisões no contexto } \\
\text { escolar; } \\
\text { - contribuíram para } \\
\text { aprofundar a visão sobre } \\
\text { educação, desenvolvimento } \\
\text { e aprendizagem, a partir de } \\
\text { uma perspectiva menos } \\
\text { linear, mais crítica, } \\
\text { interativa e dinâmica. }\end{array}$ \\
\hline
\end{tabular}

Quadro VI - Categorização da entrevista de Bianca

\begin{tabular}{|c|c|c|}
\hline $\begin{array}{l}\text { Categorias } \\
\text { descritivas }\end{array}$ & O que a entrevistada mostrou & Interpretação \\
\hline $\begin{array}{l}\text { Pontos } \\
\text { determinantes } \\
\text { da experiência }\end{array}$ & $\begin{array}{l}\text { Que o que mais se destacou foi o “modo } \\
\text { de trabalho, em parceria, a partir de um } \\
\text { projeto... junto com a equipe, que } \\
\text { auxiliou muito na época em que eu tinha } \\
\text { uma turma muito difícil". Iniciou com } \\
\text { uma avaliação "sobre o processo de } \\
\text { aprendizagem e análise do percurso, de } \\
\text { como os alunos faziam para elaborar os } \\
\text { conhecimentos... como estavam } \\
\text { utilizando o raciocínio, a memória, } \\
\text { nestas situações. Foi um trabalho } \\
\text { dinâmico, integrado e muito prazeroso, } \\
\text { que me fez rever a forma como } \\
\text { estávamos trabalhando..". Que aprendeu } \\
\text { que, identificando o processo de } \\
\text { aprendizagem de cada aluno, "com uma } \\
\text { análise mais especifica, você consegue } \\
\text { oferecer ... uma proposta mais eficaz". }\end{array}$ & 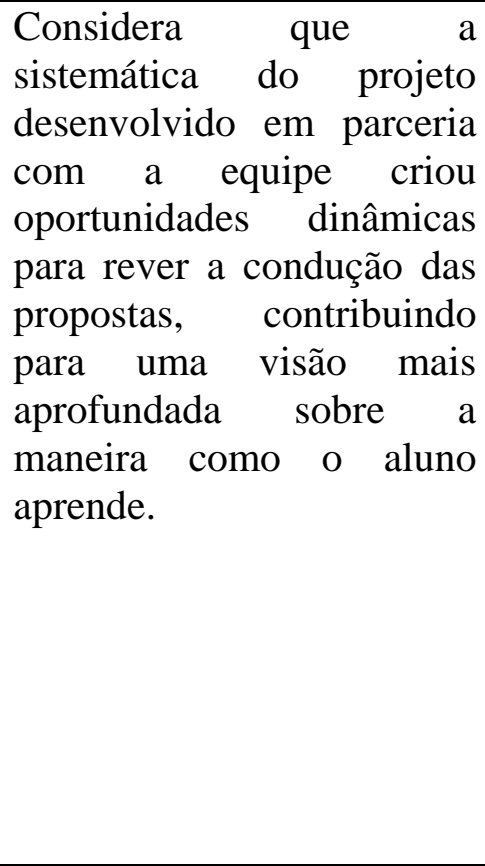 \\
\hline $\begin{array}{l}\text { Transformações } \\
\text { na atuação que } \\
\text { perduram }\end{array}$ & $\begin{array}{l}\text { Que a proposta "possibilitou novas } \\
\text { descobertas com os alunos; os } \\
\text { professores ganharam com a parceria } e\end{array}$ & $\begin{array}{l}\text { Dizem respeito: } \\
\text { - a maior domínio sobre o } \\
\text { modo como o aluno }\end{array}$ \\
\hline
\end{tabular}




\begin{tabular}{|c|c|c|}
\hline & $\begin{array}{l}\text { os alunos também". Que esses resultados } \\
\text { permitiram- lhe ampliar o "olhar sobre } \\
\text { como a criança constrói este } \\
\text { conhecimento". Que, no momento, } \\
\text { procura "trabalhar com a bagagem que a } \\
\text { experiência proporcionou, mas nem } \\
\text { sempre dá, pois as demandas atuais dos } \\
\text { alunos" perpassam por "necessidades } \\
\text { diversificadas, exigindo do professor } \\
\text { novos conhecimentos". Face à } \\
\text { complexidade das novas demandas, } \\
\text { admite que a bagagem já de domínio do } \\
\text { professor "teria que ter mais } \\
\text { conhecimentos da parte de } \\
\text { aprendizagem", fundamentos referentes } \\
\text { à "estrutura do pensamento desses } \\
\text { alunos, de conhecer mais esses meninos } \\
\text { com mais comprometimentos associados } \\
\text { à surdez", admitindo que, assim, sentir- } \\
\text { se-ia mais segura, com maior domínio } \\
\text { das necessidades dos alunos. }\end{array}$ & $\begin{array}{l}\text { constrói conhecimentos; } \\
\text { - à necessidade de se } \\
\text { manter em constante } \\
\text { formação, para sentir-se } \\
\text { mais bem preparada diante } \\
\text { das novas demandas que o } \\
\text { professor está encarregado } \\
\text { de acompanhar. }\end{array}$ \\
\hline $\begin{array}{l}\text { Aspectos que } \\
\text { contribuíram } \\
\text { para a atuação } \\
\text { como docente }\end{array}$ & $\begin{array}{l}\text { Que se referem às "discussões em grupo, } \\
\text { individuais, observações, trocas de } \\
\text { dados”. Que, de forma complementar, as } \\
\text { "assessorias e cursos voltados para as } \\
\text { necessidades da escola" contribuíram, pois } \\
\text { vinham ao encontro da solicitação do } \\
\text { grupo. Assinala que alguns cursos } \\
\text { oferecidos para a rede de ensino, por serem } \\
\text { muito genéricos e não estarem vinculados } \\
\text { às situações da prática dos professores que } \\
\text { ali estavam, não satisfizeram: "Quando as } \\
\text { formações são muito gerais, em geral não } \\
\text { contemplam a teoria; até pode ajudar, mas } \\
\text { a prática, em geral, fica deslocada, pois os } \\
\text { formadores já dizem que não entendem de } \\
\text { surdo". }\end{array}$ & $\begin{array}{l}\text { Destaca, entre os aspectos } \\
\text { que contribuíram: } \\
\text { - as atividades individuais e } \\
\text { coletivas com tematizações } \\
\text { da prática; } \\
\text { - observações e trocas de } \\
\text { experiência. } \\
\text { Argumenta que as } \\
\text { assessorias e cursos } \\
\text { contratados com fim } \\
\text { específico atenderam, mais } \\
\text { efetivamente, às } \\
\text { necessidades do professor, } \\
\text { do que as temáticas } \\
\text { genéricas oferecidas a toda } \\
\text { rede de ensino. }\end{array}$ \\
\hline $\begin{array}{l}\text { Principais } \\
\text { falhas } \\
\text { observadas }\end{array}$ & $\begin{array}{l}\text { Dizem respeito à interrupção de projetos } \\
\text { que eram eficazes e que, de forma } \\
\text { abrupta, foram substituídos por novos } \\
\text { encaminhamentos, de maneira que } \\
\text { "acaba-se implantando propostas de } \\
\text { maneira geral, irrestrita... e a gente } \\
\text { acaba apagando as coisas que davam } \\
\text { certo". Que "a maior angústia que o } \\
\text { professor enfrenta é a falta de } \\
\text { continuidade dos projetos. Os } \\
\text { educadores buscam, desenfreadamente, } \\
\text { soluções e, muitas vezes, aspectos que } \\
\text { traziam soluções... morrem”. Que o }\end{array}$ & $\begin{array}{l}\text { Enfatiza, entre as falhas: } \\
\text { - a descontinuidade dos } \\
\text { projetos que ajudaram o } \\
\text { professor e que não se } \\
\text { mantiveram, pela falta de } \\
\text { apoio da equipe. Assinala } \\
\text { que, paradoxalmente, o } \\
\text { próprio professor que é } \\
\text { beneficiado com as } \\
\text { soluções da proposta, } \\
\text { mesmo com autonomia, } \\
\text { não a mantém; } \\
\text { - o deslocamento da equipe }\end{array}$ \\
\hline
\end{tabular}




\begin{tabular}{|c|c|c|}
\hline & $\begin{array}{l}\text { professor é seduzido pelo novo e, mesmo } \\
\text { com autonomia, "não mantém... muda } \\
\text { procedimentos, mudam-se abordagens". } \\
\text { Que, sem a parceria mais próxima da } \\
\text { equipe, "o professor fica sozinho e, aí, } \\
\text { cada um faz o que acha melhor". Que, } \\
\text { hoje, “a dinâmica da equipe mudou, } \\
\text { recaindo no ombro do professor" dar } \\
\text { conta de resolver, sozinho, as } \\
\text { dificuldades das quais ainda não tem } \\
\text { pleno domínio. Admite que, } \\
\text { principalmente nesse momento, novas } \\
\text { demandas estão surgindo, por isso a } \\
\text { Secretaria de Educação não deveria ter } \\
\text { deslocado as equipes das unidades } \\
\text { escolares. }\end{array}$ & $\begin{array}{l}\text { da escola para atender } \\
\text { outras demandas, exigindo } \\
\text { que o professor assuma, } \\
\text { sozinho, situações que ele } \\
\text { acredita ainda não } \\
\text { dominar; } \\
\text { - fragmenta-se a linha de } \\
\text { trabalho à medida que não } \\
\text { se estabelece, } \\
\text { coletivamente, um eixo } \\
\text { norteador mediado pela } \\
\text { equipe. }\end{array}$ \\
\hline $\begin{array}{l}\text { Condições que } \\
\text { favoreceram a } \\
\text { relação com o } \\
\text { aluno e a } \\
\text { intervenção }\end{array}$ & $\begin{array}{l}\text { Que a experiência possibilitou } \\
\text { compreender melhor "como cada um dos } \\
\text { alunos estava construindo suas } \\
\text { aprendizagens, trazendo meios para fazer } \\
\text { minhas mediações e intervenções". Que, } \\
\text { com esses dados, retomava "a própria } \\
\text { organização dos grupos, flexibilizando } \\
\text { tempos e espaços na sala de aula, } \\
\text { adotando novas propostas e priorizando o } \\
\text { desenvolvimento de competências". Que } \\
\text { aprendeu a valorizar a singularidade de } \\
\text { cada aluno: "Cada aluno é um, com suas } \\
\text { peculiaridades, e as experiências vão se } \\
\text { vinculando para outras necessidades". } \\
\text { Nesse sentido, refere-se aos registros do } \\
\text { desenvolvimento das atividades, } \\
\text { valorizando "as observações escritas sobre } \\
\text { as atitudes e comportamentos dos alunos, } \\
\text { analisando e discutindo com eles, como } \\
\text { chegaram até aquela resposta, quais os } \\
\text { raciocínios informais e formais que } \\
\text { utilizou, qual o conceito que tem ou não", } \\
\text { dados sobre seu processo de conhecimento } \\
\text { que ajudaram na análise. Que transformou } \\
\text { sua visão sobre o aluno, concebendo-o } \\
\text { "como uma pessoa global, um ser que tem } \\
\text { toda uma engrenagem... está pensando... } \\
\text { tem um tipo de casa, de experiência, tem } \\
\text { um tipo de pensamento diferente do outro, } \\
\text { para chegar a uma resposta". Que, em } \\
\text { resposta a essas peculiaridades, "como } \\
\text { professora, tenho que oferecer vários } \\
\text { caminhos... para eles conseguirem } \\
\text { construir". }\end{array}$ & $\begin{array}{l}\text { Destaca: } \\
-\quad \text { a possibilidade de } \\
\text { compreender: a } \\
\text { singularidade do aluno } \\
\text { (experiências, bagagem } \\
\text { cultural, interesses, atitudes } \\
\text { etc.); a complexidade do } \\
\text { funcionamento } \\
\text { psicológico; como planejar } \\
\text { individualmente } \\
\text { intervenções pertinentes } \\
\text { estas necessidades e a cada } \\
\text { situação; farecimento da } \\
\text { - o favorecimes } \\
\text { adequação dos projetos } \\
\text { curriculares, contribuindo } \\
\text { na tomada de decisões para } \\
\text { a estruturação dos espaços } \\
\text { e tempos possíveis para a } \\
\text { realização das atividades; } \\
\text { - a sistematização dos } \\
\text { registros como suporte de } \\
\text { reflexão do processo de } \\
\text { desenvolvimento do aluno: } \\
\text { estratégias e percursos } \\
\text { alternativos que ele } \\
\text { constrói para elaborar } \\
\text { idéias, conceitos e } \\
\text { solucionar conflitos } \\
\text { cognitivos. }\end{array}$ \\
\hline
\end{tabular}




\begin{tabular}{|c|c|c|}
\hline $\begin{array}{l}\text { Condições que } \\
\text { possibilitaram } \\
\text { trocas } \\
\text { conhecimento } \\
\text { interdisciplinar }\end{array}$ & $\begin{array}{l}\text { Que foi importante estabelecer parcerias } \\
\text { que a complementassem de forma } \\
\text { competente, com boa vontade, abertura } \\
\text { para o diálogo e, acima de tudo, } \\
\text { considerando-a como parte integrante } \\
\text { desse processo. Nesse sentido, expressa: } \\
\text { "O meu posicionamento estava pautado } \\
\text { na minha atuação constante, sentindo-me } \\
\text { autor do meu fazer pedagógico e, dessa } \\
\text { forma, com condições de partilhar com } \\
\text { os demais os meus saberes". } \\
\text { diante das adversidades, o professor, } \\
\text { sozinho, não "resolve questões; que com } \\
\text { as trocas, ele consegue". Manifesta ter } \\
\text { sentido prazer em "trabalhar com estas } \\
\text { parcerias, pois a gente ia vendo as } \\
\text { soluções". Que essa experiência, } \\
\text { mediante o "encontro de conhecimentos } \\
\text { diferentes, ajudou-me a fazer de um jeito } \\
\text { diferente... e auxiliou a ter um olhar mais } \\
\text { apurado para a forma como aqueles } \\
\text { alunos com surdez estavam aprendendo" }\end{array}$ & $\begin{array}{l}\text { Revela, entre as condições: } \\
\text { - a cooperação entre equipe } \\
\text { e professor, estabelecendo } \\
\text { diálogo para } \\
\text { complementação do fazer } \\
\text { pedagógico; } \\
\text { - a valorização do saber } \\
\text { docente, assegurando ao } \\
\text { professor a importância de } \\
\text { seu papel; } \\
\text { - o compromisso dos } \\
\text { profissionais ao buscarem } \\
\text { soluções, valendo-se dos } \\
\text { conhecimentos } \\
\text { possuem; } \\
\text { - a análise de diferentes } \\
\text { áreas, enfocando as } \\
\text { variadas formas como os } \\
\text { alunos elaboram estratégias } \\
\text { e executam suas tarefas. }\end{array}$ \\
\hline $\begin{array}{l}\text { Relação com o } \\
\text { aluno com } \\
\text { deficiência, } \\
\text { impasses } \\
\text { instaurados }\end{array}$ & $\begin{array}{l}\text { Que os maiores questionamentos } \\
\text { adentravam na falta de condições iniciais } \\
\text { para a escola desenvolver uma proposta de } \\
\text { trabalho que suprisse as necessidades do } \\
\text { aluno com maior comprometimento: } \\
\text { "Diante das dificuldades com uma } \\
\text { população mais comprometida, as } \\
\text { adaptações curriculares não são fáceis... } \\
\text { precisamos de uma maneira diferente, um } \\
\text { trabalho sério para ele e para os } \\
\text { familiares". Que emergiam do grupo } \\
\text { proposições instigantes quanto ao papel } \\
\text { que os educadores especializados na } \\
\text { educação de surdos deveriam assumir, } \\
\text { diante desses impasses: "Eu, como } \\
\text { professora, preciso oferecer vários } \\
\text { caminhos para eles conseguirem construir } \\
\text { conhecimento, mas para o professor é } \\
\text { difícil descobrir sozinho o caminho de } \\
\text { cada um... crianças com déficit de atenção, } \\
\text { surdos com deficiência visual, com } \\
\text { paralisia cerebral, com deficiência } \\
\text { mental... Ele vai se beneficiar só com a } \\
\text { LIBRAS? É uma questão que, para mim, é } \\
\text { muito séria". Que um trabalho voltado } \\
\text { para a diversidade de condições da } \\
\text { população que a escola está recebendo não } \\
\text { se esgota com a construção de um } \\
\text { programa bilíngüe: “Eu acho isso justo e }\end{array}$ & $\begin{array}{l}\text { Destaca que os maiores } \\
\text { impasses inserem-se na: } \\
\text { - necessidade de a escola } \\
\text { implementar propostas e } \\
\text { metodologias que } \\
\text { considerem as } \\
\text { especificidades de uma } \\
\text { população com maior } \\
\text { comprometimento; } \\
\text { - articulação de propostas } \\
\text { formativas que ofereçam } \\
\text { ao professor da área de } \\
\text { deficiência auditiva } \\
\text { condições concretas de } \\
\text { delinear um ensino de } \\
\text { qualidade a todos os } \\
\text { alunos, mesmo que } \\
\text { inseridos também numa } \\
\text { perspectiva bilíngüe; } \\
\text { - utilização de recursos que } \\
\text { gerem um movimento de } \\
\text { análise das necessidades } \\
\text { dos alunos, definindo os } \\
\text { múltiplos caminhos a } \\
\text { serem traçados. }\end{array}$ \\
\hline
\end{tabular}




\begin{tabular}{|c|c|c|}
\hline & $\begin{array}{l}\text { certo com a população surda, só que nós } \\
\text { não temos só uma população surda... } \\
\text { ninguém está vendo isso... como você vai } \\
\text { poder oferecer pra essa pessoa condição } \\
\text { de vida, uma escola de qualidade?" } \\
\text { Conjugar todas essas necessidades exigiria } \\
\text { hoje recursos como os anteriormente } \\
\text { utilizados: “instrumentos metodológicos } \\
\text { que nos ajudassem a enriquecer e } \\
\text { sistematizar nosso pensar - observações, } \\
\text { registros, reflexão destes dados, avaliação, } \\
\text { sínteses dos projetos e o próprio } \\
\text { planejamento pedagógico iam compondo a } \\
\text { organização das ações educativas e a } \\
\text { tomada de decisões, levando-se em conta } \\
\text { as necessidades, interesses, o processo de } \\
\text { aprendizagem e o nível de conhecimento } \\
\text { do momento". }\end{array}$ & \\
\hline $\begin{array}{l}\text { Concepções de } \\
\text { deficiência }\end{array}$ & $\begin{array}{l}\text { Que sua visão de deficiência considera a } \\
\text { equiparação de condições que permitam o } \\
\text { surdo aprender: “A surdez não compromete } \\
\text { a aprendizagem, se houver uma } \\
\text { comunicação adequada... não trato o } \\
\text { surdo diferente... eu acho que ele tem que } \\
\text { ter tudo aquilo e muito mais que o ouvinte } \\
\text { tem...”. Considera que a aceitação da } \\
\text { LIBRAS como língua em veiculação na } \\
\text { escola criou novos canais de abertura, } \\
\text { "você chega muito mais no aluno, e ele } \\
\text { tem condições de se desenvolver... e até } \\
\text { fazer faculdade”. Entretanto, admite que, } \\
\text { se tratando de outras deficiências } \\
\text { associadas à surdez, seriam necessárias } \\
\text { adaptações metodológicas e na avaliação, } \\
\text { "para o professor se situar e adequar sua } \\
\text { abordagem". }\end{array}$ & 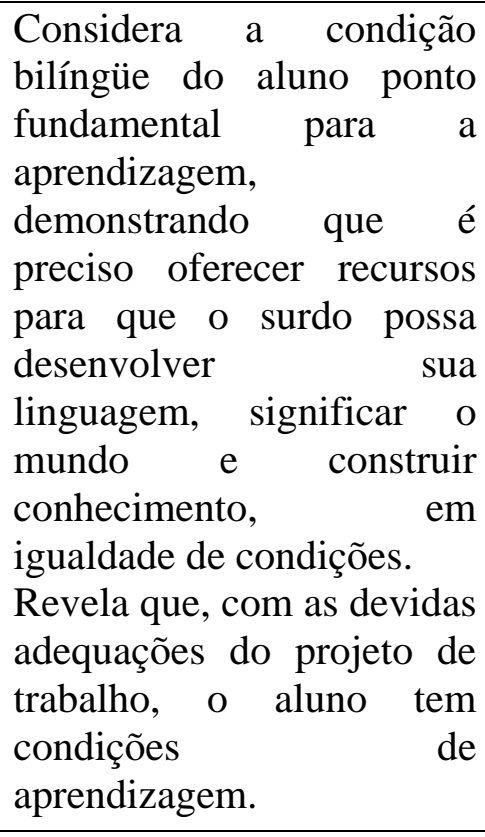 \\
\hline $\begin{array}{l}\text { Referenciais } \\
\text { teóricos que } \\
\text { ajudaram no } \\
\text { manejo do } \\
\text { cotidiano } \\
\text { escolar }\end{array}$ & $\begin{array}{l}\text { Que os fundamentos teóricos ofereceram } \\
\text { rumos para atingir os objetivos } \\
\text { pretendidos, favorecendo descobertas a } \\
\text { partir de outros parâmetros que foram } \\
\text { esclarecendo as situações e oferecendo } \\
\text { novos dados: "Você começa a entender as } \\
\text { dificuldades dos alunos, a ausência de } \\
\text { compreensão em determinados conceitos". } \\
\text { Que, a partir dessas descobertas, reconhece } \\
\text { que o aluno não aprende porque "ele não } \\
\text { tem alguns conceitos específicos, que lhes } \\
\text { forneçam dados", e não porque não é } \\
\text { capaz. }\end{array}$ & $\begin{array}{l}\text { Aponta que os referenciais } \\
\text { teóricos tornaram possível } \\
\text { a abertura para novos } \\
\text { conhecimentos, produzindo } \\
\text { novas formas de } \\
\text { compreender as } \\
\text { dificuldades do aluno e } \\
\text { criando condições } \\
\text { favoráveis para atingir os } \\
\text { objetivos propostos. }\end{array}$ \\
\hline
\end{tabular}


Quadro VII - Categorização da entrevista de Larissa

\begin{tabular}{|c|c|c|}
\hline $\begin{array}{l}\text { Categorias } \\
\text { descritivas }\end{array}$ & O que a entrevistada mostrou & Interpretação \\
\hline $\begin{array}{l}\text { Pontos } \\
\text { determinantes } \\
\text { da experiência }\end{array}$ & $\begin{array}{l}\text { Que começou a trabalhar sem nenhuma } \\
\text { experiência, pois o que havia aprendido } \\
\text { na faculdade - "teorias, métodos de } \\
\text { reabilitação" - só se referia a uma } \\
\text { realidade com condições ideais: "Que eu } \\
\text { ia poder trabalhar na reabilitação de } \\
\text { crianças de três, quatro anos com pais } \\
\text { que estimulassem em casa...". Que, ao } \\
\text { chegar à escola especial para alunos } \\
\text { surdos, outra realidade foi revelada: “O } \\
\text { primeiro grupo que eu peguei já chegou } \\
\text { tarde à escola, com doze, catorze anos e } \\
\text { não se comunicavam, não tinham } \\
\text { nenhum código, não liam, não escreviam. } \\
\text { Foi chocante! Eu não estava } \\
\text { preparada". Que, nessas condições, “fica } \\
\text { muito claro que a formação ocorreu na } \\
\text { própria unidade, através do respaldo de } \\
\text { quem estava lá - uma equipe com } \\
\text { orientadora pedagógica, fonoaudióloga, } \\
\text { psicóloga e assistente social trocando } \\
\text { com as professoras". Que o professor, } \\
\text { compartilhando com parceiros } \\
\text { competentes, "aprende no dia-a-dia, nas } \\
\text { relações com a equipe e com outras } \\
\text { professoras". }\end{array}$ & $\begin{array}{l}\text { Ter se deparado com uma } \\
\text { nítida discordância entre os } \\
\text { conhecimentos acumulados } \\
\text { na formação inicial - } \\
\text { bagagem enriquecedora de } \\
\text { materiais teórico- } \\
\text { metodológicos, todavia, } \\
\text { formuladora de um ensino } \\
\text { ideal, que parecia só existir } \\
\text { virtualmente - e, por outro } \\
\text { lado, os conhecimentos } \\
\text { requeridos pela prática que } \\
\text { pudessem levá-la a } \\
\text { compreender uma realidade } \\
\text { viva, complexa } \\
\text { imprevisível. participado de um } \\
\text { Ter para } \\
\text { processo formativo com } \\
\text { seus pares e equipe técnica, } \\
\text { o que lhe proporcionou } \\
\text { apoio e trocas de } \\
\text { experiência, superando } \\
\text { essa dissonância. }\end{array}$ \\
\hline $\begin{array}{l}\text { Transformações } \\
\text { na atuação que } \\
\text { perduram }\end{array}$ & $\begin{array}{l}\text { Que a Secretaria de Educação tinha, } \\
\text { dentre suas metas, a formação continuada } \\
\text { do professor e a manutenção da equipe na } \\
\text { escola, o que evidenciava seu princípio } \\
\text { formador, mesmo sob a ameaça de } \\
\text { descontinuidade administrativa, tão } \\
\text { comum na gestão pública: “A formação } \\
\text { interna nos levava para frente, era um } \\
\text { processo coletivo, sólido... contribuindo } \\
\text { para sistematização da nossa prática e } \\
\text { esta transformação foi se operando } \\
\text { dentro de mim, na minha prática e } \\
\text { ninguém me tira...". Que as mudanças } \\
\text { foram configurando seu papel } \\
\text { profissional: "Cresço, minha prática } \\
\text { muda, eu reflito sobre... e, no momento } \\
\text { que eu mudei, ninguém tira mais, são } \\
\text { tijolinhos que eu adquiri naquele } \\
\text { momento; passa a fazer parte da minha } \\
\text { vida, do meu fazer”. Que mudou seu }\end{array}$ & $\begin{array}{l}\text { Ter vivenciado uma } \\
\text { experiência de formação } \\
\text { continuada no contexto } \\
\text { escolar, que, por meio do } \\
\text { apoio da equipe técnica, } \\
\text { pôde se constituir num } \\
\text { fator de fortalecimento do } \\
\text { grupo e manutenção de um } \\
\text { trabalho formativo que } \\
\text { superou as mudanças da } \\
\text { gestão pública. } \\
\text { Dentre as transformações, } \\
\text { assinala: } \\
\text { - sistematização da prática } \\
\text { pedagógica; mudanças internas, } \\
\text { - muas pessoa), } \\
\text { subjetivas (na sua pesser } \\
\text { ao refletir sobre sua prática } \\
\text { profissional e o "ser } \\
\text { professor”; }\end{array}$ \\
\hline
\end{tabular}




\begin{tabular}{|c|c|c|}
\hline & $\begin{array}{l}\text { olhar: "o que eu percebia, a forma como } \\
\text { eu agia... eu tinha um olhar simples, não } \\
\text { tinha muitos elementos para analisar e, } \\
\text { muitas vezes, a minha ação era } \\
\text { inadequada". Sentindo-se mais } \\
\text { preparada, foi possível “enxergar mais, } \\
\text { compreender as dificuldades e, diante } \\
\text { dos impasses, você passa a ter outra } \\
\text { possibilidade, o enfrentamento passa a } \\
\text { ser com muito mais qualidade e a } \\
\text { intervenção é muito mais positiva". Que } \\
\text { admite ser a pessoa que é "porque tive a } \\
\text { possibilidade de conviver com todos } \\
\text { esses alunos, com todos esses parceiros, } \\
\text { tanto da equipe técnica, quanto dos } \\
\text { professores, nós somos um grupo muito } \\
\text { forte”. }\end{array}$ & $\begin{array}{l}\text { - uma leitura mais } \\
\text { aprofundada sobre a } \\
\text { realidade educativa, que } \\
\text { contribuiu para ampliar } \\
\text { suas condições na } \\
\text { mediação pedagógica e ao } \\
\text { lidar com as dificuldades, } \\
\text { atuando de forma } \\
\text { pertinente e segura. }\end{array}$ \\
\hline $\begin{array}{l}\text { Aspectos que } \\
\text { contribuíram } \\
\text { para a atuação } \\
\text { como docente }\end{array}$ & $\begin{array}{l}\text { Que destaca a contribuição da } \\
\text { parceria, “essa troca constante, } \\
\text { relacionada à realidade do professor, } \\
\text { das questões do dia-a-dia. Você não se } \\
\text { sente sozinho e... tem clareza onde está } \\
\text { acertando". Que, por exemplo, no } \\
\text { enfrentamento das dificuldades } \\
\text { relacionadas às resistências e de falta de } \\
\text { abertura para o outro, procura-se } \\
\text { trabalhar tal situação: "Nesse nosso } \\
\text { caminhar na educação de surdos... antes, } \\
\text { como oralistas, percebíamos resistências } \\
\text { para mudança, mas nós continuamos } \\
\text { juntos... e trabalhamos a resistência } \\
\text { dando a ela o resultado do nosso } \\
\text { trabalho e o outro, vai se modificando... } \\
\text { muito mais do que ler todos aqueles } \\
\text { textos... concepções, práticas, modelos, } \\
\text { eles estão todos lidos, mas precisam ser } \\
\text { vividos, experimentados. A possibilidade } \\
\text { de ter esse grupo de apoio, de ter uma } \\
\text { formação em parceria e estar no grupo, a } \\
\text { qualidade do trabalho é refletida em } \\
\text { resultados”. Que a promoção dessa } \\
\text { parceria não delimitava os saberes de cada } \\
\text { um e, além disso, não se sentia solitária } \\
\text { com seus problemas, “... pois realizavam } \\
\text { trocas, grupos de estudos, soma de saberes } \\
\text { - entra o meu conhecimento e o do outro, a } \\
\text { minha experiência, o meu fazer, mas está } \\
\text { acrescido o olhar do outro, que não anula } \\
\text { o meu, é um olhar que acredita no que } \\
\text { estou fazendo". }\end{array}$ & 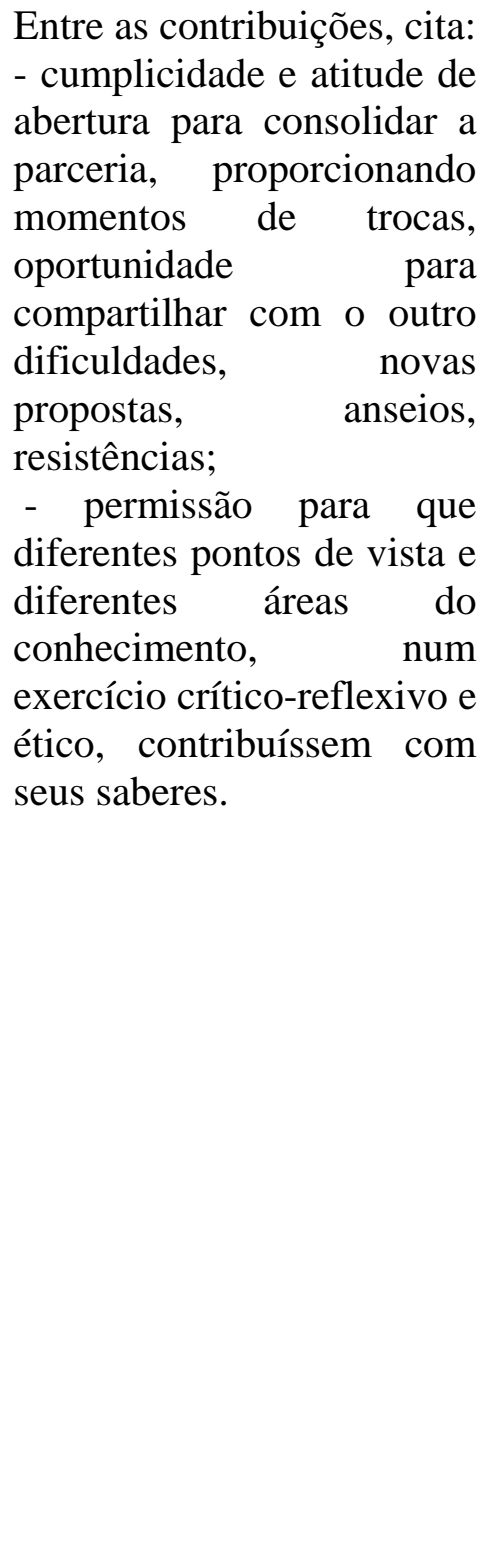 \\
\hline
\end{tabular}




\begin{tabular}{|c|c|c|}
\hline $\begin{array}{l}\text { Principais } \\
\text { falhas } \\
\text { observadas }\end{array}$ & $\begin{array}{l}\text { Que, assim como os professores, os } \\
\text { profissionais da equipe interdisciplinar } \\
\text { também estavam em formação, “apesar } \\
\text { de ter a formação técnica, que o } \\
\text { professor não tem, muitas vezes também } \\
\text { estão se formando em serviço" e que, por } \\
\text { essa razão, é necessário que o grupo } \\
\text { respeite "o tempo de cada um; não dá } \\
\text { para exigir aquilo que ele não tem; é } \\
\text { trabalhar conjuntamente para o } \\
\text { crescimento de todos”. Que a parceria só } \\
\text { se concretiza com abertura para o outro: } \\
\text { "As relações são importantes; o quanto } \\
\text { você está aberto para mudar, o quanto } \\
\text { você aceita as intervenções do outro, é } \\
\text { muito pessoal de cada um... e pode se } \\
\text { tornar um entrave, pois tem pessoas que, } \\
\text { em alguns momentos, não conseguem se } \\
\text { abrir e, às vezes, acabam se fechando } \\
\text { mais para o outro". "É preciso, sempre, } \\
\text { refletir, avaliar, pois, se em um momento } \\
\text { ele não está aberto, em outro estará". } \\
\text { Que, entretanto, diante dessas posturas, } \\
\text { constata que “as relações se desgastam". }\end{array}$ & $\begin{array}{l}\text { Indica entre } \\
\text { dificuldades: } \\
\text { - os profissionais da } \\
\text { equipe, mediadores da } \\
\text { atividade formativa, } \\
\text { também estavam em } \\
\text { formação e nem sempre } \\
\text { tinham total domínio dos } \\
\text { assuntos suscitados, não } \\
\text { conseguindo colaborar com } \\
\text { a discussão; } \\
\text { - falta de aceitação do } \\
\text { outro com seus limites e } \\
\text { diferenças, levando ao } \\
\text { desgaste das relações; } \\
\text { - resistência à mudança e } \\
\text { falta de abertura para } \\
\text { inovações. }\end{array}$ \\
\hline $\begin{array}{l}\text { Condições que } \\
\text { favoreceram a } \\
\text { relação com o } \\
\text { aluno e a } \\
\text { intervenção }\end{array}$ & $\begin{array}{l}\text { Que foi muito importante refletir a } \\
\text { prática, tendo a contribuição de um } \\
\text { parceiro próximo, mais } \\
\text { competente: “Vendo um profissional } \\
\text { competente, outro professor, o parceiro } \\
\text { da sala ao lado, a interferência de um } \\
\text { profissional da equipe, que vem te } \\
\text { auxiliar nessa construção". Foi uma } \\
\text { prática que se transformou em } \\
\text { sistemática de trabalho “constante, } \\
\text { ultrapassando dificuldades ou mudanças } \\
\text { de administrações, decorrente da } \\
\text { importância dada à Educação”. "Isto } \\
\text { continua comigo até hoje, no meu fazer } \\
\text { pedagógico". Que esse processo } \\
\text { contribuiu para a elaboração conjunta do } \\
\text { projeto pedagógico, com o apoio de } \\
\text { profissionais experientes na área, que } \\
\text { permaneceram muito tempo na no na } \\
\text { escola: “Se eu tinha um aluno que eu não } \\
\text { conseguia atingir, que apresentava mais } \\
\text { dificuldades de aprendizagem, de } \\
\text { comportamento ou questões emocionais, } \\
\text { eu buscava ajuda. Observávamos, } \\
\text { discutíamos juntos e buscávamos um } \\
\text { caminho para atender melhor cada um e }\end{array}$ & $\begin{array}{l}\text { Sinaliza, entre as } \\
\text { contribuições: } \\
\text { - reflexão sistemática da } \\
\text { prática, propiciando buscar } \\
\text { novos direcionamentos na } \\
\text { condução do trabalho, na } \\
\text { criação de estratégias e na } \\
\text { interação com os alunos, } \\
\text { concebendo-os em suas } \\
\text { múltiplas dimensões; } \\
\text { - possibilidade de situar-se } \\
\text { e construir novos saberes, } \\
\text { observando, na prática, a } \\
\text { intervenção de parceiros } \\
\text { mais experientes que, } \\
\text { durante muito tempo, } \\
\text { colaboraram a partir de sua } \\
\text { vivência na escola; } \\
\text { - apropriação de } \\
\text { conhecimentos articulados } \\
\text { à prática e ao cotidiano } \\
\text { escolar, que permanecem, } \\
\text { até hoje, contribuindo com } \\
\text { seu fazer pedagógico. }\end{array}$ \\
\hline
\end{tabular}




\begin{tabular}{|c|c|c|}
\hline & $\begin{array}{l}\text { trocávamos impressões, e daí chegar a } \\
\text { algumas soluções, de forma mais } \\
\text { coletiva”. Que essas trocas se } \\
\text { constituíram em “um procedimento } \\
\text { interativo... um espaço onde todos } \\
\text { tinham possibilidade de conhecer melhor } \\
\text { o aluno de que se falava, integrando a } \\
\text { visão, num sentido mesmo do ser inteiro, } \\
\text { tanto na aprendizagem quanto no } \\
\text { desenvolvimento". }\end{array}$ & \\
\hline $\begin{array}{l}\text { Condições que } \\
\text { possibilitaram } \\
\text { trocas e } \\
\text { conhecimento } \\
\text { interdisciplinar }\end{array}$ & $\begin{array}{l}\text { Que as atividades formativas foram } \\
\text { estabelecidas mediante a parceria com a } \\
\text { equipe e com as assessorias, de acordo } \\
\text { com a necessidade do grupo. Que, na } \\
\text { parceria com a equipe, tinha-se como } \\
\text { perspectiva buscar, coletivamente, } \\
\text { soluções e integrar saberes: "Os } \\
\text { profissionais não se limitavam apenas à } \\
\text { sua própria área, mas buscávamos } \\
\text { somar saberes... para se ter uma visão do } \\
\text { aluno enquanto desenvolvimento, do seu } \\
\text { modo de ser, das suas necessidades - era } \\
\text { assim que a gente trabalhava". Que a } \\
\text { equipe mediava a formação, e um de seus } \\
\text { membros, alternadamente, coordenava o } \\
\text { grupo, espaço onde as idéias eram } \\
\text { partilhadas e todos contribuíam: } \\
\text { "Quando a equipe está preparada, ela é } \\
\text { interdisciplinar, não só no nome - ela é } \\
\text { toda interativa, todos os profissionais } \\
\text { têm esse olhar para a criança por } \\
\text { inteiro... para assim conseguirmos } \\
\text { formar este cidadão de direitos... com } \\
\text { autonomia e que tenha condições de se } \\
\text { impor... com condições de lutar pelas } \\
\text { próprias necessidades... essa sim é a } \\
\text { verdadeira inclusão". Que o apoio } \\
\text { constante contribuiu para sua } \\
\text { aprendizagem: “Permite um crescimento, } \\
\text { mudança da prática, no dia-a-dia, } \\
\text { partindo da real necessidade dos } \\
\text { profissionais e do grupo de alunos". }\end{array}$ & $\begin{array}{l}\text { Avalia que os processos de } \\
\text { trocas não ocorriam apenas } \\
\text { numa direção, mas que } \\
\text { eram compostos por } \\
\text { atividades com os } \\
\text { assessores e, internamente, } \\
\text { com a equipe técnica. } \\
\text { Reconhece que esses } \\
\text { agentes formadores criaram } \\
\text { condições para: } \\
\text { - promover um movimento } \\
\text { interativo, mediante a } \\
\text { articulação de } \\
\text { conhecimentos com a } \\
\text { prática, envolvendo todos } \\
\text { os atores, convergindo para } \\
\text { as necessidades do grupo, } \\
\text { no sentido de compreender } \\
\text { o aluno de forma } \\
\text { interdisciplinar. }\end{array}$ \\
\hline $\begin{array}{l}\text { Relação com o } \\
\text { aluno com } \\
\text { deficiência, } \\
\text { impasses } \\
\text { instaurados }\end{array}$ & $\begin{array}{l}\text { Que seu olhar adquiriu maior amplitude, } \\
\text { tornando o trabalho fundamentado e a } \\
\text { relação com o aluno, mais aberta. } \\
\text { Entretanto, tornava-se necessário } \\
\text { encontrar uma forma de comunicação } \\
\text { que conseguisse estabelecer uma perfeita } \\
\text { comunicação e que não comprometesse a } \\
\text { compreensão das informações que }\end{array}$ & $\begin{array}{l}\text { Considera, entre seus } \\
\text { questionamentos, que: } \\
\text { - a conquista de uma visão } \\
\text { mais aprofundada do aluno } \\
\text { foi favorável, entretanto } \\
\text { não eliminou totalmente } \\
\text { suas dificuldades na } \\
\text { mediação da }\end{array}$ \\
\hline
\end{tabular}




\begin{tabular}{|c|c|c|}
\hline & 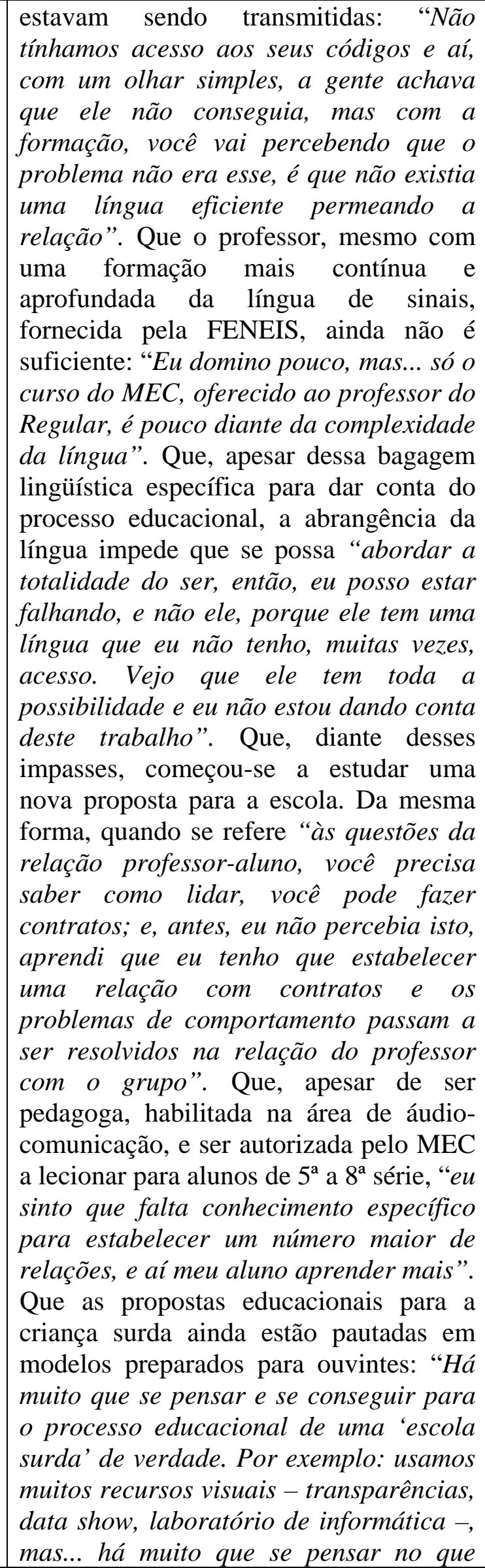 & 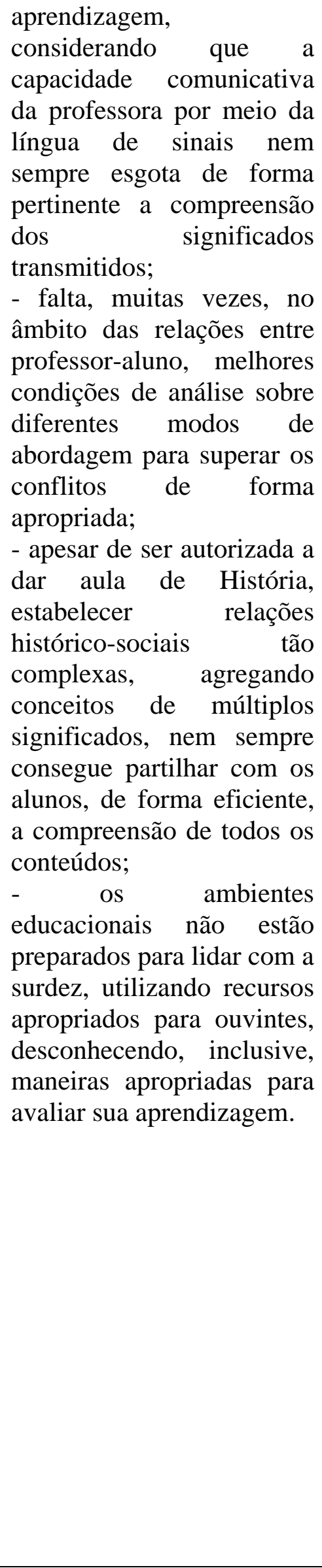 \\
\hline
\end{tabular}




\begin{tabular}{|c|c|c|}
\hline & $\begin{array}{l}\text { seria melhor para a criança surda". Que } \\
\text { a própria questão que envolve a avaliação } \\
\text { dos alunos reflete os impasses } \\
\text { enfrentados: "Como seria uma avaliação } \\
\text { para surdos... não sei se estou avaliando } \\
\text { o conhecimento especifico do meu } \\
\text { objetivo dentro da área de História, ou } \\
\text { se estou avaliando quanto ele sabe de } \\
\text { Língua Portuguesa, que é sua segunda } \\
\text { língua na modalidade escrita, e que não } \\
\text { é a língua em que ocorre o processo de } \\
\text { aprendizagem, pois dialogamos em } \\
\text { LIBRAS. Precisaria avaliá-los por meio } \\
\text { de LIBRAS”. }\end{array}$ & \\
\hline $\begin{array}{l}\text { Concepções de } \\
\text { deficiência }\end{array}$ & $\begin{array}{l}\text { Que, estudando, o professor vai se } \\
\text { formando e compreendendo melhor o } \\
\text { aluno e que sua concepção sobre a } \\
\text { deficiência mudou: "Passamos a ver o } \\
\text { aluno como um ser com potencial e não } \\
\text { como alguém que tem falta de alguma } \\
\text { coisa". Que "a criança é diferente, tem } \\
\text { uma língua diferente, e quem tem que se } \\
\text { adequar ao surdo sou eu, o professor. } \\
\text { Ela é uma criança, tem uma forma de } \\
\text { comunicação diferente, uma língua } \\
\text { diferente, mas tem toda a possibilidade } \\
\text { de desenvolvimento integral, pleno como } \\
\text { qualquer outra criança". Que essa } \\
\text { concepção não desconsidera "que ele não } \\
\text { ouve e... que ele tem um biológico que } \\
\text { exige uma série de recursos visuais, mas } \\
\text { isto não é um impeditivo para que as } \\
\text { relações aconteçam, dentro da língua, do } \\
\text { desenvolvimento da identidade surda e } \\
\text { do seu modo de ser e agir". Que, mesmo } \\
\text { não ouvindo, o surdo possui outro canal } \\
\text { de acesso e esse fator não compromete a } \\
\text { aprendizagem, levando-se } \\
\text { consideração esses outros meios. }\end{array}$ & $\begin{array}{l}\text { Argumenta que a surdez } \\
\text { não impõe limites à } \\
\text { aprendizagem, se forem } \\
\text { considerados os meios } \\
\text { necessários para que o } \\
\text { aluno se comunique. } \\
\text { Mesmo admitindo a } \\
\text { existência de uma } \\
\text { constituição biológica com } \\
\text { deficiência auditiva, o foco } \\
\text { de sua análise é colocado } \\
\text { no potencial do sujeito, e } \\
\text { não na condição de perda } \\
\text { sensorial. Reconhece, } \\
\text { ainda, que no } \\
\text { responsabilidade está no } \\
\text { professor, que deve } \\
\text { encontrar meios para } \\
\text { estabelecer diálogo com o } \\
\text { surdo, de forma que esse } \\
\text { consiga internalizar } \\
\text { significados como qualquer } \\
\text { criança, permitindo-lhe } \\
\text { desenvolver sua identidade. }\end{array}$ \\
\hline $\begin{array}{l}\text { Referenciais } \\
\text { teóricos que } \\
\text { ajudaram no } \\
\text { manejo do } \\
\text { cotidiano } \\
\text { escolar }\end{array}$ & $\begin{array}{l}\text { Que a bagagem adquirida não lhe } \\
\text { propiciou condições de admitir que esteja } \\
\text { totalmente pronta, "porque eu acho que a } \\
\text { gente está o tempo inteiro se } \\
\text { constituindo... Vamos mudando, cada } \\
\text { qual no seu tempo... foram mudanças } \\
\text { gradativas envolvendo a equipe toda da } \\
\text { escola... uma mudança de paradigma”. } \\
\text { Que foram etapas que ela registra como } \\
\text { "transformações acontecendo numa } \\
\text { ligação muito direta com a prática". Que }\end{array}$ & $\begin{array}{l}\text { Revela } \\
\text { impregnadas } \\
\text { intencionalidade, } \\
\text { orientadas para considerar } \\
\text { as múltiplas dimensões da } \\
\text { deficiência e a valorização } \\
\text { das trocas e parcerias, } \\
\text { numa perspectiva } \\
\text { transformadora ras } \\
\text { concepções e paradigmas. } \\
\text { Na educação de surdos, }\end{array}$ \\
\hline
\end{tabular}




\begin{tabular}{|l|l|lr|}
\hline os aportes teóricos das assessorias, tais & considera os referenciais \\
como as de Zilda Gesueli e Wilma & teóricos que apontam para \\
Favorito, ambas da UNICAMP, & a visão da deficiência como \\
trouxeram ensinamentos relevantes sobre & diferença, dando ênfase no \\
o "processo de aquisição de leitura e & potencial e nas \\
escrita, da gramática, e nós fomos & experiências visuais que \\
percebendo que se tratava de duas & direcionam as relações de \\
línguas, com gramática diferente”. Que o & aprendizagem. \\
professor Carlos Skliar, da UFRGS, & \\
trouxe outro referencial da deficiência \\
"como diferença e o trabalho com as \\
potencialidades, e não mais como uma \\
dificuldade, uma deficiência”. \\
Que, a cada nova criança, novos \\
conhecimentos se fazem necessários: \\
"Com uma criança com outra deficiência \\
associada ... fui compartilhar a formação \\
com profissionais do Centro de Apoio \\
para Deficiência Visual... Foi muito \\
interessante, pois aprendi a vê-la por \\
inteiro, não só ouvidos ou visão". Que, \\
"hoje consigo perceber o tempo do \\
outro... hoje eu tenho outro olhar, então \\
estas trocas são muito legais... Quanto \\
mais preparado o professor estiver, \\
melhor será o atendimento".
\end{tabular}

\subsubsection{Comentários sobre os significados levantados}

Buscou-se estabelecer, com a organização dos quadros dos principais significados identificados nos depoimentos, uma análise comparativa entre os pontos de vista das entrevistadas.

$\mathrm{Na}$ análise desses depoimentos, constatou-se que a experiência formativa em estudo gerou diferenciados pontos de vista, em termos de concepções, valores, atitudes, ora convergentes, ora contraditórios entre si. De certa forma, verifica-se que, no bojo das manifestações, as questões que emergiram foram se enredando, como fios que compõem uma trama de interpretações sobre as vivências profissionais das educadoras entrevistadas, criando-se, assim, uma textura variada, plural, enriquecida pelos múltiplos perfis de quem as teceu. 
A apresentação dos itens a seguir resultou da organização dos aspectos abordados pelas entrevistadas, contidos nos Quadros da Primeira Categorização:

\section{PONTOS DETERMINANTES DA PARCERIA - Marcas em Evidência}

Diante da questão desencadeadora, do diálogo entre entrevistadora e entrevistadas, foi ressaltado dessa experiência o que ficou mais presente, os pontos determinantes para a formação desses educadores, aspectos que foram se repetindo ao longo da entrevista.

- Criação de espaços para refletir a prática: A maioria das educadoras entrevistadas descreveu a parceria entre professores e equipe como possibilidade para compartilharem suas experiências, trocarem idéias, tendo como base a compreensão teórica dos processos de aprendizagem dos alunos. Em relação à boa qualidade da experiência, houve consenso, particularmente quanto ao suporte técnico e à percepção de maior segurança e autonomia, por parte do professor, mediante o apoio especializado. Revelaram uma clara visão das possibilidades e potencial do trabalho em parceria, conforme quadros indicados a seguir: IV (p. 144), III (p. 140), II (p. 136), V (p. 148), VI (p. 153), VII (p. 158) e I (p. 131).

- Continuidade da Formação: Considerações quanto ao despreparo que sentiram, ao saírem da faculdade, para enfrentarem as situações escolares, pontuando que estas se mostraram muito distantes das situações estudadas na academia, e o quanto foram importantes os saberes constituídos em parceria com uma equipe de apoio. Quadros: III (p. 140), V (p. 148 ) e VII (p. 158 ).

- Ampliação da capacidade de identificar, com mais clareza, as necessidades educativas dos alunos: Pelas relações com a equipe e as assessorias, o que representou crescimento profissional, nos aspectos técnicos, nas condições relativas à interação com o aluno e a família, com mais abertura e flexibilidade, compreendendo sua condição de forma mais dinâmica. Quadros: III (p. 140), II (p. 136), I (p. 131), IV (p. 144), VI (p. 153) e V (p. 148). Possibilitou-lhes, no contexto da diversidade, redirecionar seu fazer-pedagógico, pautado em uma visão mais específica dos alunos, tomando decisões adaptadas à realidade de cada um. 


\section{TRANSFORMAÇÕES PROMOVIDAS NA ATUAÇÃO DO PROFESSOR}

- Compreensão mais aprofundada do aluno: Concordância de que as condições de formação oferecidas a essas educadoras ampliaram o olhar sobre o aluno, contribuindo para um amadurecimento teórico e uma tomada de decisões com a construção de uma prática mais fundamentada. Quadros: VI (p. 154), II (p. 136), VII(p. 159), III (p. 141142) e I (p. 131).

A perspectiva analisada pelas educadoras resgata os princípios de uma ação que estabeleceu diálogo entre diferentes saberes e desenvolveu projetos que, sobretudo, “ofereceram oportunidades para a criança pensar”, apresentando-lhe desafios cognitivos, mais do que conteúdos esparsos que não tinham significado para ela. Quadro III (p. 140).

- Incorporar uma sistemática de análise de registros e materiais: Educadoras revelaram que foram mobilizadas a imprimir uma prática de estarem sempre apoiadas em registros de observações, produções dos alunos, relatórios de avaliação deles e na leitura das condições encontradas nas unidades escolares, a fim de se apurar o conhecimento sobre o contexto educativo e gerar dados para validar e acompanhar as transformações dos alunos, da ação educativa e da própria escola, em constante movimento. Quadros: V (p. 148), I (p. 131) e IV (p. 145).

Essas transformações, que permaneceram até hoje na expressão das entrevistadas, não impedem que o professor sofra com os impactos dos momentos atuais, marcados pela grande complexidade das situações educativas que requerem adaptações e recursos mais específicos. Quadros: V (p. 149), III (p. 141), VI (p. 154) e VII (p. 158).

\section{CONTRIBUIÇÕES E FALHAS - Encontros e desencontros}

Entre os fatores que contribuíram para a formação, dois aspectos foram mais amplamente destacados. Entre as falhas e dificuldades apontadas, três aspectos parecem ter comprometido negativamente o processo formativo. Esse conjunto de dados das entrevistadas evidenciou um movimento de oscilação, ora enfatizando falhas e dificuldades, ora efeitos favoráveis, em um nítido movimento de polarização. 
Os fatores que contribuíram de forma mais significativa para a atuação dessas educadoras aparecem citados de forma complementar:

- Apoio técnico e espaço coletivo de trocas de experiências: Discussão sobre situações vivenciadas pelo professor no contexto escolar, ressaltando a importância do processo compartilhado pelo grupo diante das dificuldades. As considerações das professoras Luísa e Ana chamam atenção para as situações presenciadas nas escolas regulares, onde, por ausência de suporte técnico, os professores do Ensino Fundamental não conseguem resolver suas dificuldades. Quadros: III (p. 141), II (p. 136), V (p. 149) e VII (p. 159).

- Ampliação de conhecimentos e fortalecimento do papel profissional: Novos conhecimentos para sustentação de uma prática mais consciente e autônoma, fortalecendo a idéia de autoria do processo educativo; os diálogos, ampliando as possibilidades de essas educadoras refletirem e definirem rumos para o seu papel profissional, de forma mais intencional e com mais autoridade e segurança. Quadros: IV (p. 145), II (p. 136), V (p. 149), VI (p. 154), VII (p. 159) e I (p. 132).

Mais do que ouvir queixas e problemas concretos que as afligiam, a formação em parceria com a equipe contribuiu, na visão das professoras Manoela e Maria, para que fosse criada uma relação positiva de confiança. Quadros: II (p. 136) e IV (p. 145).

Quanto aos fatores considerados como falhas e limites da experiência, foram apontadas a forma de participação do professor e a responsabilidade da equipe e da estrutura institucional:

- Descontinuidade das ações e falta de compromisso de alguns profissionais: Certo descompromisso, superficialidade e dificuldade de cumprir a programação planejada por parte de alguns profissionais da equipe, comprometendo a eficiência da proposta. A entrevistada Luísa argumentou que, internamente, o grupo como um todo, por imaturidade, não conseguia dar conta das pautas de trabalho; dificuldades dos educadores nas discussões dos temas, talvez por excesso de ansiedade, não conseguiam ser mais objetivos. Não ter conseguido atender todos os compromissos do trabalho formativo foi assinalado por quatro das sete entrevistadas. Quadros: III (p. 141), II (p. 137), V (p. 150) e I (p. 132). 
O depoimento da educadora Larissa sugeriu dificuldades técnicas dos profissionais da equipe, admitindo ser necessário encontrar, de forma interativa, respostas para tais dificuldades. Quadro VII (p. 160).

- $\quad$ Falta de clareza do papel profissional: Foi apontada por três educadoras a existência de uma possível indefinição do papel, para alguns profissionais, mesclada de certa fragmentação entre as funções, gerando dúvida, quanto ao conhecimento de suas próprias atribuições como professora. Quadro V (p. 149).

Foram apontadas, também, preocupações sobre como as relações são estabelecidas entre as diferentes funções da escola, sugerindo que essa fragmentação disfarça uma relação pautada na disputa de poder, impedindo o crescimento do grupo. Quadro II (p. 137).

Foram convergentes os depoimentos de Ana, Maria e Manoela quanto às relações de trabalho: desvalorização do saber do professor - seu potencial não foi reconhecido -, sugerindo forte teor hierárquico, requerendo uma relação de reciprocidade e abertura para a complementação, a fim de que não haja insatisfação. Quadros: III (p. 141), II (p. 136), IV (p. 145) e VII (p. 160).

- $\quad$ Falta de estrutura administrativa: Por último, entre os fatores mencionados, algumas entrevistadas citaram aspectos de natureza estrutural, ora envolvendo a gestão da Secretaria de Educação, ora envolvendo a organização interna à escola. Quadros: I (p. 132) e II (p. 137).

Os impedimentos para que a equipe cumprisse seus compromissos foram apontados pelas educadoras Bianca e Manoela como decorrentes das demandas externas colocadas pela Secretaria de Educação; a descontinuidade dos projetos, sem prévia avaliação, foi o que mais despertou frustração, desconsiderando as propostas que vinham trazendo resultados e, mesmo com possibilidades de definir os rumos do seu trabalho, abandonando-os, sem muita clareza, e descartando os resultados positivos. Quadros: VI (p. 154-155) e II (p. 136). 


\section{CONDIÇÕES PROPORCIONADAS PARA MELHORAR A PRÁTICA}

As condições assinaladas refletem uma conjugação de dois fatores complementares:

- Reflexão e tematização da ação educativa: Processo assinalado pela maioria dos educadores como prática que permitia uma discussão partilhada com o outro, com um parceiro mais competente, analisando situações concretas, questões ligadas ao projeto de trabalho e conhecimentos que, com esse diálogo mais próximo, subsidiavam formas possíveis de planejar, agir e promover mudanças. A sistematização e análise dos registros parecem ter funcionado como um exercício sistemático de apoio para o planejamento, a troca de saberes e o redirecionamento das propostas. Quadros: IV (p. 145), I (p. 132), VII (p. 160), III (p. 142) e V (p. 150).

- Compreensão da singularidade do aluno: As educadoras sugeriram sentirem-se mais seguras, com domínio de conhecimentos que as fizessem compreender a totalidade do sujeito e os diferentes estilos de aprendizagem, condições propiciadoras para que o professor atenda às necessidades específicas dos alunos, adequando seus projetos de trabalho. Quadros: IV (p. 146), III (p. 142), V (p. 150), VII (p. 161) e I (p. 132).

\section{CONDIÇÕES QUE POSSIBILITARAM A TROCA DE SABERES E PRODUZIRAM UM CONHECIMENTO INTERDISCIPLINAR}

Quatro aspectos centrais constituíram possibilidades para a troca de saberes e produção de um conhecimento interdisciplinar:

- Ser um processo interativo de valorização do saber docente: A formação abriu espaço para trocas, propiciando a todos compartilharem suas idéias e produções. Essa questão é indicada como tendo promovido um sentimento favorável de conquista da valorização do saber docente. Quadros: III (p. 142) e VI (p. 156).

As professoras Maria e Ana enfatizaram, em seus depoimentos, a transformação das atitudes de receptividade do outro, de conquista gradual desses sentimentos de segurança e pertencimento do grupo pelo professor, atribuindo a si a criação de possibilidades de participação, ao se posicionar no grupo e no processo de conquista 
de espaço, analisando que o descrédito e a cobrança inicial da equipe cederam espaço para uma posição mais interativa e de confiança. Quadros: III (p. 142) e IV (p. 146).

- Integração de saberes: Na ótica de algumas educadoras, a essência do processo formativo procurou estabelecer como foco o pensar a realidade na perspectiva de vários conhecimentos, como forma de compreender as especificidades dos alunos em seus vários contextos. Os depoimentos assinalaram a importância de uma atuação articulada dos profissionais, na perspectiva de focar, interdisciplinarmente, o aluno como um todo. Quadros: III (p. 143), II (p. 137), V (p. 150), VI (p. 156), VII (p. 161) e I (p. 133).

- Postura facilitadora em ouvir o outro: O acolhimento e a escuta do professor, pela equipe, parecem ter sido condições presentes, na visão de algumas entrevistadas, contribuindo para o compartilhamento de situações que pudessem nutrir o grupo com novos conhecimentos, troca de experiências, uma atitude de abertura que buscava ajudar o outro; foi essencial contar com os professores mais experientes, com maior domínio do trabalho, recurso essencial, principalmente devido à inexperiência dos professores iniciantes, ainda pouco acostumados com a área, conforme foi assinalado por duas entrevistadas. Quadros: I (p. 133) e II (p. 137-138).

- Estar voltado às necessidades do professor e à prática pedagógica: Foi apontado pelas educadoras como possibilidade de a equipe atender às expectativas do professor, articulando conhecimentos teóricos com a realidade da sala de aula. As professoras Maria, Larissa e Beija-Flor referiram-se a como a equipe contribuiu para o reconhecimento de suas necessidades, oferecendo orientações apropriadas às situações do dia-a-dia, utilizando-as nas discussões, para elaborarem coletivamente, uma outra concepção de deficiência. Quadros: IV (p. 146), VII (p. 161) e I (p. 133).

Da mesma forma, a professora Luísa assinalou como obteve, em parceria com a equipe, uma visão mais contextualizada das situações envolvendo profissionais e funcionários ${ }^{28}$ da escola, a família e o próprio aluno. Quadro V (p. 151).

\footnotetext{
28 Para a Secretaria de Educação de São Bernardo do Campo, o grupo de trabalho era composto pelos profissionais da área de ensino, que fazem parte do Quadro do Magistério (professores) e do Quadro TécnicoEducacional (diretores e equipe técnica). Neste trabalho, empregamos o termo funcionários, como é usualmente utilizado naquele contexto educacional, para denominar o grupo da Área Operacional (serventes, merendeiras,
} 


\section{RELAÇÃO COM O ALUNO COM DEFICIÊNCIA E IMPASSES INSTAURADOS: FORMA DE ABORDAR OS PROCESSOS DE APRENDIZAGEM E UTILIZAÇÃO DE RECURSOS OU INSTRUMENTOS ESPECÍFICOS}

Há uma convergência de idéias em torno da visão, que considera essencial a construção de práticas educativas apoiadas na compreensão mais aprofundada do aluno, a fim de se desenvolver um trabalho consciente e intencional que auxiliasse as educadoras na descoberta de canais de acesso, ampliando sua comunicação com os alunos e minimizando a manifestação de conflitos. Alguns fatores parecem ter contribuído para que essas educadoras mudassem o modo como interagiam com seus alunos:

- Comunicação adequada: Os depoimentos das entrevistadas Luísa e Larissa esclareceram suas dificuldades em manter contato com a criança, por falta de recursos comunicativos, o que, por vezes, impediu que as atividades aproveitassem todo potencial da criança. Quadros: V (p. 151) e VII (p. 161-162). As educadoras revelaram sinais de uma busca constante por um maior conhecimento das condições do sujeito, para poder atingi-lo, respeitando seu momento e sua forma de expressão.

- Planejamento bem fundamentado: As professoras Bianca e Ana revelaram também a importância de estabelecer-se uma sistematização dos propósitos do trabalho a ser realizado com o aluno, utilizando-se de registros, observações e avaliações que abordassem sua realidade. Consideraram, ainda, que esses procedimentos puderam gerar uma análise mais específica sobre as melhores condições de aprendizagem, de acordo com suas necessidades e interesses. Quadros: VI (p. 157) e III (p. 143).

Todas parecem concordar que o professor não tem condições de intervir eficazmente se não tiver domínio sobre a condição do aluno, suas necessidades e especificidades, para que possam oferecer recursos de maior funcionalidade, que considerem seus interesses, sentimentos e aproveitem seu potencial, como pontuaram as educadoras Maria e Manoela. Quadros: IV (p. 147) e II (p. 138).

inspetores etc.) e profissionais ou profissionais da equipe para distinguir os professores, em alguns momentos também citados como educadores. 
A entrevistada Beija-Flor relatou algumas dificuldades enfrentadas na relação com as escolas, como professora itinerante. Para a educadora, o significado do acompanhamento dos professores especializados aos alunos incluídos no ensino regular, na ótica da escola, estava relacionado ao oferecimento de soluções e materiais para que a presença dos alunos com deficiência, na classe, fosse possível. Quadro I (p. 134).

Esse depoimento traz considerações importantes para o desenvolvimento do trabalho formativo, principalmente porque evidencia o despreparo e uma posição, até certo ponto, refratária da escola, em atender às necessidades da criança mediante adaptação das práticas e dos currículos. Revela que os maiores impasses dessa experiência foram transformar as exigências burocráticas em adequações curriculares pertinentes aos alunos e os prazos, exíguos, em momentos possíveis para que professores e alunos encontrassem formas criativas de se relacionarem. Quadro I (p. 134).

\section{CONCEPÇÃO DE DEFICIÊNCIA}

Foram assinalados alguns pontos de vista em comum, referentes à visão de deficiência:

- Expectativa de transformação: Há uma evidente manifestação de que o déficit biológico não causa impedimento para a evolução da pessoa. Mesmo considerando a existência de reconhecidas dificuldades de aprendizagem, essas educadoras sugeriram que o processo de desenvolvimento do aluno com deficiência, desde que a escola tenha clareza das necessidades desse aluno e ofereça-lhe propostas educativas adequadas, poderá transpor grande parte dessas barreiras. Quadros: I (p. 135), II (p. 139), IV (p. 147), III (p. 143), VI (p. 157), V (p. 152) e VII (p. 163).

- Recursos educativos de acesso à aprendizagem: Mesmo sinalizando suas preocupações com os comprometimentos impostos pelo déficit, as educadoras colocaram maior ênfase na condição de o professor buscar recursos que lhe permitam dar acesso mais facilitado à aprendizagem, conforme os depoimentos abaixo. Quadros: IV (p. 147), III (p. 143), II (p. 139), V (p. 152) e I (p. 135). 
As considerações das professoras Larissa e Bianca evidenciam uma concepção bem particularizada da surdez enquanto diferença e não deficiência. Sugerem, de uma forma geral, que ao considerar a surdez como diferença, busca-se dar evidência ao seu potencial e não ao déficit. Centralizam essencialmente essa abordagem na diferença lingüística e na capacidade de o surdo desenvolver-se integralmente, se respeitadas as condições que mantenham uma comunicação visual. Consideram que os bloqueios de aprendizagem que possam ocorrer são decorrentes da ausência de acesso ao seu código lingüístico, enfatizando que esse aspecto está diretamente relacionado aos processos de construção da identidade do surdo, subjetividade marcada por experiências e domínio de uma língua diferente que, portanto, exigem outros referenciais que não sejam os oferecidos à criança ouvinte. Quadros: VII (p. 163) e VI (p. 157).

Basicamente, todas as educadoras assumem a responsabilidade de buscar recursos para atender o aluno, de acordo com as necessidades dele, sejam elas visuais, sonoras, motoras ou táteis, entre outras, criando um ambiente que ofereça acesso à aprendizagem, organizado dentro de padrões apropriados para cada criança. Quadros: VI (p. 157), V (p. 152), I (p. 135), II (p. 139) e IV (p. 147).

\section{PREPARAÇÃO PARA A PRÁTICA, CONSIDERANDO OS REFERENCIAIS TEÓRICOS QUE AJUDARAM NO MANEJO ESCOLAR}

As interações entre professores e equipe técnica foram destacadas em função das oportunidades permanentes de reflexão, estabelecendo elos da teoria com a prática, que os ajudaram a compreender as situações vivenciadas e, com mais fundamentos, refletir criticamente suas concepções e práticas. Quadros: II (p. 139), VII (p. 163-164) e V (p. 153). Esses momentos parecem ter oferecido ao professor possibilidades para apropriar-se, cada vez mais, dos conhecimentos necessários para atuar com mais segurança, mantendo-se atualizado e revendo sempre suas concepções. 


\subsubsection{Segunda categorização}

Conforme já exposto anteriormente, a segunda categorização - Categorias Conceituais objetiva analisar as transformações no âmbito do "ser professor", do "saber" e do "fazer pedagógico”. Serão apresentados, a seguir, os três agrupamentos do conteúdo das entrevistas, a partir dos referenciais dessa vertente epistemológica.

\subsubsection{Categorias conceituais}

\section{PERCEPÇÕES E SENTIMENTOS DOS EDUCADORES EM RELAÇÃO AO PAPEL PROFISSIONAL QUE EXERCIAM NO DESENVOLVIMENTO DO PROJETO PEDAGÓGICO}

Buscou-se entender como o professor, naquele contexto formativo, configurava seu papel profissional sob as influências de uma organização institucional estruturada mediante relações envolvendo diferentes atores, funções, práticas, recursos e conjunturas técnicoadministrativas, operando dentro de princípios $^{29}$ que buscavam investir em uma formação docente voltada para o próprio contexto educativo.

Essa categoria focaliza a forma como as educadoras entrevistadas compreendem a dimensão de seu papel, o significado da ação educativa e a importância dos processos de mediação assumidos na relação com os alunos e na relação com seus pares, nas situações formativas que vivenciaram.

Nesse sentido, relacionamos os principais pontos abordados no material de análise:

- Autonomia e valorização do papel do professor: A maioria das entrevistadas reconheceu a importância da parceria, mas admitiu que, mesmo com a contribuição da equipe, definia os rumos de seu projeto de trabalho, contando com seus próprios recursos para poder atuar com autonomia, sentindo-se, as entrevistadas, fortalecidas, principalmente diante de uma realidade que lhes exigia iniciativa para responderem às

\footnotetext{
${ }^{29}$ Constam dos documentos oficiais Caderno de Metas e Plano de Trabalho da Secretaria de Educação e Cultura.
} 
demandas. Algumas admitiram que a representação social do papel do professor deflagra desvalorização, como revelam suas falas:

[...] mesmo com todo este suporte, ninguém precisava dizer para mim por onde ir; eu devia traçar o meu caminho, eu ia olhando o que mais interessava para o meu aluno. Isto sempre era muito respeitado... eu cresci como professora. O professor era ouvido e recebia também muitas contribuições. Eu acho que eu adquiri uma grande autonomia e uma responsabilidade enorme para trabalhar, com este material rico. (Professora Beija-Flor)

[...] eu sempre me senti ouvida, mas eu falo, eu me coloco e eu conquistei esse espaço, pois, no meu trabalho, eu me posiciono. [...] o educador está desvalorizado, a gente tem pesos diferentes socialmente, e é até engraçado quando a gente chega nas escolas regulares, as pessoas já perguntam: "Você é psicóloga?” / "Não, eu sou professora itinerante”, aí vem a resposta... "Humm, eu acho que ela não vai dar conta do recado". [...] eu tenho certeza que hoje existem situações que eu me sinto forte para resolver. [...] existem momentos que a gente age com muita autonomia, mas existem momentos que nossas ações exigem discussões. (Professora Luísa)

[...] a representação do papel do professor deflagra uma desvalorização a ser superada. (Professora Ana)

[...] acredito integralmente na autonomia do professor e o quanto ele pode participar do processo pedagógico, se conseguir efetivar seus propósitos, embasado no conhecimento teórico e na sua prática e também estar atuando juntamente com seu grupo. (Professora Manoela)

[...] e quando você vai de encontro a (sic!) um técnico, e ele te dá apoio e você compra a idéia, você tem que ser parte dessa relação, autor de seus projetos... porque a teoria sem a prática não é nada... a teoria você compõe com a sua realidade. [...] O importante é você ter parcerias que te complementem com competência e boa vontade e você se sentir parte deste processo. [...] a minha intervenção era ouvida, tinha liberdade de falar e me sentia amparada[...]. (Professora Bianca)

[...] não funciona se houver imposição, mas era troca, soma de saberes, uma parceria onde entra o meu conhecimento e o do outro, a minha experiência, o meu fazer, mas ele está acrescido de outro olhar, então não fica só o meu olhar, é outro olhar que vem constituir, que vem somar, que vem ajudar, mas não me anula, me respeita, é um olhar que acredita no que eu estou fazendo. (Professora Larissa)

As vivências relatadas parecem ter possibilitado a essas professoras uma conquista de maior segurança para desenvolver seu trabalho, sendo pontuada a importância de serem ouvidas e respeitadas como profissionais, principalmente porque a teoria sem o saber da prática não se justifica. Enfatizaram, entre outros fatores, o poder de decisão para adotar as contribuições que melhor atendessem às necessidades dos alunos. 
- Posicionamento profissional: Foi destacada pelas entrevistadas a maneira como o professor se posicionava frente ao projeto pedagógico, em uma dimensão social, refletindo na forma como a instituição e os demais educadores avaliavam seu desempenho, legitimando seu saber e as atitudes tomadas com os alunos.

[...] comecei a cavar o meu espaço para falar... eu pertenço a este grupo, vocês também vão ter que me ouvir, ou seja, ouvir o que a professora também tem a dizer e não só ouvir a psicóloga, fono, serviço social etc., e aí acho que foram vendo que todo mundo tem o seu lugar ali. (Professora Maria)

[...] no início, a equipe não acreditava no meu trabalho, talvez porque eu era nova, aí depois eu fui aos poucos me posicionando e levando à frente o que eu acreditava. [...] Você nasce deste meio, mas você também o modifica, e o homem tem necessidades que o faz mover e correr atrás, e aí você vai se desenvolvendo e vai ajudar as coisas a se desenvolverem, mesmo com dificuldades você pode mudar [...]. (Professora Ana)

[...] O meu posicionamento estava pautado na minha atuação constante, sentindo-me autora do meu fazer pedagógico e, dessa forma, com condições de partilhar com os demais os meus saberes. [...] Então, hoje, todo mundo só está focando no bilingüismo, eu acho isso justo e certo com a população surda... só que nós não temos só uma população surda... nós já fomos uma escola que atendia pessoas só com surdez... mas... essa população vai mudar... e ninguém está vendo isso... que ela precisa de muitas coisas mais... Será que ele vai se beneficiar só com a LIBRAS? É uma questão... que pra mim é muito séria [...]. (Professora Bianca)

[...] O período que eu vivenciei esta experiência, com este tipo de interação, tornou-me uma profissional mais consciente e crítica, tanto em minhas ações, quanto nas relações, no planejamento das aulas, considerando a condição visual do aluno e suas necessidades escolares, os seus interesses, expectativas dos familiares, respeitando-os, avaliando o aluno de forma processual. [...] eu quero conhecer e encontrar os meios, as minhas estratégias de trabalhar. (Professora Luísa)

[...] precisa estar com essa disposição para crescer, cada professor envolvido, cada um que está acreditando é um parceiro nessa mudança, e a equipe fica na manutenção dando firmeza na concepção teórica. [...] quando penso para onde está indo essa educação... no ensino regular.... o nãosucesso na aprendizagem, que às vezes a gente fala "nossa ... tantas crianças surdas aí, com tanta dificuldade na segunda língua" e você ouve um colega dizendo que no ensino regular está da mesma maneira. [...] Nós estamos vivendo num momento em que é muito claro tudo isso... a gente está indo contra ao que está posto, a nível federal, que é essa grande inclusão indiscriminada do surdo. (Professora Larissa)

A complementação e apropriação de novos conhecimentos, na opinião dessas entrevistadas, forneceram melhor qualificação e maior domínio dos aspectos singulares da criança, 
relacionados ao contexto social; assim, a partir desses fundamentos, responder com mais desenvoltura e determinação às situações de aprendizagem, menor insegurança, motivando-as a estarem sempre em movimento, conscientes de sua responsabilidade, com o reconhecimento dos demais, pela sua atuação. As condições e fragilidades educacionais apontadas por algumas entrevistadas não estavam circunscritas, apenas, às condições técnico-pedagógicas, mas às questões do âmbito das políticas educacionais de maior complexidade, que as inquietavam.

- Compromisso profissional: Algumas entrevistadas consideraram o compromisso profissional fator que repercutiu para que a instituição e seus pares respeitassem seu trabalho e adquirissem confiança em seu saber. Nos depoimentos, foi ressaltada a importância de o profissional sentir-se seguro ao partilhar os conhecimentos da prática, respondendo com envolvimento às demandas de seu papel, inclusive as de natureza social.

[...] quando o professor se sente seguro, respeitado em suas ações e encontra parceiros, seja em outro colega ou profissional da equipe para com ele arriscar, planejar, acertar, errar, começar de novo; tudo fica mais fácil, mais fácil ele ir em busca desse outro profissional para estar aprendendo, para estar dialogando, para estar trocando e, quando ele se sente parceiro as coisas melhoram. (Professora Maria)

[...] a educação tem um dinamismo e o profissional tem que acompanhar, tem que se envolver, tem que estar apaixonado. Este dinamismo, esta paixão pela educação vai repercutir em seu modo de ser, não dando oportunidade ao descompromisso e ao desânimo. [...] o professor tem um papel dominante e significativo nas mudanças educacionais. Ele é capaz de mobilizar ou estacionar os grupos... Independente da situação escolar que o grupo enfrente, o professor tem que mobilizar esforços, competências para realizar seu trabalho. (Professora Manoela)

[...] você tem que comprar a idéia... porque quem vai trabalhar com isso é você. Então não adianta fazer de conta, a gente até pode fazer de conta, mas, na realidade, não é esse o seu papel [...]. (Professora Bianca)

É importante estar envolvida, comprometida com o trabalho, ter claro o papel importante do professor como mediador nessa intervenção, que suas atitudes tenham clareza da intencionalidade, acredito que assim resultarão bons frutos, que conseguirei evoluções com todos diante de suas dificuldades e potencialidades. (Professora Ana)

[...] eu escolhi ser professora, foi minha escolha, é uma coisa que eu quis, mas sei que muita gente que está na educação não foi uma escolha clara, muitas vezes acaba se acostumando, não por gostar... não é a maioria, mas é um problema que, quando aparece, é berrante... aquela pessoa não deveria 
estar ali. O sistema público não cobra, mas deveria ir ao Conselho de Ética, não dá pra pessoa passar pela vida de muitas pessoas e destruir um monte de cabecinhas e continuar indo para a profissão docente, precisaria ser mais consciente. (Professora Luísa)

Esses relatos assinalam que a transformação do papel exercido pelo professor acompanhou as solicitações e demandas, procurando dar respostas às situações e problemas do dia-a-dia e, assim, legitimar o valor de "ser professor". Entretanto, a educadora Luísa sugere que dedicação e esforço são indispensáveis, chamando atenção para o fato de o próprio professor contribuir para a construção de uma identidade profissional fluida, ambígua e, até certo ponto, frágil.

O reconhecimento da importância do papel do professor é assinalado pelas entrevistadas como dependente da posição e compromisso que esse profissional assume perante a realidade educacional, principalmente porque, na visão dessas educadoras, estão envolvidos fatores humanos valiosos, uma diversidade de condições referentes ao aluno que não podem ser ignoradas. Manifestam-se inconformadas com o descompromisso docente e a negligência do sistema, que não assume posições mais severas no controle da qualidade da ação pedagógica.

- Articulação dos profissionais: Algumas entrevistadas citaram a importância da qualidade da relação estabelecida entre professores e equipe, atuando em parceria, organizando momentos de trocas, ajudando a amadurecer posições e novas idéias.

Nós tínhamos uma equipe que atuava junto ao Centro de Apoio, uma orientadora pedagógica, uma assistente social e uma psicóloga, e os maiores ganhos era essa troca. O sentar, o planejar, registrar e refletir o registro. Então, por felicidade, estava num grupo que isso era uma prática. E, com o diálogo com o outro, a gente começa a ver outras questões que, sozinho, não vê. [...] As situações batem na nossa porta e a gente precisava desse olhar que nos foi dado. [...] no momento que essa formação continuada é compartilhada, você vai adquirindo outros saberes e aí eu posso ter esse conhecimento pra tentar prever o que pode acontecer. (Professora Luísa)

Eu sou a pessoa que eu sou porque eu tive a possibilidade de conviver com todos esses alunos, com todos esses parceiros, tanto da equipe técnica, quanto dos professores, nós somos um grupo muito forte. [...] a parceria, essa troca constante, relacionada à realidade do professor, das questões do dia-a-dia... Você não se sente sozinho e você tem clareza onde está acertando. (Professora Larissa) 
[...] recebíamos o suporte técnico nos HTPC’s, onde trocávamos as dificuldades que cada professor tinha para integrar o seu aluno e trabalhar com os professores. (Professora Ana)

Entretanto, na visão da maioria das entrevistadas, a complementaridade de ações entre professor e equipe ficava, muitas vezes, comprometida, fosse pela pouca clareza dos papéis profissionais, pela falta de compromisso de alguns ou pelo excesso de demandas assumidas por outros profissionais da equipe. Frente a isso, o estabelecimento de um relacionamento interpessoal que facilitasse a comunicação entre os membros do grupo e estabelecesse uma cumplicidade com o trabalho sofria conseqüências devido a esse distanciamento. A existência de barreiras entre professor e equipe foi manifestada como questão nem sempre discutida, revelando pouca habilidade na superação das diferenças e imposições.

[...] eu sinto que um dos dificultadores é a questão da definição de papel com clareza, até onde vai a intervenção de cada um dos profissionais e como o professor deve apropriar-se desse conhecimento... a gente tem um limite de atuação, o professor tem um papel. [...] Mas olha, eu penso que aqui no Centro de Apoio a gente sempre conseguiu espaço. Os professores falavam e o que eles diziam tinha eco. Os profissionais também estavam engajados na prática, dispostos a construírem juntos. (Professora Luísa)

[...] a equipe não conseguia fazer muita coisa que planejava, nem todos os professores eram atendidos, sempre se estava em débito com eles e, por outro lado, o professor sempre estava cobrando. [...] tinham alguns profissionais que entendiam a dinâmica da sala de aula, outros não... Uns eram mais compromissados do que outros... então se trabalhava com esta diversidade de profissionais. Tinha essa questão da individualidade de uns conseguirem contribuir mais e outros menos. (Professora Beija-Flor)

Observação, reflexão, discussão, diálogos, trocas com o outro, eu acho que ficou interrompido, muitas vezes, devido à multiplicidade de atribuições da equipe, fora da escola. [...] Eu acho que isso é uma coisa muito forte, que pega mesmo no inconsciente, mesmo não querendo, o professor não se chega à equipe e a equipe não se chega ao professor. (Professora Manoela)

[...] se você vai numa sala de aula, senta e só fica olhando a professora e depois não dá um retorno pra ela, ela, na segunda vez que você for, não vai te respeitar. Agora, está em você quebrar isso. [...] Somos diferentes e, às vezes, o envolvimento dos profissionais repercute de formas bem diferentes na proposta. Você tem que estar bem envolvido e, às vezes, você vê profissionais que agem de forma superficial. (Professora Ana)

Havia uma troca muito grande, mas, às vezes, eu achava que alguns profissionais não consideravam o papel do professor, ou melhor, o meu saber como professora... podia ser porque eu era nova no trabalho com crianças pequenas, não davam tanto valor assim, mas, para saber do aluno, tinham que recorrer a mim . [...] saber ouvir é colocar o que parece que não é certo de uma forma não impositiva. [...] Eu acho que, na parceria, o colega 
também pode fazer algo para contribuir para a melhoria do trabalho. [...] é uma coisa que a gente conquistou poder falar das relações e avaliar a parceria... (Professora Maria)

As vivências mencionadas destacam a importância do diálogo fundamentado em bases de respeito e confiança, e que os conflitos ocorridos contribuíram positivamente para esclarecer os entraves, melhorar as relações e buscar espaço no grupo, para manifestação de suas convicções. Por mais que se confirme a importância das contribuições dos profissionais nessa parceria, a construção desse processo coletivo, segundo algumas entrevistadas, também depende do envolvimento particularizado de cada profissional, repercutindo na coesão e na própria confiabilidade do grupo.

- Compreensão do tempo do outro: Algumas entrevistadas referiram-se às falhas que ocorreram na construção de uma prática por, muitas vezes, não saberem ouvir o outro ou não valorizarem seu processo de conquista, aspectos centrais para que as relações de reciprocidade pudessem ser almejadas. Os recortes abaixo revelam que, em se tratando de compartilhar um processo de construção envolvendo tanto o aluno quanto o professor, são indispensáveis formas de organização das aprendizagens que considerem o processo de elaboração das pessoas envolvidas.

[...] os conhecimentos... que as meninas (referindo-se à equipe)... exigiam... a gente ainda não estava ali, faltava um pouco do pessoal da equipe técnica olhar o professor como parceiro. [...] junto com o professor eu tenho que tentar construir... junto com os gestores... tem que ser tudo um conjunto. [...] sentar, planejar, registrar, refletir é muito importante e com as observações da equipe é possível observar melhor o tempo do aluno, as oportunidades que ele precisa realmente para observar e deduzir a atividade [...] eu sinto isto no ensino itinerante... coisas que não estão de acordo... mas eu tenho que ver muito bem como falar e o que eu vou eleger naquele momento, porque não dá pra chegar e falar tudo de uma vez, eu tenho que tentar construir junto com ele, tem que ser um conjunto. (Professora Luísa)

[...] Para os meus parceiros, nós estávamos nos formando todos ao mesmo tempo; com certeza, eu tinha ali no grupo pessoas que já tinham outro olhar já diferente, mas eles tiveram paciência comigo e falaram "vamos investir, porque ela vai mudar". Foram vários momentos, e as transformações acontecendo numa ligação muito direta com a prática. [...] Eu acredito no outro, que, embora naquele momento não esteja aberto, num outro momento ele vai estar. (Professora Larissa) 
A importância que essas entrevistadas evidenciaram do processo formativo foi o de ter-se constituído um importante mecanismo de crescimento profissional, à medida que, no convívio com impasses e dificuldades, buscou-se criar condições para que cada um se responsabilizasse pelo crescimento grupal.

\section{IDÉIAS E CONCEPÇÕES SOBRE A PESSOA COM DEFICIÊNCIA E SEU MODO DE CONHECER, QUE EMBASARAM A PRÁTICA DO EDUCADOR}

Nessa categoria, foram reunidas as manifestações das entrevistadas, referentes às concepções de como compreendem o contexto educativo: o lugar ocupado pela teoria na visão das entrevistadas, no diálogo estabelecido com seu próprio fazer pedagógico, ao refletirem sobre o manejo da sala de aula, e na criação de uma pluralidade de mediações necessárias às situações apresentadas no dia-a-dia, na interação com a pessoa com deficiência.

- Vários prismas, múltiplos saberes: Todas as entrevistadas fizeram menção à importância da aquisição de novas abordagens teóricas, demonstrando preocupações com sua competência em dominar conhecimentos sobre a aprendizagem, aprofundando o olhar sobre a criança, para poderem intervir nas situações da sala de aula com maior clareza e segurança.

Assinalaram que, com esses conhecimentos, embasaram suas ações e que os pressupostos teóricos estudados por meio da leitura de vários saberes, proporcionaram instrumentos de análise e compreensão da deficiência de forma ampla, auxiliando-as a tomar decisões eficazes na reconstrução de práticas pertinentes às necessidades educativas dos alunos, conforme fica expresso nos relatos abaixo:

[...] a gente estuda de como a criança aprende... há diferenças... não adianta ler só sobre deficiência, eu vou ter que me apropriar disso para esgotar as situações. [...] eu fui reapresentada para outros teóricos pelo olhar dessas pessoas, que ampliaram a visão sobre a Educação. [...] A teoria me ajuda fornecendo dados importantes sobre o desenvolvimento anátomofisiológico e psicológico da criança e do adolescente, trazendo reflexões sobre as possibilidades da escola... Há conhecimentos que, pra mim, são básicos... (Professora Luísa)

[...] Eram vários profissionais com seus saberes e experiências e o professor, também contribuindo para a evolução dos alunos e para buscar novos conhecimentos diante de um novo desafio ou dificuldade. [...] Há necessidade de conhecer o aluno e quais suas necessidades, qual o canal de 
melhor acesso para o conhecimento. Para isso, é necessário que o professor tenha conhecimentos sobre as deficiências e buscar práticas que facilite a interação com o aluno. (Professora Ana)

[...] nos auxiliou a ter um olhar mais apurado para a forma como aqueles alunos com surdez estavam aprendendo. [...] como a criança constrói este conhecimento. $\mathrm{O}$ encontro de conhecimentos diferentes ajudou a fazer de um jeito diferente. [...] parâmetros que vão te clareando bastante 0 conhecimento e você começa a entender por que ele não tem alguns conceitos específicos, que lhes forneçam dados. (Professora Bianca)

As formações tiveram como objetivo instrumentalizar o educador com abordagens teóricas acerca do desenvolvimento e da aprendizagem; as de conteúdo psiquiátrico, de relações interpessoais, proporcionaram momentos de análise para refletir sobre a prática, compreender o que ocorre na sala de aula, possibilitando tomar novas decisões. (Professora Manoela)

[...] recebi informações e assuntos que desconhecia, pude organizar conhecimentos, vivenciar situações, comparar práticas, tirar conclusões e aprimorar meu pensamento. Autores diversos, Piaget, Vygotsky, análise das fases do desenvolvimento, a construção do conhecimento, como a criança aprende, desenvolvimento infantil à luz da psicanálise, o vínculo mãe-filho; foram temas debatidos que me ajudaram muito. (Professora Maria)

As discussões aconteciam com as diferentes áreas e isto ampliava muito nosso conhecimento sobre aprendizagem, sobre a criança, abria-se um leque de possibilidades. [...] a gente tinha uma gama muito grande de teoria e o que foi mais importante nisso tudo foi a possibilidade de várias áreas, vários conhecimentos estarem falando da mesma forma. Eu pude, assim, construir a criança que eu trabalhava e, conhecendo melhor, organizar meu caminho. (Professora Beija-Flor)

[...] buscava-se a soma de saberes, para se ter uma visão total do aluno enquanto desenvolvimento dele próprio, do seu modo de ser, do seu jeito, das suas necessidades, era assim que se trabalhava. Eu sabia exatamente o que eu queria transmitir, mas não tinha uma forma de comunicação, muitas vezes, eu não percebia a resposta do aluno... Essa dificuldade permeava todo o processo... e, na relação com o aluno, admitia-se "ele não consegue"; era um olhar simples. Com o tempo, com a formação, com a parceria... o que você percebe?... é que não existia uma língua eficiente permeando a relação. (Professora Larissa)

[...] teve momentos que a maneira como a equipe deu a devolutiva, a resposta foi tão generalista... e você quer de outra maneira... mas em alguns momentos falta humildade para falar... "Eu não tenho clareza sobre isso"; ela não tem que saber tudo... mas eu queria ouvir da pessoa "Olha, eu não sei”... Acho que deve ser difícil para eles serem humildes... se for conhecimento da sua área, é constrangedor... mas eu nunca ouvi ninguém falar "Vamos ter que ir atrás juntos"... é delicado, até nesta de ter a responsabilidade de pesquisar com urgência para dar a devolutiva. (Professora Luísa)

[...] era só bater na porta e a gente era atendido... só que muitas vezes a equipe não tinha respostas... precisava pesquisar e, muitas vezes, você 
ficava frustrada porque demorava e a gente queria respostas imediatas e não assumia o seu limite e também o seu compromisso, mas, dependendo do profissional, não havia devolutiva. (Professora Beija-Flor)

A atividade partilhada com a equipe conduziu o grupo à apropriação de conhecimentos que, na visão de algumas entrevistadas, não se esgotam, exigindo estudo constante. Mostraram que a conjugação de vários campos do conhecimento pressupõe a segurança e domínio do seu próprio saber, sugerindo que a qualidade dessa interação implica que os conhecimentos específicos desses profissionais estejam sempre atualizados. Consideraram também que, dependendo do profissional, reconhecer com humildade os próprios limites pode ser constrangedor.

- Novos paradigmas: As entrevistadas consideraram que as proposições teóricas possibilitaram rever concepções e buscar a superação de estigmas que marcam a criança com deficiência e a própria área de Educação Especial, fazendo-as refletirem sobre novos modelos de trabalho, já não mais centrados nas dificuldades e na deficiência, mas na busca de um conhecimento mais amplo e integrado, sem perder de vista a singularidade e especificidade dos alunos.

Os relatos abaixo sugerem a transposição de uma abordagem pautada nas dificuldades para uma educação que atribuía importância às especificidades da criança, valorizadas como referência de seu desenvolvimento e das condições de aprendizagem, de forma que as propostas aproveitassem o máximo de suas possibilidades sem, entretanto, estigmatizá-las. Nesse intercâmbio de idéias, a professora Luísa narra o empenho da equipe em compartilhar a construção de um modelo de relatório que oferecesse uma visão mais integrada do aluno, que pudesse representar com clareza seu desenvolvimento e contribuísse para que a leitura dos dados não gerasse distorções. A entrevistada revela como a construção de um instrumento de trabalho permeou um exercício reflexivo, enriquecedor. A manifestação da professora denota a importância dos pressupostos teóricos que atravessaram a elaboração dos relatórios e a linguagem como instrumento imprescindível de formulação e comunicação de idéias, desafiando os educadores a balizarem suas análises e interpretações, principalmente por se tratar de um documento em que as informações não poderiam ser imprecisas, nem suscitarem uma visão pouco otimista dos alunos. 
[...] hoje, a gente olha o aluno de uma forma interdisciplinar, que foi uma contribuição da equipe, percebendo suas transformações, seus ganhos, aquilo que ele já consegue... porque essas crianças, essas pessoas são muito rotuladas, já pela falta [...] eu comecei a usar palavras, expressões que eu não tinha, essas pessoas foram me enriquecendo. [...] A gente precisa avaliar o aluno com outras pessoas e não dá para colocar informações isoladas. [...] Parece bobagem, mas precisa tomar cuidado com o sentido que se quer dar... de forma mais fidedigna, focando o seu crescimento e não só o que falta... (Professora Luísa)

[...] eu sempre acreditei no indivíduo surdo, nas suas possibilidades, na sua igualdade, sempre, e não trato o surdo diferente... (Professora Bianca)

[...] Ver a criança com seu potencial, tentando procurar o máximo de propostas que ela possa ganhar, para se transformar, estar mais atenta, mais aconchegada, com estímulos variados, importantes para ela ser desafiada a todo o momento. (Professora Beija-Flor)

[...] É necessário conhecer o aluno, quais são suas necessidades, qual o canal de acesso do conhecimento, para isso é necessário ter certo conhecimento sobre a deficiência e buscar práticas que facilitem a sua interação com o conhecimento. Para falar de deficiência, é preciso se envolver com a realidade e não escondê-la, fingindo que a aceita só porque, ao falar do cego, as pessoas tendem a não querer falar que ele é cego, que é surdo ou deficiente mental. Ele tem necessidades especiais e tem uma deficiência. O professor tem que apostar na superação destas dificuldades e trabalhar para isto. Intervir para que a aprendizagem dele evolua... é o nosso papel intervir nessa mudança. (Professora Ana)

Outros depoimentos também ressaltaram os novos sentidos atribuídos à deficiência, dando ênfase ao potencial e à capacidade de superação do aluno diante das dificuldades impostas pelos aspectos orgânicos. Esses novos sentidos também convocam o professor a se apropriar de dados que indiquem as necessidades específicas de cada aluno, para poder oferecer a intervenção adequada a cada caso, conforme é enfatizado pelas entrevistadas.

[...] é importante saber... como lidar com cada um dos alunos, pois cada um aproveita diferente. Como vou aproveitar melhor a visão, a comunicação? São saberes que não se resumem ao contato com o aluno, eu tenho que ter fundamentos da deficiência visual para atingi-lo melhor. [...] As muitas contribuições teóricas que me fizeram ver que o desenvolvimento não tem regras fixas... esse "desenvolvimento gradual e contínuo"; ele vai ter um jeito próprio, um ritmo próprio... e que esses momentos de reflexão fazem você conhecer e propor, de forma mais crítica, as propostas pedagógicas. (Professora Luísa)

[...] passamos a ver o aluno como um ser com potencial e não como alguém que tem falta de alguma coisa. Essa mudança se deu com todo o grupo; fizemos grupos de estudo, chegávamos antes do horário de serviço para estudar, dentro da área específica da surdez. [...] Os modelos criados são, 
em geral, os utilizados para crianças ouvintes, há muito que se pensar do que se conseguir para o processo educacional de uma "escola surda" de verdade. [...] Vejo que ele tem toda a possibilidade e eu não estou dando conta deste trabalho. [...] Pelo tanto que eu possa conhecer a língua de sinais (curso FENEIS), não é ainda suficiente... é pouco diante da complexidade da língua, apesar de dar conta do processo educacional, mas a sua abrangência vai restringindo eu poder abordar a totalidade do ser, então, eu posso estar falhando, e não ele, porque ele tem uma língua que eu não tenho, muitas vezes, acesso. (Professora Larissa)

O aluno, desde que tenha comunicação adequada, não compromete a sua aprendizagem; eles se desenvolvem quando há outros comprometimentos associados - orgânicos, emocionais - as necessidades são maiores, exigem que o professor saiba trabalhar, pois cada criança é uma, e você deve pensar nesse aluno como uma pessoa global... ele tem toda uma engrenagem, cada um tem um tipo de pensamento diferente para chegar a uma resposta e eu, como professora, preciso oferecer vários caminhos para eles construírem esse conhecimento. O caminho de um pode não ser o do outro e o professor precisa ter claro isto. A intervenção vai exigir do professor muita observação para você conhecer o aluno. (Professora Bianca)

Apesar da deficiência, existe um sujeito que eu preciso conhecer. Através de parcerias produtivas, estratégias bem elaboradas, adaptações e recursos específicos e um ambiente acolhedor, temos possibilidade de ajudá-lo a se transformar, a reconhecer suas necessidades, desejos, possibilidades, fazer uso de sua consciência e agir no mundo. (Professora Maria)

O atendimento educacional específico a que se referem as educadoras Larissa e Bianca, para o aluno com surdez, coloca em questão as dificuldades a que a criança surda é exposta em ambientes educativos que não compartilham com ela da mesma língua. Essas educadoras sugerem que apenas a língua de sinais pode propiciar ao surdo condições dialógicas para que ele se envolva em um processo de ensino-aprendizagem, tendo como seus interlocutores docentes com o domínio de seu código lingüístico.

As demais entrevistadas acrescentaram em seus depoimentos a capacidade de transformação e superação das dificuldades, desde que o professor conheça a criança e lhe sejam oferecidos recursos específicos, ambiente acolhedor e propiciador de desafios, intencionalmente planejados.

Nem todas as entrevistadas referiram-se, diretamente, às concepções sócio-históricas, contudo muitas colocaram ênfase no papel da escola, das práticas pedagógicas e das interações sociais como instâncias decisivas para provocar avanços no aluno. Ressaltaram, também, a ação do professor na mediação das atividades, impulsionando o desenvolvimento a partir de estímulos 
e criação de oportunidades de escolha e recursos oferecidos por intermédio dos colegas que desempenham o papel de mediadores da aprendizagem.

- Construção do Projeto Coletivo, mediado pelas assessorias: Assinalaram que as assessorias representaram atividades que propiciaram a articulação de conhecimentos teóricos importantes e ofereceram caminhos para a produção de projetos adaptados aos alunos, estimulando e fornecendo ao grupo novos significados ao seu trabalho. Foram ressaltados conhecimentos específicos à área de atuação, necessários para se ter pleno domínio da deficiência e para se reinterpretar os objetivos do trabalho. Sugeriram, também, que esse acompanhamento desafiava-as a entrar em contato com aspectos teóricos ainda não vistos e necessários.

[...] a assessoria da Professora Úrsula teve uma contribuição importantíssima em nosso grupo, que até hoje direciona nosso trabalho. Ela conseguia mobilizar o professor a perceber essa diversidade do aluno, as suas especificidades. (Professora Manoela)

[...] o quanto a Professora Elcie nos levou a refletir sobre aspectos referentes ao deficiente visual, a formação de conceitos, de alertar sobre outros canais de recepção. Ela refletia muito sobre o nosso domínio técnico e que nós não poderíamos ser generalistas... tendo que se especializar naquilo que faz. (Professora Luísa)

[...] As transformações na prática da educação de surdos aconteceram ... tivemos uma assessoria com a Zilda Gesueli, da Unicamp, que falava que não dava para fazer sinal e falar junto, que na verdade a gente estava misturando duas línguas diferentes e que isso fazia uma grande confusão na cabeça do aluno. Aquilo me chocou, porque, no início, eu acreditava no oralismo e a gente só falava... e não conseguia se comunicar... comecei a usar os sinais, e ela ainda vem dizendo que eu estava usando duas línguas diferentes ao mesmo tempo. Isso interferiu direto na minha prática; eu não conseguia entender o que ela estava me dizendo naquele momento, então o meu olhar em relação ao aluno também passava por essa incompreensão. (Professora Larissa)

[...] acho que esse período de assessoria da professora Úrsula, específica para a nossa área, na estimulação essencial, foi muito importante para mim... além das questões teóricas, ajudou a organizar a rotina de trabalho e as intervenções individuais aos alunos, nas discussões em grupo e nos encaminhamentos bem direcionados. Para as crianças com maiores comprometimentos, a utilização do protocolo / escala de DAVID WERNER. Depois, o período de cursos e discussões em grupo... o professor Rinaldo falando de outro aspecto... da constituição do sujeito com abordagem psicanalítica.... que, a princípio, me chamou muita atenção pelo meu desconhecimento... houve um período de falar... "não sei nada" ... ou de ter contato com um saber que eu não sabia possuir... muitas dúvidas 
permearam minha mente, uma delas era como conciliar pedagogia e psicanálise. (Professora Maria)

- Atividades formativas gerais: Foi apontado pelas entrevistadas que a bagagem teórica trazida nos cursos e atividades formativas oferecidas para a rede de professores, em geral, nem sempre complementou as discussões promovidas no contexto escolar, pelo contrário, para algumas entrevistadas, essas atividades discutiam posições teóricas, muitas vezes, contraditórias.

[...] as abordagens teóricas, muitas vezes, são contraditórias. As dificuldades de aprendizagem, por exemplo, são interpretadas de maneira bastante diferente, dependendo da perspectiva teórica que se adote. (Professora Manoela)

[...] eu achava que tinham muitos cursos, que tinham coisas contraditórias e se precisava ter uma visão do que a gente ia seguir: psicanálise, uma visão histórico-social, precisaria uma definição, mas eu acho que realmente não é uma coisa fácil. Vendo o todo da educação, fica inconsistente. (Professora Luísa)

Quando as formações são muitos gerais, em geral não contemplam, pois a teoria até pode ajudar, mas a prática, em geral, fica deslocada, pois os formadores já dizem que não entendem de surdo. (Professora Bianca)

Convictas de que as abordagens teóricas podem instrumentalizar o professor para que ele desenvolva uma reflexão mais abrangente sobre o processo educativo, aprofundando o olhar sobre a criança e estabelecendo conexões com a prática pedagógica, essas educadoras indicaram crença na co-responsabilidade do grupo para manter um diálogo em que são partilhados saberes e projetos concretos de ação, com diferentes campos teóricos.

\section{PRÁTICAS DOCENTES INCORPORADAS}

As idéias que compuseram essa categoria de análise, diretamente relacionada ao fazer pedagógico, deram ênfase às manifestações das entrevistadas, com referência às oportunidades oferecidas ao professor, pela proposta formativa, de refletirem a prática à luz das teorias que foram apresentadas nessa formação. O assunto tratado provocou reflexões intensas no momento da entrevista, talvez por estarem expressando considerações diretamente articuladas às práticas de sala de aula e às preocupações com sua competência em construir um projeto pedagógico que fosse determinante na formação dos alunos. 
Partimos, portanto, da identificação das posições assumidas pelas entrevistadas em relação à práxis docente, para integrar esses depoimentos às condições e fatores que foram sendo referidos e ao modo como relatam que planejaram seus projetos, interagiram e avaliaram seus alunos, aspectos que ganharam importância por direcionarem a tônica que imprimiram ao ensinar e ao aprender.

Os depoimentos ressaltaram os seguintes tópicos:

- Idéia de processo, movimento, direção a ser tomada: Buscando relatar como o processo formativo interferiu na prática pedagógica, as entrevistadas ressaltaram, inicialmente, idéias que sugerem um processo em constante movimento. As demandas geradas pelo cotidiano parecem estimulá-las a estarem continuamente em busca de direção, sempre pesquisando novos caminhos, pois o processo educacional é dinâmico e exige capacidade de decisão para poder gerar transformações.

[...] descobrir novos caminhos e modos de agir, facilitando a aprendizagem dos alunos, favorecendo a troca de experiência entre os profissionais envolvidos e, conseqüentemente, desenvolver um pensamento mais autônomo. Estes elementos me ajudaram a tomar decisões, intervir, refletir, compreender, organizar, transformar, enriquecendo minha prática e me tornando um educador mais comprometido. (Professora Manoela)

[...] Hoje, vejo que as parcerias decorrentes da formação de áreas específicas contribuíram para que pudesse ampliar conhecimentos, modificar pensamentos e buscar um caminho pedagógico agregando diferentes informações e saberes. [...] então eu acho que tudo isto é uma busca constante, um conhecimento que não tem fim, porque quando você acha que já sabe tudo sobre uma criança, surge outra, que você fala: " $E$ agora, o que eu vou fazer?”. Então você está sempre em busca de novos conhecimentos. (Professora Maria)

[...] neste processo de continuidade, esses conhecimentos são importantíssimos para se começar a trilhar esse caminho de ser educador. [...] Eu acho que eu não tinha "esse olhar" e pensar nessa condição de "processo", de perceber o caminho das coisas, olhar para as situações como um processo e que as respostas não são imediatas na educação. É uma coisa que eu aprendi com as meninas (referindo-se à equipe), que tudo depende de uma construção, principalmente na educação especial, a gente lida com uma série de questões desconhecidas, a gente conhece, mas nunca conhece tudo... (Professora Luísa)

Estudando sempre, a gente vai se formando e se aprofundando nesta parceria; eu acho que a gente está o tempo inteiro se constituindo... (Professora Larissa) 
A gente nunca se sente totalmente preparada para a prática, a gente sempre está aprendendo e eu sempre me senti desafiada para o trabalho... [...] Sempre estamos aprendendo novos conhecimentos, novas atitudes em relação ao aluno. (Professora Ana)

Algumas entrevistadas fizeram menção à formação inicial, revelando as condições de incompletude, tão evidentes ao sair da faculdade, acrescidas do impacto provocado pelo desconhecido.

Para falar na formação continuada eu acabo sempre pensando na formação inicial que eu tive... e que me trouxe a idéia de que não estava tudo pronto e que a coisa não terminava ali... é um processo de continuidade... (Professora Luísa)

Eu tinha acabado de me formar, então eu não tinha muita prática... e assim, para mim, esta experiência foi um ponto de referência... todo mundo era minha base, principalmente a orientadora, que estava sempre pronta para me socorrer... se eu tivesse saído da faculdade e ido para uma classe sem equipe de suporte... eu estaria totalmente perdida... (Professora Ana)

[...] eu terminei a faculdade e comecei o trabalho, então uma das coisas que eu percebi é que a faculdade, a teoria, tudo aquilo que a gente aprendeu lá não dava a base... ou não formou naquilo que eu precisava... na escola especial para alunos surdos, não tinha a mínima noção do que eu ia fazer... a formação aconteceu dentro da própria unidade através do respaldo de quem estava lá. A equipe era formada por fonoaudióloga, psicóloga, orientadora pedagógica e assistente social, e acontecia a troca com as outras professoras. (Professora Larissa)

- Reflexão sobre a prática: Ressaltaram a contribuição reconhecida do projeto para a instrumentalização do professor por meio do exercício reflexivo sobre a prática, tendo como suporte a teoria. Algumas delas declararam a necessidade de parceria mais constante para estabelecerem-se relações com a teoria e repensar as dificuldades enfrentadas com a aprendizagem dos alunos, buscando entender, sob vários prismas, a complexidade do processo de desenvolvimento de cada aluno e ter maior criticidade na elaboração do projeto pedagógico.

[...] tinha uma equipe na unidade escolar e fazíamos várias reuniões, acompanhamentos, trocas de verdade com os professores... às vezes, tínhamos encontros com profissionais específicos e, outras vezes, com a equipe toda... vários temas, questões relacionadas ao aluno, de aprendizagem, alfabetização, buscava-se olhar sob vários ângulos, o que temos que levar em consideração para compreender melhor o aluno. Alguns profissionais iam para a sala de aula trabalhar com a gente e, depois, 
discutíamos as propostas... [...] para poder transformar a prática, isso não acontece só de ouvir e decidir mudar. Você escuta, discute, reflete, atua e, diante das dificuldades, que podem sempre ocorrer, você tematiza algo mais específico para seu aluno. (Professora Beija-Flor)

Refletindo sobre prática e tendo alguém próximo, um parceiro mais competente que vem te auxiliar nessa construção. (Professora Larissa)

Refletíamos estabelecendo relações da prática com a teoria, buscando o equilíbrio, de acordo com os nossos objetivos, ou seja, ter sempre clareza da nossa intencionalidade voltada para o dia-a-dia. (Professora Ana)

[...] retomar que caminho era melhor para o aluno, isso eu consegui aqui no Centro de Apoio. [...] existem certos autores, até porque trazem a teoria para a prática, que fica fácil fazer a ponte, mas em outros momentos, não; esse acompanhamento da equipe é necessário. Para mim, é importante os pontos que elas trouxeram para ampliar esta visão de Educação, não só do miudinho. [...] e que esses momentos de reflexão fazem você conhecer e propor, de forma mais crítica, as propostas pedagógicas. [...] Por felicidade, estou num grupo em que a reflexão do registro e do planejamento é uma prática. Reflexão em cima do registro. (Professora Luísa)

- Formação em contexto: O trabalho em parceria, desenvolvido pela proposta, ofereceu conhecimento mais próximo do cotidiano escolar, estabelecendo elos entre o fazer pedagógico e a realidade do aluno. As entrevistadas admitiram que, nessa perspectiva, conseguiram compreender as situações de aprendizagem que emergiam na sala de aula e estabeleceram propostas que atendessem com mais consistência os objetivos e as necessidades educativas, podendo, assim, acompanhá-las em seu processo de desenvolvimento, com mais clareza. Instigadas sobre a questão da autonomia, indicaram que a parceria mais próxima da equipe não impediu que refletissem caminhos possíveis para suas ações, apesar de que, mesmo com preparo, as situações novas provocavam ansiedade, em vista de sua imprevisibilidade.

[...] você tenta levar esta teoria para a sala de aula, "o que eu posso tirar da teoria para acrescentar na minha prática pedagógica, referente ao aluno...”. [...] é um movimento que não pára... [...]. O modo como me relaciono e intervenho, interagindo com os alunos, falando, acolhendo dúvidas e comentários, propondo caminhos alternativos para que atinjam seus objetivos... caminhos que ultrapassam a sala de aula, vão para fora da escola, para a comunidade e para a família. (Professora Manoela)

[...] A formação interna nos levava para frente, era um processo coletivo, sólido. As formações foram contribuindo para a sistematização da nossa prática e esta transformação foi se operando dentro de mim, na minha prática. O professor não fica solitário com os seus problemas, pois realiza trocas, grupos de estudos, troca entre professores, onde se fala sobre o seu projeto e o que está dando certo. Eu destaco... a parceria, essa troca 
constante, relacionada à realidade do professor, das questões do dia-a-dia. (Professora Larissa)

[...] quando eu estou vendo o aluno, fico analisando a situação para entender o processo que ele está fazendo para ele se apropriar do conhecimento... eu penso que eu não tinha esse olhar para dentro da prática; você passa um tempo com esse aluno, com grupos de alunos e você precisa avaliar o que foi feito com ele ... percebe daí os avanços, quais os obstáculos. [...] tomei uma postura, tive um pensamento, mas não refleti muito e depois eu trouxe para o grupo e aí a gente descobre... a gente erra, mas daí você retoma e você tem essas pessoas para pensar junto. (Professora Luísa)

- Aprendizagem compartilhada: As entrevistadas destacaram a importância do papel do outro na construção do conhecimento, tanto nessa parceria entre professor e equipe, quanto nas interações com as crianças, em que elas e os adultos aprendem com seus pares. Algumas assinalam a responsabilidade do professor, compreendendo que o processo de desenvolvimento e aprendizagem tem como ponto de partida intervenções planejadas, indispensáveis para definir caminhos para o aluno, ou mesmo pelos parâmetros de parceiros mais experientes, que os desafiem em suas atividades. Os conhecimentos adquiridos parecem ter possibilitado a mediação de situações de aprendizagem com mais clareza e desenvoltura, conforme relatos abaixo:

[...] eu penso que a criança precisa de um parceiro; não é na fala do professor que ela aprende, mas com os conhecimentos próprios dela em contato com o outro... a gente também é assim, até o nosso vocabulário, eu passei a usar palavras, expressões que antes eu não tinha, esses parceiros foram me enriquecendo... (Professora Luísa)

Nós, educadores, temos uma responsabilidade muito grande em saber como direcionar o conhecimento destes alunos, prestando atenção ao que ele fez e às relações que estabelece com outras crianças e com os adultos. (Professora Manoela)

[...] eu sinto que eu ajudo o professor, mesmo sendo professora da classe integrada, sem estar na itinerância; quando eu pontuo alguma coisa a professora olha e fala "eu não tinha visto por esse lado". Se pudesse ter mais trocas com os professores do Regular, facilitaria também para o aluno, não só para o aluno com deficiência. [...] Tem momentos que sou a mediadora e momentos que outras crianças colaboram nessa interação... esse ano eu estou trabalhando em parceria com o $2^{\circ}$ ano do Ciclo II, onde as crianças interagem e elas se sentem desafiadas. (Professora Ana)

[...] a nossa equipe contou com a experiência dos professores mais antigos do Especial, mas com o crescimento do programa de inclusão, a parceria exigiu um trabalho novo com os professores que iam chegando para o grupo, pois muitos iam para um trabalho em parceria com o professor do Regular sem nunca ter dado aula para uma criança com deficiência, sem experiência 
no Especial e nem no Regular. Neste sentido, foi instituído o trabalho em duplas com uma professora mais antiga e uma companheira nova, para trabalharem juntas. (Professora Beija-Flor)

- As múltiplas dimensões da realidade educativa: As educadoras consideraram que a proposta formativa contribuiu com saberes que ampliaram a visão que possuíam da escola, focalizada em suas múltiplas dimensões, que admitiram interferir na proposição de suas metas e na identificação das reais necessidades educacionais de seu alunado. Na maioria das entrevistas, observa-se que um dos componentes principais desse conhecimento refere-se às ações dos professores em torno da família. Essa aproximação representou, na opinião dessas educadoras, a possibilidade de desenvolver um projeto educativo mais articulado com o contexto sociocultural do aluno e abrir espaço para o diálogo e parceria com os pais:

Essa formação é essencial para o nosso trabalho, porque, ao saber da realidade que eu estou vivendo aqui dentro desse município, sabendo da realidade dessas escolas e com os pais dos alunos, eu vou saber o que é que vai emergir daí, [...] a equipe trouxe saberes importantes, oferecendo abertura para olhar o todo da escola... quando eu estou vendo o aluno, tento ver o processo que ele está fazendo para aprender; quando vejo a família, tento ver o contexto em que esta família se encontra, vê-la como parceira; quando eu olho para a escola, eu a vejo nessa condição de processo... (Professora Luísa)

Eu acho que a família do aluno com necessidades especiais precisa ser muito bem assessorada. Independente onde o aluno estiver - escola especial, classe integrada ou inclusão -, ela precisa de apoio, pois ela se sente muito cobrada por ela mesma. O professor precisa da mãe completamente junto com ele, trabalhando em conjunto. Só o trabalho da sala de aula não é suficiente... (Professora Ana)

[...] quando você começa a ouvir a família e entender o que ela fala... é compartilhar com o que ela traz, colocando-se mais próxima, ela fica mais aberta, isso eu aprendi com a equipe, fui apurando o olhar... (Professora Beija-Flor)

[...] aqui no Centro de Apoio, o envolvimento da família, por se tratar de crianças pequenas, é muito grande e existe a possibilidade da gente transformar esse olhar da família pra essa criança; nos atendimentos sistemáticos, pode-se estar com a mãe e com esta proximidade estar mostrando como ela pode agir com o filho e, nesse convívio, a gente mantém uma boa relação... de falar da escola, da casa, de coisas que permeavam essa relação mãe-filho e essa relação entre a escola e a família... [...] dos encontros... novas descobertas para a família, que começa a dar significado aos pequenos gestos, olhares direcionados e percebem seus filhos com possibilidades. (Professora Maria) 
[...] uma coisa que eu acho que a gente tem muita facilidade, principalmente em um país como o nosso, com tantos problemas sociais... é de culpabilizar a família. A família que não dá, que não faz, sem ter todo aquele olhar para a família, dentro de um contexto histórico, que essa família também pode estar passando por uma série de dificuldades. (Professora Luísa)

[...] eu não estou aqui para ser melhor que ela, que o meu papel é diferente do dela, que ela é mãe e que eu sou professora, não é melhor nem mais importante. Porque elas vêm com esse receio porque você é professora, trabalha na escola, que sabe mais do que ela... então vai querer mandar nela. [...] Ela tem muitos saberes sobre a criança que eu não tenho e ela precisa me passar isso, e eu vou dizer como é esse filho, longe dela. [...] vou ter que criar vínculo com a mãe, essa confiança dela no meu trabalho, para aí poder continuar. A partir do momento que você consegue esse vínculo, vão acontecendo mudanças, ela começa a ficar mais aliviada, entra na reunião sorrindo, querendo ver a produção do filho, porque vai ter alguma coisa pra ver do filho... (Professora Ana)

Esses depoimentos revelaram as preocupações em colocar a família no eixo do processo educativo, estabelecendo com ela uma relação de mão dupla, inserindo-a na dinâmica escolar como parceira que contribui com seu saber, ao mesmo tempo em que, orientada, aproxima-se mais da criança e passa a acreditar mais em sua evolução. Por outro lado, as falas das professoras Luísa e Ana ilustram as preocupações diante de uma realidade tão comum ao pensamento de muitos educadores.

- Acompanhamento aos alunos incluídos no Ensino Regular: Foram muito citadas pelas entrevistadas as situações vivenciadas no acompanhamento aos alunos incluídos na Educação Infantil e no Ensino Fundamental, objeto de estudo das atividades formativas com a equipe, processo esse relatado como uma experiência desafiadora, que buscava atender às demandas do Programa de Inclusão. As entrevistadas mostraram as preocupações em acompanhar o programa de inclusão, de forma a encontrar caminhos que, passo a passo, respondessem às dificuldades e anseios do professor das escolas envolvidas, revendo concepções, abrindo novas perspectivas para a criança, discutindo idéias que as fizessem acreditar na capacidade de aprendizagem daqueles alunos. Mostraram também que, no início, era tudo muito novo e que tanto as escolas como as professoras da Educação Especial estavam otimistas:

[...] olha, uma coisa bem legal que aconteceu... é que quando veio este "bum" da inclusão... então os alunos que nós atendíamos na estimulação começaram a ser incluídos. A princípio, pavor para todos, para o professor 
que ia para a Educação Infantil levar o aluno... acho que o principal era a escola aceitar o aluno da Educação Especial, esse primeiro momento era assustador. (Professora Maria)

[...] nesses anos de itinerância, eu passei por vários momentos, por momentos que eu passava pela porta do professor e ele não me deixava entrar; depois eu passei por um momento em que eu batia na porta e ele me deixava entrar, mas olhava com desconfiança... a gente começou a entrar de forma diferente na escola, a gente não ia direto bater na porta do professor... a apresentar a nossa proposta ao diretor... no início era muito cru... chegava lá e "pá”... "Eu sou professora itinerante e vim observar sua aula”. Hoje eu penso como seria a minha reação... (Professora Luísa)

[...] o diretor via com maus olhos... a comunidade ficava resistente... Nossos HTPC's aconteciam tanto junto às professoras do regular... esses encontros com a equipe, no HTPC, davam abertura para se ter orientação do que fazer para melhorar esse trabalho nas escolas, [...] como eu poderia ajudar o professor a diminuir a sua angústia... às vezes, eu achava que por mais que a gente a ajudasse, a angústia não cessaria... elas precisavam de mais ajuda, de mais colaboração... (Professora Ana)

[...] com este planejamento cuidadoso, a gente tem uma transformação na forma de pensar, no olhar... mas para transformar a prática, ah, isso... não acontece de repente, só de ouvir... o professor precisa de mais respaldo, porque imagine como fica uma classe com trinta e cinco alunos com diferentes condições e o professor se deparar com algumas crianças com necessidades que ele não imagina quais sejam e com exigências de tarefas imensas. E, os "alunos do Especial” pintando e bordando na sala... o professor tem que se virar pra dar conta e os alunos correrem atrás do que era exigido... Não havia flexibilização de objetivos. [...] naquela situação, solidarizando-nos com a professora, motivando-a, deixando-a falar, pois ela merece ser respeitada como pessoa, este foi o grande ganho desta parceria. (Professora Beija-Flor)

[...] o processo inicial... também foi de estar chegando na escola fazendo essa escuta... de tudo que ele tinha de angústias, de medos, de reservas, que eu também tinha, porque para mim também era novo... e estar dizendo pra ele o que eu também sentia e que a gente ia tentar fazer o melhor juntos. Isto foi um ganho muito grande... porque professor falando para professor... os receios que você tem eu também tenho... de estar acalmando e de estar falando "nós vamos caminhar juntas”. (Professora Maria)

[...] cada escola está no seu momento, mas esta escola... eu não tenho dúvida que se chegar um aluno com deficiência visual, eles sabem o que fazer e onde procurar recursos. Eles têm professores que não se removem com freqüência, então toda formação que foi oportunizada naquela época se mantém. (Professora Luísa)

[...] tinham muitos diretores que eram bem receptivos e corriam atrás de condições... compartilhavam com as idéias e faziam com que as propostas fossem efetivadas... e, desta forma, fomos conseguindo adaptações, recursos, conquistando espaço e provando que aquilo dava certo. [...] em 2000, já conseguíamos ser presentes semanalmente, estreitando uma parceria com as professoras do Ensino Fundamental, acho que estávamos mais experientes e, por outro lado... o professor do fundamental sentindo-se 
acolhido e nós, cúmplices desse processo, as trocas foram mais assertivas e sistemáticas, facilitando a confiança e o crédito às orientações. (Professora Beija-Flor)

Assinalaram a inexperiência inicial em desenvolver trocas com outros profissionais, sendo observado que não bastava o compromisso pedagógico; era necessário possuir habilidade para dividir preocupações ainda pouco comuns àquela realidade. A escola defendia-se daquilo que não dominava e, nesse sentido, não era suficiente chegar com discurso, pois o professor sentia-se invadido com essa nova realidade.

Nesses momentos, a equipe parece ter contribuído para mediar tais dificuldades e traçar caminhos possíveis para dar outro sentido a essas trocas. Essas revelações explicitam momentos vivenciados de impotência inicial diante da incompreensão do trabalho inclusivo, exigindo, algumas vezes, a intervenção mais direta da equipe.

As entrevistadas revelaram que o processo interativo contribuía não apenas para partilhar as dificuldades dos alunos, mas como espaço de escuta e fortalecimento do professor; porém reconheciam os limites de certas situações, uma vez que o processo estava atravessado por uma série de fatores de ordem administrativa, organizacional, disciplinar, além das questões de ordem pedagógica e curricular do Ensino Fundamental. Eram tarefas, procedimentos que os professores das escolas deveriam cumprir, que dificultavam, muitas vezes, articular propostas e criar espaços de diálogo em que fossem neutralizadas as dificuldades, não das crianças, mas dos profissionais envolvidos, que precisavam de tempo e formação para reconhecer suas próprias possibilidades e se tornarem mais receptivos ao aluno.

As dificuldades parecem ter sido superadas, em diferentes momentos, pelas escolas, de forma bem peculiar. Manifestaram que, nesse processo contínuo de trocas, cada escola respondeu sob a influência da ação mais direta do diretor, sendo motivo de entusiasmo, principalmente quando começaram a encontrar saídas com mais autonomia. A possibilidade de encontros com os professores, em espaços específicos criados pela própria escola para que se efetivassem essas parcerias, significou um grande avanço na visão das entrevistadas, em especial quando esses espaços oportunizavam discussões sobre a prática, as situações concretas que lhes traziam angústia, como depuseram algumas delas. 
Com essa compreensão, admitiram que as escolas avançaram ao considerar as necessidades educativas docentes objeto de reflexão em espaços de trocas, criados pela escola, como apontaram as entrevistadas. 


\section{Capítulo IV}

\section{REFLEXÕES SOBRE OS DADOS ANALISADOS}

"O passado nos cerca e nos preenche; cada cenário, cada declaração, cada ação conserva um conteúdo residual de tempos pretéritos. Toda consciência atual se funda em percepções e atitudes do passado; reconhecemos uma pessoa, uma árvore, um café da manhã, uma tarefa, porque já os vimos ou já os experimentamos. E o acontecido também é parte integral de nossa própria existência...”

David Lowenthal

\subsection{As marcas de uma vivência em transformação}

Duas nítidas idéias ficaram expressas nos relatos: as manifestações das educadoras, mesmo referentes a um período anteriormente vivido, foram apresentadas em função das marcas, ainda vivas, que a formação continuada promoveu; recuperá-las não constituiu tarefa difícil, pois dizem respeito a uma bagagem que embasa seu trabalho ainda hoje. Nesse aspecto, como propõe Lahire, momentos marcantes e singulares de experiências passadas estão sempre, no princípio das ações futuras, agindo como um todo. A síntese de tudo o que é vivido anteriormente é reconstruído, gerando, assim, novas práticas (LAHIRE, 2002 p. 46-47). Isso significa que:

[...] as situações sociais (das mais formais e institucionais às mais informais), nas quais vivemos, constituem verdadeiros "ativadores" de resumos de experiências incorporados, que são nossos esquemas de ação (no sentido amplo do termo) ou nossos hábitos e que dependemos assim fortemente desses contextos sociais (institucionais ou não institucionais) que "tiram" de nós certas experiências e deixam outras em estado de gestação ou vigília (IBID, p. 59).

Na análise, foi sendo desvelada uma multiplicidade de questões, conhecimentos, idéias, valores incorporados, transformando cada entrevista em um espaço de releitura das situações mais significativas dessa proposta. Fica nítido que os fatos marcantes foram destacados por quase todas, mas com ênfases muito específicas, talvez devido à repercussão, em cada educadora, das diferenças como os grupos eram constituídos e se organizavam. 
Da combinação dos dados analisados - questionários e entrevistas -, foi possível configurar a trajetória construída pelo grupo de profissionais entrevistadas. Embora sejam todas professoras habilitadas em Educação Especial, vinculadas a uma mesma gestão pública municipal, e tenham partilhado de um mesmo modelo de proposta formativa, cada qual, com sua trajetória pessoal, foi influenciada por experiências bem distintas e, particularmente em seu contexto de trabalho, por uma multiplicidade de fatores próprios à dinâmica de cada unidade escolar e de cada grupo em que estavam inseridas.

A diferenciação em alguns aspectos, tais como modo de participação, envolvimento com o projeto pedagógico, forma de organização e enfrentamento do cotidiano, fez dessas profissionais um grupo bastante heterogêneo, o que tornou seus relatos mais enriquecedores. Nesse sentido, foram reveladores de uma pluralidade de sentimentos, significados e representações que ecoaram da singularidade desses sujeitos e seus grupos, mediados por diferentes relações com seus alunos, comunidade escolar, colegas de atividades, com a direção e a com a própria Secretaria de Educação, refletindo em seu exercício profissional.

De acordo com Vygotsky (2003), focalizando o comportamento humano do ponto de vista histórico-social, para entender as modificações decorrentes das relações entre indivíduos e grupos sociais, deve-se analisá-lo em sua essência, desde a origem dos acontecimentos, sem fragmentá-los, pois cada sujeito, em sua singularidade, envolvido em uma rede interdependente de contextos e papéis sociais, reelabora seu percurso de forma distinta. $\mathrm{O}$ autor admite que:

[...] somente os dados desse período revelarão a verdadeira origem da reação e suas ligações com outros processos. Através de um estudo de toda história de uma reação, podemos obter uma explicação integrada das suas manifestações internas e de superfície (IBID, p. 91).

As complexas relações envolvidas nos ambientes sociais e escolares, nos quais essas educadoras estavam inseridas, promoveram uma história educativa que, ao ser examinada em suas transformações, em seu processo de desenvolvimento, permitiu compreendê-la em sua extensão e profundidade. A análise das entrevistas ofereceu a possibilidade de revelar "as relações dinâmico-causais reais subjacentes ao fenômeno” (IBID, p. 82). 
Sabemos, entretanto, que os fragmentos recolhidos das experiências, como também a abordagem utilizada para a leitura dos dados, embora enriquecedores para buscar respostas às nossas perguntas, poderiam ser interpretados sob uma multiplicidade de outras questões desse período, concernentes a ações educativas tão complexas.

As marcas e indícios dos depoimentos das educadoras, sobretudo em função da direção tomada pela pesquisa, estabelecendo conexões entre dois grupos de categorias complementares, ofereceram respostas aos objetivos e questionamentos propostos por este trabalho.

Dessa forma, os aspectos aqui elencados são resultado de uma síntese do diálogo que fomos fazendo, considerando três focos de análise, referentes aos objetivos desta investigação, que foram discutidos, em alguns momentos, de forma correlacionada:

1. O primeiro discutirá sobre os significados que a proposta formativa teve para esses educadores e as transformações em seu papel profissional;

2. O segundo tratará dos dados referentes às transformações nas concepções das educadoras;

3. O terceiro contemplará as transformações da prática pedagógica.

\subsection{Tomada de consciência sobre o papel profissional}

Assinalamos, a seguir, os significados indicadores das transformações que a proposta formativa provocou no papel profissional das educadoras entrevistadas e os fundamentos que nos deram base para identificar o que foi assinalado.

O primeiro indicador desse movimento de renovação foi o novo sentido atribuído ao "ser professor”: passou de uma percepção que impedia as educadoras de acreditarem na possibilidade de seu papel provocar mudança, para uma outra percepção, na qual passaram a assumi-lo como fator importante para a contestação de práticas estáticas, indo em busca de bases que lhes dessem sustentação para inovar. 
Foi marcante para a reflexão das professoras a parceria estabelecida entre professor e equipe e os modos como o grupo concretizou essa proposta formativa. Desenvolvendo uma relação mais próxima de valorização da identidade profissional do professor, puderam: tomar consciência de outras possibilidades, em um contexto educativo de tantas emergências, tão envolvido por dúvidas e sensações de impotência e profunda incompreensão das dificuldades; e posicionar-se em seu grupo de trabalho como educador imbuído de seus propósitos.

Esses dados reiteraram posições como as de Nóvoa (2000), que considera a maneira como o professor sente e está na profissão, admitindo ser "mais adequado falar em processo identitário realçando a mescla dinâmica que caracteriza a maneira como cada um se sente e se diz professor” (p. 16 - grifo do autor), e Pimenta (2003), que considera que a identidade não se adquire como um produto, como algo imutável, mas sim como um processo de “construção do sujeito historicamente situado” (p. 164).

A análise do expresso na fala das educadoras evidenciou que elas assumiram a construção de seus projetos, decidindo os rumos de seu trabalho e investindo em seu aprimoramento a partir de sua própria ação, consciente e decisiva, cabendo aos profissionais da equipe, como mediadores da proposta formativa, a criação de espaços favoráveis para que fosse estabelecida uma relação pertinente de trocas e parcerias.

Esses dados divergem de afirmações de Nóvoa $(1995,2000)$ quando o autor alerta para os riscos de o processo compartilhado com especialistas separar a “concepção da execução”, descaracterizando o saber do professor e desvalorizando seu papel. Parece fundamental, na visão desse autor, compreender tal processo de modo articulado, abrindo espaço para o posicionamento do professor como forma de superar a dicotomia entre os saberes e combater a representação de uma identidade pouco valorizada.

A análise evidenciou que essa forma compartilhada - abrindo espaço para o posicionamento do professor - ocorreu na formação continuada sem outros possíveis riscos, evidenciando, entretanto, ser resultante também da realidade subjetiva de cada professora que, com seus propósitos pessoais, foi mobilizada por essa motivação, assumindo uma atitude de autoria do seu trabalho. Ainda assim, não incidiu no perigo que Nóvoa considera o maior risco de fazer frente à visão dos próprios educadores: mostrarem-se resistentes em romper com uma visão acrítica rotineira, que só contribui para acentuar a desvalorização do saber pedagógico. 
Nesse sentido, a formação possibilitou aos professores sentirem-se situados e determinados quanto aos objetivos de suas ações, e não se submeterem acriticamente a determinações unilaterais. Isso reitera o que Nóvoa (1995) assegura a respeito do que as experiências formativas devem impedir: “[...] um 'paternariado pela negativa', baseado na anulação das competências dos diversos atores e inventar um 'paternariado pela positiva', construído a partir de um investimento positivo de todos os poderes” (p. 30).

As referências das professoras quanto à parceria na formação continuada evidenciaram coincidir não somente com o posicionamento de Nóvoa, como também com as críticas e receios manifestados por Pérez Gómez (1995), quando este ressalta que a autoridade do professor, em função do suporte especializado, pode produzir um abismo entre teoria e prática. De certa forma, tal aspecto resgata uma questão histórica voltada para a dicotomia entre aqueles que concebem os projetos pedagógicos e os que executam assimetricamente posicionados, sendo que o professor, fatalmente desvalorizado, submete-se, muitas vezes, a transmitir propostas distanciadas de sua realidade.

Conforme os dados apontados pelas entrevistadas, a formação criou oportunidades nas quais uns aprenderam com os outros, propiciando possibilidades em ultrapassarem as barreiras que comprometiam sua participação, por omitirem suas idéias e posições claras sobre suas ações. Esses dados reiteram as idéias de Nóvoa (1995), quando o autor considera que a formação docente pode possibilitar a criação de condições favoráveis ao fortalecimento do professor: "mais do que um lugar de aquisição de técnicas e de conhecimentos, a formação de professores é o momento-chave da socialização e da configuração profissional” (p. 18). Da mesma forma, ilustraram o que Nóvoa (1999) salienta em relação aos sentimentos de fracasso que atingem o professor, provocando um permanente mal estar diante de suas dificuldades, evidenciando a necessidade de ser considerado e olhado com mais confiança.

Entre a imagem idealizada e a realidade vivida, o professor enfrenta uma crise (do grego krísis, que significa decisão) que, segundo o autor, pode se transformar em alavanca para a tomada de decisão frente a seu percurso. A maioria das entrevistadas trouxe respostas de um movimento muito intenso, na perspectiva de estarem sempre em busca de meios mais inovadores, inconformadas com o trabalho de colegas que revelam acomodação ou pouco empenho pessoal para transpor os obstáculos com seus alunos. Isso assinala que para o professor estar em constante confronto com a luta pelo direito das pessoas com deficiência, 
diante da constante sensação de impotência, de barreiras aparentemente intransponíveis, esses impasses nem sempre são evitáveis e requerem reflexão.

Para que o professor possa acreditar em seu trabalho, antes de tudo precisa acreditar nas possibilidades de transformação da pessoa com deficiência e, mais do que isso, acreditar que possa ousar na criação de caminhos que sejam decisivos para tal transformação. Nesse sentido, Cavaco (1999) pontua questões referentes ao profissional no exercício de suas funções, no enfrentamento das constantes preocupações do dia-a-dia incorporando suas dificuldades, amoldando-se aos recursos e sofrendo com a própria crítica de sentir-se incapaz.

O professor vive no seu cotidiano de trabalho as contradições que pressente, mas que não tem espaço para esclarecer, nem oportunidade de aprofundar, atormentam-se inquietações que não partilha porque tem medo de perder a face, de fragilizar a imagem de sucesso que procura compor (p. 189).

As trocas de experiências, descritas pelas entrevistadas como possibilidade de o professor adquirir maior compreensão dos processos de aprendizagem, foram momentos que lhes forneceram mais clareza sobre as direções a serem tomadas. A percepção assinalada de maior segurança ao se sentirem valorizadas pela equipe, assumindo com determinação e compromisso os rumos de seu projeto de trabalho, envolve, segundo Fazenda (2002a), um regime de co-propriedade do saber, de uma intersubjetividade que depende do compromisso coletivo com o projeto pedagógico e que apenas a integração de conhecimentos torna-se insuficiente.

$\mathrm{Na}$ análise, ficou expresso o esforço de algumas professoras para fazerem-se ouvir e serem consideradas, dando provas de sua consciência sobre seu papel, mesmo que desconhecendo, muitas vezes, a extensão de sua responsabilidade. As evidências de fragmentação das funções e a pouca clareza dos papéis profissionais, assinaladas pelas educadoras, parece, por outro lado, ter dificultado que algumas delas sentissem segurança em se posicionar, principalmente quando enfrentavam problemas para estabelecer relações da teoria com a prática, ou nas ocasiões em que se confrontavam com uma nítida desvalorização de seu papel. Revelou-se, assim, que, ao se sentirem incapazes, não conseguiam ter autoridade sobre suas próprias atividades nem expressar sua competência como professoras, sendo assinaladas situações 
concretas, percebidas de como foi importante a atuação ponderada de alguns profissionais da equipe não apenas analisando os problemas e mediando dificuldades ocorridas, mas também realimentando sua prática e investindo nas relações e no seu potencial.

A parceria, defendida pelas entrevistadas como possibilidade de valorização do papel do professor, de serem ouvidas e respeitadas como profissionais, pressupondo uma atitude de complementaridade ante o conhecimento, sendo reconhecidas e aceitas em suas possibilidades e limites, foi uma realidade construída, embora, em algumas situações, os dados tenham apontado dificuldades e necessidades nem sempre solucionadas de forma completa. Nesse sentido, os relatos assinalaram, de um lado, fatores de natureza técnica, relacional e institucional, envolvendo fragilidades nas condições de a equipe, os professores e a escola exercerem seu papel; de outro lado, a busca da equipe pela compreensão das dificuldades e obstáculos que apontavam a existência de diferenças e imposições entre funções, com divisões hierárquicas, dependendo do grupo, bem definidas.

O descompromisso e a superficialidade de atuação de alguns profissionais da equipe, revelando, em alguns momentos, pouco domínio técnico, também foi apontado como fator nem sempre discutido. Essas situações foram reveladas por algumas entrevistadas com certa compreensão e tolerância, sugerindo que, diante dos problemas que emergiam da prática, fossem encontradas respostas, de forma interativa, apontando que para esses impasses, mais do que cobranças “daquilo que o técnico não tem”, dever-se-ia partir para uma perspectiva em que as discussões dos problemas fossem construções complementares conjuntas.

De certa forma, as ponderações de algumas educadoras em relação às fragilidades da equipe evidenciaram uma atitude de empatia, considerando a necessidade de prezar uma relação que pudesse refletir, também, como gostariam de ser respeitadas em suas próprias dificuldades, estratégia considerada por elas como uma forma de incentivar o momento ativo de cada um, buscando criar situações de envolvimento, em que todos pudessem contribuir com os colegas suas dificuldades.

É importante destacar que as interações entre os professores e suas equipes foram retratadas, por algumas entrevistadas, como experiências que abriram espaço para que as preocupações, dificuldades e anseios fossem compartilhados, evidenciando-se abertura para compreender o 
momento de cada um, colocar-se no lugar do outro, sobrepujando diferenças e manifestando um profundo respeito pelas formas de atuação de cada um.

Há, entretanto, situações em que foram demonstradas posturas inflexíveis, que desconsideraram o processo de crescimento do professor. As expectativas da equipe, em alguns momentos, exigiam que a ação do professor já tivesse atingido total autonomia. Pertinente a esses depoimentos das entrevistadas está o comentário de Fazenda (2003a) a respeito de uma visão interdisciplinar que pressupõe o abandono de posições por demais rigorosas, unilaterais, que impedem olhar para os pequenos avanços, impedindo a abertura a novas conquistas. Há referências de algumas entrevistadas que manifestaram com satisfação os momentos de conquista do grupo, em que as relações foram trabalhadas, sendo mencionada a valiosa contribuição da equipe em cultivar espaços onde eram avaliados os relacionamentos interpessoais.

Cinco das entrevistadas, entretanto, revelaram exigência com seu próprio papel e o da equipe, considerando a responsabilidade de agirem com consciência, referindo-se às implicações sociais e éticas de ações impensadas. A preocupação com o domínio dos papéis indica, também, preocupações com as atribuições e responsabilidades de cada área, como forma de um não interferir no campo do outro - "onde está o limite da atuação de cada um”-, deixando entrever uma visão segmentar e compartimentalizada dos diferentes papéis e, por outro lado, a insegurança de não saber - "o que eu faço com isso efetivamente” -, refletindo dificuldades do professor em estabelecer um diálogo da teoria com a prática, ou talvez excessiva preocupação em não pisar em terreno alheio. Nesse aspecto, poderia estar revelando, de um lado, ausência de uma visão dialética na atuação interprofissional, mostrando um movimento que, por vezes, definiu responsabilidades, indicando campos delimitados de especialização, impedindo que os temas fossem discutidos em uma linguagem que, na visão de Fazenda (2002b), não é de um, mas de vários; e, de outro lado, que a falta de um detalhamento mais explícito sobre os compromissos de cada área talvez tenha impedido que os educadores produzissem um conhecimento mais integrado. 


\subsection{Transformações nas concepções das educadoras}

Ao longo da entrevista, ficaram expressas pelas educadoras, sujeitos da pesquisa, as diferentes concepções assumidas quanto à visão da escola, de homem, dos processos de aprendizagem, de desenvolvimento e deficiência, que foram emergindo a partir de uma multiplicidade de

significados construídos por elas durante sua formação. Buscamos desvelar indícios e pormenores expressos nas impressões dessas educadoras, considerando-se que neles estavam implícitas suas concepções sobre a aprendizagem dos seus alunos e o tipo de ensino que acreditavam poderem promover o desenvolvimento deles.

Refletir sobre essas práticas e condutas do professor propiciou identificar concepções compartilhadas pelo grupo, pelas deliberações coletivas da escola, surgindo os sentidos e significados das ações dos indivíduos de processos de intersubjetivação. A análise dos depoimentos das professoras assinalou a parceria entre o grupo, percebida de maneira dinâmica, interferindo prospectivamente nos processos de desenvolvimento e aprendizagem do aluno, ilustrando do eixo teórico o conceito de internalização (Vygotsky, 2003).

Uma nova concepção sobre o aluno foi sendo construída quanto à relação que ele estabelecia com o conhecimento, referindo-se à superação de posições educacionais destituídas de desafios, que reduziam exigências por desconhecer a amplitude de seu potencial. Com novo significado, a partir de uma abordagem interdisciplinar, pela leitura de diferentes profissionais, a concepção de deficiência das entrevistadas possibilitou-lhes conquistar maior amplitude na compreensão das relações educativas, considerando a singularidade dos sujeitos como um processo em constante transformação, dependente das condições educacionais criadas.

Essa mudança é reiterada por Fazenda (2002a), quando a autora enfatiza que, nesse regime de co-propriedade de concepções, está envolvida uma "mudança de atitude perante o problema do conhecimento, da substituição de uma concepção fragmentária pela unitária do ser humano” (p. 31). Essa maneira, revelada pelas entrevistadas, de compreender a educação como um processo em constante movimento, em que o educador reconstrói suas idéias por meio do estabelecimento da intersubjetividade e do diálogo, da interação de experiências e saberes, articulando teoria e a prática, aponta para uma dinâmica de mudanças a partir da 
reflexão da própria prática, em que o educador confirma essa orientação transformadora do fazer pedagógico.

Corroboram com essa prática refletida as posições defendidas por Schön (1995) sobre a formação docente baseada na construção do conhecimento por meio da reflexão, análise e problematização da prática que, segundo Pimenta (2005), possibilita ao professor responder às situações novas, diante da imprevisibilidade do cotidiano.

Das sete entrevistadas, cinco delas afirmaram a importância de o professor estar alicerçado em um eixo teórico que lhe ofereça uma visão mais aprofundada do aluno, como ponto de partida para organização das suas idéias e descoberta de canais de acesso das melhores condições de aprendizagem.

Assinalaram, também, que esse conhecimento propiciou-lhes o estabelecimento da comunicação com o aluno permeada por diferentes linguagens, em que puderam conhecer melhor os sentimentos deles, seus desejos, a dinâmica de suas interações, como reagem às atividades e, com maior domínio, puderam transpor as barreiras que são colocadas entre o professor e a criança, por desconhecimento da realidade dela.

As entrevistadas demonstram suas tentativas de oferecer caminhos alternativos de desenvolvimento ao aluno procurando meios de interlocução com ele, admitindo que sua condição orgânica, mesmo quando apresentada com maior gravidade, não compromete que se desenvolva, desde que se busque utilizar-se de ferramentas sociais e culturais como recursos pedagógicos que potencializem as condições da criança.

Os postulados de Vygotsky (2003) corroboram com essa discussão admitindo que as intervenções educativas ativam a aprendizagem, estimulam e propulsionam para frente a maturação, promovendo transformações e oferecendo acesso ao conhecimento. Destaca como fator de abertura para o desenvolvimento os processos de mediação, ressaltando a importância da ação pedagógica planejada com objetivos deliberados, como meio auxiliar dos processos de aprendizagem, considerando que para "engendrar uma série de processos de desenvolvimento interior precisamos dos processos corretamente construídos de aprendizagem escolar” (p. 106-107). 
O autor considera, ainda, que a deficiência não interfere diretamente na personalidade da criança, pois, entre os seres humanos e seu mundo físico, coloca-se o ambiente social com todas as condições que podem contribuir ou impedir seu desenvolvimento e suas ações com o mundo, revelando que "diferentes modos e com outros meios, os processos compensatórios conseguem construir um caminho distinto, que considere as peculiaridades de cada criança” (VYGOTSKY, 1983, p. 14).

A partir da análise dos dados, acreditamos que o modo como foram, em parceria com a equipe, planejadas e refletidas as práticas e estratégias de intervenção possibilitou ao professor ter em mãos material esclarecedor das necessidades específicas da criança para elaborar atividades que estimulassem seu desenvolvimento.

A análise dos dados evidenciou que, para as professoras, a tendência de construir práticas pedagógicas tendo como referência as dificuldades e limitações da pessoa com deficiência, indicativo de uma concepção que coloca ênfase na constituição biológica da deficiência, foi algo superado. Cabe, entretanto, assinalar certa dubiedade nessa afirmação frente a outras afirmações nas quais os educadores chamaram atenção para a importância de o professor conhecer, com profundidade, a criança e ter acesso aos dados sobre sua condição de saúde, inclusive às avaliações diagnósticas.

As discussões dos profissionais da Educação Especial com os da escola regular em busca de se desenvolver um diálogo em torno do potencial da criança com deficiência, numa proposta inclusiva, parece ter desencadeado, no próprio professor especializado, novas reflexões sobre as possibilidades de o seu trabalho produzir e provocar mudanças nas concepções e condutas dos educadores. Ultrapassar as barreiras da descrença e do pessimismo e provar para as escolas as condições de o aluno poder aprender como os demais foi um novo percurso, assinalado como permeado por receios e desafios, propiciando ao próprio professor da Educação Especial oportunidades para rever a direção de seu trabalho, suas concepções, a adoção de novas idéias que teriam de partilhar com os demais colegas do Ensino Fundamental. Provar para o professor do Regular as condições que tornam possível à criança com deficiência aprender exigiu de si mesmo maior segurança em suas convicções e posições, para poder, com decisão, propor mudanças. 
Consideramos que a ruptura com um pensamento marcado pela visão de uma única forma de pensar a Educação Especial possibilitou o crescimento de uma bagagem anteriormente assimilada como suficiente para o domínio das situações que o professor já enfrentava. Ao compartilhar crenças e conhecimentos que são valorizados, pode-se criar a ilusão de que só essa forma de pensamento esgota a possibilidade de trazer respostas eficazes ao professor. Nessa questão, foi mencionado como fundamental o papel da equipe, discutindo essa relação entre saberes e domínios teóricos que, diante de suas contradições, trouxeram, na visão das entrevistadas, ganhos para todo o grupo.

Outro aspecto muito ressaltado foram os espaços formativos específicos para cada área de atuação a partir da mediação das assessorias, que trouxeram para os educadores conhecimentos teóricos importantes, provocando nos professores a necessidade de dominarem conhecimentos específicos que os qualificassem em suas áreas. Entretanto, as entrevistadas evidenciaram que as propostas pautadas em conteúdos estabelecidos, de forma genérica, distanciados do contexto educativo e das peculiaridades do aluno, impediram que houvesse uma articulação da teoria com a prática, não assegurando que as dificuldades do professor pudessem ser discutidas. Algumas entrevistadas, contudo, admitiram que houve possibilidade de discutirem outras temáticas de maior abrangência da Educação, o que lhes pareceu válido se esses momentos não tivessem fragmentado as áreas de ensino em função do domínio dos docentes que ministravam os cursos, por eles estarem mais voltados para o ensino regular e terem definido que não entendiam de Educação Especial.

Ao focalizarem as contribuições da equipe nas trocas, tematizações e atividades com as assessorias, as entrevistadas revelaram que a formação dos professores partia da realidade vivenciada por eles no contexto escolar, como procedimento que abrisse espaço para a superação das dificuldades. Verificamos, pelos dados das entrevistas, um movimento coletivo que provocou no professor a necessidade de refletir sobre sua prática, buscando respostas que dessem um novo rumo ao seu trabalho, considerado pelas entrevistadas como um desafio coletivo.

Cabe levantar um questionamento para reflexão referente ao quanto o professor buscou, nesses conteúdos teóricos, condições para estar mais consciente de sua prática, despertado pelo movimento reflexivo de sentir-se com maior domínio, mais bem preparado como profissional, com mais fundamentos na articulação da prática com a teoria, ou quanto essa 
busca foi provocada mais pelo enfrentamento de dificuldades que exigiram respostas a soluções de natureza técnico-utilitárias, na maioria das vezes impulsionadas pela instabilidade dos conflitos e que, portanto, mesmo que tivessem um caráter provisório, poderiam ajudar no enfrentamento mais imediato dessas situações.

\subsection{Transformações da prática pedagógica: aprendizagem baseada no contexto escolar}

“[...] estamos acostumados a considerar o objetivo e o resultado como prioritários; o percurso, mero instrumental para atingir a meta. Entretanto, as mudanças que estamos vivendo exigem uma nova perspectiva. Se o caminho for tão importante quanto 'o quê', teremos então a possibilidade de manter agregados o círculo de jade e o seu furo, a plenitude e o vazio. O como pode colorir de sentido os conteúdos da experiência.”

A. Melucci,

A bagagem de que as educadoras pesquisadas revelaram ter-se apropriado ao longo do período em que vivenciaram essa proposta mostrou que elas tomaram como ponto de partida a reflexão da prática pedagógica. Isso possibilitou-lhes compreender os fenômenos da aprendizagem, elaborar conhecimentos, incorporar uma nova visão sobre os alunos em uma sistemática de trabalho mediada pela equipe, pautada no questionamento e na interpretação das ações tendo como referência a teoria que a fundamentava.

A análise mostrou um processo em constante movimento, em uma dinâmica interativa de avanços e retrocessos, implicando uma busca constante do professor. Esses dados mostraram que a Proposta de Formação provocou mudanças e novos direcionamentos à proposta de trabalho. Foram experiências relatadas que tiveram uma abrangência que ultrapassou as programações instituídas de forma genérica, para interagir com o cotidiano escolar como algo dinâmico, contextualizado, para propiciar aos alunos com deficiência condições para que adquirissem saberes necessários ao seu desenvolvimento e participação em sua comunidade e na família como pessoas atuantes no meio, aptas a analisar as situações vividas e, como cidadãos, expressarem suas necessidades e manifestarem seus pontos de vista. Nesse sentido, as considerações assinaladas levam-nos a crer que um dos significados desse processo formativo para as entrevistadas foi tomada de consciência das necessidades educativas com 
um posicionamento que as fizeram estabelecer uma análise minuciosa e aprofundada dos diferentes momentos que vivenciaram, com a equipe, essa construção compartilhada.

Entre os aspectos marcantes que consideraram ter produzido mudanças qualitativas em sua prática pedagógica, referem-se ao fato de a proposta formativa estar voltada para as necessidades de seu cotidiano, problematizando questões que provocavam dúvidas e dificuldades para definir a melhor alternativa de trabalho. Revelaram um envolvimento com a proposta e muita vitalidade na forma como descreveram as atividades e experiências que construíam; a todo o momento, avaliavam suas incongruências, buscando novas alternativas de trabalho que pudessem tornar as aprendizagens mais significativas para os alunos. Nesse aspecto, Garcia (1995) destaca a importância de que os momentos formativos do professor ofereçam condições para que ele recupere o entusiasmo e a "predisposição para afrontar a atividade com curiosidade, energia, capacidade de renovação e de luta contra a rotina” (p. 63).

As impressões quase unânimes das entrevistadas revelaram uma preocupação em discutir a relação do professor com o aluno, estendendo o olhar para além da deficiência e das dificuldades que pudessem surgir em decorrência das suas condições. Admitiram estarem conscientes de sua responsabilidade em estabelecer propostas que assegurassem ao aluno acesso ao conhecimento, por meio de intervenções planejadas, que promovessem situações de aprendizagem desafiadoras.

Observamos, em nossa análise, que as propostas manifestadas por algumas entrevistadas esboçavam uma atuação pedagógica de valorização de diferentes linguagens, aproveitando estímulos e espaços variados, não se detendo unicamente à sala de aula. A preocupação com o bem estar do aluno, seu conforto e acolhimento, principalmente com aqueles que não conseguiam manter um contato físico estável e, tampouco, expressar com facilidade seus sentimentos e idéias, parecia ser um constante foco de atenção do professor.

As situações tidas como de aprendizagem envolvendo, principalmente, propostas que não se limitassem às atividades motoras e criassem condições para os alunos manifestarem indícios de seu pensamento exigiram um persistente percurso do professor em aproveitar situações, mesmo aquelas referentes aos cuidados físicos, transformadas em acesso para a proposta desejada. Esses dados dos depoimentos das entrevistadas foram claramente expressos por Mazzotta (2002, p. 33), ao afirmar que: 
$\mathrm{Na}$ discussão das necessidades educacionais é fundamental não desconsiderar sua interdependência com as demais necessidades humanas, tais como aquelas apontadas nos clássicos estudos de Maslow, ainda que as mesmas não sejam interpretadas de forma hierarquizada. Assim, necessidades fisiológicas, de segurança, de participação social, de estima ou reconhecimento e as de auto-realização estão intricadas nas necessidades educacionais comuns e especiais cuja satisfação inclui a atuação competente das escolas. (grifo do autor)

As possibilidades de traçarem objetivos para algumas crianças com maiores comprometimentos estavam diretamente relacionadas com os registros do professor e análise dos progressos da criança, passo a passo. Há, nesse sentido, segundo Masini (2004), a constituição de alguns requisitos básicos necessários que, entretanto, não são suficientes ao processo educativo, tais como o conhecimento das especificidades dos alunos, a definição de metas, clareza das condições envolvidas, propostas sistematizadas com etapas bem delineadas, recursos apropriados àqueles que estão envolvidos, entre outros, principalmente os relacionados à "disponibilidade dos profissionais aptos a lidar com o aluno e com os recursos apropriados” (p. 42).

Tanto na escola especial quanto no acompanhamento às crianças incluídas no ensino regular, a preparação de um planejamento cuidadoso revelou-se necessário, conforme relato das entrevistadas, tanto para o atendimento do aluno como na parceria com o professor e, nesse aspecto, o registro e a reflexão teórica dos apontamentos do professor parecem ter sido o referencial de análise da realidade vivida, funcionando como um exercício de trocas de saberes, em que as práticas foram dialeticamente reconstruídas, coletivamente, a partir da elaboração de novas idéias, com o suporte da equipe. Nesse sentido, as posições de Fazenda corroboram com as afirmações das entrevistadas, ao considerar que o professor amplia sua visão sobre sua prática (movimento intrapsicológico) fundamentado na teoria, o que implica criar oportunidades formativas que validem seu saber e estes possam dialogar com suas ações e com outros conhecimentos em um contexto interativo e dinâmico (movimento interpsicológico), em que todos se sintam parte desse diálogo, respeitando-se o espaço e tempo do professor (Ibid, 2003b).

Admitimos que, de tal maneira, para se compreender melhor o processo de aprendizagem da criança, as professoras levaram em conta seus conhecimentos teóricos ao registrarem suas análises, ao mesmo tempo em que, seguindo as orientações de seus parceiros, em um diálogo 
interativo, realizaram um movimento interpsicológico. Mediante essas trocas compartilhadas, reviram posições, produzindo a internalização de saberes que o fizeram repensar sua prática, em um movimento intrapsicológico. Dessa forma, a função desempenhada pela linguagem mostrou ser instrumento de reflexão e reconstrução do conhecimento, o que contribuiu para que os processos de mediação entre educadores e entre educadores e seus alunos pudessem favorecer o intercâmbio de idéias, mobilizar análises e reorientar as propostas pedagógicas para novos caminhos, como foi relatado pelas entrevistadas, ao mencionarem a importância da análise sistemática dos registros.

Mesmo que as educadoras tenham admitido que definiram os rumos das propostas, ainda assim a reflexão com a equipe pareceu-lhes imprescindível, instrumento necessário para se sentirem mais confiantes. Essas considerações são corroboradas por Pimenta (2003), ao admitir que o domínio da práxis deve estar em permanente construção, tendo como base as necessidades e os permanentes desafios que o ensino, como prática social, lhe coloca.

As mudanças ocorridas foram interpretadas pelas educadoras como aquisição de habilidades que possibilitaram enfrentar as situações do cotidiano, decidir rumos e atuar com mais segurança diante das demandas e adversidades decorrentes do contexto da deficiência. O pensamento das educadoras, expresso nas entrevistas, aponta para a condição de se perceberem mais bem preparadas, apropriando-se de conhecimentos, e de compartilharem com a equipe os saberes da prática que lhes ofereceram melhor compreensão dos fenômenos da aprendizagem dos alunos, e de poderem intervir com mais decisão e intencionalidade.

Fusari e Rios (1995) reiteram tais condições, considerando que o profissional competente "é aquele que sabe fazer bem o que é necessário, desejado e possível no espaço de sua especialidade” (p. 40). Os autores consideram que o professor não pode ter expectativas de adquirir um modelo pré-definido de atuação a ser seguida, mas como um processo de construção contínua, dinâmica e coletiva pautada na realidade do contexto. Nesse aspecto, a relação educador-contexto lança mão de uma práxis espelhada nas condições dos sujeitos envolvidos, de suas possibilidades e limites. Na visão dos autores, o fundamental é construir um saber fundamentado em conteúdos a serem transmitidos e dominar técnicas que respondam às características e necessidades dos alunos e do contexto, definindo um direcionamento pautado no compromisso ético e na responsabilidade de ocupar o lugar que lhes compete (FUSARI e RIOS, 1995, p. 40-41). 
Essa transformação constituiu fator de fortalecimento coletivo, na medida em que trouxe para as educadoras uma sistemática de trabalho em parceria que, de acordo com elas, abrigaram tematizações de propostas que, ao serem compartilhadas com o grupo, criaram enriquecedores debates. Entretanto, ficou expresso que esses momentos estavam sempre muito centrados em responder às necessidades que emergiam da relação com os alunos, referentes às situações de aprendizagem ou comportamentais.

As condições institucionais do contexto escolar, produto das relações entre os sujeitos, como indicam os dados, entraram no debate formativo para alguns grupos, mais do que para outros. Algumas entrevistadas referiram-se à dificuldade de o professor utilizar esses espaços como forma de construção de propostas, mais do que manter um clima de queixas e lamentações por suas dificuldades, como se não dependessem dele as soluções.

Tratar de temas sociais, políticos e humanos e suas implicações para o projeto pedagógico tomaram mais corpo quando os fundamentos infringiam a possibilidade de o aluno com deficiência ser atingido em seus direitos. Constatou-se que a história desses grupos necessitou de um tema aglutinador que impedisse a visão individualista das práticas e, nesse aspecto, a equipe, em muitos dos grupos, constituiu-se um mediador favorável, quando imprimia uma visão menos técnica, não alienante, e mais social dessa construção coletiva do projeto pedagógico. Nessa direção, a atuação das equipes, numa compreensão interdisciplinar dos conflitos, pôde contribuir para ampliar a visão sobre os problemas institucionais.

Essa questão reitera a visão de Contreras (2002), que considera que o professor envolvido num diálogo reflexivo não apenas elabora idéias, como tem a possibilidade de analisar e reconstruir suas concepções sobre os condicionantes que envolvem e delimitam as relações sociais e de trabalho e, assim, definir a que interesses pretende servir. É consistente com as apreensões vividas pela equipe a preocupação desse autor referente à tendência do professor em limitar os processos reflexivos unicamente às questões concretas do conhecimento pedagógico ao contexto mais imediato, distante da complexidade dos processos de ensino, das relações e das dinâmicas sociais nas quais estão inseridos (Ibid, 2002, p. 230-234).

Na visão das entrevistadas, refletir sobre a prática do professor, individual ou coletivamente, envolveu uma atitude de abertura para o outro e, nessa relação, criou-se a possibilidade de 
elaborações mentais acessadas que, sozinho, o professor não conseguiria elaborar de forma autônoma.

Outro aspecto destacado quanto às reflexões da prática mediadas pela equipe referiu-se à possibilidade de tomarem posse de dados, informações e conhecimentos que, articulados pela leitura de diferentes profissionais, contribuíram para a obtenção de uma visão mais aprofundada da criança, repercutindo nas condições de esses educadores oferecerem propostas mais apropriadas e desafiadoras aos alunos. Os postulados de Vygotsky (1983) corroboram e ampliam essa discussão, ao considerarem que as propostas pedagógicas devem superar a visão indiferenciada das metas minimalistas (grifo do autor), buscando condições educativas que acolham as especificidades dos alunos, principalmente as que se referem à deficiência.

As proposições de Vygotsky ressaltam o respeito à diversidade e à criação de práticas flexíveis que atendam às necessidades específicas dos alunos, tornando-as mais integradoras e eficazes. Essas questões envolvem o desdobramento de dois aspectos fundamentais, abordados nos estudos da formação do professor, criticamente discutidos por Mazzotta (2003, 2006). O autor analisa que, se por um lado, uma perspectiva assistencialista, muitas vezes, reduz exigências, sobretudo aos indivíduos que apresentam acentuados comprometimentos, por outro, uma perspectiva padronizada da deficiência, tendo como referência condições genéricas, descaracterizam suas necessidades. Em ambos os casos, essa configuração da deficiência impede que as pessoas tenham acesso a ambientes enriquecedores que contribuam para sua integração e/ou inclusão social. O autor considera, ainda, que a adesão a uma ideologia de inclusão incondicional pode dar margem a equívocos dessa natureza na compreensão das reais condições individuais e sociais de uma parcela significativa da população, que necessita de intervenções e recursos diferenciados ou especiais em relação aos que já estão disponíveis para utilização (Mazzotta, 2006, p. 10).

No conjunto dos depoimentos das educadoras entrevistadas, a parceria da escola com a família foi apontada como fator constitutivo do projeto pedagógico, revelando uma realidade escolar envolvida por fenômenos extremamente complexos. Isso pressupôs que a realidade educativa fosse considerada em suas múltiplas dimensões ampliando as condições da escola de redefinir suas metas com a identificação das reais necessidades educacionais do aluno. 
A aproximação e o estabelecimento de vínculos com os pais dos alunos possibilitaram, de acordo com as entrevistadas, romper resistências, compreender a realidade do aluno e criar um projeto de trabalho mais articulado com seu contexto sociocultural. Esses depoimentos reiteram as considerações de Elias (1994) que, ao discutir as formações sócio-históricas e as forças que movem as relações entre indivíduo e sociedade, admite que o modelo conceitual de que os profissionais se apropriam para definir aquilo que é vivenciado pelo indivíduo, na realidade, representa um conjunto de peças que não compõe o todo das situações. Há, como se refere o autor, uma análise incompleta, com lacunas, sem uma visão do todo, impedindo que se compreenda como o conjunto de indivíduos forma uma sociedade e as maneiras específicas como essa sociedade se transforma, mantendo um curso histórico, muitas vezes, não planejado por qualquer um dos indivíduos desta relação.

O autor analisa que podem ser estabelecidas relações para criar uma ordem social em que a ação do indivíduo com os outros e com seu meio permita, de um lado, um equilíbrio entre necessidades e inclinações pessoais dos indivíduos e, de outro, as exigências feitas a cada indivíduo para manutenção e eficiência do todo social. Elias (1994) ressalta, entretanto, que esse equilíbrio só coexiste entre os indivíduos se todos estiverem livres de conflitos, preocupações e desfrutarem com satisfação dessa estrutura social (Ibid, p. 16-30).

Outro aspecto mencionado nos depoimentos das entrevistadas baseou-se nas situações vivenciadas no acompanhamento aos alunos incluídos na Educação Infantil e no Ensino Fundamental, processo esse relatado como uma experiência desafiadora, assumida em parceria com o professor do ensino regular, buscando atender às demandas dessa proposta. Acreditar nesse processo de interlocução com o ensino regular, re-significando a deficiência, envolvia, na fala das educadoras, uma série de tarefas e procedimentos que se defrontaram com as exigências de ordem administrativa, organizacional e disciplinar, além das questões de ordem pedagógica e curricular do ensino regular, que dificultavam, muitas vezes, articular propostas e criar espaços de diálogo pedagógico em que fossem neutralizadas as diferenças, não das crianças, mas dos profissionais envolvidos, que precisavam de tempo e formação para reconhecerem suas próprias possibilidades e tornarem-se mais receptivos à criança. Tais condições são reiteradas por Mazzotta (1998), que enfatiza não serem suficientes as garantias legais e a declaração dos propósitos ideais da inclusão, sendo necessário identificar as condições reais da escola pública, para se dimensionar seus ajustes. 
Na visão das entrevistadas, a possibilidade de encontros com os professores em espaços específicos criados pela própria escola para que se efetivassem as parcerias significou um grande avanço, principalmente quando esses espaços oportunizaram discussões sobre a prática, as situações concretas que lhes traziam angústias e dificuldades de estabelecerem uma relação mais positiva com a criança.

Providências pedagógicas, tais como adequação curricular e criação de recursos adaptados aos diferentes alunos, parecem ter exigido um processo de negociação que mereceu um projeto mais amplo com as escolas como um todo, envolvendo profissionais, funcionários, comunidade e direção, para que fossem respeitadas as condições singulares dos alunos e suas necessidades específicas. Esses aspectos são corroborados por Mazzotta (2006), que alerta para as medidas arbitrárias de extinção dos auxílios e recursos especiais, deflagradas impositivamente, desconsiderando, de forma perversa, as reais condições daqueles que deles necessitam. Defendem uma inclusão radical, denominada pelo autor como selvagem, resultante de estratégias ideológicas manipulatórias que, em nome da superação das desigualdades sociais, culturais, econômicas e políticas, mascaram diferenças individuais (Ibid, p. 2). Masini (2004) também ressalta a responsabilidade dos envolvidos no processo de inclusão, alertando para que sejam analisadas as condições e limites da escola, possibilitando a concretização de um projeto em benefício da criança deficiente.

$\mathrm{Na}$ fala das entrevistadas, ficou expresso que os maiores impasses dessa experiência foram: transformar as exigências burocráticas em adequações curriculares pertinentes aos alunos; os prazos restritivos, em momentos possíveis, para que professores e alunos encontrassem formas criativas de se relacionarem, aprendendo uns com os outros; e, fundamentalmente, de se transporem as barreiras impostas pelo olhar sem expectativas, que cega e impede a escola de caminhar.

Refletindo sobre esses depoimentos, verifica-se que o caminho para enfrentar os impasses não está focado em julgar os professores por eles, muitas vezes, não conseguirem viabilizar um ensino de melhor qualidade, mas em viabilizar que os compromissos estabelecidos pela administração pública, em seu Plano de $\operatorname{Metas}^{30}$, ao tornarem as escolas mais inclusivas,

\footnotetext{
${ }^{30}$ Entre os documentos elaborados pela Secretaria de Educação e Cultura, o Caderno de Metas estabelece, em seu plano de trabalho, diretrizes para o desenvolvimento de ações para "consolidar uma política pública que
} 
estabeleçam condições formativas, de forma que as escolas estejam preparadas para atenderem às necessidades que a proposta requeira.

Mazzotta (2002) considera que as necessidades educacionais dos alunos são configuradas de maneira contextual, estando vinculadas “ao que deles se espera e ao que é oferecido pela escola” (p. 32). A análise das entrevistas assinalou como essencial que a atenção educacional a essa parcela da população, para que corresponda às suas necessidades peculiares, requer professores preparados, equipes de apoio que conheçam o que realmente tais alunos necessitam. Reconhecer esses itens essenciais e uma forma de implementar uma proposta de formação continuada aos docentes envolve uma atitude de indagação constante, em que se aprenda com as respostas encontradas.

contribua para a prevenção, deteç̧ão precoce e atendimento educacional, facilitando a inserção e inclusão de crianças e jovens deficientes na sociedade atual” (S. Bernardo do Campo, Caderno de Metas, 2001). 


\section{CONSIDERAÇÕES FINAIS}

“[...] disposição do ser humano de espantar-se diante das pessoas, do que elas fazem, dizem, parecem, diante dos fatos e fenômenos, da boniteza e feiúra, esta contida necessidade de compreender para explicar, de buscar a razão de ser dos fatos. Esse desejo sempre vivo de sentir, viver, perceber [...].”

Paulo Freire

O objetivo central desta investigação foi analisar o que permaneceu da proposta de formação continuada de professores de Educação Especial realizada em São Bernardo do Campo, no período de 1996 a 2003.

Buscar conhecer o que foi essa formação para aqueles que a vivenciaram por meio da expressão de quem viveu a realidade estudada, realizando a análise de seus depoimentos, gravados e posteriormente transcritos, foi a diretriz deste trabalho. Sem dúvida, o registro das situações apresentadas do ponto de vista das professoras entrevistadas foi um caminho extremamente profícuo, constituindo uma escolha apropriada, por revelar singularidades dos diferentes percursos tomados pelos grupos de profissionais, a tônica e o modo que o grupo imprimiu ao projeto pedagógico, assumindo-o como instrumento de análise e reflexão e como organizou esses espaços centrados nas necessidades e peculiaridades de cada contexto escolar, de cada comunidade, envolvendo alunos, famílias e educadores.

Por outro lado, foi também um caminho difícil o de descortinar a complexidade dessas relações no ambiente onde, cotidianamente, os alunos, cada um com suas especificidades, aguardavam propostas educativas para conseguirem aprender. Esses elementos, imbricados, trouxeram desafios teóricos e metodológicos, o que requereu cuidados para que a compreensão do que as professoras comunicaram se fizesse explícita para quem acompanhasse a análise. Assim, a retomada dos fundamentos teóricos permitiu conhecer mais profundamente as percepções e significados atribuídos pelas participantes a esse modelo formativo, ao analisar as entrevistas a partir das categorias "ser professor", "fazer pedagógico" e "saber”, após a primeira categorização, realizada a partir da retomada dos objetivos e das perguntas das entrevistas, voltadas para a obtenção de respostas a esses objetivos. 
A análise permitiu apontar alguns resultados importantes, embora muitos outros merecessem ser mencionados. Foram marcas relevantes dessa vivência passada e que permanecem como elementos que contribuem na direção tomada pelo trabalho das professoras entrevistadas: a maior clareza de seu papel de professora e de identidade profissional; a descoberta de condições singulares para responder à complexidade das situações na relação com a criança; o modo como se posiciona diante de seu saber, como busca recursos e complementação para suas dúvidas; a valorização do potencial do aluno, em constante desenvolvimento, transpondo a cristalização de significados com forte ênfase na organicidade da deficiência; o redirecionamento da visão sobre as condições de aprendizagem do aluno e as possibilidades de inclusão no ensino regular; a compreensão de que uma dinâmica coletiva em que o processo dos saberes do professor e dos fazeres pudessem ser integrados fortalecia-a para assumir com as crianças e jovens um processo educativo de ampliação de seus espaços de atuação e aprendizagem; a clareza de que a família, como estrutura, não pode ser estigmatizada por não acompanhar os padrões estabelecidos pela escola; a importância do conhecimento que o professor deve ter sobre o aluno e suas condições, para que seu projeto de trabalho seja mais dinamizador da aprendizagem.

A manifestação dos modos de pensar, ser e agir dessas educadoras transitou entre a dimensão do vivenciado e o idealizado por elas nas expectativas relacionadas ao papel da equipe. Isso ficou evidenciado nas avaliações e críticas, por um lado, revestidas de rigor e severidade, demonstrando a seriedade e importância depositadas na atuação pedagógica, e por outro, tendendo a atribuir ao outro - no caso, à equipe ou, mais genericamente, à escola - a responsabilidade pelo não acontecido.

As entrevistas convidaram as professoras a retomar um caminho percorrido, envolvido por um conjunto de impressões, idéias, sentimentos e situações concretas, registrando depoimentos preciosos, que trouxeram à tona seus posicionamentos em suas múltiplas relações, os saberes gerados, as decisões marcantes, os desafios frustrados, o vivido entre parceiros e as mudanças em suas práticas.

A análise das entrevistas evidenciou que as situações enfrentadas pelo professor no confronto com as adversidades do dia-a-dia representaram uma experiência de reflexão contínua. Apesar de a parceria com a equipe ter sido considerada favorável e de inegável contribuição, por mediar esse processo e trazer saberes essenciais para a relação, ficou constatado que 
outros fatores, indissociáveis no contexto escolar, também contribuíram, dentre eles: a organização do grupo; o fato de a escola propiciar ao professor espaços alternativos para, com a equipe, refletir situações emergenciais; o projeto pedagógico, dinamizando práticas, problematizando questões mais amplas vinculadas às relações da escola com a família.

Definimos, assim, nessa costura de dados, as questões que evidenciaram aspectos fundamentais para a identificação do que permaneceu da proposta de formação, considerando como os sujeitos envolvidos nessa construção, nesse processo, e como, nesses momentos, tais atividades repercutiram no grupo como fruto da organização coletiva.

Para a pesquisadora, o significado desta investigação representa a possibilidade de buscar respostas sobre a efetividade de um processo que foi idealizado com esses grupos de trabalho... Como educadora, o desejo de submeter à avaliação uma proposta, na qual acreditou e esteve envolvida... Como pesquisadora, a proposta de um distanciamento para que a avaliação se fizesse dos dados provindos da leitura das professoras que vivenciaram a proposta de formação continuada.

Está imbricada no significado desta investigação, para a educadora, a preocupação com o investimento público e o que ela, de fato, concedeu aos alunos que dependem “dessa atuação" mais consciente do professor. Nessa preocupação, está agregada a questão de que os projetos de formação docente representam muito pouco as condições e realidade de seu público, o que traz sérios descompassos entre as necessidades do ensino e as propostas oferecidas pelos órgãos gestores. O que ficou exposto integra suas preocupações atuais como pesquisadora e representa também o lugar de onde fala a educadora. Cada momento impõe algum novo desafio - nesta dissertação, o que se apresentou foi o indispensável distanciamento daquele contexto de seu próprio trajeto profissional de educadora para que, assumindo outro papel, pudesse analisá-lo.

Do desejo da educadora, a pergunta assim se fez: "Esta proposta estaria criando recursos para a qualificação do professor, para que ele pudesse superar as dificuldades de ensino, no contexto da diversidade e enfrentar as dificuldades dos alunos apontados como sem condições de aprender?”. 
Da proposta da pesquisadora, adveio a tentativa de distanciamento e avaliação, como forma de refletir sobre uma proposta de formação docente, no contexto escolar, que se propôs responder à complexidade das situações envolvidas com a criança e o jovem com deficiência.

Retomar tal processo foi significativo, não porque foi delineado na crença de tomá-lo como parâmetro para futuras ações formativas, e sim porque esta investigação poderá indicar alguns elementos relevantes no desencadeamento de novos questionamentos sobre os planejamentos de formação continuada do professor, ou convidar a reflexões sobre a quê uma formação continuada precisa estar atenta; se o projeto de formação oferece condições para o professor refletir sua prática, planejar e definir caminhos com mais clareza, tendo como base as necessidades da população atendida: Os professores interagem com que representação desses alunos, com as carências e desigualdades, ou com os ganhos? Como o professor lida com suas próprias dificuldades advindas de um conhecimento que se revela incompleto? Lidar com condições emergenciais poderia levar os educadores a uma postura técnico-utilitária de buscar respostas imediatas, sem o devido aprofundamento?

Longe de admitir que os aspectos aqui levantados esgotem a totalidade das situações manifestadas pelos dados da pesquisa de campo, esperamos que possam gerar novos conhecimentos, principalmente no reconhecimento da importância de propostas formativas que aliem o "singular” como foco de análise das práticas construídas a partir de um processo que se fortalece no "coletivo". 


\section{REFERÊNCIAS}

ALVES, A.J. O planejamento de pesquisas qualitativas em Educação. Cadernos de Pesquisa. São Paulo, n. 77, p. 53-61, maio/1991.

AMARAL, L. A. Formação profissional e concepção de deficiência: onde o ponto de encontro? - II Congresso Multidisciplinar em Educação Especial promovido pela UEL. Londrina, PR, 1999.

AMIRALIAN, N.L.T. Inclusão, integração, conceitos, abrangência e viabilidade na realidade brasileira. Trabalho apresentado no Instituto de Psicologia da Universidade de São Paulo, 1999.

et al. Conceituando deficiência. Revista de Saúde Pública. São Paulo, v. 34, n. 1, p 97-103, 2000.

ANDRÉ, M. E. D. A. A pesquisa no cotidiano escolar. In: FAZENDA, I.C.A. (org.) Metodologia da Pesquisa Educacional. São Paulo: Cortez editora, 1989, p. 35-45.

ANDRÉ, M. E. D. A. (org.) Formação de Professores no Brasil (1990-1998). Brasília DF: MEC/INEP/COMPED, Série Estado do Conhecimento ${ }^{\circ}$ 6, 2002.

BENEVIDES SOARES, M.V. Cidadania e direitos humanos. In: CARVALHO, J.S. (org.) Educação, Cidadania e Direitos Humanos. Petrópolis, RJ: Editora Vozes, 2004.

BOGDAN, R.C. e BIKLEN, S.K. Investigação qualitativa em educação: uma introdução à teoria e aos métodos. Porto: Porto Editora, 1994.

BOSI, E. Memória e sociedade, São Paulo: Companhia das Letras, 1994

BRUNER, J. Atos de significação. Porto Alegre: Artes médicas, 1997.

A cultura da educação. Porto Alegre: Artmed, 2001.

CARVALHO, R.E. Temas em educação especial. Rio de Janeiro: WVA Editora, 1998

. Experiências de assessoramento a sistemas educativos governamentais na transição para a proposta inclusiva. Movimento - Revista da Faculdade de Educação Federal Fluminense. Rio de Janeiro, nº 7, p. 30-59, 2003.

CAVACO, M. H. Ofício de professor, o tempo e as mudanças. In: NÓVOA, A. (org.). Profissão professor. Porto: Porto Editora, 1999.

CHAKUR, C. R. S. L. Níveis de construção da profissionalidade docente: um exemplo com professores da 5a a 8a série. Cadernos CEDES, n. 36. Educação Continuada, p.77-93, 1995.

COLLARES, C. A. L; MOYSÉS, M. A. A; GERALDI, J. W. Educação Continuada: a política da descontinuidade. Educação e Sociedade, n. 68. Campinas: CEDES, p. 202-219, 1999. 
CONTRERAS, J. A autonomia de professores. São Paulo: Cortez Editora, 2002.

CROCHIK, J. L. Atitudes a respeito da Educação Inclusiva. Movimento - Revista da Faculdade de Educação Federal Fluminense. Rio de Janeiro, n. 7, p. 19-38, 2003.

EISNER, E. W. e PESHKIN, A. (org.) Qualitative Inquiry in education: the continuing debate. New York: Theachers College, Columbia University, 1990.

ELIAS, N. A sociedade dos indivíduos. Rio de Janeiro: Jorge Zahar Editor, 1994.

ESTRELA, M. T., MADUREIRA, I. e LEITE, T. Processos de identificação de necessidades: uma reflexão. Revista de Educação, v.VIII, n.1, p. 29-47, 1999.

EZPELETA, J. e ROCKWELL, E. Pesquisa participante. São Paulo: Cortez Editora, 1989.

FAZENDA, I.C.A. (org.) Novos enfoques da pesquisa educacional. São Paulo: Cortez Editora, 2001.

(Col. Educar)

Interdisciplinaridade: um projeto em parceria. São Paulo: Edições Loyola, 2002a.

Integração e interdisciplinaridade no ensino brasileiro: efetividade e/ou ideologia. São Paulo: Loyola, 2002b.

Interdisciplinaridade: história, teoria e pesquisa. 7. ed. Campinas, São Paulo: Papirus, 2003a. (Col. Magistério: formação e trabalho pedagógico)

. Interdisciplinaridade: qual o sentido? São Paulo: Paulus, 2003b.

FERREIRA, M. C. M. e FERREIRA, J. R. Sobre inclusão, políticas públicas e práticas pedagógicas. In: GÓES, M. C. R. e LAPLANE, A. L. F. Políticas e práticas de educação inclusiva. Campinas, SP: Autores Associados, 2004.

FREIRE, P. Educação e mudança. Rio de Janeiro: Paz e Terra, 1979.

Conscientização: teoria e prática da libertação, uma introdução ao pensamento de Paulo Freire. São Paulo: Editora Moraes, 1980.

. Educação como prática da liberdade. Rio de Janeiro: Paz e Terra, 1980.

. Pedagogia do oprimido. 17. ed. Rio de Janeiro: Paz e Terra, 1987.

Pedagogia da autonomia: saberes necessários à prática educativa. São Paulo: Paz e Terra, 2001.

FUSARI, J. C. e RIOS, T. A. Formação continuada dos profissionais do ensino. Cadernos CEDES, n. 36. Educação Continuada, p. 37-45, 1995. 
GARCIA, C. M. A formação de professores: centro de atenção e pedra de toque. In: NÓVOA, A. (org.). Os professores e a sua formação. Lisboa: Publicações Dom Quixote, Instituto de Inovação Educacional, 1995.

GARCIA, C. M. Desenvolvimento Profissional dos Professores. In: NÓVOA, A. (org.) Formação de professores para uma mudança educativa. Porto: Porto Editora, p. 136-261, 1999.

GAMBOA, S. A. S. A dialética na pesquisa em educação: elementos de contexto. In: FAZENDA, I. C. A. (org.). Metodologia da pesquisa educacional. São Paulo: Cortez Editora, 1989, p. 91-105.

GUBA, E. G. Subjectivity and objective. In: EINER, E. W. e PESHKIN, A. (org.). Qualitative inquiry en education: the continuing debate. New York: Theachers College, Columbia University, 1990.

JANNUZZI, G. A luta pela educação do deficiente mental no Brasil. São Paulo: Cortez/Autores Associados, 1985.

JAPIASSU, H. Interdisciplinaridade e patologia do saber. Rio de Janeiro: Imago Editora Ltda., 1976.

. Prefácio. In: FAZENDA, I. C. A. Integração e interdisciplinaridade no ensino brasileiro: efetividade e/ou ideologia. São Paulo: Loyola, 2002.

Editor, 2006.

e MARCONDES, D. Dicionário básico de Filosofia. Rio de Janeiro: Jorge Zahar

KASSAR, M. C. M. Marcas da história social no discurso de um sujeito: uma contribuição para a discussão a respeito da constituição social da pessoa com deficiência. Cadernos CEDES, n. 50. Relações de ensino: análises na perspectiva histórico-cultural, p. 41-54, 2000.

LAHIRE, B. O homem plural: os determinantes da ação. Petrópolis. RJ: Editora Vozes, 2002.

Ática, 1997.

Sucesso escolar nos meios populares: as razões do improvável. São Paulo: Editora

LARROSA, J. e SKLIAR, C. Habitantes de Babel: políticas e poéticas da diferença. Belo Horizonte: Autêntica, 2001.

LIMA, M. S. L. A formação contínua do professor nos caminhos e descaminhos do desenvolvimento profissional, 2001. Tese (Doutorado em Educação) Faculdade de Educação da USP. São Paulo, SP.

LURIA, A. R. Pensamento e linguagem: as últimas conferências de Luria. Porto Alegre: Artes Médicas, 1987.

LÜDKE, M. e ANDRÉ, M. E. D. A. Pesquisa em Educação: abordagens qualitativas. São Paulo: EPU, 2004. 
MACHADO, N. J. Conhecimento e valor. São Paulo: Editora Moderna, 2004.

MASINI, E. A. F. S. Quais as expectativas com relação à inclusão escolar do ponto de vista do educador? Educar em Revista. São Paulo: Memnon. v. 7, n. 42, p. 26-28, 1999.

Ação Psicopedagógica. II Ciclo de estudos de Psicopedagogia Mackenzie. São Paulo: Memnon / Editora Mackenzie, 2000.

Uma experiência de inclusão: providências, viabilização e resultados. Educar em Revista, n. 23, Curitiba: Editora UFPR, 2004.

MAZZOTA, M. J. S. Fundamentos de Educação Especial. São Paulo: Pioneira, 1982.

. Trabalho docente e formação de professores de Educação Especial. São Paulo: EPU, 1993.

Educação Especial no Brasil: História e políticas públicas. São Paulo: Cortez, 1996.

A inclusão e integração ou chaves da vida humana. Congresso Ibero-Americano de Educação Especial, 3. Foz do Iguaçu, PR, 1998.

. e SOUSA, S. M. Z. L. Inclusão Escolar e Educação Especial: considerações sobre a política educacional brasileira. Estilos da Clínica - Revista sobre a infância com problemas, Instituto de Psicologia. Universidade de São Paulo. v. 5, n. 9, p. 96-108. São Paulo: USP, IP, 2000 .

Deficiência, educação escolar e necessidades especiais: reflexões sobre inclusão sócio-educacional. Cadernos de Pós-graduação, Universidade Presbiteriana Mackenzie, São Paulo, n. 7, p. 15-34, 2002.

Identidade dos alunos com necessidades educacionais especiais no contexto da política educacional brasileira. Movimento - Revista da Faculdade de Educação Federal de Fluminense, Rio de Janeiro, n. 7, p. 11-18, 2003.

A inclusão social depende da ação de cada um e de todos. Revista Adverso/ Associação de Docentes da Universidade Federal do Rio Grande do Sul, n. 140, p. 9-11, mar. 2006.

Reflexões sobre Inclusão com Responsabilidade. In.: Faders- Fundação de Articulação e Desenvolvimento de Políticas Públicas para PPDs e PPHs no RS. http:// www.faders.rs.gov.br/política_gestao_inclusao. 2007.

MELUCCI, A. O Jogo do EU. São Leopoldo: Unisinos, 2004.

MONTEIRO, S. B. Epistemologia da prática: o professor reflexivo e a pesquisa colaborativa. In: PIMENTA, S. G. e GHEDIN, E. (orgs.) Professor reflexivo no Brasil: gênese e crítica de um conceito. São Paulo: Cortez Editora, 2005, p. 111-127. 
MORIN, E. A cabeça bem feita: repensar a reforma, reformar o pensamento. Rio de Janeiro: Bertrand Brasil. 2004.

NAJMANOVICH, D. O sujeito encarnado: questões para pesquisas no/do cotidiano. Rio de Janeiro: DP\&A, 2001.

NÓVOA, A. (org.). Os professores e a sua formação. Lisboa: Publicações Dom Quixote, Instituto de Inovação Educacional, 1995.

Profissão Professor. Porto, Portugal: Porto Editora, 1999.

Vidas de Professor. Porto, Portugal: Porto Editora, 2000.

OLIVEIRA, M. K. Vygotsky e o processo de formação de conceitos. In.: LA TAILLE, Y. de et al. Piaget, Vygotsky e Wallon: teorias psicogenéticas em discussão. São Paulo: Summus, 1992.

Vygotsky: aprendizado e desenvolvimento, um processo sócio-histórico. São Paulo: Scipione, 1993.

Pensar a educação: contribuições de Vygotsky. In: CASTORINA, J. A. et al. Piaget e Vygotsky: novas contribuições para o debate. São Paulo: Editora Ática, 1995, p. 51-83.

Sobre diferenças individuais e diferenças culturais: o lugar da abordagem históricocultural. In: AQUINO, J. G. (org.) Erro e fracasso na escola: alternativas teóricas. São Paulo: Summus, 1997.

Vygotsky e as complexas relações entre cognição e afeto. In: ARANTES, V. A. (org.) Afetividade na escola: alternativas teóricas e práticas. São Paulo: Summus, 2003.

OLIVEIRA, R. D. e OLIVEIRA, M. D. Pesquisa social e ação educativa: conhecer a realidade para poder transformá-la. In: BRANDÃO, C. R. (org). Pesquisa participante. São Paulo: Editora Brasiliense S.A., 1985.

ORGANIZAÇÃO MUNDIAL DE SAÚDE. http:/portalweb05.saude.gov.br/portal/ arquivos/pdf/manual2.pdf.

PADILHA, A. M. L. O que fazer para não excluir Davi, Hilda, Diogo... In: GÓES, M. C. R. e LAPLANE, A. L. F. Políticas e práticas de educação inclusiva. Campinas, SP: Autores Associados, 2004.

PATTO, M. H. S. A família pobre e a escola pública: anotações sobre um desencontro. Psicologia USP. São Paulo, v. 3, n. 1-2, p. 121, 1992.

PÉREZ GÓMEZ, A. O pensamento prático do professor: a formação do professor como profissional reflexivo. In: NÓVOA, A. Os professores e a sua formação. Lisboa: Publicações Dom Quixote, Instituto de Inovação Educacional, 1995. p. 93-114. 
PIMENTA, S. G. Itinerário teórico-metodológico de uma pesquisadora. In: TRINDADE, V.; FAZENDA, I. C. e LINHARES, C. (orgs.). Os lugares dos sujeitos na pesquisa educacional. Campo Grande, MS: Editora / UFMS, 2001, p. 253-277.

. Formação de professores: saberes da docência e identidade do professor. In: FAZENDA, I. C. A. (org.). Didática e interdisciplinaridade. Campinas, SP: Papirus, 2003, p. 161-178.

PIMENTA, S. G; GHEDIN, E. (orgs.). Professor reflexivo no Brasil: gênese e crítica de um conceito. São Paulo: Cortez Editora, 2005, p. 17-52.

QUINONERO, E. G. Contribuições do sistema de ensino na construção do sujeito coletivo na escola. 2002. Dissertação (Mestrado em Educação) Universidade Metodista de São Paulo. São Bernardo do Campo, SP.

REGO, T. C. Memórias de escola: cultura escolar e constituição de singularidades. Petrópolis, RJ: Editora Vozes. 2003.

SÃO BERNARDO DO CAMPO. Secretaria de Educação e Cultura. Departamento de Ações Educacionais. Proposta Curricular, 2004, v. I.

Secretaria de Educação e Cultura. Departamento de Ações Educacionais. Caderno de Metas: 2001, 2002 e 2003.

SATO, L. e SOUZA, M. P. R. Contribuindo para desvelar a complexidade do cotidiano através da pesquisa etnográfica em Psicologia. Psicologia - USP. Instituto de Psicologia, Universidade de São Paulo, v. 1, n. 1, p. 29 - 47. São Paulo: USP / IP, 2001.

SAWAIA, B. (org.). As artimanhas da exclusão. Petrópolis. RJ: Editora Vozes, 2006.

SCHÖN, D. A. Formar professores como profissionais reflexivos. In: NÓVOA, A. Os professores e a sua formação. Lisboa: Publicações Dom Quixote, Instituto de Inovação Educacional, 1995.

SEVERINO, A. J. Metodologia do trabalho científico. São Paulo: Cortez Editora, 2002

SKLIAR, C. A surdez: um olhar sobre as diferenças. Porto Alegre: Mediação, 1998.

. (org.) Educação e exclusão: abordagens sócio-antropológicas em educação especial. Porto Alegre: Mediação, 1999.

Pedagogia (improvável) da diferença: e se o outro não estivesse aí? Rio de Janeiro: Editora DP\&A, 2003.

SMOLKA, A. L. B. O (im) próprio e o (im)pertinente na apropriação das práticas sociais. Cadernos CEDES, n. 50. Relações de ensino na perspectiva histórico-cultural. p. 26-40, 2000.

Sobre significação e sentido: uma contribuição à proposta da rede de significações. ROSSETTI FERREIRA, Maria C. et al. Rede de significações e o estudo do desenvolvimento humano. Porto Alegre: Artmed, 2004. 
SOARES, M. e FAZENDA, I. C. A. Metodologias não-convencionais em teses acadêmicas. In: FAZENDA, I. C. A. (org.). Novos enfoques da pesquisa educacional. São Paulo: Cortez, 2001.

SOLÉR, T. R. F. Opinião de educadores sobre a inclusão escolar de alunos com deficiência visual em uma escola municipal de ensino fundamental. 2003. Dissertação (Mestrado em Distúrbios do Desenvolvimento) Universidade Presbiteriana Mackenzie. São Paulo, SP.

SOUZA, V. M. Formação em serviço de professores da Secretaria Municipal de Educação de São Paulo: 1956 - 2004. Gênese: transformações e desafios. 2005. Dissertação (Mestrado em Educação) Faculdade de Educação da USP, SP.

SPINELLI, M. O médico, o deficiente auditivo e sua família. In: MASINI, Elcie F. S. (org.). Do sentido... pelos sentidos... para o sentido... Niterói: Intertexto; São Paulo: Vetor, 2002.

THIOLLENT, M. Crítica metodológica, investigação social e enquête operária. São Paulo: Editora Polis, 1982

Metodologia da pesquisa-ação. São Paulo: Cortez, 2007.

TOURAINE, A. Iguais e diferentes: poderemos viver juntos? Lisboa: Instituto Piaget, 1997.

Igualdade e diversidade: o sujeito democrático. Bauru, SP: EDUSC, 1998.

VÉRAS, M. P. B. Exclusão Social - Um problema de 500 anos. In: SAWAIA, B. (org.). As artimanhas da exclusão. Petrópolis, RJ: Editora Vozes, 2006.

VYGOTSKY, L.S. Obras escogidas. Fundamentos de defectologia. Madri: Visor, 1983.

Aprendizagem e desenvolvimento escolar. In: VYGOTSKY, L. S. et al. Linguagem, desenvolvimento e aprendizagem. São Paulo: Ícone / Edusp, 1988.

Pensamento e linguagem. 2. ed. brasileira. São Paulo: Martins Fontes, 1989.

e LURIA, A. R. Estudos sobre a história do comportamento: símios, homem primitivo e criança. Porto Alegre: Artes Médicas, 1996.

A construção do pensamento e da linguagem. São Paulo: Martins Fontes (texto integral traduzido do russo por Prof. Paulo Bezerra - livre docente em literatura russa pela USP), 2001.

A formação social da mente: o desenvolvimento dos processos psicológicos superiores. São Paulo: Martins Fontes, 2003.

VEIGA-NETO, A. Incluir para excluir. In: LARROSA, J.; SKLIAR, C. (orgs.) Habitantes de Babel: política e poética da diferença. Belo Horizonte: Autêntica, 2001, p. 105-118. 


\section{GLOSSÁRIO}

Aprendizagem / Desenvolvimento: Vygotsky realizou uma série de investigações para esclarecer as relações entre o aprendizado escolar e o desenvolvimento das funções mentais. Essas investigações concentram-se no nível de maturidade das funções psíquicas no início da educação escolar e na influência desta sobre o desenvolvimento. Concluiu que as matérias escolares básicas atuam como facilitadoras de outras matérias e as funções psicológicas por elas estimuladas desenvolvem-se ao longo de um processo complexo, comprovando a natureza social e cultural do desenvolvimento das funções superiores e a responsabilidade das práticas educativas para a promoção do desenvolvimento. Revela-se a importância da escola e da ação planejada do professor na criação de oportunidades deliberadas que reflitam numa crescente complexidade do comportamento da criança. Para o autor, o fundamental é que, na aprendizagem, a criança aprende o novo e só é considerada adequada a aprendizagem que antecede o desenvolvimento e que está à sua frente, respeitando-se a possibilidade de imitação (VYGOTSKY, 2001, p. 302-333).

Alteridade: Expressão derivada do latim alteritas, que significa estado, qualidade daquilo que é outro, distinto; antônimo de identidade. A alteridade deficiente utilizada por Skliar (2003) é um termo que não está ligado à pessoa ou ao grupo com deficiência ou à sua deficiência em particular, mas à manifestação que considera o deficiente como “outro”, evitando desigualá-lo com termos, os mais variados, que encerram representações tomadas como inovadoras, mas sempre resultantes de um discurso normalizador.

Autonomia: Deve ser entendida, segundo Contreras (2002), como a independência intelectual que nutre a idéia de emancipação pessoal, valorizando a autoridade e a supressão da dependência de apoio e a ingerência de especialistas em campos necessariamente do professor. A busca pela autonomia recupera a visão de um ideal democrático que pressupõe o distanciamento crítico e o compromisso com os propósitos educativos.

Ciência: "Em seu sentido amplo, a ciência é um saber metódico e rigoroso, isto é, um conjunto de conhecimentos metodicamente adquiridos, mais ou menos sistematicamente organizados e suscetíveis de serem transmitidos por um processo pedagógico” (JAPIASSU e MARCONDES, 2006, p. 44).

Conceito: Pode ser considerado como "ação de conter, ato de receber, germinação, fruto, feto, pensamento. O conceito pode ter, do ponto de vista lógico, duas propriedades: extensão e compreensão" (JAPIASSU e MARCONDES, 2006, p.50).

Concepção: O termo origina-se do latim conceptio, que significa ação pela qual um ser é concebido, gerado; o ato de conceber ou criar mentalmente, de formar abstrações; conhecimento, idéia, opinião (Larousse Cultural, 1999). Segundo Amaral (1999), o ato de conceber e ser concebido - idéias e opiniões - expressa necessariamente regras de conduta que influenciam o discurso teórico, referindo-se à visão de mundo que se vai construindo, influenciada pela ideologia, ética e moral.

Conhecimentos científicos e conhecimentos cotidianos: Para Vygotsky, os conhecimentos científicos são adquiridos pela aprendizagem e pelo ensino, a partir de um sistema consistente de inter-relações. Os conhecimentos cotidianos estão pautados nas relações com o mundo na 
atividade prática imediata. Segundo o autor, apesar de se desenvolverem em direção opostas, eles estão intimamente relacionados. Há, nessas noções, a evidência da importância do papel da escola no desenvolvimento de procedimentos de instrução que favoreçam o avanço conceitual dos alunos, processo esse que não ocorreria espontaneamente.

Currículo: Deriva do verbo latino currere, que significa percurso, jornada, caminho (Larousse Cultural, 1999).

Defectologia: O termo, segundo Van der Veer e Valsiner, era utilizado tradicionalmente pela ciência que estudava a criança com vários tipos de problemas, os quais eram denominados “defeitos” relacionados às áreas mental e física. O interesse de Vygotsky pelos problemas de defectologia surgiu por volta de 1924, com sua publicação envolvendo temas sobre a importância da educação social de crianças deficientes e o potencial da criança para o desenvolvimento normal (VYGOTSKY e LURIA, 1996, p. 73-75).

Deficiência: De acordo com os documentos da Organização Mundial de Saúde (OMS), deficiência pode ser definida como "uma perda ou anormalidade de estrutura ou função psicológica, fisiológica ou anatômica, temporária ou permanente, incluindo-se a ocorrência de uma anomalia, defeito ou perda de um membro, órgão, tecido ou qualquer outra estrutura do corpo, inclusive das funções mentais. Representa a exteriorização de um estado patológico, refletindo um distúrbio orgânico, uma perturbação no órgão” (OMS, 1989). Em 22/05/2001, entretanto, revendo essas nomenclaturas, a OMS estabeleceu a Classificação Internacional de Funcionalidade, Incapacidade e Saúde (CIF). A CIF, enquanto documento de abrangência mundial, retorna definições substituindo o enfoque negativo da deficiência, na perspectiva da funcionalidade, observando as atividades que o indivíduo pode desempenhar, visando à sua integração social. Admite-se, nessa concepção, que a funcionalidade e a incapacidade dos indivíduos estão diretamente relacionadas ao ambiente onde vivem, sendo fator determinante no processo de elaboração de instrumentos de avaliação e estabelecimento de políticas inclusivas (Revista Brasileira de Epidemiologia, 2005). Segundo Mazzotta (1996), nos documentos oficiais, os educandos com deficiência são inapropriadamente denominados "portadores de necessidades especiais".

Desenvolvimento profissional: É concebido como um processo contínuo, de modo a não conceber os professores como produtos acabados, mas como sujeitos em construção, em constante evolução e desenvolvimento, apoiados no contexto escolar (GARCIA, 1995).

Desvantagem: Segundo a Classificação Internacional das Deficiências, Incapacidades e Desvantagens, desvantagem é: "prejuízo para o indivíduo, resultante de uma deficiência ou uma incapacidade, que limita ou impede o desempenho de papéis de acordo com a idade, sexo, fatores sociais e culturais. Caracteriza-se por uma discordância entre a capacidade individual de realização e as expectativas do indivíduo ou do seu grupo social. Representa a socialização da deficiência e relaciona-se às dificuldades nas habilidades de sobrevivência” (Revista Saúde Pública, v. 34, n.1, São Paulo, fev. 2000).

Dilemas: Zalbaza (1994, p. 61) conceitua como o conjunto de situações bipolares ou multipolares que se apresentam ao professor no desenrolar de sua atividade profissional. $\mathrm{O}$ autor refere-se aos dilemas quando se trata de articular exigências prescritas nos programas oficiais com as necessidades concretas dos alunos. 
Disciplina: Do latim discere, que significa "aprender”. Tem o mesmo sentido de “ciência” e “disciplinaridade”. Para Japiassu (1976, p. 72), significa a exploração científica especializada de determinado domínio homogêneo de estudo, isto é, o conjunto sistemático organizado de conhecimentos que apresentam características próprias nos planos do ensino, da formação, dos métodos e das matérias.

Discussão: Na concepção de Thiollent (2007, p. 34), discussão ou diálogo é diferente de debate. Na discussão, pesquisador e participantes estabelecem um "vínculo intelectual", chegando a um consenso acerca da situação ou de um modo de agir. Já o debate é pautado na defesa de posições pelos interlocutores.

Diversidade / Diferença: Skliar alerta para as representações enganosas do termo, referindose a uma distinção fundamental entre diversidade e diferença. "Diversidade" cria um falso consenso, a idéia de que a normalidade hospeda os "diversos", mascara normas etnocêntricas e serve para conter a diferença. Por outro lado, “diferença” não se coloca apenas como espaço retórico, mas como construção histórica e social, efeito de conflitos sociais ancorados em práticas compartilhadas de significação e representação (SKLIAR, 1998, p. 13). Citando Boaventura de Souza Santos, Véras (2006) conceitua a diferença no enfoque da desigualdade e, nesse sentido, refere-se aos indivíduos que estão fora do padrão de referência, que, mais especificamente, fogem à homogeneidade convencional, provocando sua exclusão social. A autora admite que "os adeptos do universalismo negam as diferenças, buscando a homogeneização com base no princípio da cidadania e igualdade abstrata de direitos” (IBID, 2006, p. 36-37). Nesse aspecto, referindo-se às posições de Santos, os riscos de o indivíduo estar incluído são grandes, mesmo que desigualmente.

Educação Especial: Segundo Mazzotta (1996, p. 11), essa modalidade de ensino "caracteriza-se por um conjunto de recursos e serviços educacionais especiais organizados para apoiar, suplementar e, em alguns casos, substituir os serviços educacionais comuns, de modo a garantir a educação formal dos educandos que apresentem necessidades educacionais muito diferentes das da maioria das crianças e jovens”.

Educação Inclusiva: A despeito da polarização entre Educação Especial e Educação Inclusiva, cabe ressaltar aqui abordagens que eliminam esses contrapontos e chamam atenção para aspectos essenciais ao processo educativo. Mazzotta (1998), ao falar de inclusão escolar, defende uma abordagem dinâmica baseada no princípio da não segregação, que possibilita uma melhor compreensão da relação entre o educando e a educação escolar, sendo definidas a organização das situações de ensino-aprendizagem mais condizentes com as necessidades educacionais a serem atendidas (IBID, 1998). Dessa forma, segundo o autor, são necessárias adaptações e modificações na organização e funcionamento da educação escolar, para que os alunos com necessidades educacionais especiais possam usufruir dos recursos escolares de que necessitam para atingir os objetivos de aprendizagem.

Fenômeno: O termo tem um sentido ambíguo, oscilando entre a idéia de "aparecer com brilho" e a idéia de simplesmente "parecer”. Assim, o fenômeno é algo pouco seguro e, em última instância, uma ilusão. Daí a oposição metafísica entre o ser e o parecer: o ser em si não pode ser percebido por nossos sentidos; aquilo que nos aparece é apenas a diversidade dos seres particulares. O termo "fenômeno" adquire, então, o sentido genérico de "tudo o que é percebido, que aparece aos sentidos e à consciência” (JAPIASSU e MARCONDES, 2006, p.105). 
Incapacidade: Segundo a Classificação Internacional das Deficiências, Incapacidades e Desvantagens, incapacidade é: "restrição resultante de uma deficiência, da habilidade para desempenhar uma atividade considerada normal para o ser humano. Surge como conseqüência direta, ou é resposta do indivíduo a uma deficiência psicológica, física, sensorial ou outra. Representa a objetivação da deficiência e reflete os distúrbios da própria pessoa, nas atividades e comportamentos essenciais à vida diária” (Revista Saúde Pública, v. 34, n.1, São Paulo, fev. 2000).

Interdisciplinaridade: Segundo Japiassu (1976, p. 74), caracteriza-se pela intensidade das trocas entre os especialistas e pelo grau de integração real (grifos do autor) das disciplinas, no interior de um projeto específico de pesquisa.

Internalização: Segundo Vygotsky, é no processo de trocas nas relações sociais (atividade interpessoal) que os indivíduos produzem, apropriam-se, transformam as atividades e “internalizam-nas” como elaboração própria (atividade intrapessoal). O processo de reconstrução interna pelo sujeito é denominado internalização. "Chamamos de internalização a reconstrução interna de uma operação externa” (VYGOTSKY, 2003, p. 74). Portanto, na internalização há algo de "fora" - cultura, práticas sociais, material semiótico sendo assumido, “internalizado” pelo indivíduo (SMOLKA, 2000, p. 28).

Mediação: Na perspectiva vygotskyana, trata-se de um conceito fundamental, explicado por dois aspectos complementares, conforme assinala Oliveira (1992): de um lado, refere-se ao processo de representação mental, considerando que se o homem é capaz de operar mentalmente sobre a realidade, supõe, portanto, a existência de conteúdos mentais de natureza simbólica, conteúdos que representem os objetos do mundo real no universo psicológico do indivíduo. São conteúdos que substituem, representam o real na ausência dele, transcendendo as experiências perceptíveis e que são base para a elaboração mental superior. Por outro lado, o processo de mediação que se interpõe entre o sujeito e o objeto de conhecimento tem natureza social; a cultura constrói e fornece ao homem, ao longo de sua vida, "formas culturalmente dadas de comportamento", num processo em que atividades externas interpessoais transformam-se em atividades internas, intrapessoais (IBID, 1992, p.26-27).

Necessidades educativas: Admite-se que a eficácia da formação continuada está associada, entre outros fatores, ao nível de envolvimento dos educadores nos processos de diagnóstico das necessidades formativas, na formulação dos objetivos e na avaliação. Nesse aspecto, autoras como Estrela, Madureira e Leite (1999) defendem a visão reflexiva do professor sobre a prática pedagógica, mecanismo de identificação das necessidades educativas. Para as autoras, a melhor definição é analisada por Mesa e seus colaboradores, que apontam serem as necessidades educativas "o conjunto de preocupações, desejos, carências e problemas sentidos ou percebidos pelos professores no desenvolvimento do processo pedagógico” (IBID, 1999, p. 32).

Necessidades Educacionais Especiais: Segundo a Resolução $n^{\circ}$ 02/2001, artigo 5, necessidade educacional especial é entendida como:

1) Dificuldades acentuadas de aprendizagem ou limitações no processo de desenvolvimento que dificultem o acompanhamento das atividades curriculares, compreendidas em dois grupos:

a) Aquelas não vinculadas a uma causa orgânica específica;

b) Aquelas relacionadas a condições, disfunções, limitações ou deficiências. 
2) Dificuldades de comunicação e sinalização, diferenciadas dos demais alunos, demandando a utilização de linguagens e códigos aplicáveis;

3) Altas habilidades (superdotados), grande facilidade de aprendizagem que os leve a dominar rapidamente conceitos, procedimentos e atitudes.

Nexos: Relação de idéias entre si, ligação, vínculo, união, conexão. É ainda: coerência, relação harmônica, lógica (Dicionário Larousse Cultural).

Parceria: O termo é referido no dicionário como reunião de indivíduos para certo fim, com interesse comum. A concepção aproxima-se da idéia originada no grego paidéia, uma forma de parceria que, segundo Fazenda (2002b), pode referir-se ao exercício de troca entre as pessoas: o indivíduo tem a possibilidade de ampliar seu universo de conhecimentos com alguém mais experiente. Numa visão dialética, na parceria todos crescem com o encontro, se houver receptividade e abertura (FAZENDA, 2003a, p. 38).

Pluralismo: O termo surgiu do latim pluralis, tendo, segundo, Japiassu e Marcondes, duas interpretações: 1) Doutrina que afirma a pluralidade ou multiplicidade de seres individuais e autônomos, considerando o real como múltiplo, irredutível a um princípio único. Willian James é considerado o representante do pluralismo. 2) Num sentido ideológico ou político, corresponde à atitude de aceitação de uma pluralidade de opiniões, atitudes ou posições diferentes ou divergentes que, no entanto, se respeitam mutuamente (JAPIASSU e MARCONDES, 2006, p. 219).

Práxis: Entre os gregos antigos, o termo designava a atividade prática, em oposição à teórica. Há também referência na posição marxista ao conjunto de atividades que visam a transformar o mundo e, em particular, os meios e as relações de produção (Dicionário Larousse Cultural). Na concepção de Pimenta, a práxis recupera a relação da ação com a reflexão, evidenciando a unidade inseparável constituída pela teoria e a prática, a partir da "análise crítica (teórica) das práticas e da ressignificação das teorias, a partir dos conhecimentos da prática (práxis)” (PIMENTA, 2005, p. 44).

Processos Compensatórios: Formas alternativas de ação. Para Vygotsky (1983, p. 16-24), a teoria da compensação descobre possibilidades criativas de desenvolvimento, orientadas para a superação das dificuldades por meio da reorganização de todas as funções de adaptação do indivíduo, voltada para uma necessidade objetiva de acordo com as peculiaridades de cada um. Dessa forma, a concepção do autor interliga fatores de ordem biológica aos fatores de ordens social e psicológica, propondo um novo referencial de equilíbrio em que há uma ampla compensação das diferentes funções psicológicas.

Relação dialógica: Autores como Freire (2001) e Fazenda (2003a) admitem que dialogia é mais abrangente do que diálogo e pressupõe a compreensão do outro, daquilo que é anunciado. As enunciações confrontam-se e provocam transformações nos indivíduos. Freire (2001, p. 11) admite que a verdadeira dialogicidade abre espaço para que os sujeitos aprendam e cresçam na diferença, de forma ética. Baseados numa relação dialógica e dialética entre educadores e educandos, o autor admite que todos se transformam e se humanizam. A dialética própria da abordagem interdisciplinar traz o sentido de complementaridade daquilo que o sujeito conhece e acredita, complementando-se ao que ele desconhece, enunciado pelo outro. Nesse sentido, o exercício de dialogar com nossas próprias produções, extraindo novos indicadores, também exige, segundo Fazenda (2003a), habilidade e abertura para novos 
conhecimentos. "Dialógica” porque, nesse processo, novos dados despertam novas buscas, dúvidas e conclusões.

Representação: Uma idéia representa um objeto, portanto implica uma semelhança ou imitação da realidade, "estar no lugar de”. Os signos, portanto, “representam”, na visão de Vygotsky (2003), a realidade percebida pelos sujeitos.

Sentido / significado: Na interação com os objetos, estão envolvidos "significados” singulares, pessoais ao sujeito. Há uma relação contextualizada com o objeto, marcada pelas experiências anteriores, valores interiorizados, que vão produzindo conotações específicas um “campo de significações”. Para Vygotsky (1989), o sentido é a soma de todos os eventos psicológicos que a palavra evoca em nossa consciência. "É um todo fluido e dinâmico, com zonas de estabilidade variável, uma das quais a mais estável e precisa é o significado” (IBID, 1989, p. 125).

Signo: A noção de signo foi amplamente trabalhada desde as obras de Platão e Aristóteles e revela ser um termo de difícil conceituação, com diferenciadas interpretações, dependendo dos autores. Reportamo-nos às pontuações de Smolka (2004), apresentando citações de Santo Agostinho: "Chamamos de signo a todo que significa algo, e entre estes, encontramos também as palavras.... Ainda chamamos de signos (insígnias) as bandeiras militares, que são signos em sentido próprio, coisa que não se pode dizer das palavras.... Toda palavra é signo, mas nem todo signo é palavra... Quando falamos, fazemos signos, donde provém a palavra 'significar', 'signafacere'. Um signo é aquilo que se mostra ao sentido e que, fora de si, mostra ainda alguma coisa ao espírito [...]”. A palavra é o signo de uma coisa, podendo ser compreendido pelo interlocutor quando proferido pelo locutor (SANTO AGOSTINHO, apud SMOLKA, 2004).

Trilhas: Pistas, marcas, atalhos, vereda, caminho a seguir (Dicionário Larousse Cultural). 


\section{APÊNDICE A}

\section{Contextualizando a educação do município}

“[...] não existe uma cultura brasileira homogênea, matriz de nossos comportamentos e dos nossos discursos. Ao contrário: a admissão do seu caráter plural é um passo decisivo para compreendê-la como um "efeito de sentido", resultado de um processo de múltiplas interações e oposições no tempo e no espaço.”

Alfredo Bosi

A região do Grande $\mathrm{ABC}$, no estado de São Paulo, é reconhecida nacionalmente por sua importância no cenário econômico do país. Durante muito tempo, representou um pólo industrial de destaque em função de sua capacidade de produção, principalmente no setor automobilístico, atraindo um contingente migratório expressivo advindo de diferentes partes do Brasil.

Historicamente, como analisa Quinonero (2002), o município teve como base o crescimento de dois tipos de atividade industrial: a moveleira e, em seguida, a automobilística. Segundo a análise da autora, o município fez parte das lutas trabalhistas, tendo destaque no período do regime militar os movimentos de resistência e mobilização nacional com projeção política, devido à adesão da população aos grandes momentos pró-democracia contra a ditadura.

Hoje, o município apresenta uma nova configuração econômica, já não se destacando no cenário industrial, mas abrindo espaços para o setor de serviços, em um campo bem diversificado.

São Bernardo do Campo está situado na região metropolitana do planalto Paulista e possui uma extensão territorial de $411 \mathrm{~km}^{2}$ (representados por 29,2\% de zona urbana, 52,2\% de zona rural e 18,6\% referentes à represa Billings), fazendo divisa com os municípios de Santo André, São Caetano do Sul, Diadema, Cubatão e São Paulo. Segundo os dados apresentados pelo Compêndio Estatístico $2005^{31}$, a população é de 773.055 habitantes, sendo:

\footnotetext{
${ }^{31}$ Fonte de dados oficiais do município - anuário elaborado pela Secretaria de Administração da Prefeitura Municipal de São Bernardo do Campo, contendo informações resultantes do banco de dados dos diferentes serviços e órgãos públicos e privados.
} 


\begin{tabular}{|c|c|}
\hline Até 3 anos: $6,72 \%$ & De 15 a 18 anos: $7,86 \%$ \\
\hline De 4 a 6 anos: $5,06 \%$ & De 19 a 29 anos: $20,67 \%$ \\
\hline De 7 a 10 anos: $6,36 \%$ & De 30 a 59 anos: $38,67 \%$ \\
\hline De 11 a 14 anos: $7,28 \%$ & Acima de 60 anos: $6,33 \%$ \\
\hline
\end{tabular}

O município apresenta uma realidade educacional com evidentes disparidades, conforme dados abaixo:

\begin{tabular}{|c|c|c|}
\hline Faixa etária & População $^{\mathbf{1}}$ & Matrículas iniciais $^{\mathbf{2}}$ \\
\hline Até 3 anos & 51.949 & 2.397 (creches) \\
\hline De 4 a 6 anos & 39.117 & 24.360 (pré-escolas) \\
\hline De 7 a 10 anos & 49.166 & 49.775 (1 ${ }^{\mathrm{a}}$ a $4^{\mathrm{a}}$ série) \\
\hline
\end{tabular}

Fontes:

${ }^{1}$ Estimativa populacional calculada pelo IBGE/2004

${ }^{2}$ Ministério da Educação, Instituto Nacional de Estudos e Pesquisas Educacionais

A rede de ensino contava, em 1997, com 76 (setenta e seis) escolas de Educação Infantil - que não conseguiam absorver a demanda nessa faixa etária -, 2 (duas) escolas especiais para alunos com múltiplas deficiências, 1 (uma) escola para alunos com surdez, 1 (um) centro de apoio para alunos com deficiência visual e 1 (um) centro de apoio à estimulação essencial para crianças na faixa etária de 0 a 6 anos.

A cada ano, esse quadro sofreu uma significativa transformação, apresentando, no final da década de 90, em função da aprovação da Lei nº 9.424/96 e com a municipalização do Ensino Fundamental, um aumento significativo de alunos na faixa etária entre 7 e 10 anos.

Em decorrência desse crescimento, verificou-se, no período, uma efervescência de medidas voltadas principalmente à discussão da Proposta Curricular e do Plano de Formação dos Professores. Em 1999, com a aprovação do Estatuto do Magistério ${ }^{32}$, regulamentado pela Lei

\footnotetext{
${ }^{32}$ Considerado uma conquista da rede municipal, com a garantia de algumas reivindicações, tais como 2 horas de HTPC (Horário de Trabalho Pedagógico Coletivo) e 2 horas de HTPL (Horário de Trabalho Pedagógico Livre), criando um novo conceito de formação docente, voltada para ações formativas em serviço e vinculadas ao desenvolvimento do Projeto Pedagógico Educacional.
} 
Municipal $\mathrm{n}^{\circ}$. 4.681/98, de 26 de novembro de 1998, novos direcionamentos foram registrados no âmbito da formação centrada no contexto escolar, refletindo e investigando o cotidiano escolar e a ação educativa, coordenados pela equipe escolar. 


\section{APÊNDICE B}

\section{A Educação Especial no município: trilhas percorridas}

A história da Educação Especial no município de São Bernardo do Campo evidencia-se por uma característica pouco comum à esfera pública, já que matricular crianças consideradas “anormais” não era uma prática usual nas escolas do sistema público de ensino, tampouco a criação de serviços especializados para esse fim, responsabilidade transferida para instituições privadas.

Apesar de na Constituição de 1988 constarem vários dispositivos determinando ao setor público estatal a “obrigatoriedade de oferta de educação especial” (FERREIRA e FERREIRA, 2004), havia uma escassez de recursos apropriados para a educação dessas crianças. Contudo, é preciso destacar que, em diferentes momentos, a presença marcante da comunidade refletiu na conquista de recursos especializados no município, com a manutenção exclusiva do poder público.

Os documentos consultados destacam que, desde a década de 50, a administração municipal de São Bernardo do Campo historicamente reconheceu a necessidade de criar escolas para os alunos com deficiência que não apresentassem plenas condições de serem atendidos pelas escolas regulares.

Preocupados com as precárias condições de atendimento oferecido pelas entidades assistenciais, única forma, na época, de acesso à educação, pais e profissionais conquistaram apoio e, em 1957, o então prefeito Aldino Pinotti instalou a primeira classe para deficientes auditivos, que recebeu a denominação de Escola Municipal de Surdos.

De acordo com os registros documentais ${ }^{33}$ da história da Educação da cidade, a Educação Especial, devido ao aumento gradativo da demanda escolar com deficiência auditiva, apontou para a necessidade de expandir suas vagas. Foi então que, em 1973, novas classes foram criadas anexas ao Colégio Brasília, transferidas após três anos para um espaço mais amplo,

\footnotetext{
${ }^{33}$ Os registros referentes à história da Educação Especial do município constam de documentos oficiais, muitos deles não publicados, fazendo parte dos arquivos da Secretaria de Educação e Cultura. A pesquisadora consultou também folheto publicado em 2002, por ocasião das comemorações de 45 anos da Educação Especial no município e a Proposta Curricular - 2004. A memória viva de alguns educadores ainda pode ser referência, como as informações da primeira professora da Escola Municipal de Surdos, Prof ${ }^{a}$. Walda Bastos Duarte, que gentilmente esclareceu alguns dados para esta pesquisa.
} 
porém adaptado, no Parque Santo Antônio, recebendo o nome de Núcleo de Educação de Deficientes da Audiocomunicação (NEDAC). Mais tarde, em 1980, a unidade recebeu a denominação que marcava a homenagem do município à sua educadora Neusa Bassetto, assim denominando: Escola Municipal de Educação de Deficientes da Audiocomunicação "Neusa Bassetto" (EMEDAC).

Sua proposta de educação apoiava-se na concepção oralista, com abordagem multissensorial, embasando uma pedagogia corretiva para o desenvolvimento da linguagem oral como forma de comunicação primeira e a escrita, inteiramente baseada na oralidade, com o suporte dos sistemáticos trabalhos de leitura orofacial.

Em 1988, a escola foi instalada em novo prédio, construído para esse fim, com equipamentos de treinamento para o desenvolvimento do potencial auditivo dos alunos. Na época, foi determinante a assessoria da professora Alpia Couto, da UERJ, que coordenou a formação dos educadores e a reformulação das propostas pedagógicas, principalmente no que tange ao desenvolvimento de práticas voltadas ao treinamento da fala, linguagem e audição, com forte matiz terapêutico.

No entanto, o contato com novas pesquisas foi revelando aos profissionais, pouco a pouco, as dificuldades encontradas pelos surdos no desenvolvimento das linguagens oral e escrita, conduzindo-os a um redirecionamento de uma nova proposta educacional.

Um outro discurso sobre a surdez aproximava as propostas pedagógicas da "comunicação total”, gerando novas mudanças no modelo de educação. Essa nova visão sugeria a exposição da criança ao maior número possível de informações, valorizando uma multiplicidade de canais de comunicação - auditivo, visual, oral, de sinais, gestos, desenhos, sons, mímicas, escrita, entre outros, considerando o potencial da criança e se aproximando de paradigmas direcionados à concepção do homem como um ser indivisível, constituído por uma pluralidade de condições. Nesse aspecto, muitos dos sinais utilizados nessa abordagem eram retirados da língua de sinais, acompanhados, porém, da gramática da língua portuguesa, mantendo-se, assim, um sistema referenciado pela língua oral - o português sinalizado. Nessa fase, cursos e assessorias com profissionais da DERDIC-PUCSP proporcionaram novos espaços formativos. 
Contudo, nos últimos dez anos, com a efervescência dos movimentos mundiais em torno da educação bilíngüe ${ }^{34}$, uma nova visão da surdez passou a ser considerada, interferindo nas decisões educacionais. Nesse período, diversos docentes, como Moura, Skliar e representantes do INES-RJ, entre outros, trouxeram aos educadores suas contribuições, revelando o que vinha sendo produzido, em termos de educação para surdos e como esses sujeitos poderiam reconhecer-se agentes desse processo.

Como todas as discussões, esta e tantas outras foram objeto de estudo constante. Nas diferentes fases, as transformações ocorridas ofereceram à escola a oportunidade de repensar constantemente suas práticas e acompanhar a evolução das correntes teóricas da educação.

Na área do ensino para deficientes mentais, em 1967, atendendo às solicitações da população, a prefeitura estabeleceu uma parceria com a Associação de Pais e Amigos dos Excepcionais (APAE), responsabilizando-se pela manutenção dos funcionários e merenda escolar. Em 1970, o então Departamento de Expansão Cultural, representando naquela época a Secretaria de Educação e Cultura, criou o Serviço de Educação Especial, substituindo a APAE na condução do ensino para os alunos com deficiência mental. Nesse momento, destacou-se a supervisão da professora Jay Arruda Pizza.

Refletir sobre as condições necessárias para a educação das crianças com deficiência tornouse um processo permanente, em que foram promovidas a organização de cursos de formação para professores e a instalação de duas unidades escolares atualmente denominadas Escola Municipal de Educação Básica Especial "Rolando Ramacciotti” e Escola Municipal de Educação Básica Especial “Marly Buissa Chiedde”. A partir daí, novas oportunidades foram surgindo, propostas pelas diferentes administrações, para os alunos com acentuados comprometimentos cognitivos, neurológicos, sensoriais, psíquicos, entre outros. Estabeleciase uma posição diferenciada no contexto da educação especializada, na medida em que diferentes gestões faziam constar, em seus planos de governo, uma atenção à área de Educação Especial, oferecendo respostas aos movimentos de pais, bem freqüentes no

\footnotetext{
${ }^{34}$ Segundo publicação da UNESCO, a educação bilíngüe refere-se ao direito que as pessoas que utilizam uma língua diferente da oficial do país têm de serem educadas em sua língua materna. Em relação à educação do surdo, as interpretações, segundo Moura (2002), consideram, inicialmente, que os surdos devam desenvolver sua língua materna (L1), ou seja, a língua de sinais, na convivência com surdos adultos usuários da língua, para posteriormente serem expostos ao ensino da língua oral e/ou escrita, tendo como base a língua portuguesa (L2).
} 
município. Assim, assistia-se a diferentes formas de atendimento e à criação de adaptações significativas nas propostas, atendendo uma população quase sempre marginalizada.

Partindo desse pressuposto, foram realizados cursos e oficinas considerando-se as peculiaridades de uma população que necessitava de novos enfoques e recursos, dando sustentação aos estudos que apontavam para a importância da transformação e ressignificação da Educação Especial, num momento extremamente importante, em que os temas exclusão e inclusão tomavam conta dos debates.

Nesse período, a assessoria da professora Úrsula Heymayer e as contribuições da professora Rosita Edler Carvalho convidavam os educadores a repensar suas práticas e, principalmente, como o educador poderia dar sustentabilidade a um atendimento educacional que proporcionasse um espectro de caminhos desejáveis para o ensino desse alunado, singularizando as propostas e oferecendo múltiplos canais de interação e inclusão social.

A crise por que passava a Educação Especial exigia que seus educadores repensassem seus valores, concepções e práticas e, para tanto, a formação docente proporcionou ganhos importantes.

No que diz respeito ao ensino das pessoas com deficiência visual, a primeira sala de recursos foi criada em 1973, registrando a ênfase marcante que o município procurava dar à Educação Especial. Assim, foi instalada no Grupo Escolar de Nova Petrópolis, em classe anexa à EEPSG "Maurício Antunes Ferraz", para cinco alunos, o primeiro agrupamento com vistas a suprir recursos educativos a uma demanda ainda não conhecida. Em 1989, em favor da ampliação de vagas, o atendimento foi transferido para a EEPSG “Iracema Munhoz”.

Só em 1996, em instalação própria e com recursos e equipamentos especializados, foi inaugurado o Centro Municipal de Apoio ao Portador de Deficiência Visual "Nice Tonhozi Saraiva” - CMAPDV, conjugando atividades educativas, fosse no acompanhamento realizado pela professora habilitada à escola regular e no apoio à escolarização da criança com deficiência visual, ou contribuindo na inclusão social de pessoas de todas as faixas etárias que adquiriram a deficiência. Configura-se assim, segundo Solér (2003, p. 62), um atendimento de caráter mais amplo, como serviço de apoio que planeja, reflete e oferece condições concretas propiciadoras da inclusão social e escolar mediante diferentes programas e modalidades de 
ensino, utilizando-se recursos adaptados para baixa visão e cegueira, extrapolando o atendimento de sala de recursos.

Ainda hoje, os professores especializados desenvolvem um trabalho itinerante de apoio aos alunos e professores do ensino regular e das escolas especiais para alunos com surdo-cegueira e múltiplas deficiências, além dos atendimentos específicos desenvolvidos diretamente no Centro de Apoio, em alfabetização braile, atividades de vida diária, orientação e mobilidade, recursos gráficos, soroban, adaptação e confecção de materiais, grupos temáticos e educação física. Há também o desenvolvimento de oficinas para educadores, famílias e comunidade, com a finalidade de ampliar o conhecimento sobre a deficiência visual. São atividades planejadas com o intuito de promover programas integradores da escola - comunidade pessoa com deficiência.

A reconstrução desse trabalho, com a assessoria da professora Elcie Salzano Masini, trouxe uma valiosa contribuição na releitura dos requisitos para o desenvolvimento do processo inclusivo (objetivos claros, registro e sistematização de dados) para que, com isso, os educadores pudessem responder às condições necessárias para lidar com as circunstâncias decorrentes da inclusão.

Compondo as áreas de atendimento, destacou-se a criação do Programa de Estimulação Precoce, em 1991, posteriormente denominado Estimulação Essencial, constituindo-se em um espaço destinado a crianças de 0 a 6 anos, com deficiência e/ou atraso no desenvolvimento neuropsicomotor. Apesar do crescimento da demanda, o programa, em 1995, sofreu com o “descontinuísmo”, pois, por não ter recebido o devido apoio da administração, deixou de funcionar. Em 1996, por iniciativa da Educação Especial, a Secretaria de Educação e Cultura estabeleceu parceria com a Secretaria da Saúde, passando a estabelecer novos rumos para o Programa de Estimulação Essencial, promovendo a formação dos profissionais da saúde e da educação, na perspectiva de implantar um modelo de atuação complementar de prevenção das deficiências.

Procurou-se, então, investigar as causas das deficiências de maior prevalência no município e observar as modificações necessárias a serem implementada, no acompanhamento preventivo materno-infantil. 
Das ações conjuntas entre Saúde e Educação, sob a supervisão do professor José Salomão Schwartzman, efetivou-se, em 2000, a criação do Passaporte Materno-Infantil, conforme foi registrado em relatório avaliativo 2001-2002:

O desenvolvimento do Programa de Prevenção das Deficiências, visando ao acompanhamento dos fatores de risco, em momentos específicos da formação do bebê (antes do nascimento) e da criança (após o nascimento), deve-se à eficaz utilização do Passaporte Materno-Infantil (PMI). Mediante a ação competente dos profissionais no atendimento à população da sociedade civil mais atenta ás necessidades preventivas, dos agentes comunitários de saúde, como articuladores entre comunidade e a esfera governamental e, com o reconhecido papel desempenhado pelas empresas parceiras, o PMI tem contribuído para consolidar os propósitos de intervir de forma antecipada no acompanhamento à gestante e à criança (Programa de Ação Complementar Saúde-Educação - Relatório de acompanhamento das principais ações realizadas 2001-2002).

Esse trabalho, de âmbito educativo e de renovação das ações preventivas da Saúde em parceria com a Educação, projetou o trabalho da Educação Especial, tornando-a uma área privilegiada para investigação e orientação da comunidade. Por outro lado, as idéias inclusivas mobilizaram a gestão pública a destinar a antiga Escola de Educação Infantil “Ernesto Augusto Cleto” para que a Educação Especial instalasse ali o Programa de Estimulação Essencial. A parceria com a Educação Infantil foi gradativamente delineando o percurso para o desenvolvimento de um trabalho planejado com os professores habilitados no acompanhamento das crianças e escolas.

Na ocasião (em 2001), os recursos das escolas e dos projetos pedagógicos começaram a ser adaptados, alcançando-se, finalmente, a definição de procedimentos para orientação das unidades escolares, descritos no Caderno de Metas - 2001" : "Implantar e implementar diretrizes, princípios e procedimentos para a educação inclusiva garantindo formas de acompanhamento comuns entre as áreas até dezembro/2002”. Contudo, no que diz respeito aos alunos com maiores comprometimentos, nem sempre isso ocorreu, uma vez que, naquele

\footnotetext{
${ }^{35}$ Instrumento de trabalho da escola na medida em que, ao ser implantado em 2001, estabelece princípios, diretrizes e metas dinamizando o diálogo entre a administração e a escola e entre esta e a comunidade. Apresenta, a cada ano, os indicadores que delineiam o processo escolar na rede de ensino municipal deste município (Caderno de Metas, 2001, p. 2).
} 
momento, as escolas ainda não encontravam as condições para que pudessem, de fato, compreender suas especificidades.

Para que os alunos continuassem seu processo educativo, tornava-se indispensável permanecerem nas Escolas Especiais e Centros de Apoio. Assim, com a parceria entre os professores habilitados e as escolas regulares, foram sendo criadas alternativas para que, gradativamente, outras crianças fossem incluídas.

Outras propostas inclusivas foram mantidas por meio das Classes Integradas, espaços reestruturados a partir das classes especiais absorvidas na rede estadual, por ocasião da municipalização do Ensino Fundamental, em 1998. Houve uma reorganização dos agrupamentos, adequação do currículo e do sistema de avaliação, fundamentados nas Diretrizes Nacionais para Educação Especial na Educação Básica - Resolução nº. 2/2001 do Conselho Nacional de Educação / Câmara de Educação Básica (CNE/CEB), tendo-se como objetivo a passagem do aluno para as classes regulares.

Em 2000, a Educação Especial instituiu a EMEBE “Fernando de Azevedo” como espaço destinado a integrar todas as ações formativas das equipes e professores envolvidos no acompanhamento do aluno com deficiência incluído nas classes regulares e nas integradas ${ }^{36}$.

Em se tratando dos jovens, as propostas de profissionalização para os alunos com deficiência mental e múltiplas deficiências puderam ser ampliadas em 1980, com a criação das Oficinas Abrigadas de Trabalho, fruto do movimento de pais, com o apoio do Rotary Club. Mediante parceria com a Prefeitura do Município de São Bernardo do Campo, foi possível uma significativa expansão de alternativas de trabalho, não apenas em ambiente protegido, mas também como estrutura mediadora de estágios e contratações em empresas e comércio.

Em 1989, por meio de convênio, a condução das Oficinas passou exclusivamente para as mãos dos pais e comunidade, em parceria com a administração pública.

\footnotetext{
${ }^{36}$ Classe Integrada é a denominação fornecida aos espaços existentes nas escolas regulares destinados aos alunos que não se beneficiavam de imediato das programações oferecidas. Diferiam das classes especiais na medida em que se buscava criar objetivos claros de um projeto com prazos determinados vinculados à passagem para as classes regulares, sem que padecessem da ausência de recursos específicos para suas condições e características.
} 
No ano de 1991, a Associação Santo Inácio para Integração do Trabalhador Especial (ASIITE) recebeu da Prefeitura a concessão de terreno, hoje com $90.000 \mathrm{~m}^{2}$, onde são desenvolvidos programas de horticultura e projetos alternativos que dêem sustentabilidade ao desenvolvimento de alguns projetos, como a terceirização de mão-de-obra na área de jardinagem.

Em 2000, foi criada a Escola Municipal de Arte-Educação Integrada, instalada em um prédio histórico tombado, datado de 1922, com a finalidade de agregar programas de Arte-Educação da Educação Especial, idealizados para integrar pessoas com deficiência por meio de atividades como: dança, teatro, escultura e artes plásticas. Nesse contexto, também foram desenvolvidos cursos para os educadores se apropriarem de recursos, linguagens variadas e formas de expressão que pudessem mediar o trabalho inclusivo nas escolas regulares.

Outros espaços integrados foram planejados interligando o trabalho especializado e a infraestrutura da Secretaria do Desenvolvimento e Cidadania. Nesse âmbito, foram planejadas atividades formativas para jovens com deficiência mental entre 14 (quatorze) e 17 (dezessete) anos, visando a oferecer-lhes maior independência, autonomia e inclusão social, além de ser criado um espaço onde fossem oferecidos cursos voltados para absorção, no mercado de trabalho, de jovens com deficiência, egressos das escolas regulares e das classes integradas.

Nessa perspectiva, diferentes programas foram estruturados na tentativa de absorver as demandas de uma população ainda muito pouco assistida, quanto ao acesso a bens públicos.

A complexidade desse processo de implementação de programas que oferecessem à população com deficiência novos caminhos para sua inclusão social exigiu, em diferentes momentos, a avaliação das condições concretas e necessárias para que fossem concretizados tais desafios.

Em 2004, novas medidas foram criadas, sendo reestruturado o Programa de Inclusão, firmando o compromisso com todas as escolas da rede em oferecer garantias não apenas de vagas, mas de desenvolver um trabalho educativo singular, específico e de qualidade para as crianças com deficiência. 
Mazzotta (1998) faz uma análise decisiva de que, além das garantias legais, a escola pública deve identificar e dimensionar as mudanças necessárias que propiciem a inclusão desses alunos.

Assim, diante da preocupação de se oferecerem à população alternativas de acesso à escola, observou-se uma gradativa expansão do atendimento, inclusive àqueles considerados "mais comprometidos” e com dificuldades de acesso à Educação.

Em seus 50 anos de existência, a Educação Especial do município de São Bernardo do Campo tem sido uma estrutura institucional marcante na criação de condições para a educação da pessoa com deficiência. Crianças, jovens e adultos conquistaram, ao longo desse período, o direito de acesso aos espaços educativos.

A compreensão desse movimento histórico, traçado por todos os integrantes que acompanharam, em diferentes momentos, tal processo, constitui fundamento essencial para a interpretação da lógica que dá sentido à experiência. A partir desse conjunto de informações, fica estampado o lócus onde os educadores, sujeitos e agentes da pesquisa, encontram-se situados.

Esse movimento histórico reconstrói o cenário do lugar onde os educadores contam suas experiências, revelam suas produções, falam de suas descobertas, exprimem sentimentos e percepções de como protagonizaram seu papel, inseridos numa organização institucional pública.

Pode parecer difícil pontuar, com objetividade, questões concretas, principalmente as mais longínquas e, com elas, estabelecer nexos entre dados, muitas vezes pouco visíveis, sobretudo aqueles cujas causas possuem raízes muito profundas. Contudo, ainda que reconstruir a ação coletiva de um tempo passado seja indispensável para a análise dos dados investigados, a organização desse material recolhido traz articulações com um processo educativo vivo, referências, portanto, de memória, vinculadas à ação pedagógica de um tempo presente.

As cenas vividas pelos educadores, nas situações do dia-a-dia da escola, são infinitamente singulares a cada realidade e compõem uma trama não facilmente compreensível. Há de se traçar um itinerário que conduza o investigador em identificar, nesse permanente movimento 
educativo, a dialética entre objetividade e subjetividade, e discutir, na perspectiva dos participantes, como cada um deles, sujeitos do estudo, produziram conhecimentos, lidaram com as situações vivenciadas e criticamente interpretam hoje essa experiência real, vivenciada no período em estudo (1996-2003).

Nessa direção, Paulo Freire (1985) considera essencial conhecer "os modos de pensar e os níveis de percepção do real” dos grupos pesquisados, e acrescenta que:

Para muitos de nós, a realidade concreta de uma certa área se reduz a um conjunto de dados materiais ou de fatos cuja existência ou não, de nosso ponto de vista, importa constatar. Para mim, a realidade concreta é algo mais que fatos ou dados tomados mais ou menos em si mesmos. Ela é todos esses fatos e todos esses dados e mais a percepção que deles esteja tendo a população neles envolvida (p. 35). 


\section{APÊNDICE C \\ O papel constitutivo da instituição pública}

"Quanto mais for levado a refletir sobre a sua
situacionalidade, sobre o seu enraizamento espaço-
temporal, mais emergirá dela conscientemente
carregado de compromisso com a sua realidade, da
qual, porque é sujeito, não deve ser simples
expectador, mas deve intervir cada vez mais."

Paulo Freire

Nesse contexto de produções, foram realizadas as entrevistas, envolvendo depoimentos de educadores de cinco unidades escolares da Educação Especial pertencentes ao Departamento de Ações Educacionais da Secretaria de Educação e Cultura do Município de São Bernardo do Campo.

A estrutura institucional implica a existência de seções que sejam dinamicamente articuladas entre si, reguladoras das necessidades de todo sistema de ensino, responsáveis pela definição das diretrizes educacionais, dos parâmetros curriculares e das formulações avaliativas.

Contudo, a rede pública de ensino de São Bernardo do Campo, mesmo estabelecendo em seu Plano de Governo (1997-2000) diretrizes orientadas para a implantação de um projeto educacional de atenção integral à criança e ao adolescente (Anexo $\mathrm{n}^{0}$. 6), somente a partir de 1998, com a municipalização do Ensino Fundamental de $1^{\text {a }}$ a $4^{\text {a }}$ série, seguindo recomendação da Emenda Constitucional $n^{\circ} 14^{37}$, conseguiu absorver a demanda escolar de alunos entre 7 e 10 anos.

No início dessa fase, segundo Quinonero (2002, p. 16), as equipes de trabalho enfrentavam dificuldades pela falta de articulação de enfoques e pela inexistência de um projeto educacional orientador das ações coletivas.

A gestão democrática concebida, um dos pontos essenciais do processo de construção da autonomia escolar, parece não ter se expressado, nessa fase, como princípio consolidado. Mas

\footnotetext{
${ }^{37}$ A Emenda Constitucional n ${ }^{\circ} .14$ - EC14, de 12 de setembro de 1996, cria o FUNDEF - Fundo de Manutenção e Desenvolvimento do Ensino Fundamental e de Valorização do Magistério -, assegurando a universalização do Ensino Fundamental, segundo promulgação do artigo 212 da Constituição Federal de 1988 (BRASIL, Constituição Federal: 1998 - Capítulos II, III e IV da Educação, da Cultura e do Desporto).
} 
identifica-se, em 2000, um movimento das equipes gestoras da Secretaria de Educação para a elaboração de um instrumento de trabalho que oferecesse parâmetros às escolas e definisse as diretrizes educacionais para a implantação de um modelo de escola mais identificado com a realidade e os problemas da comunidade.

No intuito de produzir um referencial esclarecedor de suas prioridades, o primeiro Caderno de Metas foi lançado em 2001 expressando como objetivo ser "elo de aproximação entre administração e sala de aula, teoria e prática, conectando as Políticas Públicas com o cotidiano da escola” (São Bernardo do Campo, Caderno de Metas - 2001, p. 1).

Nesse aspecto, destacam-se as considerações levantadas quanto ao fortalecimento da escola e das decisões locais, principalmente na valorização da parceria escola-comunidade, com ênfase no diálogo para consolidação de uma Escola Para Todos.

Com essa perspectiva, de maneira característica, o estímulo à participação dos pais foi consolidado por meio dos movimentos liderados pela comunidade, visando a conquistar uma escola democrática, não padronizada e aberta à diversidade de seu alunado, inclusive para alunos com graves comprometimentos até então não assumidos nem mesmo por instituições especializadas.

Diante dos desafios apresentados, principalmente em relação ao processo de municipalização do Ensino Fundamental, passaram a ser necessárias medidas administrativas para criar uma nova estrutura do sistema educacional, adequadas ao desenvolvimento da Educação Básica. Não se tratava apenas de uma transformação nas questões de âmbito físico e material para funcionamento das escolas, mas também político e, sobretudo, pedagógico. Havia, nesse momento, uma explícita ausência de alguma estrutura consolidada para as demandas advindas desses novos encargos educacionais, entre elas a definição do modelo de gestão e da própria concepção pretendida de escola pública.

Tais aspectos ganharam especial importância nesse período. Com a expansão da educação, avançaram as idéias sobre Educação para Todos, como está registrado no Caderno de Metas 2001, intitulado Diretrizes de Trabalho: “Consolidar uma política pública que contribua para a prevenção, detecção precoce e atendimento educacional, facilitando a inserção e inclusão de 
crianças e jovens com deficiência, na sociedade atual” (São Bernardo do Campo - Caderno de Metas, 2001).

No período de 1998 a 2000, as decisões do âmbito da municipalização tiveram prioridade, principalmente porque o discurso dominante centrou-se na implantação de uma política educacional que não prevalecesse unicamente o número de matrículas, enfatizando a criação de recursos dirigidos ao atendimento de qualidade para assegurar o acesso, a permanência e o sucesso de seus alunos.

Na área de Educação Especial, cabe considerar que foram realizados concursos públicos para a ampliação do quadro docente, com vista ao acompanhamento dos alunos incluídos nas escolas regulares e atendidos nas salas de recursos, buscando integrar os docentes das diferentes áreas de ensino.

Assim, para definir a linha de trabalho a ser seguida pelas escolas, a Secretaria de Educação e Cultura estabeleceu como eixos norteadores os seguintes compromissos: Formação Continuada dos Professores ${ }^{38}$, como condição de valorização do magistério; Construção de uma Escola Democrática para Todos; Preservação do Ambiente; e Ampliação da Participação da Comunidade na tomada de decisões para a educação.

Nesse aspecto, fazia-se necessário valorizar a ação compartilhada do Quadro Técnico Educacional, regulamentado pelo Estatuto do Magistério, Lei $n^{\circ}$. 24681/98, em cujo artigo $8^{\circ}$ estão definidas as funções das equipes que atuariam com as escolas:

Art. 8. O Quadro Técnico Educacional compreende as funções de apoio técnico que atuarão nas áreas de:

- Suporte às ações pedagógicas;

- Supervisão;

- Planejamento;

- Orientação nas áreas de ensino.

\footnotetext{
${ }^{38}$ A Formação Continuada dos Professores, segundo Quinonero (2002), é planejada anualmente a partir de um diagnóstico da equipe técnica, sendo estabelecidos cursos em horário de serviço e fora dele, podendo ser organizado nas próprias escolas ou para um conjunto de educadores da rede de ensino.
} 
O Quadro Técnico da Secretaria de Educação, no âmbito da Educação Especial, era composto por: 8 (oito) orientadores pedagógicos, 7 (sete) psicólogos, 7 (sete) fonoaudiólogos, 6 (seis) assistentes sociais e 2 (dois) terapeutas ocupacionais, todos atuando nas unidades escolares especializadas e no programa de educação inclusiva.

O contexto organizacional estudado pode ser mais bem explicitado por meio dos quadros que seguem, onde estão representadas quatro seções: Educação Infantil, Ensino Fundamental de $1^{\text {a }}$ a $4^{\mathrm{a}}$ série, Educação de Jovens e Adultos e Educação Especial. A complexidade desse cenário administrativo está expressa esquematicamente nos organogramas a seguir (Quadros I e II).

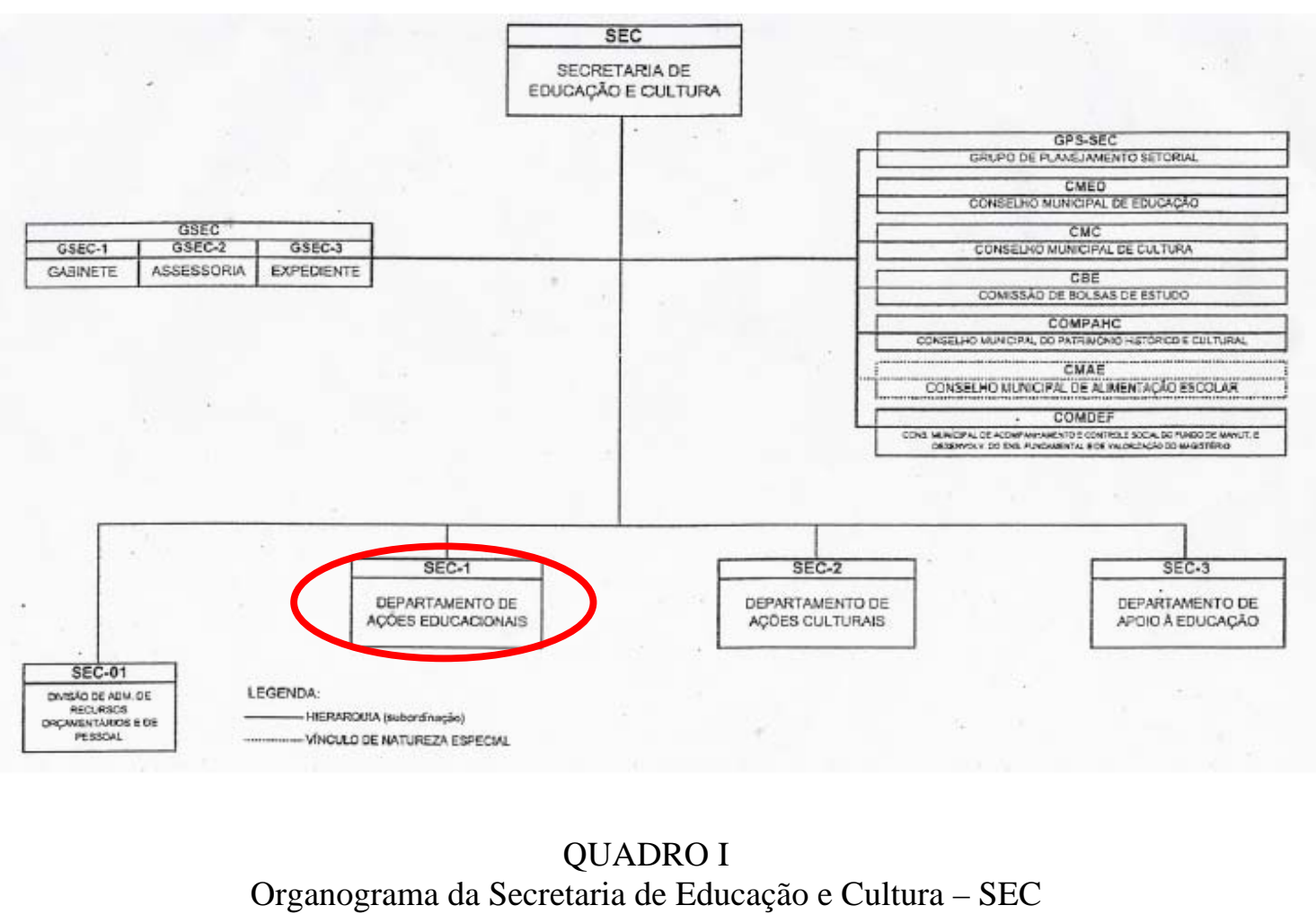




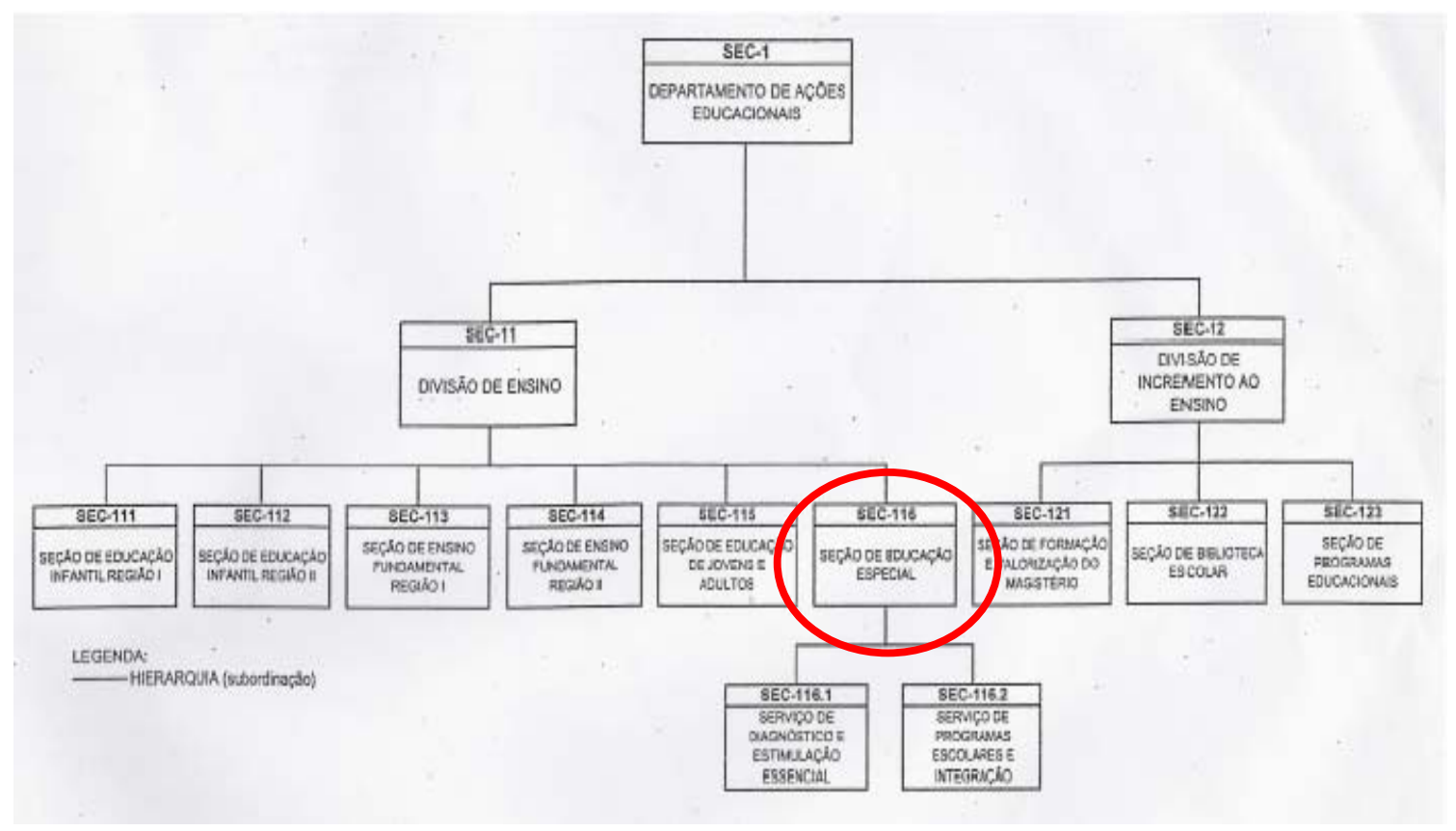

QUADRO II

Organograma do Departamento de Ações Educacionais - SEC-1

Conhecer essa estrutura e percebê-la em sua totalidade contribui para a compreensão das bases em que foram sedimentadas as ações formativas dirigidas ao quadro docente das unidades escolares. Por um lado, a estrutura explicita um território administrativo complexo, compartimentado que, por vezes, não identifica as possibilidades de as diferentes áreas de ensino partilharem estruturas semelhantes. Por outro, na perspectiva de se consolidar uma educação voltada para a diversidade, ficam expressas condições insuficientes e restritivas para o desenvolvimento de ações compartilhadas entre as diferentes áreas e programas.

A organização dos programas exigia dos dirigentes e coordenadores de áreas buscarem mecanismos de superação das barreiras estruturais decorrentes das exigências de suas próprias demandas, criando mecanismos de parcerias entre as áreas de ensino para sair de suas clausuras.

De acordo com os documentos ${ }^{39}$ consultados, o processo de formação contínua era planejado para os diferentes segmentos de ensino de forma integrada, havendo, entretanto, atividades específicas para cada modalidade de ensino, bem como a capacitação dos profissionais da

\footnotetext{
${ }^{39}$ Caderno de Metas do Departamento de Ações Educacionais - 2001, 2002 e 2003.
} 
equipe técnica que atuaria nas unidades como formadores, no acompanhamento das atividades docentes.

Em 2001 e 2002, foram desenvolvidos estudos para a elaboração do Plano Municipal de Educação (PME) ${ }^{40}$, como prevê a Constituição Federal - art. 165, para o período 2003-2010, com base nos fundamentos do Plano Nacional de Educação e nos documentos internacionais, para consolidação de uma Política Educacional voltada à democratização da escola pública, ao atendimento das reais necessidades da comunidade escolar e à valorização dos profissionais da educação. Nesse contexto, as metas definiam como prioridade a melhoria da qualidade de ensino, o respeito às diferenças e à pluralidade cultural, garantindo o acesso de todas as crianças em idade escolar às escolas públicas do ensino regular.

No PME, destacam-se as diretrizes formuladas para a formação continuada dos profissionais da educação, de acordo com a Lei de Diretrizes e Bases da Educação Nacional e a Lei 9.424/96, a qual dispõe sobre o Fundo de Manutenção e Desenvolvimento do Ensino Fundamental e de Valorização do Magistério. Nesse sentido, a Lei 9.424/96 focaliza uma política da Secretaria Municipal de Educação consolidada, segundo registros, de valorização do magistério, estabelecendo metas de investimentos, prioritariamente para formação de seus educadores, estimulando um projeto formativo conforme as necessidades educativas da população atendida, relativas às condições insatisfatórias do ensino.

O professor foi chamado a refletir sobre as condições de enfrentamento dos problemas de não aproveitamento escolar, evidenciado pelos índices significativos de alunos não alfabetizados ao término da $4^{\mathrm{a}}$ série do Ensino Fundamental, principalmente porque essa realidade ainda era muito nova, diante da recente municipalização do Ensino Fundamental.

O texto existente na Proposta Curricular, apresentado a seguir, refere-se à interpretação produzida pela Secretaria de Educação sobre os subsídios dos programas de capacitação para as escolas municipais:

${ }^{40}$ O PME representou, por ocasião de sua implantação, um momento de estudo e reflexão de todos os profissionais, alunos e pais, que contribuíram na elaboração das metas em atendimento às reivindicações e necessidades dos diferentes segmentos da comunidade escolar. 
O mapeamento dos dados sobre as condições do ensino comprova as deficiências e lacunas do sistema educativo, criando um referencial de análise sobre a realidade daquele contexto, servindo como ponto de partida para a organização de novas pesquisas e a criação de recursos, estratégias e meios pedagógicos para situar a problemática e ressignificar a capacitação dos profissionais. (Proposta Curricular, 2005). 


\section{ANEXO No .1 \\ DIAGRAMA \\ CONFIGURAÇÃO TEÓRICA: FORMAÇÃO DOCENTE}

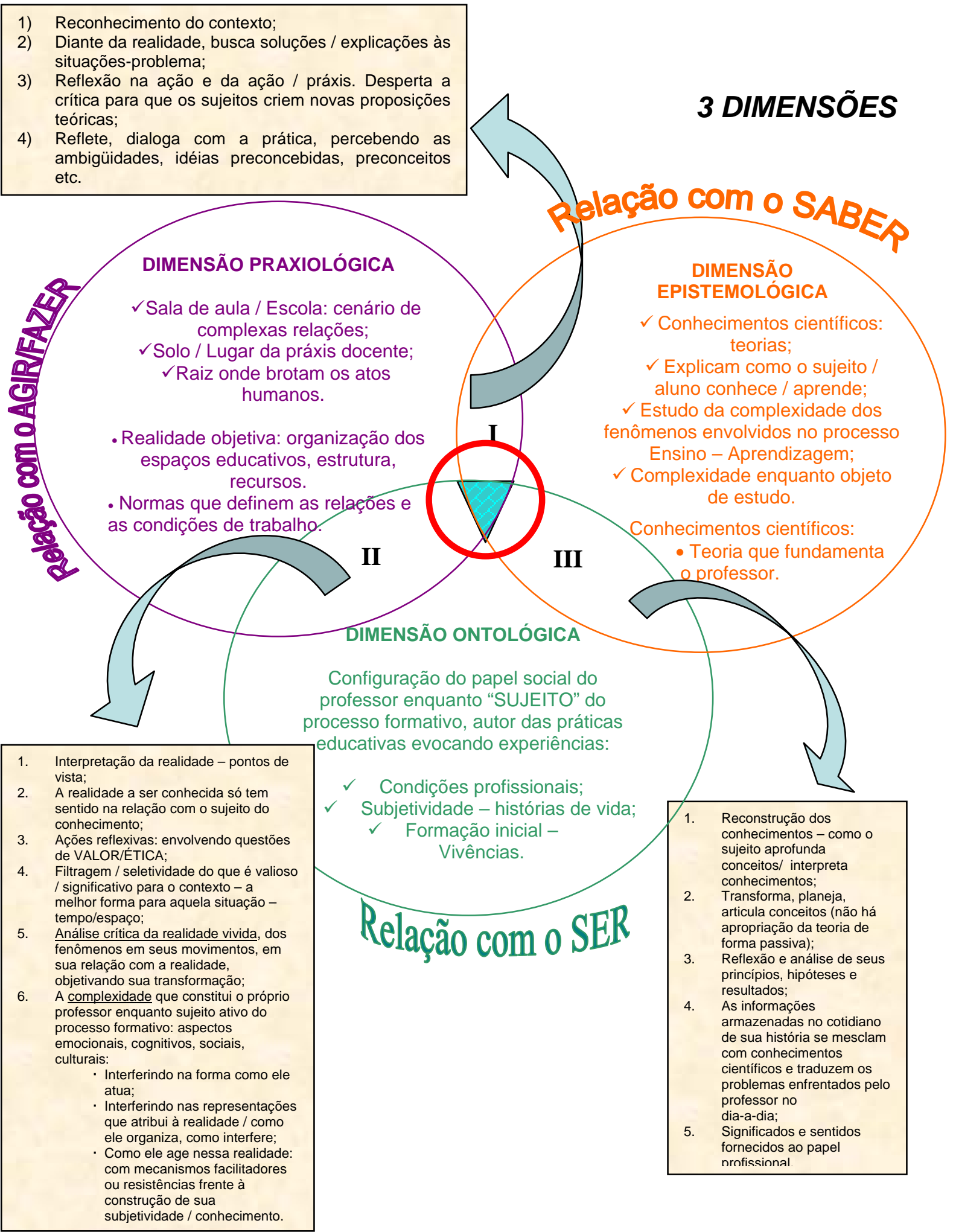

FIG. 1 
* Na intersecção desses planos, estão situados fatores essenciais que devem ser considerados na formação do professor.

* A ação pedagógica, no contexto da diversidade, necessita compreender a complexidade desse processo e (re)dimensionar as condições em que são planejados e desenvolvidos os projetos educativos.

FOCO DE CONVERGÊNCIA DA AÇÃO FORMATIVA:

Integração das diferentes dimensões (saber, fazer, ser)
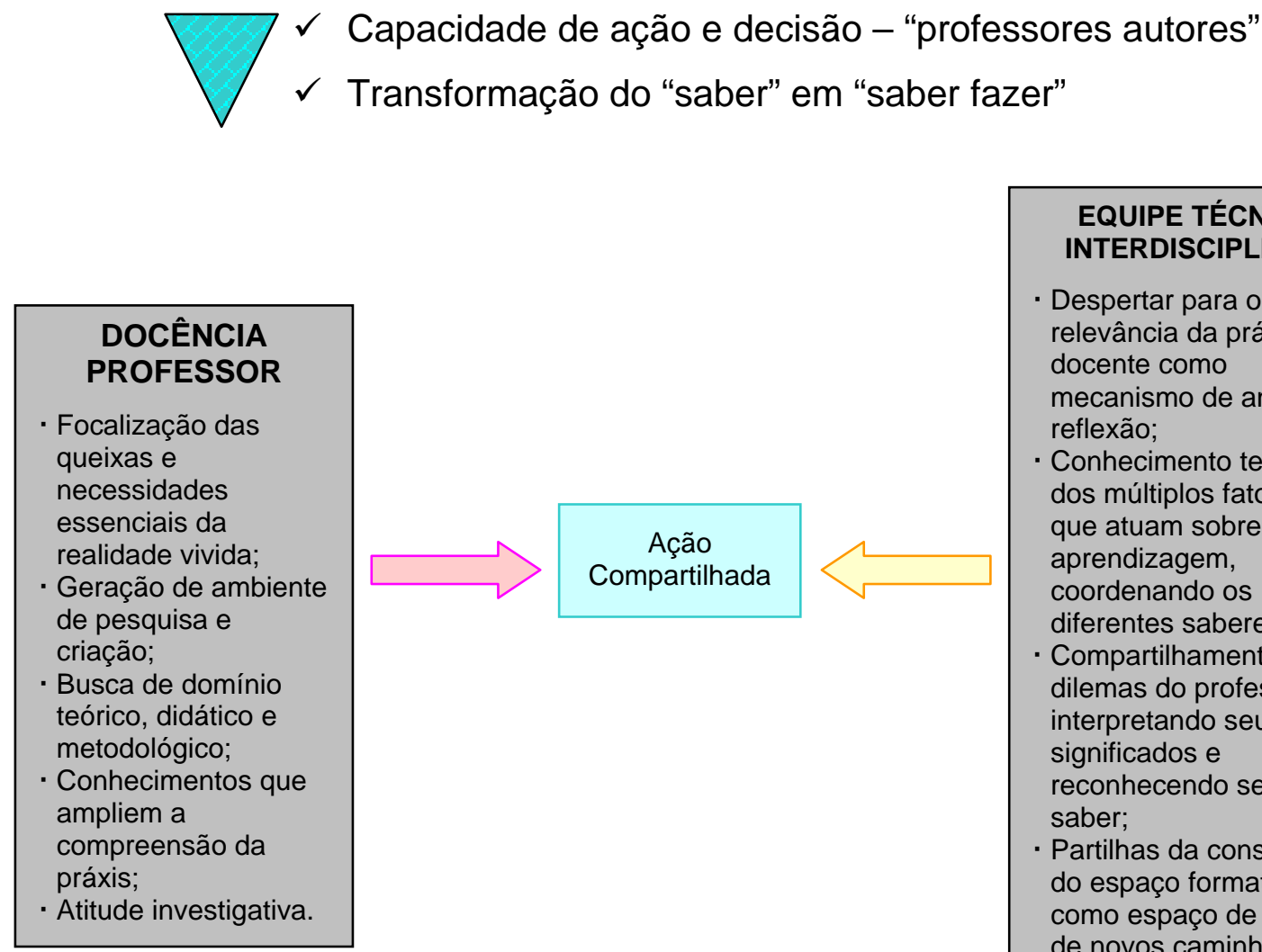

EQUIPE TÉCNICA INTERDISCIPLINAR

- Despertar para o valor e relevância da prática docente como mecanismo de análise e reflexão;

- Conhecimento teórico dos múltiplos fatores que atuam sobre a aprendizagem, coordenando os diferentes saberes; - Compartilhamento dos dilemas do professor, interpretando seus significados e reconhecendo seu saber;

- Partilhas da construção do espaço formativo como espaço de criação de novos caminhos.
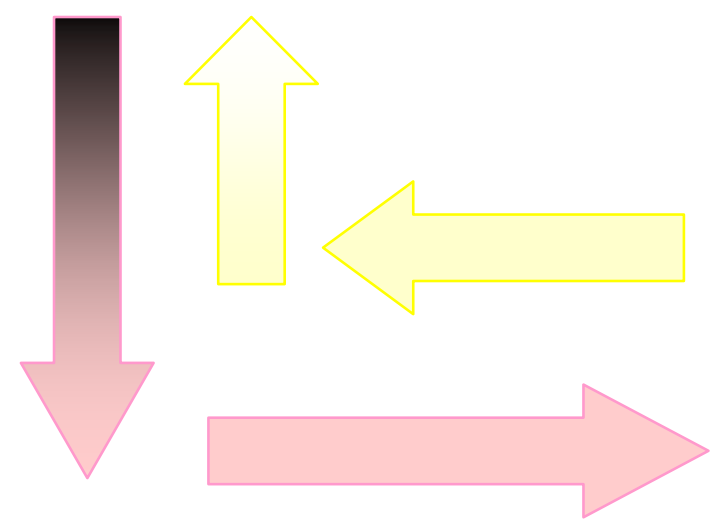


\section{ANEXO No. 2 \\ CARTA AOS PARTICIPANTES DA PESQUISA}

Educador,

Como parte de minha Dissertação de Mestrado pela Universidade de São Paulo - USP, buscarei entrevistar educadores que participaram da formação contínua em serviço, em parceria com a equipe interdisciplinar.

Gostaria de poder contar com sua colaboração nesta parte inicial da pesquisa, pois suas informações poderão contribuir com este estudo no campo da formação docente.

Estarei entrevistando 6 (seis) professores que, como você, participaram dessa experiência entre 1996 a 2003.

Neste trabalho, não tenho a intenção de fazer nenhum juízo de valor sobre os programas formativos, mas de compreender, no ponto de vista dos educadores, como eles atenderam suas necessidades pedagógicas na perspectiva de obter melhores condições para lidar com a diversidade.

Por uma questão de sigilo, os (as) educadores (as) não serão identificados nominalmente na pesquisa, mesmo porque esta realidade deve ser estudada mais amplamente sem a preocupação de nos determos na autoria dos relatos. No entanto, você pode escolher um cognome para podermos fazer referência sem revelarmos sua identidade.

O projeto de pesquisa será entregue à direção da escola e estará à sua disposição para obter mais dados, caso necessário.

Meus sinceros agradecimentos pela sua disponibilidade, pois sua participação é de fundamental importância.

Tanya Cecília Bottas de Oliveira e Souza

São Paulo, abril de 2007.

Fones:

(11) 5575.3649

(11) 9993.0041 


\section{ANEXO No. 3 \\ PROJETO: FORMAÇÃO DO PROFESSOR \\ NO CONTEXTO DA DIVERSIDADE}

\section{Educador,}

Como parte da pesquisa sobre formação docente, apresento a você este questionário, considerando a formação desenvolvida no período de 1996 a 2003, compartilhada com a equipe técnica, na perspectiva de oferecer aos educadores condições que thes possibilitassem encontrar alternativas na resolução dos problemas enfrentados no dia-a-dia com seus alunos.

Solicito a gentileza de responder objetivamente as questões e ser o mais sincero possível, expressando de maneira franca o que realmente pensa a respeito do assunto.

Caso julgue necessário, sinta-se à vontade para acrescentar comentários.

Não há necessidade de identificação, apenas registre o cognome escolhido:

\section{QUESTIONÁRIO}

\section{Dados Gerais}

a) Sexo: $F(\quad) \quad M(\quad)$

b) Idade: anos

c) Estado civil:

d) Filhos: ( ) Não ( ) Sim - Quantos: ( )

e) Raça ou etnia: 
a) Nível Médio:

( ) Normal

( ) Habilitação específica para o Magistério

( ) CEFAM

Ano de Conclusão:

b) Curso Superior:

( ) Instituição Pública

Ano de Conclusão:

( ) Instituição Privada

c) Pós-Graduação (Especialização) em:

( ) Instituição Pública

( ) Instituição Privada

3. Atuação na Rede Municipal

a) Situação Funcional:

( ) Professor efetivo da rede municipal

( ) Professor efetivo da rede estadual, cedido à rede municipal

( ) Professor admitido na rede municipal - caráter de substituição

b) Ano de ingresso na rede municipal:

c) Área de atuação na rede municipal:

( ) Educação Infantil

( ) Ensino Fundamental

( ) Educação Especial

( ) Educação de Jovens e Adultos - EJA

d) Experiência profissional:

( ) Educação Infantil

( ) Ensino Fundamental

( ) Educação Especial

( ) Educação de Jovens e Adultos - EJA

e) Atuação em outras redes? Qual(is)?

4. Formação Contínua Desenvolvida pela Rede Municipal

a) Durante o tempo em que está na rede municipal, você tem participado de:

( ) Cursos de formação

( ) Palestras

( ) Grupos de estudo

( ) Seminários

( ) Outras atividades que, no seu entender, contribuem para sua formação 
5. Relacione os eventos que você avalia como tendo contribuído para a sua formação:

\begin{tabular}{|l|l|l|}
\hline EVENTO & ANO & CARGA HORÁRIA \\
\hline & & \\
\hline & & \\
\hline & & \\
\hline & & \\
\hline & & \\
\hline & & \\
\hline
\end{tabular}

6. Quais as temáticas que você acredita terem sido fundamentais para o seu aprofundamento teórico?

7. Quais obras e publicações contribuíram para a sua formação e o aprofundamento de seu conhecimento sobre a aprendizagem dos alunos e a deficiência? 


\section{ANEXO No. 4 \\ ROTEIRO DA ENTREVISTA COM OS PROFESSORES}

\section{Questão Introdutória:}

"O que você destacaria em sua trajetória como tendo sido determinante na formação continuada em serviço, desenvolvida em parceria com a equipe interdisciplinar?"

Conjunto de questões abertas, balizadoras, a serem propostas de acordo com a evolução da entrevista. A pesquisadora conduzirá a entrevista estimulando os educadores a argumentarem suas proposições e relatarem situações que possam esclarecer os dados abordados, pontuando aspectos, sem rigidez, e adaptando-os de acordo com a exposição de cada entrevistado, envolvendo os seguintes tópicos:

$\checkmark$ Transformações que esta experiência promoveu em sua atuação até hoje;

$\checkmark$ Aspectos da formação que parecem ter contribuído mais significativamente para a atuação do educador e principais falhas observadas;

$\checkmark$ Condições proporcionadas para melhorar a prática com o aluno, solicitando exemplos de como ocorreu;

$\checkmark$ Condições de a parceria com a equipe possibilitar trocas de saberes e produzir um conhecimento interdisciplinar que contribuísse para a atuação docente;

$\checkmark$ Relação com o aluno com deficiência, impasses instaurados com mais freqüência e formas de abordar os processos de aprendizagem. Utilização de recursos ou instrumentos específicos;

$\checkmark$ Concepção de deficiência, considerando se a relação estabelecida com o conhecimento ficava delimitada pela deficiência;

$\checkmark$ Preparação para a prática, considerando os referenciais teóricos que ajudaram no manejo do cotidiano escolar;

$\checkmark$ Outras questões que se configuraram no modo como o educador se relacionava com os alunos e nos modos de intervenção na sala de aula. 


\section{ANEXO No. 5 \\ CARTA DE AGRADECIMENTO}

São Paulo, agosto de 2007.

Agradeço sua disponibilidade e atenção respondendo ao questionário e participando da entrevista que muito contribuiu com o andamento da pesquisa, cujo objetivo é verificar qual o ponto de vista dos educadores sobre a experiência desenvolvida com relação à formação continuada.

Após esta etapa de coleta de dados, pretendo apresentar à escola a síntese do trabalho e, caso seja necessário e de interesse da escola, será possível discutirmos o tema que me levou a esta investigação.

Obrigada.

Tanya Cecília Bottas de Oliveira e Souza 
ANEXO No. 6

\section{PLANO DE GOVERNO DA SECRETARIA DE EDUCAÇÃO E CULTURA DO MUNICÍPIO DE SÃO BERNARDO DO CAMPO - DEPARTAMENTO DE AÇÕES EDUCACIONAIS (frente)}

\footnotetext{
$-$

PREFEITURA DO MUNICÍPIO DE SÃO BERNARDO DO CAMPO

SECRETARIA DE EDUCACÃO E CULTURA

DEPARTAMENTO DE ACYOES EDUCACIONAIS

I - Não existia uma política pública definida na gestão anterior, encontramos 0 sistem a de ensino totalm ente fragmentado no que diz respeito a:

melhoria de qualidade de ensino;

valorização dos profissionais de ensino;

- integração entre modalidades de ensino, Departamentos e Secretarias afins;

- manutenção e ampliação dos equipam entos educacionais.

II - A politica atual da Secretaria de Educação e Cultura na área de educação tem como eixo principal a diretriz geral de governo que é uma política de atenção integral a criança e 0 adolescente, que se traduz nas diretrizes estabelecidas, que são:

1) Ampliação de oportunidades de acesso a escola através do aumento de vagas nas diferentes modalidades de ensino, tendo como parâmetro estudos de dem an da da região.

2) Ampliar a perm anência da criança, jovem ou adulto na escola através do aumento de carga horária nos períodos de aten dimento.

3) Formação continuada dos educadores de maneira sistemática e em serviço (HTPC) e após o horário de serviço.

4) Assessorias especializadas para as equipes técnicas e professores nas diferentes modalidades de ensino.

5) Gestão coletiva da escola através da reorganização e discussão com os educadores do regimento escolar, bem como estimular a participação da comunidade através dos conselhos de escola, associação de pais e mestres e grêm ios estudantis.

6) Estabelecimento de convênio com as unidades executoras, objetivando repasse de recursos para aquisição de materiais de consumo, didático e m anuten ção das unidades escolares.
} 


\section{(verso)}

7) Estudos visando a reorganização curricular através da redefin ição dos conteúdos de ensino, avaliação e reorgan ização do trabalho pedagógico.

8) Pesquisas e aquisição de materiais pedagógicos visando a instrum entalização dos educadores da rede.

9) Autonomia da escola através da construção de um Projeto Pedagógico Educacional nas unidades escolares que retratem a realidade das mesmas, e que estejam em sintonia com as diretrizes da Secretaria de Educação e Cultura.

10) Valorização dos profissionais da Educação através da aprovação do Plano de Carreira do Magistério.

11) Estabelecimento de um a política pública para o portador de deficiências que tenh a como paradigm a:

- a inclusão escolar dos deficientes no ensino regular;

- atendimento especializado complementar para atender as suas necessidades específicas.

12) Programa MOVA - S. B. Campo, cujo desenvolvimento se dá através da articulação com o conjunto das ações municipais de alfabetização de jovens e adultos da região, unido ao MOVA Regional.

13) Estabelecimento de programas que visem a integração inter Secretarias e Departam entos, bem como as modalidades e níveis de ensino.

14) Planejamento das ações da Secretaria de Educação e Cultura que garantam a continuidade dos programas educacionais utilizando-se de instrumentos legais, pedagógicos e administrativos, mas principalmente - através da participação dos educadores e da comunidade nos referidos projetos.

SEC.1, em 19 de maio de 1999

\section{ELIANE GOMES QUINONERO \\ Diretora}

Departamento de Ações Educacionais

EGQ/jitc 
ANEXO No. 7

\section{TRANSCRIÇÕES DAS ENTREVISTAS}

\section{Beija-Flor}

A entrevista foi realizada na unidade escolar, onde a educadora exerce suas funções docentes. Duração da Entrevista: 2 horas e 05 min

E: O que você destacaria na sua trajetória profissional como tendo sido determinante para a formação continuada em serviço, desenvolvida em parceria com a equipe interdisciplinar da unidade escolar?

BF: Bom... Em primeiro lugar, no tempo em que a gente está se referindo, a gente tinha uma equipe presente na unidade escolar, então essa equipe fazia várias reuniões, ela fazia acompanhamentos, ela... fazia trocas na verdade com o profissional, dependendo da demanda e da necessidade do professor. Então nessa fase, a gente teve momentos com profissionais específicos, e outros com a equipe toda... Então a gente abordava várias questões, relacionadas ao aluno, a gente teve formação sobre alfabetização, sobre a formação de olhar para a criança em diferentes ângulos, diferente do que tem mencionado, nos diagnósticos, quais são os cuidados, o que a gente tem que levar em consideração ou não... A gente teve profissionais que vieram dentro da sala de aula trabalhar com a gente, e depois a gente conversava sobre tudo que a gente tinha feito... A gente tinha uma gama muito grande de teoria, um leque de enfoques... Então o que foi mais importante nisso tudo, foi assim, a oportunidade de você ter contato com diversos profissionais falando sobre uma mesma coisa que é a criança... Eu poderia, pude é... constituir a criança que eu trabalhava... Entende... Então com várias informações, eu pude fazer o caminho que eu ia trilhar, ninguém falava pra mim que era por aqui, todo mundo falava algumas coisas, e eu ia olhando o que mais interessava para a clientela que eu tava. Isso era muito respeitado na equipe. Então assim, o professor era ouvido... A gente tinha... Tinha reuniões de debate, mas eu acho que a gente tinha muitas contribuições... Então eu acho que, pra mim, em especial, adquiri uma autonomia grande, uma responsabilidade enorme, né pra trabalhar, e um material rico... Né? Algumas dificuldades, muitas... Tivemos, também... A gente tinha sim... A gente achava que o tempo não era bom... Né? ... Sempre faltava tempo... A gente sempre tava falando isso... O tempo é pequeno, a gente não tem tempo para discutir suficiente, a gente não tem tempo pra fazer material, a gente não tem tempo pra refletir... Isso é uma queixa do professor. Mais eu acho que a gente tinha mais... subsídios, a gente tinha onde procurar, hoje a gente não tem mais.

E: Você diz, hoje não tem mais porque, esse processo formativo compartilhado com a equipe foi transformado?

BF: Hoje o espaço formativo com a equipe... Ela é estanque ... Então ela aparece em alguns momentos, muitos momentos, são muito mais administrativos nessa escola do que pedagógico, eu acredito... E assim, sendo uma escola especial, a gente atendendo uma clientela muito específica, até com muitas dificuldades motoras, emocionais... com a família, a gente tem pouco suporte... Então a gente não tem nem um referencial, a gente não tem nem uma leitura citada... A gente tem reuniões semanais, mas elas não são aproveitadas pra esse tipo de suporte teórico.

E: Vamos voltar àquele período. Fale mais sobre as transformações que a proposta promoveu na sua atuação? Como esse contato com uma equipe de diferentes áreas, com diversos profissionais, com saberes tão específicos contribuíam com o professor? Você mesma disse que incorporava essas contribuições, e você mesma balizava isso para o desenvolvimento do seu projeto de trabalho... Que transformações você sente que ocorreram, de forma mais significativa, em você?

BF: Eu acho que é assim... Na minha prática na verdade, eu tinha uma equipe interdisciplinar, que por exemplo, discutia, fazia grupo de família, atendia a família. Eu aprendi, junto com um psicólogo, e junto com o serviço social que estavam lá a, por exemplo, interpretar um diagnóstico e entender o que se dizia e ver por trás, potencialidades, possibilidades, eu também aprendi com a equipe, procurar novos caminhos, com esse aluno, fazendo intervenções que o desafiasse, foram nas discussões que a gente teve, onde estes temas eram coletivamente tratados. Então assim como profissional, mudou o meu jeito de olhar para essa pessoa... É na verdade, eu achava que ele sabia algumas coisas e iria aprender algumas comigo, mas depois eu vi que ele tinha possibilidades imensas, e aí a gente vai apontando isso com um trabalho diferenciado, pois cada criança é uma criança. Então se eu tinha... dez alunos, por exemplo, mas os dez eram diferentes... a estratégia tinha que ser diferente, as atuações tinham que ser diferentes até as exigências... Então eu acho que cada um dentro da minha equipe que estava junto comigo,convergia para este trabalho. Então até hoje eu me recordo e quando acontece alguma coisa: "- Ai se a ....estivesse aqui como psicóloga"... nortearia a gente, e chamaria para conversar alguma coisa, e a gente trocar, e eu ir pra frente "- Ai se eu tivesse o assistente social tal", sabe... Então, isso faz falta... Isso foi o diferencial, eu acho que o que possibilitou para o meu profissional crescer como professora. Quando eu fiquei na equipe, eu fiquei como professor coordenador e aí eu vi que a equipe queria que eu fosse uma espécie de gerente daquela equipe... Que eu os gerenciasse, que eu desse as diretrizes de como a equipe deveria funcionar, de tal forma que cada um deles, pudesse contribuir... No final do ano era muito assim, interessante que eles queriam assim ... Pra onde vamos dirigir nosso projeto esse ano? A gente vai caminhar como? E aí a gente ia discutindo, avaliando...e definindo as prioridades de ação. Vamos fazer um grupo de linguagem com o psicólogo, vamos fazer uns projetos interessantes com os adolescentes e, então a gente acabava se dividindo nas propostas da escola... e a gente conseguia, fazer semanalmente reuniões, avaliando o que a gente tinha feito... $\mathrm{O}$ que a gente não conseguia, porque muita coisa ficava pendente pois o tempo era pequeno para tanta demanda. A gente não conseguia atender todos os professores... sempre estávamos no débito com eles, na verdade e o professor sempre estava cobrando, e ele sempre estava no débito com a gente...também. Mas a gente conseguia avaliar e, eles conseguiam entender aonde a gente estava falhando... A gente, no fim ficava muito preso nas emergências, porque a escola tinha tanto aluno e tantas coisas que a gente acabava trabalhando muitas vezes só na emergência... Mas eu acho, que em muitos momentos a gente conseguiu fazer um trabalho com planejamento e cumprir o que tínhamos nos proposto, em relação ao professor... Então, nós implantamos uma discussão de caso, com os professores, reuniões de nível, ou por módulo, isto é...com realidades semelhantes para haver maior troca entre eles. Contemplando esses professores e a gente conseguia chamar também o professor que estava com maior dificuldade com o seu agrupamento. Mas... faltava muito para atingir aquilo que sentíamos que eles necessitavam, mas tudo isso foi bem interessante, que enquanto eu estava lá mais perto da equipe pude contribuir pois eu tinha a experiência como professor e fazia diferença pois os profissionais podiam entender melhor o lado do professor... Tinham profissionais das diferentes áreas e claro que tinham alguns que entendiam da dinâmica da sala de aula, mas tinham 
outros,que não... Uns eram mais compromissados, outros não... Então, a gente trabalhava com essa diversidade de profissionais também...

E: Como você analisa esta questão?

BF: Tinha essa questão da individualidade, e assim... para contribuir mais ou menos.

$\mathrm{E}$ : Sim, e essa questão das relações, no acompanhamento ao professor do regular como professora itinerante, período que você fez o trabalho de acompanhamento à inclusão... Como foi esta parceria e a relação mantida com os membros da equipe? BF: Bom nesse período, no começo, era tudo muito novo, e no começo estávamos muito otimistas porque havia uma recepção muito boa do trabalho que o Especial estava oferecendo, nenhum de nós sabia ainda, aonde a gente estava pisando, e nem quem iria nos receber, o que a gente estava querendo na verdade.

E: Não estava claro para a escola regular!?

BF: Nós tínhamos uma proposta para o trabalho em parceria com a escola regular... Então a gente chegava e propunha algumas questões, mas a escola tinha inúmeras queixas... um monte de questões, eram colocadas para gente... Para observar outros alunos, não só aqueles que havíamos nos proposto, e trocar idéias sobre eles. É... alguns momentos, no início... Foram bem tranqüilos, outros nem tanto. Tanto que eu fazia assim, quando... no começo, a gente tinha muitas escolas e muitos lugares, a gente se dividia. Tinham regiões muito distantes e aí, a gente podia constatar a dimensão de São Bernardo... a gente falava assim, ah depois da balsa, apesar de distante era mais prazeiroso, mais tranqüilo trabalhar do que ir para o centro de São Bernardo... Porque o pessoal do centro era mais difícil de escutar, mais difícil de trocar e talvez mais difícil de aceitar a inclusão, pois as diferenças eram maiores e os padrões de avaliação menos flexíveis, quem estava muito longe do centro, na zona rural, já era mais aberto... Quando a gente chegava, falavam: "- Nossa, ainda bem que vocês chegaram para falar com a gente"... Então, sentia-se a diferença de recepção...

$\mathrm{E}$ : As escolas mais centrais você sentia que exigiria mais de vocês ?

BF: Sim, porque era nítida a resistência.

E: Você conseguiria explicar?

BF: São muito resistentes à qualquer questão que possa trazer problema às regras, eles querem que você na verdade resolva o problema, eles em geral, não querem tentar junto com você, resolver... Quem está mais longe, quando o professor itinerante chega, a escola quer falar, quer que você escute, e por outro lado ela escuta mais você, ela... encontra possibilidades de trocar, de mudanças para as situações...

E: Estas diferenças tão nítidas seriam devido a que, na sua opinião?

BF: De recursos... De profissionais das equipes do regular, que não vão tão regularmente, por serem escolas muito distantes, pois os profissionais não têm condução da Secretaria... É... naquela época, toda orientação a ser realizada para as escolas depois da Balsa era complicada,não era toda hora, que se conseguia ir pois até os transportes públicos para lá eram difíceis, nem todo mundo queria supervisionar essas escolas... Então de repente, a demanda do centro é que te sugava mais e você acabava deixando de ir lá, onde até trazia mais retorno... Mas, eu sempre achei bem interessante trabalhar depois da Balsa, a recepção era muito melhor... As crianças eram muito mais trabalhadas e inclusive, afetivamente, elas eram mais acolhidas, os educadores tinham uma visão diferente do trabalho com a criança com deficiência. Mas, de um modo geral, no começo as escolas se mostraram muito receptivas... depois que começamos a desenvolver uma sistemática de trabalho, um trabalho mais estruturado, parece que os gestores das escolas quando perceberam que não tínhamos soluções prontas, mas que juntos estaríamos pensando em saídas..e que a escola tinha suas tarefas e nós as nossas... Mas eles não gostavam muito dessa história das tarefas deles... Porque eles queriam, é que a gente resolvesse a questão daquele aluno, que eles já tinham este pensamento que era uma questão que o Especial é que tinha que resolver..... Então isso gerou mal estar, às vezes, alguns conflitos, alguns mal entendidos. Às vezes, as próprias professoras também queriam que a gente oferecesse material, muito material, um monte de material, para ocupar as crianças... E queria que a gente já tivesse pensado como elas deveriam trabalhar... Quando a gente trazia para a escola situações para serem refletidas juntos, o que elas estavam pensando, o que elas sugeriam pra gente pensar junto... elas ficavam muito bravas... E não queriam refletir... então, esse foi um ponto que eu achei mais difícil do trabalho em parceria com os professores do regular.

E: Como esse trabalho evoluiu?

BF: Eu tenho uma análise. Existe uma cobrança muito grande no ensino regular, no fundamental... E na verdade isto faz com que a escola exija das crianças o desempenho já estabelecido..

E:Para todas as crianças?

BF: Pra todas as crianças... Não se considera o tempo da criança, então assim, as crianças têm que aprender, e parece que o ritmo de aprendizagem, ele é desconsiderado... Então todo mundo tem que saber aquilo e em determinada época do ano, então, o professor tem que se virar pra dar conta... Os alunos têm que correr atrás do que era exigido. Nós acompanhávamos alguns alunos com faixa etária bem diversificada, havia crianças muito novas... Outras, um pouco mais velhas e todos tinham que dar conta da mesma coisa. Os alunos, que os professores itinerantes acompanhavam, ficavam anos-luz para trás da sala. Não havia flexibilização de objetivos.Quando nós chegamos, com a proposta inclusiva, encontramos uma coisa só, era tudo homogêneo. Para todo mundo... mas para "os alunos da educação especial", como eles denominavam... não tinham exigência nenhuma... Eles estavam ali... Entende? Então, a gente começou a conquistar espaço para a criança, na conversa com os professores, provando que eles também iriam aprender... Então, fomos analisando com eles, que dentro de uma atividade, que os professores davam os nossos alunos podiam responder de uma outra forma tão adequada quanto... A gente mantinha o acompanhamento, conversando com o professor para ver qual era a reação que o aluno tinha... E a gente ia pontuando outras formas de desenvolver a mesma atividade, como a aprendizagem poderia ocorrer e seus ganhos. Assim, a criança foi realmente conquistando os professores ali... Entendeu? Então era realmente difícil mostrar para os professores, exatamente isso, pois eles, inicialmente, queriam que levássemos um material diferenciado, que fosse confeccionado no nosso núcleo pra ocupar aquela criança... Porque ela tinha que ter uma ocupação... Porque a sala estava lá, e as outras coisas que ela não conseguia, tinha que ser desenvolvida para as demais crianças...

$\mathrm{E}$ : Estas questões eram acompanhadas pela equipe?

BF: A gente discutia em reuniões semanais, a gente trazia para a equipe que nos assessorava... Cada um de nós trazia, para ver, quais os procedimentos de nossa ação... O que ficava mais evidente para a equipe técnica era essa questão da padronização do ensino... A gente acabava se reportando a uma equipe técnica, e ela ficava para fazer essa mediação com o regular... Eu vi alguma coisa diferente, foi... no EJA... É que ai foi um trabalho que já começou por solicitação do grupo para se pensar propostas conjuntas...No EJA as professoras itinerantes falavam diretamente com os professores de sala, porque elas tinham horário já determinado para isto.

E: Nesse acompanhamento ao EJA como você avalia?

BF: Quando eu acompanhei o EJA... Então a gente falava com os professores, e a gente conseguia nas reuniões, encontros, que era possível falar sobre os nossos alunos... como eles eram... Contar um pouco sobre sua história... Quais as suas formas de aprender e que eles também conseguem. Foi interessante porque, mesmo tendo professor que achava que eles tinham que 
ter uma atividade diferenciada pra preencher o tempo, tinham outros interessados em fazer coisas diferentes... Então eu acho que no EJA a gente acabou contribuindo muito mais com a formação, do que no fundamental... Porque a gente tinha acesso direto aos professores e no fundamental era mais difícil de haver espaço. Na verdade, a gente tinha acesso, às vezes, só conseguíamos com o diretor, a PAP, que atendia depois diretamente o professor, por outro lado quando conseguíamos fazer o trabalho diretamente com o professor, raramente as PAP's estavam presentes nas nossas orientações... Nós achávamos interessante a PAP estar, até pra ela poder estar dando continuidade às trocas com a professora.

E: Dar continuidade...?

BF: Isso... Geralmente as diretoras estavam mais presentes, e não havia um acompanhamento da PAP , com relação às crianças com deficiência. Eram transmitidas as orientações e muitas vezes não podíamos acompanhar e trocar com o professor nossas observações da sala de recurso. Na época as PAP's se dividiam, ficavam meio período na sala de aula, e meio período como Professor de Apoio Pedagógico(PAP)... Às vezes a gente chegava na escola para as orientações e não podíamos nem falar com o professor nem com a PAP pois ela estava no período em que era professora e não tinha como sair da sala para acompanhar as orientações. Então, não dava para se saber quando poderíamos falar com o professor se naquele período a PAP da escola era docente. Mas nitidamente aonde eu entendo que a gente conseguiu fazer uma formação ao professor e com um grupo grande, foi no EJA, conseguimos algumas questões, até mudança de visão do aluno.

$\mathrm{E}$ : A estrutura permitia um acesso mais facilitado ao professor?

BF: Sim, no EJA... Tanto que a gente pode planejar um trabalho com o nosso Centro de Apoio em parceria com os professores do EJA, com reuniões de discussão da prática, de estratégias, encontrando juntos,saídas para os nossos impasses, eles eram mais receptivos, para construir novas propostas. Além disso, a gente saía a semana inteira pra rede trazia tudo quanto era queixa dos professores das escolas do fundamental, e muitas questões referentes aos alunos... A gente tinha que ter um espaço de escuta pelo menos... Isso que eu acho importante, porque a equipe oferecia esse espaço de escuta... Pra gente trazer nossas angústias, trazíamos as questões que nos afligia, o que a gente encontrava nas escolas de mais difícil, mas tínhamos a equipe nesse espaço, pra fazer esse desabafo e discutir saídas.

E: Esse suporte... teórico, ajudava a transformar as questões que mais traziam dificuldades para o avanço do trabalho em parceria com as escolas? Como você avalia esta questão das mudanças de análise de como a criança poderia ultrapassar as suas dificuldades... Eram trabalhadas pela equipe, como era a sistemática de trabalho?

BF: Olha... nós tinhamos reuniões semanais... E se discutia alguns textos que eram foco da queixa coletiva... compartilhando as questões que eram vivenciadas pelo grupo, o grupo conversava muito... Trocava muito... E também em duplas... Porque teve uma época que no Centro de Apoio que a gente trabalhava em duplas de professores, que atendiam a mesma região. Era muito interessante esse trabalho, de dupla, porque não é só um olhar... A gente ia trocando nossas idéias, traçando caminhos, então nessas trocas, acabávamos enriquecendo o trabalho... Nas outras reuniões procurava-se trocar questões mais específicas das áreas ... Questões pontuais, sobre a sala de aula, na conversa a gente ia dando um direcionamento... Ou um texto, ou um material pra levar para a escola, para ser discutido... Então, íamos criando um referencial de intervenção na escola e assim, íamos tendo subsídios, na verdade, para levar para o grupo de professores das escolas acompanhadas. Mas, era muito mais nas questões técnicas, nas necessidades do profissional, daquilo que o profissional solicitava... Então era bem voltado para a prática do dia a dia. E também, era assim no Centro de Apoio (Fernando de Azevedo)... quando ele começou, ele começou com poucos professores. E alguns professores mais antigos da rede, da Educação Especial... Então a equipe contou muito com a experiência desses professores, de cada profissional que partilhou este projeto. Mas ficou mais difícil quando o projeto cresceu e com um número maior de crianças incluídas, o grupo começou a receber muitas professoras novas na rede... Ficava muito delicado você acompanhar o processo escolar de uma criança no regular sem experiência de Educação Especial e de ensino regular, sem saber nada da rede de ensino, sem saber como realizar o acompanhamento... o caminhar, então, ficava mais difícil. Daí foi feita uma acomodação, um mais antigo e um mais novo, as duplas que comentei. Pra poder estar trabalhando junto, tivemos que retomar muitas questões que o grupo já havia avançado... Tivemos que voltar porque eram muito importantes, certas questões básicas.

E: Na sua experiência, visualizando esse trabalho que vocês desenvolveram... tanto com fundamental quanto com o EJA, em parceria com a equipe, e também em parceria com o Professor, quais as possibilidades desse trabalho oferecer recursos para o professor transformar a sua prática? E a visão que ele tem sobre a criança com deficiência?

BF: Olha eu acho que com este planejamento cuidadoso, a gente tem uma transformação no olhar, no... pensar... e...quando a gente tem um local que desenvolva um trabalho refletido, quando você tem a possibilidade de refletir, pessoas que falam a mesma coisa...( porque assim, não é só falar uma vez é você estar o tempo todo discutindo), analisando para poder transformar a prática, isso não acontece de repente só de ouvir, e o outro dizer: é eu vou mudar. Você escuta muita gente. Você escuta muitas vezes a mesma coisa, discute e aí você começa a pensar, o que você tem na sua mão. E você começa a pensar... trabalhar... E você diante das dificuldades, que podem sempre ocorrer, você buscar estudar e pensar em alguma coisa mais efetivamente, mais específica para aquele aluno. A gente no fundamental, ia uma vez a cada quinze dias, devido o aumento de escolas para acompanhar. Quando começamos conseguíamos ir uma vez por semana, em cada escola. Depois começamos abraçar mais e mais, em detrimento da qualidade do trabalho, pois éramos poucas para a itinerância e São Bernardo muito extenso, conseguíamos em muitas escolas, ir duas vezes ao mês, quinzenalmente, muito pouco... Pra conversar sobre todas essas questões com o professor, é muito pouco, insuficiente. E o professor por mais boa vontade que ele tivesse, enfrentava pressões avaliativas, exigências do trabalho com a alfabetização e com as operações matemáticas, principalmente, tinham prazo determinado pela Secretaria, para que as crianças soubessem ler até uma determinada data... Então esse professor tinha uma exigência tão grande que, eu acredito que ele não encontrava outra saída, senão, exigir do Especial respostas, para essas crianças.

$\mathrm{E}$ : $\mathrm{E}$, neste clima de exigências como ficava a criança?

BF: É, tinha professor que a gente falava coisas, que ele não acreditava no que a gente falava, entendeu? Tinham professores que acabavam ficando assim... na retaguarda... Então a gente falava, eles escutavam... e a gente achava que assim, não estávamos atendendo esse professor... A gente não conseguia muitas vezes atingir muitos deles. porque não era isso que ele queria. Então,o tempo que o professor sempre fala, é um tempo necessário, porque senão a gente não muda... As pessoas, o pensamento não muda, dessa forma, sem maior envolvimento, o professor teria que ter mais respaldo...porque... imagine como fica a classe com trinta alunos com diferentes condições e o professor se deparar com algumas crianças com necessidades que ele não avalia quais sejam, nós chegamos a encontrar, três alunos nossos, na mesma sala... Com mais trinta, trinta e cinco... Dependendo do lugar... Com exigências assim de tarefas imensas. E os nossos alunos... Os nossos... era assim que eles eram considerados, "nossos"... pintando e bordando na sala na sala porque estavam desmotivados, não tinham uma atenção individual... Não tinham as atividades que, os envolvessem, então, o professor ficava mesmo muito estressado com essas crianças... Então pensar em mudar o olhar do professor sobre essas crianças,exigia de nós uma estratégia muito bem elaborada, às vezes apelávamos para a sensibilidade dele para ver o que a criança estava sentindo nessa situação... "-Olha... É uma criança... Tem só essa idade... Será que se a gente conseguiria fazer alguma coisa dessa forma? Vamos ver se eu 
consigo ajudar para mudar essa situação?... Olha ela está entendendo... Ela está olhando pra você"... Então assim eram coisas tão básicas que a gente tinha que trabalhar... Pra motivar esse professor, o que a gente conseguia dar, era às vezes tão pouco, que eu acredito que se a gente mudou, pelo menos foi fazer o professor olhar para aquela criança...que está lá... Eu acredito que esta professora tem direito de falar, ela merece ser respeitada, como pessoa, e a ela ser oferecida uma formação adequada, sistemática, acho que já foi um grande ganho nosso...

E: Não seria objetivo da proposta, ampliar as ações e trabalhar com todos os segmentos que talvez possibilitasse maiores conquistas, tais como adaptação curricular, avaliação mais flexível, outras estruturas de acesso?

BF: Não, porque, no início, também, a Secretaria de Educação não tinha um planejamento integrado com o Especial, e assim o Especial enfrentava meio sozinho a situação com as escolas. Então as exigências para professor vêm da Secretaria e o diretor executa, exigindo resultados do professor e este, por sua vez, exige dos alunos. São questões, que a gente tem que responder... mas tinham muitos diretores que eram bem receptivos, adaptavam as exigências do órgão central. Assim, desenvolvíamos um trabalho de conquista individual. Trocávamos propostas e algumas coisas, eles iam atrás... não era uma regra, haviam diretores que acolhiam e compartilhavam o trabalho. Faziam com que todas as nossas sugestões fossem efetivadas... E aí, a gente acabava conquistando espaço e provando que aquilo dava certo, e eles se empolgavam pra fazer para outros alunos... A gente acabava fazendo várias barganhas, ou seja, para que um aluno nosso obtivesse alguma adaptação, ou algum recurso, a gente acabava atendendo outros que eles queriam... Porque aí, a gente fazia essa troca de informações.

$\mathrm{E}$ : Parece que diante dos resultados, das descobertas das possibilidades das crianças, o grupo foi melhor acolhido? Isto não significa que a proposta e seus objetivos talvez não estivessem tão claros para as escolas e quais os passos a curto, a médio e longo prazo?

BF: Sim. . Mas para final desse período, mais ou menos 2003, nosso centro de apoio, já conseguia desenvolver um plano mais estruturado com mais clareza das propostas com as devidas justificavas, sendo apresentado ao diretor, tais como,redução do número de alunos, auxiliar de salas... A gente conseguia fazer reuniões com o professor com ajuda da auxiliar, conseguimos que a família fosse mais acolhida e ouvida. Que chamassem mais essa família para que conversassem mais... Para entender a dinâmica da família, e assim... também entender um pouco mais o aluno... Em muitas escolas, isto foi um processo gradativo mas nas escolas depois da Balsa, o processo foi mais rápido, conseguiu-se com mais receptividade. O fato é que fomos conquistando a confiança de todos. Aprendemos muito também sobre o regular e quem era a criança do regular. Mas a criança da educação especial era uma criança que eles foram aprendendo a conhecer...

eu acho que a Educação Especial dentro do fundamental também ajudou...nessa questão de chegar mais perto da criança e compreender o que ela precisa, na questão da família... Nossa! Quando nós chegamos no fundamental, a família parecia que não existia, estava distanciada. Estranhamos muito, porque estávamos tão acostumados a atender família, a chamar a família, acolher, escutar... perguntar um monte de coisa, ajudá-la, acabar sendo até um pouco íntimo daquela família. Eles entenderam essa necessidade de acolhimento e muitos diretores começaram a atender família com a gente. Eles queriam saber como fazer, como lidar com o tema deficiência, com a família. O acolhimento da família eu acho que também na educação especial, no currículo é importante saber... atender, acolher, E que a família tenha a escola como parceira e não um lugar que só cobra... E os filhos não têm lugar que os entendam...

E: Vocês acreditam que esta parceria criou possibilidade de se rever concepções, sobre a criança, família, entre outros aspectos?

BF: Eu acho que muitas coisas... Não sei se assim, se a gente conseguiu no todo, mas... por exemplo... uma criança que não conseguia associar as suas necessidades de evacuação no local da escola, próprio para isto- o banheiro e fazia em qualquer lugar da escola. Isto causou muitos problemas e a criança começou a ser muito discriminada, na escola. Achava-se que a criança estava agredindo... que a criança era mal-educada... na fala de professor...Conversando com a família pudemos entendê-la e descobrir que na casa da criança não tinha vaso sanitário... Todo esse trajeto valeu à pena... porque em várias questões de procedimentos para os alunos com deficiência que estavam sendo incluídos o caminho serviu também para os demais alunos da escola. Então, muitas escolas, a partir dos atendimentos familiares, conseguiram mudar o olhar. Ficamos até marcadas no bom sentido... eu achava engraçado, que algumas escolas quando a gente chegava, a diretora já falava : “- Olha já chamei a família... Já conversei com a família... Tem isso, isso e isso..." Mas isso dependia muito da sensibilidade dos educadores e da sua disponibilidade, não era uma regra incorporada, ainda.

$\mathrm{E}$ : Todos estes aspectos foram sendo compartilhados com a escola de forma mais ampla, principalmente com o professor?

BF: No começo...a gente achava que era extendido, através da PAP e do diretor mas nem sempre e muitas vezes o professor não sabia de nada... Então a gente começou a fazer umas reuniõezinhas com os professores mantendo uma pasta de orientações realizadas, com essa dinâmica... contendo as informações mais importantes, que tinham que ser socializadas, melhorou.

E: E os espaços formativos para os professores?

BF: ... O HTPC raramente a gente podia utilizar pois era utilizado para uma formação mais geral, para as demandas da escola.. Algumas escolas tinham disponibilidade de colocar um inspetor na sala... para o professor ficar com a gente discutindo as situações, mas não era o ideal pois as crianças ficavam sem um professor efetivamente... Então a gente sempre conversava... a primeira vez com o diretor... e íamos acertando possibilidades com ele. Porque se a gente tivesse um espaço de pelo menos uns quarenta minutos para ficar com o professor da classe, não era suficiente, mas já ajudava... Foram conquistas pequenas, mas conseguimos cavar um espaço onde, às vezes, chamávamos todo mundo, num espaço tão pequeno de tempo para falar tanta coisa ... Como itinerantes em 2000, conseguimos ser mais presentes nas escolas, estreitando esta parceria com as escolas do ensino fundamental, sentíamos mais atuantes e podíamos acompanhar os alunos com mais eficiência e o professor sentia-se mais acolhido, cúmplice do processo. As trocas eram mais acertivas e sistemáticas, facilitando a criação de confiança e crédito nas orientações feitas pelos professores da Educação Especial. Quando o número de alunos aumentou, a sistemática sofreu uma queda, aliada às exigências de crianças alfabetizadas até setembro de cada ano em setenta e cinco por cento da classe. Todas as ações avançadas em relação à criança com deficiência ficou em segundo plano.

E: Nesse processo formativo em parceria com a equipe, você assinalou vários caminhos percorridos, que esta formação possibilitou. Quê pontos você acrescentaria nesta dinâmica formativa?

BF: Só que assim... A gente tinha o tempo para refletir mas nunca era suficiente, e às vezes era igual o professor do regular, que queria, também respostas imediatas...e nem sempre se teve espaço suficiente para a equipe acompanhar tudo. A equipe daqui ela falava quando conseguia, quando não conseguia... dependendo do profissional..que estava fazendo parceria com você tinha compromisso. Outros não, a pessoa ia fazer um estudo, e vamos ter uma devolutiva... mas dependendo do profissional você tinha que ir por outras vias...Você vai conversando com outro profissional mais próximo para poder ver se a questão era resolvida...

$\mathrm{E}$ : Você avalia que isto se deve ao planejamento, à sistemática de trabalho 
BF: Tinham plano de trabalho pra ser efetivado,mas no que se refere às emergências, ou as situações problema que aparecessem na escola para resolução mais imediata dependia do profissional... que se envolvia, às vezes dando conta até de responsabilidades de outros... Porque às vezes, como o profissional dava conta.... aí a gente corria para aquele profissional... Então de repente, era uma questão específica de uma área, mas ele não dava conta... os professores, então, iam para quem era mais disponível e resolvia. Que ia batalhar pela suas dificuldades. A gente sempre teve nítido, alguns profissionais estavam sempre sobrecarregados... e outros profissionais que não estavam... comprometidos, ou assim, que se perdiam na ação.... Na verdade, eu vou acreditar que eles se perdiam. Tanto que nas avaliações do final de ano que a gente sempre fazia, a questão era muito difícil falar para a equipe...como um todo. Se você perguntasse: "a equipe funcionou?" A gente falava: “- Ahh... É muito difícil de falar"... Porque aí, às vezes vai falar que não funcionou? Porque a grande maioria dos problemas que não se discutia era porque, se você tinha sete profissionais, três trabalhavam... davam conta da questão... Então ... muita coisa ficava pra trás...Então as avaliações acabavam sendo pontuais até por uma reivindicação dos profissionais da equipe... Porque quando se começava, a fazer a avaliação... e eram abordados pontos negativos, os profissionais sentiam-se muito incomodados. Então era melhor a gente começar a pontuar melhor...

$\mathrm{E}$ : E você acha que essas avaliações traziam efeitos positivos no redirecionamento desse trabalho da equipe?

BF: Eu acho que nos últimos tempos, que aí eu fiquei com a equipe como professor coordenador... a gente conseguia fazer uma leitura mais equilibrada dessa avaliação, juntos você recebe todas aquelas críticas, todas aquelas questões e aí partir pra uma ação, pro próximo ano... Que assim... No final do semestre, a gente fazia semestral na verdade... Então a gente... para o próximo semestre agente redirecionava... questões mais importantes... Uma das coisas mais legais que eu gostava, da equipe era que a gente conseguia ler essas avaliações... E pontuar, sabe? Para cada profissional... onde pesou... E o que eu posso tentar resolver, para o semestre que vem... Como que a gente vai fazer nessa direção. Esse exercício a gente fez muito... só que muitas vezes, a gente não conseguia fazer... pois a demanda de Secretaria... acabava desfocando para outras questões... A gente acabava não conseguindo fazer esse paralelo... mas procurávamos ficar mais perto dos professores que estavam com mais dificuldade, que precisavam mais da equipe próxima... Eu acho que quando a Úrsula veio fazer a formação dela... com um jeito de formação diferente... que era falar, sentava no chão com o professor, conversando, atendendo, e aí depois que a gente falava muito de... com outros professores de ser verdadeiro...eles desconfiavam das possibilidades e diziam: "Não adianta ter um monte de teorias que não tem nada a ver comigo"... "Eu quero saber é lá na sala de aula... E a Úrsula veio exatamente pra isso... Pra saber lá na sala de aula, toda aquela teoria"... Pontuando com o professor, ou com um grande número de professores... aquelas questões que a gente visualizou naquele lugar, naquele espaço... Então a gente conseguia mais estar lá com o professor, tentando chamar o professor pra sala, sentar lá junto com ele... Isso a gente conseguiu fazer com alguns professores... Eu lembro que alguns professores que agente fazia discussão de casos... Eles falavam assim: "- Nossa, eu nunca imaginei que esse aluno tivesse tantas questões, tantas possibilidades" Então eu achei que essas questões foram interessantes. Eu achava sempre que a equipe... não dava conta...? Eu não sei o porquê a gente acha essas coisas... Mas enquanto equipe a gente tinha muita dificuldade... para fazer a equipe andar como a gente planejava...

$\mathrm{E}$ : Diante dessas dificuldades como a equipe viabiliza respostas para poder efetivar o planejamento?

BF: É... Eu acho que, a equipe acabava girando em torno de uma área... Geralmente era a pedagogia... E a gente traçava todas as questões do que vamos trabalhar... E aí dependendo dos profissionais, a planificação fluía... Outros... na verdade exigia uma coordenação mais direta... às vezes o profissional não sabia nada daquela criança, então a gente dava umas pontuadas, nessa questão... mas, precisava de um coordenador, porque a equipe... não conseguia ter a maturidade de estar trabalhando para um objetivo só... e corria-se o risco de ficarem cada um na sua, fazendo como um todo... A gente não conseguia sair do multi... Sabe... Era cada profissional com seu saber, contribuindo, ali na hora, a gente não conseguia convergir, ser um pensamento nosso... A equipe tentava trabalhar nessa questão da "Inter"... por exemplo, não tinha, aquela coisa de ... Ah! então eu sou psicóloga, e a psicóloga não podia falar nada de pedagogia... Não tinha isso...a gente compartilhava as questões, então, quem tinha um saber a mais para compartilhar sobre aquela situação, contribuía mais...e isso era respeitado...

Hoje parece que aqui nesta escola retrocedeu, cada um só fala da sua área: se vou falar sobre linguagem, eu só posso falar com a fono... Aí você fala: "Pelo amor de Deus... Quando a fono não está, eu falo com quem?" Então assim, está muito mais compartimentado, do que antes... E antes eu achava... que a gente era multi... Então assim... eu acho que a gente era um multi, mas tendendo à inter. Entendeu? Trocava-se mais... a equipe era mais autônoma não precisava de coordenação, mas a gente andava mais
menos
juntos, a gente discutia mais juntos e além disso tinha reunião pedagógica... com o professor, onde toda equipe estava porque a gente achava que várias cabeças, vários, profissionais iam com aquele professor de uma forma melhor do que ele estar falando individualmente... com cada profissional... A gente acabava ganhando um tempo grande... e trocando muito mais... Então sempre conseguia-se que o profissional desenvolvesse com o professor algumas propostas e resolvesse seus impasses. Ou, um atendimento, porque o professor também, ele precisava de um respaldo pra poder atender essas famílias. O professor pensar numa reunião de pais, analisar as questões que seriam importantes trabalhar com a família, ouví-la, orientá-la, revelar os pontos positivos do filho ..., uma escuta dessa família... que trouxesse mais dados pra você trabalhar as questões do aluno... então, a gente fazendo junto...o professor, muitas vezes o professor, falava assim: "- Nossa, eu vou, eu vou fazer minha reunião de pais diferente agora..."

E pensar em outras questões de pais... que não seja de resultados de sala de aula, porque... o grande nó nosso era trazer resultados de sala de aula, e alunos que realmente não estavam ainda com uma evolução muito evidente você poderia desestimular os pais.

E: Na questão da família como exemplo que você traz... que transformações você destacaria nesta formação que foram essenciais para o trabalho do professor?

BF: Bom, eu vou explicar como professora, eu acho que é bem isso... Você tem uma criança que chora o tempo todo... Que grita o tempo todo, e aí você não entende por que ela faz isso... Aí você fica com ela um tempo, e ela continua... Você fica, e ela continua.... Quando você começa a atender a família e começa a ter mais escuta do que ela traz... Então se você escuta mais, e você se coloca como alguém próxima dessa família... ela fica mais aberta... Então, isso eu aprendi, fazendo atendimentos com a família...e com um profissional diferente da pedagogia... Porque a pedagogia não dá esse suporte, a faculdade não dá isso, então se você faz um atendimento com uma psicóloga... E você escuta o que ela fala, como ela faz com os pais... depois que o pai vai embora, você troca figurinhas com esse psicólogo... Ela vai traduzindo algumas questões que você observou também... Então assim, o seu olhar vai ficando mais apurado... dá uma outra possibilidade... para você... você abre um leque grande... de possibilidades de olhar essa família... Então eu acho que os profissionais, contribuem muito... quando fazem um atendimento de família com você... com o olhar de vários profissionais... este conhecimento pode oferecer informações... que não seriam estanques... não fechariam a minha ação com ele, por exemplo, o diagnóstico inicial pode funcionar como um instrumental que podia vir a dar idéias... hoje... o professor fica sem dados da criança, de suas necessidades, a gente recebe uma criança sem nada... recebe com um levantamento de dados... e assim alguns aspectos 
específicos você não tem como avaliar, se ela por exemplo precisa de adaptações, uma alimentação diferenciada.... Não temos mais nenhum dado dela, você tem que procurar em um outro lugar... Acho que só um formulário só de dados iniciais, parece uma escola de fundamental, onde a criança dá o nome, endereço, CEP, telefone... uma pessoa de contato... parece muito isso.

$\mathrm{E}$ : As questões citadas como necessidades educativas especiais não são apontadas para o professor?

BF: Não, são apontadas muito sutilmente... Muito sucintamente...

Então assim... Se ela manteve contato...... Se ela entrou na sala... Se a criança teve possibilidade de trabalhar com um material mais estruturado ou não... Então assim... É muito estanque... Muito pequenininho... O que traz pra gente... Aí você sabe... Você começa do zero... Até por que essa criança vai fazer parte de um grupo... Você como profissional precisa de alguns dados... para continuar trabalhando... para entender um pouco aquela criança... para entender um pouco a dinâmica da família... Você acaba criando algumas estratégias... mas não que tenha como orientação, você investigar mais, você entrar mais a fundo nas questões dessa criança... Isso é como eu falei que era antes. Você pega um estudo bem feito você fala: “- Nossa, as crianças gostam disso, e disso... Então eu vou propor certas atividades... Gosta de brinquedos estruturados... Ele sabe brincar... Vou, começar com uma caixa, com alguns brinquedos interessantes... Estava escrito lá, quais os brinquedos que ele tinha preferência... Acabava colocando aquilo... desafiando... Hoje tudo é novo, aí você escolhe uma caixa... você sabe que ele gosta de brinquedos, porque a faixa etária é pra isso... mas você vai tateando, você vai pesquisando e a sua investigação é muito maior na sua responsabilidade... Você acaba tendo que procurar caminhos pra atender essa criança...

$\mathrm{E}$ : Você comentou que no período de formação você teve maior contato com uma equipe interdisciplinar...e isto lhe proporcionou maior conhecimento, abrindo um leque de possibilidades para compreender a deficiência. Como foi isso? Como isso era tematizado..

BF: A gente tematizava esse grupo... É... A gente, tinha até HTPC naquela época... Então no HTPC, quando ele veio... Ele veio num formato que a gente conseguia, ser mais flexível... A gente na verdade, antigamente a gente era mais autônomo. A Equipe era mais autônoma... Mas ela conseguia fazer algumas coisas, que por exemplo hoje eu analiso e... não vejo mais.... Ela era uma equipe que começava lá da sala dos técnicos, passava pela direção, e chegava no professor como equipe. Porque ainda tinha aquela questão da equipe técnica, com a direção, e os professores... Dois grupos separados... Mas assim, a equipe conseguia dentro da dinâmica da escola, cavar vários espaços..e furar isso. É inegável...esta contribuição da equipe. Então por exemplo, a gente sentia necessidade de módulos iniciais, de ter algumas questões mais específicas, com os professores... Então a gente via possibilidades de que a gente fosse instrumentalizado. Eu lembro muito assim, dos psicólogos fazendo vários bonequinhos, fazendo uma cena... para gente poder trabalhar algumas questões de relacionamento com os alunos... Como que a gente podia abordar... Isso, prendia a atenção dos professores, e eles conseguiam depois... Escutar a teoria, fazer uma relação, fazer uma reflexão do que eu faço... Como vejo?... Isso é muito mais efetivo. Era muito mais efetivo e aí, a equipe percebeu que era desse jeito que tinha que fazer... E ela fez bastante... Eu acho que ela fez bastante. Mas... Também, eu acho que ainda falta, porque assim, é uma gama de atendimentos grandes, nós temos uma complexidade de questões. E naquela época, que eu me lembre, que me marcaram, que foram importantes, eram dias que eu realmente saí da escola e, aprendi, refletia, e hoje, por exemplo, quando eu escuto algumas questões... eu penso a gente precisa de novo esquematizar daquela forma, parece que os problemas não são mais da responsabilidade da escola Antigamente quando a criança voltava para nos visitar, todo mundo se entusiasmava. Isso era importante, porque assim, a gente teve um caminho, a gente deixou alguma coisa importante, a gente foi o porto seguro pra ele... E hoje, com uma equipe nova... toda nova... a gente escuta isso, do tipo assim... Parece que ele fez uma tarefa, acabou, guarda, e a gente não quer nunca mais saber sobre aquilo... Então, isso é uma coisa que me dá saudade...Eu acho que as relações eram cuidadas... antigamente. A equipe técnica fazia isso... Então de repente, tinham alguns profissionais que não estavam muito legais... Você via que haviam professores que estavam desmotivadas, ou muito bravas... E a equipe tinha um espaço de escuta pra essas coisas, nessa situação... Hoje eu vejo que assim, a gente pode ficar brava... Pode ficar nervosa... Pode ficar desmotivada, que você tem que se virar.Então, essa é uma coisa que eu também sinto saudade... De uma equipe mais próxima. O professor com professor, ele não consegue fazer isso. Um cafezinho não dá tempo... um cafezinho você dá uma respirada, para continuar... Você não tem um espaço onde você possa conversar algumas coisas, que te alivia, e acaba ficando mais pra frente.Isso... mas as tematizações eram interessantes....E o que mais dispersou o grupo, eu acho... foram as benditas metas da secretaria... Nossa!!!... Parar um HTPC pra falar de metas da secretaria... dos cadernos de metas...o pessoal queria morrer... morrer... porque as metas eram umas metas que a gente não conseguia atingir... A gente não conseguia entender às vezes, as metas...

E: Você acha que a secretaria montava um o caderno de metas muito distante da realidade da escola ?

BF: Muito distante... Exatamente. Muito distante da escola... Eu achava que a direção não tinha um papel de, vamos dizer, trazer a escola mais próxima dos cadernos de metas... ou, trazer esse caderno de metas mais próximo da realidade, ele era considerado um fardo na verdade pra qualquer profissional... Eu acho que é assim... até os Diretores mesmo falavam... "Ai, a gente tem que avaliar o caderno de Metas"... Eu achava aquilo pesado... Aí, a tarefa já vinha com essa fala... E aí, a gente também não se atentava... porque a gente poderia sugerir... poderia estar complementado... Implementando... Não tinha essa informação... Então, a gente acabava escutando aquilo... Às vezes você não prestava atenção e, voltava... como uma coisa que você estava perdendo tempo, na verdade. Foi nessa época, que teve professores que falavam que o HTPC era hora de trabalho pedagógico perdido... Alguma coisa assim... Sabe? Alguma coisa assim, porque o diretor gastava muito tempo tratando do caderno de metas...

E: As experiências que você teve possibilidade de compartilhar com a Equipe tanto na escola especial quanto dando acompanhamento à Inclusão do ensino regular possibilitaram grandes avanços. A que você atribui esta transformação que parece unir o grupo?

BF: Você conta com profissionais...para um mesmo sentido. Os projetos eram correlacionados, por exemplo : Vamos abrir a escola, passar os muros! Tínhamos suporte O que tem pra lá? O projeto era do professor ainda... porque a equipe contava muito com o profissional que estava lá. Isso ainda é um grande nó dentro da educação especial... Então um professor anda com os alunos pela redondeza, faz estudos de meio ,mas ele precisa de estrutura, que muitas vezes não está disponível. Então... Não adianta você falar vou trabalhar um mercado com um aluno de 20 anos... Eu vou trabalhar o supermercado com ele? Não! Eu vou ao supermercado com ele... Isso é uma estratégia do professor...Sair na rua com o seu aluno? Assusta qualquer profissional... Porque ele tem que ser um profissional desafiador . Você conta com você... Com o que você ensinou... Com o que você trabalhou com os seus alunos. Você conta com tudo isso...Então está em xeque... a visibilidade que teve o seu trabalho... e você ter uma parceria com essa família... Porque você vai pra fora da escola... Então, você tem que ter o aval dessa família e elas apostarem nesse seu projeto... É muito legal também... cansa, é exaustivo... Porque tem problemas... Então imagina assim, nessas calçadas maravilhosas... Você andar com uma pessoa que tem miopia em alto grau. Que tem dificuldades motoras, para que essa pessoa, vá e volte sã... Porque assim... Então assim, essa responsabilidade faz com que a pessoa se ressinta...porque nem sempre se tem alguém que banque com você. A administração tem que bancar tudo isso... 
Tem que bancar um atraso seu na rua... Tem que bancar que você, que aconteceu alguma emergência... Oferecer recurso... A equipe, ela tem te dar um respaldo... De você ter tempo pra procurar lugar... O tempo pra fazer contato, o tempo pra fazer reunião de família... O tempo pra você trabalhar com esses alunos... Porque você vai sair da escola... Surpreende porque você vai passar uma imagem dos alunos de conquista ... E você precisa de alguém para estar com você... Pra a hora que você olhar... a pessoa faz assim pra você... Tudo bem? E você continua... fortalecido. Com a equipe naquela época, A gente achava interessante...o projeto e a equipe acabava contagiando os professores, até porque a gente contava com todos os profissionais... para estar junto no projeto... Então para as saídas... não precisava ser "a pedagoga", " a orientadora"... podia ser a assistente social... podia ser a fono, quem estivesse lá... naquela agenda, quando fosse planejado, e tivesse disponibilidade do tempo... Aí ia lá e inseria no grupo... então aí ela tomava parte daquilo, fazia todas intervenções... Ficava junto do planejamento... Junto com o professor... A equipe mudou... e assim, a Educação Especial, ela ultimamente tem mudado muito...está perdendo o seu específico. Então, se você for pensar na formação... Ela tem que pensar nestas questões, desde a direção que desconhece estas questões até a equipe e os professores... Quando os diretores novos começaram a chegar que vieram do Fundamental... Que vieram pra nossa escola... A gente tinha uma equipe técnica mais voltada para o contexto escolar... A gente era dessa escola da educação especial e o diretor tinha experiência com Educação Especial, mas agora... a gente acolheu esse diretor... contou para esse diretor o que agente fazia... o que era importante e como a gente entendia isso... a equipe técnica mudou... não fez mais essa ponte com os diretores... e os diretores pensavam que eles eram uma parte, um profissional à parte da equipe, e aí começou a esbarrar assim... Do que é meu, e o que é seu... num descompasso muito grande... E aí, então esse projeto não consegue andar mesmo.

E: Voltando nas questões formativas que você compartilhava com a equipe, como você analisa as condições proporcionadas para melhorar a prática?

BF: Qual foi o momento em que eu tive mais formação... Porque eu acho que esses dois anos em que estou na sala de aula, eu não recebi uma formação... Eu tava falando esses dias... Gente, quando eu estava na equipe técnica... Eu fazia no final do ano, uma pastinha assim... de textos, essas coisas assim pra você ativar e deixar lá... Em dois mil e cinco, quando eu fui para a escola em sala de aula... Eu não recebi nada... Então assim... Não tinha pasta, não tinha nada... Em dois mil e seis também não... De dois mil e cinco para dois mil e seis... De dois mil e seis para dois mil e sete... Então assim, é o subsídio, ele vem pouco pro professor, e ele se ressente disso... de questões teóricas... Ou de um... Olha tem um texto interessante, eu vou deixar aqui para quem quiser ler.... Porque tinha antigamente umas pastas em cima da mesa... Porque assim, mesmo que não desse tempo em HTPC, para passar... Era xerocado... E ficava em cima da mesa... Quem tivesse tempo tava olhando... Tinha possibilidade... Hoje nem isso tem... Não tem material... A gente brigava por uma biblioteca do professor só... Hoje ninguém fala nada disso entende... Tudo é coletivo, tudo é de todo mundo... Não tem... Então assim, parece que falar de específico, e falar de uma coisa mais reservada é um palavrão... Entende? Parece que você quer ser clínica, ou que você quer ser médica, quer ser alguma coisa assim entende?... Não entendem que você precisa de um material específico... Aí em contrapartida falam pra você assim... Que você tem que se adaptar a um material de grande porte... Aí você fala: "-Isso eu tenho desejo, mas eu não sei, dá pra você me ajudar?" Porque você não tem nenhum material... Nenhuma formação... Nenhum papel te falando como que você consegue fazer uma coisa dessas... Então ... Eu acho que naquela época a equipe era bem... Assim... Tinham coisas muito estanques também... Tinha lá falando que você que tinha trabalhar de tal forma... Eu lembro de uns planejamentos que tinha haver... Que eu fiz: "- Olha o planejamento da sua sala, do seu módulo..." Né? Tinham essas questões, só que assim... A gente acabava vendo aquilo... E a gente ia conversando que aquilo não era legal... Desse jeito não era... Aí você acabava reformulando... Com sua prática... Hoje não tem nem isso tem... A gente não tem nem um norteador... Então às vezes eu falo assim... Olha a gente tem um material... Que fala sobre brincadeiras... Vamos ver? Nossa que legal...O material que você tem! Mas o material era da professora Úrsula, da assessoria... Então assim, os antigos receberam, quem foi embora, levou tudo... E quem está aqui não se apropriou... Então é uma judiação, eu acho! A gente acaba... Não dando continuidade, para os ganhos que se teve. Os profissionais mais novos, eles vão precisar dessa formação. Nem a escuta das necessidades... porque agente não tem espaço pra falar! Então o HTPC é completamente administrativo... E quando não é... deixa-se um tempo de planejamento... mas que é tomado, por outras questões e não para as necessidades da sala de aula. A gente recebe alunos com muitos comprometimentos... E o que mais assusta quando a gente recebe alunos agora é a tal degeneração... pequenos, novinhos... E uma degeneração em andamento... muito rápido... Essa criança que... no ano passado andava, que nesse ano já está em cadeira de rodas... E daqui um mês, está disfágica talvez... O que a escola vai fazer de importante para ela? E vai deixar coisas boas pra essa pessoa, nesta condição? Aí fica todo mundo pensando... o que que é um pedagógico para a criança? O que eu posso contribuir para uma criança com esse quadro, tão grave? Então eu acho que... toda a formação que eu tive... e que eu tive a felicidade de estar em contato com vários profissionais, faz com que eu consiga... olhar aquela criança... e consiga entender que ela precisa vivenciar em um espaço agradável... Porque eu lembro da minha escola... Como escola dita de crianças felizes... Que elas vem pra cá porque é uma coisa gostosa... Elas vem sorrindo, então... Pra essas crianças também tem que ser um espaço gostoso de acolhimento... Pra estas famílias também.. Então... A importância da família... Se já era importante para aquela clientela... Hoje é imprescindível! É imprescindível: a escuta, o colo, a cumplicidade com essa família...É assim... Saber que isso, é vital... Eu tenho vinte e quatro anos nessa unidade escolar... Então... De todo tempo que eu tenho... poucos óbitos eu presenciei... do tempo que estou aqui como professora... Dois anos que eu voltei, vários óbitos... então é uma coisa... que a gente não está acostumada... Então olhar essa criança como potencial... que ela tem... Tentar procurar o máximo de coisas, que ela possa estar ganhando aqui, ou seja... estar mais atenta, mais acordada, mais alimentada, mais aconchegada... com estímulos visuais, sensoriais... Essas questões eu acho que são importantes para ela. Isso eu consegui visualizar com a formação específica... com a formação de uma criança muito pequena... com a formação para ver a família, de uma forma diferente... E não ser só a mesma pessoa que tem que fazer tarefas, $\mathrm{E}$ eu falo... E eu tenho que estar junto com ela... Ensinando essa mãe também... Sendo mais parceira... Mais competente, tanto para esta criança... quanto para esta família... Faz uma diferença muito grande pra mim... Então eu consigo, entender que trocas de fraldas, é minha tarefa sim... porque na troca, eu pego nessa criança... eu aconchego, eu falo dessa perna, do pezinho, de um monte de questões dessa criança que nesse espaço pedagógico eu posso oferecer pra ela... Então só consigo ter essa tranqüilidade... porque eu fiz formação anterior, porque as outras pessoas que estão chegando agora... Elas passam essa atividade para auxiliares... Então ela... não se apropria disso e o espaço da troca, e o espaço da criança lá bem pequenininha... que você olha pra ela, e ela presta atenção pra você... você põe uma música, você toca nela... você fala das partes do corpo dela, você fala da roupa... dá informações pra essa criança... Isso é pedagógico pra essa criança... Talvez não seja pedagógico para um aluno mais velho que já sabe ir ao banheiro tranqüilamente. Então... isso é toda a formação que eu tive, todas as questões que eu tive... durante todo tempo, aqui nessa escola... me deu base para isso agora... Também me deu base pra ficar questionando... Então é aqui mesmo que ela tem que estar? Não vou nunca falar que ela não pode estar aqui, enquanto eu não achar que, é isso mesmo... Questiono quais são as propostas que vamos oferecer para ela? Como a gente vai fazer? Eu vou oferecer alimentação junto com todo mundo... Se ela come de seringa...? Então se é legal para os outros, é legal para ela? Ou ela precisaria de um espaço mais reservado, porque a atenção dela é tão pequena, que ela não 
sabe se ela escuta o barulho do refeitório, ou se ela come... Aí assim... O comer é importante para ela... então a gente tem que garantir isso... então são coisas que a gente tem que estar levando em consideração, pois esperam isto de mim porque... a gente tem uma visão diferenciada... e está ali para isto.

E: Você diz então, que a infra-estrutura pra essas crianças com necessidade, precisam ser revistas?

BF: A infra-estrutura, o acolhimento, a atenção...tudo a gente abriu a porta da escola... só que a gente abriu nos moldes de uma criança que tem condição diferente, de ficar cinco horas aqui suportando transporte. Criança que usa cadeira de rodas o tempo todo, que precisa ser tirada para descansar, vem com um transporte de uma hora e meia, fica no período intermediário na cadeira de rodas... então, ela não vem para um espaço que ela possa deitar... não tem uma música, ela vem numa mesma condição de criança mais estável, sem tantas necessidades específicas, inclusive motoramente... Então... a gente precisa realmente, parar e pensar sobre aquilo que devemos oferecer para elas. E esse oferecimento que temos, isso é uma coisa que a gente está questionando muito... porque a gente não vai negar vaga, e a gente não vai negar atendimento... só que eles precisam de coisa melhor... porque a gente é uma escola especial... se a gente fosse uma escola comum... que não tivesse nenhuma informação... e ainda... estivesse há décadas para oferecer atendimento para essa criança... seria, nossa!!! que bacana essa escola! Só que é nosso dever hoje. Nosso dever está lá na lei que ela pode vir para cá, e deve ser atendida bem... A gente só está deixando entrar... Então a gente tem como escola especial, e como professores habilitados, que oferecer condição adequada para isso... e a formação que nós tivemos naquela época ajudaria o professor de hoje pensar nestes aspectos essenciais. Algumas coisas me incomodam muito, nessa escola hoje... que parece que a gente invade... Então esse... descompasso que eu entendo, do novo e do antigo... Então as professoras antigas, elas preconizam algumas questões... Aí então isso é tido como uma coisa ultrapassada... ou porque hoje, o importante é só a leitura, e a escrita... Porque a gente precisa fazer da escola especial, uma escola! E isso é uma fala que me incomoda, porque eu sempre achei que uma escola especial fosse uma escola. Mas agora parece que uma escola é aquela que tem leitura e escrita pra todos os lados e não produções... Porque se você tem produções, o aluno está sendo trabalhado, em todos os aspectos só que ele tem um caminho pra isso... Eu fiz uma avaliação diagnóstica quando eu o recebi... eu sei o que eles conseguem fazer...... E ai agente vai caminhando... Então o pessoal pode falar dessas questões ... E ai eu argumento, e chamo para ir à minha sala ver as produções... Que assim, eles não estão lá só por estar... Eles estão sendo toda hora desafiados... Só que hoje... depois de um ano e meio com minha sala da manhã, eles sabem que o lápis é para desenhar... Que o papel é pra desenhar. Que tem figuras que eles podem colar, que a cola é pra colar... Porque até então... eles estavam em outras exigências, eles precisavam de outras coisas... Então hoje eles não comem cola, eles não comem tinta... Eles brincam com isso... Eles não estão usando isso, como estratégia para alguma outra coisa... Eles tão brincando...e de acordo com o meu planejamento... E eu sempre fui chamada, e sempre com a pergunta das letras, das palavras... E sempre que eu argumento que os meus alunos estão nessa faixa e estão caminhando...então na leitura e escrita.... eles estão fazendo esse tipo de coisa, eu não estou oferecendo a leitura ainda, até porque na sala tem meu nome, tem o nome deles no papel, e o que eles conseguem... é identificar... como se identifica um lápis, um brinquedo, um desejo....Então está lá, mas o que está sendo trabalhado, é anterior a escrita...

$\mathrm{E}$ : Como você concebe este processo de desenvolvimento?

BF: Então você tem que fazer atividades interessantes, e fazer intervenções, desenvolver uma rotina bem estruturada pra eles... e desafiá-los... Eu acho que o grande lance é... desafiar o aluno sempre... Então isso, eu acho que dá a diferença do aluno, então em um ano... com intervenções interessantes, com desafios e com rotina... Ele apresenta produtos completamente diferentes, do que você espera, não esperar ele estar "pronto para"... Ele precisa sim, até porque eu acho que o tempo corre contra eles... porque assim... quanto mais tempo vai passando, e menos ele faz... ele vão ficando apático... você tem um instrumento que é a sua intervenção. É o faz a diferença para o nosso aluno, não adianta.... a gente esperar o tempo dele, que não aparece. Eu tenho um exemplo bárbaro pra dar... O ano passado com os grandes, numa faixa etária de dezoito anos a vinte e quatro anos, que era a minha sala, a gente estava na rua andando, era uma saída pelo bairro... e ai a gente passeava muitas vezes e acabava pegando vídeo na locadora, tirando xerox, no xerox do bairro... E ai, eu falei que eu queria ir até à locadora, buscar um filme, porque a gente ia ver um filme no dia seguinte... Ai eu perguntei quem queria, me levar na locadora? Porque já fazia o que?... seis meses que a gente ia e voltava... Aí um aluno falou que ele poderia ser guia... Então vão ser dois guias, vocês vão ter que trabalhar entre vocês... escolher qual é o melhor caminho, pra esse grupo ir, e aí minha responsabilidade era levar esse grupo até a locadora, sem ninguém se machucar, então, passando por faixa... de pedestre, aquelas coisas todas, porque eles eram os responsáveis... Foi muito legal porque assim... a gente andou, andou... a locadora estava ali no meio e a gente não chegava nunca na locadora.... fizemos uns caminhos muito loucos... de repente um aluno falou assim... a gente está perto da locadora! Aí eu falei.. como você sabe? porque este prédio é do lado da locadora... Aí eu falei, mas como que a gente vai chegar? Porque a gente está a pé! Aí ele começou... Não! Eu acho que a gente já passou por essa escola... E se a gente já passou, agente veio ao contrário. Sabe assim, ele começou a traçar o caminho e estruturar um pensamento com lógica... e eles acabaram chegando na locadora... pelos referenciais que ele me mostrou... Então, apesar dele não conseguir ler e escrever, mas sabe se virar no mundo... e muito bem...... Era uma outra leitura.... a gente fez um projetinho de vídeo... Então, a gente começou a falar sobre vídeo, sobre gênero... romance, aventura, etc.... A gente começou a fazer alguns esqueminhas pra eles identificarem... Então, eles iam atrás desses filmes, a gente fazia eleição para o gênero que seria na semana... Aí via quem podia ir lá escolher o filme... Aí fizeram carteirinha da locadora ao longo do ano... No final do ano, como era, uma vez por semana, a gente ia falando o nome dos filmes que a gente assistia, porque tirava xerox da capinha... Fazia lá um resuminho Aí a gente tinha assistido, acho que vinte e cinco filmes mais ou menos.... Aí eu falei: "Gente, assistimos vinte e cinco filmes!" Aí eu fui colocando os VHS's, as fitas, que a gente tinha aqui na biblioteca... Aí o meu aluno falou assim: "- Professora, eu li vinte e cinco histórias"... Eu escutei vinte e cinco histórias, mas você diz... como assim??? Mas eu assisti o filme... Então assim, não tem uma história escrita? Aí eu falei... Tem... Então eu li!...Então ta!!! Então assim... uns sabem... Mas, outros você dá os instrumentos, outro canal... Então assim, essas questões, a gente tem que atentar na escola, não adianta ficar lá pondo cartilhinha... pondo letras, pondo palavras, sem significado nenhum... E eles decorando... Então eu acho exatamente isso... A pessoa que consegue ler, ler e contar pra você o que leu... Eu acho que tem que investir... Tem que investir mesmo... Não é a escola especial que vai dizer que não é pra fazer esse tipo de coisa... Mas quem não tem a condição pra isso, a gente também tem que instrumentalizar para o mundo, porque a gente fala que quer instrumentalizar pra trabalho... E eles também tem que chegar no trabalho... O que não pode é sonegar...

Eu acho que é bem isso, e agora então fazendo um paralelo... Você faz um conselho de classe e perguntam pra você... Você já ta pondo palavras? Só pra eles pensarem... Não ainda não... Eles ainda estão brincando, só que eles tão brincando e aprendendo... Só que eles vão talvez chegar lá... só que eles tão brincando ainda...Não com letras, porque eles estão no objeto, eles tão dando função para aquelas coisas... Então eu acho que esse é o caminho da educação especial...

$\mathrm{E}$ : Para encerrar o que você gostaria de acrescentar?

BF: Eu acho que... o aspecto formativo... e algumas questões que hoje precisariam ser revistas. O profissional estar mais perto do professor e ouvi-lo Isso faz a diferença... Isso eu aprendi, porque ouvi muito, então assim, o que eu acho que o professor gosta é exatamente isso... É importante, ter um tempinho pra falar sobre suas questões de dificuldade ou angústias, 
e sair de lá assim, com algumas coisas para tentar contribuir. Foram coisas que eu achei muito importante... Falar sobre discussões de caso... Também acho importante porque você reúne um número grande de profissionais, não tem um olhar só... $\mathrm{E}$ aí, todo mundo contribui, cada um desses profissionais... Se colocando, e o que ele traz de diferente da profissão dele... E isso engrandece muito... Tudo faz com o que o professor cresça... Quando a formação é só no coletivo, eu acredito que se tem, vinte professores... Cinco vão se interessar... Eu acho... É muito pouco... É uma formação que você joga uma sementinha e tem poucos frutos... Eu acho que quando a formação é no téte a téte, ele surge um efeito muito maior, até porque, isso eu não sei te falar se isso acontece pelo jeito que foi oferecida a formação... Ou se a questão, é pela questão histórica.... entre equipe e professor... Mas eu acho que pelo que eu vi todos esses anos... Se a equipe chama esse professor, e eles trocam, conversam... pode ser um número grande de profissionais... Ele surte muito mais efeito do que no coletivo... Então se eu fosse fazer alguma coisa... Eu ia privilegiar alguma coisa seriam os cursos menores e ambientalizar a formação... ter um espaço para que o professor se concentre... Então hoje isso não tem isso... Eles querem que você tenha concentração após dez horas de trabalho, eles querem que você fique sentada horas numa cadeirinha que não tem nem encosto. Não tem lugar pra você escrever uma anotação... Então assim, se você já não anotava, hoje você não anota mesmo, eu acho que antes tinha esse cuidado... Isso era importante e hoje se perdeu...

$\mathrm{E}$ : Eu quero lhe agradecer, suas contribuições foram valiosas. Muito obrigada.

$$
* *
$$

\section{Manoela}

A entrevista foi realizada na unidade escolar que a docente exerce suas funções, em horário de trabalho, em período em que os alunos estavam em aula de Educação Física.

Duração da Entrevista: 1 hora e 48 min

E- Você poderia destacar como tendo sido mais determinante na formação continuada em serviço, desenvolvido em parceria com a equipe interdisciplinar? Referindo-se mais especificamente ao período de 1996 a 2003.

M- Bom, a parceria sempre é bem-vinda...as formações que a gente teve, a colaboração da equipe nos momentos que foi solicitado ela sempre traz acréscimos à nossa prática pedagógica...As formações tiveram como objetivo procurar instrumentalizar o educador. As abordagens teóricas, acerca do desenvolvimento e de aprendizagem; as de conteúdo psiquiátrico; de relações interpessoais, proporcionaram momentos de análise, para refletir sobre a prática, compreender o que ocorre na sala de aula, possibilitando tomar novas decisões; descobrir novos caminhos e modos de agir, facilitando a aprendizagem dos alunos, favorecendo a troca de experiência entre os profissionais envolvidos e, consequentemente, desenvolvendo um pensamento mais autônomo. Estes elementos me ajudaram a tomar decisões, intervir, refletir, compreender, organizar, transformar enriquecendo minha prática e me tornando um educador mais comprometido.O que eu...o que eu coloco de observação na...na minha trajetória que é mais de trinta anos de educação especial, é que, mesmo tendo uma boa formação, boa assessoria, as vezes essas informações essas teorias,...esses estudos, se perdem na nossa prática... E-.e você avalia que isso era decorrente de quê?

M- Então...é...o...eu percebo que...por exemplo, a equipe em si, a estrutura da equipe não favorece essa continuidade dada nas assessorias e..nas reuniões que a gente tinha..

E- A que se deve isto?

M- Porque... o envolvimento com os professores ele não é contínuo...As vezes parecia que a formação estava desvinculada do trabalho diário, e apresentavam um caráter superficial.

E- Então,...como eram, então, organizados esses encontros para você me esclarecer essa questão da continuidade?

M- Bom, os encontros, eles eram organizados...em reuniões quando a gente solicita ou quando a equipe mesmo observa alguma coisa que tem que estar mais perto do professor......e são mesmo.. as formações que a gente tem..nesses encontros que às vezes não eram contínuas ...

E: as formações que você diz tinham mais um cunho teórico...?

M- Então, eu percebia como... mais teoria. Então a teoria..ela anda muito perto da prática...porque... assim...você tem a teoria e você pega essa teoria e tenta levar na sua sala de aula o que eu posso tirar da teoria para me acrescentar na minha prática pedagógica atento no aluno..

E: como ocorria no dia-a-dia,..a parceria com esses diferentes profissionais...de diferentes áreas..e,.essa relação que você fala da teoria com a prática,?

M- A relação da teoria com a prática pedagógica pra mim é sempre um momento de reflexão. A teoria me ajuda a analisar a prática, problematizá-la e redefini-la, portanto ambas articulam-se dinamicamente.

No entanto, as abordagens teóricas, muitas vezes são contraditórias. As dificuldades de aprendizagem, por exemplo, são interpretadas de maneira bastante diferentes, dependendo da perspectiva teórica que se adote.

Mas também, cada abordagem apresenta contribuições diferentes e importantes em relação aos aspectos da vida mental. Diante disso, como a teoria me ajudou no cotidiano escolar? Confesso que muitas vezes me sentia bastante confusa em relação a isso. O que me ajudou na reflexão foi observar as atividades dos alunos a partir das diferentes abordagens teóricas. Piaget diz, por exemplo, que quando ensinamos alguma coisa à criança, a impedimos de realizar uma descoberta por si mesma. Já Vygotsky enfatiza a participação do outro no processo de conhecimento afirmando que o indivíduo fará sozinho o que hoje faz com cooperação. Tivemos algumas formações onde o enfoque teórico foi baseado em Piaget, porém na minha prática, na análise feita com os alunos durante vários anos, Vygotsky teve uma contribuição bastante significativa, embasando vários projetos realizados (ver anexos). Fazendo junto, demonstrando, fornecendo pistas, instruindo, dando assistência, pude interferir no desenvolvimento proximal de meus alunos, contribuindo para os processos de elaboração e desenvolvimento que não ocorreriam espontaneamente. Este foi um período bastante rico, tendo reflexos positivos até hoje. Nos últimos anos com a política de educação inclusiva, que vem favorecendo a inserção dos alunos no ensino regular, fez com que crianças e adolescentes com deficiências múltiplas e de maior gravidade, que outrora ficavam apenas em casa, buscassem atendimento, surgindo então a necessidade de atendimento especializado com recursos, adaptações de grande porte e de um currículo diferenciado. A partir de 2002, nossas discussões e reflexões buscavam um novo olhar para estes novos alunos, assegurando um redirecionar e qualificando nosso trabalho pedagógico atendendo, acima de tudo, suas necessidades e interesses respeitando suas especificidades. Atualmente nosso currículo é baseado na abordagem ecológica e funcional, compreendendo que todas as atividades a serem desenvolvidas com os alunos fazem parte do contexto ambiental, social, cultural e familiar. Esta proposta ressalta a concepção sócio-interacionista, colocando no outro a função de mediador entre o indivíduo e o mundo, possibilitando a ele adquirir, não só linguagem, mas também conhecimento. Então,.eu, no meu entender, quando você 
tem uma teoria você vai checar essa teoria na sua prática, e você.tem que ter parceiros para estar... dialogando, contando experiências,..tirando de um e de outro pra você ver o que vale e o que não vale...porque muito da teoria, dentro da sua sala de aula...na sua prática, não serve...ainda mais você trabalhando com a deficiência...então o que você tem...você teria que ter depois dessa formação...depois dessas reuniões...você teria que ter grupo...grupo de estudo..é...você teria que ter... um momento pro professor ta colocando suas dúvidas, seu acertos, seus questionamentos, suas opiniões, suas reflexões..não é? E você, como outro, você ter essa troca.

$\mathrm{E}$ : e isto não ocorria, sistematicamente?

M- Eu acho que isso que é falho...isso foi não...isso é falho..

E: Em que sentido?

M-...porque eu acho que é difícil você se reportar num período... e esse período ser estanque...parou um período e começa outro período...por quê? O reflexo de um período vai para o outro eu acho que a Educação...a educação ela...ela é um movimento que ela não pára...então o que você vai adquirindo ao longo dos anos você vai trazendo...pra frente...você não fala: "Bom, agora fechou um período e agora eu vou para um outro período". Não, a educação ela leva......e você, por exemplo, eu...em tantos anos eu já participei de várias mudanças de currículo, não é...e você sempre acaba..levando coisas...dos outros anos...

E: Nesse período que nós estamos estudando como v. analisa essa estrutura que você mesma citou que está falha? Como isso foi tratado pela escola, você acredita que seria necessário que tipo de encaminhamento....?..

M: Olha...se não ocorreu eu, particularmente, acredito que mais profissionais a gente tentou levar...a nossa profissão pra frente. Eu acredito muito na autonomia do professor...muito. Então...é o professor...ele, se você não..entende um lado, você procura outro, e você procura aonde? Nos seus parceiros ou se você não encontrar no seu parceiro você tem que procurar em você mesmo você tem que encontrar em você mesmo aquilo que você acredita....então se eu acredito em alguma coisa e eu tenho certeza que aquilo vai dar certo e não encontro alguém pra me respaldar...pra me acrescentar, eu vou tentar fazer isso de alguma maneira...buscando quem? Buscando as pessoas que concordam comigo, a...família...porque eu sempre trabalhei muito com família...então é...essa autonomia que o professor tem..que ter ele tem uma força muito grande, ele consegue mobilizar um grupo...eu acredito que os professores podem mobilizar um grupo também. Então.....eu acredito nisso...eu...muitas vezes eu trabalhei sozinha...não é bom trabalhar sozinha...não acredito que seja o ideal...mas...é... por falta de uma estrutura e por falta até de um dinamismo na própria escola eu, muitas vezes, tive que me virar sozinha...não contando é....muitas vezes...com a minha própria equipe de trabalho.

E- V. poderia me explicar melhor? Essa falta de estrutura...

M: É...essa não continuidade....é...eu vejo, como...é....como que eu posso te explicar...vamos...vamos... dizer...é...por exemplo...atualmente eu vejo a escola em compartimentos...ai...como que é na escola? Tem a diretoria, tem as salas técnicas, tem a salas de formadores, tem as salas de aula...tudo muito bem dividido...e cada um com a sua função...não é...a diretora tem a sua função, a equipe técnica tem a sua função, os professores tem a sua função...e você ouve muito isso...cada um com a sua função. Muito bem. Cada um tem que ter a sua função, mas a escola tem que funcionar...essas funções tem que se entrelaçar...tem que se entrelaçar...tem que formar um dinamismo que o professor...tanto o professor quanto a equipe quanto a não tenham oculto a questão de poder...que eu acho que isso é uma coisa muito forte que pega...mesmo no inconsciente...mesmo não querendo...o professor não se chega à equipe...a equipe não se chega ao professor. Então fica...é....as relações eu acho que atrapalham muito esse dinamismo...eu chegaria muito perto de relações. Então, eu já até dei sugestão que essa formações deveriam além da...do teor de teoria, de planejamento, de currículo, ter assim um tipo de uma formação para o professor...para todos os elementos da escolas saber se organizar...saber se organizar, ser mais claro, ser mais objetivo. As vezes a gente tem reuniões que demoram, demoram, demoram, demoram e quando você vai ver não foi...o objetivo daquela reunião não foi atingido, entendeu...então, eu acho que numa escola também, as relações, a organização é...também fazem parte...teriam que fazer parte dessa formação.

E: Nesse processo, como ocorriam as situações formativas? Em que medida esta descontinuidade prejudicava o desenvolvimento formativo?

M: Eu a...sim...eu acho que...é...contribuíram, entendeu? O que... meu ponto é assim que contribui toda formação, tudo que se fala sobre...é currículo, aprendizagem... é formação..tudo que vai acrescentar na sua classe em sala de aula é bem-vinda, sempre colabora...mas não... o problema é que não há continuidade...

$\mathrm{E}:$ Em que sentido?.

M: Observação, reflexão, discussão, diálogos, entendeu?... trocas com o outro, então isso...eu acho que ficava interrompido. E também me coloco...como professora, as vezes isto também trazia conflitos. Por quê? A gente também tem que dar mão a palmatória, que também, o professor, ele tem uma dose de culpa...nisso...eu acho... Por exemplo, o professor, ele, tem que ser muito profissional, para não entrar naquela de corporativismo, meu colega é meu colega e é meu amigo...então, mesmo que eu veja que ele está errado em algumas questões, eu não vou falar com ele porque senão ele vai ficar triste comigo, vai ficar aborrecido comigo...então, quantas vezes será que a gente, como grupo, solicitou adequadamente pra essa equipe que ela fosse mais próxima, que ela fosse mais atuante, de que maneira será que a gente colocou essas questões pra essa equipe? Porque como as relações não estão bem, a gente também não pode falar que a culpa é só do outro, a gente também tem que se colocar como colaborador dessa..parceria que não está se dando...então eu acho que não adianta a gente falar assim: "não é culpa do técnico...não, é culpa da administração"...eu acho que a gente não tem que é...procurar culpados...a gente tem que ver o que nós falhamos pra tentar consertar...porque isso a gente tem reflexo até hoje, a gente tem reflexo...e o professor...se a equipe não faz, ele cruza as vezes e não faz também, ele fica esperando, e na educação a gente não espera...por que? Porque o nosso aluno não pode perder. O nosso aluno ele está lá, se você não dá pra ele aquilo que ele está precisando, ele perde, ele não recupera mais...então a educação não pára...então eu acho assim que essa questão básica das relações e da estrutura eu acho que não sei como...não sei como...talvez uma assessoria, uma pessoa diferente do grupo que viesse...entendeu? Isso porque...eu sentia antes...e agora também...eu não sei se ta tão diferente também...

E: Você fala de estar sozinha...e muitas vezes ter que desenvolver o seu trabalho solitariamente. Eu gostaria que você.analisasse os momentos em que ocorria a formação, o que ela representava para suas necessidades educativas...eu queria que você comentasse se as possibilidades de trocas, nos momentos que ocorreram trouxeram contribuições pra você ter maior domínio sobre o seu trabalho?

M- Sim. Houve mudanças significativas para quem se propôs a participar dessas mudanças e mesmo assim, houve (e há) algumas dificuldades neste processo: oportunizar encontros mais freqüentes para dinamizar a continuidade dos estudos iniciados na formação: debates, trocas de experiência, registros, avaliações; como contextualizar a escola como grupo diante das mudanças ocorridas num momento de transição, onde a nossa prática deveria ser repensada, questionada, reformulada em algumas questões, em decorrência das concepções de educação em relação à deficiência; a falta de articulação entre equipe escolar e professores, favorece a tendência a sobressair no grupo: ação isolada, descontentamentos, falta de continuidade nas ações das propostas apresentadas, aspectos das atitudes pessoais interferindo no profissional, submissão, 
acomodação que pode ser decorrente de "o não fazer do outro, também me desobriga a fazê-lo" ou "eu não sei, também não vou correr atrás", falta de entusiasmo. Porém, acredito integralmente na autonomia do professor e o quanto ele pode participar do processo pedagógico, se conseguir efetivar seus propósitos, embasados no conhecimento teórico e na sua prática e também estar atuando juntamente com seu grupo, mesmo quando exista pouco acompanhamento da equipe. Em 1999 foi realizado um projeto de "visita domiciliar", com um agrupamento de 9 (nove) alunos com idade entre 16 a 20 anos. A maioria apresentava dificuldades na comunicação, eram dependentes na vida diária, com dificuldades comportamentais advindas basicamente dos próprios comprometimentos. Por ser um grupo muito dependente houve necessidade na época de atuação, de 2 (dois) professores de educação especial, para que houvesse a possibilidade de efetivar o plano de trabalho pedagógico estabelecido para estes alunos. O principal objetivo era que esses alunos fossem mais independentes em AVD e tanto os conteúdos como as estratégias do programa tinham esse propósito. A parceria entre os profissionais contribuiu para a efetivação do nosso trabalho como também para atender as necessidades do grupo. Contudo nas nossas avaliações não estávamos observando mudanças significativas nas atitudes dos alunos. Reorganizamos nossa proposta e consideramos ser indispensável a participação efetiva da família no processo educacional. Na escola, os alunos estavam sendo preparados nas questões de AVD, mas, em casa, no seu ambiente, como estariam? Qual era a participação da família neste processo? Qual a participação do filho(a) nesta rotina? Era colaborador(a)? Tinha oportunidade de interagir? O que gostava ou não de fazer? Fazia escolhas? Como era tratado? Estes e outros questionamentos fizeram parte de nossas reflexões e optamos por conhecer melhor cada família fazendo visitas domiciliares. Devido à disponibilidade do serviço, foi possível a vinda de mais uma professora e por isso o nosso projeto foi viabilizado. Duas professoras ficavam com o agrupamento na escola, direcionando as atividades aos interesses e necessidades dos alunos, favorecendo um atendimento mais individualizado em alguns momentos, enquanto eu fazia as visitas, observando, inicialmente como era a dinâmica familiar e depois, propondo a participação dos filhos e responsáveis nos programas sugeridos.

Durante as visitas, os familiares eram orientados buscando-se alternativas para um melhor desempenho e organização da rotina. Também havia momentos em que os pais vinham até a escola tanto para participar, juntamente com os filhos, das atividades (banho - cozinha - horta) como também participar de grupos com o setor de psicologia em questões como: expectativas, dúvidas ou qualquer assunto relacionado por eles sugerido. As famílias que foram atendidas pelo projeto, admitiram a importância em estar incentivando e proporcionando possibilidades de atuação na vida familiar, dando oportunidades para que o filho(a) pudesse se desenvolver com mais autonomia. Reconheceram também que, infelizmente, o trabalho foi iniciado tardiamente, tanto pela escola, quanto por eles, dificultando a aquisição de conhecimento. No ano seguinte, o grupo não permaneceu o mesmo sendo cada aluno transferido para outro agrupamento e o trabalho direcionado às famílias foi interrompido porque não havia, naquele momento, disponibilidade de professor para este projeto. A segunda experiência, na questão familiar, foi em 2003 com o projeto "Participação e inclusão do jovem no ambiente familiar", o qual foi realizado com uma turma de seis alunos entre 13 e 14 anos, do módulo "Educação para o trabalho". Uma das propostas pedagógicas deste módulo era a do trabalho desenvolvido com material reciclado, que era separado e distribuído às demais salas, conforme as características do material (latas, papelão, papel, revistas, garrafas, PET). Alguns alunos, da sala, apresentavam dificuldade nesta atividade, mostrando no desempenho e nas atitudes falta de interesse, pouca ou nenhuma iniciativa, além da falta de entendimento nas situações propostas. Alternativas foram criadas para os alunos, com maiores habilidades para este trabalho, através das parcerias com as demais salas. Em alguns dias da semana, em horários estabelecidos, os alunos em questão, participavam das atividades com outros agrupamentos, enquanto os demais desempenhavam outras atividades. Paralelamente a este trabalho foi iniciado o projeto já mencionado onde o enfoque seria incluir a família no planejamento de um programa diferenciado que contribuísse para o desenvolvimento progressivo da independência, autonomia, frente às diversas situações na busca de uma integração familiar e social. Inicialmente foi feito um contato com os pais, através de reuniões, para informá-los sobre o projeto e como seria a sua implantação. A maioria dos pais era conhecida e também o ambiente familiar, pois já se haviam feito visitas domiciliares em anos anteriores para conhecer a casa dos alunos (ambientes, organizações, conhecer o entorno da casa, a família, os objetos e/ou animais de estimação). Dessa maneira foi mais acessível o diálogo e o início do programa. Nas conversas com os familiares, foi constatado que os alunos poderiam beneficiar-se deste programa, participando mais das tarefas domésticas, dos cuidados pessoais e de um relacionamento familiar mais próximo. Foram formulados registros para acompanhamentos, observações, avaliações para melhor atingir os objetivos propostos. As primeiras atividades em casa foram dirigidas para o horário das refeições, ampliadas posteriormente para atividades de banho; outras tarefas realizadas em casa e saídas. Cada atividade foi desmembrada em passos com a seqüência de execução. Assim o grau de desempenho com independências ou com ajuda pode ser registrado e avaliado por meio de indicadores com respectivas legendas e datas e também com registros escritos com questões a serem respondidas. A freqüência das anotações era flexível levando-se em conta a disponibilidade da família e sugerindo os finais de semana para reforçar as atividades solicitadas. Estes mesmos registros foram adaptados para uma família onde a mãe (a única responsável) conseguia ler, mas não escrevia. Na avaliação final os pais consideraram o resultado satisfatório, conforme registros realizados (ver anexo dos registros). Este projeto consta da atual Proposta Curricular da Educação Especial conforme solicitação da supervisora Maria Aparecida Cormedi, mesmo sendo um processo idealizado neste período que estamos comentando.

E: mesmo com essa citada descontinuidade, ainda assim você se refere a uma parceria. Então houve possibilidades de contribuição?

M: A parceria sempre.....contribui....esses últimos anos, dois, três anos, a gente está fazendo um trabalho bem coletivo...e...nosso agrupamento de jovens dois, baseado no currículo funcional, que é a nossa nova proposta curricular, que a gente tem que trabalhar em grupo, porque o aluno, ele vai desenvolver as atividades que ele necessita para a sua vida futura...então você não tem só o seu grupo de alunos você tem os grupos de alunos também de outros professores...então, esse trabalho de parceria entre os professores só acrescenta, só enriquece,..e, o que precisa para se efetivar? O grupo precisa estar muito bem entrosado. Porque se você tem um grupo que não é entrosado, esse trabalho de parceria fica também truncado. Por que? Porque ou você trabalha com o grupo, sofrendo a toa, com o direcionamento dado que não é aquele que você está querendo dar à sala de aula, à proposta, ou você fica fazendo à parte...para que esse grupo..fique bem e pra você poder trabalhar. Então, eu, por exemplo, eu, particularmente, eu tenho muita dificuldade de trabalhar num grupo onde as pessoas não pensam da mesma maneira e não vão... ao foco...do trabalho. O foco tem que estar contemplado na sua ação em sala de aula, na escola, no seu trabalho...no coletivo.

$\mathrm{E}$ : Você falou do currículo funcional, como ele foi construído...havia clareza dos objetivos que havia necessidade de atingir?

M: foi construído ao longo do tempo quando a gente percebeu que a nossa "clientela" de alunos estava cada vez mais comprometida... e o que a gente estava proporcionando pra eles não estávamos contribuindo mais, a proposta estava inadequada não dando mais resultados, então a gente precisava de algo mais efetivo...

$\mathrm{E}$ : E como se deu esta construção? 
M: Isso, por isso que eu acho que tudo que acontece tem que ser continuado, tem que ter uma continuação...e...e aí a gente pegou uma nova proposta curricular que é baseada em eixos, não é, que você trabalha o eixo escolar, o eixo familiar, o eixo da comunidade, do trabalho, o eixo do lazer, e essa proposta atinge não só o aluno como a escola também, porque toda a escola tem que estar mobilizada. Então você não vê mais uma professora trabalhando numa sala de aula fechada com o seu grupo de alunos...certo? Apesar que a gente ainda tem um pouco, mas...a escola já está caminhando pra esse lado e eu já vejo um movimento diferente. Então a escola ela tem que participar como um todo e não como repartições....pensar coletivamente.

$\mathrm{E}$ : E como isto foi evoluindo? A formação contribuiu para esta construção?

M: Para o professor todas as formações que tivemos...todas as assessorias, a gente teve assessorias maravilhosas...nós tivemos assessorias que foram muito boas até pra minha vida pessoal.. a assessoria que a Úrsula deu aqui na escola, não sei se foi nessa época, foi... de uma riqueza enorme, que até hoje ela contribui,..ela contribui até hoje...então ela deu uma norteada na nossa... organização, na rotina escolar, que a gente aproveita sempre...

E: E nessa dinâmica de formações existentes nesse período como a que a Profa Úrsula promovia, como era dada a continuidade desse processo, como se desdobravam os estudos e como eram desenvolvidas as atividades com esses diferentes saberes, diferentes profissionais? E como as propostas iam sendo discutidas?

M: Então, ela... tinha muita experiência e muita sabedoria, então ela conseguia mobilizar o grupo e essa diversidade.de profissionais..porque o que estava faltando...na educação era pensar nas especificidades dos alunos.... os educadores têm que avaliar os alunos e atingí-los nas suas diferenças...nós também, nós também somos diferentes, então, a pessoa que lida...com as pessoas..no caso da direção, de uma equipe, de uma assessora, ela vai ter que ver que a diversidade existe entre os profissionais que ela está formando...e provavelmente não vai atingir todos da mesma maneira,...alguns aproveitam...alguns aproveitam naquele momento de entusiasmo e depois vão perdendo...vão se desanimando no dia-a-dia...

E: Você tocou num aspecto sobre as diferenças entre as pessoas como você era envolvida na sua condição profissional, como pessoa, como profissional......você se sentia parte desse processo formativo? Ele atendia suas necessidades?

M: Me sentia, me sentia parte porque em cada formação que eu tinha e que ia de encontro ao que eu acreditava eu agarrava com tudo e levava pra minha pratica...na hora...

E: Então você admite que cada professor, com suas necessidades peculiares, deveria ser atingido de uma forma específica, com a formação?

M: Com certeza, esse é o básico. Pra mim, pela experiência que eu tenho durante anos de educação especial, o professor se ele não é atingido e se ele não se sentir..fazendo parte...integrante sendo verificada suas necessidades formativas por essa mesma equipe......ele não consegue realizar esse trabalho.

$\mathrm{E}:$ Você acha que os espaços criados, os procedimentos e as relações estabelecidas eram pertinentes pra isso?

M: Então, os espaços eles foram pertinentes...só que, a própria estrutura escolar não permitia que se aprofundasse e que se levasse adiante... as discussões, o acompanhamento, os retornos das discussões iniciais...

E: Como assim?

M: O professor ele... pode ter uma autonomia realmente...numa escola e desenvolver seu trabalho com mais segurança. Eu vou dizer com experiência própria. Pode...se ele tiver embasamento, se ele embasar muito bem o que ele está propondo. Se ele tiver clareza onde quer chegar e expor o que...... ele ta fazendo e ele apresentar resultados, ele tem autonomia. Ele não pode falar: "não, eu não faço porque a equipe não deixa...eu não faço porque a direção é autoritária"...não, é mentira...eu posso provar, porque em todos esse anos eu nunca deixei de fazer aquilo que eu acreditava e toda vez que eu mostrava o meu trabalho, toda vez que eu provava que aquilo dava certo, que aquilo tinha resultado, eu era ouvida e eu era incentivada a continuar...pela própria equipe...então, tudo bem...é... por isso que eu acho que o professor ele tem uma força enorme...na estrutura escolar...muito grande...o professor ele... não sabe o quanto ele pode conseguir ele próprio...claro...com um...é...com uma ajuda de profissionais, dos diferentes saberes que estão na escola pra isso mesmo..mas sempre há necessidade de um acompanhamento mais próximo dessa equipe para o professor e para o aluno.

E: Esses diferentes saberes, mesmo com esta questão, da estrutura e da descontinuidade na construção do trabalho que a equipe desenvolvia, eles traziam possibilidades de transformação pra sua experiência, pra sua formação? Você acha que houve maior domínio sobre a criança, que você comentou que gradativamente foi tendo possibilidade de acesso à escola ela... foi melhor compreendida...

M: Olha...é...eu acho que....falar em estrutura de equipe pra mim é um pouco complicado porque...eu... não compartilho com algumas coisas dessa estrutura de equipe... São pessoas competentes, são pessoas que tendem muito a colaborar...são pessoas que tem uma boa formação, então tem tudo pra que fosse de uma maneira diferente. Vejo também...é...que as vezes...é....a solicitação que elas tem fora da escola também é muito grande... Então é uma equipe que as vezes não está dentro da escola frequentemente e que são muito solicitadas pra outras tarefas...e...e aí elas se perdem porque é muita coisa...a gente também quando começa a fazer muita coisa a gente acaba se perdendo......e não dando tempo para as coisas que geralmente são importantes...então a gente vê assim, muito atropelo, muita coisa, muita...muita solicitação e pouco espaço na própria escola...porque eu acho assim que os professores eles tem que ser vistos muito de perto.....porque o professor ele ta lá na...ele ta todo dia com o aluno...cinco horas por dia, as vezes acontece alguma coisa e ele não tem com quem falar...lógico que você vai falar com o seu colega de...mas morre aí...tá. As vezes o que acontece na sala de aula teria que ser discutido pra que aquilo fosse mais questionado... refletisse mais sobre o que aconteceu...em reuniões, em conselho. Então poder falar "olha, aconteceu isso...olha ..." eu acho que tem coisa que tem que ser aprofundada...as vezes quando a gente queria falar e não tinha ninguém procurava o colega, tem uma outra coisa...se essa equipe não está tão próxima do professor...numa discussão...como pode ocorrer um diálogo... se as vezes o outro nem sabe qual é o seu problema....ele não sabe opinar sobre a prática...do dia-a-dia...então ele não sabe a amargura que o professor está... as vezes tendo...as queixas que ele está tendo...ele não tem conhecimento.....então ele começa a observar..."ah, é um grupo desanimado...é um grupo que não participa"...mas por que? Mas por que ele não participa...por que ele está desanimado? Muitas vezes a gente tem que falar coisas no corredor...organizar planejamento...tudo...na correria...e não é assim que a gente deveria fazer..não é? Eu... vejo a nossa escola como um todo que não consegue agregar...eu gostaria muito de ver a escola como um todo, um coletivo mais coeso...sabe como aquela escola da Ponte: salas de aula que fossem...sem tanta carteiras, lousa, mesa...entendeu...ambientes gostosos onde as pessoas circulassem...que.tivessem prazer de estarem lá.

$\mathrm{E}$ : $\mathrm{E}$ o que te impede discutir a pertinência dessa estrutura para que a formação tenha um espaço mais aglutinador em torno das necessidades dos alunos? Depende de quê?

M: Aí que eu coloco a questão da personalidade e da diversidade de cada ser humano...não é? Por quê? Tem pessoas que tem essa capacidade de agregar o grupo de mobilizar. Eu acho que por exemplo... eu com esse pensamento poderia ter mobilizado muito mais...entendeu? E não procurado... fazer tanto as coisas sozinha...poderia ter mobilizado mais...hoje com mais experiência e fazendo o que eu faço...hoje eu mobilizo muito mais..

$\mathrm{E}:$ Como assim? 
M: Em alguns momentos não era ouvida...em outros momentos não me aventurava...por quê? Eu me envolvia tanto no meu trabalho... eu ia... embora...e sentia que muitas vezes as pessoas não me acompanhavam...era difícil me acompanhar...hoje me acompanham mais...por que? A educação mudou e eu em outros tempos pensava exatamente como deveria ser a educação que é agora...há vinte anos atrás eu entendia a educação como ela é hoje e nesta época as professoras e a educação eram mais tradicionais...

$\mathrm{E}$ : Com um currículo mais funcional...como é hoje é mais pertinente para o aluno?

M: Eu já atendia isso há muitos anos atrás...e............coloco vinte anos...vinte anos atrás...o grupo era mais tradicionalista, então eu não conseguia parceiros para discutir...hoje eu encontro. Os profissionais talvez não percebessem essas necessidades, a concepção foi mudando e agora é possível ver o aluno de outra forma e criar um currículo mais pertinente.

E: Coloque um pouco mais estas questões...você falou de vinte anos atrás...eu pediria que você traga mais alguns dados desse período de dez anos para cá...

M: Que é um período de transformação. Então, aí foi um período que eu me aventurava mais...porque aí eu podia ampliar os meu horizontes eu sabia que eu podia contar com os meu colegas, eu podia sair com os meus alunos...podia participar de.estudos de meio.. Havia direcionamento para isto..

E: Você tinha oportunidades?

M: Tinha oportunidades pra isso, para criar um planejamento e ter mais parceria...

$\mathrm{E}$ : Mesmo com essa ausência da estrutura da equipe?

M: Tinha essa oportunidade. Tinha essa oportunidade...porque também você faz a oportunidade...você faz...a oportunidade ela não cai de mão beijada na sua mão...você tem que criar...você tem que ir atrás dessa oportunidade.

E: E essas experiências você acha que contribuía pra você mudar a visão do aluno e acrescentar o conhecimento sobre esse aluno, sobre a aprendizagem dele...?

M: É, nessa fase que a gente teve um trabalho...inclusive que eu comecei a fazer um trabalho domiciliar...foi nessa fase...é...que eu ia na casa do aluno...orientar a família...e pra que isso pudesse ocorrer a escola teve que ter uma estrutura...e teve... tinha...eu saía pra ir na casa dos alunos e um grupo de professores...de três professores ficava na sala...a equipe também...naquela época...era bem...era bem participativa, a gente tinha colaboração...então por que? Porque eu vi um movimento na escola e quando você percebe que tem um movimento na escola você vai...você ta indo...você abre espaço e outro vai se achegando também...p porque tem um entusiasmo...eu acredito muito no entusiasmo da proposta...muito. Eu acho a... que quando uma proposta entusiasma, eu acho que todos se envolvem.

E: Isso foi em que período?

M: É...esse foi um período...ai deixa eu ver uns sete...há uns dez anos atrás. Tanto é que quando a gente fez a assessoria da Nina, que..ela foi a assessora que falou muito do currículo funcional, que instrumentalizou a gente pro currículo funcional, e eu mostrei pra ela o trabalho que...que eu tinha feito de visita domiciliar...ela falou assim: "eu não acredito que você fez isso sozinha!".

E: Foi um período que o professor tinha apoio? As assessorias estavam envolvidas?

M: esse projeto...que eu fazia de visita domiciliar, foi em 1999 a Úrsula foi um pouco depois. Então foi um período de muita transformação na escola, aliás desde o período..que foi instituído o construtivismo...... Eu acho que a educação foi passando por transformações que vem de encontro ao que eu penso...ao que eu acredito...então por isso o meu entusiasmo... E eu sempre fui uma pessoa que eu me entusiasmo muito com propostas novas, que envolvam não só o aluno, como tudo que faz parte da vida do aluno.

$\mathrm{E}$ : Nesse contexto de transformações como a equipe interdisciplinar contribuía com seus saberes?

M: Com certeza...não vou falar que foram muitas vezes...(risos), mas nas poucas vezes que eu quis uma parceria, eu consegui...principalmente com os psicólogos A Psicologia ou mesmo a orientação pedagógica em alguns momentos...eles sempre podem colaborar. Eu acho que o que emperra é a estrutura...e a maneira de cada um encarar a sua...o seu saber...entendeu? Eu sou professora...a outra é técnico...mas os saberes eles se entrelaçam...eles se entrelaçam, eles não se separam...não...não...ela é professora..não, ela professora e ela é capacitada...se não é capacitada, vamos capacitá-la.

E: Você citou que alguns profissionais se envolviam mais com a formação então vamos por aí...como se dava esta parceria com estes profissionais pra gente ter um exemplo, como se davam as trocas com esses profissionais?

M: Muita troca. Por exemplo, com a Elisa, ela fazia grupo com os alunos e com as professoras, ela fazia dinâmica...então a troca era muito próxima... e,como... quando a troca é próxima, a naturalidade fica melhor.

E: Havia....aquilo que você falou que as vezes o profissional fica muito distante da sua realidade, com esses profissionais ocorria isso?

M: Era muito melhor. Então eu acho que esse é um ponto importante. Quando você tem uma naturalidade com o outro...você troca mais, flui muito mais...se você tem uma barreira você não consegue, porque quando você começa a falar, o outro num...você percebe num...na fala, nas ações...na...na...na...no que vem...você não percebe nada nele, então o que que acontece? Você procura outro. E quando você tem que conversar com ele não é de uma maneira natural, entendeu...de profissional...então eu acho que por isso que as relações são truncadas pois os profissionais não conhecem a realidade do professor...

E: Mas neste caso, como ocorria essa dinâmica de troca, as discussões com esses dois profissionais que você citou.

M: Trocas próximas... Horários...específicos...isso...era freqüente, era semanal, as vezes quinzenal quando não podia...mas mesmo quando não ocorria por problemas que não faziam parte deles, algumas atribuições, algumas atividades que eles tinham que desenvolver, eles chegavam...eles falavam pra gente...notificavam: "olha eu não vou poder fazer por causa disso, mas uma próxima aula eu reponho"...então, você tinha confiança nesses profissionais...

E: Porque eles estavam ao seu lado...

M: Porque eles estavam ao meu lado e ao lado do aluno porque a gente via resultado com os alunos... e eu pergunto por que os técnicos tem que ficar distantes dos alunos? Essa é minha pergunta...por quê fica distante da realidade do professor? Por que o técnico tem que ficar na sala discutindo...em reuniões... e o professor na sala de aula...sozinho com seus problemas por que não pode ficar junto?

E: Então essa experiência com profissionais da equipe técnica ocorria e eles dominavam a sua realidade? Estavam dentro da sala de aula com você?

M: Mais perto...mais perto...

E: Nesse período a equipe estava mais perto?

M: É...agora, o que se fala hoje da orientação pedagógica.ou dos profissionais..é...que o técnico, o orientador pedagógico, ele não precisa ficar em sala de aula...então veja bem.como ele vai dominar a nossa realidade?..

$\mathrm{E}:$ Como reflete no seu trabalho?

M: É...então... o orientador pedagógico se ele dá formação ao professor...ele precisa.....observar o aluno em algumas atividades, o professor...mas ele não precisa ficar só...dentro de sala de aula, ele precisa conhecer mais de perto. Então teve 
um período da minha vida profissional que eu fui PAP...professor de apoio pedagógico...então eu dava aula num período e no outro período eu ficava como PAP na escola e...qual era o meu trabalho? Em sala de aula com o professor. Então eu assistia aula, eu ficava junto com o professor...eu chamava esse professor...discutia os textos da parte teórica... fazia apostila, dava pra ele sugestões de atividades...trocava com esse professor. Então, o que eu percebia? Que era possível uma orientadora pedagógica fazer esse trabalho também...em sala de aula...próximo ao professor. Vai entrar todo dia? Não precisa. Vai entrar toda semana? Talvez não. Mas vai ter que ter um momento que ele vai ter que estar junto. Sentado lá observando? Não... atuando junto ao professor...entendeu? mas trocando mais de perto.

E: Então, Manoela, você traz dados, que dão impressão de uma certa fragmentação entre os profissionais, que o desenvolvimento formativo não se dava de forma integrada pela equipe, centrado em determinadas pessoas da equipe e não na equipe como um todo, ocorria assim?

M: Sim...

E: Quer dizer,que as pessoas que compartilhavam desenvolviam as ações formativas em separado umas das outras?

M: Sim.

E: Então a equipe não tinha uma coesão interna que tratasse das ações formativas no coletivo?

M: Não acredito que tinha...não acredito que tinha isso...entendeu...eu...eu particularmente, não via essa ação coletiva da equipe que impulsionasse o grupo para uma proposta coletiva...não via, por isso que eu sempre achei que o trabalho era fragmentado, acho que ...era fragmentado...

$\mathrm{E}$ : Vamos ver se eu entendi...Nessa... experiência que você teve como professora de apoio pedagógico....num período e no outro como professora..você quer explicar que você concretizou algo que você acreditava que a equipe ou seja a orientação pedagógica ou mesmo a área de Psicologia ou as demais áreas pudessem realizar?

M: Sim, eu tive essa experiência muito boa...é...tive contatos com professores muito abertos, que até hoje falam : "nossa eu sinto saudades daquele tempo...porque...é...porque além da teoria, você dava a prática...me ajudava, entrava em sala de aula"...tive também professores resistentes que quando eu entrava me viam como uma observadora: "que será que ela vai observar? Que será que ela vai fazer?"...e...pouco a pouco a gente vai quebrando isso também, por que depende...da nossa ação...se você vai numa sala de aula, você senta e só fica olhando a professora e depois você não dá um retorno pra ela...ela..na segunda vez que você for, ela não vai te respeitar ela vai ser uma professora.... que vai se queixar...não é?. Agora, está em você quebrar isso....por isso que eu acho que a equipe ela tem uma força também muito grande. Por que? Ela não vai ser a transmissora de prática, de teoria...ela vai ter que ser uma equipe que vai ter que conhecer cada professor que está lá...como que ele é... como ele se desenvolve no seu papel, por isso que eu acho também que tem a área de Psicologia...que nessa... parte, eu e a psicóloga éramos muito próximas ela sabia detectar no profissional...questões que deveriam ser abordadas, eles tinha esse cuidado...eu acho esse cuidado faz parte também.. da escola como um todo. Entender aquele profissional...por que aquele profissional está tão desmotivado...o que está acontecendo com ele e quais os reflexos no aluno... $\mathrm{E}$ : Se refere aos aspectos referentes à vida pessoal e profissional do professor?

M: Sim, isso eu acho importante ...

E: Então, essa relação interdisciplinar da equipe, você não visualizava nesse período, nessa equipe em particular? Eram saberes que eram manifestados, mais pontualmente sem uma interelação?

M: Não, da maneira que eu encarava a educação...porque é assim, como eu te falei, eu consigo separar o profissional do pessoal. É...quando você está com essa mesma equipe numa reunião...é...assim, que não tem nada a ver com a educação...mais assim...uma reunião mais light...vai...num cafezinho, num bate-papo, é diferente...aí, as brincadeiras, tudo.parecia bem tranquilo..mas, eu conseguia separar esses momentos descontraídos...de lazer, que tem na escola também, na hora do café, na hora de uma reunião... tem algum tempinho mais pra você estar descontraindo...mas eu procurava separar esses momentos, pra que isso não influenciasse na minha maneira de pensar...então pessoal é uma coisa...profissional é outra. Então, eu acho que,nesse lado profissional, eu acho que a equipe não manteve esse coletivo não conseguia coordenar de forma integrada...não soube manifestar o coletivo...integrar o grupo

$\mathrm{E}$ : Você percebia, em sua realidade que os profissionais, que compartilharam com você, de algumas áreas, atuavam mais individualmente, ou você acha que eles conseguiam garantir os conhecimentos necessários juntos com você sobre a dinâmica escolar, sobre o processo da criança ....do desenvolvimento e aprendizagem da criança?

M: Eu acho que não tendo essa inter-relação, não dava como aprofundar muita coisa...né...então, se fica muito na superficialidade...e o dia-a-dia não é superficial...o dia-a-dia é complexo,...então, as coisas tem que ser muito bem aprofundadas, porque senão fica na superficialidade...fica aquela relação superficial...reuniões superficiais, entendeu...então, eu acho que isso...poderia ocorrer

$\mathrm{E}$ : E como estas questões eram supridas se não conseguiam esgotar todas as necessidades que você tinha?

M: Mas... acho que sim, porque eu solicitava mais, questionava mais...coisas me eram dadas para ler,...livros...sim, aí...por isso que eu acho, quando tem essa troca tudo flui natural...tudo flui...eu chego para o profissional e digo: olha, eu li esse texto aqui...e pra minha sala eu acho que eu posso fazer um trabalho baseado nestas questões, olha a minha proposta é essa, o que você acha?..." daí você vai ler...aí você vai falar: "vamos discutir juntos"...aí eu vou começar...vou mostrar pra você: "olha, eu comecei e está assim...mas eu encontrei isso que eu acho que tem que ser mudado, e eu não estou conseguindo como, será que você me ajuda? Você tem uma idéia...você pode me ajudar?" Então é isso que eu acho que falta...é exatamente isso...trocas mais freqüentes .

$\mathrm{E}$ : E na sua concepção não existia uma estrutura que abarcasse essa continuidade, essa periodicidade...essa...frequência?

M: Isso...isso...exatamente...eu não vou nem falar que era má vontade...que era... descaso...eu acho que se a estrutura fosse diferente...se tivesse momentos.mais disponíveis com uma periodicidade constante, entendeu...tudo muito mais próximo do professor, eu acho que tudo seria diferente.

$\mathrm{E}$ : Você acha que o problema era da estrutura interna que impedia um acompanhamento formativo mais próximo, da competência interna da unidade escolar ou é algo que era inviabilizado pelo órgão gestor da Secretaria?

M: Não, eu acho que o órgão gestor da Secretaria dava uma certa liberdade pra que a escola se mobilizasse e encontrasse caminhos.....eu não acho...eu acho que a estrutura interna...da escola precisava coordenar esse processo formativo e encontrar saídas para a organização das prioridades. Se uma escola....internamente, se mobiliza como grupo, ela vai ter força pra até reivindicar alguma coisa pra chefia que está emperrando...

E: Então naquele momento, a chefia ou a Secretaria oferecia elementos positivos pra isso...No entanto, internamente você acha que a Escola não conseguia criar possibilidades...?

M: Então, mas quando você questionava, o que a coordenação dizia? Que a equipe tinha muitas atribuições que não dependiam deles...tinha coisas que vinham da chefia e que não dava para que eles não desenvolverem...que eram...trabalhos, reuniões envolvendo vários projetos da Educação Especial como um todo e não só da nossa escola...é....a equipe tinha que fazer outro trabalho fora da Escola, entendeu...então eles falavam: "gente...to também de mãos atadas....a gente está sendo solicitada...não tem como"...então, veja bem...é. o nosso acompanhamento não se realizava por completo.... 
E: Existia uma multiplicidade de funções?

M: Isso...isso...entendeu? Que também eu acho que é um...prejudica...que é um elemento que dificulta essa...esse trabalho...porque se você tem uma função dentro da sua escola e você tem um tempo pra isso...você vai conseguir se adaptar a isso. Agora se você tem que ficar um pouco na escola, um pouco fora...um pouco lá, um pouco cá...fica mais difícil.

$\mathrm{E}$ : E você acompanhava essas funções externas e o que significava para o seu trabalho?...como professor? Como você sentia... você traz um dado de que alguns profissionais tinham um compromisso com a parceria e se justificavam e abriam espaços para desenvolver as pendências. Isto não era uma regra?...

M: Com... a escola..não só comigo...eles se envolviam com todos e davam retorno para todos por isso eram respeitados. então acho que estes de certa forma ajudaram a construir o trabalho formativo.Nestes anos de atuação com a educação especial (32 anos), importantes abordagens teóricas serviram de base às reflexões sobre o desenvolvimento do indivíduo, sua afetividade e educação. Algumas dessas abordagens, exerceram considerável influência no nosso grupo, levando-nos à reflexões sobre as metodologias e conteúdos apresentados.Porém, este processo, geralmente, era marcado por alguns conflitos, exatamente por causa desse excesso de atribuiç̃̃es da equipe. A complexidade das relações que ocorriam na escola, a diversidade de fatores presentes no cotidiano, muitas vezes, estabeleciam distâncias entre a teoria e a prática devido a escola como um todo não participar do processo pedagógico escolar. Via (e vejo ainda) a escola dividida em salas (diretoria, equipe, sala dos professores; salas de aula...), cada um, procurando desenvolver da melhor forma possível suas atribuiç̃es, porém isoladamente.Não identificava a escola como um grupo, onde os saberes individuais colaboravam e enriqueciam o coletivo. Havia ações individuais ou parcerias; uma equipe técnica que não conseguia articular-se com o grupo de professores (e vice-versa), para questões mais voltadas à própria prática. Muitas vezes, as reuniões voltadas para este fim, perdiam-se os objetivos propostos inicialmente, e reinava um descrédito da situação. Em decorrência desses fatos havia muita insatisfação. $O$ lado profissional não conseguia sobrepor estes aspectos devido à própria imaturidade do grupo, em lidar com os conflitos (eu também me incluo). Enfim, diante dessa realidade, os saberes da experiência se perdiam, enfraqueciam, não evoluíam diante do grupo escola e procuravam se consolidar nas ações individuais ou de pequenos grupos. É o que eu sempre senti foi assim se, uma equipe faz reuniões periódicas,só com as equipes, essas reuniões tem que ser em benefício da escola e dos professores...e muitas vezes a gente não via os reflexos das propostas dessas reuniões..."o que são discutidas nessas reuniões?"... Porque se a equipe tem que trabalhar com o professor...pra dar suporte pra ele em sala de aula, se ele vai fazer uma reunião, ótimo...então essa reunião tem que acrescentar para o professor.

$\mathrm{E}:$ Você tinha domínio do projeto formativo..instituído pela Educação Especial e... efetivamente como isso deveria ocorrer ou você não chegava a tomar conhecimento?

M: Muitas vezes eu não chegava...a absorver ou talvez nem procurasse...entender? Porque veja bem...faziam parte do caderno de metas que estava na escola mas ficava lá e a gente também não tinha tempo para absorver na totalidade, não dava...porque o dia-a-dia do professor, é corrido... o professor não tem muito espaço...e a falta de espaço que o professor tem, faz muita falta...pra esse professor...pra dinâmica dele...muita falta...e a gente tem muita falta de...de tempo para tomar conhecimento de todos os documentos..

E: Quais os espaços vocês tinham para a formação?

M: Bom, a gente...em reuniões...no começo desse período não tinha o HTPC? O HTPC foi criado.. um pouco depois não sei...então, mas mesmo o HTPC teria que ter esse momento..e não dá.. Eu também acho que também não ele também não é organizado de uma tal maneira, que o professor tenha a maior parte dele...entendeu? É...também ele é usado pra muitas outras coisas, entendeu...agora a gente pode dizer que está começando..de tanto a gente reclamar, de tanto a gente falar: "gente, a gente precisa de tempo...a gente precisa de tempo para o planejamento...a gente precisa de tempo pra trocar com os profissionais sobre o currículo novo que está entrando agora que é o currículo funcional...a gente precisa de troca...a gente precisa de estar conversando com os nossos parceiros...a gente precisa..."; e vários HTPCs não sobrava nem um tempo...bom, é recados, algumas formações, né,...assuntos que se perdem...né, e que se demoram, então um assunto que você pode resolver em dez...quinze minutos as vezes ficava uma hora....por que? a turma viajava...em idéias que não se efetivavam...

$\mathrm{E}$ : Como você sentia a formação, você sentia-se preparada para enfrentar o dia a dia?

M- Nunca me senti completamente preparada, tanto do ponto de vista teórico quanto da prática. Acredito que o educador tenha que se renovar constantemente, através da sua pratica, decorrente da própria necessidade e da evolução da educação.

Nesta trajetória formativa pude sim, refletir sobre as ações que pudessem transformar minha prática, considerando novas formas de ensino. Partir para ação, efetivando o que acreditava baseado, tanto na teoria, quanto na prática, na busca de novas alternativas. A educação transforma-se continuamente.

Em cada período, ela assume novas características quanto às funções, idéias, concepç̃̃es que embasam nossas práticas e que também estão relacionadas às mudanças na sociedade. Em 1976, por exemplo, nosso currículo tinha uma abordagem comportamentalista, onde havia a necessidade de se definir com clareza e operacionalmente os objetivos que se pretendia atingir e para a organização das seqüências de atividades. Hoje, a criança recebe informações e ativamente as transforma. Diante destas transformações, o professor, o educador, não deve ficar alheio e sim ter autonomia de decisão, de superar limites, desafios e encontrar novos caminhos. Mas o que fazer quando estas transformações não são compartilhadas, discutidas, avaliadas, reavaliadas pelo grupo - escola? O que fazer com os sentimentos que acompanham o professor no diaa-dia (alegrias, tristezas, angústias, entusiasmo, esperança...)? o que fazer para mudar esse quadro, enquanto as ações não forem conjuntas?

Nesse período que estamos analisando, com os projetos realizados (relatórios) consegui pensar em algumas respostas para estas questões:procurar ter ações mais coletivas; o professor ter um papel mais dominante e significativo nas mudanças educacionais; ele é capaz de mobilizar ou estacionar os grupos; autonomia, baseada em ação consciente, embasada em teoria que sustente sua prática, faz com que direcione ações mais coletivas, justificando-as perante o grupo da escola. Este dinamismo, esta paixão pela educação vai repercutir em seu modo de ser, não dando oportunidade ao descompromisso, ao desanimo. Este professor / educador terá mais condições de contaminar positivamente quem com ele compartilhar do processo educacional.

Os HTPCs..não eram bem aproveitados...essa é uma queixa nossa...a atual direção está se empenhando para que esse HTPC tenha uma efetividade melhor... mas, é difícil...não sei o que acontece...parece que o tempo voa e não se esgota tudo.

E: Então você acha que é uma questão de dificuldade de coordenação?

M: Eu acho......também...eu acho que é uma dificuldade de coordenação também.

E: Diante disso quais as influências mais significativas que você sentiu mesmo diante dessas dificuldades apontadas, o que você proporia pra que esses saberes inter-disciplinares contribuíssem para que esse professor no dia-a-dia tivesse maior domínio da criança e do processo de ensino/aprendizagem, fazendo uma leitura da sua experiência nesse período... de noventa e seis pra cá...que foi o período que você descorreu.

M: Olha, é preciso considerar, realmente as diversidades...é uma palavra tão usada...as diferenças individuais e não só do aluno, mas de toda a equipe da escola....eu vejo que essa questão é importante ser observada para que cada um seja 
compreendido em suas peculiaridades... que a escola não fosse ...feita de divisões..sem essa complementação.entendeu? Eu acho que o que dificulta...a complementação..são as.relações...do dia-a-dia eu acho ... que isso se perde... quando não tem uma coesão entendeu...essa... divisão de papéis atrapalha...eu sei que tem que ter.... função da direção... a equipe tem outra função...o professor tem uma função, tudo bem, senão ia ser uma bagunça...se não tivessem essas função...mas, tem que ter uma hora em que essas funções se juntam, tanto a do professor, quanto a da equipe quanto a da administração...e um colabora com o outro. Acho que ia favorecer...ia contribuir com muita coisa...com tudo...

$\mathrm{E}$ : Mas o que seria necessário pra que isso ocorresse realmente...pra que toda a escola caminhasse de forma complementar...?

M: Bom, primeiro a gente ter clareza do objetivo do que realmente a gente quer pra nossa escola...Mas eu acho que... o grupo não tem clareza...o grupo não tem clareza...mesmo nessa nova proposta curricular, que é o currículo funcional, a escola ainda não abraçou essa proposta...não abraçou...por que não abraçou? Porque ainda a gente não tem discussões suficientes, a gente não pode deixar tudo na mão do professor não é porque aqui é uma escola...então a gente está com uma proposta nova...a escola não...ainda não está envolvida nessa proposta...a gente tem grupos... envolvidos...grupos tentando um envolvimento....mas olha, eu vou te falar...é mais com o grupo de professor do que com a escola como um todo...A gente vê o grupo de professores desgastados...por quê? Porque a gente tem professor que tem grupo de alunos muito difíceis e procuram se virar sozinhos as vezes...ou com o seu parceiro...com pouca troca...entendeu...e no momento da Educação que a gente está, que a gente precisa dessa parceria...

E: Qual a forma que a equipe encontrava para se organizar pra suprir dificuldades...

M: Então, mas veja bem...mesmo assim ficava e fica ainda uma coisa meia quebrada, porque você fala com um profissional, com outro..parecia não haver unidade. Então, acabava não aglutinando o trabalho, ficando centrado em alguns...

E: Você acha que o grupo ainda precisa estar melhor assessorado?

M: O grupo... eu acho que precisa...eu vou falar como professora, o grupo precisa de formação...contínua...isso é muito importante.... professor e ele quer estar sempre atualizado...ele precisa ler...ele precisa estudar...ele precisa discutir...ele precisa ver outras escolas...ele precisa estar em contato com outros profissionais...outras propostas...e a gente fica na escola, na escola, na escola, então tem que vir muita gente de fora, a gente tem que sair da nossa escola e ir para outras entidades, conhecer o que o pessoal está fazendo, ter essa troca, ter essas discussões... não ficar tão fechado na escola, entendeu...tem que sair...a gente tem que sair com o aluno, mas a gente também tem que sair...conhecer, porque um profissional bem capacitado quem é que vai sair ganhando? É o aluno...é o aluno...a família...não pé...que é...a nossa proposta é essa...então a gente tem que ter esse tipo de caminho...

E: A estrutura da Educação Especial tem algumas peculiaridades, em função das necessidades específicas, das adaptações ou vamos dizer assim, .dessa diversidade de condições que o professor precisa considerar, exigindo um debruçar mais próximo do professor para cada aluno...como por exemplo, a questão do número de alunos na sala de aula, ajuda o professor a ter maior domínio da situação. Que outros aspectos você acha que para atender melhor o aluno exigiria uma estrutura mais adaptada, que outros aspectos o professor ficaria mais assessorado?

M: Eu acho que por exemplo...o aluno tem que ficar na escola, pela legislação, cinco horas.....existem grupos de alunos que se beneficiam com cinco horas.. mas, existem aqueles outros que não...então se você está atendendo a necessidade do aluno...qual é a necessidade real do aluno? É ficar duas horas na escola com qualidade, ou é ficar cinco horas sem condições de qualidade...ou ficar uma hora e meia, duas horas com qualidade...que a resistência do próprio aluno permita e ele ter que ficar por causa da...da...então ter essa...essas normas ...deveria haver maleabilidade de horários.

E: Maleabilidade...

M: Essa maleabilidade de horário pra cada grupo de alunos...tem aluno que cinco horas é pouco...se você pensar bem, porque é um grupo de alunos que dá pra você desenvolver vários conteúdos, e a capacidade deles de entendimento está num nível capaz de aproveitar cinco horas...tem aluno que deveria estar na escola por uma hora pois toma muito medicamento, vem cedo... e não aproveitam pois é desgastante para eles ...entendeu, então eu acho que esse jogo deveria ser permitido na educação...Ter um horário...também...isso eu acho que deveria ter...o professor deveria ter um horário de planejamento...de maior dedicação para o próprio aluno...

$\mathrm{E}: \mathrm{E}$ isso não pode ser realizado no HTPC?

M: Não, porque as vezes não dá...tempo para todas as adaptações necessárias e aí mesmo com as horas de trabalho coletivo e a individual para o professor que tem um aluno com maiores comprometimentos, este horário não é suficiente para todas atividades preparatórias e registros dos encontros com familiares;do caderno de recados; da agenda do aluno; avaliação;etc. E: Mesmo no horário de trabalho pedagógico livre...

M: É.. o .horário livre...a gente usa muito, até horário em casa. Essa última assessoria que a gente fez com a Nina, que ela ajudou a gente a implantar o currículo funcional, ela disse que na escola dela, uma vez por semana os alunos não vem, porque o professor ele tem que se organizar, ele tem que estudar, ele tem que fazer um planejamento, ele tem que fazer um registro...então tudo bem um dia eu acho que não, mas se a gente puder ter um horário semanal pra gente estar se organizando, também seria bom...

E: Seria para este trabalho formativo?

M: Isso, porque daí a gente podia ter um contato com os parceiros, com a equipe, um horário específico para formação da equipe, entendeu...discussões mais freqüentes...porque, o que eu vejo...as discussões são muito espaçadas, então você vai...você vê um assunto hoje...aí as vezes o assunto se perde, nem existe mais...ou se existe, quando acontece já...o problema é outro...o problema já é outro...entendeu...então essa falta de espaço e de tempo também é um dificultador...

E: muito bom...e o que você gostaria assim de complementar que você acha que contribuiria ou acrescentaria pra fechar essa nossa entrevista?

M: Bom, o que eu... gostaria de falar é que a Educação tem um dinamismo, ou melhor...tem que ter um dinamismo..e.as pessoas têm que estar preparadas para isso.. o educador precisa estar apaixonado pela educação...ele tem que se envolver...tem que ter envolvimento profissional e não só envolvimento pessoal...você não tem que fazer com que as relações se ajeitem só no pessoal...as relações têm que se ajeitar no profissional.para o bem da escola..o pessoal estando bem o profissional vai...mas se só o pessoal estiver bem e o profissional não, como ficam os alunos...então você vai ter uma escola...onde as relações podem ser amistosas e todos "um amiguinho do outro", "passando a mão na cabeça"......e o problema vai ficando...e o aluno vai sobrando...isto não dá para acontecer...pode-se ficar tudo muito bem...no pessoal mas e no profissional? Então acho que tem que ... a pessoa que trabalha com educação tem que ter essa clareza do seu papel...por quê? O coletivo se forma pela reunião desses individuais....então, o individual pessoa e o individual profissional precisam estar coerentes, o pessoal e o profissional andando juntos, ...então é isso que eu trago da minha experiência... uma escola que os profissionais tenham clareza do seu papel e os aspectos pessoais não emperrem o profissional... eu idealizo e eu tenho certeza que ela vai existir...

E: Com a sua contribuição... 
M: A minha contribuição é essa de que o pessoal ande junto com o profissional... Espero ter contribuído (risos) e espero que um dia essa 'escola da ponte' possa ser a nossa

E: Eu agradeço sua valiosa contribuição para este trabalho, com dados tão envolventes.

$$
\bullet *
$$

\section{Maria}

A entrevista foi realizada na unidade escolar, onde a entrevistada desenvolve suas atividades, como professora.

Duração da Entrevista: 1 hora e 45 min

E: Como você avalia a formação continuada desenvolvida em parceria com a equipe interdisciplinar entre 1996 e 2003, período em que estas atividades eram desenvolvidas na unidade escolar. O que você destacaria como tendo sido determinante para sua formação?

M: Bom, é...pensando em equipe, só equipe da escola...ou pensando em equipe interdisciplinar que até propôs algumas assessorias e vieram pessoas de fora...

E: Ambos faziam parte da proposta, que você vivenciou no dia a dia com a equipe?

M: Sim, eu penso que assim....é, eu tive, no decorrer desse período, duas experiências diferenciadas. Uma na escola esta...na escola especial, e outra no programa ...desse serviço de educação especial que até então se chamava estimulação precoce. Então eu tive duas experiências aí...

$\mathrm{E}: \mathrm{E}$ como estas experiências repercutiram na sua formação?

M: É...o comecinho, ainda na outra escola de Educação Especial, uma experiência de assessoria, não sei se pode citar nomes, com a Profa Úrsula, que foi excelente, comecei com ela, e acho que esse período de assessoria da Úrsula pra mim foi muito importante, acho que foi um ponto de destaque...e depois, já na outra unidade de Estimulação Essencial, a assessoria da Úrsula também, mas com um formato mais específico, voltada para crianças de zero a seis, que era o foco do nosso trabalho. Então, nesse período, acho que esta assessoria com a Úrsula foi uma coisa que eu posso destacar para minha formação. Esse percurso com a Úrsula, assessora da AACD enfatizara o desenvolvimento da criança, tendo referências a teoria de Piaget e a utilização da escala de desenvolvimento de David Werner, além de nortear e organizar nossa rotina de trabalho com atendimentos individuais. Contamos nessa unidade com a assessoria por aproximadamente dois anos- noventa e oito a dois mil, com observações pontuais, discussões em grupo e encaminhamentos bem direcionados.

E: a base teórica que direcionou o trabalho era apenas a piagetiana?

M: Depois nós tivemos nesse período também o Profo Rinaldo Voltolini, já com base psicanalítica, falando de um outro aspecto ...também de crianças pequenas, mas dessa constituição do sujeito, mais nessa linha da Psicanálise...que a princípio chamou muito a minha atenção, pelo meu desconhecimento é...passou por um período de falar..."não sei nada" de um saber que eu não sabia possuir. A princípio, um curso a toda rede da Educação Especial, tendo como proposta um melhor conhecimento de crianças com Distúrbios Globais do Desenvolvimento (DGD). Foi um curso que se transformou em assessoria com encontros quinzenais e mensais com parte do tempo para estudar a teoria e estudos de casos. Neste período, muitas dúvidas permearam minha menteuma delas como conciliar Pedagogia e Psicanálise? Outros cursos, palestras, outros profissionais precisaram passar pelo Serviço e por mim para que eu começasse a compreender e refletir e colocar em prática esses novos conhecimentos.

$\mathrm{E}$ : E com esta bagagem que você foi adquirindo como era trazida para o cotidiano das suas atividades com os alunos e como a equipe se integrava?

M: Então aí eu já vou falar mais dos meus trabalhos na estimulação...aí a partir de noventa e nove e eu estou aqui até hoje, como Centro de Apoio, eu me sinto privilegiada, pois trabalhei com pessoas que eu tinha como referência profissional...então assim, tanto na psicologia, como mesmo na pedagogia, de parceiro mesmo, fazíamos muitas trocas...tanto professor com professor...como professor com psicologia, fono...era um trabalho com um número reduzido de profissionais e que possibilitava esse encontro melhor, essa troca melhor. Agora assim, a princípio, sempre...pensando e percebendo, que existia a troca, mas eu via que desconsideravam um pouco o papel do professor...não tanto professor como professor, porque falava-se mais da prática, da atividade, do dia-a-dia, como eu via aquele aluno...agora, com relação a fono, a psicologia, eu percebia que desconsideravam um pouco o meu trabalho...

$\mathrm{E}:$ Como você percebia?

M: Desconsideravam o meu saber como professora. Podia ser até, como eu era nova...na unidade, é...o trabalho era novo pra mim podia ser que era mesmo uma iniciante, eles não conheciam o meu trabalho e não davam tanto valor assim...mas, percebia que pra saber daquele aluno tinham que recorrer a mim...então recorriam, e ficavam questionando, porque eu fazia aquela atividade, qual era o meu objetivo, é...o que seria desse aluno depois de tudo o que eu havia planejado...isso é função....do meu trabalho...eu observo... planejo, faço a ação, reflito, vejo o que eu tenho que mudar do meu trabalho...mas numa visão geral, quando se falava desse aluno, quando a equipe se referia a esse aluno, eles estavam se referindo ao trabalho que eu tinha feito,percebia que o foco era eu, não o aluno.

E: Como você sentia estas questões referentes ao seu papel profissional?

M: Eles passando conhecimento e o que eu fazia, qualquer um poderia fazer. Mas isso foi mudando através das assessorias, das trocas, do conhecimento do meu trabalho.

$\mathrm{E}:$ Você acha que foi uma conquista de espaço?

M: Eu acho que foi um conjunto...eu acho que foi assim eu recebia essas informações, esse conhecimento...eu...fazia desse conhecimento, e...tentava usar na minha prática...é...e eu consegui...depois de um tempo, assim, acho que falar da mesma maneira...acho que elas conseguiam me entender por que eu também...acho que..as entendi. Mudou a forma de me colocar no grupo. Comecei a cavar o meu espaço para falar..."eu pertenço a este grupo, vocês vão ter que me ouvir, quero dizer ouvir o que a professora tem a dizer e não só ouvir a psicologia, fono, serviço social"...

E: O seu posicionamento repercutiu como você esperava?.

M: É. E acho assim, que essa outra questão...T.O., fono, psico, acho que...foram vendo que todo mundo tem o seu lugar ali...e se nós estamos num espaço pedagógico, educacional, é isso que tem que ser o forte...

E: Não prevalecia?

M: Desse conjunto. Eu acho que com o tempo eu consegui me colocar de uma forma diferenciada. Até, as últimas reuniões que participaram esse equipe...que foi desmembrada...é....de ser elogiada, de falar "poxa, você mudou...to vendo no que você mudou"...e que na verdade acho que mudamos todas. 
E: Você poderia fazer uma análise da participação do professor, no sentido dessa percepção sua, de ter que lutar para conquistar seu espaço no grupo.

M: Como eu avalio... É...eu penso assim...que nesse momento, o professor precisa cavar o seu espaço também...e procurar não ser um mero executor...Acredito que quando o professor se sente seguro,respeitado em suas ações, encontra parceiros, seja outro colega, seja com os profissionais da equipe para arriscar,planejar, acertar, errar, começar de novo...tudo fica mais fácil.

E: Você acha que a forma como a formação foi idealizada pode favorecer a participação do professor a ocupar esse espaço? M: Olha, eu penso que vai do professor. Eu acho que assim, uma palavra que você usa bastante,já... que eu estou percebendo, que eu acho que é importante, é a parceria. Quando o professor se sente parceiro, fica mais fácil ele ir em busca desse outro profissional para estar aprendendo, para estar dialogando, para estar trocando,...e quando ele se sente parceiro, as coisas...melhoram. E, assim, acho que quando ele não se sente parceiro daquele colega de trabalho...ou ele vai por outros caminhos a procura desse conhecimentos...ou ele burla...ou ele...finge que sabe o que está sendo colocado e não sabe. Diz que vai desenvolver o que é solicitado não faz.

E: Você acredita essa questão da parceria, depende muito de como a relação foi estabelecida entre o grupo?

M: Ô...é assim, de você ser considerado, é...das pessoas irem falar com você e saber te ouvir também...é...colocar o que parece que não é certo nesse momento, de uma forma não impositiva...falando olha " isso que você faz não é o correto, porque eu sei como é que faz...então tem que ser feito dessa forma"...eu acho que não...acho que...na parceria mesmo né...na relação....nisso de considerar o que o colega também pode fazer pra contribuir...porque tudo isso é voltado para uma coisa só né...para a melhora do trabalho...pra...um trabalho diferenciado com esse aluno que você tem. Eu acho que é um procedimento intencional,em que mudamos todos...equipe e professor. Se a intenção foi, que eu me modificasse...eu me modifiquei... mostrando que do jeito que eles estavam fazendo também não era tão correto, né...só o saber deles é que vinha...

E: Unilateral...

M: Isso, é...eu seria uma mera executora do saber que eles estavam me fazendo favor de dar, sabe...acho que aí não...

E: Você acredita que com essa busca, essa sua transformação, em um esforço do professor para se fazer ouvir vocês tiraram daí grandes ensinamentos..você acredita que em outros momentos isso se transformou, amadureceu, essas relações de troca? M: Acho que sim, porque assim, é...foram conhecendo o meu trabalho também...foram conhecendo a profissional, é...e também eu acho que professor...de um modo geral...não desconsidera o conhecimento do outro...eu acho que isso é bem interessante...o professor está sempre aberto para receber informação da Psicologia, da fono, da T.O., da fisio eu penso que com a maior facilidade ele consegue falar "bom, isso que eu ouvi dessa profissional serve pra esse tipo de trabalho...pra essa conduta com esse meu aluno".... professor vai adaptando e vai pegando pra si o que serve e vai transformando isso em prática.

E: Você considera que estes conhecimentos, saberes específicos que fundamentava a sua prática, eram trazidos por cada área de forma correlacionada?

M: Ahn...eu acho que vinha em parte, fragmentados e eu conseguia transformar num todo...numa criança...porque não dá pra você falar "essa criança agora eu só vou trabalhar a partir de fono...só vou trabalhar a constituição do sujeito, só vou trabalhar motor"...eu acho que é naquela dinâmica...eu tinha um todo...e empregava o todo. Quero dizer, o conhecimento teórico e prático em uma única criança, as informações mesmo que sendo discutidas em separado, eram integradas na criança como um todo.

E: E na intra-equipe você sentia essa fragmentação? Ou eles tinham uma leitura dinâmica mais integrada da criança?

M: Globalizada...digamos assim? Eu penso assim...que em alguns momentos eu falava do todo e cada um pegava pra si a sua parte...eu percebia isso, tanto que...eu sentia muita dificuldade em algumas assessorias de estar. Vendo o que era da pedagogia.. eu não conseguia separar...a pedagogia...a atividade que eu fazia ali...de uma criança inteira e de estar fragmentando...e estar falando "agora é só motor...agora é só isso...agora é só aquilo"...

$\mathrm{E}$ : E nas assessorias? Você fazia a sua leitura...?

M: Até nas assessorias, vinha assim, mais da área específica...e aí sim eu falava "não, isso eu vou transformar"...

$\mathrm{E}$ : Mas assim, internamente na equipe você sentia que o grupo de especialistas faziam uma leitura mais específica da criança....?

M: Eu penso que sim até porque procurávamos os profissionais, de acordo com a necessidade de cada área.

$\mathrm{E}$ : Que transformações essa experiência em parceria com a equipe provocou na sua prática, que permanece até hoje? O que contribuiu e que falhas ocorreram?

M: Olha eu acho que mudou todo o meu processo...de trabalho e continua mudando, tanto o meu como a estrutura, organização e funcionamento de toda unidade e dos profissionais que por ela passaram e ou permanecem. A princípio a parceria com a equipe possibilitou a transmissão de conhecimentos e não troca de saberes. Aos poucos, ao me apropriar das informações, colocá-las em prática e conseguir dizer daquilo que fazia, com registros, planejamentos, avaliação das ações, encaminhamentos, comecei a me sentir parte do grupo e a atuação do professor passou a ser considerada como profissional que produz e compartilha conhecimentos.

E: Você sente que nas atividades propostas tanto pela Profa Úrsula, quanto pelo Profo Rinaldo vocês, professores e equipe, conseguiam fazer juntos essa ponte com a prática, ou você se acostumou a realizá-la sozinha?

M: Não me sentia solitária não, porque até nas assessorias tinham estudos de caso...então sempre tinha um caso...se não fosse meu, era de uma colega e assim, não sentia que...ela comentava isso...era apresentado um caso só....sozinho...então era...era aquele caso, daquela unidade então que todos ali tinham um parecer sobre aquela criança, e era discutido.

$\mathrm{E}: \mathrm{E}$ as práticas como eram compartilhadas?

M: Num estudo de caso você podia ver...qual a ação da Psicologia, da fono, do professor...o que que estava ali acontecendo...pra que um dos assessores é...fizessem..os apontamentos, uma discussão sobre o caso...mas não era,...separadamente. Na formação isso era uma prática, a discussão de um caso, o estudo de um caso, discussão de temas que eram abordados pelos assessores que não ficavam muito esclarecidos pelo grupo, depois era retomado. Acho que essa formação acontecia, e acontece ainda... pelo menos nessa unidade,...pode até ser de um formato diferente, mas os estilos de formação em HTPC é uma coisa que permanece.

$\mathrm{E}$ : E as transformações que este processo provocou no âmbito da criança, no âmbito da prática, quais foram?

$\mathrm{M}$ : A medida que o tempo passa, as experiências se multiplicam e vou adquirindo novos e diferentes conhecimentos, sinto-me mais fortalecida nas ações, nos recomeços, nas novas práticas .

E: Então, a formação lhe forneceu meios para conduzir sua prática com mais segurança?

M: Acredito que o conhecimento socializado fornece elementos para transformações e mudanças. No período desse projeto em especial,recebi informações de assuntos que eu desconhecia, pude re-organizar conhecimentos, vivenciar situações, comparar práticas, tirar conclusões e aprimorar o meu pensamento. 
E: A experiência então, ofereceu...melhores condições para você conseguir compreender seus alunos?

M: Claro. Eu vou te dizer a cada dia eles vêm diferentes...então eu acho que é uma busca...é um conhecimento que não tem fim...porque quando você fala "acho que agora eu sei trabalhar com criança que apresenta esse quadro"...aí chega um outro que você fala "e agora...esse daí...o que eu vou..fazer o quê? Então você está sempre em busca...é mas...assim, muitos do que eu consigo fazer veio de todo esse conhecimento que foi adquirido.

E: Diante deste enriquecimento teórico, você sentia-se preparada para a prática? Houve algum referencial teórico, em particular, que ajudou nesse sentido? Como a teoria ajudou no manejo do cotidiano escolar?

M: Ao iniciar o trabalho com crianças de zero a seis anos, portadores de múltiplas deficiências, DGD, deparei-me com um universo desafiador e em alguns momentos desconhecido. Piaget, Vygotsky, fases do desenvolvimento, construção do conhecimento, como a criança aprende, desenvolvimento infantil à luz da psicanálise, instrumentos metodológicos, o compromisso com a criança e sua família, a organização e estrutura dos atendimentos, a rotina da educação infantil, a inclusão, a parceria com o professor do ensino regular. Um conjunto de elementos fundamentais de estudo, aprendizado, mudanças e conhecimento. Cursos, assessorias, formação em HTPC, palestras, discussões, trocas de experiências. Parceiros indispensáveis na construção e reflexão de práticas mais acertivas.

$\mathrm{E}$ : Você assinalou as contribuições que o serviço social possibilitou? Como essas intervenções eram mediadas na relação com a família?

M: Então, sempre partindo de uma demanda que vinha do professor, se eu estava observando alguma situação que a assistente social poderia intervir...então era através da demanda que eu levava que ela fazia esse trabalho com a família, e mesmo das outras áreas, tinha áreas específicas, por exemplo da Psicologia, que vinha através da demanda do professor mesmo.

E: Você realizava algum trabalho voltado para os pais? Como você inseria a família em seu planejamento?

M: Então, aqui na estimulação, no centro de apoio... o envolvimento da família, por se tratar primeiro de crianças pequenas, a possibilidade da gente de estar transformando esse olhar dessa família pra essa criança, propiciava esse encontro ahn...mais sistemático...é....de estar falando dessa criança pra essa família...a mãe, em muitos atendimento que eu faço, que eu fazia, entrava no atendimento, então existia essa proximidade ...durante o atendimento estar mostrando pra essa mãe como agir com o seu filho, como era essa criança...e...nesse convívio a gente tinha uma relação boa, de falar da escola, de falar de casa, de falar das coisas que permeavam essa relação mãe e filho, essa relação unidade escolar e família... acho que um grupo menor, privilegia essa situação...então, o trabalho com pais, tanto no atendimento, como nas conversas que aconteciam de estar encaminhando para o serviço social, para a Psicologia...em uma época da estimulação existia um grupo de pais que a psicóloga e a assistente social trabalhavam, com assuntos específicos, coisas também que elas não contavam pra gente, para o professor, elas falavam nesse grupo de pais...

E: Como esta experiência ,em parceria com a equipe, contribuiu no acompanhamento à criança incluída, como você vê esse processo com o professor da educação infantil ?

M: Olha, uma coisa bem legal que aconteceu na estimulação, é que quando veio esse "bum" da inclusão, nós começamos juntos...eu não me lembro exatamente o ano, mas deve ter sido dois mil e um...dois mil, dois mil e um...então os primeiros alunos que nós atendíamos começaram a ser incluídos, e a princípio, pavor pra todos..para o professor da unidade que ia para escola...que ia estar levando esse aluno....acho que o principal era uma escola regular aceitar o aluno da educação especial, então esse primeiro momento...é foi assustador...pra todo mundo. E depois assim, esse acompanhamento, de algumas crianças, foram poucas, foi bem gradativo, como é que o professor da unidade escolar regular, recebia o professor da educação especial? A princípio, o que eu via é...que eu estava indo pra...falar mal do que eles não estavam fazendo, o que eu sentia um pouco...que eu iria desconsiderar tudo o que ele estava fazendo lá...e...ter soluções, né..."você que vai me dar soluções...você que vai me ensinar o que eu tenho fazer com esse aluno?"... eram as perguntas que a gente enfrentava quando chegava. Mas eu acho que, o processo inicial, também foi de estar chegando nessa escola fazendo essa escuta desse professor, de tudo que ele tinha de angústias, de medos, de reservas, que eu também tinha, porque pra mim também era novo... e estar dizendo pra ele que tudo que ele sentia eu também sentia......e que a gente ia tentar fazer o melhor...juntos. $\mathrm{E} .$. isso foi um ganho muito grande desse professor itinerante, desse professor junto da educação especial, porque acho que professor falando com professor...falando "eu sei o que você faz...o que você faz eu também faço... os receios que você tem eu também tenho...e o que você conhece desse aluno, eu também conheço um pouquinho dele"...de estar escutando, de estar acalmando e de estar falando, "nós vamos caminhar juntos". E uma coisa que eu achava muito interessante...de alguns aluno...quando chegava era assim olha "eu posso dar bronca porque ele tirou o sapato e jogou no amiguinho? Eu posso mudar ele de lugar porque com aquele não deu certo? "...e...o que eu devolvia era "E se fosse outro menino, que não fosse esse, o que você faria?"..."Eu ia lá falava pra ele: coloca o seu sapato que isso não pode fazer!"...eu falei "E porque você não pode falar pra esse menino dessa forma?". Os encontros aconteciam semanal ou quinzenalmente. Tínhamos como proposta a observação da criança na rotina da sala e um momento com a professora, para que ela pudesse falar de suas dúvidas, das questões relacionadas à aprendizagem, comportamento da criança, etc. Muitas vezes percebi que a minha contribuição estava em devolver à professora as estratégias que ela já havia planejado, realizado e não se dava conta, colaborar com sugestões a respeito de mudanças na rotina, adaptações no posicionamento da criança, de mobiliário, material escolar, em fazê-la confiante nas atitudes que tomara quanto ao comportamento do aluno, na aposta das possibilidades da criança. Procurava mostrar-me próxima a essa professora, compartilhar e contribuir com experiências significativas para a criança, para a classe, para a professora e para a escola. Foram necessários documentos, materiais para registros, relatórios, enfim, elaboração de procedimentos que mostrassem o tipo de acompanhamento realizado, as intervenções e encaminhamentos propostos pela professora itinerante e pela equipe técnica da estimulação precoce - Educação Especial. A equipe gestora da Educação Infantil também começou a participar dos momentos de troca com a professora. Posteriormente a equipe técnica da Educação Infantil também compôs o agrupamento para "colaborar" com a equipe da Educação Especial.

E: Vocês foram se situando e aprendendo no processo?

M: É...e também é uma coisa nova, era uma criança diferente? Diferente, mas criança. Então que...vai fazer tudo como uma outra criança qualquer...e que a gente tem que estar...atento a algumas coisas e fazer o que faz com qualquer criança...mas de que maneira...as vezes repetir mais vezes....as vezes chegar mais próximo, as vezes modificar um pouquinho uma folha de papel, uma cadeira, uma mesa, mas que são crianças mas que naquele momento ela seria professora dessa criança também, como das outras. Acho que essa experiência, do início da inclusão, foi bastante gratificante também, eu já cheguei me sentindo parceira desse professor, e ele é que foi aos poucos se sentindo também...meu parceiro porque acho que... tem também aquela coisa..."mais uma que vai vir aqui...olhar, ir embora, e eu vou ficar sem resposta".

$\mathrm{E}:$ Como a equipe se integrava com nesse processo de parceria seu com o professor na inclusão?

M: Então, isso também teve alguns procedimentos... A princípio ia só professor itinerante com professor...e professor e equipe escolar. Eu observava, fazia as intervenções, voltava e dizia para o grupo o que estava acontecendo. E assim, quando tinha 
situações muito específicas, a gente pedia para o profissional...da Psicologia, T.O., fono, acompanhar no próximo encontro... esse profissional também observava qual a dificuldade dessa professora e no que ela podia estar contribuindo.

$\mathrm{E}$ : Você encontrava nas diferentes situações a equipe que tinha essa preocupação em estar ajudando?

M: Em fortalecer a prática, se eu precisasse...essa retaguarda então se eu precisasse seria lá. Depois, num outro momento desse processo, a minha equipe, a equipe de orientação técnica do infantil- EOT do infantil, também começou a tomar parte desse processo de inclusão, e assim, quando eu deixei de ser itinerante, esta sistemática já estava incorporada também pela Educação Infantil em parceria com a equipe do Especial.

E: Como o Centro de Apoio de Estimulação Essencial vê a conquista de autonomia da escola de educação infantil, com referência à inclusão dos alunos?

M: Como centro de apoio os objetivos da inclusão até hoje, é que o professor do centro de apoio se afaste da unidade quando aquela unidade se sente fortalecida em trabalhar com esse aluno,...quando os profissionais da EOT também falam "olha...esse...essa criança não precisa mais do centro de apoio"...mas é um consenso ..

E: Então é um processo de transformação em que essa escola vai assumindo a educação desta criança como parte dela?

M: Isso, vai se apropriando dessa criança.

$\mathrm{E}$ : Você sente que a formação nessa parceria com a equipe, contribuiu para você fazer uma nova leitura de como deveria chegar no professor da educação infantil? Você assinalou como exigia do professor itinerante muito envolvimento "caminhávamos muito"...ou seja, que aprendizagens nessa relação intra- equipe the permitiram amadurecer a relação de conquista na educação infantil?

M: Acho que o que aconteceu comigo nesse processo de formação, até chegar ao professor de inserir esse aluno na inclusão, me deu essa experiência esse cuidado de chegar na unidade escolar e ter esse professor como parceiro ele fica lá na escola cinco dias na semana...quatro horas por dia...e ...na verdade, quem deveria conhecer mais, me dar mais dados sobre essa criança, seria ele. Então acho que todo esse processo que eu passei...é....me fez mudar, e chegar lá com esse cuidado...de têlos como parceiro, e falar olha "você conhece o suficiente desse aluno...eu vou estar falando algumas coisas que eu penso que você não está observando...ou....pensa que não sabe"...

E: Essa leitura...você acredita que foi possível você fazer junto com o seu grupo...sobre estes aspectos... avaliando criticamente essas relações formativas?

M: É uma coisa que eu penso que diferencia essa unidade de outras é...a gente ter essa possibilidade de estar falando de relações...é...saber sim, como é aquela criança...onde ela se situa o que pode se fazer com ela...quem vai fazer o que por essa criança...e também disso...dessa relação..."olha, você está me desconsiderando...eu também sei falar dessa criança......penso que você pode atuar de uma outra forma sim"... uma questão que sempre acontecia, por exemplo, de posicionamento...de uma criança...de um PC grave...então, muitas vezes eu procurei ajuda de uma T.O....pra me falar de posicionamento, de mesa, de cadeira, de material...e...chegava depois e falava "olha...quem sabe mais disso dessa criança é você...então você sim vai até poder me ajudar"...então isso acontecia. Não sei se isso acontece em todas as unidades, mas lá...não era uma coisa muito tranqüila não viu, mas...depois...ficava uma coisa bem gostosa, bem tranquila, porque a gente sabia separar também o profissional do pessoal...aqui também foi um processo, não foi logo das primeiras vezes que isso aconteceu não.

E: Como você analisa essa experiência que você teve com diferentes áreas, que não é uma prática muito comum nas administrações públicas... manter uma equipe interdisciplinar em parceria com o professor, buscando essa formação continuada em serviço pautada na realidade, da sala de aula, como você expôs? Foi uma experiência que contribuiu mas que na sua análise necessitaria ajustes...e quais são esses ajustes que você avalia que sejam importantes ocorrer?

M: Passei por esse processo com períodos conturbados, considerando diferentes especificidades, diferentes personalidades, diferentes práticas e níveis de conhecimento. Hoje, vejo a parceria, decorrente da formação de áreas específicas, contribuir para que pudesse ampliar conhecimentos, modificar pensamentos e buscar um caminho pedagógico, agregando diferentes informações, saberes e meus novos saberes. No entanto, novos ajustes são necessários: continuidade dos cursos em parceria com profissionais e tematizações específicas escolhidas pelos professores do centro de apoio; colaborar com profissionais que trabalham mais de um período, oferecendo formação além do horário de HTPC no horário de trabalho.

E: Você levanta uma questão interessante...gostaria que você esclarece um pouco melhor...quando você faz essa leitura positiva da contribuição das áreas...você ,entretanto,não vê uma integração de saberes desse sujeito como um todo, e você traz como preocupação...que esses diferentes saberes...estejam voltados para suas necessidades educativas, sendo contemplado de forma mais...pontual e direta. Como você avalia que a equipe poderia contribuir com uma visão mais integrada...

M: Olha, era uma equipe atuante sim, mas, de qualquer forma, não sei se eu não estou me expressando bem, mas via essa equipe fragmentada mesmo...nessas áreas...cada um na sua área. É...então assim...via dessa forma, exatamente...as áreas fragmentadas e tinha que voltar...e assim....convergia tudo...para o professor e para aquele aluno. Então quem é tinha que fazer todo esse entrelaçamento aí? Era o professor.

$\mathrm{E}$ : Do ponto de vista prático você traz uma contribuição das diferentes áreas, mas que até certo ponto trazia uma criança fragmentada para você fazer a leitura integradora. E neste aspecto, qual é a possibilidade do professor poder fazer uma leitura integradora de criança....uma realidade tão específica como a que vocês vivenciam?

M: Não sei, minha experiência... dizia o seguinte eu ouvia...todas...e canalizava para aquela determinada criança...um pouco de cada, nas discussões de caso é que se integrava mais, por exemplo, se uma criança...tinha uma suspeita de de autismo, qual era a área que vinha junto com o professor? A Psicologia...então ali, professor e psicólogo é que falavam do caso, e outras áreas contribuíam como dava ali...mas assim, sempre tinha...uma discussão coletiva, mas sempre tinha o professor com algum profissional de uma das áreas, porque num estudo de caso, numa discussão, levava-se assuntos específicos. E sempre uma das áreas é que ia dar aquele contorno todo. E assim, as outras pessoas contribuíam da maneira que achavam que complementava. E todo mundo dava sua colaboração, por exemplo, no encaminhamento escolar da criança...então nesse momento, todas as áreas precisavam estar opinando de alguma forma pra falar "vai pra determinada unidade? O que que vai precisar? De um acompanhamento nessa área...o que que você vai poder sugerir pra esse professor que está recebendo esse aluno?"

$\mathrm{E}: \mathrm{O}$ que você gostaria de colocar a mais... desse processo que você vivenciou, e o que você acha importante complementar? M: Olha, acho que pra encerrar, eu avalio que foi uma experiência muito positiva e, "não é fácil perceber que desconhece o que pensa conhecer "...não é fácil se defrontar com sua inexperiência e "ignorância"... não é fácil ouvir e não compreender. Aí, você se percebe selecionando informações, transformando teoria em ação, questionando suas práticas ou seus formadores, sofrendo e refletindo. Menos experiente em algumas situações, começando de novo em outras, descobrindo novas informações, novas práticas, aprendendo, reaprendendo, recomeçando sempre se for preciso.

E: Muitas vezes o professor expressa um sentimento de estar no "front" das situações e muitas vezes sozinho para decidir situações difíceis, como você analisa? 
M: Eu acho que em determinados locais isso é uma realidade, mas não posso dizer isso... dessa unidade que eu trabalho. Porque é uma coisa pessoal, se tem uma coisa que está me incomodando muito, que eu não vejo o que fazer...eu abro minhas portas e vou procurar alguém pra me dar um auxílio porque sozinho, entre quatro paredes, o professor até pode fechar a porta e fazer o que ele quiser...agora, ele pode abrir a porta e falar "vamos fazer um bom trabalho" é...eu penso, de novo, que aqui eu sou uma privilegiada, não tenho necessidade de fazer isso.

E: Você acha que a sistemática de trabalho da equipe, do mesmo jeito que você ia em busca, abria as portas, como você mesma assinalou, a equipe também se apropriava do seu fazer pedagógico, entrando na sua sala?

M: Ah sim, porque, as informações que a equipe tinha do aluno era do que eu falava ou do trabalho que estivesse realizando a equipe viesse pra observar. Então, muito do que a equipe sabe do aluno, é através do trabalho do professor.

$\mathrm{E}:$ Neste aspecto, a parceria no contexto da sala de aula se concretizou?

M: Eu acho que não dá pra você falar de qualquer situação, de qualquer aluno, ou de qualquer situação escolar, se você não está ali na prática, se você não está vivendo se você não conhece, se você efetivamente não põe a mão na massa, o que você falar é...eu vou ficar ressabiado, porque você não tem esse conhecimento prático. Então é primordial, em qualquer uma das áreas, que numa escola, pra falar de qualquer coisa da educação, do escolar, da pedagogia, da prática, tem que estar junto. E: Para encerrar eu gostaria de agradecer sua contribuição. Muito Obrigada. M: Imagina, eu que agradeço. Eu espero que eu tenha contribuído.

$* *$

\section{Ana}

A entrevista foi realizada em uma Escola Municipal de Educação Básica de Ensino Fundamental, onde a entrevistada exerce suas funções como professora especializada.

Duração da Entrevista: 1hora e 37 min

E: A professora Ana, que vai nos dar essa entrevista é professora de Classe Integrada...e eu gostaria primeiro, de perguntar...o que você destacaria, como tendo sido determinante na formação continuada em serviço, desenvolvida na parceria com a equipe interdisciplinar, desde o período que você ingressou, até 2003 ?

A: Então, pra mim o que foi mais importante foi bem no começo mesmo, que eu entrei e fui direto...pra Escola Especial...e ainda por cima eu tinha acabado de me formar...então eu não tinha muita prática, tinha trabalhado só seis meses em outra Prefeitura...e assim, pra mim foi um ponto de referência, porque lá tinha toda a equipe...tinha fono, orientadora pedagógica, psicóloga, assistente social...e a gente trabalhava todo mundo junto...o tempo inteiro...então nós tínhamos reuniões que a gente chamava de estudo de caso, onde a gente pegava pra estudar mesmo...onde a gente via mesmo a questão da prática onde a gente deve melhorar, aonde a gente pode estar ajudando...todo mundo sentava pra discutir isso e depois a gente levava paro o grupo maior.. Lá também nós tínhamos assessorias, que eram super interessantes, a gente teve com a Profa Úrsula e com o Profo Rinaldo Voltolini...que eu não consegui participar...e a gente tinha formação de grupos também...não tinha HTPC, mas parecia que o tempo rendia mais do que agora...era menos corrido. E isso se tornou a minha base, todo mundo era minha base, todo mundo era ponto de referência, principalmente falando da orientadora pedagógica,...então era como se eu tivesse ela como referência, onde eu tivesse que ir pra me socorrer...onde eu falava "aqui eu preciso de ajuda"...era ela que me socorria mais, ela me ajudou muito, muito mesmo...então assim, se eu tivesse saído de lá, da faculdade, direto para uma classe integrada como hoje, ou direto para trabalhar numa sala de recurso, eu estaria totalmente perdida...porque é como se eu tivesse sem nenhuma referência...de "como trabalhar"..."qual o olhar pra essa criança com deficiência?"..."o que deve ser feito?"..."o que ajuda em classe?"...e isso eu consegui direto com ela e com as troca com os professores do Especial e com a equipe que a gente tinha lá.

E: Você sentia nesse grupo de profissionais uma possibilidade de troca de saberes com os seus e com a sua prática pedagógica...como era isso..essa interligação de diferentes saberes?

A: No começo eu acho que a gente começa às vezes pensando que eles são a chefia, os profissionais, depois a gente começa a perceber que não é isso...que realmente tinha uma troca. Quando eu cheguei eu São Bernardo eu cheguei meio...ansiosa eu peguei uma turma que não era assim, uma turma de pequenos, era uma turma adulta...e eu lembro que a faixa etária era de mais ou menos vinte e dois anos...vinte anos...eram bem mais velhos. E eu estava...como agora preparada para a alfabetização. Isso foi uma coisa que sempre me aguçou, e eles já tinham passado dessa fase. Mas eu também não aceitava o fato de não trabalhar isso mesmo se for a questão de letramento, de "não trabalhar isso"... eu não aceitava e daí quando eu cheguei a orientadora falava "Olha Ana, baixa a bola, menos...calma"...e isso eu não aceitei...esse "baixar a bola"...eu continua aí, com as minhas expectativas...fui atrás, consegui investir na questão do letramento...do nome e fui associando esta parte com o trabalho que eu tinha lá que era oficina. Então, eu continuei com aquela expectativa que eu tinha, eu sabia que eu não ia chegar ao máximo de alfabetização...não...com eles, mas eu também não ia desistir de trabalhar nada e aí, aos poucos, eu comecei a perceber que as meninas começaram a acreditar no meu trabalho...primeiro elas achavam "ah, ela é só uma menina que está começando, nova da faculdade, cheia de expectativas", mas depois elas viram que não...que aquilo que eu estava fazendo estava ajudando sim...que eu tinha organizado...estava melhor a questão de organização de pensamento deles...que mesmo"não estando alfabetizados"...mas a questão do pensamento estava melhor...e isso eu consegui e aí eu comecei a ser um pouco mais respeitada...e aí a gente conseguia fazer uma troca mesmo e não mais assim na cobrança da "chefia" do "o que você está fazendo?"...mas esta experiência cada um em sua área permitiu uma troca de saberes que muito ajudou a evolução dos alunos e também eu poder buscar novos conhecimentos.

$\mathrm{E}$ : Isto lhe deu mais segurança frente ao grupo?

A: É, aí a gente começou a trocar muito mais, sobre isso.

E: Você sentia que nestas trocas havia uma unidade nas diferentes áreas, na equipes que você... teve oportunidade de compartilhar?

A: Sim, elas tinham uma unidade. Mas ao mesmo tempo, cada uma sabia "o que podia ajudar mais"..então eu lembro que...a Elisa, que era a psicóloga aqui no começo...as vezes eu tentava fazer alguma coisa e tinha dificuldade...e ela "você tentou dessa forma?"...então eu falo pra você...estavam todas pensando no mesmo objetivo...eram unidas...mas cada uma dentro da sua área...da sua especialidade, da sua área...tinham um olhar que me ajudava...e aí eu não tinha visto daquela forma, e aí a gente manejava e a gente terminava chegando num acordo. 
E: Essa experiência provocou que tipo de transformação, na forma como você atua e se estas permanecem até hoje? Você, olhando retrospectivamente, os diferentes momentos que você partilhou com a equipe desde que chegou na escola especial, quais foram as mudanças mais importantes na sua trajetória.

A: Eu fiquei...mais ou menos um ano e meio...na primeira unidade, e aí logo a Secretaria de Educação municipalizou o ensino fundamental. Neste momento todas as classes especiais do Estado vieram para a Prefeitura. E a Educação Especial do município não concordava com a forma que eram conduzidas essas classes, eles queriam mudar isso também...não ser uma classe especial como eram antigamente, que ficavam os alunos ali até ..., assim...esquecidos...então eles passaram a chamar de classe integrada , pra que de fato tivesse uma integração com o ensino regular...

$\mathrm{E}:$ Mas não era a mesma coisa?

A: Não, era diferente da classe especial, integrávamos mais...Eu lembro que teve uma remoção e...ninguém queria...estava com medo de arriscar ir para o regular como professora da classe integrada... Eu lembro que teve muita gente que recusou, que não quis..e a equipe também procurava um perfil de professor que tivesse flexibilidade... um professor que tivesse autonomia, que tivesse dinamismo pra estar se relacionando com o fundamental, não podia ser acomodado...enfim...tinha essa preocupação também, que tivesse um bom relacionamento para fazer parceria...que estava iniciando... Então algumas professoras ficaram com medo de escolher...

E: Foi mais uma indicação que atendesse o perfil desejado?

A: É. E aí isso terminou indo pra mim, que era novata. Eu fui convidada, mas eu estava tranqüila, porque eu não tinha assim, nenhum ranço, nenhuma raiz formada com o grupo da escola, mas já tinha tido alguma base no Especial, para ter maior autonomia Não estava crua, mas também não estava enraizada. E aí eu aceitei o trabalho com a integrada e assim, eu amei esse trabalho porque a gente ainda não cortou o vínculo com o Especial...

$\mathrm{E}$ : Você tinha uma equipe, mesmo dando aula no fundamental?

A: Eu tinha uma equipe, a equipe do Especial era a mesma equipe da Integrada, e daí a gente tinha os atendimentos individuais, as reuniões coletivas, uma vez por mês, como a gente tinha lá...e as vezes tinha os atendimentos de grupos de alunos, porque os alunos lá no Especial tinham atendimento com a psicóloga de grupo...então a psicóloga vinha até aqui, e fazia os atendimentos com eles. Enquanto isso, a OP conversava comigo. Então, quinzenalmente a gente se encontrava. $\mathrm{O}$ professor de Educação Física também vinha quinzenalmente e ele fazia assim...uma aula ele que dava e eu ficava ajudando ele...e já deixava uma programação que a gente tinha para desenvolver não repetição, mas uma continuidade. Esse trabalho da Educação Física sempre junto com a sala do regular. Então eram vinte e oito alunos, mais os seis alunos da integrada, todo mundo junto.

E: Além dessa área outras disciplinas eram desenvolvidas integradamente?

A: Artes também, a gente conseguiu fazer esse vínculo com a professora de Artes do Especial. Ela vinha quinzenalmente e dava as aulas para os vinte e oito, mais os seis alunos e na aula seguinte, eu e a outra professora do regular dávamos continuidade no trabalho dela. Então a gente manteve essa parceria e assim, funcionava muito bem porque assim, além de tudo muitos dos alunos tinham estudado na Escola Especial, então eles vieram de uma certa forma...atendidos numa qualidade melhor...e quando vieram pra cá não perderam as atividades, e a adaptação não foi tão brusca no ensino regular, pois os alunos do regular não tinham estas áreas com professores específicos de Artes e de Educação Física.

$\mathrm{E}$ : E a perspectiva de passagem para a classe regular, no sentido da continuidade desses alunos, ou seja, como trampolim; existia isso... a possibilidade de serem incluídos na sala?

A: Tinha eu sempre pensei dessa forma, que a integrada seria uma caminho pra inclusão... Trabalhar esse aluno, a parte social dele...integrado junto com os demais alunos...junto com as crianças do regular...onde o número de crianças é muito maior...e como ele vai se acostumar num grupo maior...como ele vai se organizar, qual o canal de entrada desse aluno...de repente barulho incomoda demais...como vai ser feito...

E: Mas só no aspecto social e a aprendizagem de outras áreas?

A: Para que ele aos poucos se adaptasse e entrasse de vez no ensino regular. Então essa classe integrada fica assim como um rodízio...eles não ficariam muito tempo...ficaria uns três anos...que seria o máximo de tempo pra esse aluno...

$\mathrm{E}:$ Os questionamentos que se fazia com a classe especial do estado por ficar muito tempo, não era assim?

A: A classe especial ficava...sem tempo determinado e a gente buscava sempre integrar os alunos novos, pra estar começando com esse trabalho novo... porque, quanto mais velho mais difícil a inclusão dele no regular, por conta da faixa etária dos outros. Que é uma exigência do regular, então a gente consegue manter uma criança até doze anos no regular sem nenhum problema...ele não vai se sentir... diferente, tão grande. Mas quando começa a ficar com uns quatorze anos, ele mesmo começa a se incomodar de estar junto com uma turminha de dez anos, ele já fica incomodado com isso... Então a gente se preocupava com qual idade que esse aluno tinha que ir pra integrada...qual agrupamento...tudo era pensado...não era assim, sem planejamento, tinha-se objetivos .

E: Sim...era um processo planejado com a equipe?

A: Planejado. Totalmente planejado.

E: Então existiam, metas que você sabia onde você queria chegar?

A: Exatamente.... E assim, nós tínhamos os HTPCs com todas as professoras das integradas...Nós nos reuníamos...e....todas as professoras das integradas faziam um HTPC mensal ...os outros HTPCs a gente fazia no regular, até mesmo pra dar conta dos projetos...das avaliações que a gente tem que fazer no ensino regular pra que realmente acontecesse a integração.Uma vez por mês a gente se encontrava...e aí nesse encontro...era muito legal...porque a gente trocava as dificuldades e as necessidades de cada deficiência, como esse aluno está progredindo...o que é melhor pra fazer...o que deu certo na minha turma...e também a dificuldade que cada professor tinha de integrar os seus alunos...porque nesta escola foi super fácil trabalhar a integração, porque quando a escola inaugurou, já inaugurou com a sala integrada. Todos os professores que vieram pra cá eram novos e já acostumaram com a integrada aqui...então, essa classe, nunca foi vista com maus olhos, nunca foi visto com preconceito...já se tornou natural desde a inauguração. Já, em escolas antigas, que depois tiveram classes integradas, tiveram resistência. Não se encontrava professor na escola que quisesse fazer parceria com a professora da classe integrada. Havia casos que até o diretor via com maus olhos, a comunidade ficava sempre mais resistente...então, essas professoras sofreram um pouco mais. Então, esses HTPCs, eram os momentos pra gente trocar tudo isso..."que tal fazer tal projeto"..."se você fizer isso ajuda dessa forma"...ou então até mesmo para perceber que não era só ela que estava passando por aquilo, que tinha outras também e que a gente estava buscando alternativas, a gente se sentia e via que a gente não estava tão perdida, nem sozinha....nesses encontros. $E$ toda vez que tinha os encontros, tinha alguém da equipe...então tinha a psicóloga...a orientadora pedagógica...a assistente social...junto nesse HTPC quando a gente fazia. Então tinha toda uma orientação do trabalho da gente e o que a gente podia fazer pra estar melhorando esse trabalho...nas escolas.

E: Você sentia que havia um compartilhar com os seus pares...com os professores e com a Equipe? 
A: Com a equipe e com os professores. Havia também atendimentos- as vezes precisava... chamar a família...daí a assistente social já estava lá...no HTPC...então já conversava com a gente, já agendava...já vinha na escola...ou então as vezes as escolas faziam o HTPC formativo na nossa escola porque tinha essa integração do Especial com as escolas.

$\mathrm{E}$ : Ajudando na mediação e...na interação de vocês com os demais professores?

A: Com os demais professores e isso facilitava muito...depois...eu tive um segundo concurso...porque aí quando eu fui pra escolha não tinha mais vaga na integrada e também não tinha vaga na Escola Especial e a única classe que tinha pra escolher era a sala de recursos e fazer itinerância. Então eu trabalhei durante...quase dois anos...foram um ano e seis meses de sala de recursos, num período era itinerância para acompanhar esses alunos que iam no outro período para a sala do regular. O único problema é que eu tinha outro concurso de 30horas e só para a sala de recurso e itinerância eu deveria fazer quarenta horas pra fazer itinerância no horário contrário...Eu tinha que trabalhar com trinta horas porque eu já tinha trinta horas, do primeiro concurso...então assim...eu podia fazer itinerância com os professores do mesmo horário...na época eu fazia com os substitutos dos professores, estagiárias que ficavam um pouco na aula e atendiam aos professores...ou as vezes eu conseguia uma possibilidade de eu fazer assim ó...os professores da tarde, por exemplo...então assim...esse professor vinha de manhã e fazia uma hora comigo de atendimento, e a diretora deixava ela tirar essa uma hora de HTPC, por exemplo, porque era uma hora de formação que ela estava junto comigo e a equipe do Especial. A PAP estava junto...então fica eu, a PAP da escola e o professor que tinha aula no período. Mas isso assim algumas escolas que estavam preocupadas com o aluno mesmo...não é porque agora ela é da tarde que eu não posso trabalhar essas possibilidades desde que seja o melhor pra esse aluno...a diretora organizava os horários. Então a gente via em algumas escolas essas possibilidades.

$\mathrm{E}$ : O objetivo era realmente ter possibilidade de espaços pra conhecer esse aluno e fazer essas trocas?

A: É. Porque eu trabalhava com aluno ele fazia o atendimento comigo na sala de recursos,...mas a gente nunca se encontrava porque ela estava a tarde...e eu de manhã.. Então pra ter esses momentos, as escolas mesmas faziam essas possibilidades de horas...pra não perder isso...porque a gente precisava assim "será que essa professora da sala de aula está ajudando?"..."será que eu posso estar ajudando-a de uma outra forma?"..."qual o limite desse professor?"..."como é que é essa inclusão nessa sala...os alunos só ficam nesse espaço...é uma inclusão de verdade?".

E: Buscar caminhos para chegar mais perto do professor e compartilhar suas dificuldades?

A: Sim, e tudo isso são coisas que a gente precisa falar pessoalmente...então não tinha como não ajeitar os horários

$\mathrm{E}$ : E como eram esses momentos... você com as professoras do regular...como você sentia?

A: Eu sentia que por mais que a gente pudesse ajudá-la, a angústia que ela tinha era muito grande. No fundo todas sentem que elas estão sozinhas...que elas precisavam de mais ajuda, de mais colaboração pra estar atendendo esse aluno...que a professora promete algo que não consegue cumprir...que é a redução de número de alunos, que é conseguir com a Secretaria estagiária em sala de aula pra estar com esse aluno junto com ela...então assim, eram promessas que a Secretaria de Educação não cumpria...nem para as mães desses alunos que foram incluídos, nem para as professoras desses alunos incluídos. Então em relação a esse respeito ou esse "desrespeito" foi muito grande, porque quando a gente quer qualidade... "Ah, a inclusão está aí, a inclusão está conquistando o mundo "está, mas, como isso está acontecendo dentro da escola...como de fato isso está acontecendo em cada lugar? Se é pra gente fazer algo, então vamos fazer bem feito...e isso infelizmente não está acontecendo, ainda hoje.

E: Nesse momento você acha que está assim, mas já teve algum período que havia recursos?

A: Eu acho que o elemento positivo foi quando começou: "vamos começar com as classes integradas. "Vamos preparar esse aluno para ser incluído?" Ótimo...agora a gente sabe que tem alunos que já conseguem ir direto pra inclusão. Só que então vamos respeitar realmente o números de alunos em sala e oferecer recursos. Isso não é respeitado ainda hoje. E assim, a troca de experiências, a formação para o professor do regular, por exemplo, esse ano está começando só agora, mas a inclusão já está acontecendo há muito tempo e há muito tempo os professores estavam sem nada. Agora...esse ano parece que alguns professores tiveram. Não digo uma formação, propriamente dita, mas encontros com outros professores que tinham esses alunos incluídos...se não me engano, bimestralmente...

E: Naquele período que você teve a experiência formativa, que você deu aula na classe integrada e na sala de recursos que aspectos dessa formação parece ter contribuído, mais significativamente, pra sua atuação? E que falhas você via nesse processo?

A: O que foi importante...as assessorias que a gente teve, de formação com a profa Ursula,...que uma das coisas que ela colocava muito que era com "aquela atividade que você estava dando para aquele aluno está fazendo ele pensar? Ou não?". Isso é uma coisa...uma frase que eu levei assim...para o meu dia-a-dia. Então quando eu preparava uma atividade...quando eu estava fazendo uma coisa, eu pensava "tem desafios?" Então parece que ficava uma coisa bem na minha cabeça quanto a isso....um desafio pra mim mesma. Porque eu ser executora, isso é muito fácil...e de repente fazer aquilo que você está fazendo, de fato, está mudando o pensamento, aí é outra coisa...e uma das coisas que a gente sabe...que o aluno portador de deficiência tem... dificuldades de pensar...

$\mathrm{E}$ : Então esse processo formativo funcionava para você refletir sua prática e como envolver os alunos em um projeto transformador?

A: Era,porque eles costumam fazer muito assim... de qualquer forma... por causa de determinado problema...de qualquer jeito e acabar com aquilo... e a gente tem que fazer...é isso mesmo...é buscar esse pensamento...é fazer com que ele pare pra pensar e elabore. Isso é uma das coisas que a gente conversava muito na assessoria.

$\mathrm{E}$ : E com o a equipe? Dava-se continuidade a esse trabalho desencadeado pela assessoria?

A: Aí nós tínhamos as reuniões de níveis que eram chamadas que era chamado naquela época. Então assim, a gente continuava com textos...a gente lia textos, a gente discutia sobre aquilo...e também a gente trazia práticas...e...se alguém tem alguma coisa pra mostrar, ou então, como nós éramos sempre acompanhados pela coordenadora...é...ela mesma combinava com a gente..."você vai mostrar tal trabalho...porque ai...é bem isso que a gente está trabalhando"...então assim...."isso não foi muito legal"...nunca ninguém era colocado muito na berlinda, porque não era essa...o nosso objetivo...mas as vezes a gente sentia que assim..."medo de errar" é a palavra."ai eu não vou falar isso...é melhor eu ficar quieta...isso não é da minha área e eu não vou falar que deve estar errado"...não é... E aí no começo todo mundo fica muito assim quieto... mas depois todo mundo começa a ver que precisa disso..dessas trocas.

E começa a se perceber que a equipe não estava ali pra te...condenar...ou está ali pra te cobrar...ou fiscalizar... e aí se começava a trabalhar junto com você e a gente colocava em pratica as atividades...as nossas práticas pedagógicas...a gente sempre tinha que ler um texto....a gente sempre estava junto...vendo o teórico, estudando...pra ver se aquilo que muitas vezes a gente estudava era realmente aquilo que a gente estava aplicando.

$\mathrm{E}$ : Estes aspectos envolviam o professor no redirecionamento da sua prática e, que aspectos lhe pareciam falhos nessa parceria interdisciplinar. Que questões seriam importantes repensar?

A: Repensar? Eu acho que primeiro é...o medo que o Especial tinha quando se falava em Fundamental não olhar com carinho para os nossos alunos especiais...não vai gostar dos alunos como a gente gosta não vai tratar como a gente trata...então tem 
muito disso...porque esse pessoal...a tendência é ter um olhar diferente, afinal de contas, assim, está todo mundo pensando sobre isso...refletindo sobre eles...e o nosso olhar está sempre pra eles, e o Fundamental ele tem olhar não só para o aluno especial, mas como também pra todos, aliás pra maioria e menos ainda para o Especial. Então, o afastamento é muito grande...

T: Você acha que realmente há diferença, a formação fez diferença para esse professor especializado ter um olhar diferenciado?

A: Eu acho que é assim, o Especial, ele tem olhar específico na criança, não para rotular, não pra dizer "olha, esse aluno tem Síndrome de Down", porque ele tem especificidades que precisam ser conhecidas, e dessa forma, o trabalho fica mais facilitado. E ele vai buscando também cada vez mais alternativas para facilitar a aprendizagem... O Fundamental, não consegue ter esse olhar...não porque não queira...porque ele não consegue dar conta...ele vai ter que ter um olhar sobre trinta e cinco ao mesmo tempo e todo mundo tem que ir lá...trabalhando... Não é que ele não está respeitando...ele até sabe que aquele aluno precisa mais dele, mas ele não tem técnica para isso.

$\mathrm{E}$ : E a forma como vocês tinham a formação poderia ajudar?

A: Eu acho que ele precisaria de ajuda mesmo...de formação de...ter alguém pra procurar... teriam que ter essas experiências. Porque eu percebo que às vezes eu posso...eu sinto que eu ajudo algum professor...mesmo estando na integrada, sem estar como itinerante...o fato de eu estar trabalhando com o aluno na sala...quando eu pontuo alguma coisa...quando eu falo alguma coisa, a professora olha...a professora fala assim "eu não tinha visto por esse lado...eu nem pensei isso dessa forma...eu nunca tinha pensado que a minha fala poderia ter sido desse jeito"... Então, mesmo estando com os membros do ensino regular...eu percebo que assim...se elas pudessem ter tido mais contatos com uma equipe com mais constância...ou as dificuldades pudessem ser assim mais trocadas... facilitaria até o aluno do regular. Seriam assim, passos pra ela refletir mais, a prática dela...

E: Quando você fala destes aspectos são evidencias que o professor tem?

A: Sim, mas é tão corrido...no dia-a-dia, na sala de aula, com o aluno...é tanta exigência, que as vezes assim...é...é tudo muito vapt-vupt e pronto, tudo muito assim...é...não que seja superficial...o pessoal vem muito pra trabalhar e tal...mas a relação do professor mesmo...relação humana...isso não tem aprofundamento muito, porque não dá tempo...é muito corrido...e uma das coisas que o pessoal também precisa, necessita, é esse aprofundamento de relacionamento. Uma das coisas que eu tive na faculdade de Educação...quando a minha professora "que a gente só desenvolve algo, se a gente se envolve... E isso é pra tudo...isso ficou na minha vida para o resto da vida...em qualquer coisa que a gente vai fazer a gente tem que estar muito envolvida....seja até num relacionamento a dois... E principalmente no nosso trabalho...você só terá um bom desenvolvimento se você tiver um bom envolvimento também. Então não dá para o professor que tem o aluno especial não se envolver...eu não digo se envolver emocionalmente...chorar pelas coisas piegas...não...mas se envolver de fato com o trabalho e na potencialidade desse aluno...pra que ter esse desenvolvimento temos que produzir...

E: Você falou dessa questão desse olhar para a especificidade, não para rotular. Quando você assinala isto você quer dizer o quê?

A: Porque assim, na faculdade a gente tem muita reflexão sobre isso...muito...de estudos...de como que se fala...qual a linguagem hoje...o que se diz..."não se fala mais nisso", qual a atualização dessa linguagem...e eu tive uma...essa professora de Educação ela falava muito...ela era lá da USP. E ela falava muito disso "ninguém fala ai o cego... não pode falar cego mesmo ele sendo cego, não pode...não pode falar surdo", mas o fato é que ele é, e todo mundo fala, e ele não se sente ofendido por isso...ele é até respeitado por isso...ele é cego sim e vai ler pelo braile...ele é surdo sim...ele vai estudar Libras...então por que não falar assim "os deficientes mentais" sim.. "necessidades especiais" sim o síndrome de down" sim...que ele tem sim uma deficiência mental...por que não? Porque fingir que ele não tem...eu acho que isso é muito pior... Não respeitar de fato a necessidade dele...

E: Esta é uma posição ainda difícil de discutir, você não acha, porque as pessoas se preocupam em não discriminar e muitas vezes fazem outras diferenças mais sutis. O que você acha?

A: Você fica com esse medo de dizer algo "não, ela não pode ter diagnóstico...ela não pode..."...não vai rotular, muito pelo contrário, vai estar demonstrando que ele tem essa necessidade, que ele tem direito à uma educação diferenciada sim, que ele tem direito à outros espaços, porque ele precisa...não é pra rotular...não vai precisar ir pra carteira dele...na chamada dele..."aluno com isso"...não...mas precisa-se saber pra poder até ajudá-lo no que ele precisa... Então eu acho que assim, não é rotular...é saber com quem a gente está lidando...qual é a necessidade que esse aluno de fato tem...porque se eu conheço, fica mais fácil pra eu ajudar... Se eu estou envolvida naquilo que eu estou conhecendo...se eu sei o que eu estou fazendo, eu vou poder ajudar....agora trabalhar com algo que eu desconheço...aí fica mais difícil...

E: E...e nesse sentido, como você sente essa questão para a aprendizagem?

A: De fato...ele tem uma defasagem...ele tem uma dificuldade sim para aprender algumas coisas...mas não é uma coisa fechada...não dá pra fechar...é como se você sofresse um acidente de carro e falassem assim "ah, você não vai mais conseguir andar"...depois vai lá e anda...então não tem como fechar e nem deve fechar... Mas a gente tem que saber que ele tem uma dificuldade e a gente vai ter que estar apostando nessa dificuldade e trabalhando nessa dificuldade...intervindo nessa deficiência para que a aprendizagem dele evolua...porque assim...ele nasceu com alguma problemática, mas ele não precisa ficar estável nessa coisa...em hipótese alguma. Ele nasceu, mas ele modifica isso e o mundo também vai modificar ele... E o nosso papel é esse...intervir nessa mudança...

$\mathrm{E}:$ Você, em relação....além do...voltando na questão, você disse que a grande falha...uma das falhas que...é o distanciamento que as vezes as equipes do regular e a equipe do especial têm. Você vê outra questão aí, da própria interação da equipe, no atendimento, na parceria com o professor como se dava isso...você acredita que isso pudesse ser de outra forma?

A: Eu tive uma equipe muito boa...então fica difícil falar...Eu acho que segundo...naquela questão do envolvimento...pra você poder desenvolver algo, você tem que estar bem envolvido...e a gente tem profissionais que... agem de forma superficial...e, pronto isto em todas as área a gente tem isso...

$\mathrm{E}$ : Tem a ver com o compromisso que ele assumiu?

A: Então eu acho que isso é que falhava em alguns passos... E outros...eu acho que eles poderiam ter trocado mais...eu acho que quando eu sai de lá...eles começaram a ter essa prática de trocas entre as equipes...das duas escolas especiais. E na época nós apontamos isso para os professores... Que precisava ter tido mais essas trocas...tanto o professor, como o professor da escola especial, como as equipes...

A: Agora, as classes integradas não são mais supervisionadas pelo Especial, houve toda uma mudança e aí eu parei de ter assessorias do especial...parei de ter a equipe do especial...e o fato da classe integrada estar dentro da unidade do fundamental, então eu passei, a ter uma outra equipe... a equipe do fundamental e não mais a equipe do especial...Quando eu tinha só assessoria do especial... então eu tinha os cursos e formações junto com o pessoal do especial... eu tinha a equipe do especial me assessorando, nós tínhamos toda essa parceria, mas com essa troca, nós da integrada, nos sentimos super perdidas...Primeiro porque foi assim..a sistemática de acompanhamento era diferente...totalmente diferente, então era assim... 
profissionais que não tinham a mesma experiência no especial... a gente estava dentro do ensino regular, tendo que fazer as coisas do regular, mas...também com o aluno do especial. Então assim, o nosso trabalho...fica isolado e sem apoio, como até hoje a gente ainda não tem...

E: Então vocês perderam todo aquele trabalho formativo?

A: É...tanto que nós estamos tendo agora somente do fundamental... isso até hoje... dois mil e dois até hoje nós temos só do fundamental... Minha matrícula... meu concurso é do especial... mas eu sou totalmente do fundamental... Então as minhas formações são todas voltadas para o fundamental não tenho mais assessoria do especial... não tem nada... apesar de ter o aluno especial...

E: Vocês não têm um canal de comunicação para analisar estas perdas?

A; Isso a gente fala sempre... nós ganhamos... "ah, porque a gente começou a fazer mais parte do Fundamental", mas e daí? não era um problema de equipe... era um problema de como que o professor da integrada está trabalhando na escola regular...

E: Seria aquilo que você falou de qual perfil de professor de integrada se fala para desempenhar um papel de mediador na relação com o regular não é?

A: Isso... Então na verdade não eram problemas de formação de equipe... era um problema de envolvimento desse professor aqui no fundamental... Então nós poderíamos continuar tendo as formações pelo especial... e a prática nossa do dia-a-dia nós já estamos aqui... a gente já tem as trocas aqui...então não teria a necessidade de ter assim formação só por aqui

E: Haver uma integração entre as duas equipes, por exemplo?.

A: Ter as duas formações...

$E$ : Ou as equipes se integrarem para um mesmo fim.

A: Também... Nós tivemos o PROFA aqui em São Bernardo quando eu comecei a trabalhar, que foi uma formação para o Fundamental... muito boa... o fato da gente estar aqui, o que a gente pode fazer, isso foi bom... foi muito bom... Mas as outras formações que eu tive... todas as outras formações que eu tive aqui dentro eu nunca usei nunca com o meu aluno. Nunca, eu sempre tinha que ficar lá olhando ouvindo e imaginando se dava para adaptar ou não...E muitas vezes não dá pra adaptar...

$\mathrm{E}$ : $\mathrm{E}$ você teria alguém pra trocar sobre isso, no dia-a-dia?

A: Não, eu tenho que fazer a minha adaptação, com a minha experiência. Eu não sinto assim...totalmente solitária porque eu tenho hoje mais segurança no que eu estou fazendo... Eu tenho segurança no meu trabalho... devido a tudo que eu já vivi... a tudo que eu já trabalhei... ao que eu construí no especial... e isso me trouxe segurança... então eu me sinto sozinha devido à ausência de trocas, mas eu me sinto segura... Diferente se eu entrasse hoje na rede e fosse trabalhar na integrada... eu não saberia o que fazer... tanto que tem um monte de profissionais que falam "o que eu que faço...como que eu faço...como é que você faz isso?"... "Como é que isso dá certo?". Não sabem nem como vai ficar a inclusão do aluno dela e com as outras crianças. Então por isso um professor novo hoje, realmente sofreria muito... tendo esse trabalho...

E: Você acha que assim, o professor não está tendo uma visão mais específica do aluno?

A: É...porque ele tem o aluno especial, mas não está tendo formação específica pra isso...

E: Só para uma criança Sem deficiência.

A: Aí me preocupa também porque o fato de o professor da integrada sentir isso... um professor também que tem uma criança incluída também deve sentir... Eu ainda consigo trocar, porque assim... eu não perdi as amizades do especial, é a minha base ... Então eu ainda consigo entrar em contado, eu ainda consigo fazer algumas trocas, mas isso assim é algo que eu posso ter, porque eu já tive...

E: Que outros fatores, além da formação continuada, podem ter contribuído para o desenvolvimento dessa sua atuação, como professora? Nesse período...

A: Eu acho que além dos fatores de formação de faculdade. Porque assim.... - "Ah... A faculdade não forma ninguém, não ajuda ninguém"... Mas assim, a gente tem que pensar, o que foi feito com essa faculdade, e qual o movimento seu com essa faculdade, não é? Então, a gente não sai aqui pronto da faculdade? Não. Aliás, agente também não se sente pronto, não é? Mas aí, dizer que a faculdade não ajuda você ter base, aí eu não concordo... Então assim. Eu tive uma boa formação, eu aprendi bastante coisa, e isso me ajudou muito... Eu acho que não me ajudou, talvez muito assim, na prática do dia-a dia do meu aluno, mas a visão dele, a visão que você tem sobre esse aluno, os desafios que eu tenho com ele, isso me ajudou, essa reflexão me ajudou, essa visão de como eu vou, de como eu vejo esse aluno do especial... Como eu vejo esse aluno com necessidade, foi o que me ajudou...

E: E nesse sentido... Como é que você vê esse aluno com necessidade especial, com deficiência?...

A: Aí, assim, você entra até na pergunta de quando eu entrei na faculdade, não é?: "- Por que é que você escolheu esse, a Educação Especial?" Era a que o pessoal fazia... Eu acho que assim... Primeiro por curiosidade mesmo, não é... De como que é esse trabalho, de como que é esse desenvolvimento de um, de alguma criança com necessidade especial... Quando eu era criança eu tive alguns amigos com síndrome de Down, e eu não conseguia entender, o que era aquilo. Na minha escola tinha classe especial, e eu tinha medo daqueles aluninhos que ficavam me olhando. Então foram algumas experiências de infância, que me buscou a fazer a faculdade. Então eu sempre tive muita curiosidade de entender mesmo, de como que é isso? Como que é a mãe? De... Como que é a visão dele de mundo?... Foi diferente da minha? É muito diferente? Será que eu que estou tendo preconceito de imaginar que foi diferente? Então isso, essas curiosidades, foi o que me fez buscar essa faculdade. Então assim, eu nunca encarei (eles) como alguém... Coitado, alguém inferior. Nunca meu olhar foi assim, mesmo antes de fazer a faculdade... E com a faculdade me ajudou mais ainda, a buscar assim, a ter atitudes, que ajudassem esse aluno a fazer o que ele pode. Então esse era o meu grande papel, eu saí da faculdade com essa idéia... De que assim, ele tem uma deficiência sim, ma ele é capaz sim... E isso, aí eu sai assim, meio que com sede de trabalhar e aí assim, fazer com que esse aluno consiga aquilo que eu acreditava... De que ele vai conseguir aprender/fazer alguma coisa... Que foi aquilo de que quando eu cheguei... "Ahhh abaixa a bola"... E eu não consigo abaixar a bola...

E: Quando você fala das contribuições que você teve em parceria com a equipe e indicações que você assinala de aceitar as limitações do aluno, você vê aí uma perspectiva que desacredita no processo evolutivo ou a equipe, na prática, apesar dessa questão de falar pra você "abaixa a bola" foi possível desenvolver uma concepção de desafio...?

A: A princípio eu entendi assim... Ahhh eles não acreditam no meu trabalho. Porque eu sou nova... Aí depois, eu falei assim... : - "Será que os meus alunos são muito deficientes, e eu não tenho experiência específica pra falar com eles?"... Além de todos os relatórios que eles dão, quando eu cheguei acho que uma semana, acho dois dias para conversar, falar sobre a escola, e você ler o prontuário dos alunos e relatórios, aí quando eu comecei a ler, tinham relatos, assim que me deixavam bem...preocupada. Não vou dizer assustada, mas assim, intrigada... Porque assim, mostravam aspectos muito negativos do aluno, agressividade, muito grande... Então eu já comecei a ficar assim pensando: -"É eu acho que eu estou querendo mudar o mundo!"... E quando eu tive assim, o primeiro contato, a primeira semana com eles, aí eu senti assim... No que elas estavam querendo falar... Porque assim, eles tinham comprometimentos, assim, mais acentuados do que eu estava imaginando... E eu acho que eu percebi que, o que elas estavam imaginando do que eu estava querendo, pela experiência delas, mas... Hoje eu 
vejo que elas estavam certas de que eu estava imaginando pegar uma turminha, que não era o perfil que eu ia pegar... Que era aquela classe que ficava em classe com o professor... Então quando eles disseram baixa a bola, era... pra dizer pra eu me preparar, porque era um outro tipo de turma que eu estava pegando... E não assim, olha... Eles não são capazes disso, é melhor você desistir... Mas eles não queriam assim... "Como vamos falar?" E aí, a primeira semana eu entendi isso, não é... Que olha, é diferente do que você imaginava, eles são maiores, mais velhos, o trabalho vai ser duro... Então, eu fiquei assustada, assim no começo, porque não eram crianças eram quase homens e mulheres...

E: Eles eram egressos de algum grupo/tipo de trabalho, ou sempre tiveram no especial?

A: Sempre tiveram no especial... alguns já tinham sido trabalhados a questão de alfabetização, uma série de coisas, vinham de vários grupos... Então assim... Do grupo que eles estavam antes, conseguiram evoluir, outros conseguiram ir pra outro lugar... Eles terminaram ficando na Oficina de Trabalho com vinte e poucos anos, mas dá pra dizer que eles já tinham aprendido um pouco mais...

E: Mas eles foram envolvidos com propostas de letramento ou não se buscava isto?

A: Sim, então assim, a questão de identificação o nome, foi uma das coisas que eu vi que tinha que ser trabalhado com eles... Com placas, de símbolos, que foi o que eu trabalhei... E que eles, antes quando eu cheguei, eles tinham muito um trabalho só de... . executarem atividades motoras...

E: E essa equipe lhe ofereceu caminhos/ possibilidades de você abrir estes novos desafios, ou você que trouxe esta questão e ajudou-as a pensar?...

A: Eu acho que assim, metade da equipe acreditava na proposta, metade não... Então assim... Eu tive algumas pessoas que acreditaram no que eu estava falando e nas possibilidades do meu trabalho. E outras, falavam assim... "Já tão com vinte e poucos anos..."não vão fazer mais nada"...

E: Então... Nesse sentido você também contribuiu pra transformação da visão que tinham do aluno? Mas havia abertura?

A: Havia... Em nenhum momento elas falaram assim, não, você não vai fazer isso, que isso não vale a pena, que isso nós já tentamos... Isso não... Elas deixaram primeiro para eu me situar, e depois começaram a discutir as formas de abordagem... "Como você ta pensando de conseguir isso"?... Então, tinha espaço pra estar falando... E aí elas... Tinha abertura .. E aí foi caminhando... Eu lembro que uma das coisas também, quando eu já estava na Oficina e eles trabalhavam na horta e teve uma professora da outra classe que falava que a horta estava murchando... Porque assim, não dá pra ficar trabalhando só na horta... e só a horta... Vamos buscar um pensamento em cima disso... a questão não é só, ali, ficar com regador... na horta, e depois passar batido por isso...

$\mathrm{E}$ : Que eram questões operacionais, unicamente?..

A: Sim, operacionais... Tinha um outro dinamismo... Tinha outra coisa por de trás também...é perceber o que o aluno está pedindo, sem saber como expressar... Eu me lembro de uma coisa: nós fizemos uma árvore de natal... e eram alunos que tinham muita dificuldade... motora também, de concentração, de auto - flagelamento... Eles não se viam mais como sujeitos... E eu lembro bastante de uma aluna, que ela assim, ela se mordia muito, sangrava os lábios, jogava coisas... E isso era uma das coisas que eu mais trabalhava com ela, isso dessa auto-estima dela... E isso, às vezes, eu passava batom na saída, ou depois do intervalo... Eu passava batom e não tinha espelho na sala, uma vez ela ficou assim, olhando, mas fixamente... E eu falei: Você quer passar? Quero... E aí eu comecei a passar e dei outros batonzinhos para ela... E sempre depois que ela tomava banho, fazia a higiene bucal, ela passava o batonzinho com a gente... Então isso, eu percebi que assim, ela parou de morder os lábios... E ela adorava se olhar no espelho. Então, eu acho assim... os objetivos que eu visava para esta aluna, dela se valorizar, de se achar bonita, isso com ela eu consegui... Numa coisa simples, num olhar simples de perceber o que ela estava pensando quando ela estava me olhando... Quando eu estava passando batom e percebi o seu olhar...

$\mathrm{E}$ : Sem se expressar e conhecendo suas necessidades você chegou mais perto dela.

A: Isso... E aí, assim, nós começávamos no final do ano, nós fizemos uns cartões de natal, fizemos uma árvore de natal, com vários enfeites, e colocamos assim, ficou assim, bem artesanal... Mas foram eles, que tinham decidido/conseguido fazer... Eles ficaram super felizes, porque nem mesmo em casa tinham feito... Nós colocamos no corredor. E aí qual a sensação que eu tenho... Porque assim, no começo, nem eu também acreditava em tudo isso...

E: Que você pudesse transformar?.

A: Diante... dos alunos com aquela deficiência toda... Eu nem via, assim... Em que realmente que eu vou poder ajudar... Será que eu vou ser capaz de... Será que eu estou sendo muito ambiciosa?

E: E você acha que o professor... Não só do especial, de regular, que tem essa criança, incluída ele, diante das dificuldades fica menos ambicioso em conseguir ultrapassá-los com a criança? Ele não acredita nesse potencial dele? De transformação? A: Sem dúvida... Ele precisa de alguém por trás também... dando uma base, uma valorização... acreditando... Que ele consegue... Porque tem horas que assim, a evolução deles, é sempre muito lenta, então se a gente não tiver sempre uma reflexão com alguém, e ir parando pra pensar, no que esse aluno conseguiu e avançou, a impressão que dá é a que a gente não conseguiu nada... Nisso assim, até hoje, mesmo que dando trabalho, na hora que eu tenho o conselho, que eu pego as pastas, que eu pego as primeiras atividades, pego as coisas que eu começo a ver... Ele evoluiu sim... mas no dia-a-dia, as dificuldade, ali vou trabalhando... Mas, depois que você vê o resultado final do projeto, e você vê essas coisas assim... Ahhhh, ele evoluiu sim... Então sempre precisa ter o momento de você dar uma paradinha...e ver aquilo que o seu aluno já conseguiu... Refletir, para você continuar, ou mudar alguma coisa... Ou ainda, até mesmo para te ajudar a acreditar no trabalho. Assim, se continua..

T: A s sistemática a a equipe pra pauta nesses A: Também... Refletindo, revendo, o que estava caminhando... Vamos tentar de outra forma, vamos continuar desse jeito porque está dando super certo... Sempre a gente tinha alguma reflexão... E hoje a gente tem entre professores, mais... A gente às vezes, por exemplo a equipe...vem fazer conselho... Algumas vezes nós temos uma equipe cristalizadora... Raramente alguém da equipe vem para fazer parceria mostrar o que você está fazendo de bom e refletir com você... Esse ano a gente está com uma equipe e dá para sentir a diferença, como que era bom, com a nossa equipe do Especial. Porque, agente também sai assim arrasada...com essa equipe do regular. Esse ano, a gente teve alguns conselhos há pouco tempo, que sentiu assim... ahhhh obrigada, não é... Deu certo... É isso mesmo... Porque a gente sabe que o trabalho está na nossa mão sim... Então não precisa ninguém dizer para a gente, que... Olha... Não deu certo! ... Você deu alguma coisa diferente pro aluno? Você fez um trabalho dedicado com eles ... Elas ao contrário tem uma relação de só culpar o professor... A gente jáestá se sentindo meio incompetente, porque a gente não consegue... A gente precisa de trocar mesmo... O que vamos fazer... O que a gente pode mudar, e não só receber culpas. Quando o professor é envolvido com seu trabalho, com uma crítica, ele não precisa de mais ninguém, porque ele sabe que ele próprio vai conseguir...

E: Eu queria que você falasse um pouco mais como é na prática a relação com o aluno com deficiência? Como é que você...lida com os impasses. Essa parceria que você teve com a equipe interdisciplinar foi importante para você, que te instrumentalizou de certa forma, até hoje... Na situação atual, mesmo não tendo uma parceria de uma equipe... você consegue lidar melhor com as questões da sala de aula? Como então é na prática a relação, com o aluno com deficiência, que deficiência 
é essa? Que você tem hoje, e quais os espaços que estão instaurados, assim com mais freqüência, e como, que você lida com isso na relação com a aprendizagem...?

A: Então assim... As deficiências que eu tenho hoje... Eu tenho alunos que tem mais dificuldade de aprendizagem, e alguns problemas emocionais... tem aluno assim com problema psiquiátrico...de epilepsia, tenho aluno autista, com retardo mental, tem uma aluna também que têm algumas disfunções neurológicas, ela tem tremores na mão... Ela tem uma dificuldade visual e isso automaticamente deixa ela com dificuldades no aspecto da aprendizagem... Eu tenho aluno que tem um transtorno de comportamento, é hiperativo, tem uma dificuldade de aprendizagem muito grande, e de comportamento precisando de uma assistência médica. Então assim, dificuldades que eu tenho? Às vezes, em manter parceria com a família, eu acho que isso a grande questão conseguir os pais como parceiros...

E: Aqui no regular você encontra abertura para se aproximar dos pais?

A: Eu acho que é difícil, eu acho que a família do aluno com necessidade especial, ela precisa ser muito bem assessorada... Independente aonde ela tiver, na integrada, incluída, na escola especial, ela precisa de uma assessoria... Porque ela também se sente muito cobrada por ela mesma... E isso, dessa situação de mãe, dessa situação de... O que ela pode fazer? E aí a gente precisa da mãe completamente junto com a gente... Seja na questão, de outras necessidades que ela precisa providenciar, um atendimento com um fonoaudiólogo, de uma medicação, de um trabalho com terapeuta ocupacional que vai ajudar... Então, a gente vai sempre estar com a mãe junto, pra estar trabalhando em conjunto, porque se a gente não tiver essa parceira... só o trabalho de sala de aula não é o suficiente... Se tivessem outras coisas, estaria ajudando muito, porque assim, como um filme que eu já vi, que eu espero que você tenha assistido... "Do luto à Luta"... Ė uma coisa que toda a família tem que passar mesmo... Ir à luta pra eles, e eles vão ter que ir a luta para conquistar as coisas que o filho necessita...e, muitas vezes são mães sem nenhuma informação..., a maioria delas, então, se ela não tiver uma assessoria de alguém... olha é dessa forma que você consegue... É em tal lugar...coisas bem simples mesmo, se ela não tiver isso, ela vai ficar totalmente perdida, porque ela sozinha ela não vai achar...Porque os hospitais, eles não dão informações suficientes para isso... Não tem um profissional que a mãe encontre ao sair da maternidade ou de algum serviço médico e lhes oriente... olha, o negócio é assim, mas você tem tais e tais lugares para ir, a assistente social, vai com você te acompanhar... vai fazer inscrição em tal posto, existe estimulação precoce...Mas, não existe isso ainda nos hospitais. Então as mães vêm, sem nada...São bem desinformadas... Ou, às vezes quando você encontra algumas delas mais engajadas com a situação do filho e correndo atrás, você tende a dar mais informação para essa mãe, você ajuda mais ainda... Porque você vai dando mais informações, vai tendo mais troca com essa mãe, ela vai acreditando mais no filho... Ou aquelas mães que largam de vez...

E:Você acha que dependendo do profissional que ela encontra... Que ela encontrou, na frente, a partir do conhecimento que ela teve dessas experiências, transforma essa forma de ver? O filho....

A: Transforma... Porque assim, eu já tive mães, que na reunião de pais me falavam assim, eu não sei o que eu estou fazendo aqui, eu não sei o porque que eu tive esse filho... Eu devia ter abortado... Se eu soubesse antes, eu tinha abortado...

E: Esse é um impasse sério? Que não é um impasse, só de relação com a aprendizagem da criança... Como é que você lida com isso, Porque você nesse momento, apesar de você tem tido toda uma bagagem, uma parceria por exemplo com uma equipe... E hoje você está aí com essas demandas, e precisando se sentir autônoma, e capaz de resolver essa necessidade que também é da família... Como você lida com uma situação dessa?

A: Aí eu fico pensando assim, aí eu vou bem lá atrás... Porque lá na época que tínhamos a parceria com a equipe do Especial, nos tínhamos apoio das profissionais para trabalhar com a família e elas também trabalhavam com ela, então, você guarda algumas coisas, e vai mudando de acordo com a sua necessidade do dia à dia. Então, com essa experiência que eu tenho hoje, assim... A primeira coisa que você tem que fazer ao receber a mãe, é ouvir, porque ela vai querer falar toda a angústia dela, que ela tem diante daquilo... Então a primeira coisa que eu faço é ouvir mesmo essas mães... E aí então a partir daí a gente começa a fazer alguns contratos de relações... Você fica de um lado ajudando, com uma fala que conforte ela... Que eu não estou aqui, pra querer ser melhor que ela, que o meu papel é diferente do dela, que ela é mãe... e que eu sou professora... E que meu papel é diferente, e não melhor... Nem mais importante, muito pelo contrário... porque elas vêm com esse receio, às vezes... Porque você é a professora, trabalha em escola especial, que sabe mais que eu, vai querer mandar em mim.... Não é isso... Ela tem muito saber sobre a criança que eu não tenho... E que ela precisa também me passar isso, e eu vou passar pra ela como é esse filho aqui, longe dela... e que é diferente... E o que eu faço que muitas vezes dá certo, que ela poderia fazer em casa... Então eu inicio assim... Vai ter que criar esse vínculo com a mãe... Essa confiança dela no seu trabalho... Para aí poder continuar, pra poder ter uma postura em relação a esse trabalho.... E aí a partir do momento que você consegue esse vínculo, e nos primeiros meses ela começa a perceber que vai acontecendo uma mudança, aí ela começa já vir assim mais aliviada... Ela já entra na reunião sorrindo... Já vem assim, querendo ver a produção do filho, porque vai ter alguma coisa pra ver do filho...

E: Começa a ter expectativas positivas?

A: As expectativas... Eu lembro de uma reunião, a minha primeira reunião de pais de integradas aqui, que eu tive uma conversa com a orientadora pedagógica... Que ela me colocou isso, que era pra eu mostrar o que eles tinham conseguido e avançado... O que eles tinham conseguido de positivo na escola, e não o que ele não tinha conseguido... Porque o que eles não fazem, as mães já sabem... Ninguém precisa contar pra ele... Então isso é uma coisa que eu levo até hoje... Então assim, é mostrar pra mãe, olha... Olha o que ele conseguiu, olha o que ele já está conseguindo, olha o que ele fez... Lembra de pedir isso? E aí como que está em casa... Sempre a mesma pergunta... Como é que está em casa? E a tal coisa, tal probleminha, como é que está, funcionando? Como você está vendo agora, como ele está te respondendo? E: Olhar para as conquistas...

A: É... e a partir do momento que você busca nela esse olhar. Então assim, hoje todas as mães vêm à reunião, elas vêm nas exposições, vem assistir apresentação, então isso... é muito legal... Elas também, estão valorizando, estão gostando mais do filho... Porque isso que a gente/ele sente... Numa última apresentação que eu tive de dança, uma mãe falou pra mim: "Eles ensaiaram direitinho?" Estava com medo do filho passar vergonha, medo dele errar em frente ao público. eu falei assim pra ela: "Será que isso é o mais importante?" Ele vai sempre ter dificuldade motora não vai? "-É, ele vai!" ... "Então, qual o problema se ele errar o passo?" E qual o objetivo maior nosso? Será que é ele acertar todos os passos?... Eu acho que não é esse o objetivo, não é? Aí ela: "é verdade!" Eu acho que o fato dele estar aqui, se expondo... Sabendo que ele também é capaz. E mesmo assim ele está se expondo... Então, o nosso objetivo foi alcançado... Porque ele também sabe que ele erra os passos... Não precisa ninguém falar isso... Mas mesmo assim ele quer, então é respeitar a iniciativa da criança...

Então, são essas coisas que eu acho que precisa ser trabalhado com a mãe... porque vai valorizando a criança. Portanto, essa parceria com a mãe é importante, muito importante... e acreditamos que isto também contribui num trabalho de construção de aprendizagem, a gente trabalha de outra forma, isso facilita o aluno, acho que assim, facilita todo o aluno... Porque ele vai construindo a aprendizagem dele com segurança. Agora, quais são as estratégias que eu vou utilizar pra esse aluno... Aí eu acho que assim são questões específicas... E você vai perceber a cada aluno, qual o caminho de... Qual entrada de cada aluno... ali você vê a relação de professor-aluno mesmo, é um termômetro entre você, e ele... Por exemplo, eu tenho uma 
aluna, que o canal de entrada dela é o auditivo... Então não posso ter o canal visual com ela... Porém auditivamente agente consegue tudo com ela... E eu tenho outra que ela é totalmente visual... Se eu falar muito ela não consegue pegar nada... Ela precisa ver, ela precisa pegar... Então agente vai buscando estratégias, de acordo com a necessidade de cada aluno... E isso assim, essas coisas, não está escrito em nenhum lugar... Aí o professor vai ter que... No dia-a-dia, o tempo que você tem trabalhado... E assim, buscando mesmo... Vendo se aquilo lá funcionou, e o que você pode melhorar pra esse aluno... Então tem aluno que, o tempo dele é mais curto... Então você tem que fazer uma atividade mais curta pra ele... Quando, é que aquele lá ele demora muito mais, eu tenho que apresentar outra atividade... Respeitando o mesmo conceito, e respeitando assim... É hora de atividade de Português, é hora de atividade de português... Cada um ta dentro da sua limitação, mas todos trabalhando Português...

$\mathrm{E}$ : E entre eles, você consegue ver assim, uma parceria?

A: Sim, tem parceria... Às vezes tinha até cola, porque assim, tem umas meninas que fazem mais, e têm outras que ficam de olho pra ver. Existe parceria, a gente tem assim, em jogos, porque sempre no jogo precisa do outro, não tem como você ficar jogando alguma coisa sozinho... Então, as parcerias nos jogos pedagógicos... É muito bom... Que ele vai ter que assim, esperar o momento do outro, respeitar/aceitar as diferenças do outro, mas que ele já ta se irritando, e que às vezes não é tão certo assim... então eu vou colocar minha aluna que é totalmente auditiva com a visual, a visual vai ajudando ela, e ela socorrendo a outra... Então tem que pensar em atividades e jogos que vão estar tendo essa troca entre eles também... Hora de biblioteca, é hora de biblioteca, vai todo mundo... A gente está na roda de conversa... O que a gente ta falando aqui agora? Então a gente ta tendo sempre chamando a atenção deles.... Antes, então é melhor ter uma roda de conversa, pra gente falar do final de semana... alguém quer falar alguma coisa de casa, falar alguma novidade... Não adianta ficar falando do ponto, de conteúdos distantes da experiência dele. De alguma coisa, então ele precisa, naquele momento... Então tem esse espaço... a gente cresceu muito nisso, ele conseguiu, pra uma outra escola... E sempre buscando a atenção dele, seja visual, seja auditiva, uma hora isso, tem que chamar... Porque assim, ele tem atenção curta, ele se dispersa muito, se dispersa... E o meu papel é esse, é buscar,o tempo todo a atenção deles, pra gente poder estar trabalhando... Mudando sempre pra forma certa, mudando sempre a mesma, a forma de você trabalhar... Mesmo assim você tem diversas maneiras pra que todos entendam... Porque pra mim, precisa ser de um jeito, mas que pra ela precisa de outro caminho, com o mesmo assunto... Você consegue trabalhar o mesmo aspecto, mas de formas diferentes... Uma hora você fala, uma hora você dramatiza uma hora um pedacinho de vídeo, e aí é o que termina entrando em vários cenários do jogo...

E: E você é sempre mediadora, ou você introduz também outras crianças na coordenação de algumas atividades?

A: Sim, porque a minha classe e a classe do regular que eu trabalho. Eu sempre trabalho com uma classe do regular e esse ano eu estou trabalhando com uma classe só em leitura com a quarta série... Um momento de trabalhar com leitura e escrita com a quarta-série, com um projeto... Então em todos os momentos os alunos têm interferências de outras crianças, de outros alunos, ai então assim... têm parceiros, têm modelos, mostrando pra eles, tentando dar ajuda pra eles, aí eles se sentem desafiados, então isso é muito bom...

E: Bom, você acredita que a deficiência delimita a relação da criança com o conhecimento? Na sua experiência, com tudo que você traz de experiências?

A: Eu acho que não é a deficiência, que delimita...O que limita...eu acho que, quem faz isso é o ser humano, com o olhar que ele tem... Porque ele pode também delimitar alguém sem nenhum problema... Se ele tiver um olhar repressivo, se ele tiver um olhar fechado para coisas... Ele pode pegar um aluno que faça dele/ daquele falar complicado/ pouco caso... "ah esse menino aí.", então o que, ... O que limita a deficiência, não é o fato dela em si, mas o olhar do outro, porque se ele tiver um olhar, com pré-conceitos, que não acredita no potencial, ele não vai acreditar no aluno, com deficiência, então assim... Saber que deficiência é, que tipo de deficiência, que tipo de habilidades... aonde ela acerta, aonde ela não acerta, o que ela precisa, não vai delimitar o trabalho do conhecimento, da prática, muito pelo contrário... Vai ampliar o conhecimento dele sobre as coisas... E ele vai buscar desafios pra quê? Ou investir em outra porta/ forma de entrada que é mais fácil para ele estar aprendendo... Não se deve insistir/ investir em algo, que ele já sabe que não tem entrada, e sim buscar outros caminhos... mas não fechados, sempre com meta ao olhar do outro, e não a restrição...

$\mathrm{E}$ : Então você acredita que nesse processo de criar caminhos alternativos pra criança, o fundamento, que vai transformar são essas propostas, que você leva como alternativa...?

A: $E$ aí você vai poder fazer isso, sabendo, tendo um conhecimento, daquilo que ele tem, que ele tem... De que ele precisa...

E: Você sentia-se preparada para a prática? E assim, houve algum referencial teórico, que a ajudou nesse sentido... Se você puder me dizer, assim, que teoria foi essa, que referencial teórico foi esse, pra você, e como essa teoria, favorece o manejo do cotidiano?

A: Se sentir pronto na prática, eu acho que pronto a gente nunca se sente, não é? A gente vai sempre aprendendo... Mas eu sempre me senti, como eu posso falar? Sempre desafiada, ou induzida, pra você iniciar um trabalho... Você tem a necessidade de um fazer, e aí você faz... Porque assim, uma das coisas, você nasce pronto para o meio, mas você modifica esse meio... Você não vai ser sempre alheio ao resto... E por que você não vai? Porque essa necessidade está no homem... A partir do memento que você tem uma necessidade, você vai atrás disso... Você vai desenvolvendo... você vai desenvolver coisas, pra mudar isso, e isso assim, com todo ser humano, não é?... Ele vai ter necessidade, ele tem um ambiente que ele tem uma dificuldade, e ele vai buscar... Ou ele vai mudar aquilo que ele não está gostando... Mas, ele só faz, porque assim, ele não vai ficar parado... Então, teoria que eu tive, que eu trouxe de faculdade, me ajudou bastante, tinham... assim, pra trabalhar em creches com crianças, não é, então na creche tem essa inclusão também... com os pequenos, trabalho com adultos. Tem horários diferentes, tem o pessoal da equipe que estava lá, e deu um apoio, mas isso te ajuda muito, também a você ampliar a teoria... Mas assim, se fosse hoje, por exemplo, ahhh e me dissessem você vai trabalhar com autista, bem grave, que eu nunca trabalhei... Não tenho ainda essa experiência, nunca peguei um aluno assim, eu vou dizer que preciso de apoio? Mas essa necessidade minha de buscar recursos, vai me ajudar? Vai... E isso assim, mesmo estando com alguma segurança, a gente está sempre pronto pra iniciar as coisas...

$\mathrm{E}$ : E assim, como você vê a teoria, tendendo a ajudar numa situação de manejo, por exemplo, de uma situação que você, até então, nunca teve experiência...

A: Por exemplo, se eu fosse agora pegar uma autista Será que aquele teórico me ajudaria? Eu acredito que sim... Porque eu acho que assim, as pesquisas, tudo, não estão ali à toa... Não foi do nada que alguém discutiu e analisou tal deficiência ou dificuldade. Então assim, não é também pra virar uma cartilha. Não é isso, mas vai poder vir mudar, algumas coisas, ou esclarecer algumas dúvidas, me faz ir atrás de mais coisas para me ajudar... Ajuda muito, mas não pode ficar presa à teoria... temos que.fazer a ponte com a prática. Não pode também ficar muito só na prática que você vira também, um executor, e isso também não é o ideal, então agente tem sempre que estar buscando na teoria sim, fundamentada sim, e agente também precisa ver se aquele fundamento da teoria, condiz com a prática da sua necessidade... Mas pra isso você precisa de estudo pra você poder saber até, ir contra, ou a favor da teoria. Junto com a prática com a teoria. Formação é sempre uma busca ... Porque se não... a gente volta ao antes, fazer aquilo ali e acabou.... 


\section{Luísa}

A entrevista foi realizada em uma das salas da Seção de Educação Especial, na Secretaria de Educação e Cultura, pois o Centro de Apoio, onde a educadora trabalha, estava com todas as suas salas ocupadas, por ocasião do agendamento. Duração da Entrevista: 1 hora e 50 min

E: Nós vamos iniciar a entrevista com Luiza e eu vou começar, perguntando a você:- o que você destacaria, em sua trajetória profissional no período de 1996 a 2003, como tendo sido determinante na formação continuada em serviço, desenvolvida em parceria com a equipe interdisciplinar da sua unidade escolar?

L: Para eu começar a falar na formação continuada eu acabo, sempre, pensando na formação inicial que eu tive, a formação acadêmica, eu não posso deixar de pensar nela também. Então eu acho que, muito do que eu penso veio também da formação acadêmica e que me trouxe já a idéia de que não estava tudo pronto, e que a coisa não terminava ali. Então essa idéia, nesse processo de continuidade da academia como um primeiro momento, um momento básico...importantíssimo, mas uma momento mais...pra gente começar a trilhar esse caminho de ser um educador, pois eu acho que a gente está o tempo todo aprendendo. Agora em trabalho, eu passei por três locais de trabalho. Eu fiz um estágio, durante um ano, depois eu fui para o Centro de Ensino Supletivo na área da deficiência visual, e depois vim para o local que eu trabalho agora aqui na Prefeitura de São Bernardo. Os dois primeiros locais, o estágio e o Centro Supletivo, eu me sentia muito só, porque eu não tinha com quem trocar, então toda aquela coisa da academia, de você ser aluno, de você ter grupos, eu perdi....quando fui pra esses dois locais. E quando eu cheguei no Centro de Apoio, é...eu percebi que eu tinha apoio e, eu pensei "poxa, eu vou ter com quem trocar"...mas também tem aí...uma questão, que é a convivência em grupo, como é dividir as idéias, que até então, eu tinha que tomar algumas decisões quase que sozinha, eu sinto muito isso na escola, as vezes, quando eu vejo o professor do regular sozinho, houve situações que realmente foram insustentáveis, na primeira resolução e o que primeiro me vem na cabeça é que o professor deve estar sozinho, para ele estar nesse estado, não conseguindo ter idéias, pensar de outras formas, a situação que ele está vivendo...

E: Sem espaço de troca?

L: Isso, sem espaço de troca.

$\mathrm{E}$ : Nesse período que estamos analisando, a partir do seu ingresso no Centro de Apoio, o que você verifica em relação a essa perspectiva que você está analisando, de não estar sozinha, de você estabelecer trocas?

L: Então, o nosso grupo era constituído por uma maioria de professores, pessoas formadas na Pedagogia com habilitação e uma equipe de referência que a gente chama de equipe técnica. Nós tínhamos uma orientadora pedagógica, uma assistente social e uma psicóloga. É elas atuavam, diferentemente das outras escolas do regular, dentro do nosso próprio Centro de Apoio e durante esses três anos, ou até um pouco mais, porque atualmente a coisa também mudou, eu senti também assim, que um dos dificultadores era a questão de definição de papel com clareza, até onde vai, até onde vem essa intervenção da assistente social, da psicóloga ou da orientadora e, como o professor, eu acho que uma das minha dificuldades era o que o professor deve se apropriar, e o que ele não deve, porque...a gente tem um limite aí na atuação...o professor tem aí um papel, e o assistente social outro, começando pelas dificuldades. Agora um ponto de ganho enorme é essa troca, porque eu começava a observar a questão, que até então, eu não tinha parado pra pensar. Então, hoje, quando tem uma criança fora da escola...não é que isso tenha que ser uma norma, mas a primeira coisa que eu penso é "essa criança não pode estar fora da escola"...é um conhecimento, uma coisa que eu preciso estar exercitando...é uma coisa que eu preciso exercitar.

E: Que você está acrescentando no seu saber?

L: Isso, a criança não pode ficar fora da escola, e eu penso: por que ela está fora da escola? Ao mesmo tempo, não caí em uma coisa que eu acho que a gente tem muito facilidade, principalmente em um país como o nosso, com tantos problemas de culpabilizar "a família...a família que não dá"...sem ter todo aquele olhar que essa família está dentro de um contexto histórico...que essa família também está passando por uma série de dificuldades.

E: De situações sociais específicas?

L: É e de situações sociais, que não é praticamente o que elas queriam também, por exemplo, falando especificamente da assistência social, eu sempre lembro da assistente social que a gente teve nesse período...sempre falou isso..."gente, não vamos ser tão inocentes, tão ingênuos...de achar que primeiro a família não está fazendo o próprio papel dela...tem até momento em que a família pode não estar fazendo o papel dela, mas não vamos logo de cara achar isso, vamos olhar pra isso de uma outra maneira, de uma forma mais abrangente...e vamos na verdade, compreender esta situação"...isso foi uma das coisas que eu muito aprendi com essa pessoa..."e vamos olhar pra eles como nossos parceiros, e não como alguém para por a culpa, para competir. Eu sempre penso, nessa área em específico, na conversa que eu acho que a assistente social tinha com alguns profissionais da saúde, ela tinha uma entrada mais fácil...não que o professor também não devesse ter...eu acho que ele deveria até ter, mas acaba até para decidir aqui, caindo essa questão da assistente social ser uma facilitador no diálogo...eu achava isso muito importante...ela trazia algumas dicas, falava algumas coisas específicas de funcionamento dessas instituições em si.

E: Você falou duas questões que eu queria que você esclarecesse melhor você sentia nessa equipe que você tinha, da Pedagogia, do Serviço Social e da Psicologia contribuições, saberes específicos, de cada um em separado, ou era um trabalho interativo? E neste sentido, como você via a sua participação?

$\mathrm{L}$ : Eu acho que durante esse tempo a gente teve momentos, onde a coisa fluía melhor e eu me sentia...assim...me apropriando...mesmo...e outros momentos que não, eu sentia que..."você ta dividindo esse conhecimento comigo, esse olhar, mas o que eu faço com isso efetivamente?" Como é que eu transfiro isso pra prática?" Eu não acho, as vezes uma das coisas que me irrita muito no Brasil, a gente tem essa coisa da política do Projeto...e as vezes o projeto ele não é avaliado realmente e é cortado...então isso me dói...eu sinto que assim...é...em alguns momentos a gente não retomou os pontos que deveria mudar...e achou realmente que estava errado e já mudou o foco de discussão...então nesse sentido que eu acho ruim. Outra coisa, durante essa formação a gente tinha essa equipe, mas nós recebemos formações de pessoas de fora, que eu acho que tiveram um papel enorme, pois quem está de fora dá pra ver com um outro olhar. Mas o que eu sentia, em alguns momentos, eu até penei, porque eu tive um início de estar querendo conhecer muitas coisas, então tudo que era formação que a Secretaria oferecia, eu saia correndo atrás...e eu achava que tinha muita coisa contraditória, assim, é meio que um apanhado geral, mas aí..."o que a gente vai seguir? No que eu acredito mais?" Tem que ser "o que esse grupo acredita mais". Que linha que a gente vai tentar seguir?" Porque tinha o profissional que acreditava mais na linha da Psicanálise...tinha o profissional que acreditava mais no histórico-cultural. É complicado e as vezes, também, sentia que tem que ser procurado uma definição, mas 
eu acho, que realmente não é uma coisa fácil e é uma coisa que eu não sei se...a gente procurar no nosso sistema como se fosse um todo de educação, fica muito claro...até inconsistente.

E: É? Por que você acha que também os profissionais da equipe posições que pareciam fragmentadas?

$\mathrm{L}$ : Sim, eu acho que refletindo até de certa forma, o grupo das pessoas da equipe também tinham posições diferentes. Não que eu também ache que isso seja fácil, mas eu acho que a maneira como a gente vai conduzir o grupo, ou melhor, a maneira como foi conduzida, até permitiu um movimento maior. Agora, o da Secretaria como um todo, eu acho que tem uma série de falhas e a outra coisa assim...que eu sempre penso...quando eu penso nas meninas...é...porque eu penso...são minhas companheiras...e são todas minhas parceiras e são pessoas das quais eu gosto muito, independente das nossas diferenças de posicionamento teórico...mas...é...eu olho...assim...todo esse processo...tudo que a gente estuda de como a criança aprende...é óbvio que não é igualzinho, mas...dando o primeiro passo...eu lembro que eu sou uma profissional, educadora, sei tudo assim entre aspas, sobre educação, eu também vou passar por esses processos, que eu também devo saber, não adianta só ler sobre aquilo, falar sobre aquilo, eu também vou ter que me apropriar disso, de outras teorias, outros temas. As vezes eu acho que as meninas...elas também conhecem isso, elas sabem disso, mas o conhecimento que elas construíram foi sendo sedimentado aos poucos e, as vezes eu acho que elas exigiam que também a gente já tivesse construído. Exigiam e, as vezes a gente ainda não estava ali. Eu acho que aí faltava um pouco dessa visão, do mesmo jeito que eu tenho que olhar a família como parceira, o pessoal da equipe técnica tem que sempre olhar o professor como parceiro. Eu sinto isso no ensino itinerante, que é o que eu desenvolvo, que ao entrar na sala de um professor do regular, eu posso entrar lá e ver várias coisas que não estão de acordo com a deficiência visual, eu não vou deixar de falar disso, mas eu tenho que ver muito bem como falar. O que eu vou eleger e em que momento, porque não dá pra eu chegar e falar tudo de uma vez. Então, junto com o professor eu tenho que tentar construir isso, junto com ele, e junto com os gestores, tem que ser tudo um conjunto. A partir do momento que a gente abraça a questão essas questões precisam ser pensadas. Eu acho que o primeiro momento que nós fizemos isso na escola, as primeiras anotações, elas me deixavam sem chão. "Ai meu Deus". Tudo eu pensava "e agora?" Entrava em ebulição...e aí na hora da gente sentar pra ver a realidade da prática... nem sempre a gente conseguia contar com o apoio que a gente queria, por outras demandas.

E: Você se sentia sozinha?

L: Sentia...muitas vezes sim.

$\mathrm{E}$ : E as situações do cotidiano suas demandas do dia-a-dia...eram compartilhadas pela equipe...e discutida?

L: Então... um defeito ou uma qualidade do pessoal...é...eu acho que o nosso grupo, o grupo com o qual eu trabalho, é um grupo que eu me identifico muito, eu gosto das pessoas, elas não são indiferentes...e eu sinto que a gente tem muitas afinidades...só que nem sempre essas afinidades no conjunto, elas não ajudaram...uma das características desse grupo é a ansiedade...esse grupo é um grupo muito ansioso, então as vezes os momentos que a gente tinha pra compartilhar as situações, eles são determinados, porque eles tem que estar dentro de uma rotina, dentro de uma agenda, dentro de um cronograma...que é uma questão da instituição, de estrutura...de horário, de tempo, "e daí eu chego e eu quero dividir...e as situações não marcam hora. Mas, uma coisa que eu tentei muito aprender com as meninas,eu não sei se eu já estou nesse grau...mas eu sempre tento pensar nisso...que foi uma contribuição...que elas me transmitiram "gente, não dá pra gente o tempo todo apagar incêndio"...então, também é uma fala...que eu sempre ouvia..."puxa mas eu estou quebrada, quando é que elas vão apagar meu incêndio?"(risos) Mas eu fui tentando pensar um pouco desse outro jeito, que se a gente buscar algumas contribuições na teoria, trazer algumas experiências, daquilo que a gente priorize, é...com certeza daria pra se ter base pra você lidar com essas situações de incêndio...só que tudo também é uma construção...hoje eu tenho situações que com certeza não estão mais incendiando, por conta disso, porque eu já sei resolver...eu me sinto forte pra resolver...só que quando acontece, ainda alguma situação que eu não sei resolver a gente quer essa parceria.

E: Você acha que você ainda precisaria de outros materiais, outras discussões, outras reflexões?

L: É, porque...cada vez que a gente vai caminhando, principalmente na educação e na educação especial...a gente vai lidando com uma série de questões desconhecidas a gente conhece, conhece, mas nunca conhece tudo...porque a gente está trabalhando com pessoas...então a gente lê lá sobre a baixa visão...da acuidade visual de $0,2 \ldots$.....décimos, e aí? O que isso quer dizer? Mais cinco e dois décimos de visão enxerga como? Com apenas noventa e dois décimos de visão não enxerga, o que eu vou fazer com isso? Isso é importante saber, o quanto ele enxerga? É eu sei que é...mas como interpretar? $\mathrm{E}$ : Interpretar essa questão para cada um, para cada contexto?

L: De cada um. E aí a gente traz para situação concreta. Na minha formação básica, acadêmica, eu fiz essa opção pela educação especial, e dentro da educação especial fiz essa opção pela área da deficiência visual eu sempre brinco nas escolas, que a inclusão ela não bateu na porta só do ensino regular, ela bateu e está batendo na porta da sociedade como um todo...e do especial também, porque as áreas foram também segmentadas...antes o visual só queria cuidar do visual, o auditivo do auditivo...e não dá mais pra separar...não dá...não existem assim casos que o seu conhecimento esgote. Na verdade eu acho que eles desafiam os educadores, os médicos, os psicólogos, eles desafiam o mundo. E a gente vai aprender muito com isso, só que quem fica realmente no fronte,é o professor, e é a pessoa que vai ficar mais angustiada...porque ele vai estar procurando...as vezes uma forma de comunicação e tem casos que a gente não sabia como incluir casos que mesmo com a formação você não tem plena segurança. Eu tendo a minha base de formação, que é a deficiência visual, mas a comunicação também é uma das questões essenciais para você ter esse contato, entre aspas, pois na deficiência visual você se relaciona através da comunicação. É onde você vai trazer saberes, que não vai ser só contato, o tempo todo tatear, mas eu tenho que ter isso como princípio, principalmente com essa base da deficiência visual. Daí eu chego e não consigo nem me comunicar...fica uma angústia enorme, que caminhos que a gente vai seguir? Eu sinto que o sentar e planejar, por exemplo,estes instrumentos metodológicos que a gente usa muito na escola, o planejamento, registro e reflexão do registro, eles são necessários e já fazem parte do nosso dia-a-dia, porque ainda muitas escolas não utilizam esses procedimentos...eu caminho pelas escolas públicas e vejo isso...

E: Que não é uma prática?

L: Que não é uma prática...acessível ao professor. Por uma série de razões, mas não é. Então, por felicidade, estou num grupo que isso é uma prática. Só que essa reflexão em cima do registro, nem sempre ela consegue ser tão compartilhada como é propósito dos profissionais, por conta de outras demandas...então as vezes eu planejei, eu registrei, eu mesma li o meu registro, as vezes eu coloquei lá um monte de indagações...e não consegui compartilhar.

$\mathrm{E}$ : Essas questões que você assinalou como dificuldades puderam ser avaliadas?

L: Dentro do grupo eu acho que sim, agora numa macro-estrutura eu não sei como é que ficou isso. Às vezes eu tenho a impressão de que é muito complicado nesta estrutura maior da Secretaria, às vezes a gente fazia uma queixa...porque sempre...a Secretaria tem seus instrumentos de avaliação...então nós nos juntávamos todos os professores, todos os profissionais da equipe e a gente discutia o que acontecia em aula, o que aconteceu...o que não aconteceu e por que não aconteceu...e via que a gente estava distante, que a gente não tinha conseguido chegar àquilo que estava como...meta...proposta pela Secretaria, só que por vezes, o que a gente colocava ali, registrava na Avaliação das Metas, 
muitas vezes a leitura da chefia, das pessoas que estavam de fora, tinha outros desdobramentos uma conseqüência que a gente jamais imaginava que fosse acontecer...então as vezes a gente tinha reclamado de algo "x" e a conseqüência veio de um jeito que a gente não conseguia fazer correlação. A gente fazia uma avaliação que eu achava bastante produtiva para o grupo, mas nem sempre os encaminhamentos eram aquilo que...nós identificávamos.

E: De certa forma você fala de uma falta de sintonia entre Escola e Secretaria, não validando as ponderações dos educadores? Neste aspecto avaliando essas transformações, na sua experiência, você já falou que hoje você já tem mais traquejo pra lidar com as situações, além da própria prática de registro e reflexão. Que outras transformações você acha que essa atuação em parceria proporcionou pra você?

L: Então, quando eu penso o que cada profissional dessa equipe trouxe, uns continuam trazendo, são saberes importantes, de áreas do conhecimento humano, que é uma abertura no olhar, no todo da escola. A minha prática é constituída de dois momentos: eu tenho um momento de interação direta com o aluno e tenho um momento de interação direta com outras escolas do ensino regular onde eu vou lidar com o...inspetor e, tenho também o outro foco que são os familiares dos alunos...na verdade são três momentos bem diferentes: quando eu estou vendo um aluno, pensar no aluno...tentar entender o processo que ele está fazendo pra ele se apropriar do conhecimento; quando eu olho pra família...tentar ver em que contexto essa família se encontra,vendo-a como parceira; quando eu olho para escola,ver que essa escola também tem um contexto...que essa escola também está construindo uma prática. Eu penso que eu não tinha esse olhar antes de trabalhar nesse centro de apoio, nessa condição de processo e com essa estrutura mesmo de olhar dentro da prática. Se a gente for falar de coisas mais específicas: é, eu terminei a graduação...em noventa e seis. Na minha graduação eu estudei uma série de coisas de como se alfabetiza, o que deve ser feito e tal...mas quando eu fui trabalhar mesmo no EJA, porque eu fiquei um tempo com adulto, não passava por esse processo de alfabetização e, depois eu vim pra cá. Eu acabei tendo que atuar nesse processo de trabalho. E aí, eu considero que ter acesso ao que essas pessoas conheciam de alfabetização me ajudou muito a retomar o caminho. Isso eu acho que foi uma coisa, que eu consegui aqui: o melhor possível definir que linha metodológica que você vai trabalhar nesse momento da alfabetização...e isso era uma coisa que eu...que eu não tinha clareza. Outro momento que eu acho que pra mim foi muito bom, neste processo, que foi uma interpretação do sujeito autista eu jamais me esqueço daquele curso do Rynaldo Voltolini que depois, em alguns momentos a gente também discutiu com o pessoal, dentro da equipe. E dessas amostras,dessa possibilidade de entendimento que era uma coisa que eu conhecia o mínimo dentro da Pedagogia...a gente lê, estuda, vê alguns casos...e a gente traz pra nossa prática...a gente tem as situações que estavam batendo na nossa porta e eu acho que nesse momento precisavam desse olhar que foi dado. Eu lembro, também, da atuação de uma psicóloga...foi a segunda psicóloga que passou pela equipe...ela foi fazer uma observação em sala de aula...coisa que eu sempre gostei...(não são todos os colegas que gostam)...eu já...até porque na minha prática acadêmica, sempre foi assim,eu sempre gostei disso. Não é fácil, tem horas que você vai ouvir coisas que..."puxa, mas eu não tinha pensado sobre isso"...mas eu não tenho esse receio. Então, a gente tinha essa prática e ela era muito afobada, a gente discutia casos que eram mais complexos...em determinado espaço dos encontros e depois dessa discussão, existiam uma série de encaminhamentos. Um dos encaminhamentos possíveis seriam as observações em sala de aula, com o intuito de ver as coisas que estão acontecendo entre professor e aluno e partindo dessa interação real ver o que poderia ser sugerido. Eu me lembro, dessa entrada em sala de aula, dessa psicóloga, eu estava com um aluno muito complexo, que tinha deficiência visual, cegueira, e comprometimentos psiquiátricos, que ninguém até então tinha diagnosticado. Era muito difícil, tanto que essa criança a gente já tinha tentado várias formas de atendê-lo melhor, de dialogar com ele, mesmo as vezes que ele funcionava, era sozinho pois ele não conseguia ficar em grupo. Então a gente estava estudando a melhor forma de atendê-lo, mas a gente também sofria com isso, porque "poxa vida, vai ficar o tempo todo sozinho?". São pressupostos que são importantíssimos pra educação que é a aprendizagem com o outro...e eu não sabia se isso dava pra acontecer.

$\mathrm{E}:$ Você se refere à parceria e às trocas entre os alunos?

L: Acontece sempre, não é? Mas existem exceções, então nesse caso a gente estava estudando, até porque a gente não desistia do grupo, de criar possibilidade do aluno se envolver com o grupo e aprender com os colegas. Então ela foi pra uma observação deste aluno, no individual e foi também em uma observação dele em grupo...e aí a gente fez uma aula com sorobã, um pouco de interação com a mãe, que também estava assistindo a aula pra aprender, então a minha aula era com a mãe e com o aluno, pois o sorobã é um instrumento muito específico, os pais precisam contribuir, se apropriar...então a aula era para os dois, pra mim e para o filho...e a psico observando. Depois, a gente terminou a aula, tudo, e a gente teve um momento de troca...e muitas vezes a gente não conseguia fazer um momento de troca logo em seguida...por questão de rotina, e aí eu lembro de uma colocação que ela me fez que eu fiquei tão...na época assim "ai mas não é possível"...sem chão mesmo... "por que ela está me falando isso?"...mas, eu acho que as vezes a gente tem uma resistência inicial, que a gente precisa quebrar também e hoje eu agradeço muito por ela ter me dado aquela referência...que foi uma coisa simples...ela falou assim "vocês daqui falam o tempo todo..." aí até parafraseando o professor..."no tempo do deficiente visual...que tempo que ele leva pra explorar coisas, que o tato é diferente da visão"...ela meio que brincou comigo e falou dessa coisa que nós batíamos tanto, "e você não deu tempo pra ele explorar o sorobã". E eu fiquei..."como não dei tempo?"... eu acho que foi um apontamento tão importante pra mim...naquele momento, porque foi eu estava com tanto receio de que esse aluno tivesse uma crise, tanto receio que esse aluno não desse certo, que ele não gostasse e que dali desencadeasse um momento de conflito, porque isso acontecia, que eu tirava uma atividade e punha outra, tirava uma atividade e punha outra, e ele não tinha tempo de aprender...eu não sei se especificamente eu acho que é um olhar coincidente com o psicólogo...não sei se era só ela que poderia ter feito isso, mas foi ela que fez esse apontamento que era uma coisa até que eu já conhecia...daquele dia em diante, eu tomei mais cuidado ainda com a questão do tempo...o tempo que ele precisa realmente pra observar...

E: Essa questão do tempo que você assinala, principalmente na educação especial, é algo que mobilizou, por que o outro expôs uma fragilidade sua?

L: Sim, às vezes os outros dizem, "nossa, mas porque um apontamento desses pode ter te deixado sem chão?"... porque instintivamente era uma coisa que teoricamente eu já sabia. Por isso que me deixou assim desapontada, eu ainda tentei justificar, porque eu sou sempre assim...eu já até falo para as meninas, quando a gente vai trabalhar junto eu falo "olha, na hora que vocês forem...provavelmente vai ser assim. Quando vocês me trouxerem apontamentos novos eu vou falar, eu vou justificar, aí quando eu vou pra casa você começa a refletir...não dá pra ser instantâneo...eu não consigo, quando você me falar uma coisa eu vou ter que pensar...se eu concordar ou é porque eu já pensava assim ou é porque eu não estou pensando em nada...(risos). Eu não vou concordar de cara...eu vou ter que parar pra pensar nisso...e as vezes... eu sentia falta de questionar...eu sei que não é fácil fazer, porque eu também tenho que fazer isso com os meus alunos e é difícil...teve uma momento xis...daí depois passou um tempo teve um momento y, e tem situações que o momento é imprescindível pra você fazer a ponte ali, na hora, e as vezes isso passa.

$\mathrm{E}$ : Você falou na questão da aprendizagem com o parceiro, do papel do outro na aprendizagem, que você citou do isolamento dessa criança, do atendimento individual...como você analisa a questão do outro...na aprendizagem do professor com o outro parceiro de equipe? 
L: Então, eu penso...talvez seja um jeito até ingênuo, mas eu penso nela, mais ou menos como a gente pensa das outras crianças também, que a criança precisa do parceiro...que não é na fala do professor que ela aprende, mas é na fala do parceiro ali, com os conhecimentos dela que ela vai estar aprendendo...eu penso que a gente também é assim, eu sinto isso, eu sinto que até no meu vocabulário eu passei a usar palavras, expressões que eu não tinha...nossa!, muitas porque essas pessoas foram me enriquecendo...e uma outra coisa muita clara também, que fez uma grande diferença que...não é que deixou de ser difícil de fazer, não é que deixou de dar trabalho, continua dando muito trabalho, é difícil, porque a gente tem que pensar e pensar muito, é o momento do relatório. Nós temos relatórios semestrais e esses relatórios também foram conquistados em uma construção com a equipe, uma maravilha...eu sei que daria pra ser de outro jeito, mas desse jeito foi uma construção passo a passo, pensando em cima da nossa elaboração.

E: Como é que foi construído?

L: Pelo menos pra mim foi bom, a gente tem uma série de vícios...você passa um tempo...com essa pessoa, com esse aluno, com um grupo de alunos, e você precisa avaliar o que foi feito com ele...o que você planejou...e daí, sempre fica os três pontinhos...as reticências...vamos fazer esse bloco, portifólio, vamos fazer mais um tipo de documento, que diz o que a gente percebeu de avanços, quais foram os obstáculos desse período que a gente travou ali com os alunos...e isso é feito semestralmente, mas que também passou por vários momentos. Então, primeiro a gente fazia um relatório, cada um no seu programa. Uns trabalham com braile, olham o aluno só no braile, eu trabalho o sorobã, olho lá o aluno só no sorobã, cada professor também fazia isso...e as meninas da equipe elas apontavam várias coisas muito interessantes, porque a leitura que foi feita...a gente também não estava preparada para isso...

E: Como assim?

L: Eu escrevia, eu entendia o que estava "dito", super interessante esse papel da escrita, nunca você se pergunta..."quem vai ler?" Então a gente fazia isso, o outro colega lia o nosso relatório e como troca, vinham as devolutivas de fora: "dá pra entender, mas olha, eu que estou de fora, eu não participo, eu não consigo entender o que você quis dizer com isso aqui, o que você está dizendo realmente desse aluno?" E aí a gente foi tomando mais cuidado com as palavras...eu acho que foi uma coisa que a gente aprendeu muito- que palavras que eu vou usar e, as vezes isso parece bobagem, eu não quero ser extremista, porque também eu não gosto de ser "mas tem palavras que eu não posso usar de jeito nenhum" ou melhor, tomar muito cuidado...e verificar se é realmente esse sentido que você está querendo dar, o que você realmente está querendo falar dessa pessoa...porque é uma avaliação, então eu acho que a gente passou muito por isso...e passou por um momento da gente ficar emburrada, porque tiveram muitas devolutivas, e elas não eram só "confetes", e a gente ficava pensando, então você ficava naquela coisa "ai eu estou me esforçando tanto e não está dando certo"mas eu penso que também assim, que muitas vezes a reação do grupo era exagerada, por questão dessa ansiedade que o grupo tem...

$\mathrm{E}:$ Mas este processo obteve ganhos? Então valeu o sacrifício?

L: Eu acho, que isso é uma outra coisa, esse grupo tem muita ansiedade...e quando via que o relatório não estava tão bom assim sofriam, reclamavam. Na brincadeira a gente falava: "entre mortos e feridos salvaram-se todos"...e hoje a gente está num outro processo. Hoje a gente faz esse relatório de uma forma coletiva, então o aluno tem um relatório só, de todos os programas, a gente se reúne e faz. Dá um trabalho!...falta horário, mas você olha o aluno por inteiro,você troca ali naquele momento..."olha, ele está fazendo isso no sorobã".Mas vem a outra colega e diz: "ah!, mas eu dei uma atividade numa outra aula que ele teve que usar o sorobã e se embananou", então você começa tentar criar uma visão mais interdisciplinar...não estou nem falando de trans, mas de inter...

E: Pensar interdisciplinarmente até mesmo na elaboração dos relatórios foi uma prática instituída que permanece?...

L: Interdisciplinaridade foi uma contribuição das meninas...

E: Você vê o aluno como um todo e o grupo contribui para esta constituição.

L: Principalmente da orientadora pedagógica e da psicóloga, que nessa questão estava muito fragmentada, eu acho que desde o início, pelo menos quando eu cheguei nessa equipe, elas estavam insatisfeitas com o formato do relatório, mas ainda não tinham conseguido pensar numa forma e isso foi acontecendo...e a gente chegou nisso hoje, que está bem legal. Tem horas que eu olho assim e digo "puxa"...você vê...porque tem diferentes momentos na vida da gente, e quando se vai evoluindo... eu leio e eu fico tão feliz por eu ter participado daquela produção, porque eu acho que está fidedigna, a gente está conseguindo dizer do aluno, a gente está conseguindo dizer da nossa proposta, a gente consegue estabelecer objetivos gerais que devem permear todos os programas, a gente consegue falar dos objetivos específicos e consegue fazer uma avaliação baseada no que o aluno já sabe e não no que falta... (risos). No começo era assim,no começo era muito assim..."ele não faz, ele não faz, ele não faz, ele não faz"...

$\mathrm{E}$ : $\mathrm{E}$ isto se transformou.

L: E a gente falava, mas isso não é verdade, porque o aluno sabe muito. Eu lembro até de uma primeira vez que eu vi isso eu disse nossa!, isso está me parecendo "destruição". Ela ( orientadora) falou assim "não é isso, ninguém está pedindo para falar o que ele não sabe...porque você já me falou, por que não aparece o que ele faz?" Então você fica péssima..."a gente precisa ver o que já tem", porque essas crianças, essas pessoas são muito rotuladas já pela falta...e a gente, entre aspas, especializadas, continua trabalhando com a falta...

E: Você acha que essa deficiência delimita a relação com o conhecimento?

L: Pensando que trabalho com a deficiência visual e que esse sentido é responsável por grande parte das informações recebidas do ambiente, do controle do corpo, do espaço, promovendo a integração da pessoa. Pensando que as crianças videntes aprendem por imitação espontaneamente, brincando, explorando objetos que lhe chamam a atenção visualmente. Pensando que os pais, por vezes, sentem-se inseguros de como educar os filhos e com a revelação da deficiência da criança essa insegurança toma dimensões ainda maiores. Entendo que a deficiência visual pode delimitar sim a relação com o conhecimento, se desde o nascimento, ou o mais cedo possível, a criança não contar com uma educação 'sistematizada', organizada, onde possa ser ensinada pelos caminhos perceptuais que apresenta.

E:Que outras questões se configuram no modo como você se relaciona com os alunos e nos modos de intervenção na sala de aula?

L: Acho que poderia dizer de duas estratégias que sempre utilizo: ao propor a atividade saber se o aluno julga-se capaz de realizá-la sozinho; e quando a finaliza saber por que escolheu aquele caminho / jeito. Penso que assim posso mapear um pouco de como ele 'pensa'. È claro que na interação do grupo um tem que ouvir o outro, valorizar sua tentativa e a do outro, mas juntos definirmos o que é cientificamente melhor.

$\mathrm{E}$ : Você assinalou muito, a contribuição que para você foi muito importante, da visão histórico-cultural, basicamente, referente à valorização das transformações. Como você analisa este aspecto na aprendizagem?

$\mathrm{L}$ : Eu penso que a gente, o Centro de Apoio , mais uma vez, ele é um lugar especial mais por conta disso. A gente às vezes trabalha com uma criança, e pode acompanhá-la até o final do Ensino Médio... então a gente vai crescer muito nessa relação, porque a gente vai conviver desde bebê, até o Ensino Médio, essa é uma convivência contínua, e prazerosa. Isso também era uma fala muito da nossa assistente social..."gente dá pra ter conhecimento com prazer?" "Vamos buscar isso" Tinha horas que 
eu ficava "ai meu Deus, mas essa tabuada é chata, não sei como o aluno consegue ter prazer fazendo tabuada toda hora?" Ela falava "então, mas não precisa chegar nos extremos, não precisa ter prazer toda hora"...

E: Quando você cita a questão da ponte entre teoria e prática....a tematização, muitas vezes, não era compartilhada da forma como vocês queriam, ou esperavam... identificando essa prática de uma forma, mais inteira, com essa teoria na mão. Aprofunde mais este aspecto.

L: Então, e eu penso que essas coisas aconteciam...e elas não aconteciam só por uma questão da maneira como era conduzido pela equipe técnica...mas também por um comportamento do grupo, pela ansiedade, a gente tinha...e até hoje ainda tem uma prática as vezes de estabelecer uma pauta e depois fugir dela...então, eu penso que ali a gente tinha que olhar um pouco pra essa coisa de dinâmica de grupo.

E: Como assim?

L: Para aprimorar aí os papéis, e tentar seguir...definindo um pouco os papéis que cada um tem...e as vezes eu sinto que no Centro de Apoio...uma característica desse grupo, de...que a gente ainda não consegue muito definir prioridades, a gente define, mas a gente não consegue seguir o que a gente definiu por "n" motivos...porque aconteceu uma situação xis e y que precisava ser remediada, etc, etc.

E: Outras demandas?

L: Não,porque, às vezes, eu acho que a gente não tinha condições de filtrar. Então, muitas vezes, pelo impulso mesmo,a gente projetava muitas coisas e não conseguia dar conta. Eu acho, que precisava de mais maturidade, tanto que o que aconteceu...é...que houve uma proposta de mudança da Secretaria e a gente acabou pendendo e hoje a gente não tem mais uma equipe desse formato...a gente na verdade tem uma equipe que faz atuações pontuais na escola...de acordo com a solicitação. Então essa interação ela ficou em menor grau agora...

E: Você acha que ficou mais distanciado da sala de aula? Quando você fala pontual o que você está querendo dizer?

L: Nós não temos mais a presença da psicóloga, da assistente social em todos os momentos coletivos...a gente tem alguns momentos, e acaba sendo pra uma discussão de casos. Vêm de acordo com a sua solicitação.

L: Isso atende uma certa demanda, mas eu em particular ,nem sei se são todos os meus colegas que concordam com isso, eu sinto falta um pouco desse olhar...

E: O cotidiano da sala de aula já não é um foco do trabalho da equipe?

L: Não é. Eu acho que agora a gente tem que trabalhar junto só com a orientadora pedagógica. A equipe, só em casos pontuais que a gente chama.

Se bem que os nossos registros, os nossos planejamentos, não são mais solicitados, só a orientadora. Então, o que eu sinto de diferença é que o grupo de professores ampliou-se, então tem um grupo que já tinha uma base, e um grupo que chegou. E: Sem a experiência que vocês tiveram? E o grupo mais antigo não poderia partilhar essas experiências?

L: Por enquanto a gente ainda está partilhando nessas trocas, porque estão bem diferentes, esses olhares. Uma das coisas que está aproximando esse olhar tem sido esses momentos de relatório. Porque quando a gente vai fazer esse relatório em conjunto, muitas vezes, o outro ainda vem com aquele olhar, digamos que a gente já passou por isso, e só vê o que o aluno não faz...e aí a gente está trocando dados...mas ainda tem muita coisa para conversar.

E: Vocês sentem abertura...nesses momentos?

L: Eu sinto, mas eu tenho receio de, às vezes, atropelar o outro, porque nós somos todos educadores ali.

E: Quando você olha essas trocas, não só no aspecto do relatório, mas de uma forma geral, para esse parceiro da escola regular, quando você está na itinerância, o que você analisa, na medida que você teve oportunidade de ter toda essa vivência formativa.

L: Então então na época que a gente tinha assessoria com a professora Elcie ela falava "meninas, vocês precisam escrever sobre itinerância". Eu acho que é um momento muito positivo da minha atuação,a possibilidade de realizar essa modalidade de ensino....acho que é assim...mas nem está escrito nada na LDB...eu não lembro de ter visto nada escrito sobre itinerância. Mas com certeza nesses documentos, na LDB tem alguma coisa, mas eu não consigo lembrar nem se é modalidade mesmo. $\mathrm{O}$ Centro de Apoio usa como modalidade de ensino e nesses anos...de itinerância...eu passei por diferentes momentos...eu passei por momentos em que eu passei na porta do professor e o professor não me deixava entrar, depois eu passei por um momento que eu batia na porta do professor, ele me deixava entrar e me olhava com desconfiança...depois eu passei por um momento, que eu primeiro batia na porta do diretor. A gente começou a entrar na escola de maneira diferente, a gente não ia mais direto bater na porta do professor, não que ele não fosse o nosso principal foco,sempre foi, mas a gente quer o diálogo com o professor mas passamos primeiro pelo gestor por uma apresentação da proposta. Porque no começo a gente era muito cru...a gente chegava lá e pá..."eu sou o professor itinerante...eu vim observar a sua aula"...o professor falava "ai o que elas querem?". Realmente...era muito difícil. Hoje em dia eu penso nisso e penso qual seria a minha reação se eu fosse o professor do regular e já estivesse com um desafio desse trabalhar com uma criança, no qual a maioria das vezes os professores não se sentem preparados para lidar e de repente chega uma outra pessoa que vai olhar pra você e tal. A gente já tinha nessa época a prática de registrar esses encontros. Então, a gente ia para a observação, ficava lá escrevendo no nosso caderninho, depois...não conseguia, muitas vezes, trocar os dados com o professor...e só ia trocar na outra vez que voltasse...imagina o que eles não falavam "meu Deus, o que ela escreveu de mim...e o que tanto ela anotou?" Realmente eu acho que era...terrível, mas isso tudo...mudou...e mudou nesse processo de trazer os problemas para a Equipe, as vezes esses incêndios. Eu já cheguei chorando no Centro de Apoio: "ai...a professora falou isso, isso e isso".Uma vez eu lembro que eu cheguei arrasada, porque eu tomava tanto cuidado pra não fazer nada que assustasse o professor, e ela falou "você é muito invasora" e aquele dia tinha um monte de gente...e eu falei "eu não sou hipócrita" Ela falou que eu joguei o papel na mesa dela, mas eu não joguei. Bom, essa foi uma situação xis, foi uma pessoa que me incomodou muito...e que eu acho que eu fiquei numa situação que eu não me conformava com aquilo, da reação que a professora trouxe, mas hoje em dia eu agradeço a essa professora, eu agradeço às meninas da equipe que tanto me ouviram, porque a gente conseguiu dali, vivenciar num outro momento...depois, numa outra itinerância, a minha orientadora chegou a uma conclusão de que ela precisava intervir...e como tinha essa parceria com a equipe, ou a orientadora, ou a assistente social iam com a gente: "Vamos juntas ver o que está acontecendo" Aí a gente foi...começou a limpar um pouco a situação...e a gente começou a rever um pouco o nosso papel, porque a nossa intenção era boa, mas a maneira como a gente estava fazendo não estava muito clara. Daí para frente,nós fomos organizando nossos procedimentos para a orientação do ensino itinerante...parece uma coisa assim, mas tivemos que passar por isso, por esse momento de estabelecer os combinados. Às vezes, a gente fala "mas isso foi combinado com essa criança"...a gente tem que conversar isso com o professor e ir se aproximando: "olha, o Centro de Apoio é assim, tem essa proposta de trabalho, você está convidado pra ir lá".

E: Foi uma enriquecedora conquista?

L: É...uma conquista...é uma nova conquista todos os dias. Então, a gente teve todos esses momentos. Hoje em dia, ou melhor, faz muito tempo que eu não sei o que é um professor me olhar em sala de aula com cara feia. Eles não olham mais com cara feia, porque eles estão ali pra entender o que a gente está tentando trazer. Também, eu sinto que talvez até o que 
amenize mais é que eu me cobro também "nossa, mas eu estou falando tudo o que eu devo falar?"...e é difícil porque é onde eu acho que a gente ainda tem muito o que construir. Às vezes eu priorizo o que eu vou falar ao professor em relação às adaptações que ele precisa fazer, mas pelo menos, no momento que a gente vive agora, eu quero ser parceira do professor, não quero ser omissa, mas eu quero ser parceira dele. Eu não quero só ficar apontando o dedo para o que está errado e quero propor que o Centro de Apoio ajude nas necessidades "você precisa de um material adaptado?"..."o que o Centro de Apoio pode fazer, que encaminhamentos pode dar". De um tempo para cá, por conta dessa coisa de repasse de verbas da Secretaria de Educação para as APM, as escolas podem adquirir os materiais, porque elas tem repasse pra isso...mas, de novo, eu não quero que a escola tenha que quebrar a cabeça pra procurar lugares sozinhas...eu quero já trazer coisas pra escola...porque eu quero vir com essa informação "olha, a folha com diagramatura cento e vinte você pode achar em tal e tal lugar, não adianta você comprar vergê porque é dura demais e as crianças vão ficar com os dedinhos doloridos". Porque é uma experiência que eu acho que a gente tem que trazer a coisa já toda escrita que é pra ser compartilhada...e para o professor também.

$\mathrm{E}$ : Nesse processo que você assinalou em que você, muitas vezes, não foi respeitado, no início talvez da própria aprendizagem da equipe, que muitas vezes te atropelava,você sente que isso você absorveu com muita clareza para o seu trabalho de itinerância?

L: Com certeza...eu acho que sim foi duro, é óbvio, a gente é ser humano...eu sempre penso nisso...e aí eu já acho que é uma característica minha...eu acho que sempre tem coisas pra gente melhorar...mesmo dentro da itinerância...é uma coisa que eu falo para as minhas amigas e tento convencê-las disso... "gente, eu acho que não dá pra gente ficar dez anos na mesma escola...a gente vai viciar o nosso olhar...a gente vai ficar sempre vendo as mesmas coisas, você já tem os amiguinhos... os vizinhos, o trabalho itinerante não é esse. Então, eu sempre falo "olha, vamos revezar as escolas...a gente tem tipo uma proposta...três anos numa escola, depois troca, você forma, você aprende...você consegue desenvolver um trabalho, depois você troca e vai pra outra escola"...e quando a gente faz essa troca, a gente chama isso de passagem, quando eu troco de escola, a minha primeira itinerância, eu vou lá e levo a minha companheira, a nova itinerante, apresento, passo tudo,o carinho que a escola teve comigo, a gente faz essa passagem...e aí continua. A gente tem uma relação boa interagindo com várias escolas. Agora, tem escolas que são muito interessantes, eu acho que se as escolas estivessem no mesmo momento, eu acho que isso aconteceria com todas, mas realmente as escolas estão em momentos diferentes. Eu lembro que eu tive uma escola, que aliás foi uma que esteve no projeto piloto, Cassiano Faria, eu era parte integrante da escola, então, o quadro de funcionários, por exemplo, na época que também teve laboratório de informática, que teve todos aqueles recursos, eu estava lá na foto de quadro dos funcionários, eu participava das festas...e foi uma conquista, porque foi nessa escola também que a professora me fez chorar...e que a direção não permitia a minha entrada lá. Eu lembro, que quando eu cheguei eu tive uma recepção bem fria nessa escola, mas as coisas foram caminhando.Eu lembro que eu perguntei: "mas, eu sinto que eles não entendem o nosso trabalho"...eu ficava o tempo todo, o tempo todo nisso e as meninas "então o que você acha que a gente pode estar fazendo pra que eles tenham esses entendimento do trabalho?"Aí eu falei: "olha, se vocês me permitirem eu vou levar os meus apontamentos gerais, eu vou levar os relatórios que a gente faz aqui,o livro, eu quero mostrar pra eles o que a gente faz, porque eles estão vendo pedaços do trabalho...e aí fica realmente difícil". Eu não sei, pode ser uma coisa pequena, mas a partir do momento que eles viram quantos detalhes...quantos momentos eram construídos durante o trabalho...inclusive eu construí o meu cronograma naquele momento. Hoje a gente nem faz mais isso...mas, quando eu construí o meu cronograma, eu discuti muitas coisas com eles..."quais são os melhores dias pra eu vir?" Hoje a gente só avisa com antecedência...e se tiver algum problema a escola retorna e fala "olha, nesse dia não dá, vamos marcar outro dia"...mas tem hora que eu tenho que construir junto...mudou a relação...mudou...e eu sentia que faltava, nessa escola em si, estava faltando esse diálogo... a partir do momento que teve, a entrada foi diferente...a gente passou por tantas situações nessa escola com um aluno...que é um aluno tão inteligente, que veio com uma baixa visão severa, mas muito inteligente...mas que teve momentos muito difíceis...ele...ele teve algumas crises na escola...que se fosse no primeiro ano que eu cheguei lá eu não sei o que teria acontecido...ali...naquela escola. Só que ele...graças a Deus, a gente estava num outro momento, que a escola foi super parceira, que se preocupou com o menino durante todo momento que ele esteve lá...pensando temas de aprendizagem, não só convivência, socialização...nada disso...

$\mathrm{E}$ : Você acha que com esse crescimento desse processo interno, intra-equipe, que fez parte da rotina de trabalho, refletiu na forma como se assume os alunos incluídos, não só...ofertando um espaço, mas se apropriando de saberes que vão beneficiar essa criança?

L: Eu sinto isso, eu sinto sim. Atualmente essa escola, por exemplo, não tem nenhum aluno com deficiência visual, mas eu tenho certeza que se chegar, eles sabem o que fazer...eles sabem onde procurar os recursos, o que fazer...eu não tenho a mínima dúvida, até porque há outras questões também que vão condizer com isso. Essa escola é uma escola central, ela não tem muita rotatividade de professores, então toda formação que foi oportunizada naquela época é mantida. Tem professor que também se mantêm, então isso, diz muito. E é uma das escolas nas quais a gente conhece na rede, então a gente quando vê um aluno com muita dificuldade", não que a gente determine a escola...mas as vezes a gente, diante de uma dificuldade, a gente indica um lugar que vai ser bom para o aluno. A gente teve um caso, acho que de uma aluna múltipla, sem comunicação, paralisia cerebral, baixa visão, muito complexa...e uma das escolas que a gente pensou, e falou pra mãe ir conhecer era esta mas,também...porque a gente sabia que...não ia ser fácil...não ia estar tudo pronto, não é nada disso, mas é que a compreensão e o acolhimento seria diferente. Depois a gente desdobraria o trabalho junto. Mas nesse caso, a mãe acabou optando...por si e definiu em levar para uma escola perto de casa. Então, se foi dado uma oportunidade pra ela de conhecer várias escolas, ela que vai escolher...e ela escolheu uma outra escola por conta dela...

$\mathrm{E}$ : Agora o desafio de vocês é conquistar outras escolas...

$\mathrm{L}$ : Sim...que é isso que a gente tem que fazer...e junto com a equipe que está vendo isso. Uma coisa que me incomoda...que eu sempre falo para as meninas "eu sei...eu sei os valores que estão em questão...em jogo, mas a gente trabalha na escola pública...defende a escola pública e colocamos nossos filhos na escola particular",então...isso me incomoda...eu não tenho filho, mas me incomoda...a partir dos meus critérios essa escola seria uma escola onde eu colocaria o meu sobrinho...que é a criança que eu mais amo...eu confio no ensino lá...eu ficaria feliz...porque eu acho que ela por tudo que eu vivenciei ali, e aprendi com eles...ela me mostrou que ela olha pra criança...

$\mathrm{E}$ : Mas este processo vivenciado anteriormente pode ser continuado, não pode?

L: Sim, poderia. São Bernardo tem muitas boas escolas, mas é uma rede grande, uma outra coisa que me incomoda também...que eu vejo dessas itinerâncias e que eu tenho trazido...mas eu acho que até pela demanda de coisas, as meninas ainda...não caminham para isso...que é o olhar do itinerante,e todos terem o mesmo procedimento, e o interessante que está acontecendo também...inclusive que tem alguns técnicos, do infantil, do fundamental...que tem a possibilidade de voltar um pouco a ouvir sobre outros olhares...de ter discussões em conjunto nesse sentido, e considerar o professor itinerante como um educador...ele é um professor na essência, o jeito...parece que não, mas o jeito que a gente é recebido, a entrada que a gente tem na escola é diferente da equipe técnica, e eu acho que, de certa forma...pra mim foi muito bom...eu consigo saber muito bem dos problemas das escolas, eles estão bem abertos pra falar "olha, senhora, eu consigo adaptar esse livro até a página 
xis...depois eu não consigo mais"...ai eu vou recorrer pra isso..."e aí...que solução que a gente pode arranjar?"...e a gente vai tentar ir se interando, porque...num momento em que a gente vive...mesmo com essa coisa de reserva e tal...ainda tem escolas que estão com dificuldade...sim...muitas dificuldades...até...por questões dos antigos diretores, como administrou, como não administrou e parece que vai mais verba se você tem mais crianças alfabetizadas, com bom desempenho, é uma confusão danada, e o diretor sofre muito com isso,aí a gente acaba tendo que...eu não sei como é essa coisa de verba...o que eu sei é que as necessidades dos alunos são essas...eles precisam disso e quando a gente não tem, a gente vai ter que procurar esses recursos de um outro jeito...e aí se coloca o que a gente pode estar fazendo. Mas o que eu queria dizer é que quando a gente faz essas idas a várias escolas, às vezes a Secretaria que faz aquelas avaliações do tipo... prova Brasil. A gente fala: "aquela escola deve ter ido bem...aquela escola", porque a gente está vivendo isso...e eu sinto...que eu gostaria que a Secretaria olhasse...que ela fizesse de verdade...é olhar pra essas escolas...pra umas escolas pra lá da balsa...não dá pra você olhar como você olha para as do centro. Nesse momento ela precisa de mais apoio que as daqui do centro. Uma das escolas que eu freqüento, ela é linda, é uma região de balsa, ela é a única instituição pública que tem ali, a única escola, tem posto de saúde, a escola é incrível para aquela comunidade. Agora dá para ter livres instrumentos, avaliação genérica, para todas as escolas? Não dá. Aí sempre aquela escola acaba apresentando resultados insatisfatórios, porque ela precisa de outra condição, de outro olhar...

E: Isso é essencial, principalmente se estamos querendo construir uma escola inclusiva.

L: Isso.

E: Você falou... esse seu processo formativo e algumas falhas, que outros fatores você analisaria nessa formação continuada em parceria com a equipe interdisciplinar que você acha que contribuiu para a sua atuação e repercute até hoje? Você lembra de mais alguma coisa que você gostaria de assinalar?

L: Eu não sei...não posso te dizer das outras escolas, mas eu acho que tem sempre um caráter pessoal de cada um...eu acho que a equipe com quem eu trabalhei...a equipe com quem eu trabalho agora, elas são pessoas competentes,pessoas que estão sempre procurando essa formação continuada pessoal. Então elas estão ali nesse processo com a gente, mas elas não descuidaram da própria...formação,estão sempre buscando, então eu acho que...é estimulante, pra mim, foi muito estimulante quando a gente começava uma reunião, que tinha lá um título...era uma revisão literária...e muitas vezes, uma dessa discussões, textos que elas estavam lendo numa pós, textos que elas estavam lendo num mestrado, num curso específico elas discutiam com a gente, acho isso legal, porque apesar da gente ser educador de terceiro mundo...tem muita coisa boa, tem muita gente boa escrevendo, muita gente boa falando, com pensamentos interessantíssimos, e as vezes a gente não consegue ter acesso a tudo...então era o momento em que eu precisava de...enriquecimento...era um grupo que sempre trazia isso...e trazia de formas diferentes a parte científica, mas trazia também em forma de cultura. A nossa orientadora, que permaneceu durante esse tempo todo e agora, uma das professoras também assumiu o posto de orientadora pedagógica, uma delas, ela traz sempre essa questão que a gente falava, discutia com a assistente social, nos momentos de trabalho coletivo, de existir propostas onde a gente fosse ao teatro, onde a gente fosse ao cinema e isso era uma coisa que era bem interessante. Nem sempre a gente consegue realizar, mas já teve momentos em que a gente foi em apresentações no teatro, muitas vezes aproveitando as coisas da própria cidade, que eu acho que elas não são bem utilizadas...então a gente tem amostras de cinema brasileiro...amostra de cinema internacional...na própria cidade super barato...dez reais e não se aproveita.

E: Eu queria que você falasse um pouco mais, do seu papel como profissional, e aí fazendo inclusive um elo com, essa questão que você fala do aspecto compartilhar conhecimentos que você foi se apropriando.

L: Então, às vezes eu até brinco, brinco e falo sério também, eu não sei se é porque a maneira como...eu vou me colocando e interagindo com os meus colegas às vezes eu falo assim "olha, vocês não estão me dando bronca"...eu brinco, parece que tudo está dando certo, está bom...e não é isso, mas é que depois eu mesmo repenso e eu falo "não, não é isso"...porque quando a coisa não está bem a gente senta e discute...agora eu acho que já teve momentos muito difíceis no nosso Centro de Apoio...muitos de sair muito angustiada...de formação...que ninguém queria ir pra formação...porque estava pesado, estava difícil...é...aí entram também essas questões pessoais, você vê pessoas com bastante conhecimento, pessoas que tem o mesmo objetivo...mas, alguma essência aí diferenciada, que naquele momento foi muito aflorada e que...nossa, nós não queríamos...todo mundo falava "ai meu Deus, hoje vai ter formação com...", já teve momentos assim também...mas eu sempre me senti ouvida...o que eu quero dizer é isso. Agora, eu tenho um problema, porque eu também falo muito e...eu conquistei esse espaço...é...quando eu cheguei...eu penso assim...as meninas elas me conhecem de um jeito e eu...eu falo pra elas "gente, eu não vou chegar em todo lugar e vou ser assim"...as vezes a gente vai pra uma reunião e eu fico quietinha... "ah, mas você não falou nada"...eu falo: "mas são postos diferentes e as pessoas estão falando e eu estou processando. Agora no meu trabalho eu tenho um outro posicionamento...

$\mathrm{E}:$ Você se sente acolhida e consegue se expor com mais tranqüilidade?

L: Isso. A minha preocupação, até por conta de que o grupo cresceu muito é de as vezes a gente não atropelar os colegas, vir com muitos pensamentos e não dar espaço para o outro...e outra coisa que eu acho que a gente sempre teve aí que não é fácil e não é fácil em lugar nenhum e que eu acho que a gente ainda pode melhorar, é no gerenciamento de conflitos, eu acho, porque que eles existem e vão existir isso eu acho que não tem nem o que discutir...agora como gerenciar isso eu acho que as vezes a gente se perde.

E: Nessas experiências eu vou resgatar algo que você colocou lá, no começo, e que pra mim é fundamental esclarecer melhor, essas relações de conquista de espaço para compartilhar saberes, e como o seu saber se coloca?

L: Então pra eu falar disso, tem a coisa de valorização desses profissionais, no social...não apenas nessa equipe eu acho que o educador, o professor ele está desacreditado, a gente tem pesos diferentes socialmente, é até engraçado, quando a gente chegava nas escolas...é..."ah, você é psicóloga?"..."não, eu sou professora"...aí vem e fala "hum, acho que ela não vai dar conta do recado"...e depois as coisas foram mudando...então, eu sinto hoje quando eu chego e falo "eu sou professora itinerante"...se as pessoas conhecem o trabalho elas não vão mais fazer careta, mas se não conhecem, vão pensar "hum...quem é essa?"...mas durante um tempo, até falam "ai, você é a assistente social, você é a psicóloga?"..."que são esses profissionais que vão comumente resolver essas situações"...

$\mathrm{E}$ : e vocês demonstraram sua competência e provaram o seu saber.

L: A gente vem justamente falando o contrário, que a gente precisa sim desses profissionais, que a gente precisa desses saberes, mas é a lida educacional...no dia-a-dia e nas rotinas das escolas que a gente vai ter que aplicar...isso é do professor. Uma das coisas que eu questiono aqui da Secretaria de Educação, é que, a maioria das vezes, os documentos daqui eles são elaborados pelos técnicos, eles escrevem, eles registram isso...no estatuto do magistério eu entendi assim, que uma das funções desse povo é fazer os documentos e eu sinto que muitas vezes as coisas não fluem por conta disso, porque é uma coisa que não é diferente do PPE que é verdadeiramente feito pela escola...Porque o PPE, feito pela escola, é nosso. "Ah, tem vários erros assim..."mas foi um erro nosso, um erro coletivo...vamos estudar, vamos melhorar...

$\mathrm{E}$ : E esses documentos você acha assim que não legitimam o saber do professor? 
L: Sim, E até por conta disso, que pra mim eu vejo como uma maneira de camuflar...eles não tem autores, alguns tem, outros não, então alguns colocam os autores, qual foi o grupo que mais se reuniu pra fazer aquilo e outros..

E: Cite um exemplo de documento que desconsiderou a visão do professor.

L: Olha, a proposta curricular,não tem. E...na proposta curricular...houve até uma possibilidade de participação...não foi o que a maioria da rede queria... a maioria da rede queria discutir muito mais, mas houve um pouco de participação. Os cadernos de validação...eu estava lendo os cadernos de validação de gestão, que é interessantíssimo, de como funciona o ensino fundamental. Eu não sei falar aí do Infantil, eu não sei como é isso nas escolas do infantil...e sei até que a constituição...a Educação Infantil assim, ela sempre foi vista como uma menina dos olhos, sempre bem olhada. E eu sinto também nas poucas escolas de Educação Infantil, eu sinto um envolvimento grande assim, é uma história assim já bem adiantada...diferente do fundamental que está se fazendo agora. O caderno de validação de gestores, ele não tem os autores e totalmente à parte da escola...do PPE...do acolhimento...dos primeiros dias de aula...da ficha de rendimento do aluno e do que eu entendi que aconteceu, é que eles tentaram registrar aquilo que já acontecia...mas mesmo o que já acontecia não era tão unificado assim,então tem esse documento para unificar e se vem pra unificar, tinha que ser discutido. Então, você ainda encontra professores que não entendem direito a ficha de rendimento...

$\mathrm{E}$ : Você acredita que eles perdem oportunidades de ouvir o professor?

L: E perdeu um momento ótimo de ser discutido...E aí a gente passa por um outro momento, que eu até entendo, mas eu não sei se é essa a melhor maneira, quando você está em uma reunião de conselho e a ficha está toda torta...e um profissional vem e fala "você não leu o gestão?" Eu sei que o professor tem que ler o "gestão" só que infelizmente isso não vai garantir que ele conheça...a leitura ela é essencial, mas se apropriar é outra coisa...e aí eu acho que a gente perde de concretizar o slogam da Secretaria, tem um slogam de tentar construir a coisa democraticamente...só que eu acho que a gente tem que tomar muito cuidado, porque no Brasil...é que á assim...existem inúmeras questões pra definir o que é democracia, mas eu acho que a gente ainda não sabe muito bem o que é isso...porque a gente conhece isso a pouco tempo, ter escolhas e arcar com as respostas dessas escolhas...então, dizer que o que a gente faz aqui é democracia...eu no mínimo me permitiria a ter dúvidas, porque duvidar que isto está sendo realmente democrático...porque é difícil fazer isso...e as vezes a gente não consegue nunca.

E: Como é, na sua prática, a relação com o aluno com deficiência? Quais os impasses que são instaurados com mais freqüência e como você lida com os processos de aprendizagem? Há necessidade de algum recurso ou instrumento específico?

L: Avalio que em minha prática procuro dirigir o meu relacionar - se com os alunos, baseando-me no respeito, na busca por justiça nos procedimentos estabelecidos nas aulas, no afeto que é característico à convivência com crianças, no geral, e com adultos que passaram ou passam pelo momento de perda da visão. Para tal, procuro estudar e discutir com a comunidade escolar os documentos que em minha opinião ajudam a orientar as relações no ambiente escolar (ECA, Proposta Pedagógica e Regimento Escolar). Contudo, os impasses freqüentes referidos à relação remetem à definição de limites, aceitação da deficiência, definição de papéis, outros.

Quanto aos processos de aprendizagem posso dizer que uma das experiências mais lindas que vivenciei em minha profissão foi a primeira participação na alfabetização braille de uma aluna. Vê-la deslizar os pequenos dedinhos sobre as letras e soletrálas da mesma forma que os demais alunos videntes levou-me a uma sensação de CRIADORA, 'inventando' o sistema braille e 'descobrindo' a potencialidade do tato / cérebro. Vale lembrar que esse processo realizou-se no âmbito do ensino regular e que a aluna compartilhava das mesmas atividades que os demais alunos, claro que com as devidas adaptações.

Mas como nem sempre "vejo flores em você"... sinto que a principal angústia deste período esteve vinculada com alguns alunos que apresentavam além da baixa visão dificuldades de aprendizagem e no comportamento. Casos onde alunos freqüentavam pela $2^{\mathrm{a}}$ vez o segundo ano do ciclo I e não avançavam: mesmo pensando em objetivos específicos, atividades diferenciadas, agrupamento produtivo, adaptações de acordo com a condição visual, apoio pedagógico.

Não sei dizer que recursos realmente fariam diferença nesta situação... Talvez a possibilidade de transgredir o Sistema: turma com número de alunos reduzido (mas não com as mesmas dificuldades), atividades além das paredes da sala de aula, assistência constante ao professor (não só cobranças), conteúdos mais significativos...

E: Pensando neste aspecto de democratizar a escola oferecendo melhores condições de ensino, o que essa experiência, em parceria com o professor ofereceu pra você compreender melhor o aluno que você tinha sob a sua responsabilidade?

L: Então, uma das coisas, e aí eu já acho que também já veio da minha parte acadêmica, que eu acho que contribuiu muito em pensar no momento do seu desenvolvimento. Eu acho que isso foi uma das coisas que eu já tinha em mente houve muitas contribuições nesse sentido assim...olhar mais pra isso ainda, que esse desenvolvimento ele não tem regras fixas podemos dizer..que existem parâmetros que você tem que buscá-los do desenvolvimento...mas não é isso que se tem que buscar só...é também pensar...até tem uma frase que fala "é...um desenvolvimento gradual e contínuo", então ele vai ter um jeitinho próprio de estar nisso...existe esse ritmo próprio de desenvolvimento e que ele é gradual e contínuo...cada um de um jeito, mas ele existe...então olhar para a criança nesse sentido...e aí, voltando para o Centro de Apoio que a gente passa as vezes vários anos e o aluno continua ali dentro, as vezes não com os mesmos professores, as vezes não com a mesma proposta, mas que as vezes...eu passei dois anos com o mesmo aluno e eu vou substituir a aula de uma colega e a gente dá esse retorno uma para a outra..."você não sabe como eu me surpreendi positivamente com fulano de tal"..."fulana está tão mais...é....comunicativa...fulano tem a iniciativa de perguntar o que ele não entendeu, coisa que ele não tinha na minha época". T: O que você acha, a que isso se deve?

L: Eu acho que é essa questão...esses momentos de reflexão sobre a proposta...que oferece ao aluno. A gente tem no Centro de Apoio um PPE muito mais elaborado hoje do que a gente tinha no ano passado, mas ainda tem muita coisa a ser pensado, mas é uma construção que as vezes a gente queria que estivesse mais adiantada. Mas eu acho que a gente precisa dessa forma de construir coletivamente. Esses documentos da Secretaria são necessários, eles são imprescindíveis e até eu entenderia se as coisas acontecessem e ganhassem um sentido. "Olha, isso é o primeiro momento, que foi feito desse jeito...que a gente vai...isso não é fixo"...uma postura de que as coisas vão ser desdobradas com a participação coletiva...Eu acho que se o professor tiver mais espaço pra sair daquela queixa, sabe a queixa pela queixa seria pela formação...eu já fiz muito isso e de vez em quando faço... "aiaiaiaiaia"...sempre na queixa pela queixa... Isto é...exercitar a democracia pra mim é sair dessa queixa...essa queixa...existem momentos que eu posso transformar essa queixa em uma ação...que pode desencadear alguma mudança pra que essa queixa não aconteça mais...então nesse momento que eu vou fazer um documento que normatiza algumas ações da escola é um momento que eu posso aproveitar pra minha queixa deixar de existir pra minha queixa ser atendida...

E: Oferecer espaços de participação e de produção, não é?

$\mathrm{L}$ : Sim. E aí ..por mais que eu sei que é difícil, que é um sistema, que tem que se dar os duzentos dias letivos...etc...etc...etc e tal, é onde eu gostaria que tivesse momentos que a gente pudesse exercitar mais isso. E não acho também que sejam todos os professores que queiram isso não...acho que muitos não querem, mas que estão nessa posição, então eles precisam...agir 
nesse sentido. A gente tem que discutir sobre a educação... "ah, porque a educação...", mas porque...se todo mundo discute educação, será que o próprio professor...ele está discutindo educação? Ou ele está só se queixando? Ele precisa ponderar isso...porque senão fica todo mundo dizendo o que ele tem que fazer...

E: Falam por ele e sem a participação dele?

L: Isso...isso...isso é muito...

E: Ainda falando dessa queixa, e focalizando-a no âmbito do aluno, com deficiência, você sentia que essas queixas em relação às suas angústias, as suas dificuldades com relação à deficiência eram atendidas...ou você se sentiu muito falando sozinha...ou foi possível aprofundar mais sobre a deficiência...?

$\mathrm{L}$ : Eu acho que teve momentos diferentes teve momentos onde eu me senti mais atendida...e teve momentos que eu me senti menos atendida......e as vezes até por uma questão de clareza...não sei se na minha colocação da queixa ou na maneira como a outra pessoa me deu a devolutiva...é...as vezes eu sinto assim ...é...que é difícil também para o profissional que faz essa parte ...que é considerado especialista...que é da área específica...é difícil quando a gente vai com uma queixa, e a resposta ela é generalistas na verdade, muitas resposta são generalistas, mas quando você vai num particular...que é você perguntando para o outro ali personalizado...e você recebe uma resposta generalista, que as vezes não é o que você está querendo ouvir...e pode ser que não haja outra possibilidade de isso ser respondido de outra maneira, mas é...não tem como, você fica espantado no seu rosto...Pelo menos não está me dando nenhum caminho esse tipo de resposta, mas as vezes eu acho...esses profissionais eu acho...assim como pra mim em alguns momentos eu também tive que passar por isso são...a humildade também de te falar..."eu não tenho clareza sobre isso...Em alguns momentos...eu já tive momentos de conflito...porque me senti resistente....bom, você não está me respondendo o que eu estou perguntando"...e eu queria ouvir da pessoa "olha, eu não sei"...ela não tem que saber tudo...

$\mathrm{E}$ : Você acha que ...que é difícil pra equipe, para o profissionais da equipe assumirem muitas vezes as suas falhas e as suas dificuldades...

L: Eu acho que é difícil deles serem humildes...eu penso isso também quando eu estou na itinerância...né...então, eu estou num momento assim, que eu acho que se o professor não fizer pergunta xis e y...e se essa pergunta estiver muito relacionada a questões visuais, capacidade visual e eu não souber responder...ai, eu não vou me perdoar...eu vou querer ter resposta pra ele. Se for de outra área, eu vou me perdoar e vou falar "não, mas eu não sei..."...eu até tenho tranqüilidade pra falar isso "nunca ouvi falar...não sei...vamos ter que ir atrás juntos"...vamos ver o que a gente consegue...mas quando é da minha área específica, aí eu me sinto chocada...me sinto chocada...eu mesma cobro de mim...é mais delicado...e eu me sinto até na responsabilidade de ir pesquisar com urgência pra dar uma devolutiva para a escola. E, é outra coisa que eu acho que não só da historia do funcionamento do psiquismo, da história do Vygotsky, que ele começa a falar lá da crise da Psicologia naquela época dele, quando fala de Educação eu sinto muito isso, na formação do professor ele quer a solução dos problemas "gente...eu vejo assim"...ele tem uma relação abrangente, então ele quer uma pessoa que...entenda de desenvolvimento...de anatomia.Não precisa saber detalhes, mas aspectos de desenvolvimento, saber da "nossa a criança". É assim, que ela cresce...quando ela cresce acontece isso...tem os momentos de uma fase, que são mais delicados...eu acho que ele pede isso... além de todo o saber de didática, essa coisa toda, esses saberes, que eu acho fundamental...

$\mathrm{E}$ : E essa questão...em relação aos temas...você falou lá na frente que alguns temas até se chocavam, eles eram pertinentes às necessidades educativas?

L: Eu penso que eles eram pertinentes... mas como que a gente vai encaminhar esse conhecimento na nossa prática...é isso que eu digo que as coisas se chocavam...

E: Ou seja como eram contextualizados, como se trazia a teoria para o dia-a-dia do professor?

L: Sim, como é que eu vou trazer isso pra minha prática...que eu acho que ainda é uma coisa...na verdade eu tinha que ter falado disso até um pouco antes, dessa coisa do professor conhecer um pouco de desenvolvimento...do orgânico, mas ...a gente aqui, a gente fala muito nessa coisa da Educação Especial clínica...e aí essa coisa de diagnóstico...o diagnóstico no sentido classificatório ele tem seus motivos, agora o que enquanto conhecimento, enquanto que acesso à Saúde é que não pode se misturar. E aqui a gente tem uma briga assim em São Bernardo... se o professor tiver acesso à questões de saúde da criança ele já está rotulando....

E: Como se ele estivesse medicalizando a Educação?

L: Isso...imagina que um professor precisa saber disso...eu...eu não considero... que se eu puder saber sim...sobre o olho, sobre o ouvido...eu acho que é importante...

$\mathrm{E}$ : Você acha que você vai ter melhores condições de compreender essa criança e suas necessidades?

L: Sim, é diferente de você ter conhecimentos que pra mim são básicos...se você lida com essa pessoa que está crescendo, como é que você não vai saber pelo menos um pouquinho de anatomia e fisiologia...

E: Esses equívocos que, muitos educadores tem parece uma preocupação de que essa criança não seja rotulada, e o professor tenha visão...pouco exploratória dessa criança...e pouco..desafiadora...

L: Isso.

E: Você sentia na sua equipe este tipo de preocupação?

L: Em certos momentos sim, a gente teve...inclusive pessoas que passaram por lá...excelentes profissionais, mas que não acreditavam na proposta do Centro de Apoio...hoje não estão mais lá...e que eu acho também que deve ter sido muito difícil porque durante o período que esteve ali, desempenhou muito bem a sua função, mas não acreditava...não acreditava num serviço de apoio especializado...e acha que a Educação Regular dava conta. Então existiam conflitos muito difíceis...muito difíceis...

E: O grupo não conseguiu mostrar?

L: Sim...e eu acho que foram os momentos mais difíceis que nós tivemos por quê? Porque aí cai tudo como se a gente então estivesse fazendo tudo errado, então vamos parar. Embora, o grupo jamais pensou dessa maneira...sempre acreditou no serviço de apoio...sempre...e sempre ficou horrorizado com algumas questões...com algumas experiências de inclusão que se diz que são da inclusão total e que não tem nenhum tipo de apoio...é...então, pra gente isso não dava para entender, não consigo acreditar nisso....acho que só mesmo vivendo pra poder começar a pensar diferente...

E: São experiências sofridas, que só com abertura para aprender. E as escolas também se apercebem destes aspectos? L: A nossa escola...ela já tem problemas de sobra assim...de sistema, de social...é muita demanda...tive um professor que ele fala que...é....a escola há muito tempo ela não está só com o educacional...a LDB é toda uma assistência em cima da escola...e a gente fala...a gente está em São Paulo, por exemplo, mas existem lugares do Brasil que a escola é a única coisinha que tem de pública é um casebre... que é a escola...e é por ali que as pessoas vão receber correspondência, é por ali que as pessoas vão ter o mínimo de acesso...o que acontece no mundo...então ela assume vários papéis...e não é fácil...a gente só se preparou pra ser professor e na maioria das vezes com dificuldades.....e aí como é que fica, o mundo...o professor vai ter que ficar sozinho com uma complexidade tão grande? Que é outra questão que pra mim também me dói...é essa formação em Educação Especial generalista...e eu não acho que também a gente passe por isto, que a gente possa ter um profissional 
generalista que vai chegar lá na escola e vai saber lidar efetivamente com todas essas questões porque é uma questão das deficiências sensoriais...tem que saber libras e o braile...como se falasse só isso. Esses dias a gente estava em um grupo de dez professores, estudando um livro pra tentar organizar alguns materiais de matemática, logaritmo, matriz...bota isso em braile pra você ver que não é tão simples assim. O braile não serve na alfabetização...e o aluno precisa desse recurso, porque o caminho dele é ali...ele é cego...

E:Como é, na sua prática, a relação com o aluno com deficiência? Quais os impasses que são instaurados com mais freqüência e como você lida com os processos de aprendizagem? Há necessidade de algum recurso ou instrumento específico?

L: Avalio que em minha prática procuro dirigir o meu relacionar - se com os alunos, baseando-me no respeito, na busca por justiça nos procedimentos estabelecidos nas aulas, no afeto que é característico à convivência com crianças, no geral, e com adultos que passaram ou passam pelo momento de perda da visão. Para tal, procuro estudar e discutir com a comunidade escolar os documentos que em minha opinião ajudam a orientar as relações no ambiente escolar (ECA, Proposta Pedagógica e Regimento Escolar). Contudo, os impasses freqüentes referidos à relação remetem à definição de limites, aceitação da deficiência, definição de papéis, outros.

Quanto aos processos de aprendizagem posso dizer que uma das experiências mais lindas que vivenciei em minha profissão foi a primeira participação na alfabetização braille de uma aluna. Vê-la deslizar os pequenos dedinhos sobre as letras e soletrálas da mesma forma que os demais alunos videntes levou-me a uma sensação de CRIADORA, 'inventando' o sistema braille e 'descobrindo' a potencialidade do tato / cérebro. Vale lembrar que esse processo realizou-se no âmbito do ensino regular e que a aluna compartilhava das mesmas atividades que os demais alunos, claro que com as devidas adaptações.

Mas como nem sempre "vejo flores em você"... sinto que a principal angústia deste período esteve vinculada com alguns alunos que apresentavam além da baixa visão dificuldades de aprendizagem e no comportamento. Casos onde alunos freqüentavam pela $2^{a}$ vez o segundo ano do ciclo I e não avançavam: mesmo pensando em objetivos específicos, atividades diferenciadas, agrupamento produtivo, adaptações de acordo com a condição visual, apoio pedagógico.

Não sei dizer que recursos realmente fariam diferença nesta situação... Talvez a possibilidade de transgredir o Sistema: turma com número de alunos reduzido (mas não com as mesmas dificuldades), atividades além das paredes da sala de aula, assistência constante ao professor (não só cobranças), conteúdos mais significativos...

E: Pensando nesta possibilidade que o professor da Educação Especial teve de ter uma formação no contexto da escola, como eram organizados, esses encontros, periodicidade, regularidade das atividades formativas com o seu grupo, com a sua equipe...nessa relação de parceria intra-equipe.

L: Então...os espaços que nós tínhamos, eles permanecem até hoje...nós temos um horário de HTPC coletivo...que ele é lei em São Paulo, eu não sei se em outros Estados...aqui é lei...nós temos três horas por semana e o Centro de Apoio conquistou...eu penso que ele conquistou, porque teve que ser justificado...muito bem utilizado um outro espaço que é o que a gente chama de atendimento direto...onde a gente senta pra estudar, pra discutir casos...e, isso é, indireto, mas vai refletir muito diretamente, na atuação com os alunos...isso também está no cronograma, no horário e eles acontecem quinzenalmente. É...de calendário a gente ainda tem outros momentos que as vezes são realizadas as reunião pedagógicas, conselho de ciclos...que eu acho que também é um momento que acontecem coisas...o Centro de Apoio não tem conselho de ciclos, e então a gente participa dos conselhos de ciclos do ensino regular e aí no conselho de ciclo do regular a gente fala com os professores da escola, o seu gestor, e muitas vezes um representante da equipe técnica do fundamental. Eu acho também que é um outro momento de grande proveito...pra mim...eu já aprendi muita coisa nesses encontros...nesses conselhos e há lá no fundamental...muito mais essa questão da hierarquia, que o que a equipe técnica fala, dificilmente é contestado. E aí, tem dois momentos, eu acho que um não é contestado porque realmente não tem como o que ela está falando é muito importante...e tem momentos que não é contestado porque o professor não tem coragem...

E: Você acha que a relação não se abre para o professor?

L: Não, e o professor não se sente parte e, mesmo não concordando, ela não tem consciência daquele conhecimento que ela tem pra debater com aquele profissional...é...então ela acha que o debate dela não...conquista espaço.E tem essa coisa de achar que a psicóloga sabe mais...que o assistente social sabe mais e quem sabe menos é o professor...essa coisa de autoestima que envolve...

$\mathrm{E}: \mathrm{Na}$ parceria com a sua equipe, como isto era percebido?

L: Olha, eu acho, eu penso assim...no Centro de Apoio eu acho que a gente sempre conseguiu espaço e o grupo era bastante unido,a fala do professor...tinha eco...esses profissionais também estavam dispostos a construir isso. E que eu acho que até hoje a gente está construindo, tem momentos de embates e tem momentos que os próprios profissionais da equipe técnica falam os procedimentos...e não abre pra discussão...e não somos nós que não colocamos pra discussão...isso é definido pela Secretaria da Educação e Cultura e não abre pra discussão...Eu escolhi ser professora porque foi minha escolha eu sei o que eu faria fora da escola...mas é uma coisa que eu quis...e eu sei que tem muita gente que está na Educação, mas ele não...não foi uma escolha assim...é uma dor isso...uma pessoa que está ali, que lida com isso todo dia, muitas vezes acaba se acostumando...não gosta...não é a maioria, mas é um problema que quando ele aparece ele é berrante...aquela pessoa que está ali e não deveria estar. E a gente no sistema público, até o presente momento eu não vejo nessa pessoa...tanto que eu penso que devesse ir ao conselho de ética...porque eu penso que tem que resolver esse problema...não dá pra essa pessoa passar pela vida de muitas pessoas...destruir um monte de cabecinhas e continuar...então...eu penso...que...que...ai...essa ida pra essa profissão ser mais consciente, eu penso assim, e não porque foi a única coisa que deu pra fazer.

T: E essa decorrência, você acha que por isso é que muitas vezes as relações que parecem tão fechadas...

L: Isso é uma parte, eu acho que isso ainda influencia. Eu já vi coisas escritas há mais tempo...eu também já pensei sobre a questão de gênero...porque a maioria das professoras...até agora até oitava série, são mulheres...na medida que as mulheres tomaram mais esse campo de trabalho parece que...eu não sei se é coincidência só, mas a qualidade da Educação...os salários diminuíram...quer dizer...a coisa...caiu...eu fico pensando o quanto isso está vinculado à função da mulher enquanto sujeito social...e quando ela consegue exercitar isso...que é outra coisa que me dói...eu acho que todo mundo deve ter vida particular...todo mundo tem problemas particulares, mas, ainda é muito comum nas reuniões, nós mulheres, colocando os seus problemas particulares pra desculpar falhas no profissional...eu acho que também...a gente pensa no crescimentos e pensa até por conta disso....é..e tem uma formação...eu acho...eu não consigo...pra ser professor você tem que estudar...pra qualquer profissão você tem que estudar não sei quantos anos e pra ser professor você pode estudar à distância...dois anos...e você vai lidar com a vida das pessoas...isso é lei...não é questionado. Para ser médico, pra começar a pensar na vida dele de Medicina...ele vai fazer lá seis anos pra começar, mais residência, depois ele vai ver o que ele vai fazer. A gente não, em dois anos você já...tem lugares que aceitam. O que você pode esperar disso?

T: Desse sujeito...desse processo? Como será nessas condições ser mediador de aprendizagem...

L: E ao mesmo tempo, sendo que a aprendizagem leva tempo...voltando de novo pra essa questão do tempo. São muitos saberes que eu acho que são básicos que a gente precisa...isso não quer dizer que uma pessoa que não tenha passado por 
tudo isso não tenha a...porque existem pessoas habilidosas, só que eu não posso contar com essa questão do destino..."ai não, ele é um excelente professor e não teve formação"...mas isso não é regra.

E: Você acha que nesse aspecto das falhas da formação inicial, um modelo de formação continuada...pautada na tematização do cotidiano da sala de aula com uma equipe inter, poderia estar sendo favorável, nesse sentido? Da sua experiência o que você sentiu?

L: Então, eu acho que eu vivi dois momentos assim. Um que fala da Educação como um todo e outro que fala da questão do especial mesmo da minha área. A gente teve uma momento de formação que foi o PROFA...eu acho que ele era um curso super organizado, voltado bem pra prática mesmo na especialização e que a nossa equipe também fez e que a gente pode nesse momento tematizar trazer para discutir no Centro de Apoio, olha só como é complexo aprender de verdade (risos)...a gente foi pro curso...teve o curso...participava do curso...fazia as leituras, fazia as lições de casa e tinham momentos na escola pra estar retomando isso...pra você aplicar de verdade e...e...e isso foi...eu lembro até da nossa orientadora falando claramente "olha, está mudando o jeito de vocês falarem sobre alfabetização"...porque a gente não alfabetiza em si, mas a gente está ali junto, junto o tempo todo...então não dá...pra professora fazer uma coisa lá no sorobã e a gente...não, é a letra A...a primeira letrinha do nome...é essa...então tem que mostrar que isso é a letra tal...

$\mathrm{E}: \mathrm{E}$ isso transformou o conhecimento dessa área?

L: Sim...e um outro momento que eu sinto também...que apesar...dava uma canseira danada...a gente no outro dia chegava moída quando a gente ia pro Mackenzie...que a gente tinha assessoria.... e que infelizmente... é assim nesse caso...tem que fazer, tem que fazer, mas tem trabalho...aprender dá trabalho...e pra gente também tem trabalho....porque as vezes a gente tinha que ir pra lá e tinha que levar lição de casa que a gente sempre tem..trazia...dava trabalho...ai dava, mas é onde a gente...eu lembro até hoje quando a Elcie trouxe pra gente...não sei como que falava direito...mas era o sistema...áptico...Que é a gente...queria tanto falar disso e não sabia como falar disso, e prestar atenção nisso, pra poder falar disso, aflorar isso que o deficiente visual precisa tanto...e isso ela trouxe pra gente...ela disse "olha gente, acho que vocês estão querendo falar disso daqui desse tato que explora, desse tato que percebe...esse encontro do cinestésico..."...e a gente percebe, que está vindo muitas melhoras...foram muitas assim...é tudo uma questão de pensar também dessa época das assessorias...é que a gente não conseguia falar do conceito pra deficiente visual, sem imaginar que ele consegue não conciliar com a imagem...o tempo todo a gente ia pra imagem...e ela "mas como imagem menina? Como é que vocês avaliam o conceito? Se formou ou não formou conceito?"...então era uma coisa que...e também...uma coisa lá...

E: Uma reflexão sobre o ensino...

L: Porque é ir pra tentar ver um pouco desse outro caminho desses outros...canais de recepção, e que pra gente...quando eu falo do conceito xis...vem uma imagem mental, mas eu não sei qual é...eu não lembro agora o nome, mas ele não é uma imagem nesse conceito que eu tenho...ele deixa de ser real e concreto...Então ela fazia muito essa reflexão e isso eu acho que foi um momento interessante e que não dá pra ser generalista, entende...tem que ser alguém que tenha um conhecimento mais aprofundado.E aí tinha essa ponte, onde tinha a professora Elcie...tinha uma época que ia todo mundo pra lá...depois uma época que iam as meninas que foi ótimo...e a gente continuava...

E: A equipe técnica?

L: Isso...fazendo algumas intervenções. Eu achei bom esses dois momentos...a gente estava num momento que a gente estava muito cansado de ir pra lá...era cansativo...então elas traziam essas reflexões...porque o tempo não pára...não tem como...e as vezes eu me pergunto assim...até para as pessoas que trabalham com o Centro de Apoio..as vezes eu penso assim "ame-o ou deixe-o"...ai porque a gente acaba engolindo cada uma.

E: Você acha que trabalhar com Educação Especial você precisa compreender a leitura que a Educação Especial faz, pois ela ainda tem um papel a cumprir?

L: Eu não sei nem se ainda, ou se é fundamental porque o conhecimento é muito complexo e continuamos tendo uma contribuição a dar.

E: Você diria que a ação desenvolvida em parceria com a equipe possibilitava trocas de saberes, produzindo um conhecimento interdisciplinar? Esse conhecimento contribuiu de alguma forma para sua atuação como professora?

$\mathrm{L}$ :Sim. O período que vivenciei neste formato de interação/formação, com certeza, tornou-me uma profissional mais consciente e crítica, tanto em minhas ações, quanto nas reações advindas das mesmas. Isso vem ao relatar algumas ações concretas: Planejamento das aulas - levava em conta a condição visual do aluno e suas necessidades escolares; hoje considero, além dos fatos já pontuados, os interesses do mesmo, as expectativas dos familiares e a possibilidade de voltar-se aos 'temas transversais' (PCNs) e à arte intensamente. 'Respeito' maior à família do aluno - era comum, nas discussões de caso, de forma imprudente, acabar 'culpabilizando' os familiares (principalmente as Mães), por insucessos tanto no tratamento, quanto nas aprendizagens do aluno; hoje consigo compartilhar mais o conhecimento com os familiares e 'culpabilizá-los' menos, pois não pode haver parceria sem confiança e uma ação pedagógica de qualidade, em minha concepção, não se desenvolve sem a união 'Escola - Família / Cuidadores'; 'Avaliar' o aluno de forma processual - acreditava muito no momento da avaliação inicial (eficiência visual / exploração tátil) e não percebia o contexto artificial daquele momento, aferindo-lhe praticamente um veredicto; hoje acredito neste momento como parte inicial de um longo processo, e, principalmente que na situação real e social proposta (aulas) e na interação que desta emerge as potencialidades do aluno são avaliadas por um espectro mais amplo e real.

E: Você sentia-se preparado (a) para a prática? Houve algum referencial teórico que ajudou nesse sentido? Qual e como? Como a teoria pode ajudar no manejo do cotidiano escolar?

L: Gosto de afirmar que tive o privilégio de concluir uma graduação que me deixou a crença de estar pronta sim para a prática, pois, dentre os momentos acadêmicos, meu estágio foi de grande relevância, visto que sua supervisão deu-se de forma diferenciada: apresentação do pré-planejamento de cada aula ao orientador; dos materiais didáticos selecionados para aquele planejamento; aulas abertas aos professores orientadores semestralmente - o estágio foi de um ano: um semestre em escola do ensino fundamental especial e um semestre na educação infantil especial. Alguns referenciais teóricos deste período foram: L. I. Solntseva, S. M. Horosh (Teoria da Compensação na Educação Infantil - área da Deficiência Visual e Trabalho Pedagógico com os Familiares de Crianças Cegas); A. G. Litvak (Tiflopsicologia); V.A. Feoktistova (Desenvolvimento da eficiência visual, Referências para organização das ulas de Atividades da Vida Diária, Conteúdo do trabalho desenvolvido pelo tiflopedagogo na educação infantil (para crianças com deficiência visual), K. D. Ushinsky (Educação da Pessoa), L.S. Vygotsky (Psicologia Histórico-Cultural).

A teoria me ajuda fornecendo dados importantes sobre o desenvolvimento (anatomo-fisiológico e psicológico) da criança e do adolescente. [Agora, por exemplo, preciso estudar mais a fase adulta e o envelhecimento.] Trazendo reflexões sobre as possibilidades da escola, quanto à metodologia, didática, currículo, gestão. Ajudando-me a compreender um pouco mais a legislação vigente (educação, saúde, assistência social). Fazendo-me sonhar com Frenet, Rudolf Steiner, Davidov, Leontiev, Paulo Freire (não tenho certeza da escrita de alguns sobrenomes). 
E: Pensando nessas questões que você está colocando agora dessas influências, essas contribuições, essas dificuldades e efeitos positivos que teve, nesse compartilhar com equipes, com saberes e nas assessorias também, como que esse processo pode ser... apropriado pelo professor...que eu acho que isso é um foco da questão da autonomia e aí eu queria que você falasse um pouco sobre isso...quando eu me aproprio eu dou continuidade nas situações, mesmo que eu não tenha a equipe ao meu lado...e principalmente pensando em me colocar como parceiro nas experiências,em compartilhar com aquele outro que vem sem essa trajetória...ah...entendeu...sem ter passado por essa trajetória.

L: Entendi..quando eu penso nisso...e isso aconteceu nesse período lá com a gente...de ter a equipe mais presente...é...eu tenho uma preocupação...é...eu não sei qual é o conceito real de multiplicador, mas não é isso que eu quero...eu não quero ser multiplicadora de nada, eu quero conhecer uma coisa...uma fórmula de matemática e encontrar os meus meios, as minhas estratégias de trabalhar com isso...e...em alguns momentos...ahn...é...em alguns momentos...as vezes a comunicação ficava meio parecida com a minha...de agente multiplicador...e com aquela fala específica...porque eu parto pela interpretação do outro...você tem profissionais...você tem pessoas dedicadas naquela área...tem a interpretação...as vezes você vai num mesmo encontro com a sua colega e ela entendeu a fala da pessoa de um jeito e eu entendi de outro. Então, quando a coisa fica assim, e teve momentos que eu acho que isso aconteceu na nossa formação,aí eu não consigo ser autônoma...eu penso...nos momentos em que algum conceito de matemática foi trabalhado desse jeito...e não...não me deu autonomia pra depois agir...agora nos momentos em que essa formação ela foi compartilhada...e o formador continuado...não no sentido de que ele tem mais formação do que você...mas num sentido de outros saberes...aí eu sinto que não trouxe elementos pra poder ser feito com mais autonomia...Eu acho que tem realmente uma parte da nossa...do nosso trabalho onde essas duas palavrinhas formação continuada ela é essencial...porque só sabendo daquela realidade que eu estou vivendo aqui dentro desse município...sabendo da realidade com essas escolas e com os pais dos alunos, eu vou saber eu vou saber o que vai emergir daí...eu posso até..pensar..."poxa é uma cidade pequena...com sete mil habitantes..." eu posso ter esse conhecimento pra tentar prever o que pode surgir, mas na verdade eu só vou saber ali...e qual parceiro...com uma equipe pensando junto comigo naqueles encaminhamentos mais difíceis de você decidir. Embora, eu penso que tem momentos da gente caminhar junto...tem momentos que você caminha sozinho e tem momentos de supervisão que é uma coisa mais distante ainda...e que precisa também. Eu não sei, mas...depende assim de pessoa pra pessoa...o meu grupo...eu acho que...a gente...a gente nunca quer...total autonomia pra poder refletir com o outro existiu momentos que eu tomei uma postura inadequada pra escola tive um pensamento,não refleti muito e tive uma postura xis...e que depois eu trouxe para o grupo...e que eu acho que aqui eu poderia ter "Ns" desdobramentos "olha gente, essa situação...ela vai dar pra gente uma aprendizagem...a questão é...eu esqueci de olhar o caderno...se o caderno do aluno era adaptado...eu fiquei seis meses com aquele caderno e me esqueci....aconteceu de eu não olhar o caderno e a criança precisava escrever as coisas no caderno e eu não tinha o caderno e olhei quem estava na frente...eu conversei com a professora ...eu falei o que eu achava... e acabou. Se o grupo fosse diferente, eu não sei se eu teria coragem de falar isso...

$\mathrm{E}$ : Os equívocos eram aproveitados como experiência...

L: Nossa...vamos colocar aqui no nosso roteiro de itinerância...primeiro vamos sentar, combinar... na segunda...um dos focos de observação são todos os materiais, serviu pra mim não esquecer mais, mas serviu pra todo mundo...isso que eu conquistei. E: Foi uma aprendizagem difícil?

L: Sim,por isso que eu quero fazer tudo certo, porque eu fiquei vermelha tive constrangimento, mas não foi aquela coisa dolorida, entende das pessoas ficarem te fuzilando,que você esqueceu,ainda mais quando você é uma pessoa que sempre se coloca, sempre retoma...e aí você erra...daí seu erro é uma coisa e daí eu falo "ta vendo, eu errei...ninguém sabe tudo e eu esqueci de olhar"...eu acho que eu tive essas pessoas. Num outro lado, que eu também sempre lembro que eu acho que as vezes a gente é cruel...assim...enquanto corporativismo...existe isso também,o professor defendendo o professor a qualquer custo...porque...como a gente está numa rede de ensino, as redes, eu acho, que as redes que estão só com professores brigam pra ter um olhar de outros profissionais, nós que estamos com outros profissionais brigamos porque acha-se que a voz do professor tem que ser ouvida...então é um nó e...brigam assim, lógico que em determinados aspectos eu lembro de um momento também que a gente estava numa situação muito conflitante pra tentar dar um encaminhamento...eu lembro que uma das meninas, a assistente social da nossa equipe...ela trouxe assim...nós não conseguíamos pensar em nada...e ela trouxe assim...ela trouxa várias propostas...e nós rejeitamos todas...tem momentos as vezes de desconstrução...e depois ela disse "gente, vocês não precisam ficar rejeitando tudo"...porque realmente aquilo é ruim...ou não está ajudando a gente...

$\mathrm{E}$ : você citou que cada equipe estabelece relações muito peculiares com os seus professores o que você faria de contribuição com essa leitura?

L: Olha eu vou falar...eu vou ser prática...que a minha memória não é tão boa, mas eu acho que esse tempo todo que eu fui reapresentada eu acho...reapresentada a outros teóricos, também pelo olhar dessas pessoas...mas eu fui reapresentada a Paulo Freire que hoje eu sei muito...quando eu penso em proposta pedagógica eu preciso...né...relembrando, o que as meninas falaram...Madalena Freire...e tantos outros.

E: E essas posições teóricas, como eram trazidas era possível trazer isso pra sua prática...quer dizer, o seu grupo e a própria equipe, elas conseguiam acompanhar você até a sala de aula, com essas teorias...isso é um modo de dizer...conseguiam levar a teoria até a sala de aula? Como você vê isso...a questão da sua prática era..algo de domínio também delas ou vocês se encontravam no meio do caminho?

L: Então, não dá pra, de novo, fazer uma análise como tipo se fosse uma coisa constante e regular. Eu acho que existiam momento em que certos autores, até porque trazem assim um pouco mais de teoria também pra prática, então eu acho que fica também mais fácil, de trazer pra nossa prática e de fazer esse acompanhamento por parte delas, em outros momentos não. Eu lembro de uma vez que a gente leu um texto do Adorno, que foi uma reflexão enorme, acredito que complexo...e algumas pessoas saíram desse encontro achando que "não sei, o que isso está querendo dizer?"...no sentido de contemplar isso na minha prática...e pra mim...eu achei muito interessante estar tendo contato...acho que é "O fim da Educação"...um negócio assim...eu acho que é isso...no sentido de estar de novo pensando na prática pequenininha...e na prática como um todo, porque pra pensar no fundo, em educação é pensar no PPE...o que eu estou querendo...qual que é o tipo de ensino, então...eu acho que....as vezes, assim pra mim, mesmo nas formações que eu não achei que foram tão diretas...ela trouxe pontos pra ampliar um pouco essa visão mais ampla de educação...não só do miudinho...agora, existem questões do mínimo que também precisam ser respondidas.

T: Entendi.

L: E as vezes, o grau de domínio do que se traz tem que ser pensado. Então se...o nosso grupo eu acho que ele exige bastante. Já aconteceu da gente estar trabalhando com um texto de um autor que trabalha um conceito...e ter assim um embate grande de "eu não sei porque você está falando desse jeito"...e a pessoa que estava coordenando isso nesse momento trouxe isso que trouxe esse assunto também não dominava...e aí eu acho que...talvez a maneira de se conduzir devesse ser diferente. Porque não dá pra gente ficar com um ponto de interrogação pro resto...Eu domino, você não domina e ninguém vai atrás... 
E: A coordenação deveria pelo menos ter alguém com um saber a mais pra poder encaminhar discussões ou propor soluções de continuidade pra o estudo ser mais fundamentado.

L: Que é um papel também do educador se você pensar em mediador...porque as vezes as meninas fazem o papel de mediador, e nós dos alunos...eu acho assim que eu não vou responder a todas as perguntas, mas alguns instrumentos eu tenho que ter pra gente buscar essa resposta...porque senão fica sem ação...então isso eu acho que era...

E: Muito bom..

L: Mas quando fala de estudar, eu sempre achei que mesmo que as coisas não tenham o encaminhamento que eu acho que deveriam ter...eu acho que elas sempre contribuíram pra gente ter...

$\mathrm{E}:$ Ampliar conhecimentos?

L: Isso...e mesmo...porque eu sou assim...eu gosto muito dessa coisa da deficiência visual...eu acho interessante esse tato...o olho...eu acho o máximo essa baixa visão no sentido de que é uma capacidade que a pessoa tem de sem visão conhecer o mundo, explorar...eu...eu gosto muito dessa parte mesmo dos recursos...de fazer as coisas e ver a diferença que isso faz na vida da criança e de descobrir junto com ela muitas coisas como a placa de rua..."vem, vamos chegar mais perto"...coisa que ele faz instintivamente com o caderno e ele não consegue imaginar que ele pode fazer isso com outras coisas...então isso me seduz muito e eu gosto, mas, a vinda pra São Bernardo...ela me trouxe essa coisa da Educação no Geral que eu não tinha...eu estava muito fechada com o específico...talvez se eu pensasse educação especial cometendo alguns equívocos...foi não pensar nisso.

E: Mas na Educação Especial aqui de São Bernardo você sente que o horizonte abriu mais?

L: Então...eu não posso falar das escolas especiais porque aí é um outro tipo de,mas a nossa...sim...sim...tem a proposta curricular número um e agora já saiu a número dois...com a do Especial...com a do Fundamental...e isso....isso transforma o seu olhar enquanto professora porque até nas conversas com os alunos eu vejo isso como era antes e como é agora...e fica mais...mais contextualizada pra... eles porque a gente tem que estar...transitar nesses espaços também nessas etapas..

E: São contextos diferentes, transpor mundos nós estamos falando de inclusão..queria nesse momento concluir a atividade...muito obrigada..pela sua contribuição que foi muito valiosa.

L: Obrigada eu...

\section{Bianca}

A entrevista foi realizada na residência de Bianca, pois a educadora recuperava-se, na ocasião, de um problema de saúde. Mesmo estando em licença médica, por sugestão da entrevistada preferiu que fosse realizada, naquele momento, admitindo que estaria mais à vontade.

Duração da Entrevista: 1 hora e 50 min

E: Como você avalia o período de formação entre 1996 a 2003. O que você destacaria, nesta trajetória como tendo sido determinante na formação continuada em serviço, na sua unidade escolar, desenvolvido em parceria com a equipe interdisciplinar.

B: Com a equipe?

E: Sim, em parceria com a equipe técnica da escola.

B: Eu destacaria o projeto sobre raciocínio lógico matemático e psicomotricidade... um dos trabalhos importantes na minha atuação,para minha formação,para o desenvolvimento do meu trabalho. Na época eu tinha uma turma muito difícil, na área de matemática e esse trabalho, essa parceria me fez rever alguns conceitos sobre como acontece, como se desenvolve a aprendizagem. Esse trabalho foi desenvolvido junto com alguns membros da equipe, em cima de uma análise individual dos alunos e, a partir da discussão desse estudo foi feita uma proposta com base na psicomotricidade e raciocínio lógicomatemático.Na época verificamos que necessitavam estabelecer conceitos muito anteriores ao da série que eles cursavam....tinhamos duas turmas...que foram redivididas de acordo com as necessidades detectadas. Esse trabalho deu bons resultados, ao final do ano letivo, eles já estavam conseguindo acompanhar a série. Alguns alunos durante o processo foram pra outro agrupamento. Eu sei que esse tipo de trabalho junto a uma equipe funciona, dá resultado.

E: E você contava com o trabalho da equipe, das áreas, complementando o seu trabalho, no dia-a-dia?

B:.a orientadora pedagógica também ajudava, em um trabalho inter áreas.

E: Como ocorria esta parceria? Como se davam essas análises, essas discussões com a orientação, com a Psicologia, com a equipe como era construída essa sistemática de trabalho?

B:.o levantamento dos alunos com dificuldades ou necessidades foram feitos pelas professoras, nós estávamos desesperadas, não sabíamos mais o que fazer, eu e a outra professora de matemática conversamos com a psicóloga e com a orientadora e....aí nós achamos interessante estar fazendo uma análise destes alunos para verificar...quais eram as defasagens reais. Todos os alunos foram avaliados, depois elaboramos a proposta de trabalho, acho que as devolutivas eram feitas com a maior boa vontade e com competência. Eu acho que para fazer um estudo das defasagens individuais, é uma coisa que exige conhecimento .

E: E após o estudo?

B: Então, após o estudo, já tínhamos uma proposta, um trabalho a ser desenvolvido em cima dessas defasagens, a psicóloga , a orientadora na época nos davam os retornos A proposta ...não era só teórica, tinham estratégias, atividades, material, tínhamos até uma sala para desenvolvermos este trabalho específico e uma quantidade de material enorme, todo classificado, mas eu tinha autonomia para introduzir as atividades que eu achava que eram...mais adequadas ou compatíveis com a faixa etária,porque eles já tinham uma certa idade.

E: Nesse processo de complementação das necessidades educativas, nesse processo de busca de construção de uma proposta que viesse a contemplar essas necessidades, como o professor se colocava nesse trabalho?

B: Nós sentimos que o trabalho funcionava em parceria. Essa turma já estava na escola há algum tempo, já vinha com defasagens, já tinha se tentado mil e uma coisas,...e nós víamos que não apresentavam o resultado esperado, então quando você, professor, detecta ...uma dificuldade...uma defasagem dessa...e já se tentou de tudo, já se virou do avesso...e não conseguiu retorno, quando você ...vai ao encontro da equipe ...e esse técnico te dá todo apoio e faz tudo que está ao seu alcance, para que você consiga trabalhar de uma maneira adequada, você compra a idéia, você se sente parte desse trabalho, autor nessa relação, pois a teoria sem a prática não é nada...eu tenho de estar com a teoria e a prática, de acordo com os técnicos que estão me dando apoio.

$\mathrm{E}:$ Como isso era discutido? 
B: Isso, eu tinha uma gama grande de questões pra trabalhar, eu dosava da maneira que eu achasse necessária para aquela turma ou, para aquele aluno, porque, às vezes eu trabalhava ...individualmente...em duplas...com parceria entre eles. Então, eu acho que para o trabalho acontecer, você tem que comprar a idéia, porque quem vai trabalhar é você. Então não adianta fazer de conta, para que isso aconteça é necessário que tudo seja discutido.

E: Com essa experiência, como você analisa estes conhecimentos adquiridos, sobre esses alunos, como esta proposta ajudoua em outros processos, outras etapas com diferentes crianças?

$\mathrm{B}$ : Eu acho que essa experiência se tornou uma prática, um conhecimento que eu utilizo com outros alunos, com outras turmas, porque cada aluno é um, cada turma é única, as defasagens são diferentes de uma turma para a outra, de um indivíduo para o outro e, o que conseguimos incorporar, te ajuda no trabalho. Eu acho, que falta este tipo de trabalho, um trabalho mais compartilhado porque trabalhamos com indivíduos, que podem possuir outras necessidades, eu acho que essa troca essa parceria é essencial. Quando você está em sala de aula e está sozinha, não dá, porque o conhecimento que necessitamos que nos nutri só se desenvolve com as trocas, as parcerias,o diálogo,as discussões,as análises, os estudos teóricos.

E: Essa parceria, esse diálogo que você falou como ocorria?

B: Nessa época foi prazeroso estar trabalhando com aqueles projetos, com aquela proposta porque não existia essa coisa de técnico dizer: eu estou te dando a solução dessa situação...

E: Neste trabalho você disse que já haviam tentado outras propostas pois haviam outras implicações, além da surdez?

$\mathrm{B}$ : Um aluno só surdo tem um bom desenvolvimento respeitando-se logicamente a sua língua

E: Você observava outros aspectos?

B: Sim, que nós temos crianças, adolescentes surdos que tem outros comprometimentos, emocionais, sociais, neurológicos

T: Mesmo que para cada criança, como você diz, as demandas são diferenciadas, porque cada um é um, esse trabalho lhe abriu caminhos?

B: Sim, excelentes, porque na realidade, te tira aquela visão de por exemplo uma matemática que se transforma em técnica pela técnica, então você tem um olhar diferente, procura descobrir como esse aluno pensa, como ele se desenvolve. Tem outros parâmetros isso é que te trás pontes para outras crianças.

$\mathrm{E}$ : Você acha que os conteúdos, as concepções que você vivenciou na prática, te deram maiores esclarecimentos...aquilo que você pôde discutir, analisar, ahn...teoricamente também te deu maior esclarecimento pra você entender melhor aquela situação?

B: Com certeza, faço sempre observações escritas sobre as atitudes e comportamentos dos alunos analisando e discutindo com eles como chegaram até aquela resposta, quais os raciocínios informais e formais ele utilizou qual o conceito que ele tem ou não, etc Estas observações e análises me fazem refletir e me ajudam a não ficar só: "ele não sabe somar...ele não sabe"...mas ele não sabe isso por quê? Então, você parte para uma investigação, onde você percebe o quê? Que ele não tem seqüência numérica... que ele não tem participação... que ele não tem classificação... que ele não tem uma série de conhecimentos e de conceitos que ele deveria ter e porquê estão faltando.

E: Quando você fala de defasagem, você não está falando de um período único, você está falando de uma história escolar dessa criança e como isso era compreendido na escola? Ou como era trabalhado equipe com os professores, com a direção?

B: Essa proposta, por exemplo foi colocada e discutida coletivamente, principalmente para os professores dos ciclos iniciais onde se focou o desenrolar desse projeto. Do infantil, primeira série. Esta proposta de trabalho foi desenvolvida por um período de tempo. E infelizmente, depois do afastamento das técnicas envolvidas não houve continuidade.

E: Foi interrompido pela escola?

B: Acabou, eu acho que a nossa profissão .... profissão de professor... causa muita angústia e muita insatisfação...e graças...a isso se procura, às vezes até desenfreada... por soluções...e....uma maneira de você poder diminuir um pouco essa...angústia...principalmente quando você não tem parceiros,alguém que te ajude a analisar,a dar subsídios teóricos,a discutir, e fazer com que você se desenvolva com essa parceria. A tendência é que haja uma procura pelo novo,o que nos faz fazer uma troca ,esquecer até o que dava certo.

E: Isso ocorre devido a quê na sua opinião? Você acha que é mais freqüente na Educação Especial?

B: Acho que não necessariamente, mas eu acho que talvez seja um pouco mais exacerbado na educação especial, provavelmente motivados pelas dificuldades de comunicação.

$\mathrm{E}:$ Como assim? Essa angústia que você falou,que desencadeia...essa busca desenfreada de soluções, você acha que provoca o que no professor?

B: Eu acho que provoca um turbilhão, a cada novidade ficamos tão entusiasmados, e implantamos de uma maneira geral, global e irrestrita e acabamos apagando as coisas que davam certo...também.

E: Do mesmo jeito que implanta, morre?

B: É.

E: E aí...eu te pergunto...isso é uma questão importante, principalmente quando a gente está falando de escola pública. Como você analisa essa questão, na medida em que você definia seus rumos e com domínio do trabalho para poder dar continuidade. Por que será que a escola não se sente independente e permitiu que se terminasse um projeto?

B: É...eu acho que os projetos não tem continuidade porque entram pessoas novas e estas não são postas a par do que já fizemos e do que estamos realizando no momento ...estas novas pessoas trazem uma outra visão ,e nós nos deixamos seduzir pelo novo...e aí...se substitui tudo

$\mathrm{E}$ : Mas se o grupo desse continuidade?

B: Olha eu acho que a proposta era muito boa...com ótimo referencial teórico organizada...muito bem estruturada...deu ótimos resultados,uma proposta atemporal ,mas...não tínhamos mais ninguém que coordenasse. A equipe que coordenava mudou. A gente via que dava resultado, mas nós mudamos a abordagem.

E: Novos profissionais imprimiram uma nova direção para essa questão?

B: Não, não teve mais nova questão. Acabou, foi ponto final mesmo. Não teve substituto, não teve um projeto substituto para essas dificuldades, necessidades, na realidade....nós acabamos ficando ...sem essas trocas...essas discussões continuaram existindo mas sem retorno. O professor ficou mais sozinho. Cada um...cada um faz aquilo que acha melhor...

E: Acaba ficando com aquilo que acha melhor, como assim?

$\mathrm{B}$ : tinha a equipe sim... mas....mudou a dinâmica... a equipe que tinha saiu...

T: E a dinâmica?

B: A dinâmica modificou.... Se por acaso um aluno meu tivesse algum problema... familiar, pessoal, de aprendizado...eu ia conversar com a equipe....se eu quisesse, se eu não quisesse tudo bem...

$\mathrm{E}$ : Não havia uma troca ou um movimento de ambos os lados? 
B: Não. Acho que os relacionamentos se complicaram, devemos observar os dois lados...Depende muito da pessoa, se tenho alguma coisa que não estou conseguindo resolver, eu vou procurar o outro pra me ajudar...mesmo que essa pessoa não venha...

E: Até você?

$\mathrm{B}$ : Eu acho que isso te aproxima do outro começa a ter essa troca...mas tem professores que também não gostam...que acham que estão interferindo no trabalho...sei lá...eu acho que é muito difícil...

E: Você falou de interferência? Que tipo de interferência?

B: Você tem uma diferença entre partilhar...é...partilhar é você, por exemplo, ir na minha sala, fazer uma observação, sair da minha sala, me chamar uma hora e.. retornar...pois é o que vale da observação do outro ,uma resposta pra mim... eu estou trabalhando com o aluno... outra coisa é você ir na minha sala, fazer uma observação, e essa observação não ser compartilhada...você está observando quem? O aluno ou o meu trabalho?...Eu acho que aí há o estranhamento.

E: Você acha que por isso muitos professores não gostam...?

$\mathrm{B}$ : Eu acho que é por isso que muitos professores não gostam. Pois não é uma situação clara, transparente,

(interrupção)

E: Vamos lá...então nós vamos retomar com a Bianca...e...você estava dizendo Bianca...da...do professor que se fecha né?

B: Sim...eu acho assim...que a gente teve uma época em que a gente tinha observações em sala de aula,com retorno. A gente tinha discussões em grupos...e a gente tinha discussões individuais...tinha observação em sala de aula...mas era tudo com troca, eu sinto que houve uma mudança também pode ser porque, agora a Secretaria chama muito mais lá...e...os técnicos não ficam quase na escola...não ficam e...então...na realidade a gente fica meio abandonado mesmo...não tem retorno....às vezes a gente fala, por exemplo "eu preciso de uma ajuda..." mas assim, recai nos seus ombros...é você que está dentro da sala de aula, você que sabe...você que está dentro da área, mudou também relatórios...a gente trabalha por áreas...eu estou na área de matemática...faz vinte e cinco anos que eu trabalho só com matemática, então...não tem...não tem troca...não tem...por mais boa vontade, é...tem gente, certas pessoas que têm boa vontade...desculpa falar, mas não têm tempo.

$\mathrm{E}$ : Nesse processo mais próximo, com a equipe mais centrada na unidade escolar...voltada para essas trocas com o professor, quais as transformações que você sente na sua experiência. Vamos analisar esse momento que você diz que foi enriquecedor para sua prática pedagógica. Que transformações importantes você citaria...assim, as mais significativas nesses momentos de trocas, de diálogo, como você diz, tanto individual,quanto coletivo.Como você recupera isso, e que questões até hoje lhe trazem instrumentos para a sua prática?

B: Eu acho assim, quando as coisas são compartilhadas a gente ganha tudo...a gente ganha,os alunos ganham com isso você absorve e compactua.É você não está procurando sozinha.

$\mathrm{E}$ : Você comentou que a escola está construindo o bilingüismo, como imprimiram a questão, foi um processo que a sua escola assumiu? Como isso foi sendo construindo?

$\mathrm{B}$ : Eu acho assim que o indivíduo surdo...pra mim ele continua...surdo, ele continua sendo o mesmo indivíduo que eu pensava antes...eu sempre acreditei nas possibilidades...na igualdade...sempre...é, não tratei o surdo...só porque ele é surdo, de forma diferente, eu acho que ele tem que ter tudo aquilo e muito mais do que um ouvinte a questão é que a libras é de fato uma comunicação, você chega muito mais, mas eu acho que a gente está num ponto diferente entre o grupo, que...alguns professores tem muito mais facilidade com essa língua, outros professores tem menos facilidade com essa língua, então nesse aspecto eu acho que está sendo construído. Para se ter uma escola bilíngüe todos os funcionários teriam que utilizar a mesma língua...que é a libras, ter a proficiência, todos os professores teriam que ser iguais, e não é. A gente tem professor que está no nível inicial, intermediário e avançado. O conhecimento da língua, da libras é difícil, eu acho que também pra você ter esse domínio todo, você teria que estar inserido numa comunidade de surdos, participar dessa comunidade, interagir com essa comunidade, que é outra coisa que eu acho que não acontece, só acontece com alguns profissionais, mas não acredito que com a maioria.

E: E na questão do surdo, ou deficiente auditivo. Nessa construção de conhecimento, você sentiu que a formação continuada em serviço ofereceu elementos pra você compreender melhor essa transformação, essa surdez?

B: Na realidade, as formações que nós fizemos...que foi uma busca nossa foram ótimas,que estavam de acordo com as nossas necessidades. Nós chamamos o Skliar, a Vilma do INES, do Rio de Janeiro, alguns profissionais que poderiam trazer para nós novas discussões realizadas dentro da escola, foi ótimo...agora quanto a formação que a prefeitura oferece...é....a maioria não contempla.

E: É mais genérica?

B: É muito genérica, num grupo que nós fizemos formação, a gente queria perguntar certas coisas e o formador falava: "eu estou dando um curso para aluno ouvinte...eu não entendo nada de surdo...eu não sei". A maioria dos professores era da educação fundamental de primeira a quarta e para começar nós temos até a oitava...então o meu interesse, o interesse de outras pessoas seria de quinta a oitava e nem formação disso a gente teve...era de primeira a quarta...então "a professora conhece de primeira a quarta"...só nossa escola que tem de quinta a oitava, e dessa forma os cursos são para esse público, do infantil ou de primeira a quarta e exclusivamente para...alunos de escola regular.

E: Por isso, que você diz que os cursos e seminários mais voltados para a sua escola, ou escolhidos de acordo com as necessidades de vocês, da sua unidade escolar, contemplam muito mais?

B: Contemplam muito mais. Teve épocas, a gente conseguiu muitos cursos, mas mudou a chefia do Especial e aí não tivemos mais.

E: Há um descontinuismo...

B: É...aí você fica sem continuidade mesmo, porque mesmo na formação da gente em Libras ficou interrompida.

E: Porque a Secretaria dava?

B: A gente pagou uma época...a Secretaria financiou uma outra época, mas...é difícil, você tem que fazer fora do seu horário de trabalho...você tem que pagar...

E: E todas essas formações eram em horário de trabalho, essas outras que você disse que contemplavam? Assessorias e cursos?

B: Era no horário do HTPC, mas muitas vezes a gente ficava em outros dias, porque só o HTPC também não dava, mas como era de interesse...nosso, específico, de necessidade nossa...então a gente vai fazer...até pagar.

$\mathrm{E}$ : E como a equipe compunha com essas formações?..

$\mathrm{B}$ : A equipe participava do mesmo jeito que a gente.

$\mathrm{E}:$ Como isso era trabalhado no dia-a-dia?

B: É, por exemplo, a gente fez uma assessoria específica em Língua Portuguesa, como segunda língua, e a gente estava realmente precisando, porque a gente deixou de pensar em Língua Portuguesa como primeira língua, pra ser segunda língua, virou um projeto, e os técnicos, as fonos, a orientadora, eles participaram de um grupo de Língua Portuguesa. Eles dão subsídio, eles discutem... 
E: E isso reorienta o plano de trabalho e como isso é concretizado na prática?

B: No caso fica na área de Português...então quem é da área de Português participa desse projeto, participa desse grupo..

E: E da área de Matemática?

B: Na área de Matemática, nós estamos pedindo há muito tempo...mas não fomos atendida.

E: Existem algumas prioridades...estabeleceram prioridades, é isso?

B: Não, não foi estabelecido.

E: Eu vou voltar numa questão...já que você citou aqui, a surdez...quer dizer...vocês passaram por uma transformação e hoje vocês inclusive denominam surdez e não deficiência auditiva...quer dizer...essa mudança de concepção, deficiência, diversidade, surdez, deficiência auditiva...como é que isso se transformou? Como você entende isso, na questão da deficiência?

B: Eu passei pelo oralismo, pela comunicação total,agora o bilingüismo, então, as denominações pra mim são simples meras denominações, ou assim...acredita-se que deficiência é uma palavra talvez assim, muito científica...em termo de tipo doença, e a surdez é um termo acho pra mim assim, mais justo... "ele é surdo", é lógico que também essa denominação eu acho que com o tempo você vai percebendo que a gente está recebendo cada vez mais "não-surdos", ou melhor só surdos. Então a clientela, já está virando clientela... vem com outras deficiências, então eu acho que a gente vai ter que se adequar a isso também.

E: Você falou de clientela me explica por que? O que você quis dizer com a questão da clientela, em relação a sua população que você trabalha...?

$\mathrm{B}$ : Na realidade, não sei o surdo puro que a gente fala, ele tem todas as possibilidades para dar continuidade a sua vida, mesmo que não seja com a Libras,... o que eu tive de experiência....muito dos meu alunos foram fazer colegial...terminaram o colegial...alguns fizeram...estão fazendo...fizeram faculdade, estão fazendo faculdade...estão trabalhando... Algumas escolas têm o teste para o colegial, mas mesmo que tenham eles conseguem se virar.

E: Você usou o termo clientela por quê?

$\mathrm{B}$ : Porque eu acho que um aluno que tem mais defasagens...que talvez a parte pedagógica deva ser repensada, reavaliada, readaptada...adaptada...e...em termos até de expectativas do próprio professor.

$\mathrm{E}$ : Você acha que, assim, com esses comprometimentos associados à surdez compromete muito mais a aprendizagem deles? B: Eu acho que sim, eu acho que sim.

$\mathrm{E}$ : $\mathrm{E}$ isso você sente que está mais freqüente?

B: É... eu não tenho experiência direta com essa turminha que vem vindo, que é o pessoal da tarde, mas eles têm maior dificuldade. Paralisia cerebral, múltiplos.

E: Múltiplos? Eu acho assim, que sensorialmente aí o comprometimento é muito maior...ainda tem a audição...

$\mathrm{E}$ : E você acha que o professor como está enfrentando estas questões?

B: Não está preparado. Eu acho que nós não estamos preparado não. A escola não está preparada. Eu acho que tem que reavaliar... realmente olhar o que a gente tem e repensar, qual a linha que a gente vai seguir...é...qual o projeto de trabalho que nós vamos ter com essa criança, porque já vem vindo crianças com bastante dificuldade e tem algumas coisas que não posso avaliar como antes e, pedagogicamente não poderia dizer que estão, por exemplo, numa sexta série, numa sétima série, numa oitava série...em termos assim de qualidade pedagógica...com o currículo regular...então eu acho assim que é uma coisa relativa, porque tem turmas que você consegue...e já tem turmas que você não consegue mais.

E: Quer dizer, pelo que eu estou entendendo, você situa que a surdez em si não é um limitador quando são respeitadas as questões da comunicação?

B: Exatamente.

E: o que você acha desse despreparo que a escola está tendo, em relação a essa população?

B: Eu acho que tem que ter pelo menos, o mínimo de formação para os professores que estão recebendo esta criança. A gente que trabalha com surdos, existem surdos com defasagens, mas agora, a gente não sabe trabalhar com o mental, com o visual, associado.

E: Você falou na expectativa do professor...o quanto precisa trabalhar também a expectativa do professor...e aí eu...eu resgato um pouco aquilo que você falou...quer dizer o professor se vê com uma série de demandas e ele vai se frustrando quando ele se sente sozinho?

B: Vai.

$\mathrm{E}$ : E aí eu volto na questão dessa experiência...que análise você faz da proposta formativa no enfrentamento dessas novas demandas? Nesse processo de diálogo existente anteriormente, como você sentia o enfrentamento dessa população com maior necessidade ?

B: Se você tem pessoas que você pode compartilhar...que te dão subsídios pra você estar estudando...fazendo grupos de estudos, formação coletiva.

Hoje eles estão a tarde, amanhã eles podem estar de manhã...comigo, e o que eu sei? Então, eu acho que se tivesse uma equipe realmente atuante,que te desse...que te desse um suporte...de uma...seria para todos...não, por exemplo, eu estou trabalhando com uma surda-cega, vem uma menina do...do visual e vem te dar orientação pra você...e os outros que estão com essa criança? Eu, fico uma vez por semana, e encontro essa menina.

$\mathrm{E}:$ É muito pontual o atendimento?

B: Não dá...não dá uma bagagem de troca nenhuma. Eu acredito que a Secretaria de Educação, ela está tirando, toda hora, os profissionais da nossa escola e toma como prioridade, eles estarem lá...na Secretaria...

E: Para outras atividades?

B: E não para partilhar com o professor...parece agora que....a tentativa é de realmente não existir esse vínculo.

E:. E nesse modelo de maior proximidade da equipe, eu queria que você falasse que falhas foram observadas, e que contribuições ocorreram nesse processo que você que pudesse ser revistos para melhorar? Que efeitos positivos ocorreram nessa atuação mais partilhada e quais as deficiências...?

B: Eu acho assim...quando realmente havia...essa junção entre professor e equipe, a gente nem chamava de técnico, até a denominação ficou mais importante, a gente tinha muito mais proximidade, acho que tinha-se tempo...pra conversar entre a gente mesma...e cada um saber o que você estava fazendo...e você passar alguma coisa da sua experiência para o outro.

Eu acho assim que você tinha mais tempo para refletir com o outro. Eu acho que houve muitas modificações no caminho, eu acho que um tempo atrás a nossa escola era uma escola especial, era tratada como tal...nós não tínhamos pressa em passar alunos. A avaliação era adaptada, a seriação era flexível...dependia do conteúdo que você estava dando... então...eu acho que isso é...também é um facilitador.

$\mathrm{E}:$ Para o aluno você acha que havia ganhos de aprendizagem...?

B: Os ganhos de aprendizagem eram maiores, porque por exemplo, se eu tivesse num mesmo agrupamento uma ou duas alunas que tivessem condições de estar...um nível acima...dois níveis acima...a gente conseguia fazer isso, no paralelo...

$\mathrm{E}$ : Você trabalhava paralelamente com o aluno? 
B: Isso...aí você tinha condições de estar pondo um ano depois....acelerar no tempo.

E: Hoje você acha que essa seriação não ajuda?

B: Não, não individualiza, porque você tem prazo até março...você pode...por exemplo se você tiver uma...uma..reavaliação...você pode até mudar de ciclo...mudar de agrupamento... Mas você tem prazo...pra fazer. Porque a gente é tratado como uma escola regular...

E: Uma escola regular?

B: Regular.

E: Pela Secretaria?

B: Pela Diretoria lá de ensino é. É uma dificuldade você conseguir fazer adaptações...então para adaptar você tem que ter uma equipe que te dê um respaldo...que te dê subsídios....então eu acho assim que existe uma série de coisas no meio...essa coisa mesmo da mudança...para o bilingüismo...como comunicação...os pequenininhos eles conseguem te passar as sensações...te contar coisas...é uma graça... eles conversam você vê uma diferença...na educação bilíngüe.

$\mathrm{E}:$ Mais precisa?

B: É...você vê uma diferença...na aprendizagem dos alunos.Mas ao mesmo tempo, fica uma confusão, como você vai trabalhar um currículo de uma escola comum que tem o Português como segunda língua, e muitos não tem nem a primeira língua estabelecida ...eu já dei aula em lugar que não tem nem a primeira língua estabelecida...a maioria deles não tem o Português como segunda língua estabelecido...lógico, você não tem a primeira, você não tem a segunda...e isso, interfere na avaliação que você tem...desse aluno com relação a todas as matérias que exigem Português.

E: Como é que você entende o papel da sua intervenção?

B: Olha...eu acho assim...que...a gente tenta vários caminhos até conseguir atingir uma luzinha ali no fim do túnel, mas é...não é em todos os casos, eu acho que a minha prática, com os anos você vai...você tem opç̃es pra dar uma mesma coisa,você tem materiais, por exemplo, que você pode usar que são muito mais concretos, pra depois você passar...mesmo uma equação de segundo grau tem...um material concreto, você dá... proporção, também você tem mecanismos concretos pra apresentar, mas eu acho que tem alunos que você não atinge nem mesmo assim...e o que você atinge é muito pouco...o que você consegue fazer com que esse aluno absorva...é mínimo...No meu fazer...talvez eu possua essa falta de conhecimento. Sobre a dinâmica de pensamento desse aluno.

$\mathrm{E}: \mathrm{E} . . . \mathrm{e}$ nesse sentido, Bianca, como naqueles momentos .... equipe discutia essas questões?

B: Eu acho que você deve pensar nesse aluno como uma pessoa global, ele não é só... um ser que está fazendo... ele é um ser que tem toda uma engrenagem lá dentro...ele está pensando...ele tem um tipo de casa, de experiência, tem um tipo de pensamento diferente do outro pra chegar numa resposta...numa conceituação...eu acho assim, que eu como professora tenho que oferecer vários caminhos... para eles conseguirem construir...pegar um desses caminhos e falar "esse caminho é o meu", esse caminho pode ser o dele, pode não ser o do outro e...eu acho assim, pra você chegar...nesse tipo de intervenção, é difícil...porque... Porque exige muito do professor...exige muita observação...exige muito do aluno...exige muito...

E: Você precisa conhecer o aluno?

B: Você precisa conhecer esse aluno.

E: Quer dizer que desse período de troca, de parceria, te deram elementos pra você analisar essa criança hoje com mais propriedade?

B: Mas, não é suficiente porque eu tenho outras coisas envolvidas, por exemplo, eu tenho uma turminha que está numa sextasérie, essa turminha poderia ter um acompanhamento diferente, que precisam ser trabalhados lá atrás...E eles estão numa sexta-série e eu tenho que dar conta de um conteúdo de sexta série...eu tenho que retomar uma série de coisas"...essa turma eu retomei uma série de coisas, a minha amiga também retomou uma série de coisas, só que a gente chegou num ponto que eu e ela...eu e ela...juntas...não sabíamos mais o que fazer...nós não demos conta...foi bem...bem...

E: Quer dizer...precisaria de uma lente de aumento aí nas necessidades dessas crianças pra ver...

B: Para investigar direitinho...fazer um trabalho legal....eu tenho um panorama das necessidades todas, a minha amiga também tem um panorama das necessidades... mas é tanta coisa...Qual seria o ponto... onde eu teria de começar pra desenrolar esse fio?

E: E nisso você acha que sozinha você não está dando conta?

B: Nem sozinha, nem com a minha amiga.

E: Compreender toda a complexidade dessas crianças!

B: É quem sou eu?

E: quando você fala "quem sou eu", você nesse processo de parceria, como você acha que o professor era compreendido, a atuação do professor tinha um peso nesse processo?

B: Olha as minhas observações, a minha prática, minha intervenção era ouvida, eu tinha...liberdade e eu me sentia amparada...eu tinha liberdade de falar... "olha eu não concordo... aqui eu não estou conseguindo...",agora eu falo também, mas não tem...

E: Mesmo você vendo os efeitos positivos dessa experiência, tendo enriquecido a sua prática, oferecido ferramentas, você acredita que não consegue esgotar todas as necessidades...?

B: Não...não consegue não...são muitas necessidades....é muito difícil...tem dias que você tem vontade de sentar e chorar.

$\mathrm{E}: \mathrm{O}$ que parece ser mais difícil?

B: Eu acho que falta...uma parte de embasamento teórico..porque as necessidades são...diversificadas... eu acho que teria que ter mais... eu me sinto mais segura, quando eu conheço mais a área que eu estou trabalhando, porque eu estou trabalhando muito tempo nessa mesma área, então eu tenho tempo pra estudar, eu tenho tempo de ver caminhos diferentes, mas ao mesmo tempo me falta conhecimento teórico da parte de....aprendizagem, da estrutura do pensamento desses alunos...de conhecer mais esses meninos.

$\mathrm{E}:$ De como ele constrói conhecimento?

B: De como ele constrói esse conhecimento, porque as vezes a gente tenta de um jeito, tenta de outro, tenta de outro, tenta de outro e nada...uma das coisas que você vê é que muitas dessas crianças não tem nenhuma comunicação constituída, resumindo...então isso a gente se culpa bastante...eu me sinto impotente e incompetente pra tratar com algumas coisas...

E: Você acha que falta embasamento teórico...e o que você foi adquirindo anteriormente, naquele período não supre esse momento...?

B: Não supre... em grande parte..mas...esse embasamento que eu tive anterior foi que me deu esse olhar diferente... então eu procuro...se eu vejo alguma coisa, eu procuro trabalhar daquele jeito que eu sei que pode dar resultados...mas as vezes não dá... Seria muito importante ter com quem compartilhar...e com domínio. Eu sinto que há uma dificuldade que todos os profissionais tem.

E: Você quer dizer, que é uma população que todos precisariam estudar, analisar e dominar teoricamente as questões...

B: Exatamente...eu acho que sim... 
E: Você acredita que as escolas, muitas vezes, não estão preparadas para reconhecer o aluno que ela está recebendo...

B: Exatamente...eu acho assim que é....algumas coisas servem para um grupo que não servem para o outro...vamos olhar para os dois grupos, os que eu já conheço e sei trabalhar e aquele que o professor precisa de mais aprofundamento... Agora vamos olhar para o que é real...e o que é real hoje? É um surdo com múltiplas deficiências...um surdo com dificuldades outras...não adianta...os caras não vão sumir...eles estão ali...não adianta fechar os olhos...

$\mathrm{E}$ : Você sente que a surdez não está totalmente compreendida, a surdez tem nuances como qualquer indivíduo tem, com possibilidades e limites...

B: Habilidades específicas...e não são tratadas com a devida importância. Eu acho assim, que todas nós temos a mesma preocupação e não tem essa troca...

E: Você fica sem resposta?

B: Continua não tendo eco. Então, são as mesmas crianças, os mesmos alunos, os mesmos problemas...de primeira série, segunda série, terceira série, quarta série, quinta série, sexta série, sétima e oitava...e o que...entendeu...a gente não está priorizando...o que deve priorizar e o que é prioridade? Nós estamos num pacto por causa da construção do bilingüismo e a gente está priorizando o que é importante, que é á questão da língua portuguesa como segunda língua e da Libras como primeira língua, mas e o resto...do indivíduo...?

E: Você quer dizer...para onde vai...essa instrumentalização do professor sobre o bilingüismo se está colocado em um indivíduo que ele ainda não conhece?

B: É...isso, é um indivíduo que o professor não conhece na totalidade,que muitos deles a gente não conhece...e principalmente aqueles que estão vindo com mais dificuldades.

E: E só esses instrumentos que você adquiriu não vão resolver?

B: Não, pois tem algumas crianças com déficit de atenção,surdos com deficiência visual, então a Libras só não garante. E os surdos com deficiência mental, eles tem as mesmas condições? E o surdo com paralisia cerebral, que não tem atenção? Ele vai se beneficiar só com a Libras? É uma questão...que pra mim é muito séria...Então está se focando no bilingüismo, eu acho isso justo e certo com a população surda...só que nós não temos só uma população surda...nós não somos uma comunidade só surda...nós já fomos....nós já tivemos muitas crianças com outros comprometimentos também, mas não do jeito que vai estar...que está tendo daqui pra frente...essa população vai mudar...e ninguém está vendo isso... como você vai... poder oferecer pra essa pessoa condição de vida...

$\mathrm{E}: \mathrm{E}$ você acha que isto não está sendo olhado?

B: Muito pouco, entendeu? Os alunos da tarde, acho que só um ou dois grupinhos que são de crianças surdas, os demais são mais específicas e precisariam de um trabalho diferente, inclusive tem um professor que trabalha com um menino no colo, que condições esse professor tem em estar trabalhando com essa criança de uma maneira correta, entendeu...o mais correto possível...da melhor maneira possível...que o professor possa chegar em casa, deitar a sua cabecinha e dizer: "puxa, estou satisfeito"...tem que haver satisfação que advém do trabalho com resultados, da interação que eu tenho com esse aluno... 0 que ele construiu com isso...porque se eu não dou nada...o aluno está construindo o que? Se não existe essa construção, que raios eu estou fazendo? Que raio de instituição é essa que eu estou? Se ele não consegue sair alfabetizado tanto matematicamente quanto na língua, não teria...muito professor dizendo oitava série: " já deu o que tinha que dar".

E: Bem, Bianca foi muito bom falar com você....obrigada.

\section{Larissa}

A entrevista foi realizada na unidade escolar, local de trabalho da entrevistada, durante duas aulas vagas.

Duração da Entrevista: 2 horas e 10 min

E: Eu gostaria que você falasse sobre a experiência de formação continuada, que você vivenciou no período de 1996 a 2003. O que você destacaria nesta sua trajetória profissional, como tendo sido determinante na sua formação em parceria com a equipe interdisciplinar, no contexto escolar?

L: Iniciei assim, eu terminei a faculdade e comecei o trabalho então uma das coisas que eu percebi é que a faculdade, a teoria, tudo aquilo que a gente aprendeu lá não dava a base...ou não formou naquilo que eu precisava. Então quando eu cheguei na escola especial para alunos surdos não tinha a mínima noção do que eu ia fazer. Eu tinha todas as teorias, aprendi muitos métodos de reabilitação, mas não tinha a prática.

$\mathrm{E}:$ Quando que você formou?

L: Em oitenta e quatro. E aí o meu começo foi todo atravessado, todos os métodos importadinhos dos Estados Unidos, a coisa mais linda do mundo, porém na nossa realidade não fazia sentido.

E: Não fazia sentido na realidade que você vivia?

$\mathrm{L}$ : Na faculdade quando falava da reabilitação era em condições ideais, eu imaginava que ia chegar na escola e encontrar um grupinho de criança de três anos para eu começar um trabalho de reabilitação...crianças que tivessem toda a condição, que os pais pudessem dar todo apoio, mas era uma realidade muito diferente. Uma turma de alunos maiores, sem língua, sem um sistema de comunicação, com muita dificuldade a nível familiar, social...então...que estava muito longe daquele ideal.

E: Outra realidade?

L: Era uma realidade completamente diferente. Os alunos chegavam tarde à escola, eu lembro do primeiro grupo que eu peguei, eram crianças com mais ou menos doze, treze, quatorze anos, que não se comunicavam, não liam e não estavam alfabetizados.

E: Não tinha nenhum código?

L: Não tínhamos código. Foi muito chocante, porque na verdade para esse enfrentamento da realidade eu não estava preparada. Aí assim o que fica muito claro é que a formação aconteceu dentro da própria unidade através do respaldo de quem estava lá. A equipe era formada por fonoaudiólogas, psicóloga, orientadora pedagógica e assistente social, e acontecia a troca com as outras professoras.

Eu acredito que vendo um profissional competente atuando, você aprende, eu acredito muito nisso, a minha formação aconteceu no meu trabalho, no meu dia-a-dia, nas relações com a equipe e com outras professoras. Tive também formação com profissionais de fora, de acordo com a necessidade do grupo, assim acontecia a reflexão sobre a prática, esse ter alguém próximo, um parceiro mais competente que vem te auxiliar aí nessa construção, eu acredito que você aprende vendo um profissional competente, outro professor, o parceiro da sala ao lado, a interferência de um profissional da equipe, assim fui me formando.

E: Você falou da questão da reflexão era uma sistemática de trabalho? 
L: Era uma constante, assim a oportunidade que eu tive de viver com os profissionais competentes dentro da escola, essa possibilidade ultrapassa os problemas vindos das diferentes administrações, da importância que se dá à educação, essa condição ultrapassa as dificuldades, o que eu adquiri na formação é meu, continua na minha prática, no meu fazer, independente da administração, vai além das dificuldades. Somado a isso, tivemos a felicidade de ter profissionais que ficaram bastante tempo trabalhando juntos, isso também é um fator positivo.

O apoio era de acordo com a necessidade do grupo, por exemplo, se eu tinha um aluno que não conseguia atingir, que apresentava mais dificuldade, às vezes de aprendizagem, de comportamento ou emocional eu buscava ajuda, aí o aluno era observado, discutíamos juntos e buscávamos caminho para atender melhor a cada um.

Às vezes o psicólogo, outras vezes a orientadora ou a fonoaudióloga, dependendo de quem pudesse no momento, a gente discutia o caso da criança, se fosse a fonoaudióloga, por exemplo, ela atendia em outros momentos, havia troca de impressões, "olha eu percebo isso durante o atendimentos, você também percebe isso?" Então conseguíamos soluções. Outras vezes, se a dificuldade era mais a nível emocional, conversávamos com a psicóloga, e era a mesma coisa, discutíamos o que se apresentava, ela observava o aluno nas atividades e discutíamos em outros momentos, o caso era discutido com toda a equipe e assim apareciam dicas, "olha...tenta dessa maneira...vamos tentar dessa outra...vamos fazer um contato"...se precisava de algum atendimento fora da escola, eram feitos os encaminhamentos eu tinha todo suporte, não ficava sozinha no trabalho. E assim eu fui aprendendo.

E: E na questão da aprendizagem, você via essa interação com essas áreas diversas ou os procedimentos eram pontuais? Havia uma proposta interativa na questão da aprendizagem da criança?

L: Era interativa, essa era uma grande preocupação, onde tínhamos a possibilidade de todos profissionais da equipe conhecer o aluno do qual falávamos, era uma visão bem integrada, no sentido mesmo do "ser inteiro", na aprendizagem, no desenvolvimento, como um todo.

Os profissionais não se limitavam a um parecer de sua área apenas, mas buscavam a soma de saberes, para uma visão total do aluno enquanto desenvolvimento dele próprio, do seu modo de ser, do seu jeito, das suas necessidades, era assim que a gente trabalhava.

E: Você falou da descontinuidade provocada pelas diferentes administrações, mas que você acreditava na questão da competência dos profissionais que estavam com você. $E$ em relação a isso eu queria que você falasse um pouco das transformações que esta parceria trouxe pra você e como você se apropriou disso para até suportar essa descontinuidade, ou se você se sentia em alguns momentos despreparada e sem suporte?

L: Pensando na minha vida profissional percebo que eu não tinha muita consciência disso, até porque eu buscava formação fora do ambiente escolar, mas dá para perceber que quando a dinâmica é a mesma, não somente da escola, também dentro da Secretaria de Educação, quando há a preocupação com a formação dos profissionais, que o objetivo é a formação desse profissional, que é buscar uma qualidade do ensino, muda muito, há grandes possibilidades, ao contrário, quando a administração não tem essa preocupação, as coisas andam mais devagar, as possibilidades são menores, mas acredito que uma equipe interdisciplinar dentro da escola ajuda a superar essas dificuldades, lembro de momentos em que não havia investimento algum por parte da administração, às vezes um movimento até contrário, mas nós continuávamos fazendo o nosso trabalho e muito bem. Então por quê? Nós tínhamos a equipe dentro da escola e a formação que cada um de nós já havia tido, nos levava para frente, independente de tudo. Era uma construção coletiva, constante e sólida.

$\mathrm{E}$ as transformações aconteciam com todos nós. Era um crescimento muito grande. Quando passava por esses momentos em que a Secretaria não dava apoio, nós continuávamos apesar de tudo. Em outros momentos tivemos a felicidade de ter a Secretaria, a política educacional do município como parceiro,as coisas fluíam melhor, havia a possibilidade de trazer aquilo que era a necessidade real do grupo-escola, a necessidade de cada área dentro do grupo-escola, era fantástico.

É muito gostoso quando você percebe que as coisas vão mudando dentro de você, lembro de uns comentários:"lembra aquela formação...ou aquele curso? Às vezes, não havia uma sistemática, em outras vinha o formador para a escola, numa formação junto com o professor e a equipe e embora talvez não tivesse uma sistematização, uma coisa toda estruturada, a transformação se operou dentro de mim, na minha prática e isso, ninguém tira.

Não é? No momento em que eu cresço, que a minha prática muda e que eu consigo perceber isso, eu reflito sobre, no sentido que "eu mudei", ninguém tira mais.

É um constante crescimento, são tijolinhos, então aquilo que eu adquiri ali naquele momento passa a fazer parte da minha vida, do meu fazer dentro da escola.

E: Como essas transformações ocorreram em você, que transformações essa experiência promoveu em sua atuação até hoje, para que lidasse com os impasses do cotidiano?

L: Eu as percebo, me fizeram mudar o olhar. Então, o que eu percebia, a forma como eu agia, eu tinha um olhar simples, não tinha muitos elementos para analisar e muitas vezes a minha ação era inadequada, uma resposta, uma postura ou interferência inadequada. E o que acontece? A partir do momento em que você se sente mais preparada, consegue enxergar mais, compreender as dificuldades e as respostas frente ao impasses mudam completamente. Você passa a ter outra possibilidade, o enfrentamento passa a ser com muito mais qualidade, a interferência é muito mais positiva.

Embora eu não me sinta pronta, porque eu acho que a gente está o tempo inteiro se constituindo, é muito gostoso ver que vamos mudando, que cada um tem o seu tempo, hoje eu consigo perceber o tempo do outro e falar "ah, eu também já passei por isso...eu também já enfrentei dessa maneira...hoje eu tenho um outro olhar"...então isso é muito legal...essas trocas.

E: Essas questões que você traz da questão do seu olhar ser transformado, você falou "era um olhar simples", como isso se transformou na relação com o aluno?

L: Um exemplo é que eu sabia exatamente o que eu queria, mas eu não tinha uma forma de comunicação, muitas vezes eu não percebia a resposta do aluno.

E: Essa questão da comunicação, dos códigos?

L: Dos códigos. Essa dificuldade permeava todo um processo, na relação com o outro, "ele não consegue", era esse olhar simples. Com o tempo, com a formação, com a parceria o que você percebe? "Não. O problema não é esse, o problema é que não existe uma língua eficiente permeando a relação.

E: Não está tendo acesso?

L: Foi quando começou a mudança, eu passei a ver a possibilidade, isso é um exemplo na parte específica da surdez. Outro exemplo tem a ver com a relação professor/aluno.

A relação professor/aluno ela é linda, você faz contratos, eu não sabia fazer contratos, eu não tinha isso, com a formação aprendi, melhorou muito a relação, o que antes era problema de comportamento passa a ser resolvido com contratos entre a professora e o grupo, mudou demais a relação.

E: Você poderia falar sobre esta formação em parceria com a equipe, que contribuições tiveram e que aspectos precisariam ser revistos? 
L: Essa formação é um suporte constante e permite crescimento real, mudança na prática, no dia a dia. Funciona porque atende a todos, tanto quem já está a bastante tempo como aquele que chega, parte da real necessidade dos profissionais e do grupo de alunos.

A possibilidade de estar junto é muito boa, infelizmente isso não é uma prática normal nas escolas, geralmente tem um psicólogo que atende "n" escolas, como vai poder ajudar na formação, é muito pouco, não é ser parceiro, é quase nada. A cada dia, a possibilidade do profissional ali dentro, é no corredor, é no momento, é em uma necessidade real, existe o parceiro, o respaldo.

E: Você não está solitária?

L: Você não está solitária, a formação em parceria funciona demais. Eu aproveito muito o trabalho em parceria, gosto muito quando temos oportunidade de realizar trocas.

$\mathrm{E}:$ Em que momentos isto ocorria?

L: Teve momentos em que a gente tinha troca, nos HTPCs, entre professores e equipe, tivemos grupo de estudos, foi muito bom!

\section{E: Entre professores?}

L: Entre professores, organizado junto com a equipe trocas onde se diz o projeto deu certo, o que está dando certo comigo, poder dizer o que fez. Então, você ouve o seu companheiro, conhece o trabalho dele, participa. Para falar do que falha, eu sinto que os profissionais da equipe interdisciplinar, também estão em formação, apesar de terem uma formação técnica que o professor não tem, muitas vezes também estão se formando em serviço, acho difícil formar equipes interdisciplinares sem esse respeito ao tempo de cada um, não dá para exigir do profissional o que ele não tem, é trabalhar para o crescimento de todos. Outro ponto é a relação, para a formação em parceira precisa que os lados estejam abertos, não dá resultado quando um dos lados não está aberto para ela.

$\mathrm{E}$ : A questão da relação, que é um ponto que você toca que eu acho extremamente importante, na parceria, aprofunda um pouco mais isso.

L: O que eu sinto em relação a isso é importante o quanto você está aberto para essa formação, esse mudar, do quanto você consegue se abrir pra essas questões, para a interferência do outro, e isso é muito pessoal, então por isso é que eu vejo isso como um ponto a ser considerado com muita atenção no trabalho, às vezes pode se tornar um entrave, porque pode ter pessoas que num momento não conseguem se abrir...

$\mathrm{E}$ : $\mathrm{E}$ o outro como é que ele reage a isso, também tem a ver?

L: Tem a ver, tem muito a ver, o outro também está em formação e se espera que o profissional tivesse uma atitude que possibilitasse maior abertura, e vezes ele não tem, acaba fechando mais o outro. É uma questão pessoal, individual como há interações entre todos, há momentos em que os parceiros da equipe também precisam se construir, trocar experiências, por exemplo, "olha, vamos discutir isto, o professor não me recebeu bem na sala", "como que eu vou agir frente a isso"? Então ele também vai estar se construindo com o outro, ela é constante.

E: E no inverso, a questão dessa atitude, da parceria de saberes, enquanto professora como você percebia o seu saber, em pauta nessa negociação, nessa parceria, nessa troca. Havia troca?

L: Havia troca, porque eu acho que isso é que faz a possibilidade, não funciona se houver imposição, mas era troca, soma de saberes, por exemplo, "como que você tem feito? E se nós fizéssemos dessa maneira? É uma parceria onde entra o meu conhecimento e o do outro, a minha experiência, o meu fazer, mas ele está acrescido de outro olhar, então não fica só o meu olhar, é outro olhar que vem constituir, que vem somar, que vem ajudar, mas não me anula, me respeita, é um olhar que acredita no que eu estou fazendo.

E: Retomando um pouco essa questão da atitude do outro que você assinalou, quando você ainda não está pronto para essa transformação, na questão do professor, que pode não estar no momento dele estar querendo trocar, como é que fica a parceria na questão do profissional da equipe, em relação a essas resistências, que muitas vezes, um grande projeto se anula. L: Se anula, é verdade. Eu sempre acreditei muito na mudança até porque eu mudei muito, em vinte e cinco anos eu mudei demais, eu acredito que nós estamos sempre em formação, que nós estamos sempre mudando. Eu acredito no outro que embora naquele momento não esteja aberto, num outro momento ele vai estar. Mas o que acontece é que a relação se desgasta, um dia em conversa com uma amiga sobre essas questões, "a gente investe tanto e parece que a gente não vê resultado", as pessoas não compram a idéia que você acredita enquanto profissional, enquanto equipe, que vai dar resultado, se investe naquela pessoa ela não se abre, eu fiz as perguntas tentando saber "o que se pode fazer para ajudar essa pessoa a mudar?" E a resposta foi muito simples: troca o profissional, isso é uma coisa que não existe no serviço público, isso é um entrave, elas não estão abertas a mudanças, mas elas estão ali com você e você tem que trabalhar apesar disso. É um desafio que a gente vence todo dia aqui na escola.

Cabe um exemplo dentro da educação de surdos, como oralistas tínhamos toda uma concepção e um modo de fazer. Com as formações, percebemos a necessidade de mudar, foram mudanças gradativas envolvendo a equipe toda da escola. Nesse caminhar, uma mudança de paradigma, percebíamos alguma resistência. E nós continuamos juntos, nós trabalhamos com a resistência dando a ela resultados. Eu acho que a melhor coisa que você pode mostrar é resultados. Você fala do teu trabalho e do resultado do teu trabalho e o outro também vai se modificando.

$\mathrm{E}$ : E você acha, nessa parceria, a equipe como parceiro mais competente naquela área de sua formação, você sentia essa disposição para investir, como você fala?

L: Sim, eu acho o time completo, não dá pra você falar que é de uma pessoa, todo o grupo precisa estar com essa disposição para crescer, cada professor envolvido, cada um que está acreditando é um parceiro nessa mudança, e a equipe fica na manutenção dando firmeza na concepção teórica, em algum conhecimento, num novo saber que não deixa voltar pra trás... $\mathrm{E}$ isso ajuda muito na mudança, na questão das relações, acontece de pegar de frente, não só como parceiro a nível profissional, mas para uma relação particular, isso pode provocar algum desgaste. Mas eu acredito que o grupo, enquanto grupo, tem condições de vencer isso também, a gente passa por tudo isso e todos nós nos formamos e nos transformamos. $\mathrm{E}$ : Eu queria que você retomasse como essas trocas de saberes iam produzindo conhecimento em você, como isso se processava, essa sistemática te dava outra condição na relação com o aluno com a surdez, como isso nutria a sua relação com a deficiência? E se você pudesse falar um pouco, como você concebe a deficiência.

L: Estudando, aprofundando dentro dessa parceria, o meu olhar foi mudando e assim a visão em relação aos alunos mudou, passamos a ver o aluno como um ser com potencial e não como alguém que tem falta de alguma coisa.

Essa mudança se deu com todo o grupo, fizemos grupos de estudo, chegávamos antes do horário de serviço para estudar, dentro da área específica da surdez, também os PCNs, tínhamos vozes dentro da Secretaria, tinha o outro que te ouvia e te entendia. As transformações na prática da educação de surdos aconteceram quando chegaram profissionais que tinham uma visão diferente, que usavam a língua de sinais, tivemos uma assessoria, com a Zilda Gesueli, da Unicamp, ela falou num curso para todo o pessoal da escola, que não dava para fazer sinal e falar junto, que na verdade a gente estava misturando duas línguas diferentes, isso fazia uma grande confusão na cabeça do aluno, aquilo me chocou, porque eu acreditava no oralismo e 
a gente só falava não conseguia a comunicação, comecei a usar os sinais e ela vem dizendo que eu estava usando duas línguas diferentes ao mesmo tempo. Isso interferia direto na minha prática, eu não conseguia entender o que ela estava me dizendo naquele momento, então o meu olhar em relação ao aluno também passava por essa incompreensão. É muito legal isso, porque pra quem que eu fui dizer do meu estranhamento? Para os meus parceiros, nós estávamos nos formando todos ao mesmo tempo, com certeza eu tinha ali no grupo pessoas que já tinham outro olhar já diferente, mas eles tiveram paciência comigo e falaram "vamos investir, porque ela vai mudar. Foram vários momentos e as transformações acontecendo numa ligação muito direta com a prática. Tivemos ainda várias assessorias a Vani, também da UNICAMP, que falou um pouquinho mais dos processo de aquisição de leitura e escrita,da gramática e nós fomos percebendo que se tratava de duas línguas, com gramática diferente, outra assessoria do Prof. Carlos Sckliar, da UFRGS que deu uma visão da deficiência como diferença e o trabalho com as potencialidades e não mais como uma dificuldade...uma deficiência.

Veja como mudou o meu olhar, antes eu dizia: "eu tenho tudo, eu tenho a fala, eu tenho os meus objetivos, eu tenho a proposta pedagógica e eu não consigo realizar o trabalho porque o aluno não tem a fala. É aí exatamente que mudou ele é diferente, tem uma língua diferente e quem tem que se adequar ao surdo sou eu, não é ele a mim. Isso que mudou a prática, a nossa visão e a educação de surdos. Teve um período que eu trabalhei com crianças de 0 a 3 anos, 1998 , eu não tinha ainda essa mudança de olhar e tive oportunidade de participar de uma formação com o pessoal da creche, isso é muito legal...

E: Havia possibilidade de integração entre diferentes modalidades de ensino?

L: Sim, a Secretaria de Educação trabalhando como um todo, não tudo segmentado, parecendo gavetinhas. A interação que está dentro da escola, mostra que é uma concepção, que é um modelo da própria rede.

Aprendi muito, na questão da rotina no atendimento a essa faixa de idade, embora nós trabalhamos com surdos, ele é uma criança como todas as outras, mudou muito a nossa prática.

E: Quando você comenta: "ela é uma criança", aprofunda um pouco mais.

L: É uma criança, tem uma forma de comunicação diferente, uma língua diferente, mas tem toda a possibilidade de desenvolvimento integral, pleno, como qualquer outra criança. Então, quanto mais bem preparado estiver o professor, melhor será o atendimento oferecido. Nessa mesma época, quando eu tive essa possibilidade de trabalho com essa faixa de idade, eu tinha também uma criança com mais comprometimento, era uma deficiência visual junto com a auditiva e eu tive a possibilidade de ir para a formação em um outro espaço, onde tinha uma parceria com as pessoas que trabalhavam com outras deficiências, eu também aprendi, acompanhei os atendimentos, aprendi com a parceira, que ela tinha um outro conhecimento mais técnico, dentro de uma outra área, eu fui aprendendo um pouco daquela especificidade, na troca..."olha, eu percebi isso com ele ali...você percebe outra coisa?"...e a gente sentava junto pra fazer o relatório do atendimento. Assim, víamos o ser inteirinho, não só ouvidos ou visão.

Você vê quantas mudanças? E a minha prática? Só mudou, eu olhava pra uma criança com dificuldade, eu não tinha uma interferência adequada, às vezes não sabia o que fazer, com as parcerias, nos atendimentos, com a Daniela, tive também a oportunidade de estar com outro pessoal que tinha outra especialidade, o atendimento melhorou, a prática melhorou, eu já sabia o que fazer com a criança. Então é assim, o tempo inteiro em formação. E isso assim, num período pequeno você percebe o tanto de coisa que vai permeando.

E: Nessa questão de você se voltar pra sua prática, como você conseguia, era um processo específico seu. Como ocorria?

L: Não era específico meu. Ele era como se fosse uma linha da própria equipe de trabalho, não era só eu. Eram todos refletindo sobre a prática. Então ao mesmo tempo em que você estava recebendo, o seu colega também estava, era a base do trabalho. A reflexão, a volta para o nosso fazer, a partir dos cursos, das formações, mais importante era a reflexão disso tudo sobre a minha prática, às vezes junto com uma pessoa da equipe, nessa época era uma das fonoaudiólogas quem estava mais próxima de mim, ou com um grupo de professores do mesmo nível, refletíamos sobre como o novo conhecimento vai ajudar no meu trabalho, tinha sempre uma parceria, era sistemático.

$\mathrm{E}$ : Apesar de você ter dito essa questão do sujeito inteiro, do aluno como um todo, quando você relata essa questão da fono, por exemplo, isso não fragmentava esse sujeito inteiro?

L: Não, porque embora ela fosse uma fonoaudióloga, ela também tinha uma compreensão e um olhar que dava uma completude, enquanto eu estava olhando aspectos pedagógicos, da minha função de professora, ela tinha o olhar que era específico e que para aquele "ser" que estava ali na nossa frente, a gente precisava juntar tudo, não se olhava ouvidos, ou olhos, ou alguma outra coisa, a gente olhava o desenvolvimento dele todo. Quando a equipe está preparada, ela é multidisciplinar não só no nome, ela é toda... Interativa, todas as pessoas têm esse olhar. Então é muito legal!

E: Os profissionais interagiam entre si? Você tinha conhecimento de que forma a equipe interagia no preparo para mediar essa formação? Como isso acontecia, que idéia você faz disso?

L: Existia alguma formação, reuniões sistemáticas e sempre teve um elemento dentro dessa equipe que fazia convergir, que aglutinava as discussões. Esse elemento é fundamental. Então eu posso te dizer que em determinados momentos eu percebia, eu fazia uma leitura de que, por exemplo, num momento era o psicólogo, outra hora era outra pessoa, um diretor, um coordenador pedagógico, mas sempre tem que ter uma pessoa que está ali costurando.

E: Eu queria que você expusesse um pouco mais como se dava a sua relação com o aluno, quais os impasses que eram instaurados com mais freqüência, e como que você lida até hoje, nos processos de aprendizagem. Há alguns instrumentos específicos, alguns recursos por causa da deficiência deles.

L: Eu vou dizer o que mudou. A gente passou a usar a língua de sinais, na minha prática, eu vou falar de mim, no que eu sinto lá dentro da sala de aula, eu sinto que pelo tanto que eu domino da língua de sinais, a língua de sinais não é uma coisa que você aprende de uma hora pra outra, nem com trinta horas, nem com oitenta horas, como a gente vê nos cursos oferecidos pelo MEC, o meu domínio da língua de sinais é muito pequeno para eu estar fazendo esse tipo de atendimento, isso é uma das coisas, temos na escola um professor surdo, ele é um mestre da língua dele, é muito gostoso você ver essa possibilidade. E ele traz pra gente dados que a gente não percebe, isso por quê? Porque eu não domino essa língua. Então, isso é uma das coisas que ainda atrapalham a minha prática.

E: Quando você fala que você ainda não domina, você não domina o tanto necessário para o desenvolvimento do seu trabalho?

L: Tenho um domínio razoável, dá pra conversar, mas ele não é suficiente para tudo, para dar conta de todo o processo educacional e de todas as relações que ele envolve, na totalidade da constituição desse ser, em poder estar dizendo todas as coisas que ele necessita, eu não domino a língua, misturo alguma coisa da gramática do português com os sinais, essa falta de domínio da língua é uma das coisas que me faz pensar que ele tem uma língua diferente, e eu domino pouco essa língua, então eu estou falhando. Mudou muito. Porque antes a gente falava "olha, eu não consigo porque ele não tem", e hoje não, ele tem uma língua que eu não tenho. Vejo que ele tem toda possibilidade e que eu não estou dando conta desse trabalho. $\mathrm{E}$ : Você quer dizer do esforço que a escola precisa fazer para chegar mais perto das necessidades do aluno?

$\mathrm{L}$ : $\mathrm{E}$ isso é muito legal, ainda sobre a minha formação, também eu sinto que falta conhecimento específico, eu dou aula de história e eu não tenho essa formação, eu sou pedagoga, é autorizado pela delegacia de ensino, mas eu sinto que falta um 
conhecimento que me permita estabelecer mais relações, e quanto maior for esse número de relações, eu acredito que o meu aluno vá aprender mais. E com relação à própria educação de surdos, precisamos caminhar muito, o que é uma escola para Surdos? Como disse uma formadora há pouco tempo: “- é necessário não uma escola para surdos, mas uma escola surda. E o que é uma escola surda?"

Usamos muitos recursos visuais, as transparências, o data show, o laboratório de informática, mas é dentro de um modelo que se criou, do que se pensou, para as crianças ouvintes, há muito que se pensar, do que se conseguir, no que seja num processo educacional, numa escola surda de verdade. Outra coisa que pega muito, é a questão da avaliação. Tivemos várias formações sobre avaliação, dirigidas a toda rede de São Bernardo, e quando trouxemos a reflexão para dentro da escola, nós nos perguntamos como seria a avaliação para surdos, percebo que há uma confusão, eu fico em dúvida se é o conhecimento específico do meu objetivo dentro da área que eu estou trabalhando, ou se eu estou avaliando o quanto ele sabe de Língua Portuguesa, que é e sua segunda língua, na modalidade escrita, e que não é a língua em que ocorre o processo de aprendizagem. A minha língua de discussão é a LIBRAS, então o que eu tenho que considerar respeitando a LIBRAS é que ela seja também a maior consideração para na avaliação, o quanto dessa língua na modalidade escrita entra, eu tenho muitos impasses. Eu acho que a gente, nunca vai chegar e falar: "-Estamos com todos os problemas resolvidos". Não, a gente ta buscando esse processo o tempo inteiro, eu saí dum ponto onde eu não sabia lidar com os problemas, hoje eu consigo lidar com certa tranqüilidade, mas por outro lado, eu vejo outros... Um olhar que se abre pra outras necessidades.

$\mathrm{E}$ : E na questão da área de História, como é que você vê a aprendizagem num conhecimento que envolve espaço e tempo. Como é o domínio desse conhecimento, e a questão da surdez. Como é que é isso?

L: Na medida em que você conseguir resolver o problema da língua, dá para discutir sobre tudo, perceber o que o aluno já sabe, quais suas hipóteses e continuar o processo, eles tem toda a possibilidade, às vezes, o que falta pra mim muitas vezes são conhecimentos que me permitam traçar um caminho.... com relação aos recursos visuais, às imagens, e na análise das imagens, para permitir a eles acessar todo o conhecimento, mas eles não têm esse conhecimento na modalidade escrita esse é um dos nossos objetivos.

E: Esses novos referenciais do bilingüismo

L: A questão do bilingüismo, da modalidade escrita do português e a LIBRAS, é o nosso grande desafio.

E: Esses diferentes momentos que você falou, referindo-se a um processo de transformação seu e do aluno. $E$ você fala na questão da avaliação, como você vê a avaliação, considerando os padrões da avaliação existente?

L: O processo de avaliação dá referenciais para eu saber o quanto atingi e como atingir dos objetivos e ele mesmo, o processo de avaliação me mostra que eu estou falhando, eu procuro fazer a avaliação em LIBRAS, a avaliação é todo dia, então eu percebo as minhas falhas, está o tempo inteiro dando respostas do meu trabalho.

E: Você hoje, se sente melhor preparada. Você relatou que quando você chegou desprovida de ferramentas, esses referenciais teóricos discutidos na faculdade não foram suficientes. Eu queria que você falasse como a teoria pode ajudá-la no manejo do cotidiano?

L: Por exemplo, nós acreditamos no Bilingüismo, o que eu preciso? Eu preciso de mais alguns referenciais teóricos, que me permitam conhecer mais sobre o bilingüismo, eu acredito nisso, a escola necessita, é o nosso objetivo, precisamos referenciais teóricos não separados do nosso fazer, que venha nos dar essas respostas, que nos leve a refletir cada vez mais sobre o nosso fazer. É esse referencial teórico coladinho, ele vem da necessidade apontada dentro do seu fazer, ele não vem de fora, a partir da nossa reflexão sabemos o que estamos precisando. Por exemplo, como nós somos polivalentes, e atendemos de quinta à oitava, temos dificuldades nas áreas, estávamos precisando de ajuda em matemática, tivemos uma assessoria, que nos deu um referencial, tudo é refletido, é trocado, então eu acho que nunca, vem uma coisa imposta ou que diga: “-Joga fora o que você tem, que eu to colocando uma coisa" não, é uma coisa somada, interativa, se completa.

E: E esse modelo de uma parceria mais voltada para o contexto da escola, é algo que está se mantendo? Ou vocês estão se nutrindo com as experiências que tiveram?

L: Nós estamos vivendo num momento em que é muito claro tudo isso... Porque a gente está indo contra ao que está posto, a nível federal, que é essa grande inclusão indiscriminada do surdo. Então, na verdade você, forma um professor dentro da rede estadual, com sessenta horas num curso de LIBRAs, ou por exemplo, em Santo André, você coloca uma criança ou duas surdas dentro de uma classe com ouvintes, onde tem uma pessoa que passa uma vez ou duas por semana, para dar assessoria à esse professor, esse professor aprende uma musiquinha, uma série de palavras, faz uns quebra-cabeças com sinais da LIBRAS e já acha que está dando conta dessa língua. Nós sabemos que não. Que língua se desenvolve na interação com seus pares, eu acredito nisso, no nosso fazer, dá para ir até contra uma política pública, sabemos que está sendo negado à esse surdo o direito de desenvolver a sua própria língua, onde ele está será sempre o deficiente. Então, a mudança é muito forte, e o que se acredita, é o que se faz. E eu vejo que aqui dentro do município nós estamos na contramão também.

E: Por que? Você acha que hoje, o referencial da Secretaria de Educação para construção de uma escola inclusiva, está sendo posto de uma forma indiscriminada?

L: É o que eu percebo, em Diadema, em Santo André e em São Bernardo, eu não quero entrar no mérito da questão da inclusão de uma maneira geral, mas nessa que eu conheço, nessa que eu vivo, a educação de surdos eu posso falar com muita tranqüilidade, eu acredito na necessidade dele se constituir com a sua própria língua, a partir do momento em que ele se constitui com a sua própria língua, ele terá autonomia que lhe permita ser incluído em diversos lugares da sociedade, e não ao contrário. Ele se constituindo como um surdo, vai dizer o que ele quer, quiser ir para uma escola de ouvintes com um intérprete ou em uma escola só de surdos, vai fazer as escolhas, eu não posso escolher por ele, eu tenho que dar possibilidade para que ele escolha. E muitas vezes, é esse direito que é tirado. Então assim, com a inclusão dessa maneira indiscriminada, as pessoas ouvintes dizendo como deve ser a educação de surdos, é preciso que eles sejam os autores de sua educação. Por exemplo, em Santo André, a criança nasce surda, a mãe procura o serviço, ele só vai ter a inclusão.

E: Como este processo via a família?

L: A família é a grande parceira, a escola, a equipe, as assessorias, essa coisa multidisciplinar, não é sem a família. E a família, às vezes, não consegue lidar com essa criança, com a presença dessa criança diferente, precisa do trabalho dessa equipe muito presente, muito próxima, para formar também a família, que é uma família também em formação. Tem o atendimento do dia a dia, as diversas pessoas da equipe, às vezes, um assistente social dá um atendimento na parte econômica, de orientação a alguma questão, tem a parte da fonoaudióloga que às vezes faz alguns atendimentos, e dá um retorno pros pais e o psicólogo quando precisa.

Temos a APM e o Conselho de Escola, que também trazem os pais pra dentro da escola e tem o grupo de pais, geralmente realizado pela equipe e professores para os pais dos alunos que chegam à escola. Mas a gente não consegue isso cem por cento, é uma coisa bastante difícil, e daí tem uma série de coisas que emperram, os pais que vem, são os mais atuantes, são aqueles que têm mais consciência.

E: Como é que você vê com essa realidade do bilingüismo, a relação com a família. 
L: As famílias podem estar em diferentes momentos, quando a criança nasce surda, quando a criança começa a não se alfabetizar no mesmo momento que o outro, dá uma crise nessa família. Nós aqui procuramos acompanhar com reuniões, vai mostrando as possibilidades, o que você faz, vai dando toques, os pais muitas vezes não sabem a LIBRAS, e nós mostramos o que seu filho sabe, você vai acolhendo, você vai transformando. Existem pais mais resistentes, de famílias cujo sonho é que a criança fale, são necessidades das famílias, e elas vão sendo aos poucos atendidas. Você vai mostrando a possibilidade, ao mesmo tempo ela vai vendo a dificuldade, e ao mesmo tempo ela vai se moldando, na fase da alfabetização, quando começam as comparações, um filho está aprendendo, e o outro não, nas nossas reuniões procuramos mostrar que o Português é a segunda língua para o surdo, que a aprendizagem não se dará da mesma forma que a criança ouvinte. Eu não sei falar como é o pai lá fora, numa escola inclusiva, se o filho dele vai ser sempre o deficiente ali, uma pessoa que me procurou pra saber se poderia trazer a criança pra cá, essa mãe me disse que a professora falou que ela não vai passar de ano, que ela vai fazer de novo os conteúdos referentes ao ciclo inicial, mas eu não gostei, porque eu acho que a minha filha não precisa ver tudo novamente, ela precisa entender o que está sendo feito. Ela deu um exemplo, ela viu que a filha não tinha feito uma atividade de matemática, e era uma coisa muito simples, numeração básica, era uma soma, e conversando com a criança ela chegou a conclusão que a menina não conseguiu entender, que aquela cruzinha ali no meio, significava que tinha que juntar. A menina sabia o número, ela tinha o conceito, ela tinha tudo, ela só não sabia o significado do sinal de mais, que chega de uma forma bastante fácil para os ouvintes, mas não chegou para uma aluna surda incluída. Essa mãe disse: eu preciso de uma escola, que dê conta de dizer pra ela o que o outro pegou oralmente, às vezes são coisas tão simples, mas que vão emperrando todo o processo. Essa mãe me falou: "-Eu gostaria de uma escola que atendesse a necessidade da minha filha, eu acho que deve ter uma coisa por aí...

E: O pai tem possibilidade de optar? Como você conduz esta questão?

L: Eu tive algumas crianças que os pais vieram conhecer a escola, viram um pouquinho do trabalho, a criança passou por alguns atendimentos, e aí o pai falou: “- Não, a necessidade nossa é que ela fale, vou tentar uma escola junto com ouvintes". Outros logo de início percebem a possibilidade de comunicação, vão vendo os resultados e passam a acreditar nos filhos, na escola, infelizmente percebo que muitas famílias não pensam sobre a questão, deixam que os profissionais decidam sobre a vida de seus filhos, só os pais mais esclarecidos questionam e fazem a opção.

E: A visão deles é que vocês sabem definir melhor que ele, o que seja melhor para o filho.

L: Eu fico pensando que a gente tem um papel muito importante a cumprir nessa questão...

$E$ : $E$ você sente que os pais que vão se envolvendo gradativamente, com esse trabalho que a escola propõe, começam a ter um maior interesse pela língua do filho?

L: Têm casos e casos, como pai, no caso a figura masculina, só fala e a mãe é que mais próxima, vai adquirir essa língua, às vezes, um irmão. A família ainda não compra a Língua de sinais, mesmo aqueles que vendo a criança pequenininha, e que falam: "- Vou fazer um curso de sinais!" Às vezes, se contenta com um curso muito curto. Com um módulo, como se já fosse suficiente. Mas é uma coisa que falha muita vezes. A Secretaria oferece para a família um curso, mas depende muito por que...não é obrigatório... E ainda assim, demora para a Secretaria disponibilizar os recursos para o curso.

E: Porque é a Secretaria que financia?

L: É, depende de uma série de coisas, às vezes passa o ano, o pai pedindo o curso, e não tem. No momento, estamos tendo, tem um instrutor que vem, e que está atendendo os pais. mas não é para todas as famílias, às vezes, essa mãe não tem possibilidade, é complicado.

E: Essa análise, quando você assinala sobre o sujeito inteiro. Você citou a questão da identidade dele. Você acha que a escola ocupa um espaço, às vezes, muito maior do que a família.

L: O "ser surdo" engloba uma série de coisas, o "ser surdo" já pressupõe essa diferença lingüística com a família, uma dificuldade na comunicação, já nos primeiros laços que se estabelecem.

E: Você acha que há uma quebra?

L: O que é a língua materna? Você pode falar que a LIBRAS é a língua materna do surdo, quando ele é filho de pais ouvintes.

Porque é a língua dele, mas não é a língua do pai e da mãe, é uma discussão muito difícil.

E: E como ficam esses vínculos pais-filho?

L: Como ficam esses vínculos? Como fica essa família? Como fica a identidade dessa criança?

$\mathrm{E}$ : Como uma estrangeira em sua própria casa?

L: O "ser surdo", conversando com os alunos, percebemos que lembranças de uma infância muito remota, eles não tem, porque embora eles tenham vivido, não ficou registrado em termos de um sistema lingüístico, , então, é um pensar diferente, o ser surdo, se constituir dentro LIBRAS. E essa família, às vezes, não acompanha esse processo, infelizmente.

$\mathrm{E}$ : Porque ela tem outro referencial, e tem às vezes filhos ouvintes?

L: O referencial dele ainda é o da criança com audição e não com uma criança que é toda visual. Mas o direito da criança ter isto que você não consegue entender é uma questão muito delicada.

E: Você falou dessa questão, de muitas vezes, o pai negar a própria deficiência do filho, nesse processo de assumir o bilingüismo, essa negação da deficiência, pode trazer dúvidas nos profissionais? Como é que fica essa questão nos profissionais, como que você joga essa questão da diferença, e da deficiência?

L: Na presença da criança surda, cada um reage de uma determinada maneira, tem aqueles que falam assim: "Eu não sei o que fazer, então eu vou lá na escola, no médico, na fonoaudióloga, porque o pessoal sabe o que fazer", outros dizem: "- Mas eu queria que ele falasse", e tem um outro pessoal, que luta quando vê a possibilidade da diferença lingüística, e percebe a criança dizendo alguma coisa que normalmente ela não percebe em casa, então compra a idéia, a língua é outra e eu vai em frente por aí!". Então têm vários tipos de relação e também, vários tempos, as vezes, uma família precisa de um tempo maior, e outra precisa de um tempo menor, mais nunca, a escola pode deixar de demonstrar o que ela tem, o que ela oferece, a escola tem uma cara, ela está construída dentro dessa proposta, da diferença, quando você acredita, você consegue mostrar. É mostrando resultados, às vezes, até a própria mãe fala: “- Nossa, eu não sabia que ela sabia tudo isso, ou que ela conseguia dizer tudo isso, então a família passa a acreditar, e a investir. Outros relatos de pais é que as crianças ficam muito nervosas, quando não eram entendidas ou então, se criavam situações em casa, de extremo estresse, por uma coisa simples, que a mãe, ou alguém não conseguiu entender, pra essas famílias o respeito a diferença lingüística passa a fazer uma grande diferença, percebem que ele tem toda a possibilidade, cada família tem um tempo, e um modo de se relacionar com essas questões, mas a escola deve estar sempre firme no seu propósito, mostrando para que ela está aqui.

$E$ : $E$ onde fica a questão desse biológico, que trouxe um comprometimento na acuidade auditiva. Como é que fica isso na compreensão da escola?

L: Temos o embasamento teórico que o analisa, não como deficiente, mas como uma diferença lingüística, acreditamos nas potencialidades que eles tem, mas na rua ele não vai ouvir a buzina, não é porque ele usa LIBRAS que ele vai ouvir a buzina, ele vai continuar não ouvindo a buzina. É preciso considerar isso, para atender a necessidade dele, não se desconsidera, mas 
não que isso vá limitar, ou que isso seja um impedimento, favorecendo para que as interações aconteçam dentro da língua e do desenvolvimento da identidade surda, o seu modo de ser, o seu modo de agir.

E: O biológico não é visto como um limite?

L: Não, e isso eu digo, porque ele tem outro canal. Eu não descartei a perda auditiva, mas por outro lado, isto, não é determinante para o tipo de aprendizagem que ele vai ter.

$\mathrm{E}$ : Os limites muitas vezes existentes na inclusão social, devido às questões lingüísticas, é algo que no desenvolvimento do trabalho escolar é considerado para discussão com eles e com a família?

L: Nosso objetivo é formar um cidadão pleno, dentro das suas possibilidades, como um cidadão surdo, é um cidadão de direitos, autônomo, é este ser que a gente está querendo formar, para que quando ele saia, ele tenha consciência das suas limitações, mas que tenha autonomia, e que tenha condições de se impor aonde quer que esteja, essa sim é a verdadeira inclusão, ele vai ter condições de lutar pelas próprias necessidades. De estar incluído onde ele precisar, por exemplo, quando estão no ciclo quatro, percebemos um movimento de autonomia, de busca, de responsabilidade, que permita enfrentar um ensino médio, aonde ele vai estar incluído. A nossa realidade aqui é esta, ele sai, e vai ser incluído, mas ele vai lutar, a gente está tendo respostas.

E: Você acha que ele já carrega com ele ferramentas, que dê para ele conseguir, se incluir?

L: Formar esse cidadão com direitos, de viver a sua vida plenamente, ele próprio é um momento muito diferente, se você for fazer uma comparação um aluno indo para o ensino médio, sabendo que vai estar incluído, faz a matrícula é muito diferente de uma criança de seis de três, de quatro, de cinco e de sete, que você inclua ela numa sala de ouvinte, que condição de análise ele terá?Como vai construir sua identidade nesse espaço? Pela falta? É totalmente diferente.

E: Eu queria que você dissesse como você se relaciona com os alunos, e o modo de intervenção na sala de aula.

L: Para que ocorram, esses processos de ensino e de aprendizagem de uma melhor maneira você tem que ter esses profissionais, bem preparados, é cada vez mais respeitar o surdo no seu modo de ser, "olhar" para ele com toda sua possibilidade, mas na minha impossibilidade, sendo eu, nos meus limites desta língua, o que eu posso ver de como ele se apresenta.

E: Colocando a educação, dos surdos num conjunto maior de política pública educacional, você acha as peculiaridades lingüísticas assinaladas poderiam ser observadas, com a formação recebida pelo professor do regular?

L: Eu consigo falar com muita tranqüilidade do que eu vivi, eu sou a pessoa que eu sou porque eu tive essa oportunidade de conviver com todos esses alunos, com todos esses parceiros, tanto da equipe técnica, quanto dos professores, nós somos um grupo muito forte. Mas quando penso para onde está indo essa educação, ou no relato de colegas que estão no ensino regular, que vem dizendo do não - sucesso na aprendizagem, que as vezes a gente fala, nossa tantas crianças ai com tanta dificuldade na segunda língua, e você ouve um colega dizendo que no ensino regular está da mesma maneira. Penso que o problema é de formação mesmo. Eu tenho uma filha, que agora está fazendo a faculdade de pedagogia, acredito que se ela puder observar e viver com bons professores, tiver momentos de trocas de experiências e de boas práticas, dentro daquele espaço de formação, com certeza, estarão mais bem preparados. Em situações reais mesmo, com bons professores, é muito mais do que ler todos aqueles textos, todas as concepções, toda a história da educação, da prática, dos modelos, porque eles estão todos lidos, mas precisam ser vividos, experimentados.

E: Você acha que a educação especial ou a educação dos surdos, que é a sua realidade, teria alguma coisa a ensinar, para a educação regular, com essa experiência?

L: Tem. Porque a possibilidade de ter esse grupo de apoio, de ter uma formação em parceria, o estar no grupo, muito tempo, da qualidade do trabalho, se reflete os resultados. Os pais também dão o retorno: "- Poxa, se o meu outro filho pudesse ter essa possibilidade de experiências que tem aqui na escola especial...". Ele sairia mais autônomo, ele sairia com condições, o trabalho não pode estar focado só no conteúdo, em termos do conteúdo, se ele precisar, vai à luta, tem biblioteca, ele tem internet, ele tem o amigo.

E: O trabalho não está focado só no conteúdo, mas é a interpretação que ele faz desse conteúdo que você dá importância...

L: É, o como que ele interioriza, como que isso vai ter um significado, como ele vai lidar com isso, que ele tenha as habilidades necessárias para lidar com essas questões do conteúdo. Aqui é assim, mas fosse um professor de sala de recursos, dentro da escola comum, como esse professor se forma? Como se nutre? Quem foi o parceiro mais competente? Quem deu respaldo para ele na hora que ele precisou? Ninguém!

E: Você sentiu, na sua trajetória profissional, falta de um movimento mais aproximado da educação especial e da educação regular?

L: Sim, o nosso aluno surdo é antes de tudo um ser. Qual é o lugar da educação especial? Isso aí a gente, pode discutir, por que é que fragmenta?

$\mathrm{E}$ : Eu queria agradecer a sua contribuição, que foi muito valiosa.

$\mathrm{L}$ : Sempre é bom conversar com você, obrigada. 